\title{
Biblioteka
}

LingVariów

Tom 28

\section{Słowiańska frazeologia gwarowa II}

\author{
pod redakcją \\ Macieja Raka i Valerija M. Mokienki
}

Uniwersytet Jagielloński

Wydział Polonistyki 

SŁOWIAŃSKA FRAZEOLOGIA GWAROWA

II 


\title{
Biblioteka „LingVariów” \\ T. 28
}

Redaktor naukowy serii

Maciej Rak

\section{SŁOWIAŃSKA FRAZEOLOGIA GWAROWA \\ II}

\author{
pod redakcja \\ Macieja Raka i Valerija M. Mokienki
}




\title{
Biblioteka „LingVariów” T. 28
}

SŁOWIAŃSKA FRAZEOLOGIA GWAROWA

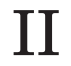

\author{
pod redakcja \\ Macieja Raka i Valerija M. Mokienki
}

Księgarnia Akademicka

Kraków 2020 
Recenzenci:

dr hab. Renata Bura

prof. dr hab. Adam Fałowski

prof. dr hab. Stanisław Koziara

доц. Елена К. Николаева

Redakcja

Tomasz P. Bocheński

Skład i łamanie

Małgorzata Manterys-Rachwał

Okładka

Paweł Sepielak

Publikacja dotowana przez Wydział Polonistyki UJ

ISBN 978-83-8138-234-2 (wersja papierowa)

ISBN 978-83-8138-245-8 (e-book)

https://doi.org/10.12797/9788381382458

(C) Wydział Polonistyki UJ oraz autorzy

\section{WYDAWNICTWO KSIĘGARNIA AKADEMICKA}

ul. św. Anny 6, 31-008 Kraków

tel./faks: 12 431-27-43, 12 421-13-87

e-mail: akademicka@akademicka.pl

Księgarnia internetowa: https://akademicka.pl 


\section{SPIS TREŚCI}

WSTĘP

\section{ZAGADNIENIA OGÓLNE}

MACIEJ RAK, Do czego się przydaje frazeologia gwarowa?

ZвYNĚK Holub, Obraz jihozápadočeské frazeologie na přelomu tisíciletí a její reflexe v literatuře.

ЕлЕНА НЕвЗоРОвА-Кмеч, Диалектизмы в субстандартных русских и польских фразеологизмах

\section{Frazeografia i BADANiA ETNOLINGWiStyCZnE}

Jerzy BARTMiński, Frazeologia a językowy obraz świata. 53

WoJciech Chlebda, Frazeologiczne zaplecze językowego obrazu świata................. 63

НАТАлІя ВЕНжинович, Діалектна фраземіка як предмет лінгвокультурологчіного аналізу

\section{ŹRÓDLA FRAZEOLOGII GWAROWEJ}

ВАлЕРИй МихАйлович МокиЕнко, Диалектная и историческая фразеология. Перспективы взаимодействия.

HARry WALter, Немецкие диалекты как источник фразеологии

АлЕкСАНдР БиРих, Диалекты как источник русской исторической фразеологии ....

Magdalena Grupa-Dolińska, Obcojęzyczne elementy we frazeologii rosyjskiej gwary staroobrzędowców w Polsce

\section{Frazeografia GWAROWA}

Gabriela Dziamska-Lenart, Gwarowe słowniki frazeologiczne języka polskiego przegląd

НАТАЛЬя АРЕФьЕвА, Актуальные проблемы создания Фразеологического словаря русских говоров Одесщинны.

FABIAn KaUlfürst, Awdijowy korpus maminorěcneje dolnoserbšćiny ako žrědło za pśeslěźowanje dolnoserbskeje dialektalneje frazeologije.

\section{FrazeOlogia ŹRÓDLEM WIEDZY O CZLOWIEKU}

Ewa MlynarczYk, Frazemy obrazujące sposób prowadzenia gospodarstwa domowego (rekonesans).

Lidia Przymuszala, Gwarowe frazeologizmy określające wiek człowieka (na przykładzie materiału śląskiego). 
Katarzyna KonczewsKa, Пашлі бабы атаваю... Баба ў парэміях гарадзенскіх беларускіх гаворак

Paulina KarPeta, Frazeologia gwarowa pogranicza małopolsko-mazowieckiego ..... 191

Ewa Sıkora, Frazeologia podhalańska w pamiętnikach i gawędach górali jako źródło rekonstrukcji językowego obrazu głodu

\section{SACRUM I PROFANUM}

Monika Bulawa, Święty Walenty we frazeologizmach i przysłowiach polskich 211

Emil Poplawski, Rok rolniczo-gospodarski w świetle przysłów w gwarach polskich (od św. Eliasza - 20 lipca, do św. Tomasza - 21 grudnia)

Renata Dźwigol, Diabelski czyli jaki? Kilka słów o motywacji nazw.

Uwagi wstępne

\section{STUDIA PRZYPADKóW}

Anna Tyrpa, Wóz albo przewóz - studium przypadku

ЕленА Ничипорчик, Диалектные лексикализованные предложно-падежные сочетания с компонентом без в русском языке

KatARZyna BolęBA-Bocheńska, Językowo-kulturowy obraz chwastów utrwalony w polskich frazemach gwarowych.

НАТАЛІя КОВАЛЕНКО, БоРИС КОВАЛЕНКО, Символіка Лексеми мак у фразеологічній картині світу 275

Bibliografia. 285 


\section{WSTĘP}

Niniejsza wieloautorska i przy okazji wielojęzyczna monografia została poświęcona słowiańskiej frazeologii gwarowej, o której wciąż wiemy znacznie mniej niż o gwarowej leksyce jednowyrazowej. Celem tej książki jest więc przynajmniej częściowe zniwelowanie zasygnalizowanej dysproporcji.

Pierwsza część - Zagadnienia ogólne - obejmuje prace Macieja Raka, Zbynka Holuba i Eleny Nevzorovej-Kmieć. Znajdziemy tu odpowiedź na pytanie o to, do czego może być wykorzystywana frazeologia gwarowa. Jak się okazuje, poza tym, że jest opisywana jako niezależny dział leksyki, z powodzeniem odwołują się do niej i twórczo wykorzystują jej zasoby etnologowie, socjologowie wsi, etnolingwiści, historycy języka i badacze regionalizmów oraz motywacji frazeologii ogólnopolskiej i prasłowiańskiej. W pracy Z. Holuba znajdziemy informacje o frazeologii czeskich gwar południowozachodnich i ich wykorzystaniu w literaturze (warto dodać, że polscy badacze, ujmując stylizację gwarową, niestety zwykle pomijają frazeologię). Z kolei E. Nevzorova-Kmieć zajęła się obecnością dialektyzmów w obrębie polskiej i rosyjskiej frazeologii socjolektalnej.

Jak wiadomo, frazeologia stanowi bardzo dobry materiał do badań etnolingwistycznych, zwłaszcza w przypadku rekonstrukcji językowego obrazu świata. Uwagi teoretyczne na ten temat znajdziemy w drugiej części tej książki - Frazeologia i badania etnolingwistyczne - w pracach Jerzego Bartmińskiego, Wojciecha Chlebdy i Natalii Venžinovič. Pierwszy z badaczy zaprezentował frazeologię jako bardzo ważny dział leksyki, jednak charakterystyka językowego obrazu świata wyłaniającego się z materiału frazeologicznego (w rosyjskim językoznawstwie używa się wręcz terminu frazeologiczny obraz świata) zawsze będzie opisem niepełnym, JOŚ przejawia się bowiem na wielu płaszczyznach języka. Z kolei W. Chlebda zredefiniował pojęcie frazeologizmu. Przywykliśmy do szkolnego ujęcia, zgodnie z którym podstawową jednostką jest wyraz, a dopiero wtórną frazeologizm (bo składa się z co najmniej dwóch wyrazów). Chlebda przekonuje nas do odwrotnego spojrzenia na tę relację. Pierwotna oralność, która cechowała kultury przedpiśmienne, funkcjonowała dzięki formułom, czyli - upraszczając zdaniom. Wyraz to konstrukt wykształcony dzięki pismu, jego długość wyznaczają bowiem spacje. Z kolei reprezentująca ukraińskie językoznawstwo N. Venžinovič 
przybliżyła w swojej pracy lingwokulturologiczną perspektywę opisu frazeologii gwarowej. Jak więc widać, etnolingwistyka ma różne oblicza, ale frazeologia zawsze zajmuje w niej ważne miejsce.

Trzecia część książki została poświęcona źródłom frazeologii gwarowej. Valerij M. Mokienko, nawiązując do historyczno-etymologicznej metody opisu frazeologizmów, którą wdrożył już w wielu pracach, pokazał, jak frazeologia gwarowa (m.in. przez swoją archaiczność i wariantywność) przyczynia się do lepszego ujęcia motywacji frazeologizmów ogólnorosyjskich, ogólnopolskich, ogólnoukraińskich itd. Dialekty są przecież ważnym, choć nie zawsze docenianym źródłem historycznej i współczesnej frazeologii i pozwalają ją lepiej zrozumieć, o czym w odniesieniu do materiału rosyjskiego - możemy przeczytać w pracy Aleksandra Biericha, a na materiale niemczyzny - Harry'ego Waltera. Frazeologia podobnie jak leksyka jednowyrazowa podlega obcojęzycznym wpływom - takie stwierdzenie to oczywiście truizm. Jednak dzięki opracowaniu Magdaleny Grupy-Dolińskiej i przywołanym przez nią przykładom z rosyjskiej gwary staroobrzędowców, która była wystawiona na wpływy polskie, niemieckie, białoruskie i litewskie, przekonamy się, że zagadnienie jest bardziej skomplikowane. Obce wpływy we frazeologii to najczęściej kalki i półkalki, rzadziej mamy do czynienia z zapożyczeniami leksykalnymi, które następnie weszły do frazeologizmu.

Dysproporcję $\mathrm{w}$ opisie $\mathrm{z}$ jednej strony gwarowej leksyki jednowyrazowej, a z drugiej - frazeologii szczególnie jaskrawo widać w zakresie słownikarstwa. Wciąż nie mamy ogólnogwarowego słownika frazeologicznego, podobnie jak i inne języki słowiańskie. Frazeografii gwarowej dotyczy czwarta część monografii, w której znalazły się prace Gabrieli Dziamskiej-Lenart, Natalii Aref'evy i Fabiana Kaulfürsta. Pierwsza z badaczek dokonała przeglądu polskich gwarowych słowników frazeologicznych i porównała zastosowane w nich rozstrzygnięcia leksykograficzne. N. Aref'eva omówiła projekt Stownika frazeologicznego gwar rosyjskich Odesczyzny, a F. Kaulfürst pokazał badania korpusowe nad dolnoserbską frazeologią gwarową.

W piątej części książki znalazły się prace, w których frazeologia została ujęta jako źródło wiedzy o człowieku. Ewa Młynarczyk zajęła się obrazem prowadzenia gospodarstwa domowego utrwalonym we frazematyce, Lidia Przymuszała, bazując na materiale z gwar śląskich, omówiła sposoby określania wieku człowieka, a Katarzyna Konczewska scharakteryzowała wizerunek kobiety w gwarach białoruskich Grodzieńszczyzny. W pracy Pauliny Karpety znajdziemy uwagi na temat ludowych zwyczajów i obrzędów, do których odnosi się frazeologia gwarowa pogranicza małopolsko-mazowieckiego. Z kolei Ewa Sikora, opierając się na pamiętnikach i gawędach góralskich, omówiła językowy obraz głodu przejawiający się we frazeologii.

Na Sacrum i profanum, czyli szóstą część monografii, składają się opracowania Moniki Buławy, Emila Popławskiego i Renaty Dźwigoł. Pierwsza badaczka zajęła 
się obrazem św. Walentego utrwalonym w ludowych przysłowiach i frazeologii. E. Popławski scharakteryzował część roku rolniczo-gospodarskiego, do którego odnoszą się liczne przysłowia. Z kolei R. Dźwigoł skupiła się na motywacji nazw z komponentem diabelski.

Niniejszą książkę zamykają prace szczegółowe. Anna Tyrpa omówiła motywację frazeologizmu Wóz albo przewóz. Elena Ničiporčik skoncentrowała się na rosyjskich wyrażeniach przyimkowych z komponentem bez. Katarzyna Bolęba-Bocheńska opisała językowy obraz chwastów (ostu, kąkolu i pokrzywy), a Natalia i Boris Kovalenkowie scharakteryzowali symbolikę maku na materiale ukraińskiej frazeologii gwarowej.

$$
* * *
$$

Jakie korzyści otrzymujemy z monografii Stowiańska frazeologia gwarowa II? Po pierwsze, możemy skonfrontować stanowiska badawcze polskie, czeskie, rosyjskie, ukraińskie, białoruskie i dolnołużyckie (w tych językach i na ich materiale frazeologicznym powstały opublikowane tu prace). Po drugie, ujęcia teoretyczne umieszone w drugiej części książki określają właściwe miejsce frazeologii w badaniach etnolingwistycznych. Po trzecie, przekonujemy się, że frazeologia gwarowa jest niezbędna do dokładnego opisu frazeologii literackiej. Po czwarte, jeszcze bardziej utwierdzamy się w przekonaniu o potrzebie gromadzenia gwarowych zasobów frazeologicznych, które są kluczem do zrozumienia kultury ludowej z jej agrocentryzmem i religijnością. Wreszcie po piąte, przekonujemy się, że podobieństwa we frazeologii gwarowej poszczególnych języków słowiańskich dobitniej pozwalają mówić o jedności Słowiańszczyzny.

Lektura Stowiańskiej frazeologii gwarowej II pozwala wyrazić przekonanie, że w dalszym ciągu frazeologizmy gwarowe pozostają ciekawym i pełnym naukowych wyzwań obszarem badań. 

Zagadnienia ogólne 



\section{MACIEJ RAK (1) \\ Wydzial Polonistyki Uniwersytetu Jagiellońskiego \\ maciej.rak@uj.edu.pl}

\section{DO CZEGO SIE PRZYDAJE FRAZEOLOGIA GWAROWA?}

Słowa klucze: polska frazeologia gwarowa, słowiańska frazeologia gwarowa, perspektywy badań frazeologicznych

Keyword: Polish dialectal phraseology, Slavic dialectal phraseology, perspectives of phraseological research

Polska frazeologia gwarowa jest badana od 1955 r., wtedy bowiem ukazał się artykuł Bernarda Sychty Element morski w kaszubskiej frazeologii (1955). Wcześniej uwzględniano ją w słownikach gwarowych na dwa sposoby - wydzielano w postaci podhaseł albo umieszczano w cytatach użycia przy poszczególnych leksemach jednowyrazowych. Jeśli idzie o pierwszą sytuację, szeregu przykładów dostarcza Stownik gwar polskich Jana Karłowicza (SKarł) - pod hasłem pies znajdziemy frazeologizmy: psy paść 1. 'prowadzić życie rozpustne, rozwiązłe', 2. 'utrzymywać stosunek z obcą kobietą, mając własną żonę' i na psie chodzić 'chodzić na czworakach' (SKarł IV: 97). Z kolei w Stowniku gwary podhalskiej Bronisława Dembowskiego (1894) natrafiamy na związek frazeologiczny taki jakby go z oka wyjon \{komuś\} umieszczony w cytacie użycia po haśle podać się na kogo 'być podobnym do kogo': „co sie tak wiedziáł podać na niego, kieby mu go z oka wyjon - podáł sie na ojca krzesnego" (Dembowski 1984: 56).

Zainteresowanie dialektologów frazeologią gwarową wyraźnie wzrosło w latach 80. XX w., co widać zwłaszcza w dorobku naukowym Jerzego Tredera (1989) i Anny Krawczyk-Tyrpy (1987), ale szczególny przełom przyniosło ostatnie piętnastolecie, wtedy bowiem ukazały się słowniki frazeologiczne gwary Dębna (SFGD), gwar śląskich (SFŚl) i gwar północno-wschodniej Wielkopolski (FGW) oraz książki Macieja Raka (2007) i Emila Popławskiego (2014).

Co łączy te i inne, niewymienione tu publikacje (ich przegląd znajdziemy w artykule A. Krawczyk (1985) oraz w tomie Stowiańska frazeologia gwarowa pod red. M. Raka i Kazimierza Sikory (2016))? Po pierwsze, podkreślano w nich bogactwo frazeologii gwarowej oraz jej odrębność w porównaniu z frazeologią ogólnopolską. Po drugie, często ujmowano materiał badawczy w aspekcie kulturowym i etnolingwistycznym (wykorzystując go przy opisie językowego obrazu 
świata i stereotypu językowego utrwalonych w gwarach), czyli - uogólniając w taki sposób, w jaki czyni to współczesna dialektologia, a więc akcent kładąc na gwarowość jednostek. Po trzecie, zestawiano frazeologizmy z różnych gwar, by w ten sposób pokazać podobieństwa i różnice. W konsekwencji takiego podejścia frazeologia gwarowa zamknęła się niejako na inne dziedziny, co nie jest wcale wyjątkową sytuacją, zważywszy, że rodząca się dyscyplina zwykle określa swoją tożsamość przez opozycję do tego, co najbliższe, i na początkowym etapie rozwoju skupia się na samej sobie.

Mając to wszystko na uwadze, można postawić pytanie, które jest zarazem tytułem niniejszej pracy: Do czego się przydaje frazeologia gwarowa? Frazeologię traktuję tu - podobnie jak autorzy poszczególnych prac, na które się powołuję - szeroko, zaliczając do niej - poza tradycyjnie rozumianymi związkami frazeologicznymi (jednostkami języka) - przysłowia (mikroteksty) i porównania, w tym tzw. stereotypowe, które ze względu na brak metaforycznego znaczenia nie były uwzględniane w zasobach związków frazeologicznych. Jak więc widać, pod względem zakresu frazeologia $\mathrm{w}$ tym opracowaniu jest bliska frazematyce w ujęciu Wojciecha Chlebdy $(1991,2010)$.

Odpowiedzi na postawione pytanie stanowią zasadniczą część pracy.

\section{Badania prasłowiańskiej frazeologii}

Polski materiał gwarowy, podobnie jak frazeologia innych gwar słowiańskich, to klucz do poznania frazeologii prasłowiańskiej. W przekonujący sposób pokazali to Valerij M. Mokienko (Мокиенко 2020) i Alexander Bierich (Бирих 2020) w artykułach umieszczonych w niniejszym tomie. W obliczu Stownika prastowiańskiego (SławSP), w którym też jest uwzględniany materiał gwarowy (podobnie jak w słownikach etymologicznych), tym bardziej doskwiera mała liczba prac dotyczących frazeologii prasłowiańskiej.

Warto tu jednak dodać, że poza zestawieniami różnojęzycznymi i sięganiem do dawnych piśmiennych poświadczeń frazeologii, w przypadku jednostek prasłowiańskich ważny jest folklor słowny. Do kategorii folklektów rozprzestrzenionych $\mathrm{w}$ folklorze różnych narodów słowiańskich należą wrony koń i zielona dąbrowa. Co prawda Jerzy Sierociuk $(2001,2008)$ widzi w nich ślad prasłowiańskiego języka poetyckiego, ale można je też traktować jako frazeologizmy o pochodzeniu prasłowiańskim.

Kolejny przykład związku frazeologicznego być może o proweniencji prasłowiańskiej utrwalony $\mathrm{w}$ folklorze słownym to $\{k t o s ́\}$ załamuje ręce. W okolicach Babiej Góry został on utrwalony w pieśni Góra się z góra rozléwá..., por.: 
Zyje já w obcéj krainie, moja miéło płace mnie, Place za mnom, lamentuje, lamentuje, ręce załamuje, Ka się kochanecek podziáł (Gazda 1938: 5).

Frazeologizm ten znajdziemy także w kozackim romansie Ïхав козак за Дунай, napisanym w 1710 r. przez Semena Klimowskiego, por.:

Їхав козак за Дунай,

Сказав: „Дівчино, прощай!”

Ти, конику вороненький,

Неси та гуляй.

- Постій, постій, козаче!

Твоя дівчина плаче.

Як ти мене покидаєш -

Тільки подумай!

\section{- Білих ручок не ламай,}

Карих очей не стирай,

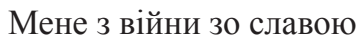

К собі ожидай!

Pieśń ta jest niewątpliwie oparta na ludowych motywach folklorystycznych, na co wskazuje poza frazą Білих ручок неламай, także wyrażenie коник вороненький.

\section{Badania historyczno-etymologiczne polskiej frazeologii}

Tematem w dalszym ciągu zaniedbanym w polskiej leksykografii jest zagadnienie pochodzenia związków frazeologicznych. Uwagi historyczno-etymologiczne znajdziemy, co prawda, w różnych pracach, np. Juliana Krzyżanowskiego Mądrej glowie dość dwie stowie (MG), Szkice folklorystyczne (Krzyżanowski 1980a, 1980b, 1980c) i Nowa księga przystów i wyrażeń przysłowiowych polskich (NKPP) - ale nie są to informacje pełne, dotyczące całości zasobu frazeologicznego. Omawiając pochodzenie frazeologizmów, Krzyżanowski jako folklorysta zwracał uwagę przede wszystkim na folklor, a przecież frazeologia ma też inne pochodzenie, w tym obce. Szczególnie dużo mamy kalk frazeologicznych z języków niemieckiego i francuskiego. Na ten temat wiemy jednak bardzo mało. Dla przykładu, jeśli idzie o germanizmy w polszczyźnie, dysponujemy dwoma słownikami: Wörterbuch der deutschen Lehnwörter in der polnischen Schrift-und 
Standardsprache Andrzeja de Vincenza i Gerda Hentschela ${ }^{1}$ i Stownik zapożyczeń niemieckich $w$ polszczyźnie pod red. Marka Łazińskiego (2008). Nie ma jednak w tych opracowaniach mowy o frazeologii, może poza niejako stereotypowymi germanizmami frazeologicznymi, czyli: tu jest pies pogrzebany, w pierwszym rzedzie i jako taki.

Dla polskich badaczy wzorem opracowania historyczno-etymologicznego frazeologii może być Русская фразеология. Историко-этимологический словарь A.K. Biericha, V.M. Mokienki i Ludmiły I. Stepanovej (БМС). W tym słowniku została zastosowana metoda historyczno-etymologiczna opisu frazeologizmów zaproponowana przez V.M. Mokienkę, na którą składa się pięć punktów, por.: 1) ustalenie wariantów jednostki frazeologicznej (terytorialnych, stylistycznych, formalnych); 2) analiza kontrastywna frazeologizmu polegająca na zestawieniach różnojęzycznych; 3) chronologia (pierwsze zanotowanie frazeologizmu); 4) uwzględnienie faktów pozajęzykowych (np. kierunków migracji); 5) wskazanie pierwotnej (wyjściowej) postaci frazeologizmu. Jak podkreśla Mokienko (1993, 2018), niezbędny w tego typu analizie jest materiał gwarowy.

Spójrzmy na dwa przykłady wykorzystania frazeologii gwarowej przy opisie pochodzenia frazeologizmów ogólnopolskich.

1.1. Frazeologizmy stomiana wdowa - stomiany wdowiec nie zostały zanotowane w gwarach, a to dowodzi, że nie są to jednostki dawne, mocno zadomowione w polszczyźnie. Jak podaje NKPP (III: 230), pierwsze ich poświadczenie w języku polskim pochodzi z powieści Teodora Tomasza Jeża Narzeczona Harambaszy wydanej w $1872 \mathrm{r}$.

Jeśli idzie o odpowiedniki z innych języków, omawiane frazeologizmy są znane w niemczyźnie: Strohwitwe - Strohwitwer i w językach słowiańskich: rosyjskim, соломенная вдова - соломенный вдовеи; białoruskim, саламяная удава саламяны уддавещ; ukraińskim, солом'яна вдова - солом'яний вдівещь; czeskim, slamená vdova - slamený vdovec; słowackim, slamená vdova - slamený vdovec; chorwackim, slamnata udovica - slamnati udovac i bułgarskim, сламена вдовица-сламен вдовеu. W innych językach zachodnio- i północnogermańskich mamy odniesienie do trawy, por.: angielskie grass widow - grass widower, szwedzkie gräsänka - gräsänkling, norweskie gressenke - gressenkemann i holenderskie grasweduwe-weduwnaar. W języku niemieckim do XVI w. też był używany podobny frazeologizm, por.: Graswitwe (do dziś znany w języku dolnoniemieckim).

Geografia wyraźnie wskazuje na zbieżności niemiecko-słowiańskie. Możemy tu więc mieć do czynienia albo z kalką z języka niemieckiego do słowiańskich, albo z odwrotną sytuacją. Rozstrzygnięcie przynosi chronologia. Pierwsze poświadczenie Strohwitwe w niemieckim pochodzi z 1715 r., a w językach

http://diglib.bis.uni-oldenburg.de/bis-verlag/wdlp/ab_H.html. 
słowiańskich słomiana wdowa pojawia się w XIX w. Jest to więc późne zapożyczenie, które nie przeniknęło do gwar (Otten 2002; БMC: 83).

1.2. Po raz pierwszy w polszczyźnie frazeologizm Szukać wczorajszego dnia zanotowano w 1586 r. (NKPP III: 416). Jest to dość dawna jednostka, dlatego ma formy wariantywne, np.: szuka wczorajszego wieczora, i gwarowe (z Małopolski) - suko wcorajsygo cienia. Także inne języki znają ten frazem, por.: den gestrigen Tag suchen (niem.), искать вчерашний день (ros.), иукати вчорашнього дня (ukr.). Autorzy БМС (s. 184) wskazują, że mamy tu do czynienia z kalką z języka niemieckiego. Świadectwo z gwar pozwala na pewne ogólne ustalenia na temat chronologii - w tym przypadku wiadomo, że nie jest to jednostka nowa.

Bez uwzględniania kontekstu dialektologicznego nie da się opisać tych frazeologizmów, które właśnie z gwar przeszły do polszczyzny ogólnej. Jest w tej grupie m.in.: $\{k t o s ́\}$ porywa się (idzie, rzuca się itp.) z motyką na słońce.

\section{Regionalizmy frazeologiczne}

Zasób frazeologii gwarowej jest szczególnie ważny przy opisie regionalizmów frazeologicznych. Użytkownik gwary w kontakcie z osobą spoza wiejskiej społeczności, przechodząc z kodu gwarowego na niegwarowy, usuwa ze swojej wypowiedzi mazurzenie i realizacje dawnych samogłosek długich oraz inne uświadomione cechy gwarowe, a także zastępuje leksemy takimi, które według niego są ogólnopolskie. Jednak w przypadku frazeologii, podejmując tego typu działania, najczęściej zachowuje poszczególne jednostki bez większych zmian formalnych. Dzieje się tak dlatego, że frazeologizm ze względu na asumaryczność znaczeniową (znaczenie związku frazeologicznego, zwłaszcza idiomu nie jest sumą znaczeń składowych komponentów) jest traktowany jako integralna całość. W wyniku takich uwarunkowań socjolingwistycznych kształtuje się zasób regionalizmów frazeologicznych o gwarowym pochodzeniu. Dla przykładu, w wypowiedziach tzw. inteligencji pochodzenia chłopskiego z Kielecczyzny można usłyszeć frazeologizmy: $\{k t o s ́\}$ wybiera się jak Gawerecki 'wybiera się gdzieś opieszale'; $\{k t o s\}\}$ trafi do Morawicy 'zwariuje'; potrzebny jak diabet w Czestochowie 'niepotrzebny'; raczy/żabi ogier 'brzydki kawaler', które nie są znane w polszczyźnie ogólnej. Można im więc przypisać status regionalizmów frazeologicznych.

Wzmożone w ostatnich latach zainteresowanie regionalizmami dotyczy przede wszystkim konkretnej leksyki jednowyrazowej, gdyż najłatwiej ją opisywać i gromadzić (trudniej badać leksykę abstrakcyjną, a jeszcze trudniej frazeologię). Można przygotować szczegółowy kwestionariusz wyrazowy (wykorzystujący ikonografię) i za jego pomocą prowadzić zakrojone na szeroką skalę badania. Jednak w przypadku frazeologii sprawa jest zdecydowanie trudniejsza. Ewentualny kwestionariusz frazeologiczny pozwoli uchwycić tylko część zasobu, pozostałe 
jednostki może wskazać jedynie autochton. Kolejną sprawą komplikującą tego typu badania jest brak wyraźnej granicy między frazeologią gwarową a potoczną. Jest to właściwie nie do rozstrzygnięcia, zważywszy na to, jak mocno gwary interferują dziś z polszczyzną potoczną. Wreszcie najpoważniejszy problem to nasza wiedza o frazeologii polskich gwar, która nadal jest fragmentaryczna. Stosunkowo dużo wiemy o frazeologii śląskiej i małopolskiej, a mało o wielkopolskiej i mazowieckiej. Do tego wciąż nie dysponujemy słownikiem frazeologicznym gwar polskich.

\section{Dialektologia historyczna}

Przejściu - $x>-k$ osobny artykuł poświęcił Kazimierz Nitsch (1916), określając dokładnie zasięg tego zjawiska. Współcześnie jest ono ograniczone do południowej (góralskiej) i zachodniej Małopolski, czyli peryferii tego regionu. W ujęciu historycznym była to jednak cecha ogólnomałopolska, o czym świadczy wyspowe występowanie poza wskazanymi obszarami m.in. na Lubelszczyźnie i w Sieradzkiem. Utrwalenie tego zjawiska w zwrocie niek bedzie notowanym np. w gwarach Gór Świętokrzyskich (poza tą jednostką nie ma tu przykładów przejścia $-x>-k$ ) również jest dowodem jego dawnego szerokiego zasięgu. W tym względzie frazeologia gwarowa przydaje się dialektologii historycznej o nakierowaniu fonetycznym.

Jeśli idzie o sprawy fleksyjne, to - jak wiadomo - zwroty np. wyjść za mąz i wsiasść na koń potwierdzają, że w staropolszczyźnie biernik był równy mianownikowi. Materiał gwarowy dostarcza znacznie więcej tego typu przykładów, por: Na świenty Mikołoj dziywki z karcy wywołoj (Popławski 2016: 189); Na święty Mikołaj przymrozu/przywozu nie wołaj (s. 191); Na święty Mikołaj chłopów do butów wołaj (s. 191); Na świynty Jakub kuláski² dłub; 2) Na świynty Jakub grul do gárka udlub (Rak 2009b). Z kolei zanotowane na Kielecczyźnie Po kiełbasie napijwa sie poświadcza formę dualną czasownika. Liczba podwójna zanikła w polszczyźnie, jej ślady znajdziemy właśnie we frazeologii, np. w często podawanych przykładach Trzy gęsi, dwie niewieście uczynity jarmark w mieście oraz Mądrej głowie dość dwie słowie, z których drugi znalazł się w tytule przywołanego już opracowania J. Krzyżanowskiego (1975).

Kuláski to podhalańska nazwa odmiany ziemniaków, które mają cienkie i długie bulwy. 


\section{Etnologia i etnografia. Historia kultury}

Wierzenia i zwyczaje ludowe utrwalone w materiale frazeologicznym były już przedmiotem prac naukowych. J. Treder w książce Frazeologia kaszubska a wierzenia i zwyczaje (na tle porównawczym) (1989) zajął się Kaszubami, opisywano także Podhale (Rak 2009a, 2020). Nie będę tu powtarzał przykładów podanych w wymienionych pracach, sięgnę do kolejnego.

Sebastian Flizak (1937: 53) w okolicach Mszany Dolnej (Zagórze) zanotował frazeologizm \{ktoś\} skrobie jak na bozy obiád 'krytycznie o osobie, która obrała zbyt dużo ziemniaków'. Mamy tu odniesienie do bożego obiadu, a sam frazeologizm ma budowę szkatułkową (frazeologizm we frazeologizmie). Na niedalekim od Zagórza Podhalu bozy obiád to 'poczęstunek dla żebraka za odmawiane przez niego modlitwy za zmarłych' (ZborSGZ: 22). Jednak porównanie podane przez Flizaka wskazuje na coś więcej, precyzuje, że na boży obiad przygotowywano dużo jedzenia. Był to bowiem zwyczaj ugaszczania dziadów proszalnych, których modlitwy miały szczególną moc, gdyż postrzegano ich jako osoby bliskie Bogu, pośredników między ludźmi i Bogiem. Boży obiad trwał czasem kilka dni, a informację o planowanej biesiadzie ogłaszał z ambony ksiądz. Dziś na Podhalu zwyczaj ten jest już nieznany, ale - jak przekonują testamenty góralskie (testament Szymona Sprocha z Lasku z 10 I 1750 r., Dobrowolski 1933: 115-116) - praktykowano go jeszcze w XVIII w. Jak więc widać, frazeologizm i teksty urzędowe (testamenty) pokazują nam historię kultury.

Odniesienia do bożego obiadu znajdziemy także we frazeologii polszczyzny ogólnej XIX w. - pomoże jak boży obiad umarłemu 'nie pomoże' (KPP: 420). W komentarzu do tego porównania Samuel Adalberg umieścił objaśnienie - boży obiad 'stypa'.

\section{Socjologia wsi - ludowy system wartości}

Frazeologia i leksyka ekspresywna dają wgląd w ludowy system wartości, o którym z perspektywy socjologii wsi dość szczegółowo pisał już Józef Styk (1988, 1993, 1999). Uwagi na ten temat zawarłem także w artykule Wartościowanie $w$ animalistycznej frazeologii gwar polskiej części Podtatrza (Rak 2016b). Nie będę tu przytaczał podanych cztery lata temu przykładów, wymienię jednak składniki ludowego systemu aksjonormatywnego, na które wskazuje zasób podhalańskich frazemów, są to: pracowitość, mądrość (rozwaga), uczciwość, prawdomówność, życzliwość, ustępliwość, gościnność, powściągliwość w okazywaniu emocji, szczodrość, stosowne zachowanie, odwaga, umiarkowanie w piciu i jedzeniu, czystość. 
O tym, że frazeologia gwarowa jest nośnikiem wartości i informacji o nich, przekonuje także przywoływana już książka A. Krawczyk-Tyrpy (1987). Okazuje się bowiem, że frazeologizmy somatyczne niosą ładunek ekspresywny i aksjologiczny wyznaczony przez uniwersalne w dużej mierze opozycje: góra-dół, przódtył, prawy-lewy, wewnętrzne części ciała (narządy) - zewnętrzne części ciała.

\section{Oralność kultury ludowej polskiej i słowiańskiej}

Odtwarzalność frazeologii w określonym kształcie formalnym i znaczeniu pozwala widzieć w niej ślady oralności. Na przykładzie pieśni serbskich zagadnienie to przybliżył Walter J. Ong (2011), natomiast dzięki artykułowi W. Chlebdy (2020a) w innej perspektywie widzimy relację frazeologii i leksemów jednowyrazowych. Dotychczasowe ujęcie zakładało, że związek frazeologiczny jest pochodną pojedynczych słów, inaczej rzecz ujmując - najpierw było słowo, a dopiero później frazeologizm. Chlebda postawił jednak tezę, która odwraca tę perspektywę: najpierw była fraza, a dopiero później zaczęliśmy wydzielać słowa. Odpowiada za to piśmienność, która wprowadziła spację, oddzielając jeden wyraz od drugiego. O tym, że w dalszym ciągu jest to sprawa umowna, przekonuje w polszczyźnie dwojaka pisowni wyrażeń przyimkowych, np. po prostu-pomatu, na pamięć - naprawdę.

$$
* * *
$$

Zaprezentowane w siedmiu punktach sposoby wykorzystania frazeologii gwarowej przekonują, że do tego działu leksyki mogą sięgać przedstawicie różnych dziedzin, w tym etymologii, socjologii wsi, etnologii i historii kultury. Widać więc, że frazeologia gwarowa wpisuje się w dość szerokie spektrum badań humanistycznych.

\section{SUMMARY \\ What is Guaranteed Phraseology For?}

The aim of the study was to show what is guaranteed phraseology for. The author has proved that there are: research into the resources of Slavonic phraseology, motivations of Polish phraseology, indication of sources of phraseological regionalisms, historical dialectology, ethnography and ethnology, rural sociology and studies on the orality of Polish and Slavic folk culture. 


\author{
ZBYNĚK Holub (D \\ SlezsKá univerzita v Opavě, Č́ESKo \\ zbynek.holub@pf.slu.cz
}

\title{
OBRAZ JIHOZÁPADOČESKÉ FRAZEOLOGIE NA PŘELOMU TISÍCILETÍ A JEJÍ REFLEXE V LITERATUŘE
}

Klíčová slova: Frazeologie, dialekty, jižní Čechy, západní Čechy, slovník, frazémy verbální a nominální, územní rozmanitost, tematická rozmanitost, modely, terénní výzkum, literatura, způsob mluvy, paremiologie, propozice, polypropozice, rodilý mluvčí

Keywords: phraseology, dialects, South Bohemia, West Bohemia, dictionary, phrasemes, verbal, nominal, territorial diversity, thematic diversity, models, field research, literature, verbal art, paremiology, propositional, polypropositional, native speakers

\section{Frazeologie lokálních nářečí}

Obecně lze konstatovat, že také nářeční frazémy, popř. frazémy oblastní, regionální apod. lze hodnotit jako příznačné pro určitou lokalitu; stejně jako běžné nářeční lexémy (srov. např. Bachmannová 1986: 1-5; Golán̆ová 2013: 66-67).

Nejprve je ale nutné vymezit předmět našeho zkoumání. Jak uvádí František Čermák, tradiční a rozšířené vymezení frazému a idiomu jakožto ustáleného a reprodukovatelného spojení slov, jehož význam je zčásti nebo zcela neodvoditelný z významu jeho komponentů, nevyhovuje, protože nepokrývá všechny typy ani všechny roviny. V zásadě však platí, že analyzuje-li se kombinatorický útvar formálně, z hlediska formálních rysů, mluví se o frazému, zatímco analýza sémantická, z hlediska relevantních sémantických rysů, opravňuje užití názvu idiom. Frazém či idiom (dále f.i.) pak lze postihnout takto: je to taková jedinečná ustálená kombinace minimálně dvou prvků, z nichž některý (popř. žádný) nefunguje stejným způsobem v žádné jiné kombinaci nebo více kombinacích, resp. vyskytuje se v takové funkci pouze ve výrazu jediném, popř. několika málo (FaI). Toto pojetí je tedy především syntagmatické a má zároveň operacionalistickou povahu; toho lze využít i k testování neznámých výrazů a identifikaci f.i. (FaI).

Z tohoto pohledu lze konstatovat, že jsme základní, ale z hlediska dlouhodobého výzkumu též poměrně rozsáhlý soubor frazémů shromáždili již v DNS (s. 388392). Stejně jako u obecnějších výzkumů frazeologie jsme zkoumali složky f.i., 
k nimž patří (minimálně) „struktura, prvky a jejich povaha, kombinace, ustálenost, počet prvků a funkce prvkư" (zpravidla vždy různě anomální povahy; srov. FaI). Nejprve však bylo nutné odlišit oblast lokální frazeologie od širšího výběru kolokací, které se objevují (např.) v promluvách rodilých mluvčích na českém jihu (srov. Bachmannová 1986: 1-5, 2011: 79-87; DNS: 133-134; Rosenkranz 1988: 86-91).

Máme-li potom jednotlivé typy frazémů klasifikovat, musíme si opětovně připomenout systémy jejich klasifikace, popř. hranice takového vymezení (např. v rámci odlišení frazémů a parémií; ale nejen v tomto př́ípadě; srov. Holub 2007: 147-149; Bachmannová 2011: 79-87). Také v této studii proto odlišujeme frazémy nominální (jmenné), verbální (slovesné), přirovnání, dále pak typy „větné”, tedy propoziční a polypropoziční, chápané dnes většinou jako parémie (Bachmannová 2011: 79-82; FaI).

Náš vzorek frazémů a parémií si tu zasluhuje pozornosti především proto, že jednotlivé záznamy pocházejí jednak z českého jihu (z Doudlebska, Prachaticka a Netolicka i z tzv. blatských lokalit, tedy z oblasti tzv. Blat; Soběslavsko-veselských (,„pšeničných, velkých či bohatých”; srov. Baroko 2017: 31-33) a Zbudovských („ovesných, menších”; srov. Kováŕ 2008, Baroko 2017: 34-36), kraje tradičně pokládaného za domov rázovitých sedláků (srov. Holub 2009: 127-143; také Bachmannová 1986); a rovněž z českého západu (z oblasti tzv. Chodska, tedy z Domažlicka; dále z Klatovska a ze širšího Plzeňska). Jsou tedy živým dokladem jazykové reflexe každodenního života (tj. modu vivendi) ve sledovaných lokalitách jihozápadočeských nářečí. V uvedených lokalitách dále nacházíme (z hlediska jazykového) četná (zachovalá) nářeční specifika. Ta se potom ještě diferencují směrem k okrajům území. Závažná je též okolnost, že svého času představoval tento úsek nejjižnější a nejzápadnější výspu tradičního českého osídlení; na jihu po tradiční lokality Doudlebska, na západě po okraj tradičního Chodska (Bachmannová 1998, 2011: 79-82; DNS; Jindřich 2007; Hruška 1907 aj.).

Současný nářeční výzkum na českém jihozápadě potom potvrzuje, že stále existuje dostatek lokalit, v nichž je potřeba i dnes navazovat na předchozí exploraci. Zejména potom tam, kde došlo k dosídlení území po roce 1945. Podobně lze odkázat na závěry, které nabízí analýza materiálu Českého jazykového atlasu, popř. provést srovnání s prvními odkazy na frazémy v internetovém Slovníku náreči českého jazyka.

Nelze pochybovat o vázanosti frazémů na místní prostředí. Mnohé z komponentů (nejčastěji v rámci přirovnání) úzce souvisí s každodenním životem obyvatel lokalit, často se způsobem hospodaření, s oblastí stravování, bydlení, poznávání životního prostředí apod. $\mathrm{V}$ dalších z nich se mohou uplatňovat místní nebo pomístní jména (Bachmannová 1986), vzácněji potom antroponyma (v př́ípadě reflexe událostí, $\mathrm{k}$ jejichž vzniku daly podnět aktivity místních občanů). V řadě př́padů 
už je význam poněkud nebo úplně zastřen (a spojení jsou chápána jako značková). Mnoho spojení také zahrnuje archaické typy pojmenování (Bachmannová 1986).

\section{Projekt frazeologického slovníku českého jihozápadu}

Projekt slovníku v současné době vychází z předběžných výzkumů, které probíhaly na území českého jihu a západu v prvním dvacetiletí 21. století. Zpočátku spíše v rámci projektů Jihočeské univerzity a Jihočeského muzea (do roku 2008), ale od roku 2009 už výhradně jenom na základě spolupráce učitelů Pedagogické fakulty, Filozofické fakulty a Fakulty aplikovaných věd Západočeské univerzity v Plzni ${ }^{1}$. Frazeologii lokálních nářečí ovšem nelze chápat odtrženě od kontextu obecné frazeologie a idiomatiky. Specifika nářeční frazeologie nacházíme vždy v úzkém sousedství specifik nářeční syntaxe (méně již morfologie) a nářečního lexikonu. Výzkum nářečí (doudlebského, blatského, prachatického a chodského; ale rovněý mluvy dalších vybraných západočeských lokalit, např. tzv. plzeňské mluvy, popř. zkoumání frazeologie a lexikonu jižních i západních pohraničních úseků našeho území... apod.) může směřovat výhradně k sestavení regionálního frazeologického slovníku.

Za frazémy přitom pokládáme, shodně s dlouhodobým odborným územ, ta dvoučlenná a vícečlenná spojení, pro něž je typická ustálená kombinace prvků (tzv. diskrétní forma), reprodukovatelnost jednotky jako celku a přímá neodvoditelnost významu daného spojení z významů jeho jednotlivých komponentů (slov nebo slovních tvarů; srov. Bachmannová 1986).

Jednotkou všech úrovní idiomatiky a frazeologie (dále i.f.) je tedy z hlediska (především) formálního frazém, z hlediska (především) obsahově-sémantického idiom. Frazém a idiom je produktem kombinací jednotek nižšího řádu všech úrovní i.f., tj. jednotkou i.f. libovolné roviny. Představuje syntagmata prvků, z nich je jeden z hlediska druhého členem extrémně omezeného a uzavřeného paradigmatu... (srov. Čermák 1982: 183; souborně: Čermák 2008). V této souvislosti musíme odlišit rovinu lexikální, kolokační a propoziční. Na pomezí kolokace a propozice stojí zvláštní oblast i.f.: množina všech přirovnání. Ta svou povahou patř́ jak

\footnotetext{
Vzhledem k tomu, že se dnes na exploraci celkem pravidelně podílejí (rovněž) profesionálové (v první řadě zmínění učitelé ze Západočeské univerzity v Plzni) i vzdělaní laici, kteří se sdružili v regionální učené společnosti Génius loci českého jihu a západu (dále GL, z.s.), dá se hovořit o postupném obnovování systematického nářečního, etnografického i mezioborového výzkumu; zejména pak na západě Čech. Zapsaný spolek GL, z.s., úzce spolupracuje se Západočeskou univerzitou v Plzni, stejně tak ale se Západočeským muzeem a s řadou regionálních muzeí. Výsledkem této spolupráce je pravidelné pořádání regionálních vědeckých konferencí).
} 
do oblastí kolokace, tak do oblastí propozice. Frazém a idiom pak je třeba nazírat v zásadě z trojího hlediska; tj. na základě vztahu

1. útvaru jako celku $\mathrm{k}$ jeho částem, komponentům;

2. vztahu jedné jednotky ke druhým;

3. vztahu jednotky $\mathrm{k}$ typu vyšších jednotek, které v kombinaci s jinými tato jednotka vytváŕí (Čermák 1982: 177-185).

\section{Frazémy z hlediska teritoriální i tematické členitosti}

Z větší části hodnotíme frazémy na základě jejich plnovýznamových členů; zpravidla u jmen a sloves. Často jsou základní sémantické hodnoty popsány u jednoho z členů frazeologické jednotky, s nímž frazém nejvíc koresponduje. V některých případech to může být u více členů. O to složitější je však popsat ty frazémy, které můžeme označit jako nářeční, diferenční (tj. frazémy, k nimž neodkazují lexémy uvedené v SSJČ, popř. obsahují nářeční prvky a nejsou zaznamenány v nějaké blízké formě, kterou SČFI považuje za spisovnou).

Doklady sběru jihočeské a západočeské frazeologie ovšem nacházíme v díle jazykovědců už od přelomu 19. a 20. století, např. pro český jih u Josefa Vavřince Duška (Hláskosloví nářeči jihočeských, 1894; Kmenosloví nářeči jihočeských, 1902) nebo Vojtěcha Kotsmícha (O podřeči doudlebském, 1868; Pohádka o dědovji a bábě, 1898), pro český západ u Jana Františka Hrušky (Dialektický slovník chodský; 1907) apod. Na českém jihu ${ }^{2}$ potom na starší výzkum navázal v době novější v povodí Blanice na Prachaticku nap̌r. Bohumil Vydra (Popis a rozbor náreči hornoblanického, 1923). František Jílek (Oberpfalcer) již hovořil o vybraných frazémech jako o typickém odrazu ,jihočeské řeči” (Jihočeský člověk a jeho reč, 1961). K frazeologii přihlíželi později také Slavomír Utěšený (Nářeči prechodového pásu českomoravského, 1960; souborněji v díle Jihočeská vlastivěda, díl Jazyk: nárečí, místní jména, slangy, 1986), Antonín Rubín (srov. články v časopisu „Naše řeč”; zejména v 80. letech 20. století), na Prachaticku Ludmila Švestková (např. 1957: 164-175) a Jana Jančáková (1970: 243-251), v lokalitách tzv. Doudlebska posléze také Z. Holub (DNS). Situaci na západě českého jazykového území sledoval rovněž Jindřich Jindřich (společně s Jindřichem Kotalem; srov. Jindřich 2007), nověji pak jazykový stav na konci tisíciletí popsal Jaroslav Voráč (Západočeská vlastivěda - část Nářčćl, 1991). Syntetické práce k jazykové situaci jihozápadočeské nářeční podskupiny vydal rovněž Jaroslav Voráč (Česká nářeči jihozápadní 1955/I, 1976/II); zde ovšem se nezaměřil na lexikon a frazeologii.

2 Zde však vymezení zkoumaných lokalit nelze ztotožňovat s územím, které je označováno jako Jihočeský kraj. 
Řadu poznatků o proměnách nářečí (tedy i frazeologie) v regionu však přinesly bakalářské, diplomové a disertační práce posluchačů a absolventů Jihočeské a Západočeské univerzity.

\section{Výzkum frazeologie a jeho konkretizace na vybraných modelech}

Strukturní klasifikace frazémů vychází z popisu ustálených slovních spojení na základě slovních druhů. Poněkud odlišně je potom třeba postupovat u přirovnání a klauzí, popř. u větných celků (zejména u parémií). U všech typů frazémů se potom snažíme najít základové (klíčové) slovo, většinou jméno (často substantivum), jindy sloveso (popř. jiný slovní druh). Klíčové slovo nám umožní zařadit frazém jak abecedně, tak tematicky (Bachmannová 1986; FaI).

\section{Př́mý terénní výzkum a jeho reflexe v literatuře i v lidové slovesnosti (podle jednotlivých oblastí)}

1. V oblasti Doudlebska (s přesahem na tzv. Vitorazsko a Novohradsko) jsme zaznamenali základní vzorek frazémů, z nichž lze určitou část označit za nářeční. V „doudlebských” lokalitách probíhal již v předchozích letech starší autorský (laický) sběr nářečních dokladů; tedy i frazeologie. Svědectví o tom najdeme v mnohých pracích doudlebských písmáků, k nimž patřili např. Jaromír Šimon (tento místní sběratel; přispíval do regionálních periodik: Pošumavský kraj, Jihočeská jednota; srov. např. Šitnerová 2008: 60-63), Karel Hlubuček (místní sběratel, zubař z Trhových Svinů; srov. Šimánek 2015; Štifter 2018), Anna Froňková (národopisná a sběratelka reálií i nářečních dokladů z Komařic, jediná žena-kočí v naší republice; spoluautorka DNS), Marie Bočková (národopisná a nářeční sběratelka z Dvorců u Borovan), Marie Běhounková (nářeční sběratelka př́iběhů a vypravování z Doudleb), Karel Janů (nářeční a vlastivědný sběratel ze Soběnova), Jan Žáček (nářeční sběratel z Borovan; srov. Homolka-Malík-Žáček 1981) aj.

Základní vzorek frazémů tu lze analyzovat na materiálu „doudlebského slovníku" (DNS; kromě diferenčního slovníku a tezauru také v části Přiběhy a pověsti $z$ širšího Doudlebska). Frazeologie doudlebského nářečí má však dnes určitý odraz i v literatuře; např. v knize Oldřicha Petráška a Zdeňki Študlarové (2017).

2. V lokalitách Prachaticka a Netolicka se od počátku 20. století v rámci nového terénního výzkumu hledaly stopy nářečních frazémů zejména v tzv. „tit’áckém” nářečí. Nelze se však omezit na malou lokalitu, kterou na Prachaticku představuje povodí horního toku řeky Blanice. Reflexe frazeologie můžeme doložit v článcích časopisu „Zlatá stezka”, který vycházel do 40. let 20. století. V rámci různých 
literárních útvarů tu nacházíme frazémy v pověstech, v hádankách, v anekdotách apod. V rámci staršího pojetí frazémů se tu ještě odlišují různá rčení a úsloví (s touto terminologií se však dnes setkáváme spíše jen v rámci literární teorie). V rovině parémií prezentují autoři článků zajímavá pořekadla, pranostiky a př́slovi (někdy se autoři dokonce zmiňují o mudroslovi), rozpočitadla, ř́kadla apod. (srov.: „Zlatá stezka”; zejména ročníky 1927-1929, 1932-1934, 1946-1947; např. 1927-1928: 25, 1928-1929: 26, 1932-1933: 193; 1933-1934: 10 an., 1946-1947: 6, 15, 72).

3. V lokalitách tzv. Blat (tzv. „ovesných” na Zbudovsku i tzv. „pšeničných” na Veselsku a Soběslavsku) jsme zatím zkoumali především slovotvorné aspekty proměn frazeologie na tzv. „pšeničných” Blatech; a to např. užití predponových sloves $v$ rámci frazémů (zejména $\mathrm{v}$ případě, mění-li prefix význam slova a následně celého frazému. Soustavný výzkum zatím na Blatech neproběhl. Základní soubor frazémů, které byly zaznamenány v oblasti tzv. „pšeničných Blat”, pochází ze sběru místní učitelky Marie Krškové z Borkovic a ze Zálší, a zvláště potom z jejích knížek blatských př́běhů a lidových vyprávěnek. Tato „spisovatelka Blat” ve své době studovala folklór a nářečí; od r. 1941 pak zachycovala lidová vyprávění a později vydávala krátké příběhy, pověsti a pohádky z Blat (1950, 1957, 1974; posmrtně: 1999 a 2000).

Zajímavé však je, že se forma i význam blatských frazémů, které ve svém díle uvádí Marie Kršková, mnohdy (téměř nebo částečně) shodují s podobou i obsahem frazémů doložených pro jih Čech sběrem Františka Ladislava Čelakovského (Čel). Připomeňme si proto alespoň některé z nich (ve výběru): přirovnání typu prskat/ praskat jak (Čel: co) mokré dřevo v ohni (něco není v pořádku/ „nedělá dobrotu” o někom, kdo se zlobí, o bouřlivé situaci): potom to praská jak/co mokré (mokrý) dřevo v ohni; slovesné frazémy: mit se $k$ dobrému (snažit se pomáhat, být užitečný, rozvíjet se/ o člověku), stát v/-e (té/tej) váze (být v/-e /tom/ stavu), vybřednout (Čel: vybristi) z kalužiny (dostat se z problému, potíží), vonět (Čel: zavánětl komu /co) pod nos (o něčem, co je někomu nepř́ijemné); zejména se slovesem být: být (koho/ čeho) $v$ bečku: byt jich $v$ bečku bylo; někdy kombinovaně: být v pytli + jedním rázem = být v pytli jedním rázem; popř. polypropoziční (parémie): Nechat šaška (Čel: -ů), hledat Vaška (Čel: a obrátit se k Vašku... dostat rozum; Čel: kombinace: nechal šaška a hledal Vaška)...

Výhradně kontextové jsou parémie Psala to hloupost a diktovala jí nenávist nebo (Na mou věru) polévka ještě není slaná! Mezi jmennými frazémy tu najdeme (např.) spojení martinské husy (také: nesplněné sliby), těžký vozka (neobratný člověk).

V oblasti „ovesných” Blat dosud nebyl systematický výzkum proveden. Doklady místních nářečních frazémů ale v literatuře nacházíme; např. v románu Karla Klostermanna Mlhy na Blatech (srov. Holub 2009: 127-143).

4. V oblasti Klatovska, Přešticka a v bezprostředním okolí Plzně se také současné analýzy zaměřují spíše na hodnocení predponových sloves podílejících se 
na utváření frazémů tehdy, pokud mění význam frazému. V souvislosti s tím bude potřebné analyzovat některé tzv. ,slovníky plzenštiny” (např. slovník Jana Hajšmana 2017, popř. společný slovník Jana Hajšmana a Petra Mazného: 2018), slovníky nářečí Přeštic a okolí (které na základě sběru místního učitele Václava Vacka sestavil Jiří Běl, 1997-1998), slovník Červeného Poříčí (který byl shromažd'ován v průběhu našeho výzkumu v letech 2002-2005). Některá ustálená slovní spojení se ale udržela jako frazém (např. jako přirovnání) již jen na českém západě. K takovému typu patří např. přirovnání lícná po hubalce.

5. V lokalitách Domažlicka (a tedy i tzv. Chodska) má výzkum nářečí mnohaletou tradici. Dnes můžeme vycházet jednak z materálu Hruškova slovníku domažlického nářečí (1907), jednak z pietní edice závěrů sběru folkloristy Jindřicha Jindřicha a učitele Jindřicha Kotala (2007).

Řadu dokladů původních „místních” frazémů ale nalezneme i v pracích dalších chodských písmáků. Např. v knihách Jindřicha Šimona Baara (zejména v Chodské trilogii či v Chodských písních a pohádkách; vyd. 1976; sbírku lidových písní s řadou jazykových dokladů J. Š. Baar r. 1923 posléze předal J. Jindřichovi, srov. Ulrychová 2012); s ohledem na starší stav jazyka však také ve Schnablově edici Knihy Pamětihodných přihod královského města Domažlic 1631-1859 (2013) a v recenzi Lydie Petráňové v časopisu „Český lid“ (2015: 375-377) nebo ve statích M. Vejlupka-Čerchovského (2010-2018). Zajímavé jsou v tomto ohledu i doklady frazémů v tvorbě J. Vrby (Chodsko pod Haltravou, 1924; Chodské rebelie, 1924-1926; Chodský černý týden, 1947; Chodský bílý týden, 1947).

Z hlediska statistického hodnocení je třeba zdůraznit, že jsme během dosavadního předvýzkumu zaznamenali na Doudlebsku 283 frazeologických jednotek (dále ,položek”; jedná se tedy o 19,7\% celkového vzorku; 38 položek není dosud zpracováno; celkem jde tedy o 321 položek, což činí 22,4\% souhrnného/sebraného vzorku; dále SV). Na Prachaticku (a Hornoblanicku či Netolicku) se zatím jedná pouze o 69 položek, tedy o 4,8\% SV (a dalších 187 položek dosud není zpracováno; celkem jde tedy o 256 položek, čili o 17,8\% SV). V regionu Domažlicka (Chodska), Klatovska a Plzeňska představuje náš model 130 položek, tj. 9,1\% SV. Dalších 257 položek nebylo dosud zpracováno (celkem jde potom o 387 položek, tj. o 27 \% SV). V oblasti tzv. Blat („ovesných” i „pšeničných”) máme zatím zachyceno 107 položek (tj. 7,5\% SV). 356 ,blatských” položek ale zatím nebylo dosud zpracováno (celek pak činí 463 položek, tedy 32,2\% SV). V souhrnu všech dosud zkoumaných lokalit je dnes zpracováno: 589 položek (51\% SV). V celku SV nacházíme položek mnohem více; celkem 1358 frazémů a idiomů (včetně přirovnání). Předpokládáme však, že po analýze 78 doložených parémií budeme moci v nejbližší budoucnosti vycházet ze základu o rozsahu 1436 položek.

Z hlediska strukturní analýzy frazeologických (popř. paremiologických) jednotek potom sledujeme různá slovní spojení z hlediska jejich vnitřního uspořádání. 
Frazémy slovesné jsou zastoupeny především spojeními se slovesem být (58 položek). Na modelu spojení s tímto verbem si můžeme ukázat nejčastější strukturní kombinace typu $\mathrm{V}+\mathrm{S}$, např. $\mathrm{V}+\mathrm{S}_{1}$ (být chovít - o nemocném staré, sešlém člověku), popř. na pomezí s přirovnáním $\mathrm{V}+\mathrm{S}_{2}+\mathrm{A}$...být (nějakého, např. pravého) fládra (mít nějaký, popř. dobrý charakter, nějaké/ dobré/ vlastnosti; Holub 2009: 127-143), $\mathrm{V}+\mathrm{S}_{2}+\mathrm{S}_{1}$ (být někoho rota: bylo nás: rota ... popř. v přirovnání: jako drabantů; že jich bilo!... hodně), $\mathrm{V}+\mathrm{S}_{2}\left(+\mathrm{S}_{7}\right) \ldots$ být štráchů (s něčím, $\mathrm{s}$ někým, někde); o okolkování, při př́lišné péči o někoho/něco, obd. vést zbytečné řeči o někom/něčem... (Holub 2009: 127-143; srov. také dělat štráchy), V + $\mathrm{S}_{4}$ / Adv $+\mathrm{S}_{2}(+\mathrm{Adv}) \ldots$ být hromadu (koho/čeho, kde; Holub 2009: 127-143).

Zastoupeny jsou také vazby předložkové $(\mathrm{V}+\mathrm{pS})$ :

$\mathrm{V}+\mathrm{pS}_{2}$.. být $z$... rodu (charakteristika rodiny: $\mathrm{z}$ rodu bláznivého, dobráckého), $\mathrm{V}\left(+\mathrm{S}_{1}\right)+\mathrm{pS}_{2}+\mathrm{A}$... být (kvitko) z jiného pole... být jiný, odlišný/ odjinud (Holub 2009: 127-143).

$\mathrm{V}+\mathrm{pS}_{4}: \mathrm{V}\left(+\mathrm{S}_{2}\right)+\mathrm{pS}_{4}:$ (být (koho/ čeho) $v$ bečku: byt' jich $v$ bečku bylo (o velkém množství; také Holub 2007: 147-158), být na truc (koho: např. kantora; advokáta, pana pátera ... být přesvědčivější než někdo; (srov. Holub 2009: 127-143); $\mathrm{V}+\mathrm{Adv} / \mathrm{A} / \mathrm{Int} / \mathrm{S}_{1}+\mathrm{pS}_{4}$ (být baf/haf/ham/n̆am na buchty - o neschopném člověku, nekňubovi), popř. $\mathrm{V}+(\mathrm{A})+\mathrm{pS}_{4}+\mathrm{Kl}$... být (dobrý) za vůz, aby hnůj nepadal...

$\mathrm{V}+\mathrm{pS}_{6}$ : být na lajici/lavici (být nemocen), být na špehu, být pod kloboukem (ženatý), být v kalupu (spěchat), být v konci (reg. tvar sg.; obec: být v koncích), být $v$ oubytě (chřadnout), být na poletu (chodit za děvčaty, být na záletech), popř. V + $\mathrm{pS}_{6} /{ }_{+} \mathrm{pS}_{6}$ : být ve starostech /o kom (o tobě)... bát se (o koho; srov. Holub 2009: 127-143) apod., kombinovaně také $\mathrm{V}+\mathrm{pS}_{6}+\mathrm{Adv} / \mathrm{S}_{7}$ (srov. výše)... být v pytli jedním rázem... (být v pytli + být jedním rázem...rychle se ocitnout v problému, popř. o něčem, co se stalo velmi rychle; srov. Holub 2007: 147-158), V + pS pod střehem (být sledován, být v centru pozornosti někoho/ostatních), popř. V + $\mathrm{pS}_{7}+\mathrm{A}+\mathrm{Adv}$... být s (plnou) pravdou ( $\mathrm{kde}$; např.: byl tam s plnou pravdou $=$ měl pravdu ve všem; Holub 2009: 127-143).

Podobně nacházíme četné vazby s adjektivem: $\mathrm{V}+\mathrm{A}$; především se složeným tvarem adj.: být bekaný (o dítěti, které zlobí), být (nějaký) darebný (postonávat), být nacuclý/nacuclej (být opilý; zejména na Doudlebsku), $\left(\mathrm{S}_{1}\right)+\mathrm{V}+\mathrm{A}$.. být/bejt horaci (o něčem; označení něčeho samozřejmého: to je horací = to je samožrejmé, to je jasné; jde tu o generačně podmíněný úzus; Kř́̌̌z 2008: 70), V + A (+ p $\left.\mathrm{S}_{4}\right) \ldots$ být hodný /za co (být užitečný, hodit se, být uznávaný /pro co, kvůli čemu), např. být hodný za pluh... (být schopen každé práce, umět každou práci... Holub 2009: 127-143), $\mathrm{V}+\mathrm{A}+\left(\mathrm{pS}_{6}\right)$ : být lícnál-ý (snažit se vyhovět, být milá,uspokojit někoho), $\mathrm{V}+\mathrm{A}+\mathrm{S}_{7}$ být kvaltem opatřený (o člověku, který stále někam spěchá).

$\mathrm{V}+\mathrm{A}\left(+\mathrm{pS}_{4}\right)$ : být tvrdý (na něco; být $\mathrm{v}$ určitém ohledu nešikovný... zejména na Doudlebsku: ve vztahu k inteligencí, k určité disciplíně, oboru, dovednosti apod.; také: být nechápavý; něco obtížně chápat; srov. SČFI 3; Říha 2002: 55n.). 
Se jmenným tvarem adjektiva:

$\mathrm{V}+\mathrm{A}$... napřr. být/nebýt málek (být/nebýt lakomý), být pozorno (o stavu před bouří), být stáŕ (s kým... stejného stáŕí s někým; srov. ČJA 1, mapu č. 8, s. 81)...

$\mathrm{S}$ vazbou verba a adjektiva alternuje také vazba $\mathrm{V}-\mathrm{Adv}$ být preščas, popr. hodně presčas... (přijít pozdě), být bek (bäckt... seschlý, „,spečený”, zestárlý), být khek/kchek (nebut' hned tak kchek; drzý; podrážděný, nakvašený; ale také smělý, frajerský: z něm. keck), být šrek (r Schreck... vylekaný), být/nebýt štont (im stand sein... být/nebýt schopen něčeho; např. být schopen něco pochopit)

$\mathrm{V}+\mathrm{Adv}+\mathrm{pS}_{4}$... být na nervy (úplně) hín (nervozní, velmi podrážděný, nervově vyčerpaný); reflexe neskl. něm. přídavného jména a příslovce; poněkud zast. ob. zničený; pryč (srov. SSJČ 2:31; SČFI 3). Spojení se vyskytuje v češtině běžně; nikoliv ale běžně s pádovým tvarem na nervy;

být (nějak) kách (kdo/na koho: je to na mňe kách; být moc kách: původně rozšířeno v Čechách obecněji; jít na někoho / na něco prŕliš rychle; být /něco/ /na někoho/ př́liš náhlé; obměna něm. přídavného jména a příslovce gah n. gäh, které se vyskytuje častěji v tvaru jäh a znamená „prudký”; srov., Kách 1924); být (na co; např. na nervy) trop (= slabý, nemocný, postižený); popř. suplement: ale jinác dobře; srov. parémii Hdo/kdo je na nervy trop, může být jináč dobře (o někom, kdo je nervózní, ale hodný); původně z fran. trop (= př́liš mnoho; hráč musel ukončit karetní hru; patrně ze starofranského throp... hromada, kupa. Později přeneseno na situace spojené s ukončením hry; posléze označení bezvýchodné situace či úplného zničení).

Podobné vazby nacházíme u 5 výskytů kombinací se slovesem dát: $\mathrm{V}+\mathrm{S}_{4} \ldots$ dát mutaci /pešperaci (o něčem/někom, co dá /kdo má s něčím/ námahu, potíže); $\mathrm{V}+\mathrm{pS}\left(\mathrm{V}+\mathrm{pS}_{2}\right.$.. dát do kouta (darovat rodičce; napřr. u parémie: Dyž dává selka do kouta, nemusí dát hned kohouta); $\mathrm{V}+\mathrm{pS}_{3}$... dát ku pohaně (odsoudit, pohanit); $\mathrm{V}+\mathrm{pS}_{4} \ldots$ dát na odstav (prestat kojit dítě).

Obdobnou strukturní analýzu jsme provedli také u dalších sloves; u vazeb se slovesem dělat (18 výskytů; rovněž u starších dokladů): $\mathrm{V}+\mathrm{S}_{4}\left(+\mathrm{S}_{3}\right)$ dělat (komu) roráty/roratve/roráte (o ženě, která někomu nadává, spílá; např. manželovi; vyčítat, hádat se: dělala mu roráte... podobně zpívat (komu) roráty/ ta jeho mu zpívala roratve (Tetour 2004: 182-184). Podoby pojmenování jsou doloženy z obce Laziště již $\mathrm{z}$ let 1794, 1862, 1865 a 1867; nářečně v podobě roráte ( $\mathrm{v}$ žen. rodě: dvě roráte, také pomn., préed rorátami... popřr. roratve). Vrefl. $+\mathrm{pS}_{4}$ : dělat (popř. na Doudlebsku srát) si přes pysky (lhát, neplnit dané sliby) apod.

Ve spojeních se často vyskytují tvary slov jít nebo chodit (včetně prefigovaných forem; celkem 34x), např. na Domažlicku V $+\mathrm{S}_{4}$ : jit hejtu/hyjtu (bez předložky na; jít na návštěvu, navštívit; srov. v Mrákově: Mager 2017: 275-289; Křŕž 2008: 48, 54, 67, 69; návštěvník = hejták); $\mathrm{V}+\mathrm{pS}_{2}$ : jit do kotejšů... (jít pod pe- 
řinu, jít spát; kotejš = původně ptačí brk, přeneseně: peřina plněná peřím; popřr. deminutivní tvar: jít do kotejšků /o dětech/výzva dětem); jít do stuncí... jít pro vodu (Kř́ž 2008: 68), V + S $\ldots$. jit dolem ... (hubnout; Holub 2009); jit šemerem... (r Schemer... člověk tající něco; tedy potajmu, jako pletichář), jít šikou (jít šikmo, ale také ,potácet se”), V + Adv (pův. adaptované adjektivum): jit šrek (přeneseně: jít šikmo; jinak ale spíše Strecke, cesta/cestou), obd. jít na šrek nebo šrekou apod.

30 f.i. najdeme u slovesa mít $\left(\mathrm{V}+\mathrm{S}_{4}+\right.$ kombinace, $\left.\mathrm{V}+\mathrm{pS}, \mathrm{V}+\mathrm{Adv}\right), 12$ f.i. u tvarů sloves brát či vzít (popř. u jejich prefigovaných podob; zejména opět v kombinaci $\mathrm{V}+\mathrm{S}$ či $\mathrm{V}+\mathrm{pS}$ ). Celkem 72 výskytı zajímavých slovesných f.i. jsme potom zachytili u různých dalších sloves. Zajímavým dokladem je spojení $\mathrm{V}+\mathrm{S}_{4}$ (z Prachaticka): sušit prachandu... (dělat, vykonávat nudnou, někdy i zbytečnou práci; prachanda: stlučené sušené hrušky a jablka; přeneseně; jinak: Koutná 1998: 287; nejstarší záznam pochází už z 19. června 1767); popondat zásuvku... vykonat pohlavní akt (o ženě; srov. popis tzv. konopické v Bušanovicích; Richterová 2005-2006: 233); hrát čampla ... (o hře oblíbené mezi chlapci na podzim, při níž se odpaloval zašpičatělý dřevěný váleček z polohy na plochém kamenu; hra je podobná tzv. špačku; srov. Nauš 2005-2006: 341). Obdobně na Blatech: táhnout sirky... (,táhnout” pryč, odejít, končit; nap̌r. hovor), vodit besedy... (vést dlouhé řeči, rozhovory; Holub 2009). Nebo na Domažlicku: metat seno... (vyhazovat seno na půdu; po senoseči, kdy se vidlemi vyhazovalo z vozu seno na místo určené k uskladnění; Kříž 2008: 69); substantivizovaná varianta tohoto frazému zní metáni sena. Z Doudlebska máme doložené f.i. hodit rám/ráf (zabít se, skončit život) či chytit prant (do čeho: o zánětu v těle; např. chytit prant do nohy; z něm. $r$ Brand... zápal, dokonce i snět'), obřikat dílo (domluvit práci), shánět slídu (poflakovat se, vyhýbat se práci), vodit telata (uvádět novou chasu do služby; srov. jmenný frazém telecí dni; Ř́ha 2002: 52n). Řadu dokladů máme na spojení s jinou pádovou vazbou: $\mathrm{V}+\mathrm{S}_{7}$ : sezvánět zvonama (na Prachaticku; přeneseně i „svolávat lidi”: tak je tam sezvánél zvonama; Tetour 2008: 218); $\mathrm{V}+\mathrm{pS}_{2}$ : vyhrabat se /vybřednout (Čel má vybř́sti) z kalužiny (na Blatech i v jiných lokalitách); ve stejném smyslu na Doudlebsku dostat se z lokáče (dostat se z problému, z potíží; srov. také Holub 2007), na Doudlebsku také $\mathrm{V}+\mathrm{pS}_{4}$ : chlistat přes pysky... (povídat nesmysly, žvanit) nebo $\mathrm{V}+\mathrm{pS}_{7}$ : ostat pod koprvadlem... (zatajit, zůstat v tajnosti /nejčastěji doma/; o něčem, co se nemá prezentovat veřejně; co má ,zůstat v rodině”).

91 výskytů jsme hodnotili u frazémů jmenných (zejména typu $\mathrm{S}+\mathrm{A}$ ). Na okrajích sledovaného území (také na Prachaticku, Domažlicku i jinde) se pak objevují zajímavá dvouslovná označení s rrídícím členem bába: kouzelná bába (ale i kouzelnice), bába čarodená (ale i čerod'enice). Označení kouzelná bába se užívá také 
pro bylinkářku (pro stařenu sbírající léčivé rostliny a pomáhající při léčení /Vitějovice). Baba čarodená/čeroděná bývá spíše zlá, hádává žena (popř. ošklivá, nepořádná, neupravená); spojení se často užívá jako nadávky: Vi stará babo čerod'ená! (srov. Čižmárová 2018: 7, 10).

V rámci procesu utváření f.i. je třeba zmínit některé zajímavé kolokační předložkové vazby:

- typu $\mathrm{pS}_{2}$ (v SV se vyskytly celkem $\left.7 \mathrm{x}\right):+\mathrm{pS}_{2}$ : do domu/ dodomu (označení vstupní části chalupy; ustrnulý genitiv tu někdy nahrazuje funkci nominativu: tady máme dodomu; Doudlebsko),

- $\mathrm{pS}_{4}$ : ve žně (tvar 4. pl.... spadl ve žně z odru na mlat, zabil se... o sběrateli pohádek, sedláku Jiřím Konopovi z Mrákovska, uvádí Mager 2017: 275-289),

- $\mathrm{pS}_{6} \ldots$ v jednej túře (Doudlebsko), na Velešínsku: v pěti hodinách...

V kombinaci s adjektivy či adverbii jsme ale popsali dalších 10 spojení.

Samostatnou analýzu (a klasifikaci) by si zasloužila i přirovnání (v SV jich najdeme 124; tedy ve formě základních položek). V rámci této studie jsme uvedli pouze př́iklady analytického prŕístupu. Některá přirovnání však nejsou doložená v SČFI 1. Považujeme je proto za lokálně, teritoriálně (popř. nářečně) př́íznaková. $\mathrm{K}$ takovým dokladům patř́ typy se základem slovesným i jmenným:

1. se základem (komparandem) jmenným (nominálním; substantivním); na pomezí parémie: $\mathrm{jS}_{1} /+\mathrm{S}_{1}(+\mathrm{A})$ : pívo jak bžunda, žádná pína $-\mathrm{DNS}$

2. se základem verbálním (slovesným; včetně relátoru, aktualizátoru: $\mathrm{V}+$ ):

2.1 u většiny sloves:

2.11 s adjektivním komparátem:

$+\mathrm{jA}$ : chodit jako mrtohlavý

$+\mathrm{jA}+\mathrm{pS}_{2}$ : běžet/běhat) jak z faldů vytržený (SČFI 1 zná jen = u vytržení; dsrov. ále DNS),

2.12 se substantivním komparátem:

$+\mathrm{jS}$ : jíst/ žrát jako/jak žiravina (dobový neologismus; DNS),

$+\mathrm{jS}_{1}+\mathrm{pS}_{6}$ : dělit se jako (náš) pálený kostelník v ouvodě (DNS),

$+\mathrm{jS}_{7}+\mathrm{pS}_{2}$ : loupat (čím) jak řetězem do větru (např. o nešetrném zacházení s nářadím; ale SČFI 1: vyvádět jak utržený od řetězu/ obecněji: ... ze řetězu; být jako na řetěze) $-\mathrm{DNS}$

$\left(+\mathrm{S}_{4}\right)+\mathrm{jS}_{4}(+\mathrm{A})$ : řezat /bit (koho/ co) jako nemastný zelí (SČFI 1 obd. velmi přísně a bolestivě fyzicky trestat, uštědřit „tvrdý” výprask; obd.: být bit jako žito, jako pes... dostat, co se /do někoho/ vešlo; dostat, až / z někoho/ cucky lítají/ lítaly; jč)

2.121 v předložkové vazbě:

+ jpS : lítat (po vsi) jako bez/bej slezena ... (pobíhat /po vsi/ jako pomatený, smyslů zbavený, pominutý, srov. DNS)

$+\mathrm{jpS}_{2}+\mathrm{pS}_{2}$ : téci jako z kadečky bez outorů (co, z koho/čeho: voda z něj tekla jako z kadečky bez outorů; DNS) 
$+\mathrm{jpS}_{4}$ : jako o př́trž (DNS)

$+\mathrm{jpS}_{6}$ : chodit/jit... (také: být/ sedět/ stát) jako po jahlách; letět jako na perutích (SČFI 1 neuvádí ani ... jako na kř́dlech; srov. DNS), plandat jako na věšáku (kdo/ co - na kom/čem): šaty na ňom plandaly jako na věšáku (měl volné šaty, visely na něm; jč); viset (něco na někom, např.: šaty /na kom) jako na plotě; šaty na ňom visely jako na plotě (šaty mu byly velké, plandaly na něm; DNS)

2.13 s klauzí:

+ jKl: jako $(k d y) b y(k o m u)$ potlouklo (chodit nepřítomně, schlíple; jč; srov. být j. m.), dělat, jako by se oslýchal/-a (jako když neslyší... záměna s lexémem ostýchat se; jč), DNS; ... jako by (komu) sezobalo (jděs, jako by ti sezobalo: smutně, nešt'astně; DNS, jč), upalovat, jako by nesl zlato (rychle utíkat; o někom; jč)

2.2 s vybranými slovesy:

2.21 se slovesem být:

$+\mathrm{S}_{1}$... jako krmený šindel (hubený; DNS), popř. jak stébélko (stébýlko; DNS); jako mrtohlavý (zmateně; např. srov. chodit jako mrtohlavý; jč),

+ A + jS : boubelatá jako hrábě (hubená; jč), dobrý jako truhla do almárky (srov. parémii: Kdo má božihodové/božohodový ruky, ten je dobrý jako truhla do almárky; o nešikovném člověku; DNS), neodbytný (prudký, otravný) jako zimnice (zbrklý nebo vtíravý; DNS), řídký jako řičice (nezdravý, vyhublý... přeneseně: jako síto; DNS), hubený jako šmytec/smytec/smyčec (DNS); zamazaný jako capouch (capouch: průduch do komína; Blata; o špindírovi), vychrtlý jako umilec (hubený, vyzáblý; srov. DNS)

+ Kl (s klauzí): (to), jako dyž do ohně leje (s elipsou; jinak: jako když olej/vodu do ohně leje; DNS), hezký, jako když vypadne ze soustruhu (neofrazeologismus; DNS)

2.22 se slovesem mit:

$+\mathrm{S}_{4}+\mathrm{j} \mathrm{S}_{1}(+\mathrm{A})$ : (v)oči jak plužný kolečka (být vyjevený, mít vykulené oči; DNS);

$+\mathrm{S}_{4}+\mathrm{jS}_{4}$ : (něco... např. nohy)... jako pamvály (silné, tlusté, obézní apod.; SČFI: mít ruce jako válečky; DNS), (vlasy) dlouhý jako záklasníky (jč);

$+\mathrm{pS}_{6}+\mathrm{S}_{4} / \mathrm{Adv}+\mathrm{jS}_{4}:$ v krku sucho jako trupel (také: mít žízeň; SČFI 1 jinak: být jako trupel),

$+\mathrm{S}_{4}(+\mathrm{A})+\mathrm{j} \mathrm{S}_{1}$ : oči (zavřené) jako umilec (o unaveném člověku; jč),

$+\mathrm{S}_{4}(+\mathrm{A})+\mathrm{jS}_{4}$ : krk (suchý) jako trupel (mít žízeň; DNS),

$+\mathrm{S}_{4}+\mathrm{j}_{4}(+\mathrm{A})$ : vlasy jako (nejměkčil černé) hedvábi (obd. herbáví; o jemných vlasech; DNS)

Na hranici přirovnání jsou ale také četná další vyjádření, která mají časti paremiologický charakter.

1. Vazby pádové:

$\mathrm{V}+\mathrm{S}_{4}+(\mathrm{j}) \mathrm{pS}_{2}$.. mit nohy z olova (srov....jako z olova; mít „těžké” nohy, ztěžka jít) 
$\mathrm{V}+\mathrm{S}_{2}+\mathrm{Komp}+(\mathrm{j}) \mathrm{S}_{2} \ldots$ mit peněz (ještě) víc než želez (transformace: o bohatém člověku)

$\mathrm{V}+\mathrm{S} 4(\mathrm{j}) \mathrm{S} 4(+\mathrm{A})$... mit oči nejmodřejší len (běžně: jako len...)

2. Vazby předložkové: $\mathrm{V}+(\mathrm{j}) \mathrm{pS}_{4} \ldots$ o prítrž (běžit/běžet, běhat, utíkat apod.; rychle, zbrkle)

3. Vazby s klauzí:

$\mathrm{V}(+\mathrm{A})+(\mathrm{j}) \mathrm{K} 1$... být lakomý tak, že by si nechal houšku u zadku/prdele ukroutit (o velmi lakomém člověku); být, sotva skrz ně (něco) vlk protáh/-l (o šířce něčeho, o úzkém prostoru, např. o úzkých oknech: byly moc úzký/ouzký, sotva skrz ně vlk protáh)

$\mathrm{V}(+\mathrm{A})+(\mathrm{j}) \mathrm{K} 1 \ldots$ být (ty jsi/'s... zlatý, dobrý)... do zlata tě zafasovat... (může jít o pochvalu nebo o výraz ironie (příklad dalších typů kolokací; Holub 2009)

$\mathrm{V}+\mathrm{S}_{2}+(\mathrm{j}) \mathrm{Kl}:$

$+\mathrm{S}_{2}+\ldots$ mit řečí, ažpřes pysky přetéká (žvanit, moc mluvit; Zaorálek 1947/2000; Ř́ha 2002).

$\mathrm{V}+\mathrm{S}_{4}+(\mathrm{j}) \mathrm{K} 1$

...někoho/ (po)hledat/ aby hledal s lucernou ve dne (Takového /člověka/, jako je on; podobného, toho aby pohledal/ hledal s lucernou ve dne... apod.; o výjimečném člověku)

Zajímavé jsou také doklady specifické valence v rámci kolokací, které mohou být základem f.i. Doložili jsme zatím 24 výskytů takových neobvyklých slovesných vazeb; následně vybíráme pouze několik př́ikladů:

V pádech prostých:

$\mathrm{V}+\mathrm{pS}_{2} \ldots$ píchnout (do čeho; vyvolat konflikt)

$\mathrm{V}+\mathrm{S}_{3} \ldots$ (vy) ňourat (někomu; vyčinit/ komu)

$\mathrm{V}+\mathrm{S}_{3}+\mathrm{Adv}$... pejchat/ komu, odkud (např. pejchá jí z hubalky = páchne mu $\mathrm{z}$ úst)

$\mathrm{V}+\mathrm{S}_{4} / \mathrm{S}_{3} \ldots$ biřmovat (koho/komu, nabít; srov. dále např. parémie: dobře nabjiřmovat včas než nihdá!; obd.: ohýbej proutek v mládí /škoda rány...)

$\mathrm{V}+\mathrm{S}_{4}\left(+\mathrm{S}_{3}\right)$ : fedrovat (něco/někomu: trpět, tolerovat, snášet /něco); např. už z r. 1587 zápis z jednání městské rady Prachatic); odvozeno: fedrovat (něco/komu) jak oficir (ironicky: nikomu nic netrpět, nic neodpustit; Starý 2005-2006:296)

$\mathrm{V}+\mathrm{S}_{4}+\mathrm{Adv} \ldots$

stlouci (něco, zejm. svarbu; dohromady... domluvit /něco, zejm. svatbu),

1. $\quad \mathrm{v}$ pádech předložkových:

$\mathrm{V}+\mathrm{pS}_{3}$ : prokazovat se, popř. jak: štědře, např. $k$ čeládce (Tetour 2005-2006: 218; v obci Laziště je k r. 1861 v Knihách ohlášek bohoslužeb doloženo ve významu „být štědrý”/ ke komu; např. o hospodáři: SOkA PT, DÚ Prachatice, sig. II-200, Kniha ohl. boh. 1864-1872) 
$\mathrm{V}+\mathrm{pS}_{4}$... sloužit (na koho; srv. dělat službu)

$\mathrm{V}+\mathrm{pS}_{7}$... trefit (s čím; o něčem, co se povedlo)... např. s vdavkama

2. s adverbiální valencí: $\mathrm{V}+$ Adv: umět/ kam

3. vzájemná vazba sloves: $\mathrm{V}+$ Vrefl. (4. p.): vidět se (dát, nechat... dát se vidět... darovat, prospět, zachovat se velkoryse + navštívit), vynajít se (dát, nechat... dát se vynajít... navštívit někoho).

\section{Parémie}

Paremie (někdy řazená mezi slovesné frazémy větné) se obvykle chápe jako stálá frazeologická jednotka poskytující celistvé shrnutí didaktického obsahu; např. přísloví, pořekadlo (často kontextová „,průpovídka”), pranostika, „okřídlená” spojení slov, někdo sem řadí i různé průpovídky, situační výroky (,sentence” a „maximy”) apod. (srov. PPM; Kania, Tokarski 1984: 216). Př́sloví, pořekadla a pranostiky jsou útvary delší než slova (většinou sestávají z jedné či dvou vět). Pojmenování se obvykle vztahuje na větší či drobnější folklórní útvary (dříve označované jako „mudroslovné”; srov. výše). V počátcích vědeckého přístupu tomu tak bylo především v rámci etnologiw a antropologie. Později se ale pojmenování začalo užívat také v lingvistice; tedy rovněž v rámci frazeologie a idiomatiky. $Z$ důvodu pozdější potřeby přesnějšího vyjadřování se dlouho odlišovaly termíny jako pořekadlo, rčení, úsloví nebo sousloví. Termínu rčení (pop̌r. úsloví, obrat apod.) se však dosud užívá spíše v rovině nevětných slovních kombinací (nejčastěji pro frazém kolokační; méně často jde o náhradu pojmenování parémie: Rčení). Základní soubor českých přísloví s ohledem na frekvenci jejich výskytu na konci 20. století dosud představuje kniha Dany Bittnerové a Franze Schindlera, která se pokouší o stanovení paremiologického minima v češtině (Bittnerová, Schindler 2003).

V našem korpusu však převažují př́ísloví prokazatelně nářeční či regionální provenience.

Jeden z nejvýznamnějších světových paremiologů, Matti Kuusi, pro všechny útvary př́śsloví užil pojmenování sananparret. Zařadil je tak do jediné (oddělené) skupiny (srov. Sananlaskut 1997: V). Kuusi analyzuje př́ísloví podle témat a následně je kategorizuje (srov. databázi Kuusi 2001).

V souboru SV je zařazeno i několik desítek pořekadel; nap̌r. z Domažlicka: co masopust dokáže, to prosinec hukáže... (Parémie tu naznačuje, že občas o masopustním veselí dochází k otěhotnění; srov. Kříž 2008: 71). 


\section{Formule}

Jako formule můžeme chápat různé kvazitransformace (např. posměšky na rozhraní dialogu: Co eště? Starý kleště!... srov. u Čelakovského: Což ještě? Staré zleště! Jedná se odpověd' nejčastěji adresovanou dětem - na otázku Co?; Holub 2007; podobně je tomu u oblastně jihočeské repliky Co? Sklo! Stejnou funkci má odpověd' na dětskou výzvu Dej mi!... Dejmy sou v komíně!; srov. Formule).

K monologickým posměškům potom lze řadit žertovné strašení dětí, např̀. na Českobudějovicku basama s fousama... (obd. běžného strašení typu bububu!), popř. na Blatech posměšek malému dítěti (ráček - mrháček) nebo posměšek dítěti, které se zmýlilo (rybička - chybička; srov. Holub 2009), popř. na širším jč území výsměšný nesouhlas, ironické popření tvrzení druhého (houby s octem na kyselo). Samostatně lze k této skupině přriřadit různé nadávky či kletby (např. $\mathrm{S}+\mathrm{pS}_{4} \ldots s a \boldsymbol{k}$ na ryby!, popř. spojení s klauzí: aby mu ruka zdřevěněla!, aby mu prdel otekla!, aby mu nos zesejratěl!... jč; doložil i Čelakovský 1949; DNS: sejra = na Doudlebsku: tvaroh).

\section{Pomezní typy frazémů}

Kombinace dvou verbálních frazémů utváří pomezní typ $\mathrm{V}+\mathrm{S}_{4}+\mathrm{pS}_{2}+\mathrm{V}+\mathrm{pS}_{4}$ : (při)vábit myši do pasti + (při)vábit na topinku suchou (koho/co, popř. do pasti), která splývá do paremiologického typu na tu topinku suchou také nepřivábi myši do pasti (zde jde o výrok popisující marnost snažení, které není podloženo dostatečnou motivací; jde tu o typické nářeční spojení; srov. Holub 2007); do jisté míry k této skupině patř́ i frazém typu V - pS + K1 (být z Dráždan, ne z Berouna; srov. DNS: 389).

\section{Současné výsledky výzkumu nářečních frazémů}

Základním předpokladem sběru f.i. v regionu je především uspokojivý kontakt s uživateli lokálních dialektů. Na západě i na jihu Čech se postupně utváríi sít' respondenti̊. Dílčí projekty jsou ovšem ve stádiu vývoje. Návrhy řešení nadřazeného projektu oblastního a nářečního frazeologického slovníku českého jihozápadu se proto musí zaměřit na charakter a typy nářečních frazémů, na specifika metod jejich záznamu i na průběžné hodnocení současného terénního výzkumu (z hlediska stavu jeho realizace i s ohledem na stanovení perspektiv). Rozšiřuje se možnost širší spolupráce místních dialektologů (zejména v rámci evidence promluv rodilých mluvčích) a posiluje se význam výzkumu v př́ihraničních oblastech. 


\section{Závěrem}

Shrnuli jsme záznamy frazémů z českého jihu (z Doudlebska, Prachaticka a Netolicka, Hornoblanicku i z oblasti „Blat”) a z českého západu (z Chodska a z Domažlicka, z Klatovska a z Plzeňska). Doložili jsme některé možnosti diferenciace frazémů směrem k okrajům území (k nejjižnějšímu a nejzápadnějšímu úseku českého osídlení), jejich vazby na místní prostředí a na různé typy frazeologických modelů. Provedli jsme syntézu závěrů dosavadního sběru jihočeské a západočeské frazeologie (s využitím odborných, vlastivědných i studentských prací).

V oblasti Doudlebska (s přsesahem na tzv. Vitorazsko a Novohradsko) jsme zaznamenali základní vzorek frazémů (283 jednotek, tedy 19,7\% SV), z nichž lze významnou část označit za nářeční. V lokalitách Prachaticka (popř. Netolicka a Hornoblanicka; 69 položek, tedy 4,8\% SV na širším Prachaticku) a tzv. „Blat” soustavný výzkum zatím neproběhl (a na Blatech). Na Prachaticku tvoří podstatnou část zdrojů záznamy sborníků „Zlatá stezka”, na tzv. „Blatech” (107 položek, tj. 7,5\% SV) výsledky sběru Marie Krškové (často s ohledem na obrozenecké záznamy, např̀ v návaznosti na sběr F. L. Čelakovského, V. Kamarýta apod., popřr. na sběr K. Klostermanna). K mluvě Klatovska, Přešticka a okolí Plzně poskytly podklad místní slovníky (např. Přešticka či Červeného Poříčí), popř. tzv. „slovníky plzenštiny" 1997-1998). Na Domažlicku má výzkum nářečí (potažmo i nářeční frazeologie dlouhou tradici. Můžeme vybírat z materálu Hruškova slovníku, z pietní edice slovníku Jindřicha Jindřicha i z řady diplomových prací posluchačů univerzit; také ale z prací chodských písmáků (celkem130 položek, tj. 9,1\% SV). V souhrnu všech dosud zkoumaných lokalit je dnes zpracováno 589 položek (51\% SV). V současném SV však nacházíme celkem 1358 frazémů a idiomů (včetně přirovnání) a 78 (doložených) parémií. Po uspořádání souborů však budeme moci vycházet ze základu 1436 položek.

Frazémy slovesné jsou nejčastěji zastoupeny především spojeními se slovesem být (58 položek); nejčastější strukturní kombinace typu V + S. Zastoupeny jsou také vazby předložkové $(\mathrm{V}+\mathrm{pS})$. Nacházíme též četné vazby s adjektivem $(\mathrm{V}+$ A); prredevším se složeným tvarem (a někdy s Adv). 91 výskytů jsme hodnotili u frazémů jmenných (zejména typu $\mathrm{S}+\mathrm{A}$ ). V SV najdeme dále 124 přirovnání lokálně, teritoriálně (nářečně) příznaková, a to typy se základem slovesným i jmenným. Doložili jsme rovněž 24 výskytů nebvyklých slovesných vazeb (valence v rámci kolokací). Upozornili jsme dále na výskyt nářečních parémií, zejména přísloví a pořekadel, popř. formulí či některých pomezních typů frazémů. 


\section{Pramenný zdroj}

Inventář domácnosti Ludmily Khernerové z r. 1736: Státní okresní archiv Prachatice (SOkA PT), AMNE (průběžně), Pozůstalosti 1731-1741, karton 102 (19. června 1767).

\section{Elektronický zdroj}

The Matti Kuusi international type system and database of proverbs. Outi Lauhakangas (2001) The Matti Kuusi International Type System of Proverbs. FFC 275. Helsinki: Suomalainen Tiedeakatemia. Dostupné z https://www.mattikuusiproverb typology.fi/ (Kuusi 2001).

\section{Seznam některých zkratek a značek}

(j) - užití frazému blízkého přirovnání, ale bez př́mého vyjádření komparátoru (implicitní typ); u přirovnání existuje možnost alternativního vyjádření

aj. - a jiné

an. - a následující

DNS - kniha Doudlebské náreči a slovník

E. M.

f.i. - frazeologie a idiomatika

FaI - Čermák, F.: Frazém a idiom, CzechEncy 2017

GL, z.s. - Genius loci, zapsaný spolek

j - komparátor u přirovnání (nejčastěji ,jako"; explicitní typ)

jč - obecně jihočeské (potvrzeno naším předvýzkumem)

$\mathrm{Kl}$ - klauze

ob. - obecné pojmenování

obd. - obdobně

p. - pád

popř. - popř́ípadě

$\mathrm{pS}_{3}$ - předložkový pád (číselné označení v dolním indexu)

s komparátorem;

$\mathrm{S}, \mathrm{A}, \mathrm{V}, \mathrm{Adv}, \mathrm{Int}$ - označení slovních druhů

$\mathrm{S}_{4}$ - číselné určení v dolním indexu = označení pádu prostého

SČFI - Slovnik české frazeologie a idiomatiky

SOkA PT... Státní okresní archiv Prachatice

srov. - srovnej (srovnání) 
SSJČ - B Havránek a kol. (red.), Slovník spisovného jazyka českého, Praha 1989;

dostupné z https://ssjc.ujc.cas.cz/.

SV - souhrnný, sebraný vzorek

zast. - zastaralé pojmenování.

\section{SUMmary \\ The State of Phraseology in the South-Western Bohemia at the Turn of the Millennium and Its Reflection in Literature}

The paper deals with phraseology of local dialects in South Bohemia (the regions of Doudleby, Prachatice-Netolice and Blata) and West Bohemia (the regions of Domažlice and Klatovy and the surroundings of Pilsen). The project of the phraseological dictionary of the South-western Bohemia is presented. The phrasemes are described in terms of territorial and thematic diversity. In the paper there are documented the collections of the South Bohemian and West Bohemian phraseology. The research of phraseology and its specification is shown on selected models. The direct field research and its reflection in literature as well as verbal art (according to particular areas) are also involved in the paper. The system of phraseology and paremiology is included as well. The phrasemes in the paper are divided into following groups: verbal and nominal, propositional and polypropositional. The characteristics of comparisons are presented, too, and so are the types of paremies. The comparisons in SČFI (The Dictionary of Czech Phraseology and Idioms) are not documented. The results of contemporary research of dialectological phrasemes are presented in the paper as well as the records of native speakers' speeches. 


\section{ЕЛЕНА НЕвЗОРОва-Кмеч ๑}

ЛОДЗИНСКИЙ УНИВЕРСИТЕТ, ЛОДЗЬ

elena.nevzorova@uni.lodz.pl

\section{ДИАЛЕКТИЗМЫ В СУБСТАНДАРТНЫХ РУССКИХ И ПОЛЬСКИХ ФРАЗЕОЛОГИЗМАХ}

Ключевые слова: диалект, социолект, субстандарт, фразеологизм

Keywords: dialect, sociolect, substandard, phraseological unit

Настоящая статья затрагивает вопросы, которые находятся на стыке исследований лексики и фразеологии с позиций диалектологии и социолингвистики с применением синхронно-диахронического подхода.

\section{I. Терминологические вопросы}

1. Основными для рассмотрения являются термины русские диалект, субcтандарт и польские dialekt и substandard. Термин диалект в российском языкознании имеет устоявшуюся трактовку, а именно: под диалектом понимается разновидность национального языка, бытующее на определенной территории, которое имеет особые (в сравнении с литературным языком) фонетические, лексические, грамматические особенности. В польском языкознании используется для этой трактовки термин regionalizm. Он применяется для обозначения фонетических, грамматических, лексических особенностей языка жителей определенного города (Wronicz 2016: 54). Но, как указывает Халина Карась, между regionalizm'ами и dialektyzm'ами в настоящее время нет четкой границы (Karaś 2010: 1).

С развитием социолингвистики в научный обиход входит термин социальный диалект (соииолект), который определяется как разновидность речи какой-либо социальной группировки. Он является частью более общего термина диалект - разновидность (вариант) данного языка, употребляемая более или менее ограниченным числом людей, связанных территориальной, профессиональной или социальной общностью и находящихся в постоянном и непосредственном языковом контакте (Потепня 2009: 468-469). При широ- 
ком понимании термина в него включаются все так или иначе обусловленные формы языка независимо от их структурно-языковых и функциональных особенностей.

В узком понимании (более распространенном в лингвистических исследованиях) социолекты - это языки (или, точнее, подъязыки) определенных социальных групп, отличающиеся от общенародного языка преимущественно лексикой, фразеологией и семантикой языковых единиц (Потебня 2009: 469).

В польском языкознании расширение диалектологии за счет социолингвистических исследований привело к появлению конкретизирующих определений у терминов gwara и dialekt: gwara ludowa, gwara miejska, gwara środowiskowa и т.д. Такое широкое понимание диалектологии не прижилось. Все подобные явления предложено трактовать к рамках социолингвистики. Расширение терминологического аппарата происходит в результате дискуссий на тему классификации вариантов польского языка (Klemensiewicz 1953; Skubalanka 1976; Urbańczyk 1979; Furdal 1973; Dejna 1980; Gajda 1982 и др.). Обобщая исследования, ученый Александр Вильконь (Wilkoń 2000) анализирует предлагаемые учеными термины, среди которых и термин socjolekt. В польском языкознании он имеет широкую и узкую трактовку. Несмотря на более частое использование последней А. Вильконь считает, что широкое понимание более уместно (Wilkoń 2000: 87-88, 94-99).

Границы между территориальными диалектами и социолектами зыбкие, но мы попытаемся разграничивать эти понятия в настоящей работе.

2. Термин субстандарт вошел в активный научный обиход русистов в начале 90-х гг. ХХ в. (см. Кёстер-Тома 1993; Кудинова 2010). Объем его понятия варьируется у разных исследователей, например: 1. диалект, язык фольклора (Кёстер-Тома 1993'); 2. частныле диалекты, жсаргоны и сочиолекты, жаргонное просторечие, интержаргон (общий жаргон), просторечно-деловая речь, грубое и вульгарное сквернословие (обсценная речь) (Химик 2004); 3. территориальные и сочиальные диалекть, нелитературное просторечие, обиходно-разговорная речь, языки-пиджины и др. (Бондалетов 2002); 4. диалект, просторечие, общий жаргон, интержаргон, сленг (Земская, Розина 1994; Вахитов 2001; Кудинова 2010; Калугина 2013); 5. просторечие (в том числе функционально-стилистическое) и жаргоны (Осипов 2003); 6. профессиональный язык, групповой или корпоративный жаргон, сленг сочиальньх группировок, тайный (условный) язык или арго (которые также являются

Зоя Кёстер-Тома к субстандарту относит диалект и язык фольклора, а к нонстандарmy - просторечие, жаргон, сленг, мат и т.п., разговорный язык, по ее мнению, занимает промежуточное положение между стандартом и субстандартом (Кёстер-Тома 1993: 17). 
составляющими понятия социолект), а также бранная и обсценная лексика и фразеология (Вальтер, Мокиенко 2004; Мокиенко 2003; Бирих 2009). Последнее понимание характерно также для Владимира Борисовича Быкова, Михаила Александровича Грачева, Владимира Станиславовича Елистратова и др.

В полонистике термин substandard не укоренился и используется редко, напр., Антонина Грибосева понимает под ним переходное языковое явление между деревенским и городским диалектами (standard wiejski (или interdialekt), standard miejski (или dialekt miejski) (Grybosiowa 1999). Также оно рассматривается как переходное явление между говором (gwara) и общим польским языком (polszczyzna ogólna), и может называться: odmiana mieszana, substandart wiejski, intergwara, interdialekt, regiolekt и др. (Wyderka 2014). Густав Акартель его заменяет термином podstandard językowy, который является синонимичным к socjolekt'ам, включающим в себя żargon, slang, argot, jezzy pospolity (Akartel 2011: 288). Мы к субстандарту относим жаргон (арго), сленг, жаргонно-разговорную речь, сквернословие с бранной (матерной) лексикой и фразеологией. Однако в данной работе сосредоточимся на жаргонном материале, составляющем ядро субстандарта, а определения жаргон (жаргонный) и субстандарт (субстандартный) будем считать синонимами с разным объемом значения. Использование в заглавии термина субстандарт, а не жаргон, как представляется, лучше отражает синхронно-диахронический или диахронно-синхронный характер рассматриваемого явления. Выбор в пользу субстандарта, а не социолекта обусловлен частотностью использования производных от него прилагательных в сочетании с такими терминами, как лексика и фразеология.

\section{II. Изучение заимствований диалектизмов в субстандарте}

Исследования заимствований в субстандарте имеет более чем столетнюю историю. В их основе лежат такие элементы, как: единицы литературного языка; просторечные слова и фразеологизмы; территориальные диалектизмы; слова других социальных диалектов; иноязычные лексемы; другие арготизмы (Грачев, Мокиенко 2008: 4-5). Описание заимствований из территориальных диалектов в литературе по субстандарту не получило широкого освещения, несмотря на то, что до середины XX века их количество в арго составляло 76\% (Грачев 2003: 13). Основные достижения в этой области принадлежат Ивану Александровичу Бодуэну де Куртене, Борису Александровичу Ларину, Василию Даниловичу Бондалетову, Михаилу Александровичу Грачеву, Валерию Михайловичу Мокиенко, Евгению Степановичу Отину, Олексу Горбачу, Марине Николаевне Приемышевой и др. Главная трудность, 
на которую обращают внимание ученые при описании данного явления, это характер словника словарей территориальных диалектов. Составители не указывают на происхождение ряда областных слов, на степень их распространенности, порой за диалектизмы принимаются арготизмы... (Грачев 2003: 13) и наоборот. Так, В.Д. Бондалетов, М.Н. Приемышева сопоставляют условные языки с территориальными диалектами. В.Д. Бондалетов в труде Арготизмы в словарях русского языка (1987) анализирует Сравнительный словарь Петра Симона Палласа, Толковый словарь великорусского языка Владимира Ивановича Даля, а также словари додалевского и последалевского периода, Словарь русских народных говоров, и предпринимает попытку „освободить" диалектные словари от арготизмов, или, по крайней мере, внести в них соответствующие пометы. Одним из источников, из которого легче всего и почти безошибочно выбрать арготическую лексику, являлся словарь В.И. Даля, поскольку лексикограф оставил в рукописях Словарь офенского языка, Словарь русско-офенский, Словарь языка шерстобитов, Условный язык петербургских мошенников. Из словарей последалевского периода В.Д. Бондалетов особо отмечает Смоленский областной словарь Владимира Николаевича Добровольского (1914), в котором используется помета усл., а также Словарь областного олонецкого наречия Германа Илларионовича Куликовского. Проведя анализ лексикографических работ, В.Д. Бондалетов делает вывод о необходимости точнейшего определения изоглос для определения статуса лексико-фразеологической единицы (Бондалетов 1987: 36). Ученый отмечает, что:

в зонах распространения арго, как правило, данное слово входит в систему местного арго и не встречается в составе местного территороиального диалекта. Носители арго в „условную” речь включают чаще всего слова „чужих” диалектов: местные слова знакомы неарготирующим и для выполнения конспиративной функции не годятся (Бондалетов 1987: 45).

Естественно и обратное движение, т.е. переход из арго в территориальные диалекты. Подтвержается это исследованиями М.А. Грачева, В.М. Мокиенко, М.Н. Приемышевой, М.Т. Дьячка (Грачев 2003; Грачев, Мокиенко 2008; Приемышева 2009; Дьячок 2000).

Этимология польского субстандарта представлена в работах Кароля Эстрайхера, Яна Лося, Генриха Улашина, Бронислава Вечоркевича, Дануты Будзишевской, Станислава Кани и др. Ученые прежде всего сосредотачиваются на заимствованиях из иностранных языков, внутренних заимствованиях - из литературного языка и других социолектов. Несмотря на долгую и богатую традицию исследований в области территориальных диалектов, систематизированное изучение заимствований единиц диалектов в польском субстандарте не представлено. 
Лакунарной областью в исследованиях остаются заимствования субстандартных единиц из диалектов иных языков, а также заимствования из иностранных языков в территориальные диалекты. Также изучение субстандартной фразеологии с точки зрения диалектных заимствований не нашло на сегодняшний день полного отражения.

\section{III. Анализ субстандартных ФЕ с точки зрения их связи с диалектизмами}

При этимологизировании, по мнению В.М. Мокиенко, необходимо уделять внимание жаргонным фразеологическим моделям, которые имеют перекличку с диалектными, литературными выражениями своего и иных языков (примеры см. в: Мокиенко 1994: 68-69) - с целью определения источника иррадиации и установления диахронической последовательности. Фразеологическая модель характерна для ФЕ зашибать/заколачивать/сшибать бабки 'жрр. халтурить', подбивать бабки 'жрр. подводить итоги, суммировать, что-л. заключать', шабашку сшибать (пск.), сбить хоря (сиб.), кальлм сбить (сиб.) 'легко заработать', зашибать деньгу/копейку 'лит.-разг. зарабатывать деньги’ (Грачев, Мокиенко 2008: 44-45). Диалектный элемент, при использовании данного метода, выявляется учеными в ФЕ вкручивать/вкрутить (вколачивать/вколотить, заколачивать), забивать баки '1. угол. отвлекать чье-л. внимание разговором; 2. угол., жрр. лгать, вводить в заблуждение когол.', заливать/залить, баки кому-л. 'обманывать, обмануть', где баки 'диал. ворон. пск. глаза' (Мокиенко, Никитина 2000: 45; Грачев, Мокиенко 2008: 46-47). Образ жаргонной ФЕ - это 'заклеить, закрыть глаза кому-л. на неправду’. Баки появляются и в омонимичных выражениях, однако не имеют отношения к 'глазам': 1. забить баки 'угол. продавать наручные часы', 2. забить баки 'комп. мол. удалять файлы bak (backup)'. Ученые также приводят соответствия с украинским и белорусским языком. Упоминают польское beki, приводя значение 'шарики, кругляшки', 'маленькие глаза' (Грачев, Мокиенко 2008: 47). В таком значении она отмечена лишь у Александра Брюкнера: baczyć (цит. baczyć, od *baki, 'oka', jak patrzyć od patry <...>) и у Витольда Дорошевского: baka 'tylko w wyrażeniu schlebiać, nadskakiwać komuś <..> $<$ może ukr. baky = oczy $>$ '.

Не выяснена этимология ФЕ бузу тереть '1. продолжать целый день собрания; 2. участвовать в скандале, 3. спорить' из-за неопределенности происхождения слова буза. М.А. Грачев и В.М. Мокиенко приводят 2 версии: 1. офен. 'пить вино', бус, бусой 'пьяница'; 2. общенар. или диал. 'сусло, молодое пиво или брага <...>', 'яблочный или грушевый квас'. В эти системы это слово вошло из тюркских языков. Возможен и вариант взаимодействия 
этих систем (Грачев, Мокиенко 2008: 70). В польском языке также есть данная единица. Из тюркских через восточнославянские языки она попала в него со значением 'напиток из проса или кукурузы' (SEBr: 51). Восточнославянское посредничество отмечено и Максом Фасмером. Второе же значение buza, которое приводит А. Брюкнер - это 'nagana buzować, wy-lub zbuzować, w 17 w., z włos. far buzzo 'gniewać się na kogo'(SEBr: 51). У М. Фасмера:

бузандать „жужжать (о мухе, шмеле)”, олонецк. (Кулик.). Вероятно, звукоподражательное; ср. бзык „овод; беспокойное состояние скота” и др., а также бузнуть „ударить с силой”, воронежск. неясное слово. Буздыхан 1. „жезл, палица, усаженная острыми шипами”, 2. „палка общинного старосты”, стар.; укр. буздиган. Заимств. из тур. bozdoyan „дубинка, палица”, чагат. buzruyan, buzduryan - то же.

Представляется, что последние из приведенных значений, образно связанных с ударом, избиением, ближе к значению 'ссориться'. С другой стороны, в составе ФЕ имеется второй глагольный компонент тереть (определяющий семантику), который в субстандарте означает '1. угол. избивать кого-л., 2. крим. мол. обсуждать'; перетереть 'бизн. крим. мол. обсудить какой-л. вопрос ' (ср. образованные от тереть - терки 'мол. напряженные отноше-ния с кем-л.', терка 'мол. дискуссия переговоры, совещание'). „Разговорная” и „ударная" метафора подтверждается ФЕ, в том числе и диалектными выражениями:

Тереть вольнку 1. Забайк. Неодобр. То же, что тянуть вольнку. 2. Сиб. Лгать, обманывать с какой-л. целью. Давать/дать тёрку кому. Сиб. 1. Наказывать кого-л. 2. Заставлять кого-л. быть осмотрительным, благоразумным, опытным (Мокиенко, Никитина 2007: 99).

Диалектизмом является и слово каюк, в ФЕ каюк пришел 'о чьей-то гибели, смерти'. Оно попало в южнорусские диалекты из тюркских языков (тюрк. 'лодка') (калуж. тут ему и пришел каюк; ярос. Каюк ему пришел; брян. Тут и пришел ему каюк; ворон. тут йиму и каюк; орл. Каюк яму таперя; смол. Eтаму делу каюк (Грачев, Мокиенко 2008: 126), а затем в речь казаков и преступников и приобрело переносное значение 'смерть' (Грачев, Мокиенко 2008: 126).

С диалектными единицами: халява, холява, халявка - бран. обл. 'неряха, растрепа, неопрятный', 'вяльй соннылй, ленивыцй и дряной'; 'непотребная женщина'; олон. халява 'задорная женщина'; симб. 'озорница, ругательницุа' (Грачев, Мокиенко 2008: 268) - пересекаются и жаргонные старая халява 'немолодая некрасивая женщина', чертова халява 'о крайне наглом, нахальном человеке'. 
Как указывает Михаил Тимофеевич Дьячок, заимствования из территориальных диалектов в субстандарт (а прежде всего в преступный жаргон) происходят достаточно активно. Среди приведенных примеров можно отметить: кукла денежная 'пачка бумаги, нарезанная по формату денег, сверху и снизу которой находятся настоящие купюры' - рус. диал. кукла 'север., запад. и сибир. пучок, прядь мятого или трепаного льна; горсть льна, предназначенного для трепания'; без базара - базара/ базару нет 'без проблем; все будет сделано' - от базарить 'затягивать беседу, кричать, разговаривать, учинять умышленный скандал' - рус. диал. (север. и запад.) базарить 'громко разговаривать, кричать, шуметь, браниться'; нести баланду 'говорить ерунду, нести чепуху', мутить баланду 'неодобр. вводить в заблуждение, обманывать', разводить баланду 'неодобр. 1. говорить вздор, чепуху, 2. лгать'; травить баланду '1. вести пустые разговоры, отвлекая внимание жертвы, 2. вести беспредметный разговор, 3. распространять ложные слухи, сплетни, 4) лгать, обманывать' - из диал. баланда 'ботвинья, холодец из заквашенного на луке отвара свекольной и иной ботвы с окрошкой' через уголовный жаргон (Мокиенко, Никитина 2000); потушить бебики 'угол. выколоть глаза' - бебики диал. и от белор. бібік 'шарик'; с бзиком 'жрр. о странном, чудаковатом человеке' - бзик от укр., польск., русск. диал. 'овод, кусающий животных и людей и вызывающий их сумасшествие'; распускать ботало 'жрр., угол. разглашать тайну' - ботало 'диал. колокольчик на шее у коров'; закрыть варежку 'жрр. замолчать', открыть/ раскрыть варежку 'начать говорить' - варежка из праслав. varga в диал. 'рот; губы'; сучий куток 'арест. одиночная камера, куда помещают заключенных-осведомителей, чтобы уберечь от расправы сокамерников' - куток в диал. 'угол'; поддать лещза 'угол. ударить' - лещ от диал. лескнуть 'ударить'; призет снять 'угол. заметить, приметить чтол.' - призет от диал. призетить 'заметить'; талан на майдан 'угол. арест. приветствие играющих в любую азартную игру' - от диал. талан 'грабеж' и перс.-тур. meidan 'площадь, поле, арена, ристалище'; хмырь болотный (зеленый) '1. угол. о неуважаемом, угрюмом или подозрительном человеке; 2. мол. нарк. об опустившемся алкоголике, наркомане' - от диал. хмырить ‘горевать, плакать' (прим. в русск. мифологии хмырь 'дух болота' (ср. названия нечистой силы для обозначения отрицательных явлений жаргон заимствует из территориальных диалектов: скес - влад. и шуйск. 'черт', офен., угол. '1. жадный человек; 2. трус', нарк. скес муло 'жадный человек' (Грачев 2005: 173)); поднять на шарап 'взять грудью, приступом' из новг. 'разбить, расхватать’ (Грачев 2005: 228). Указанные единицы отмечаются в общеуголовном жаргоне, молодежной и жаргонно-разговорной речи. Можно также отметить территориальные арготизмы (П.П. Ильин), которые позднее стали называться региональными жаргонизмами/ сленгизмами (см. подробнее Григорович 2015). К ним также причисляют единицы из жаргонизированной, экспрес- 
сивно окрашенной лексики и фразеологии, которые используются жителями определенной местности (см. Грачев 2005: 54-55), с первой линии (в г. Омск ул. Куйбышева, на которой находится психиатрическая больница. После этой улицы находится вторая линия, а первой линии нет) 'дурак, сумасшедший'; дунька с Бахаревки (Пермский край) 'дурочка, ненормальная девушка, простушка' (от названия деревни Бахаревка в Смоленской обл.). Региональный жаргон имеет тесную связь с территориальными диалектами, напр., nonacm в переплет 'оказаться в трудном положении', где переплет, согласно мнению некоторых лингвистов (см. БМС: 524), в языке рыбаков Обско-Енисейского бассейна значит , поперечные пруться или дранка, скрепляющзая остов рыбозаградительной стенки” [...]. В других диалектах, например в архангельских, переплет значит, „ллетень из из хвороста, от берега в глубь реки, для постановки мережи на залов семги”; съездить обыденкой (Иркутск) 'приехать в гости ненадолго, на один день' - ср. в (на) обылёнку - 'яросл. в один день, за один день, на один день, в течение одного дня', на обыденках - 'влад. то же, что на обыдёнку' (Мокиенко, Никитина 2007). В настоящее время территориально-диалектная окраска региональных вариантов русского жаргона проявляется в незначительной степени.

Обращаясь к польскому субстандарту, можно отметить те же тенденции, что и в русском, а именно: 1. заимствование компонентов или целых ФЕ из территориальных диалектов; 2. заимствование из территориальных диалектов через посредство регионализмов и городского просторечия; 3. заимствование из иностранных языков (диалектов) через посредство территориальных диалектов; 4. при помощи диалектной трансформации жаргонного выражения, в котором один из компонентов является: а) общепольской переосмысленной единицей, б) заимствованием из других языков или диалектов. Возможна и комбинация этих типов. Примеры:

Baśka pracuje 'угол., учен., варш. прост., разг. соображать' - baśka адаптированное русск. башка 'арг, разг. голова' через украинское посредство, в русской жаргонно-разговорной речи из тюркских языков через сибирские диалекты (Stachowski 2018) (ср. также русск. фразеол. башка варит, голова работает 'соображать'). $\left(3^{2}\right)$

Być na fleku 'разг. быть пьяным', być pod flekiem 'угол. быть пьяным' сравнимы с поморск. диал. и по структуре и по значению, и лишь по структуре с великоп. диал. być na fleku 'быть полным сил', которое соответствует нем. разг. auf dem Fleck sein. C нем. разг. eine Scheibe haben совпадает также жаргонный и диалектный (великопол.) оборот mieć szajbę- 'нарк. наркотическое опьянение', ‘диал. быть сумасшедшим, вести себя ненормально'. (3)

2 Цифра, приведенная в скобках, указывает на определенный тип заимствования, который отмечен в классификации заимствований польских субстандартных единиц, представленной в настоящей работе. 
Cukier miniać 'угол. быть голодным' - miniać от диал. minić/ mienić 'думать, у кого-л. на уме', т.е. 'досл. думать о сахаре' . $(1,2)$

Dać cynk 'угол. дать знать, передать сообщение' - ср. с диал. cynkać 'звонить'. $(1,2)$

Do rychtu 'угол. собираться на кражу' - rycht 'диал. цель', а также диал. rychtować 'подготавливать к работе, напр., какой-л. инструмент' (SGP V: 77). (2)

Dostać meszty ‘великоп. жарг. быть избитым’. В приведенном обороте семантическое ядро meszta '1. угол. ботинок, обувь; 2. краков. львовск. прост. полуботинок', которое вошло в польский из тюркских языков - mest 'обувь без каблука, также накладки на обувь в виде калош’. $(2,3)$

$I d z ́$ w pyry ‘мол. иди подальше, иди куда хочешь' - то же в велик. диал. (1)

Iść na skibę 'угол. красть, совершать кражу' - то же в великопол. диал. (1)

Faksy strugać ‘угол. ругаться’ - faksy 'великопол., мазов., поморск. диал. искривленное выражение лица' от нем. 'то же', диал. фразеол. stroić faksy 'гримасничать' (SGP II: 31). (2)

Frygle dawać 'угол. быть битым' - возможно от диал. frygać 'бросать' (SGP II: 30). (1)

Kant wsunać 'угол. убить; избить' - kant 'диал. зарубка, знак на дереве' (SGP II: 302-303). (1, 2, 4)

Klap dziakować ‘угол. разбить разломать' - от диал. dziakać 'рубить, ударять раз за разом по одному месту острым предметом’. (4)

В воровском выражении linkier ślip 'подставной свидетель' linkier от linkиз идиш 'левый', в диал. 'пенис', в воров. жаргоне 'неправильный, поддельный, плохой’ (ср. lewy, chujowy). (3)

Mieć kottunki 'нарк. быть пьяным от наркотиков; находиться под воздействием наркотиков' - koltunki от kottun 'спутавшийся в пучок от грязи или педикулеза клок волос' и 'перен. отсталый, темный, ограниченный человек', а в диал. 'человек с непричесанными, спутавшимися волосами' (ср. прест. '1. человек из деревни, 2. жертва кражи, 3. судья, 4. заключенный деревенского происхождения’ (Stępniak 1993: 245)), которое в свою очередь из украинского (а в укр. из праслав.) (SEBor: 246). (2)

Na śniże stać 'угол. стоять на страже, следить за приближением опасности и предупреждать о ней сообщников по краже' (диал.-жарг. śnira 'стража') от na szmirze stać, szmir trzymać/ szmir zabywać 'угол. наблюдать, следить, предупреждать об опасности во время кражи’ из идиш shmir halten - досл. держать стражу, в котором szmir от др.-евр. schomar 'стеречь', shumer 'сторож'. (3)

Nura dać 'угол. 1. спрятаться под лавку, скамейку, 2. учен. убежать с урока’ - то же в диал. 'убежать; спрятаться' (SGP III: 339). $(1,4)$

Piotra mieć 'угол. бояться' - то же значение у диал., варш. прост., жрр. Petra mieć, где piotr (pietr, petr pietrek) 'разг. страх', переосмысленное франц. 
petrifier 'пугать, доводить до состояния остолбенения от страха' (см. MG II: 97). (cp. baśka pracuje). $(1,4)$

Piskała mu gra ‘воров. ему везет, ему все удается' из диал. 'то же значение'. (1)

Pójść w gary 'угол. лечь в кровать, пойти бездельничать' - великоп. диал. iść na gare ‘ложиться спать', где gara 'диал. сон'. $(1,4)$

Powyrywać giry z tyłka (z dupy) 'жрр.; позн. прост. угрожать кому-л. избиением' - giry 'диал.; угол. ноги'. $(1,4)$

Robić w pory 'разг. бояться, нервничать', srać/ walić w pory 'разг. трястись от страха', trząść porami ze strachu 'разг. о ком-л., кто не может скрыть боязнь, нервозность' - pory от portki 'великопол. и малопол. диал. штаны из белого домашнего сукна' (также в других слав. языках и диал. из праслав.) (SEBor: 465). (4)

Strugni jur 'угол. обманщик, врун' - strugać, возможно, от диал. strukać 'кричать (о голосе журавля)' или strugać 'строгать' и јur от львов. прост. jurzyć 'врать, лгать' или диал. јита 'сказка' (ср. русск. жрр. рассказывать сказки 'обманывать, говорить неправду'). $(3,4)$

$W$ trymiga 'угол., жрр. быстро' - то же в сувальск. диал., от русск. вмиг 'быстро'. $(3,4)$

Wystać kogoś ciupasem 'угол. и варш. прост. перевозить арестованного из одной тюрьмы в другую’-ciupas, szupas из нем., сближенное с польским жаргонным ciupa 'угол. отделение полиции; тюрьма', которое, возможно, от диал. ciupać 'сильно бить, избивать; колоть (до боли)' (ср. пол. ciupaga). (3)

Zbić sarmak 'угол. украсть деньги из кассы, совершить кражу в особо крупных размерах', sarmak kitrać 'угол. зарабатывать деньги' - sarmak из русского угол. жаргона 'деньги; кошелек с деньгами' (ср. сара 'угол. деньги'), в котором из общетур. sary 'желтый' через диал. (курск., оренб., сиб.) сара 'деньги'. $(3,4)$

Предпринятые попытки выявления диалектизмов нельзя считать завершенными. Сложность в выявлении диалектизмов в польском субстандарте заключается в том, что словари диалектизмов, регионализмов фиксируют лексику социолектов (субстандарта) и наоборот - словари субстандарта содержат диалектизмы. Таким образом затруднительным представляется провести четкую границу между названными языковыми явлениями. Используя опыт исследования В.Д. Бондалетова, можно сказать, что и в польском языке прослеживается картина перехода диалектизмов в жаргонизмы и жаргонизмов в диалектизмы (что заметно на примере фразеологизмов, отмеченных в лексикографической работе Stownik gwary miejskiej Poznania (Gruchmanowa, Walczak 1997), а также одновременное существование оборотов, которые, в зависимости от региона их употребления, имеют жаргонный или диалектный характер. 
Проделанный анализ показал основные пути попадания единиц из территориальных диалектов в субстандарт, но точные выводы относительно этимологии субстандартных фразеологизмов можно сделать после более глубокого анализа большего по объему диалектного и субстандартного материала европейских языков. На фоне сопоставления такого материала можно проследить межъязыковые связи внутри субстандартных ареалов и начертить пути заимствования (Вальтер, Мокиенко 2004).

\section{SUMMARY \\ Dialectisms in Substandard Russian and Polish Phraseological Units}

This article broaches the questions that are at the turn of vocabulary and phraseology studies from the standpoint of dialectology and sociolinguistics using the synchronic and diachronic approach.

In the first and second parts, we discuss the terminological issues of territorial and social dialectology, based on the experience of scientists. The third part is devoted to the analysis of the history of research in the field of borrowing in Russian and Polish substandard. Next, we describe the main lexicographic works connected with dialect and substandard phraseology. In the last part of the article, an attempt is made to identify the main ways of borrowing from dialects by analyzing substandard Polish and Russian phraseological units selected from substandard dictionaries. 



\section{Frazeologia}

i badania etnolingwistyczne 



\section{JERZY BARTMIŃSKi (1) \\ Uniwersytet Mari Curie Sklodowskiej, Lublin \\ jerzy.bartminski@poczta.umcs.lublin.pl}

\section{Frazeologia}

\section{A JĘZYKOWY OBRAZ ŚWIATA}

Słowa klucze: frazeologia, językowy obrazu świata (JOS), opis JOS separacyjny a holistyczny, językowy obraz BYLICY, koncept DOMU, koncept WOLNOŚCI

Keywords: phraseology, linguistic worldview, isolationist and holistic description of linguistic worldview, linguistic view of BYLICA 'wormwood, sagebrush', cultural concept of DOM 'home', cultural concept of WOLNOŚĆ 'freedom'

Problematyka związku frazeologii z badaniami etnolingwistycznymi ma swój początek w dyskusji, jaka wywiązała się w kuluarach XIV Kongresu Slawistów w Mińsku w roku 2013 między profesorami Valerijem M. Mokienką i Harrym Walterem z jednej a Jerzym Bartmińskim z drugiej strony, na temat miejsca (a ściślej biorąc - rangi) frazeologii w rekonstrukcji językowego obrazu świata (JOS), a w ogólniejszym planie - relacji frazeologii do etnolingwistyki (która za swój koronny temat ma właśnie badanie JOS).

Teza o dominującej pozycji frazeologii - wypowiedziana mimochodem przez V. Mokienkę - wydała mi się ciekawą prowokacją intelektualną. Jeśli trzymać się klasycznej definicji jednostki frazeologicznej (,устойчивое, воспроизводимое, экспрессивное сочетание лексем, обладающее - как правило - целостным значением" (Мокиенко 1980: 4); „społecznie utrwalone połączenie wyrazów wykazujące nieregularność pod jakimś względem" (Lewicki, Pajdzińska 2010: 315)), to zasadne jest pytanie, na ile JOS można zastąpić FOS-em, tj. frazeologicznym obrazem świata, nawet jeśli przyjąć antropologiczno-kulturowe rozumienie frazeologii, jakie proponuje Maria L. Kovšova (Ковшова 2015)? We wspomnianej dyskusji uznałem, że nie da się poczynić takiego zastąpienia, i dziś chcę to stanowisko podtrzymać, a nawet może lepiej uargumentować.

Termin frazeologiczny obraz świata (FOS) - autonomizujący frazeologię jako podstawę rekonstrukcji JOS - spotkałem już wcześniej w rozprawie doktorskiej Jarosławy Iwczenko Diabet we frazeologii polskiej i rosyjskiej (2009), napisanej w Instytucie Kulturoznawstwa Uniwersytetu Marii Curie-Skłodowskiej w Lublinie 
pod kierunkiem Jana Adamowskiego ${ }^{1}$. Wtedy termin wydał mi się nieuzasadniony, a w każdym razie niewystarczająco umotywowany, skoro w literaturze językoznawczej zdobył już sobie popularność ogólniejszy termin JOS (ewentualnie JOŚ), będący odpowiednikiem ros. языковая картина мира, niem. das sprachliche Weltbild / Weltansicht, ang. worldview. Używało go i używa do dziś wielu autorów².

Termin JOS jest semantycznie wystarczająco pojemny. W języku jako systemie daje się wydzielić cząstkowe podsystemy: leksykalny, morfologiczny, składniowy, mówi się o tekstach (i „tekstemach”, włączanych już niekiedy do systemu językowego) oraz dyskursach jako tekstach w użyciu. Wszystkie wymienione podsystemy i przykłady użycia języka stanowią językową podstawę rekonstrukcji obrazu świata, choć mogą - co oczywiste - zostać potraktowane, jak to określa Stanisława Niebrzegowska-Bartmińska (2014), „,separacyjnie”. W końcu nikt nie bada od razu wszystkiego, przeciwnie, postępuje się etapami, analizuje fragmenty, zmierzając ku ujęciu całościowemu. Czy jednak zasadne byłoby autonomizować KOS, MOS, FOS, TOS, DOS itd. ${ }^{3}$, tylko dlatego, że tak jest łatwiej, a ujęcie holistyczne wymaga większego nakładu czasu, wysiłku, w końcu też miejsca? Mówienie o FOS sugeruje jego autonomię, ale może też wynikać z „pójścia na łatwiznę”, ponieważ niewątpliwie badanie frazeologizmów stanowi atrakcyjny i najprostszy sposób opisu JOS. Obserwacja praktyki badawczej pokazuje, że takie aspektowe, wybiórcze, izolujące podeście jest (zwłaszcza przez początkujących badaczy) wybierane bardzo chętnie, i nawet coraz częściej. Dokonuje się to ze szkodą dla ujęcia całościowego, którego niedawno broniła S. Niebrzegowska-Bartmińska w artykule Jakie dane sa relewantne etnolingwistycznie? (2017).

Autorka tego artykułu za istotne fakty językowe przy opisie (rekonstrukcji) JOS uznała ${ }^{4}$ a) słownictwo, gdyż „leksyka jako swoisty inwentarz kultury, żywy i dynamiczny, stale wzbogacany tysiącem nowych jednostek, jest swoistym sejsmografem rejestrującym zmiany dokonujące się w społeczeństwie, cywilizacji i kulturze"; b) integralne znaczenia słów, obejmujące zarówno strefę

Jednym z recenzentów rozprawy J. Iwczenko był Wojciech Chlebda.

2 Internetowa wyszukiwarka Google na hasło ,językowy obraz świata” wyrzuca dziesiątki i setki prac.

3 O ile pojęcie kulturowego obrazu świata (KOS) (por. Anusiewicz, Dąbrowska, Fleischer 2000: 30) jest, jak sądzę, zawarte w pojęciu JOS (określanego często synonimicznie dwuczłonową formułą językowo-kulturowy obraz świata (Rak 2007)), podobnie jak stosowane przez Idę Kurcz i Jolantę Maćkiewicz (por. Żuk 2010) pojęcie mentalnego obrazu świata (MOS), które tkwi immanentnie w obrazie językowym, jest jego aspektem, o tyle FOS frazeologiczny (Iwczenko 2009), TOS - tekstowy (Kadyjewska 2001), czy DOS - dyskursywny (Czachur 2011) obraz świata mają inny status pojęciowy, są tylko wyosobnionymi częściami większej całości, jaką jest JOS.

4 W nawiązaniu do Bartmińskiego (2010a). 
jądrową, jak i strefy peryferyjne, więc elementy kategoryzacyjne i wszystkie cechy przypisywane pozytywnie przedmiotowi - elementy o charakterze ,encyklopedycznym" i ,jawnie subiektywne"; c) formę wewnętrzną słowa -zgodnie z przekonaniem, że perspektywa oglądu zawarta jest w nazwie, tzn. w „żywych” formacjach słowotwórczych (czytelnych dla użytkowników języka) i w formacjach „martwych” (zleksykalizowanych, których znaczenie jest zatarte dla współczesnego użytkownika języka), do których dostęp dają badania etymologiczne; d) pola semantyczne, ich wewnętrzną organizację, liczbę i jakość leksykalnych eksponentów, więc „relacje nadrzędno-podrzędne (hipero- i hiponimiczne), relacje ekwonimiczne (łac. aequus 'równy') - a więc synonimy i antonimy, regularne ciągi derywacyjne oraz relacje syntagmatyczne, które można precyzyjnie opisać, wykorzystując Fillmore'owskie pojęcie ról semantycznych; e) frazeologizmy, utarte kolokacje (frazemy), metafory, czyli derywaty semantyczne; f) gramatykę (kategorie językowe); g) teksty, poczynając od minimalnych jak przysłowia po wielozdaniowe, przy analizie których wartość szczególną mają sądy presuponowane; h) dane „przyjęzykowe” - przyjęte i obowiązujące zachowania, praktyki, obrzędy, przekonania i wierzenia, bez których niemożliwe jest normalne porozumienie językowe i interpretacja wypowiedzi; i) badania ankietowe, zwłaszcza ankiety z pytaniami o charakterze otwartym (Niebrzegowska-Bartmińska 2017: 16-17).

W programie sformułowanym na użytek badań porównawczych przez Macieja Abramowicza, J. Bartmińskiego i Wojciecha Chlebdę znalazł się postulat oparcia rekonstrukcji JOS na czterech fundamentach: danych systemowych czerpanych ze słowników narodowych, danych eksperymentalnych (ankietach), korpusach i tekstach. Frazeologizmy wchodzą wraz z leksemami w skład tych wszystkich danych, są ich częścią. W kwestii źródeł tekstowych autorzy zalecali, by były to: „teksty, których wykorzystanie pozwala na uzyskanie szerokiej palety cech przypisywanych danemu pojęciu": a) przysłowia i utarte powiedzenia; b) artykuły z prasy wysokonakładowej o zasięgu ogólnokrajowym; c) podręczniki szkolne, ponieważ „,[]]opiero sięgnięcie do różnego typu danych stwarza możliwość uzyskania w miarę pełnego i zobiektywizowanego obrazu" (Abramowicz, Bartmiński, Chlebda 2009: 342).

W świetle zgłoszonych postulatów problemem nie jest to, czy w rekonstrukcji JOS uwzględniać różne typy danych - gramatykę, słownictwo, frazeologię, teksty, korpusy (które w istocie są zbiorami tekstów) - bo większość badaczy JOS skłania się ku temu, ale raczej to, na ile „dowody” czerpane z różnych danych przystają do siebie, dają spójny obraz przedmiotu; w jakim stopniu uzupełniają się czy przeciwnie: są kontrastowe, rozbieżne? A jeśli rozbieżne, a nawet sprzeczne, to jak taki stan rzeczy interpretować? Inne ważne pytanie: który typ danych pozwala wnieść do JOS informacje specyficzne, niedające się uchwycić z innej podstawy, z innego typu danych i czym to należy tłumaczyć? 
W niniejszej pracy bronię zasadności używania nadrzędnego terminu językowy obraz świata (JOS) rozumianego jako obraz językowo-kulturowy, nawiązujący do pojęcia lingwokultury. Powtarzam: JOS znajduje wyraz w gramatyce, leksyce $\mathrm{z}$ frazeologią, w tekstach (także wywołanych metodą ankietową), a frazeologizmy (i szerzej - frazemy w sensie proponowanych przez Chlebdę (1991)) są traktowane jako jeden z kilku sposobów artykułowania językowego obrazu świata. Stawiam więc raczej dalej idące pytanie, jak dane uzyskane z podstawy frazeologicznej mają się do informacji uzyskanej z innych podstaw: na ile są bogatsze? odmienne? ważniejsze? Na ile są komplementarne? Niewątpliwie dla wielu osób frazeologizmy są najbardziej atrakcyjne, wyróżniające się wyrazistością psychologiczną (ang. salience), są czymś w rodzaju przysłowiowej „,wisienki na torcie”. Ale wisienka nie zastąpi tortu.

W przypadku stereotypu MATKI dane systemowe (nazwy, etymologia, derywaty, frazeologizmy) okazały się uboższe niż dane tekstowe, poczynając od podawanych w ankietach epitetów matki typowej i prawdziwej i przysłów (Bartmiński 1998). Podobnie było w przypadku EUROPY (por. Bartmiński, Chlebda 2018). $\mathrm{Z}$ innymi konceptami może jednak być różnie, jak pokazują eksplikacje w Słowniku stereotypów $i$ symboli ludowych (SSiSL) oraz w Leksykonie aksjologicznym Stowian i ich sąiadów (LASiS). Wiele zależy od tego, co przyjmiemy za dane systemowe zwłaszcza, jak potraktujemy połączenia wyrazowe: czy do systemowych zaliczymy tylko zidiomatyzowane (frazeologizmy sensu stricto, zgodnie z przytoczoną wyżej definicją Mokienki) i łączliwe frazemy (w rozumieniu Chlebdy (1991)), czy też pojawiające się w tekstach luźne kolokacje, których liczba idzie w setki i tysiące (i które nie są traktowane jako „systemowe”).

Problem podstaw rekonstrukcji JOS i wzajemnej przystawalności wyników uzyskanych $\mathrm{z}$ różnego typu danych materiałowych przeanalizowała ostatnio S. Niebrzegowska-Bartmińska na przykładzie dwóch haseł: bylicy (Artemisia vulgaris) (SSiSL II/4) i domu (LASIS I). Przypomnę w skrócie wyniki jej analiz.

\section{BYLICA}

W przypadku ludowego obrazu BYLICY do jej obligatoryjnych charakterystyk autorka hasła (Ewa Hrycyna) wprowadziła cechy komunikowane językowo poprzez nazwy kategoryzujące (ziele, matka ziela), synonimy (bielica, bielina, bieliczka - od jasnego spodu liścia; czarnobiel - bo jej liście z wierzchu są ciemne, a pod spodem białe); wprowadziła także nazwy wielowyrazowe: świętojańskie ziele, Świętego Jana ziele, ziele dla św. Jana; sfrazeologizowane wyrażenia: krzaki bylicy, gataź bylicy; zwroty frazeologiczne: grodzić płoty bylica 'podejmować się rzeczy niemożliwej do wykonania, nierozsądnej', palić płotem, a bylica grodzić 'gospodarować niedołężnie'. Ale leksemów i typowych frazeologizmów jest w su- 
mie niewiele. Znacznie więcej informacji o bylicy znajdujemy w tekstach folkloru, zwłaszcza w pieśniach, np.:

Kárałaś mnie [matko] bylicą, zrobiłam sie bezboźnicą; A na polu byliczeńka, wiatrek ją kołysze, a już Jasio do Kasieńki, drobne listy pisze; Drzwiczki z byliczki miała, słomką je zapierała; głupi dworacy byli, że się tam nie dobyli.

Ale większość kulturowo relewantnych charakterystyk bylicy pochodzi z danych ,przyjęzykowych” - z zapisów wierzeń i praktyk. Niebrzegowska-Bartmińska pisze:

Bylica postrzegana jest wieloaspektowo, a charakterystyki składające się na jej wyobrażenie komunikowane są we wszystkich lub jedynie w wybranych typach danych. We wszystkich typach danych utrwalone zostało poświadczenie o wiotkości bylicy, jej nietrwałości, podatności na działanie wiatru oraz to, że przeciwdziała czarom, odpędza choroby i burze. W systemie i tekstach potwierdziło się, że bylica jest podobna do drzewa, jest zielona, ma białe liście, że odpędza czary, jest łączona z kobietą, jej aktywnością seksualną i kojarzona z czarownicą. Wyłącznie w tekstach ma poświadczenie składnik kategoryzujący (ziele) oraz miejsce występowania (rośnie dziko) i skojarzenie jej z kobiecą płodnością, z rozwiązłością, niestałością w uczuciach i niewiernością. Jedynie w danych „przyjęzykowych” mowa o tym, że bylicę się święci oraz to, że ma właściwości: oczyszczające, przypisywana jest jej właściwość zjednywania miłości. [...] [P]odstawę wierzeniową mają sądy o związku bylicy z czarownicą oraz takie, które mówią o jej ochronnych i oczyszczających właściwościach (zapach bylicy jest według wierzeń apotropeikiem przed złymi mocami) czy wyjątkowych działaniach w magii miłosnej. Także na legendach i wierzeniach sfabularyzowanych opiera się przypisanie bylicy cech ziela uświęconego przez kontakt z głową świętego Jana oraz to, że miała jej użyć Matka Boska, by głowa świętego przyrosła do ciała; zgodnie z przekazami Matce Boskiej włożono bylicę ziele do trumny. [Wg legend] 1) a) w bylicę wpadła głowa św. Jana i b) bylica pomaga w leczeniu bólów głowy oraz 2) a) bylica kojarzona jest z czarownicą i b) bylicę pali się w ogniskach na św. Jana (= w celu przywołania czarownicy). Cechy wchodzące w skład wyobrażenia bylicy są względem siebie koherentne i komplementarne, a utrwalone w zapisach wierzeń i opisach praktyk święcenie bylicy, jej właściwości oczyszczające i miłosne, dopełniają, niepoświadczone w innych typach danych, charakterystyki składające się na całościowy obraz tego ziela w polskiej tradycji ludowej (Niebrzegowska-Bartmińska 2017: 20-21).

\section{DOM}

Podobnie wieloaspektowo przeprowadzona analiza językowo-kulturowego obrazu DOMU (wykorzystano obszerne opracowanie Bartmińskiego i Iwony Bielińskiej-Gardziel (2015)) pozwoliła wyważyć proporcje informacji uzyskanych z pod- 
stawy systemowo-frazeologicznej do informacji uzyskanych z innych podstaw. Niebrzegowska-Bartmińska stwierdza, że

[...] we wszystkich typach danych utrwaliły się charakterystyki domu jako miejsca, w którym ma się poczucie bycia u siebie, możliwość zaspokajania niektórych potrzeb życiowych, zwłaszcza bezpieczeństwa i głodu. W systemie i tekstach dom jawi się jako miejsce, budynek, w którym mieszka rodzina (swoi i bliscy); dom jest miejscem, w którym zaspokajana jest potrzeba bycia z bliskimi, z dziećmi, w którym dzieciom przekazywane są wzory kulturowe, niekiedy też wykonuje pracę zarobkową. W ankietach i tekstach została poświadczona możliwość zaspokajania $\mathrm{w}$ domu potrzeby snu i odpoczynku. Jedynie w systemie językowym utrwaliła się cecha ochrony od zimna, a jedynie w tekstach - możliwość zaspokajania potrzeb higienicznych. Charakterystyki wydobyte z różnych podstaw materiałowych są w wysokim stopniu koherentne, a wydobyte ze zróżnicowanych podstaw źródłowych, wzmacniają siłę utrwalenia cechy (Niebrzegowska-Bartmińska 2017: 22-23).

Nieco uszczegółowiając tę charakterystykę, można powiedzieć, że bardzo wymowne są sfrazeologizowane wyrażenia dom rodzinny i dom ojczysty (mają one odpowiedniki we wszystkich językach słowiańskich), ognisko domowe, domowe pielesze; zwroty: zaprosić do domu, urzadzić coś po domowemu; nie mieć wszystkich $w$ domu 'o kimś głupim, kto ma niepoukładane w głowie’; przyjąć pod dach; pokój temu domowi; wyrzucić kogoś za drzwi; wypędzić z domu; przysłowia typu Gość $w$ dom, Bóg $w$ dom; Wszędzie dobrze, ale $w$ domu najlepiej - niewątpliwie stanowiące ,śmietankę” dokumentacji językowego obrazu domu, ale mamy też, po pierwsze, bogactwo innych danych systemowych ,niefrazeologicznych”, także wielce wymownych, jak: etymologia domu (od 'budowania'), hiperonimy domu (budynek, rodzina, ród, instytucja), liczne hiponimy (chałupa, dworek, pałacyk, willa...), synonimy (mieszkanie, sadyba, kwatera...), partonimy (pokój, kuchnia, sień, łazienka...), derywaty (domowniki, domator, bezdomny....), a po drugie - przebogate dane tekstowe, zarówno pozyskane ankietowo, jak zgromadzone w korpusie jezyka polskiego. Wszystkie te dane wzajemnie się dopełniają, są niekontrastowe.

\section{PRACA i WOLNOŚĆ}

Nie inaczej jest z dwoma innymi językowymi obrazami konceptów kulturowych, które otrzymały obszerne charakterystyki w wydanych niedawno tomach 3. i 4. LASIS, poświęconych PRACY (LASIS III) i WOLNOŚCI (LASIS IV). W artykule Bartmińskiego i Niebrzegowskiej-Bartmińskiej (2016) PRACA w kregu wartości słowiańskich i europejskich przypisano PRACY 18 cech, które mają „,certy- 
fikację" opartą na różnych typach danych. Frazeologia dostarczyła tylko pewną część charakterystyk, większość cech wyprowadzono z analiz etymologicznych nazw PRACY, z definicji słownikowych, z analizy synonimów, antonimów, derywatów, użyć metaforycznych, z badań ankietowych, z przysłów, literatury pięknej, tekstów prasowych i publicystycznych, z korpusów językowych ${ }^{5}$.

Jeśli idzie o WOLNOŚĆ, sytuacja jest znacząco odmienna. Tylko trzy cechy polskiej WOLNOŚCI - ustalone na podstawie wszystkich typów danych (Bartmiński, Niebrzegowska-Bartmińska 2019: 221-222) - mają walor ogólny, ramowy, ale pełną definicję kognitywną polskiej WOLNOŚCI budują w dużym stopniu właśnie cechy poświadczone (dookreślone) frazeologicznie. Te cechy ramowe to:

(1) 'stan pożądany, postulowany, gwarantowany prawem';

(2) 'w którym możemy sami, zgodnie z własną wolą wybierać i decydować, co chcemy robić lub nie robić';

(3) 'bez zewnętrznego przymusu, bez ograniczenia nakazami ani zakazami'.

Te ramowe cechy są regularnie poddawane uszczegółowieniu na poziomie systemowo-frazeologicznym i tekstowym ze względu na (a) podmiot, (b) zakres, (c) granice, (d) cechy i (e) przywoływane fundamenty, (f) usieciowienie.

(a) Podmiotem polskiej wolności mogą być: naród (wolność ojczyzny, kraju), grupa społeczna, klasa (wolność ludu), człowiek jako os oba (wolność osobista, indywidualna).

(b) Zakres wolności obejmuje sferę myśli, słów i działań: wyboru religii i wyznania (wolność sumienia, wolność religii, wyznania, kultu), publicznego wypowiadania się w mowie i w piśmie (wolność druku, słowa), demonstrowania swoich postaw, przekonań i orientacji (wolność zrzeszania się, wolność zgromadzeń).

(c) Granice i ograniczenia wolności mogą być narzucone i wprowadzane z zewnątrz albo przyjęte dobrowolnie przez podmiot wolności, wolność może więc być wewnętrzna i zewnętrzna. Jedna i druga może być traktowana jako wartość stopniowalna (wolność całkowita, nieograniczona vs wolność częściowa, ograniczona). Wolności można kogoś pozbawić w zupełności (odebrać komuś wolność) lub częściowo (por.: ograniczyć wolność, krępować czyjąś wolność).

(d) Cechy wolności - w dawniejszych słownikach rozróżnia się wolność dobrą $i$ zła, czemu odpowiada w dyskursach nowsze rozróżnienie wolności prawdziwej i wolności fatszywej, złudnej.

(e) Fundamenty wolności nie mają wykładników frazeologicznych, są wykładane ,dyskursywnie”, w tekstach teologicznych, etycznych i prawnych, wiązane z przyrodzoną godnością człowieka i jego naturalnymi prawami.

5 Pod kątem sposobów certyfikacji cech omówiłem koncept PRACA w artykule $O$ założeniach i postulatach lingwistyki kulturowej (na przykładzie definicji PRACY) (Bartmiński 2018). 
(f) Usieciowienie WOLNOŚCI zaświadcza sztandarowa (utarta, sfrazeologizowana) triada wolność, równość, braterstwo z czasów rewolucji francuskiej, która stała się przewodnią ideą europejskiej lewicy; WOLNOŚĆ funkcjonuje w utartych szeregach: wolność i demokracja; wolność i odpowiedzialność; wolność i solidarność (por. też: Nie ma wolności bez Solidarności); wolność $i$ bezpieczeństwo.

Ogólnie biorąc, udział idiomatycznej frazeologii i ustabilizowanej frazematyki w kształtowaniu obrazu WOLNOŚCI jest ogromny.

Stownik frazeologiczny języka polskiego Stanisława Skorupki (SF) zarejestrował dziesiątki utartych połączeń WOLNOŚCI, w tym z przymiotnikami (wolność całkowita, częściowa, nieograniczona, powszechna, prawdziwa...; klasowa, narodowa, obywatelska, osobista, podatkowa, polityczna, religijna, seksualna, hist. szlachecka, złota 'przywileje szlachty polskiej przed 1791 r.'); z rzeczownikami określającymi, czego wolność dotyczy (wolność druku, handlu, myśli, wiary, woli, wyznania; obyczajów; daw. wolność żołądka 'rozwolnienie') oraz z czasownikami, tworzącymi najliczniejszą grupę (cenić, dać, darować, gwarantować, krępować, mieć, nadać, nieść, odebrać komu, odzyskać, ogłosić, ograniczyć, okupić, otrzymać; powracać komu, przynosić, przyrzekać, przywracać, przyznawać, utracić, ubezpieczyć, ukrócić, uzyskać; także: walczyć o wolność, ginąć, umierać, walczyć za wolność; bronić, dobijać się, domagać się, pozbawić kogo, pragnąć, strzec, używać, zagrażać, zakosztować, zrzec się wolności; dążyć do wolności, być, pozostawać na wolności; korzystać z wolności, cieszyć się, (ob)darować kogo, upić się wolnością; daw. stać przy wolności) (SF II: 601-602).

Frazeologizmy potwierdzają wysokie wartościowanie wolności narodowej (wolności ojczyzny) przez Polaków, dokumentują etos walki o jej odzyskanie, łącznie $\mathrm{z}$ ofiarą życia.

Nowe możliwości badania językowego obrazu WOLNOŚCI stwarza korpus języka polskiego (NKJP), zawierający 1,8 mld „segmentów”, oparty na zróżnicowanych stylowo tekstach współczesnych, opracowany w latach 2008-2012. Korpus pozwala na szerokiej podstawie materiałowej śledzić łączliwość tekstową słowa wolność oraz - co szczególnie ważne - poznać liczbowe wskaźniki użyć poszczególnych połączeń, więc rankingować je według częstości i dzięki temu uzyskać informacje o stopniu ich uzualnej stabilizacji ${ }^{6}$.

Jeśli zadać NKJP pytanie o łączliwość słowa wolność, potwierdzi się opinia o wybitnym udziale w kształtowaniu językowego obrazu WOLNOŚCI danych frazeologicznych, frazematycznych i po prostu kontekstowych (granice między połączeniami idiomatycznymi, utartymi i swobodnymi nimi są nieostre, płynne).

${ }^{6}$ Kolokacje są w NKJP sortowane według specjalnego systemu, który pozwala odróżnić związki składniowe i kolokacyjne oraz określić istotność statystyczną danej kolokacji. W tym miejscu nie wnikam w szczegóły tego systemu. 
Połączenia wyrazowe oparte na słowie wolność idą już nie w dziesiątki, ale setki i tysiące. Rekord częstości - co znaczące - bije połączenie odzyskać wolność 312 poświadczeń. Wśród 100 najczęstszych połączeń słowa wolność z czasownikami znajdujemy następujące: dać, oddać, dawać - 95; nieść, przynieść, przynosić - 36; gwarantować i zagwarantować-29; obiecać i obiecywać-14; zapewnić i zapewniać - 15; zawdzięczać komuś - 13; głosić - 14; realizować - 9; uznać - 6; ale też: ograniczyć, ograniczać - 62; ukraść - 20; odebrać i odbierać-16, wziać5; można ją utracić, stracić, tracić - 44; niszczyć - 8, odrzucać - 8, zabić - 6, naruszać - 5. Należy walczyć (o nią) - 14, wywalczyć (ją) - 16, można ją zdobyć 17, osiagnać - 16; otrzymać - 12, znaleźć - 8, dostać - 6; zachować - 12; wykorzystać - 5; szanować-20, kochać - 26, chronić - 13, cenić - 14; poczuć - 10 .

Połączenie wybrać / wybierać wolność (112) opisywało sytuację sprzed roku 1989, kiedy wybranie wolności znaczyło tyle, co ucieczka z krajów obozu socjalistycznego ${ }^{7}$.

W licznych kolokacjach typu wolność + czasownik wolność jest traktowana jak obiekt, który można komuś dać albo zabrać, także o który się walczy jako cenną wartość, godną zabiegów.

Podsumowując wnioski wynikające $\mathrm{z}$ tego krótkiego przeglądu wybranych przykładów, można powiedzieć, że 1) frazeologizmy (w sensie ścisłym) są tylko częścią danych pomocnych w rekonstrukcji językowego obrazu świata; 2) stanowią materiał szczególnie interesujący i atrakcyjny ze względu na swoją obrazowość i ładunek emocjonalny, wnoszą informacje komplementarne wobec uzyskanych na podstawie innego typu danych; 3) ogólnie biorąc, przydatność frazeologizmów dla odtworzenia JOS jest ograniczona i zarazem zróżnicowana: jest większa w przypadku WOLNOŚCI, mniejsza w przypadku BYLICY, DOMU, najmniejsza w przypadku EUROPY; 4) Powyższe stwierdzenia odnoszą się do frazeologizmów w sensie podstawowym, tj. do związków idiomatycznych (jak je rozumieją klasycy frazeologii, V. Mokienko oraz np. Andrzej M. Lewicki i Anna Pajdzińska), także odtwarzalnych połączeń frazeologicznych („frazemów” W. Chlebdy), nie dotyczą połączeń składniowych swobodnych, regularnych, budowanych według reguł gramatycznych i semantycznych.

Kwestię niezgodności i ewentualnie sprzeczności między charakterystykami wypływającymi z różnego typu danych pozostawiam do osobnego omówienia.

7 Przed rokiem 1989 wybranie wolności znaczyło tyle, co ucieczka z krajów obozu socjalistycznego. 


\section{SumMary \\ Phraseology and Linguistic Worldview}

This study focuses on the role and place of phraseology in the reconstruction of linguistic worldview. It is proposed that the general term linguistic worldview (Pol. językowy obraz świata, JOS) be used, in the way it is understood in the Leksykon aksjologiczny Stowian i ich sąsiadów [Axiological Lexicon of Slavs and Their Neighbours] (vols. 1-5, Lublin 2015-2019) and the Stownik stereotypów i symboli ludowych [Dictionary of Folk Stereotypes and Symbols] (vols. I-II, Lublin 1996-2019). Language embraces the formal, mental, and cultural spheres; its components are lexis and phraseology, the grammar of the sentence, the grammar of text, and discourse rules. Therefore, the use of 'fragmentary' terms like mental, cultural, phraseological, textual, or discourse worldview falsely suggests an autonomy of these spheres. 


\section{Wojciech Chlebda (1) \\ Uniwersytet Opolski, Opole \\ womich4@wp.pl}

\section{FRAZEOLOGICZNE ZAPLECZE JĘZYKOWEGO OBRAZU ŚWIATA}

Słowa klucze: frazeologia, formuliczność, oralność pierwotna, językowy obraz świata Keywords: phraseology, formulaicity, primary orality, linguistic worldview

Frazeologia jest jednym z podstawowych, wręcz fundamentalnych źródeł materiału językowego dla rekonstrukcji językowego obrazu świata; można by nawet powiedzieć, że wśród zjawisk językowych, które się w takich rekonstrukcjach wykorzystuje, obszar zajmowany przez frazeologię (a zwłaszcza przez frazeologię braną łącznie z paremiologią) zajmuje miejsce wyróżnione. Tę swoją szczególną pozycję $\mathrm{w}$ bazach materiałowych etnolingwistyki frazeologia/paremiologia zawdzięcza zapewne dwóm cechom: swojej dawności i swojej obrazowości. Pierwsza cecha, dawność, rodzi poczucie głębokiego zakorzenienia frazeologii w tradycji, mocnego osadzenia $\mathrm{w}$ danej kulturze, a tym samym gwarancji trwałości wyrażanych przez nią spostrzeżeń, sądów, wartości. Zakładamy, że skoro powtarzamy dane frazeologizmy czy przysłowia niekiedy od stuleci, skoro przetrwały one próbę czasu i zostały przeniesione przez kolejne pokolenia, to zawarte w nich spostrzeżenia, sądy i wartości muszą mieć rangę dla danej wspólnoty konstytutywną, a nie akcydentalną. Dla odtwarzania obrazu świata takich właśnie cech stałych, spetryfikowanych szukamy - i z takich cech ów obraz rekonstruujemy.

Druga cecha frazeologii/paremiologii, która przyciąga badaczy rekonstruktorów, to obrazowość. Hasło obrazowość jest nieobecne w ogólnych słownikach terminologii lingwistycznej ${ }^{1}$, ale zwyczajowo rozumiemy pod nim zawarte w leksykalnej strukturze frazeologizmów i przysłów nazwy różnych konkretów

1 Zwięzłą jego definicję odnalazłem jedynie w rosyjskim specjalistycznym słowniku terminologii frazeologicznej: „Образность ФЕ. Способность фразеологизмов содержать в семантической структуре мотивирующий их значение образ, т.е. наглядно-чувственное представление о предметах и явлениях объективной действительности, возникающее в результате семантической двуплановости (см.) устойчивого словосочетания" z odsyłaczami do trzech prac Jurija Gvozdarëva, Valerija Mokienki i Armanda Nazarâna; zob. Бирих, Волков, Никитина 1993: 47-48. 
przeszłości (jej realiów), tj. nazwy przedmiotów, postaci ludzkich, czynności codziennych i świątecznych, nazwy zwyczajów i rytuałów, zdarzeń małego i dużego kalibru itp., których konkretność (znaczeniowa dosłowność) jest przytłumiana, ale nie wypierana przez całościowe przenośne znaczenie danej jednostki frazeologicznej ${ }^{2}$. Nazwy te zastygły w strukturach utartych jednostek języka jak dawne owady w bryłkach bursztynu, a frazeologia wielu takim konkretom daje wręcz jedyną formę ich współczesnego życia; por.: pantałyk (w zbić z pantałyku), panewka (w spalić na panewce), mańka (w zażyć kogo z mańki), duby (w pleść duby smalone), koperczaki (w sadzić koperczaki do kogo), czarna polewka (w podać komu czarna polewkę) $)^{3}$. Rzecz jednak do archaizmów bynajmniej się nie sprowadza, frazeologia wyrasta z nazw wszelkich realiów (por.: młócić słomę 'mówić dużo, ale bez sensu', zapalać komu zielone światto 'stwarzać przestrzeń do działania', umywać ręce 'nie brać odpowiedzialności', szyć buty komu 'intrygować przeciwko komu', wieszać na kim psy 'oczerniać kogo', lekki jak piórko 'bardzo lekki’). Każdy konkret funduje obraz, a zbiory takich obrazów pozwalają, jak to - obrazowo właśnie - napisał Valerij Mokienko w książce o znaczącym tytule Образы русской речu, „прочесть скрижали забытого прошлого” - odczytać księgi zapomnianej przeszłości (Мокиенко 1986: 4). Dla etnolingwistów, których interesują procesy konceptualizacji świata w jego najdrobniejszych nawet cząstkach, obrazowość jest istotna w szukaniu odpowiedzi na pytanie, którą swoją stroną dany obiekt świata realnego obraca się ku językowi, którą ze swoich cech osadza we frazeologizmie, z jakich swoich przymiotów pozwala ludziom budować jego stereotyp jako „,mikroteorię danego przedmiotu”, część ,potocznej teorii rzeczywistości”.

Wszystko to są sprawy dla frazeologów i etnolingwistów stosunkowo oczywiste, ale warte przypomnienia, zanim przejdziemy do spraw mniej oczywistych. Do takich bowiem należy kwestia dla rekonstruktorów zupełnie fundamentalna, czyli pytanie, co właściwie tworzy tę frazeologię, która z kolei tworzy wspomnianą bazę dla rekonstrukcji językowego obrazu świata? Jeżeli zgodzimy się, że frazeologia (czy brana łącznie z paremiologią, czy bez niej) tworzy wyróżnioną bazę materiałową dla etnolingwistycznej rekonstrukcji narodowych wyobrażeń o świecie, to z kolei co właściwie tworzy frazeologię? Jaka substancja językowa ją funduje? Na podstawie czego tak naprawdę próbujemy odtworzyć językowy obraz świata?

2 Taką „przytłumioną dosłowność” odnośnie do frazeologizmów nazwałem niegdyś udosłownieniem, pisząc: „Dobitnie podkreślam rozróżnienie pojęć «dosłowny» i «udosłowniony», rozumiejąc przez «udosłownienie» dotarcie do znaczenia pierwotnego (dosłownego) przez pryzmat systemowego znaczenia przenośnego. «Udosłowniony» więc to tyle co dosłowny, ale z przymieszką składników odpowiedniego znaczenia przenośnego" (Chlebda 2005: 230, zob. też: 269).

3 Więcej tego rodzaju przykładów prezentuje słownik Pamiątki przeszłości Agnieszki Pieli (2018).

4 Potocznej, czyli zdroworozsądkowej, „naiwnej” w Apresjanowskim rozumieniu; więcej na ten temat zob. Bartmiński 2007: 67-69. 
Jak wiadomo, istnieją dwie zasadnicze i jednocześnie biegunowo przeciwstawne odpowiedzi na to pytanie. Pierwsza wyznacza frazeologii językowej stosunkowo wąskie granice i stosunkowo niewielki obszar, o którego zasięgu pewne wyobrażenie niosą dane słownikowe. Biorąc pod uwagę tylko uznane polskie słowniki frazeologiczne typu średniego i wielkiego, odnotujemy, że Słownik frazeologiczny współczesnej polszczyzny Stanisława Bąby i Jarosława Liberka zawiera 4 tysiące jednostek, Wielki stownik frazeologiczny Piotra Flicińskiego - 4,5 tysiąca, Popularny słownik frazeologiczny Katarzyny Głowińskiej - 5 tysięcy, Słownik elektroniczny jednostek frazeologicznych Moniki Czerepowickiej - 5 tysięcy. Nowatorski Stownik wspótczesnego języka polskiego pod red. Bogusława Dunaja - jedyny, który zrównuje w prawach frazeologizmy i wyrazy na pozycjach hasłowych - wyrazów utrwala 57 tysięcy, ale frazeologizmów - znowu 5 tysięcy, jakby te 5 tysięcy było w wyobrażeniach frazeografów liczbą graniczną. Strefę średnią czy pośrednią tworzy Wielki słownik frazeologiczny PWN z przysłowiami Anny Kłosińskiej, Elżbiety Sobol i Anny Stankiewicz z 17 tysiącami jednostek i Wielki słownikfrazeologiczny Renardy Lebdy z 18 tysiącami haseł. Stownik frazeologiczny Stanisława Skorupki Andrzej M. Lewicki oszacował na 200 tysięcy jednostek (Lewicki 2010: 637), co Piotr Müldner-Nieckowski (2007: 22) skorygował na 82 tysiące frazeologizmów, a z formami walencyjnymi - na 126 tysięcy jednostek. Sam Müldner-Nieckowski oszacował swój Wielki słownik frazeologiczny języka polskiego także na 200 tysięcy jednostek, co zresztą również wydaje się liczbą zawyżoną.

Ten zasadniczy przedział między 4-5 tysiącami frazeologizmów a umownymi 200 ich tysiącami odzwierciedla przedział między dwiema koncepcjami frazeologii, znanymi jako „wąska” i ,szeroka”. Wąska - to idiomatyczna koncepcja frazeologii, w której frazeologizm musi odpowiadać (na ogół łącznie) takim kryteriom, jak utartość, odtwarzalność, obrazowość, ekspresyjność, metaforyczność, będącymi dla wyodrębniania jednostek frazeologicznych kryteriami konstytutywnymi. Szeroka - to koncepcja, w której wymogi obrazowości i metaforyczności pozostają, ale schodzą na drugi plan bądź też w ogóle przestają mieć dla konstytuowania frazeologizmów jakiekolwiek znaczenie, ustępując miejsca cesze ich reprodukowalności (odtwarzalności) w konkretnych sytuacjach mówienia. W takim ujęciu przestaje być istotna nie tylko różnica między frazeologizmami i przysłowiami, ale także między nimi a całym szeregiem innych zjawisk odtwarzalnych w języku, jak terminy złożone, formuły etykietalne, złożone nazwy własne, skrzydlate słowa, napisy miejskie, mikroteksty użytkowe ${ }^{5}$ itp.

Jednak chociaż związana z tą koncepcją liczba 200 tysięcy frazeologizmów działa na naszą wyobraźnię, nie sposób nie zapytać, jak się ona ma do innego

\footnotetext{
To, co nazywam tu mikrotekstami użytkowymi, wydaje się tworzyć strefę pograniczną między jednostkami języka (światem systemu) i tekstami (światem wypowiedzi). Ponieważ chodzi o małe teksty kliszowane, a więc reprodukowalne, jestem skłonny odnosić je jednak do jednostek systemu; zob. na ten temat Chlebda 2018.
} 
wskaźnika wielkości zasobów frazeologicznych, sformułowanego 30 lat temu przez Andrzeja Bogusławskiego. Ten znakomity uczony napisał, że wyrażenia wielowyrazowe zajmują w zasobach języka miejsce wyróżnione: „Jest ich na pewno bez porównania więcej niż jednostek jednowyrazowych - idą one jawnie w grube miliony, podczas gdy jednowyrazowce nawet przy rozszczepieniu znaczeniowym tworzą raczej grupę rzędu setek tysięcy" (Bogusławski 1989: 19). W latach 90. podczas panelu frazeologicznego w Łodzi Bogusławski powiedział nawet publicznie, że chodzi mu o wielkość rzędu setek milionów „wielowyrazowców odtwarzalnych", czyli frazeologizmów. To już jest zupełnie nowa jakość: okazuje się, że wyrazów jest w języku, zdaniem Bogusławskiego, wielokrotnie mniej niż frazeologizmów, co jawnie kłóci się z naszym potocznym wyobrażeniem o zasobach języka (można powiedzieć, że wspomniany słownik Dunaja ilustruje właśnie to potoczne wyobrażenie o proporcji jedno- i wielowyrazowców w języku: 57 tysięcy wyrazów, 5 tysięcy frazeologizmów; tak właśnie większość ludzi, nawet wielu językoznawców, myśli o składowych języka). Druga nowość to wręcz oszałamiająca liczba frazeologizmów: setki milionów, co by oznaczało, że wszystkie nasze słowniki frazeologiczne razem wzięte utrwaliły zaledwie promil rzeczywistych zasobów frazeologii naszego języka. Tych setek milionów nie jesteśmy w stanie nawet sobie wyobrazić, nie możemy też tych milionów poddać weryfikacji, dlatego, mówiąc otwarcie, nawet osoby cytujące przywołany sąd Bogusławskiego chyba czasem w jego prawdziwość powątpiewają.

Ale A. Bogusławski to zbyt wielka postać lingwistyki, by jego sądy zbyć prostym wzruszeniem ramion ${ }^{6}$. Gdyby udało się dowieść prawdziwości sądu Bogusławskiego odnośnie do liczby frazeologizmów (ściślej: wielowyrazowych jednostek języka) w zasobach systemu językowego i ich zdecydowanej przewagi nad wyrazami, oznaczałoby to jakościowy przewrót w naszym myśleniu o języku, a w kontekście pytań o rekonstrukcję językowego obrazu świata oznaczałoby, że materialna frazeologiczna baza językowa tej rekonstrukcji poszerza się o wiele rzędów wielkości. To dlatego stawiałem na początku pytanie, z czego realnie składają się zasoby frazeologiczne języka, na podstawie czego mamy ów obraz świata rekonstruować, co jest potencjalną bazą takiej rekonstrukcji i w sensie jej zasięgu (aspekt ilościowy), i w sensie rodzaju tworzącej ją substancji języka (aspekt jakościowy). To pytania fundamentalne zarówno dla etnolingwistów, jak i samych frazeologów.

Przyjąwszy, że Bogusławski ma rację i że nasz język składa się przede wszystkim z odłożonych w systemie wielowyrazowców (liczonych w setkach milionów)

6 Warto dodać, że inna wielka postać lingwistyki, Igor Mel'čuk, rozwija myśl bardzo do Bogusławskiego zbliżoną, nawet radykalniej sformułowaną: ludzie nie mówią wyrazami, ludzie mówią frazemami („People do not speak in words, they speak in phrasemes”); na ten temat zob. Mel'čuk 1995. 
i w niewielkiej części z wyrazów, zadałem sobie pytanie jeszcze bardziej podstawowe, prymarne wobec pytań kończących poprzedni akapit: dlaczego w ogóle powstały w języku jednostki wielowyrazowe, i to w tak zdumiewającej ilości? Dlaczego, kiedy i z jakich przyczyn poczęła się w języku zawiązywać frazeologia? Dlaczego ludzie nie poprzestali na wyrazach i na tworzeniu ich konfiguracji? Czy nie byłoby wygodniej, a nawet ekonomiczniej, mieć do komunikacyjnej dyspozycji pewną liczbę wyrazów jako znaków prostych, które, tworząc wypowiedzi, wprawiałoby się w ruch przy zastosowaniu reguł danej gramatyki? Czy nie wygodniej, a nawet ekonomiczniej, byłoby utrzymywać w pamięci językowej stosunkowo krótkie „znaki odrębnych desygnatów”7, zwane wyrazami, niż - obok nich, ale jednak na „miejscu wyróżnionym” - także „grube miliony” wielowyrazowych nazw odrębnych desygnatów? Pierwsza próba odpowiedzi, z grubsza jedynie zarysowana ${ }^{8}$, jest następująca.

Ta frazeologia, którą Bogusławski szacuje na grube miliony i która tak przenika język, że ludzie „mówią frazemami”, stanowi echo czy pozostałość, a tym samym świadectwo tego etapu rozwoju języka naturalnego, który nazywamy oralnością pierwotną, okresem przedpiśmiennym, po którym nie pozostał żaden materialny ślad - żaden poza frazeologią i paremiologią. To okres, w którym, jak dowodzi część badaczy, samo pojęcie wyrazu, tak dzisiaj dla nas oczywiste, jeszcze się nie wykrystalizowało. To dopiero pismo stworzyło wyraz jako samodzielną jednostkę budulcową języka, w okresie przedpiśmiennym zaś jednostką użytkową ludzkiej komunikacji była formuła. Tak pisał o niej Walter J. Ong: „nie tylko poeci [greccy], lecz cały świat oralnej noetyki, w tym świat myśli, opierał się na formułowym sposobie myślenia. Kultura oralna musi ciągle powtarzać raz zdobytac wiedzę - w przeciwnym razie ulega ona zapomnieniu; formułowe, stałe wzorce myślowe są istotne dla mądrości i efektywnego funkcjonowania” (Ong 2011: 58). Formuła, definiowana jako ,grupa słów używanych zawsze w tych samych pozycjach metrycznych do wyrażenia pewnych podstawowych treści” (Lord 2010: 109), stała się dla Onga, Alberta B. Lorda, Milmana Parry’ego czy Erica A. Havelocka podstawową kategorią opisu tekstów znanych co prawda z wersji zapisanych (jak eposy homeryckie) lub spisywanych z nagrań (jak pieśni guslarów bałkańskich), ale ukształtowanych w epoce przedpiśmiennej lub też przez ludzi niepiśmiennych, a więc pozwalających rekonstruować pierwotne oralne mechanizmy

Znaki odrębnych desygnatów to trafne określenie Witolda Doroszewskiego, który napisał: „Słownik jest zbiorem wyrazów i takich połączeń wyrazowych, które są jednostkami leksykalnymi, to znaczy pełnią takie same funkcje jak wyrazy pojedyncze, a więc są jako całości znakami odrębnych desygnatów. Pod tym względem między wyrazami a związkami wyrazowymi zasadniczej różnicy nie ma" (Doroszewski 1954: 85).

8 Szeroko rozwiniętą próbę odpowiedzi przedstawiam w rozprawce Nieskończona frazeologia. Esej o poczatkach, zamykającej drugi tom Polsko-rosyjskiego słownika par przekładowych (Chlebda 2020b). 
tworzenia, memoryzowania i odtwarzania tekstów. Wymienieni badacze doszli do wniosku, że

efektywne rozwiązanie problemu przechowania i odzyskania pieczołowicie wyartykułowanej myśli wymaga w pierwotnej kulturze oralnej, by myślenie odbywało się z pomocą wzorów mnemonicznych, ukształtowanych z myślą o wielokrotnym użyciu oralnym. Wypowiadana myśl musi przybrać kształt silnie zrytmizowanych, równoważnych jednostek [patterns], powtórzeń lub antytez, aliteracji i asonansów, wyrażeń epitetowych i formułowych, standardowych układów tematycznych [...], przysłów, które ciągle się słyszy, dzięki czemu łatwo przychodzą na myśl, a ukształtowano je z myślą o przechowaniu i łatwym przypomnieniu, lub w każdej innej postaci mnemonicznej. Doniosłą myśl spleciono z systemem pamięciowym. Wymogi mnemoniki są wiążące nawet dla składni. [...] Formuły pomagają organizować zrytmizowany dyskurs, działają też same z siebie jako wsparcie mnemoniczne, będąc zbiorem wyrażeń ciągle używanych przez wszystkich (Ong 2011: 73).

Formuliczność jest kategorią przywoływaną także w analizach folkloru polskiego:

Tekst przekształca się w formułę, która w określonych okolicznościach ma zostać powtórzona w określonej formie określoną ilość razy (zwykle trzy). Jeśli formułą staje się tekst wielozdaniowy, to jego komponenty wymykają się stopniowo spod reguł gramatyki i przyjmują postać niezmienną (Bartmiński 1990: 182).

Czy spostrzeżenia te można ekstrapolować także na inne obszary komunikacji ludzkiej okresu przedpiśmiennego? Chciałbym postawić tezę, że jednostką operacyjną w komunikacji okresu oralności pierwotnej był komunikat, komunikacyjny „odcinek mówienia”, wyrazy zaś, przynajmniej w dzisiejszym rozumieniu, były czymś w języku wtórnym, pochodnym - pochodnym właśnie od komunikatów. Tak, nawiasem mówiąc, twierdzą też niektórzy psycholingwiści i badacze języka dzieci w ontogenezie, jak Michael Halliday czy Jane Aitchison'; ten sąd podtrzymują też wyznawcy holistycznej koncepcji protojęzyka w wymiarze filogenezy, twierdząc, że

9 Halliday twierdzi np., że „,chociaż wyraz jako jednostka leksykalna, czyli leksem (tj. jednostka słownika), wcześnie zaczyna odgrywać zasadniczą rolę w rozwoju systemu językowego, to wyraz rozumiany jako jednostka strukturalna (a jest to pojęcie odrębne) ma z początku dużo mniejsze znaczenie. Wyraz jest tylko jednym z możliwych składników wypowiedzi, a małe dziecko w ogóle nie uświadamia sobie jeszcze jego roli jako składnika [...]. Z funkcjonalnego punktu widzenia język istnieje od chwili pojawienia się wyrażeń znaczących i można go badać zanim jeszcze ukształtują się wyrazy i struktury, które staną się nośnikami znaczeń” (Halliday 1980: 521-522; wyróżnienie moje - W.Ch.). W tym kontekście zob. też: Aitchison 1991: 277. 
holistyczny protojęzyk nie dopuszcza możliwości kompozycjonalnego budowania komunikatów, a jego poszczególne wyrażenia są «atomami» pozbawionymi wewnętrznej struktury. W koncepcji holistycznej wyrażenia niosą treść odpowiadającą treści niesionej we współczesnych językach przez całe frazy lub zdania i są nabywane i używane jako niepodzielne całości. Dopiero kolejny etap rozwoju języka stanowiłoby odkrycie możliwości dekompozycji wyrażeń i fragmentacja na elementy odpowiadające dzisiejszym słowom (Wacewicz 2013: 19; zob. też: Żywiczyński, Wacewicz 2015).

Rozumiem to tak, że w procesie przechodzenia od protojęzyka (przedjęzykowego, ale postanimalnego systemu komunikacji) do języka właściwego komunikat - „krótki odcinek mowy”, o którym mówią badacze ewolucji języka - w zależności od potrzeb komunikacyjnych albo pozostawał „krótkim odcinkiem”, bo okazywał się „dobrze zorganizowaną postacią komunikatu” (jak to określał Roman Jakobson; 1972: 32) i odpowiadał późniejszemu pojęciu formuły, albo różnicował się i rozpadał na inne „krótkie odcinki” - jedne odpowiadające pojęciu jednowyrazowca, inne - pojęciu wielowyrazowca. Nie tyle więc w trakcie tworzenia komunikatu dokładano słowo do słowa, jak to sobie dzisiaj wyobrażamy, ile raczej na odwrót: z ciągów werbalnych o funkcji komunikatu (z „odcinków mowy”) wyodrębniały się w procesach makrokomunikacji, czyli w długiej perspektywie czasowej, krótsze odcinki - jedne o postaci dzisiejszych wyrazów, inne o postaci dzisiejszych frazeologizmów. Było zaś wiele przyczyn i racji, dla których odcinki wielowyrazowe okazywały się bardziej ekonomiczne i sprawne w komunikacji i ostatecznie zyskały w zasobach języka przewagę. Jakie to przyczyny?

Nie sposób w krótkim tekście przywołać je wszystkie, a tym bardziej nie sposób ich w sposób należyty scharakteryzować. Jeżeli to, o czym ludzie coś mówią, co sobie komunikują, to, co przekazują sobie nawzajem w interakcjach werbalnych, nazwiemy umownie ,porcjami doświadczenia” (to owe ,podstawowe treści”, które według Lorda niesione są przez formuły), to czynnikiem dającym przewagę formom wielowyrazowym jest złożoność wielu porcji doświadczenia, która nie daje się zamknąć w objętości jednego wyrazu ${ }^{10}$. Idzie za tym nieprzemożna, egzystencjalnie ważna potrzeba kategoryzowania i precyzowania porcji doświadczenia, co wymaga budowania całostek werbalnych złożonych z dwóch części: rodzajowej i gatunkującej; bez tego niemożliwe byłoby wszak budowanie klasyfikacji i typologii, a więc i porządkowanie świata. Dodajmy do tego potrzebę wyrażania relacji między obiektami - a wyrażanie relacji również wymaga

10 Najbardziej wyrazistym przykładem takich złożonych porcji doświadczenia, które wymagają zwerbalizowania ich w formułach wielowyrazowych, są przysłowia i wyrażenia przysłowiowe, idące w zasobach języków narodowych w dziesiątki tysięcy (np. wielki słownik przysłów języka rosyjskiego gromadzi 70 tysięcy paremii; zob. Мокиенко, Никитина, Николаева 2010). 
użycia co najmniej dwóch-trzech segmentów werbalnych nazywających to, co w zakres relacji wchodzi. Szczególną rolę pośród relacji międzyobiektowych grały relacje nadawczo-odbiorcze między komunikującymi się ludźmi, rozumiane przeze mnie również jako mechanizm budowania wspólnoty. Rozumiem to tak, że pojedynczy, izolowany wyraz nie nosi na sobie śladu ludzkich operacji na nim, jest w tym sensie bezosobowy, a jego przywołanie charakteryzuje określona przypadkowość - podczas gdy zestawienia dwóch-trzech wyrazów musiał kiedyś dokonać ktoś konkretny, choćby i anonimowy; jeżeli teraz ktoś inny to zestawienie przywołuje, przywołaniem tym buduje ciągłość między czyimiś użyciami wcześniejszymi i swoim teraźniejszym, a to (co prawda wolno i niepostrzeżenie) poprzez ową ciągłość buduje poczucie wspólnoty. Uformowany ciąg werbalny zawdzięcza swój kształt nie przypadkowi, ale tradycji, nierzadko głębokiej, dlatego formuliczność sprzyja budowaniu tożsamości wspólnotowej ${ }^{11}$.

Zwracam na koniec uwagę na czynniki rytualne, magiczne, sakralne czy wprost religijne ${ }^{12}$, które nie tyle dla samego zwerbalizowania treści, ile dla skutecznego oddziałania na odbiorców potrzebowały wewnętrznych rymów, antytez, rytmizowania (co wiąże się też z czynnikami czysto mnemonicznymi), których zaistnienie możliwe jest wyłącznie w ramach ciągów co najmniej dwuwyrazowych. Stanisław Koziara trafnie dostrzegł, że zapisana i nam, współczesnym, znana już tylko w owej wersji pisanej treść Biblii wyrosła na gruncie wielowiekowej hebrajskiej i grecko-rzymskiej tradycji retorycznej, tj. z przekazu mówionego kształtowanego przez miary i schematy, którym późniejsza retoryka nadała nazwy chiazmu, hiperboli, antytezy, synkrezy, meryzmu czy toposu, a więc, jak to określam, przez „kształty formuliczne” w najszerszym rozumieniu (Koziara 2018). Jeżeli owe „miary i schematy” miały zaistnieć i spełniać swe funkcje, preferowane musiały być formuly wielosegmentowe.

Te czynniki (i zapewne wiele innych) dawały wielowyrazowcom przewagę. Przy tym wysiłek wkładany w konfigurowanie elementarnych składników budulcowych od podstaw, w wytwarzanie za każdym razem nowego zestawienia segmentów musiał pochłaniać więcej energii i był mniej ekonomiczny niż posługiwanie się ciągami wielosegmentowymi już wcześniej zestawionymi i w sytuacjach potrzeb komunikacyjnych wypróbowanymi; tak więc także i czynnik ekonomiczny dawał przewagę utartym wielowyrazowcom. Myślę więc, że formuliczności nie można ograniczać jedynie do folkloru, choćby najszerzej rozumianego: formu-

11 Tym samym odwołuję się także do czynnika dawności, o którym była mowa w pierwszym akapicie tego tekstu: kształtowaniu formulicznemu podlegają te werbalizatory „,porcji doświadczenia", które są relewantne dla danej wspólnoty (choćby nią była niewielka grupa ludzka) i które w drodze niepisanych uzgodnień społecznych uznaje się za warte przekazywania dalej w czasie, niekiedy przez wiele pokoleń.

12 Sugestię uwzględnienia w tym przeglądzie czynnika religijnego zawdzięczam Stanisławowi Koziarze. Zob. też: Obirek 2010. 
liczność ma naturę holistyczną i ogarnia całość komunikacji ludzkiej, wszystkie możliwe jej lekty. Ta frazeologia, którą oceniamy na 5 tysięcy jednostek, stanowi tylko uprzywilejowane badawczo jądro formulicznych zasobów języka; ta frazeologia, którą oceniamy na umowne 200 tysięcy jednostek, stanowi strefę przyjądrową - ale poza nimi rozciąga się ogromna sfera frazeologii najszerzej pojmowanej, która się w żadnej standardowej definicji frazeologii nie mieści, lecz która buduje samą substancję ludzkiej komunikacji i która rzeczywiście zdaje się osiągać przewidziane przez Bogusławskiego ,grube miliony”.

W tym właśnie kontekście postrzegam frazeologię dialektalną czy gwarową. Dzisiaj jest ona - a przynajmniej to, co z niej pozostało - spisana bądź spisywana, ale przez wieki jej naturalnym żywiołem był język mówiony - jeszcze niedotknięty, nieskażony przez pismo i przez świadomość słowa pisanego. Gwary niosą w sobie echo archaicznego stanu komunikowania się ludzi przedpiśmiennych i ludzi niepiśmiennych $^{13}$, które to komunikowanie się z przyczyn zarysowanych wyżej było, jak zakładam, bo musiało być, formuliczne (a więc frazeologiczne w najszerszym z możliwych znaczeniu). Jeżeli badania frazeologiczne - w tym etnolingwistyczne analizy frazeologii dla celów rekonstrukcji obrazów świata - przyjmą za swą bazę owe zaczarowane 5 tysięcy jednostek (a choćby nawet i owe zakładane 200 tysięcy), będziemy się stale poruszać po jednym i tym samym polu materiałowym. Tymczasem frazeologia pojmowana jako pochodna formuliczności języka obejmuje wszystkie lekty przeszłej i teraźniejszej komunikacji ludzkiej - i wszystkie te lekty należy objąć frazeologicznym instrumentarium poznawczym. Gwary ze względu na swą dawność, pierwotność, przedpiśmienną prymarność należą w tym kontekście do lektów o szczególnym znaczeniu. Studia poświęcone właśnie frazeologii gwar dają jej szansę wyjścia z poznawczego cienia, samym frazeologom zaś dają szansę dotarcia do źródeł procesu zawiązywania się frazeologii w języku w ogóle.

\section{SUMMARY \\ Phraseological Background of the Linguistic Worldview}

The author poses the fundamental question for theoretical phraseology and ethnolinguistics, what in fact - i.e. what verbal matter - creates language phraseology, and thus on what material basis ethnolinguists are trying to recreate the language images of selected fragments of reality. In search of answers, the author reaches back to the times of primary orality, the Literacy Theory and the research of Walter J. Ong, Milman Perry, Albert B. Lord and Eric A. Havelock on the formulas of human pre-literal

13 Rozróżniam te dwa pojęcia, przez ludzi przedpiśmiennych rozumiejąc ludzi komunikujących się w erze oralności pierwotnej, przez niepiśmiennych zaś - ludzi nie znających pisma, choć żyjących w galaktyce Gutenberga (analfabetów). 
statements. The author concludes that the formulas are not limited to Homeric epics and Balkan guslar songs, but that it is holistic in nature, it has embraced all forms of human communication in the past, and its contemporary evidence is the most widely understood phraseology (including paremiology). Thus, the author proves the rightness of Andrzej Bogusławski's thesis about the existence of many millions of fixed multi-word units in language resources, codified lexicographically only minimally. This sheds new light on the phraseological basis of ethnolinguistic reconstructions of the linguistic worldview (language picture of the world). 


\author{
НАТАЛІЯ ВЕНЖИНОВИЧ (D \\ УЖГОРОДСЬКИЙ НАЦІОНАЛЬНИЙ УНІВЕРСИТЕТ, УЖГОРОД, УКРАЇНА \\ vennata2017@gmail.com
}

\title{
ДІАЛЕКТНА ФРАЗЕМІКА ЯК ПРЕДМЕТ \\ ЛІНГВОКУЛЬТУРОЛОГЧІНОГО АНАЛІЗУ
}

Ключові слова: фразема, діалектна фраземіка, лінгвокультурологічний аналіз

Keywords: phrase, dialect phrase studies, linguoculturological analysis

Діалектна фразеологія виділилася в українському мовознавстві порівняно недавно, передусім завдяки науковим дослідженням Бориса Ларіна, Степана Бевзенка та ін. У 1959 р. у програмній доповіді Про народну фразеологію Б. Ларін окреслив місце діалектної фразеології у системі наук, визначив внутрішньо-семантичну сутність фразеологізмів, виокремивши актуальні завдання щодо вивчення народної фразеології у вузькому значенні, тобто діалектної фразеології - частини національної мови, яка „і створюється, і живе в мові народних мас": розмежування діалектної та літературної фразеології, створення обласних словників, необхідність тривалих і вмілих пошуків та записів фразеологічного матеріалу „з усієї території поширення української мови" (Ларін 1959: 35).

Діалектна фразеологічна одиниця - це відносно цілісне словосполучення (іменного, ад'єктивного, дієслівного, адвербіального типу) зі складною семантичною структурою, функціонування якого обмежується певною територією. До діалектних фразеологічних одиниць зараховують: фразеологічні одиниці - терміни певного діалекту; фразеологічні одиниці, які не відомі загальнонародній мові; фразеологічні одиниці, які мають у своєму складі діалектні слова чи форми; фразеологічні одиниці, які збігаються за своїм компонентним складом із відповідними фразеологічними одиницями загальнонародної мови, але відрізняються від них змістом; тавтологічні фразеологічні одиниці; трансформовані фразеологічні одиниці загальнонародної мови; фразеологізми, які $є$ варіантами загальнонародних фразеологічних одиниць; синтаксично трансформовані фразеологічні одиниці; фразеологічні одиниці, в яких відображено специфіку побуту та трудової діяльності народу. 
Мар’ян Демський зазначає: „Фраземи, принаймні наявні в слов’янських мовах, мають одну дуже цікаву властивість: вони позначають далеко не все пізнане людиною, а лише ті моменти, які з точки зору мовного колективу необхідно представити образно, емоційно, експресивно" (Демський 1994: 8).

Упродовж останніх десятиліть українська діалектна фразеологія досягла значних успіхів у зборі, фіксації й аналізі фразеологічного фонду української національної мови, почала вивчатися досить інтенсивно, незважаючи на труднощі, пов'язані зі збиранням діалектного матеріалу, опрацюванням та апробацією методів його дослідження. Важливий фразеологічний матеріал зафіксовано у словниках діалектної лексики, які фіксують стан фразеологічних систем українських говірок на сучасному етапі, зокрема цікавими $\epsilon$ найновіші лексикографічні видання 2019 р. Наталії та Бориса Коваленків (Коваленко Н.Д. 2019; Коваленко Б.О., Коваленко Н.Д. 2019). І вже зовсім недавно, наприкінці 2019 р., вийшов із друку перший том грунтовного словника вчених Прикарпатського національного університету Гуиульська діалектна лексика та фраземіка в украӥнській художній прозі за редакцією Василя Грещука (2019). Ці лексикографічні джерела, безперечно, стануть надійним джерелом для майбутніх лінгвокультурологічних студій.

У другій половині XX ст. з'являється значна кількість наукових праць, у яких розглянуто теоретичні і практичні питання діалектної фразеології, зокрема й лінгвокультурологічний аспект вивчення цих мовних одиниць. Серед них виокремимо такі публікації: (Бабич 1970-1971, 1978; Демський 1994; Венжинович 2007, 2012, 2016; Прадід 1992 та ін.).

Нині опубліковано праці, в яких розглянуті теоретичні питання української діалектної фразеології, що висвітлюють у різних аспектах і напрямках, зокрема встановлення культурно-національного компонента ареальних фразеологічних одиниць.

У низці досліджень із діалектної фразеології зроблено спроби визначити поняття діалектної фразеології, розмежувати фразеологізми національної, літературної та діалектної мовних систем. Досі немає загальноприйнятого визначення і єдиного розуміння поняття діалектна фразеологічна одиниця, що безпосередньо пов'язано із розв'язанням попередніх питань. У сучасній лінгвістиці немає одностайності щодо визначення поняття діалектна фразеологія. Мовознавці паралельно використовують терміни народна фразеологія, ареальна фразеологія, говіркова фразеологія, фраземіка діалекту, діалектна фраземіка. Зокрема, дослідник фразеології карпатського регіону Василь Лавер зазначає, що діалектну фразеологію творить сукупність фразеологізмів окремих наріч, говорів, говірок. Об'єктом вивчення діалектної фразеології, на думку вченого, є „фразема, що має територіально обмежене поширення, тобто мовна одиниця, яка виникла і функціонує в даному наріччі, діалекті”. Мовознавець формує своє визначення діалектної фразеологічної одиниці: 
„Терміни діалектна фраземіка, діалектна фразема неправильно змішувати 3 поняттям народна мудрість, народна фраземіка, як не можна ототожнювати терміни діалектна фразема 3 поняттями прислів'я, приказка, приповідка i т. д.” (Лавер 1991: 15). Лариса Скрипник для позначення специфічного різновиду фразеологізму загальнонародної мови, який уживається в різножанрових усних народних творах, використовує термін фольклорна фразеологія (Скрипник 1971: 58-65).

Віктор Ужченко, на нашу думку, найбільш влучним вважає термін ареальна фразеологічна одиниия, що корелює з терміном фразеологічна одиницяя як часткове із загальним у просторовій і стильовій проекції. Причинами утвердження понять ареальний, ареалогія, ареальні системи мови, структура ареальних систем учений називає розмитість поняття народна фразеологія, труднощі у визначенні специфічно місцевих фразеологізмів, наявність міждіалектних і міжмовних варіантів однієї фразеологічні одиниці, ареальний аспект місцевої фразеології, акцент на просторове іiі вивчення. До кола ареальної (діалектної) фразеології В. Ужченко відносить такі фразеологічні одиниці: які не фіксуються лексико- і фразеографічними працями літературної мови; які відрізняються від фіксованих у нормативних працях фразеологічних одиниць семантичною структурою чи формальними ознаками (фразеологічні одиниці з діалектними словами; фразеологічні одиниці, які компонентним складом відрізняються від нормативних; фразеологічні одиниці з іншою порівняно з літературними фразеологічним одиницями семантикою); мікрофразеологізми, тобто вислови, які вербалізують мікролокальні реалії (Ужченко 2003: 13-14).

Серед монографічних досліджень, що фіксують фразеологічний склад діалектних систем у XX столітті, важливо згадати працю Анатолія Івченка Українська народна фразеологія: ономасіологія, ареали, етимологія (1999), в якій автор досліджує фразеологію українських народних говорів, зафіксовану впродовж XVIII-XX ст. Монографія є синтетичним та узагальнювальним дослідженням української народної фразеології як цілісної системи, в якому об'єднано опис ономасіологічних процесів найпродуктивніших семантичних груп із метою виявлення закономірностей фразеотворенння на рівні структурно-семантичних моделей. Оперуючи значним фактичним матеріалом, автор на рівні структурно-семантичних моделей виділив 7 ареальних зон, провів етимологічний аналіз 31 фразеологічної одиниці, розподілив усі моделі на архаїчні та інноваційні.

Уперше в українській фразеологічній науці проаналізовано фразеотворчі процеси у значному обсязі з використанням психолінгвістичного експерименту субстандартні фразеологічні одиниці східнослобожанських та східностепових говірок Луганщини й Донеччини у науковому дослідженні Романа Міняйла (2001). 
Цікавим є дисертаційне дослідження Н. Коваленко (2001), яка аналізує фразеологічні одиниці шляхом ідеографічного опису західноподільських говірок, визначає структурно-семантичніі семантичні моделі та їх ареальний аналіз. Завдяки грунтовному, різнобічному аналізу взаємодії фразеологічних одиниць говірок із фразеологічним корпусом української літературної мови дослідниця виокремлює 4 групи фразеологічних одиниць суміжних і дистантних зон України: 1) фразеологічні одиниці, семантика, структура та компонентний склад яких збігаються; 2) фразеологічні одиниці з відмінними лексичними одиницями; 3) фразеологічні одиниці однакового компонентного складу, але різні за семантикою; 4) фразеологічні одиниці, які виявляють початкову інваріантну структурно-семантичну модель для певного ряду фразеологізмів. Виокремлено й проаналізовано фразеосемантичні поля, найпродуктивніші фразеосемантичні групи, семантичні ряди, пов'язані з життям та діяльністю людини: „Фізичний стан людини”, „Положення тіла в просторі”, „Розумова діяльність людини”, „Мовленнєва діяльність людини”, „Соціальний стан” тощо. У цій праці розглянуто структурно-семантичні та семантичні моделі, у яких простежуються особливості варіювань фразеологічних одиниць, а також окреслено коло проблем, пов'язаних із збиранням та опрацюванням діалектного матеріалу, апробацією методів його дослідження. Наталія Романюк (2002), досліджуючи фразеологію верхньонаддністрянських говірок нижньої течії річки Бистриці, уперше здійснила спробу комплексного діахронно-синхронного аналізу діалектних фразеологічних одиниць, описала особливості, причини і способи їх структурних і семантичних трансформацій. У науковій розвідці описано теоретичні засади вивчення фразеологізмів, подано огляд основних структурно-семантичних, функціонально-стилістичних класифікацій фразеологізмів, а також відомості про способи й причини трансформації зовнішньої та внутрішньої форм фразеологічних одиниць. Авторка проаналізувала типи якісної й кількісної трансформації структури діалектних фразеологічних одиниць, зокрема заміну компонентів діалектних фразеологізмів, редукцію та поширення структури діалектних фразеологічних одиниць, контамінацію й фразеологічний натяк. Окремо розглянуто семантичні особливості діалектних фразеологічних одиниць та трансформації їхньої внутрішньої будови в діахронному аспекті. Серед основних проблем вивчення діалектної фразеології авторка називає такі: необхідність вироблення чіткої схеми систематизації діалектних фразеологічних одиниць, та ïx структурного впорядкування, оскільки різні за походженням, експресивно-стилістичним забарвленням, способом вираження, структурою, широтою функціонального та стильового використання діалектних фразеологічних одиниць, вимагають і диференційованого підходу до їх вивчення; труднощі у виявленні специфіки фразеологічних одиниць, певного говору; встановлення їх особливостей на будь-якому мовному рівні, а також вивчення їх історичного розвитку. 
Ольга Плетнєва у своєму науковому дослідженні висвітлила фразеологію говірок центральної Слобожанщини. Значну увагу дослідниця звертає на особливості семантики та структури діалектних фразеологічних одиниць. У праці розглянуто поняття народної, загальнонародної та діалектної фразеології, а також фразеології діалекту. Також досліджено конотативні та лінгвокультурні компоненти значення діалектних фразеологічних одиниць як виразників національної своєрідності мови, менталітету іiі носіїв. Авторка визначила близько 200 структурно-семантичних моделей діалектних фразем та проаналізувала 103 найпродуктивніші структурно-семантичні моделі. Переважна більшість діалектних фразем належить до фразеотематичної групи „Людина”. Специфіка фразеологічних структурно-семантичних моделей зумовлена метонімічним або метафоричним характером переосмислення вільного словосполучення і тісно пов'язана з характерними складниками національної мовної картини світу. У праці також розглянуто системні зв'язки фразеологізмів говірок центральної Слобожанщини, подано характеристику явища фразеологічної варіантності, визначено та схарактеризовано види варіантності діалектних фразему досліджуваних говірках. У дисертації наголошується, що фразеологія центральної Слобожанщини є динамічною системою, а в основі образів діалектних фразеологічних одиниць лежать константи української культури, національні символи та етнокультурні реалії (Плетнєва 2004).

Тетяна Д'якова у своєму дисертаційному дослідженні вперше розглянула фразеологічну репрезентацію мовної картини світу ареалу як складник загальнонаціональної мовної картини світу. Авторка встановила зв'язок фразеологізмів з етнокультурою, висвітлила особливості творення ареальної картини світу, з'ясувала специфіку сематики та структури ареальної фразеологічної одиниці, виявила та проаналізувала характерні структурносемантичні іï моделі. У роботі окреслено особливості мотивації діалектних фразеологізмів з урахуванням духовної культури діалектоносіїв, простежено зв'язок сучасної фразеологічної картини світу з давніми традиціями, обрядами мешканців аналізованого регіону та загальнослов'янського континууму. Дослідниця навела методику виявлення глибини культурно-національної конотації ареальних фразеологізмів за допомогою психолінгвістичного асоціативного та соціолінгвістичного експериментів (Д'якова 2011). Оксана Шкуран (2011) у своїй науковій розвідці вперше дослідила широкий пласт діалектної компаративної фразеології східнослобожанських і східностепових говірок Середнього Подінців’я. Авторка проаналізувала динаміку компаративного фонду, виділила 98 структурно-семантичних моделей 3 компонентами-зоономенами, артефактами, охарактеризувала 56 фразеосемантичних рядів поняття „людина”, зокрема, пов'язаних із характером, розумовими здібностями, фізичними ознаками, моральними якостями. Вона визначила 
роль концептів-зоономенів, флорономенів, артефактів у ареальному компаративному фразеотворенні та виявила глибину їх вертикального культурнонаціонального контексту. А Віктор Чабаненко стверджує, що „місцеві фразеологізми органічно входять до системи експресивних засобів діалектного мовлення і $є$ вдячним матеріалом для дослідження соціолінгвістичних та психолінгвістичних основ говіркової мовленнєвої виразності, для дослідження естетичної, емотивної та волюнтативної функції живого народного мовлення, для дослідження стильової диференціації цього мовлення" (Чабаненко 1978: 105).

Закарпаття - це унікальний регіон, який упродовж багатьох віків був відірваний від споконвічних українських земель, перебуваючи у складі Угорщини, Австро-Угорщини, Чехословаччини. Українська мова на цій території завжди перепліталась з угорською, словацькою, румунською, чеською. Лише з 1945 р. після об'єднання Закарпаття з Україною закарпатці почали усвідомлювати себе українцями, а отже, розпочався розвиток української літературної мови на території регіону. Зважаючи на історичні передумови, невипадково все більше мовознавців займаються дослідженням закарпатських говорів, однак прогалиною у дослідженнях залишається мова художніх творів сучасних закарпатоукраїнських письменників.

Різноманіття мов і діалектів на Закарпатті здавна привертало увагу науковців. Нині грунтовно вивчені закарпатські говори, що представлено в багатьох наукових працях мовознавців Василя Німчука, Степана Бевзенка, Йосипа Дзендзелівського, Василя Добоша, Петра изанця, Михайла Сюська, Павла Чучки, Івана Сабадоша, Кирила Галаса, Миколи Грицака та ін.). Також науковці приділяли увагу фразеологічній системі закарпатських говорів у своїх працях, зокрема: С. Бевзенко, Й. Дзендзелівський, В. Лавер, а за останнє десятиріччя - Наталія Венжинович. Увагу мовознавців привертала творчість закарпатоукраїнських письменників, розвідки яких стосувалися в основному лексики (М. Сюсько, П. Лизанець, М. Грицак). Й. Дзендзелівський одним із перших порушив питання картографування компонентних варіантів діалектних фразем в українському мовознавстві.

Фраземікою закарпатського діалекту докладно займався і В. Лавер. На його думку, об'єктом дослідження діалектної фразеології є діалектна фразема - мовленнєва одиниця, яка виникла і функціонує в певному наріччі, говорі, характеризується територіальними діалектними ознаками (компонентний склад, фраземне значення, вторинна номінативна функція, відтворюваність, граматичні категорії) і знаходиться за межами літературної мови.

Дисертаційне докторське дослідження В. Лавера Фраземіка українських діалектів карпатського регіону стало цінним явищем у дослідженні діалектної фразеології. Воно присвячене аналізу діалектної фразеології карпатського регіону в ареальному аспекті й підкріплене першим в україністиці 
фразеологічним атласом карпатських діалектів. В атласі вміщено три види карт (карти на виявлення фразеологізмів, карти фразеологічних явищ, зведені карти), а також установлено понад 1000 ізоглос. Зібрання і попереднє оброблення діалектних фразеологізмів, а також спостереження за сучасними активними процесами в діалектній фразеології потрібні для розв'язання багатьох важливих проблем історії української мови, для висвітлення взаємодії сучасної літературної мови і діалектів, а також вивчення фразем у лінгвокультурологічному аспекті (Лавер 1991).

Віталія Папіш у своєму дисертаційному кандидатському дослідженні вперше дослідила фразеологічний матеріал художніх текстів закарпатоукраїнських митців у семантичному та функціональному аспектах, встановила співвідношення узуального та оказіонального у практиці авторського мовлення письменників. Авторка з'ясувала природу фразеологічних одиниць, динаміку їх змін у взаємодії з контекстом, виявила шляхи пристосування узуальних фразеологізмів до умов контексту та способи творення оказіональних фразем. Дослідниця виокремила регіональні особливості у межах окремих фразем, ввела у науковий оббіг оригінальний некодифікований фразеологічний матеріал, звертаючи увагу на його лінгвокультурологічний потенціал (Папіш 2004).

Вагомий внесок у вивчення діалектної фразеології української мови зробив В. Ужченко (2003), який у своїй монографії здійснив огляд діалектної фразеології за останні 30 років, показав стан вивчення фразеології новітніх говірок сходу України, активні ареальні процеси, виділив культурологічні аспекти проблеми.

Незважаючи на відчутне пожвавлення досліджень, констатуємо, що діалектна фразеологія потребує більш докладного вивчення. Важливо встановити обсяг і межі української діалектної фразеології, виявити їі основний корпус в українській мові, визначити основні напрямки й шляхи розвитку, особливо звертаючи увагу на відтворення у фраземах найхарактерніших ментальних рис українського етносу, особливостей культури, побуту, звичаїв, традицій. А це означає, що фразеологія є невичерпним джерелом для досліджень у лінгвокультурологічному аспекті.

\section{SUMMARY \\ Dialect Phrase Studies \\ As a Subject of Linguoculturological Analysis}

The article deals with the overview of the most significant works in dialectal phraseology in which phraseological representation of the language world model in the geographical range is considered as a constituent of a nationwide one. Basing oneself 
on the views of well-known phrase researchers, the author accentuates the indissoluble link of phrases with the ethnos culture, ascertains the peculiarities of forming the regional world model, clears up the specificity of semantics and structure of the geographical phraseological unit. The acquisitions have been described, in particular of the Transcarpathian phraseologists who traced a line round the peculiarities of motivating dialectal phrases taking into account the spiritual culture of dialect speakers. The link of modern phraseological world model with ancient traditions, rituals of Ukrainians, who populate different regions of Ukraine, has been traced. Following well-known, investigators of phraseology, the author picked out cultural and national connotations of geographical phrases, using contemporary scholarly methods. 


\section{Źródla}

frazeologii gwarowej 



\author{
ВАЛЕРИЙ МИХАЙЛОВИЧ МОКИЕНКО (® \\ Санкт-ПетеРБУРГСКИй УНИвеРСитет, САНкт-ПетеРБУРГ, РОССИЯ \\ mokienko40@mail.ru
}

\title{
ДИАЛЕКТНАЯ И ИСТОРИЧЕСКАЯ ФРАЗЕОЛОГИЯ. ПЕРСПЕКТИВЫ ВЗАИМОДЕЙСТВИЯ ${ }^{1}$
}

Ключевые слова: диалект, диалектная фразеология, фразеологическая единица, паремия, пословица, поговорка, фразеография

Keywords: dialect, dialect phraseology, phraseological unit, paremia, proverb, saying, phraseography

Конференция по славянской диалектной фразеологии проводится нашим гостеприимным хозяином проф. Мацеем Раком в Кракове не случайно. Известно, что Ягеллонский университет и Краковский филиал Польской Академии наук давно уже стали центрами исследования польских диалектов как в синхронном, так и в диахроническом аспектах. Не случайно, что именно в Кракове вышел фундаментальный словарь польских диалектов в 6 томах Яна Карловича - Słownik gwar polskich (SKarł), и именно здесь издавались 5 томов другого фундаментального словаря - Stownika etymologicznego języka polskiego Францишка Славского (SESł). В Кракове изданы и многие словари польского языка, в словники которых вошли диалектные слова и выражения.

Не случайно и то, что именно в Ягеллонском университете год назад получил звание профессора пан М. Рак. Мне помнится, как 15 лет тому назад на конференции в Ополе ко мне подошёл молодой студент с вдохновенными глазами и сказал: Позволит ли мне пан профессор подарить ему свой словарь - фразеологический словарь моей родной деревни? Я не только позволил ему подарить мне свой словарь, но и всю ночь изучал яркую народную фразеологию gwary Dębna, с любовью описанную в этом словаре. Это был Słownik frazeologiczny gwary Dębna w Górach Świętokrzyskich (SFGD). И не успел я насладиться чтением первого его труда, как в 2007 г. вышла ещё одна книга этого же автора - Językowo-kulturowy obraz zwierząt utrwalony w animalistycznej

1 Исследование выполнено за счет гранта Российского научного фонда (проект № 20-18-00091, реализуемый в Санкт-Петербургском государственном университете). 
frazeologii gwar Gór Świętokrzyskich i Podtatrza (na tle porównawczym) (Rak 2007). Видя, с каким тщанием и лингвистическим вдохновением написаны эти книги, я подумал: „Этот студент наверняка скоро станет профессором”.

Автором словаря, как вы уже догадались, и был студент М. Рак. И, как видите, моя научная гипотеза подтвердилась и наш хозяин - уже профессор. Причем - профессор именно Ягелонского университета, города, где и вышли его первые книги. И вот мы здесь вкушаем одну из важнейших для славянской фразеологии проблематику, передавая друг другу опыт исследования фразеологии в разных странах.

Почему же именно диалектная фразеология столь значима для фразеологических и фразеографических изысканий в масштабах Славии?

Попробую вкратце ответить на этот вопрос, заданный нам организаторами Конференции.

Во-первых, диалектный материал в нашем XXI в. требует исключительно бережного сохранения. Экология народной речи столь же необходима в эпоху глобализации и цифровых технологий, как и экология наших природных ресурсов. Если мы, диалектологи, не успеем в последний момент зафиксировать сохранившиеся пока в некоторых регионах жемчужины народного творчества, то искусственный интеллект будущего века (а, быть может, и настоящего) предаст их забвению. И неизвестно, когда ещё наши потомки откопают этот зарытый в компьютерные толщи естественный речевой талант - талант народной речи. Следовательно, на нас, диалектологов, падает задача создания заповедника народной речи, её экологической кладовой.

Во-вторых, без диалектного материала многие лингвистические теории даже ультрасовременные - повисают в воздухе подобно испанским воздушным замкам, ибо не имеют надёжного фундамента. Не секрет, что некоторые глубокомысленные рассуждения о национальном менталитете, тайнах русской или польской души, специфике народного характера строятся на песчаном основании кодифицированных литературных языков, испытавших воздействие европейской глобализации и межъязыковых влияний, либо - что ещё ненадёжнее - на материале устаревших собраний славянского фольклора полуторавековой давности - Владимира Ивановича Даля, Франтишека Ладислава Челаковского, Самуэля Адальберга, Михаила Номиса и под. За это время, однако, довольно сильно изменилась не только народная речь, но и народный (resp. национальный) менталитет и национальные стереотипы. За примерами далеко ходить не надо. Всего 20 с небольшим лет назад мы, русские, гордились тем, что являемся самой читающей нацией на планете. Сейчас же, достаточно проехаться в московском метро, чтобы читающие пассажиры были столь же редки, как белые вороны... Зато 90\% их говорят по мобильникам или шлют своим друзьям СМСки... А ведь без учёта таких изменений невозможен объективный диагноз современного национального характера и менталитета в духе Александра Гумбольдта, Александра Афанась- 
евича Потебни или Анны Вежбицкой. Именно поэтому в фундаментальных реконструкциях этнолингвистической картины мира Ежи Бартминьского и Никиты Ильича Толстого и Светланы Михайловны Толстой столь большое внимание уделяется современным диалектным записям.

В-третьих, славянская диалектная фразеология является чрезвычайно эффективным ключом, открывающим окно в до сих пор если не „тёмную”, то сильно „затемнённую” её область. Я имею в виду историческую фразеологию. Ведь увлёкшись многоаспектными синхронными исследованиями фразеологии, предложив её успешные функционально-семантические, лингвокультурологические и корпусные интерпретации, мы, фразеологии, оторвались от основы классического языкознания. А эта основа, созданная языковедами XIX - начала XX вв. для фонологии, словообразования и лексики - сравнительно-историческая методология языкового анализа.

Пролистаем самые лучшие славянские этимологические словари, над которыми трудились полтора века классики сравнительно-исторического языкознания - в том числе и профессор ягелонского университета Франтишек Славский, всю жизнь посвятивший составлению двух монументальных (но, к сожалению, не завершённых) словарей - Stownik etymologiczny języka polskiego (SESł) и Słownik prasłowiański (SławSP). Много ли мы найдём в них историко-этимологических реконструкций славянской фразеологии? - Увы, практически ничего не найдём. Великаны славянской этимологической лексикографии оставили эту работу нам, фразеологам. Но мы, увы, не спешим закатывать рукава. Кое-что здесь, правда, сделано для русской (БМС), белорусской (Лепешаў 2004), украинской (Івченко 1998), чешской (Stěpanova 1998), болгарской (Lichtenberg 2001) и хорватской (Fink-Arsovski, Kovačević, Hrnjak 2010) фразеологии.

Конечно, я имею в виду „кое-что” собственно лингвистическое, где фразеологи, подобно этимологическим исследователям лексики, реконструируют фразеологические „этимоны” собственно лингвистическими методами. Ибо мы, фразеологии, до сих пор оставляем эту область фразеологии на откуп фольклористам, этнографам и популяризаторам так называемой „культуры речи", от двух первых прямо зависимых. Их ведь уже давно интересует реконструкция образного источника пословиц и поговорок, т.е. фразеологизмов в широком значении термина. И разумеется, их опыт и ценные материалы в этом отношении фразеологам очень полезны. Достаточно назвать неоднократно переиздаваемую книгу акад. Юлиана Кржижановского Mąrej gtowie dość dwie stowie (MG) и монументальный четырёхтомный словарь Nowa księga przystów $i$ wyrażeń przysłowiowych polskich (NKPР) под его редакцией, где высказано немало блестящих и остроумных историко-этимологических расшифровок польской фразеологии и паремиологии.

К сожалению, однако, лингвистический анализ нередко их опровергает, ибо многие догадки фольклористов и этнографов, а тем более - попу- 
ляризаторов, исходят из предпочтения какого-либо экстралингвистического (исторического, мифологического, этнографического и под.) факта остальным - без собственно языкового сравнительно-исторического анализа в духе чёткой младограмматической логики при этимологических реконструкциях славянской лексики. Т.е. анализа, построенного на принципе структурно-семантического моделировании (Мокиенко 1989).

Такой анализ и требует вовлечения в этимологическую реконструкцию максимально полного фразеологического материала диалектной Славии. Ведь в отличие от лексики славянская национальная фразеология не имеет столь богатых древних языковых (resp. исторических) фиксаций. В лучшем случае некоторые идиомы инкрустированы в древнерусских, древнеукраинских, древнебелорусских, древнепольских или древнечешских письменных памятниках, ориентированных на сакральную и деловую книжность, а не на устную народную речь. И здесь диалектный материал становится, собственно говоря, „компенсатором” хронологической „недостаточности” древних языковых памятников, способствуя глубинному погружению в первоисточник и ареальную дистрибуцию той или иной фразеологической единицы. Как-то Н.И. Толстой проникновенно заметил, что ареальная характеристика языковых фактов - это хронология (resp. диахрония), положенная на географическую сетку (карту). Лучше не скажешь. Тем более - в отношении к нашим историко-этимологическим реконструкциям фразеологии. Мой собственный лингвистический опыт показывает, что если ареал восточнославянской фразеологической единицы ареально, в разных вариантах смыкается с польским, а тем более - с балтийским, то можно с полным основанием предполагать, что её „возраст” измеряется хронологическим пространством Киевской Руси, т.е. VIII-IX вв.

Внимание к ареальному пространству каждой ФЕ позволяет не только установить её приблизительную хронологию в пределах Славии, но и продемонстрировать иерархию её вариантов, что нередко помогает расшифровать и исходный образ, т.е. этимологию этого фразеологизма. Вот - в пределах лимита времени, отведённого на доклад, один характерный пример такой ареальной, вариантной и этимологической реконструкции.

Рассмотрим в спектре предлагаемого мною подхода русский народный фразеологизм не знала баба горя, купила баба порося. Его считают либо пословицей, либо поговоркой. Так, в рассказе Антона Павловича Чехова О любви он цитируется именно как пословица: „Есть пословица: Не было у бабы хлопот, так купила порося. Не было у Лугановичей хлопот, подружились они со мной. Если я долго не приезжал в город, то значит, я был болен, или что-нибудь случилось со мной, и они оба сильно беспокоились”. В современном газетном тексте его, однако, называют поговоркой: „Знаете, дорогие читатели, такую поговорку не имела баба хлопот, так... Правильно, купила 
порося... А теперь представьте, что человек не хотел порося покупать, но ему его подарили. На восьмое марта. А вообще-то он его выиграл в лотерею. Выигрывать всегда приятно, но тут - порося, а вместе с ним, сами понимаете, хлопоты...” („Советская Россия” 12 V 1988). Фразеологический (resp. поговорочный) статус этого выражения вытекает из его дефиниции, которая, в отличие от дефиниций пословиц, не имеет дидактического, назидательного смысла. Оно шутливо-иронически характеризует человека, который сам себе доставил много хлопот, неудобств, затруднений от добровольно взятых на себя обязанностей, дел и т. п. Такое определение подкрепляется многими контекстами (Жуков 1991: 210; ШСП: 14-15), напр.:

Прощай, мой друг, - сказал он, - . . я еду с Карпушей. Послушай, будь поласковее к Павлу Алексеевичу... Любаша... молча смотрела вслед мужу большими, лучистыми глазами. Он обернулся в это время, остановился и спросил коротко: - Что ты так дико на меня смотришь? - Уйди, ради Бога, уйди! - проговорила она с трудом... Шилохвостов ворчал про себя: - И здесь нет приступа - вот не знала баба горя, купила баба порося!, того и гляди, какой-нибудь несчастный роман разыграют - и все на нашу шею, на мою, то-есть, с Карпушей; мы и отдувайся после. (В.И. Даль, Павел Алексеевич Игривый).

Сколько стоило мне труда уломать его, чтобы поддержал в райкоме мой проект оросительного канала! „Не знала баба хлопот, да купила порося. Наживём мы, говорит, себе, Микола Ильич, горя с этим строительством". (В. Овечкин, С фронтовыл приветом).

В русском языке этот фразеологизм употребляется в разных вариантах, также фиксируемых словарями:

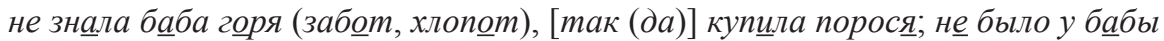
хлопот, так купила порося (поросёнка); не было у бабы беды (визгу), так купила порося.

Известны и такие варианты, как:

Не знала баба, горя, купила (родила) баба порося (В.И. Даль); Не знала баба горя, [да] купила баба порося (М.И. Михельсон; А.И. Соболев).

Образ этого народного фразеологизма, на первый взгляд, совершенно понятен: поросёнок хотя и не требует слушком трудоёмкого ухода, но всё-таки доставляет беспокойства. Один из приведённых вариантов такое беспокойство даже характеризует: не было у бабы визгу, так купила порося.

Нет ли в вариантах поговорки и других характеристик поросёнка, принёсшего дополнительные хлопоты бабе?

Действительно, в народной речи они представлены: 
Не знала баба горя (забот, хлопот), купила (родила) баба порося (Д 1: 378; Мокиенко 2007: 36-37); Не было у бабы горя (забот, хлопот, беды, визгу), так (да) купила порося (СПП: 124; ШСП: 14-15; Мокиенко 2006: 36; Пск., Ленингр., Соловьева 2001: 17; Сок.: 213); Не было на бабу хлопот, так купила шелудивое порося (Снег.: 260); Не было у бабы писку, так купила шелудивое порося (Д 3: 114); Не было у бабы скота, дак купила шелудивое порося. Пск. (СР 2: 226; СПП: 124); Не было хлопот, так купила порося. Пск. (СПП: 143); Не было беды, да порося завела. (Ан.: 207); Не было печали, так купили порося (Сок.: 345).

Как видим, просторечное слово порося 'поросёнок' в нескольких вариантах обретает прил. шелудивый (Не было на бабу хлопот, так купила шелудивое порося; Не было у бабы писку, так купила шелудивое порося; Не было у бабы скота, дак купила шелудивое порося) или может уточняться обобщающим скот (Не было у бабы скота, дак купила шелудивое порося). Теперь понятно, почему поговорочной бабе не даёт покоя визг или писк поросёнка: он оказывается шелудивым, т.е. больным, паршивым, запаршивевшим, со струпьями, коростой на коже.

Поговорка сохранила в своём составе древнюю общеславянскую форму названия поросёнка - порося. Суффикс -я (прасл. *-e) был прежде весьма активен: теля - телёнок - телята, козля - козлёнок-козлята, зверя - зверёнок (зверёныш) - зверята, котя - котёнок - котята, волча - волчёнок-волчата, робя - ребёнок - ребята и др. Поэтому и в других славянских языках эта поговорка имеет именно эту древнюю форму слова.

Белорусские варианты поговорки близки русским, но не отражают „шелудивого диагноза" поросёнка, зафиксированного русскими паремиями (Грынблат 1976: $\left.1,203^{2 *}\right)$ :

Не мела баба клопату, купіла парася (Rур.: 214; Нос.: 100; Dybow.: 14; Радч.: 248; Fed.: 19; Pietk.: 309; А. Русіновіч: 1954, Светл. 13.3.29); Іваноў, Раманава 2006: 54; Не было бабе клопатаў, дык купіла парася (Ром., Бел.: I, 302); Не мела баба клопату, купіла парася, парасё у квік, а баба ў крык (Ляцкий 1898: 30).

Украинские поговорки также обходят „шелудивость” поросёнка молчанием, зато обильно характерируют реакцию бабы на его покупку, связанную с хлопотами:

Не мала баба клопоту, так купила порося; Не мала баба клопоту, купила собі порося; Не мала баба клопоту, дак купила порося; Не мала баба клопоту та

2 * Ссылки на источники поговорки даются - в целях экономии места - в сокращениях, принятых в сборнике Моисея Яковлевича Грынблата. 
й купила порося: порося у квік, а баба у крик; Не мала баба клопоту та купила порося, - порося в кувік, а баба в крик; Не мала баба клопоту, баба в крик, а порося в квік; Не мала бабуня в хаті клопоту, то купила собі; Ой не мала баба клопіт, дак купила порося; Не мала баба роботи та собі купила паця (где паия - поросёнок) (ПП 2: 146; ПП 3: 165).

В некоторых вариантах поговорки объект покупки опускается, остаются лишь хлопоты от работы: Не мала баба роботи та найшла собі клопоти (ПП 2: 146; ПП 3: 165.). Осовремененный вариант - покупка бабой двухколёсного велосипеда: Не мав клопоту та купив собі „біду” на двох колесах (ПП 3: 124).

Возникает вопрос: случаен ли русский вариант поговорки, в котором поросёнок оказывается шелудивым или это именно вариант, раскрывающий его исходный образ?

От ответа на этот вопрос зависит этимологическая расшифровка нашей поговорки. Смысл её, на первый взгляд, достаточно прозрачен, ибо каждому понятно, что выращивание свиней - дело хлопотное. Тем не менее, именно некоторые варианты уточняют те трудности, с которыми столкнулась баба, купившая поросёнка. Он, видимо, оказался именно больным, опаршивевшим: Не было у бабы писку, так купила шелудивое порося, поэтому вёл себя неспокойно, визжал: Не было у бабы визгу, так (да) купила порося.

И такую версию исходного смысла поговорки убедительно подтверждает польский диалектный материал, зафиксированный в тезаурусе польской паремиологии - NKPP (I: 40-41, материалы):

Nie miała baba kłopotu, kupiła sobie prosię (cielę i in.); Nie miała baba kłopotu, i kupiła sobie parszywe prosię (1632); Baba kupiła prosię nie majac kłopotu (1696); Baba prosie kupiła, nie miała kłopotu, dziś jej we dnie i w nocy doma i u płotu kwiczy; Nie miała baba kłopotu, kupiła prosię: prosię w kwik, baba w krzyk; Nie miała baba roboty, kupiła sobie prosiaka; Nié miała baba strapieniá, kupiła se prosie (1894 AD, 80); Nie miała baba kłopotu, kupiła se parszywe prosię: prosię kwicy, baba krzycy (1897); Ni miała baba kłopotu, kupiła so prosę, i to prose zesrało se (1900); Zachciało się babie kłopotu, wiazała prosie u płotu (1868); Nimja baba bjêdé, kupiła so pêdé (1894); Nie miała baba kłopotu, kupiła sobie ciele (1894); Nie miała baba kłopota, kupiła sobie kokota (1954); Ni miała baba starości, kupiła se kozę (ciesz.).

В этом тезаурусе не только приводятся эти варианты, но и предлагается фольклористическая история поговорки о бабе и визгливом поросёнке: „Aluzja do bajki łańcuszkowej o babie i nieposłusznym prosięciu, poskromionym po wielu zabiegach właścicielki kijem” (MG I: 48; NKPP I: 41). Главное, однако, всё-таки не в том, как баба наказывала непослушного поросёнка, но - в причинах его визгливого поведения, доставляющего его владелице такие хлопо- 
ты. И, судя по польскому и русскому вариантам, это - именно его шелудивость, покрытость паршой, которая не даёт бедному животному покоя. Суть польского народного анекдота о некогда беззаботной женщине, купившей не просто поросёнка (за которым, как за детёнышем „грязного” животного, и без того нужен немалый уход), а - шелудивого, паршивого. Устав от хлопот столь трудоёмкого ухода, хозяйка „лечит” непослушного поросёнка палкой. Отсюда - шутливо-ироническая окраска поговорки.

То, что вариант о паршивом поросёнке исходный, доказывает его ранняя фиксация в польских диалектах. Поговорка Nie miała baba kłopotu - kupiła se parsywe prosię: prosię kwicy, baba krzyczy в польском языке зафиксирована уже с 1618 г.

Древняя фиксация и перекличка с соответствующими русскими вариантами поговорки позволяют не только объяснить её исходный образ, но и достаточно очертить ареальную „дальнобойность” на пространстве языковой Славии. Некоторые паремиологические сборники фиксируют её не только в польском, русском, белорусском и украинском языках, но и в чешском, сербском и болгарском. Но в последних трёх языках (фиксируемых сборником Фр. Лад. Челаковским наряду с польским и украинским) нет варианта с „шелудивым” поросёнком и, судя по всему, их фиксация ограничивается XIX веком: болг. Нямала баба работа, та си купила прасенце; чеш. пете́la bába trampoty, koupila si prase; серб. Немала баба беса, него купила прасе (Čelakovský 1949: 744). Судя по всему, их появление в этих 3 языках - результат типичного для XIX в. „паремиологического панславизма”, т.е. буквального калькирования русской и польской поговорок на эти языки, что особенно характерно для сборника Франтишека Ладислава Челаковского. Об этом, в частности, свидетельствует факт, что в словаре славянских пословиц Марины Юрьевны Котовой к болгарской и сербской поговорке (в иной вариации) приводятся (с пометой ср.) более „национальные” паремии: болг. Нямала си баба белица, па си купила козица; серб. Трла баба лан да јој прође дан. Словацкая же параллель поговорки о бабе вообще не упоминает ни о каком животном: Nemala baba roboty, narobila si klopoty (Котова 2000: 16).

Чёткий диагноз заимствованного характера для чеш. Neměla bába trampoty. koupila si prase убедительно ставит Вацлав Флайшганс, постоянно корректирующий панславянские параллели Франтишека Ладислава Челаковского: ,jest polské Nie miała baba kłopotu, kupiła sobie prosię" (Flajšhans 2013 II: 893).

Явно зависима от польского и русского источника литовская поговорка о поросёнке Neturëjo boba bédos, nusipirko paršą; Neturëjo boba bédos, prasimanè vaika. К. Григас, сопоставивший ее со славянскими параллелями, объективно подчёркивает, со ссылкой на польскую NKPP, что она зафиксирована на 300 лет позже польской (Grigas 1987: 160-161), что говорит о её заимствованном характере. Оригинальна и новогреческая параллель (отлича- 
ющаяся от славянских своей образностью), приводимая Ф.Л. Челаковским:

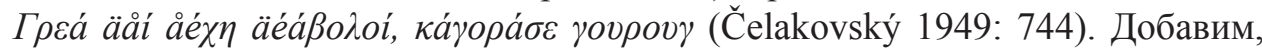
что именно отсутствие варианта с ,паршивостью” поросёнка подтверждает такую констатацию.

Я остановился лишь на трёх важных аргументах в пользу углублённого изучения славянской диалектной фразеологии. Их, аргументов, естественно, гораздо больше. Такие аспекты, как ареальный, культурологический, идеографический, лексикографический и др., конечно же, привлекают и будут привлекать внимание фразеологов-славистов. Свидетельство этому - наша Краковская конференция, где собрались верные адепты нашей - всё ещё молодой, как и проф. Мацей Рак, дисциплины - Фразеологии. Фразеологии, основа которой - живая и яркая народная славянская речь.

\section{SuMmary \\ Dialectic and Historical Phraseology: Prospects for InTERACTION}

The article analyzes the common problems of dialect and historical phraseology in Slavic languages. Compared with the great achievements of Slavic etymology and the publication of capital etymological dictionaries of Slavic languages, historical and etymological studies of phraseology look much more modest.

Work in this direction is nevertheless ongoing: several dictionaries (for example, Russian and Belarusian phraseology) and bibliographic reference books (Ukrainian, Bulgarian, Croatian, Czech) have already been created. Studies of dialect phraseology and dialectography are also not as numerous as the description and lexicography of dialect vocabulary. The perspective here is a more detailed study of phraseological dialecticisms of various areas of Slavia and the disclosure of their internal form. At the same time, reliance on the classical collections of Slavic paremiology is needed, an overview of which is given in the article. An example of historical and comparative analysis of phraseological dialecticism is also offered here: Rus. не знала баба горя, купила баба порося - Belar. Не мела баба клопату, купіла парася - Ukr. Hе мала баба клопоту, так купила порося - Pol. Nie miała baba kłopotu, kupiła sobie prosię - Bulg. Нямала баба работа, та си купила прасенце - Czech Neměla bába trampoty, koupila si prase; Serb. Немала баба беса, него купила прасе etc. The areal, cultural, ideographic, and lexicographical aspects of the study of dialect phraseology seem especially promising to the author of the article. 



\section{Harry Walter (1) \\ Greifswald, Deutschland \\ walter@uni-greifswald.de}

\section{НЕМЕЦКИЕ ДИАЛЕКТЫ КАК ИСТОЧНИК ФРАЗЕОЛОГИИ}

Ключевые слова: фразеология, диалекты, немецкий язык, историческая фразеология

Keywords: phraseology, dialects, German, historical phraseology

Германия известна тем, что её жители могут не понять друг друга, если они живут в разных землях. Иногда даже к некоторым телепередачам, где говорят на диалектах, делают субтитры, чтобы все немцы понимали. Особенности исторического развития Германии обусловили возникновение большого количества диалектов, которые очень сильно отличаются друг от друга в лексическом, морфологическом, фонологическом и синтаксическом плане. Параллельно с ними существует литературный вариант немецкого языка (Hochdeutsch), который позволяет немецкоговорящим гражданам преодолевать коммуникативные проблемы, связанные с особенностями немецкой речи в разных регионах.

Однако по поводу Hochdeutsch необходимо сделать одно важное замечание. На немецком говорят не только в Германии, но и в Австрии, Лихтенштайне (где он выступает официальным государственным языком), в Швейцарии, Италии, Франции, Бельгии (где он является одним из официальных государственных языков). Кроме того, немецким языком активно пользуются национальные меньшинства во многих других странах мира. Если отбросить специфику многочисленных диалектов и рассмотреть литературный немецкий язык, то его варианты будут существенно отличаться в Германии, Швейцарии и Австрии. Различия проявляются в фонетике, лексике (например, в присутствии в немецком определенных заимствований из языков приграничных государств), управлении глаголов, морфологии и, конечно, во фразеологии.

Современные тенденции развития немецких диалектов характеризуются некоторым сглаживанием резких границ между ними в связи с развитием научно-технического прогресса, средств массовой информации и всеобщей интеграции. Современный разговорный немецкий язык зачастую сочетает в себе особенности разных немецких диалектов, что постепенно ведет 
к некоторого рода унификации. Иногда, как ни странно, диалекты образуют новые слова и значения, которые вошли в литературный язык, потеряв свой „диалектный характер” до неузнаваемости.

На повестке дня остается всестороннее описание фразеологии диалектов, создание словарей с учетом последних достижений в области, так и всей европейской фразеографии в целом. Каждая отдельная диалектная фразеологическая единица в таком случае станет самостоятельным объектом описания и изучения, как со стороны формы, грамматики, значения, так и со стороны этимологии. Особенная ценность диалектной фразеологии и в том, что именно она нацелена на внимание к этнокультурной составляющей.

Вместе с тем в немецкоязычной лингвистике на фоне глобальных теоретических достижений все еще существует необходимость активизироваться в различных областях эмпирических исследований, что наглядно продемонстрировано в дефиците диалектных, региональных фразеологических словарей (см. Piirainen 2009: 84-86).

Лингвистический анализ отдельных фразеологизмов убедительно показывает, как местные реалии не просто определяют внутреннюю форму оборота, но и влияют на его дальнейшую судьбу. Так, до сегодня остается популярным немецкое выражение sich wie Bolle auf dem Milchwagen (auf dem Bock) freuen (amüsieren) (разг. шутл.): 'очень радоваться, быть непринуждённо весёлым' (букв. 'развлекаться как Болле [на козлах брички; на молоковозе]').

Особенно в Берлине распространено выражение, которое известно с конца XIX в. (Küpper 1993: 121). Его связывают с именем основателя известного берлинского молочного завода Болле. Молодые извозчики (парни Болле - Bollejungen) развозили молоко, сидя на козлах молоковозов и подавая сигналы звуками колокольчика. Это создавало впечатление о чём-то весёлом, бодром, радостном. Популярности сравнения способствовало и то, что оно перекликалось с припевом весёлой берлинской песни неизвестного автора: Aber dennoch hat sich Bolle ganz köstlich amüsiert (А Болле, несмотря ни на что, прекрасно развлекался) (Duden 2008: 123). Образ развозчиков и разносчиков молока берлинского молочного завода Болле из-за их молодости и весёлой манеры общения быстро стал популярным в городском фольклоре. В отличие от чисто народной образности сравнения с фамилией Болле его немецкий синоним glücklich sein wie Baccus auf dem Fass имеет интернациональные корни.

Современные исследования подтверждают региональный характер этого выражения: согласно анкетирования, проведенного в разных немецкоязычных регионах, фразему sich wie Bolle auf dem Milchwagen (auf dem Bock) amüsieren употребляли или просто смогли объяснить жители Берлина или выходцы оттуда (Mussner 2010: 145; Walter, Mokienko 2011: 74).

На севере Германии употребителен совет Kommt man über den Hund, kommt man auch über den Schwanz (посл.): 'Если главное препятствие прео- 
долено, то остальное пустяки' (букв. Перешагнув через собаку, перешагнёшь и через её хвост). Эта немецкая фразема имеет соответствия в русском языке. Например: Было бы начало, будет и конец. Пошло дело в завязку, дойдёт и до конца. Была бы голова, а хвост будет. Дело без конца что кобыла без хвоста.

Пословица употребляется в качестве подбадривания того, кто уже затратил много усилий для достижения чего-л. и требуется уже совсем немного, чтобы дело завершить (см. Шекасюк 2009: 344). Она известна как в литературном языке, так и в диалектах и фиксируется фактически всеми солидными паремиологическими собраниями, напр. в фризском диалекте Kumt em aur Hünd, da kumt em uk a ur Stört, в г. Клеве: Kommt gei over den Hond, dann kommt gei ök over de Start и др. Точную её параллель находим и в голландском языке: Komt men over de hont, dan komt men ook over den staart (Wander 1987 II: 852).

На первый взгляд образ пословицы прозрачен, поскольку действительно, переступив через большого пса, переступаешь и его хвост. Однако многие немецкие фольклористы и историки языка реконструируют в ней иной образ, совершенно не относящийся к нашему домашнему животному. Одни считают, что слово Hund здесь значит народное обозначение созвездия Сириус (букв. созвездие Пса), связанного с наименованием самого жаркого времени года - Hundstage (букв. „Собачьи дни” - 24-го июля - 24-го августа). Получается, если это знойное время прошло, то дальше будет намного легче.

На наш взгляд, более вероятно, однако, объяснение этой пословицы на основе северо-немецкого диалекта. Так, на острове Зилт (Sylt) на северо-западе Германии, во фризском диалекте пословица имеет форму Kumt em aur Hünd, da kumt em uk a ur Stört, а в городе Клеве (Kleve), также на севере Германии Kommt gei over den Hond, dann kommt gei ök over de Start (ср. также варианты пословицы в этих же регионах, приведенные выше). Прежде остров Зеланд (Seeland) не был отделён ни от Голландии, ни от Фламандии. Со временем море углубило реки, которые разделили этот остров и заметно расширило их. Вследствие этого и образовался сам остров. Западное устье реки было названо Западной Шельдой (westlichen Schelde), а в народной речи - Hunt или Hunte. Поэтому и деревня, расположенная на этой реке, была названа Хунтерниссе (Hunternisse). Река Hunte протекает недалеко от города Влиссингена (Vliessingen) по направлению к Антверпену. При западном штормовом ветре вода реки Хунте сильно подымается, а ближе к Антверпену становится мельче. Моряку, прошедшему широкую часть реки Хунте, легче плыть в своём судне по её более мелкой части, которая в народной речи и была названа „хвостом” (Schwanz) за её суженную форму. Лишь случайное созвучие названия реки Hunte с названием собаки Hund привело к народно-этимологическому объяснению пословицы. Так во всяком случае объясняет историю голландской и немецкой пословиц Шпренгер ван Айк (Sprenger van Eijk), а вслед за ним и Вандер (Wander 1987 II: 852, 924; Walter, Mokienko 2011: 213-214). 
При всей географической живописности такого объяснения, сомнения в её истинности всё же остаются. Во-первых, сам К.Ф.В. Вандер приводит любопытную „животную” параллель с близким значением из французского языка: Quand on a avalé boeuf, il ne faut pas s'arrêter à la queuе (букв. Проглотив быка, нельзя останавливаться на хвосте). Ещё более близкий образ имеет русская поговорка, записанная В.И. Далем: Собаку съел, да (только) хвостом подавился. Правда, она имеет иное значение, но характерно при этом, что значение антонимическое, укладывающееся в общую семантическую модель, где всё тело животного противопоставляется его небольшой части - хвосту: „Сделав основное дело, потерпел неудачу и не завершил его из-за мелочи”. Показательно, что эта модель имеет параллели и в других языках, напр.,

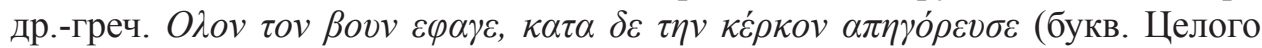

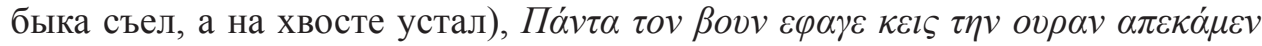
(букв. Всего быка съел, а на хвост сил не хватило). Ср. также рус. Съел волк кобылу, да дровнями подавился; итал. La coda è la più cattiva à scorticare (букв. С хвоста снять шкуру труднее всего) и под. (Михельсон 1903 II: 287). Как видим, лингвистам ещё придётся потрудиться, чтобы окончательно разгадать исходный образ пословицы, которая кажется столь понятной.

Внимание к местной истории, знание диалектных особенностей языка в ряде случаев помогают объяснить странные на первый взгляд выражения. В немецком языке широко известен фразеологизм in (aus, nach) Buxtehude [, wo die Hunde mit dem Schwanz bellen] (разг): 'где-л. очень далеко; где-л. в далёкой провинции, в тихом, захолустном месте’ (букв.: „в Бусктехуде, где собаки лают хвостом").

Оборот зафиксирован с XIX в. (Küpper 1993: 148). Бусктехуде - название маленького города в районе Стаде на севере Германии, которое ассоциируется с маленьким, незначительным местом (Duden 2008: 138). В выражении этот образ шутливо усиливается, поскольку Бусктехуде в северной Германии имеет то же негативное значение, что в средне- и верхненемецком Dummsdorf, Dingskirchen, Hintertupfingen. Однако название Buxtehude отличается от Dummsdort и Nirgendheim тем, что это не выдуманный, а действительно существующий городок. Название Бусктехуде часто намеренно искажается в Buxtehusen или Büxenhusen, которые в поговорках стали символами отдаленных мест, в которых могут происходить странные, непонятные вещи (Ср. Вальтер 2007: 59-60). Например, действие известной сказки братьев Гримм о еже и зайце происходит up de lüttje Heid bi Buxtehude (букв. „на заброшенном поле недалеко от Бусктехуде”), из чего читатель может заключить, что не только это состязание, но и само место действия является порождением народной фантазии, плодом шутки (Röhrich 2001 I: 287 сл.). Намеренную шутливость подчёркивает и частое добавление обороту wo die Hunde mit dem Schwanz bellen, которое является типичной фольклорной „формулой невозможного", явным оксюмороном (Вальтер 2007: 62). 
Сама структурно-семантическая модель выражения, означающая пространственную удаленность с оттенком невозможного, работает и в славянских языках, ср. бел.: Проиі ліха на ўзгорку, дзе пень на калоду брэша.

Однако эта необычная собака, умеющая лаять хвостом, имеет и вполне логическое объяснение, связанное именно с локальными особенностями истории и языкового взаимодействия. Оказывается, Бусктехуде еще в XIII в. основали голландские моряки, которые оказались довольно сообразительными и усовершенствовали местную практику звонить в колокола, ударяя их тяжёлым молотом. Голландцы привязали к колоколу, который в нидерландском языке называется Hunte, длинную веревку (хвост), с помощью которой и производился звон. Ну а городок стал известен как место, wo die Hunte mit dem Schwanz läutet - по нидерланд. „,bellt”.

Но самым ярким примером „диалектной” истории фразеологизма является фраза, многим известная с детства: Wenn du schön aufisst, scheint morgen [wieder] die Sonne (разг.) (досл. Если ты доешь до конца, завтра (снова) будет светить солнце): 'Призыв к ребенку доесть еду на тарелке до конца'. Всем известна ситуация: ребенок сидит за столом, а мама просит его доесть до конца: „Доешь до конца, тогда завтра будет хорошая погода” или „... тогда завтра будет светить солнце". Зачастую это утверждение связано с тем, что на дне детских тарелок имеются рисунки, часто изображающие солнышко. И когда в тарелке пусто, можно увидеть этот рисунок, т.е. солнце. До определенного возраста всех маленьких детей можно „подкупить” этим, и многие родители пользуются такой маленькой уловкой, чтобы заставить своих чад съесть всю еду в тарелке до конца. Однако дети, конечно же, вскоре понимают, что солнце светит или не светит на следующий день, независимо от того, поели они или нет. Так почему же пустая тарелка должна вызывать хорошую погоду? Да еще и на следующий день?

Выражение было зафиксировано в словаре немецких пословиц К.Ф.В. Вандера в форме 'S gibt gut Wetter, 's ist alles aufgegessen (Wander $1987 \mathrm{~V}$ : 1812). Фраза буквально означает, что если за столом ничего не осталось, то будет хорошая погода". Однако, весьма вероятно, что происхождение фразы основано на языковом недоразумении. Дело в том, что нижненемецком диалекте такое требование означает, что повар на следующий день должен будет готовить новую еду, т.к. старую всю съели, и на стол сегодня не будут подавать вчерашнюю разогретую еду, а именно: „Wenn du dien Teller leer ittst, dann gifft dat morgen goodes wedder”. А в стандартном немецком это означает: „Если ты съешь все целиком, то завтра ешё будет что-нибудь вкусное, то завтра бу-

1 https://www.abendblatt.de/hamburg/lebenswert/article107336230/Wieso-der-Hund-mitdem-Schwanz-bellt.html; https://www.schoener-reisen.at/thread/5351-buxtehude-wo-diehunde-mit-dem-schwanz-bellen/ (dostęp: 10 IX 2019). 
дет снова что-то хорошее”. „Goodes wedder” в литературном варианте немецкого языка было интерпретировано как „хорошая погода”, а не как „что-то опять хорошее". Эта фраза вошла в обиход достаточно быстро и используется в настоящее время на всей немецкоязычной территории, поэтому удивительно, что современные словари полностью игнорируют это популярное выражение.

Конечно, в немецком языке есть и выражение einen Löffel für Mutti, für Papa, für Oma... (досл. Ложку за маму, за папу, за бабушку...) или же различные виды угроз, как, например, Wenn du nicht aufisst, bekommst du nichts zu Weihnachten (gibt es keinen Nachtisch...) (досл. Если ты не доешь, тьл ничего не получишь на Рождество) (никакого десерта ...). Этот способ мотивации детей съесть еду - универсален.

Особенная „диалектная трактовка” предполагает, что невозможно найти фразы с такой же образной основой в других языках, сравни, например, русс. Ложечку за папу, за маму, за бабушку...; Если не доешь, то не вырастешь; белор. Гэты льжачку за папу, гэту за маму, гэту за браціка...; Еш, бо што не даясі, тое будзе ноччу за табою ганяцица ды за пяты кусацьь; Еш, бо калі не даясі, сіль ня будзе; Еu, прылзе з'есцьь такі і такі; укр. А підеш зі мною до лікаря (в магазин, до бабусі тощуо) - дам иукерку, морозиво і т.д.; 3 їж иматочок, бо буде бігати за тобою!; Хороші діти - завжди лишають чисті тарілки; Допоки не дойси кашу - з-за столу не встанеш, пол. zа тате, zа tate, za babcię, za dziadka, za siostre, za brata...; Musisz jeść, bo nie urośniesz! tschech. [jednou lžičku] za tatínka; za maminku, za babičku; Když to v̌̌echno sníš, budeš velký a silný! ... budeš taaaaakhle velký!

Вместе с тем немецкий диалектный оборот актуализировал семиотический статус пищи в традиционном обществе, предписывающий регламентацию поведения за столом. Практически неразработанной остается тема кормления ребенка, до нашего времени сохраняющая глубокие мифологические мотивы. Сам мир детства с его верою в чудеса и сверхъестественное наполнен архаическими многозначными сюжетами и образами. И связанными с едой в том числе. Достаточно вспомнить общеславянское наименование первой пищи - материнского молока - мамкой, а хлеба как первой твердой пищи - nапкой. Так и обращённые к ребенку просьбы доесть еду имеют основой не только заботу о его сытости, но и стремление оградить маленького человека от опасностей внешнего мира. В диалектной фразеологии белорусов в этой сфере устойчив мотив „чужого”: ребенка пугали Eu, бо цзьганы сніцица будуцьь; Еш, а то изыган ноччу прыдзе $і$ заберыць; З'еш, а то жабракі з торбамі сніцциа будуцьь. И у славян, и у немцев универсален мотив устрашения, от угрозы лишить подарка, особенно рождественского, до более популярного сегодня запугивания Бабаем или персонажем из какого-либо мультфильма. 
Проанализированные примеры демонстрируют лишь стартовые, но перспективные и многообещающие возможности погружения в историю и культуру народа.

\section{Summary}

\section{German Dialects As a Source of Phraseology}

Germany is known for the fact that its inhabitants may not understand each other if they live in different parts of the country. Sometimes even some TV shows, where they speak dialects, make subtitles so that all Germans understand the speech. Features of the historical development of Germany have caused the emergence of a large number of dialects, which are very different from each other in lexical, morphological, phonological and syntax. In parallel with them there is a literary version of the German language (Hochdeutsch), which allows German-speaking citizens to overcome the communicative problems associated with the peculiarities of German speech in different regions. Current trends in the development of German dialects are characterized by some smoothing of sharp boundaries between them in connection with the development of scientific and technological progress, the media and universal integration.

The paper discusses the influence of dialectal forms on the development of the literary language and shows this fact at concrete examples: wie Bolle auf dem Milchwagen; in Buxtehude, wo die Hund emit dem Schwanz bellen; wenn du aufisst, wird schönes Wetter. Because of their dialectal origin, there are no total equivalents in other languages for these phrases. 



\author{
АЛЕКСАНДР БИРИХ (1) \\ ТРИРСКИЙ УНИВЕРСИТЕТ, ТРИР, ГЕРМАНИЯ \\ bierich@uni-trier.de
}

\title{
ДИАЛЕКТЫ КАК ИСТОЧНИК РУССКОЙ ИСТОРИЧЕСКОЙ ФРАЗЕОЛОГИИ
}

Ключевые слова: историческая фразеология, диалекты, фразеологическая семантика, этимология фразеологизмов

Keywords: historical phraseology, dialects, phraseological semantics, etymology of idioms

1. Историческое изучение фразеологии предполагает учёт всех имеющихся лингвистических фразеологических данных: материалов литературного языка, диалектов, профессиональных и субстандартных вариантов, языка фольклора и т.п. Особое внимание необходимо уделить при этом вариантам устойчивых оборотов в живой речи, прежде всего диалектной, так как именно они часто помогают реконструировать этимон фразеологизма. На это указывал ещё Н.И. Толстой в своём докладе О реконструкции праславянской фразеологии (1973: 277): „[...] необходимо отдать полное предпочтение материалу диалектному перед материалом литературным (современным и древним, зафиксированным памятниками)".

Важность диалектов для исторического изучения фразеологии отмечал уже Б.А. Ларин, который считал, что именно в них следует искать корни славянской фразеологии (Ларин 1977: 149 и далее). С помощью диалектных, разговорных и нестандартных вариантов и синонимов фразеологических единиц можно реконструировать структурно-семантические модели и на их основе выявить первоначальный образ фразеологизмов (Мокиенко 1989: 49-95). Большую помощь в выполнении этой задачи окажет Полнылй фразеологический словарь русских народных говоров, подготавливаемый в СанктПетербургском университете под руководством проф. В.М. Мокиенко (Мокиенко 2011: 190-198; Мокиенко, Никитина 2018: 80-106). На материале этого словаря, вобравшего в себя народные выражения из большинства отечественных диалектных словарей и паремиологических собраний, уже выполнено несколько работ, связанных с образной мотивацией диалектных фразеологизмов (Никитина 2017: 71-75; Мокиенко 2018: 305-312 и др.). Важность 
диалектного материала для расшифровки исходного первичного образа фразеологизма убедительно показали работы Е.Л. Березович и её учеников (Березович 2003: 165-177; Березович, Кучко 2017: 5-15 и др.). Только после тщательного изучения лингвистических данных можно использовать для обоснования этимологических гипотез экстралингвистические факты (такие, как исторические реалии, древние обычаи, суеверия, религиозные и мифологические представления, другими словами, всю материальную и духовную культуру народа).

2. Использование диалектных материалов в исторической фразеологии открывает много новых возможностей для историко-этимологического анализа фразеологизмов. Наиболее важными из них являются:

a) возможность реконструкции первоначальной семантики и структуры ФЕ и первичного образа (внутренней формы), лежащего в их основе. Покажем это на нескольких примерах:

Слово копьл, входящее в состав фразеологического оборота $с$ копьлов (копьльев) долой, имеет в русских диалектах несколько значений, в том числе и 'короткий брусок между полозьями и коробом саней', 'сани', 'нога' и т.д. Н.М. Шанский, В.И. Зимин и А.В. Филиппов связывают это выражение с первым значением:

Копыл - короткий брусок, вставляемый в полозья саней и служащий опорой для кузова. Сани, срывающиеся с копыльев, разваливаются (ОЭСРФ: 128).

Такая интерпретация первичного образа фразеологизма $c$ копьлов долой представляется сомнительной, поскольку разваливающийся кузов саней не объясняет возникновения значения этого выражения 'умереть' .

Вторая гипотеза, выдвинутая В.М. Мокиенко, кажется более правдоподобной. Она также объясняет исходный смысл фразеологизма с копылов (копьльев) долой значением слова копьл 'опора в виде бруска, соединяющего полозья саней с кузовом, верхней частью саней'. Выражение буквально значит 'свалиться с верхней части саней'. Значение 'умереть' восходит к древним языческим ритуалам погребения на санях (независимо от того, когда летом или зимой - были похороны), известным у восточных славян. Они отражены в др.-рус. съдя на санъх, употреблённом в Поучении Владимира Мономаха (1117 г., Лаврентьевская летопись):

(1) „Съдя на саньх, помыслих в души своей и похвалих Бога, иже мя сихъ дневъ грђшнаго допровади” [букв.: „Сидя на санях, помыслил я в душе своей и воздал хвалу Богу, который меня до этих дней, грешного, сохранил”]. 
Ср. также бел. глядзець на nаповы сані 'собираться на тот свет, быть в предсмертном состоянии' и рус. на смертном одре 'при смерти, в состоянии, близком к смерти', где одр (др.-рус. одръ, одеръ) — 'погребальные носилки, кузов телеги', 'дроги с настилом, волокуша'. Приведённые выражения моделируют тот же образ, что и др.-рус. съљдя на сангх, которое было еще актуально в XIII в.

Эта же метафора объясняет выражение с копьльев (с копьлов) долой, ритуально-символический смысл которой — 'снять с саней, понести покойника на кладбище'. Забвение ритуала и незнание диалектного слова коп и обозначаемой им реалии) привели к речевой паронимической трансформации - замене слова копылл на более понятное копылто. Это „переосмысление" постепенно закрепилось как языковой факт под влиянием другой фразеологической модели — протянуть ноги, откинуть копыта, отбросить коньки и т.п., что и привело к искажению исходной образности фразеологизма (Мокиенко 1999: 34-35; БМС: 339-340).

Анализ диалектных материалов заставляет усомниться и в этой этимологии. Копьл в значении 'сани' редко используется в русских диалектах. В словаре Даля и в Словаре русских народных языков (СРНГ) это значение отмечается только для диалектов в Архангельском регионе (Д II: 406; CPHГ XIV: 300). Значительно больше примеров приведено для слова копьл в значении 'нога', ср.: - Дал ему одну плюху, а он скоряя уж и с копыльев долой!; - Как дам, что слетишь с копылков. То же значение проявляется и во фразеологизме сшибать с копьльев 'кого-л. сбить с ног': Ямщина да прасолы мастеровщину с копыльев сшибают (Сказы Бажова) (CРНГ XIV: 300-301). Характерно, что в русском языке XVIII в. отмечается и фразеологизм с ног долой:

(2) Несколько сот бочек с винами стоят издревле. Меня подчивали... и я от двух рюмок чуть не с ног долой (Фонвизин, Письма); В сраженьи нет уже пощады никакой, И всякий гражданин валится с ног долой (Чулков, Стихи на качели).

Кроме с копьлов долой, в русском языке есть и другие обороты со значением 'умереть', которые содержат ту же структуру и тот же образ: $c$ копьт (копьтков) долой, с катушек долой, с коньков долой. Во всех этих фразеологизмах компоненты копьта, катушки, коньки означают 'ноги' в переносном смысле. Поэтому буквальное значение этих оборотов также 'упасть'. Поскольку выражение $c$ копылов долой идентично вышеупомянутым фразеологизмам как по структуре, так и по семантике, представляется логичным также связать компонент копьл со значением 'нога'. Семантическая связь „падать $\rightarrow$ умереть” представляется очевидной. 
Устаревший фразеологизм на свою руку охулки не положит кто 'кто-л. не упустит своей выгоды' содержит существительное охулка, которое сегодня неизвестно носителям языка. Обращение к диалектному материалу (Д II: 2012; СРНГ XXV: 55) позволяет выяснить первичное значение этого слова 'порицание, осуждение', отмеченное в псковских, рязанских, смоленских и других говорах. Первоначально выражение охулки на руки не положит кто употреблялось, по-видимому, по отношению к хорошему мастеру, который не позволит себе выполнить плохую работу. Фразеологизм широко употреблялся в XVIII и XIX в., однако в конце XIX в. он уже вышел из употребления, ср.:

(3) Если между твоими крепостными найдутся такие, коих нравы исправлять надо, то присылай ко мне; а я на свою руку охулки не положу (Фонвизин, Друг честных людей, или Стародум); [Фадей:] Положись ста на меня: уж я на свою руку охулки не положу (Княжнин, Сбитенщик); Он на свою руку охулки не положсит, т.е. не доведёт себя до порицания (CAP $\left.{ }^{2} \mathrm{IV}: 736\right)$.

В современном русском языке лексема порох имеет только одно значение 'взрывчатое вещество', которое было распространено уже в XVIII в. Ср. такие фразеологизмы, как: вспыхнуть как порох 'о вспыльчивом человеке', пороху не выдумает кто 'о человеке, не отличающемся сообразительностью' и т.п., которые основаны на этом значении. В русском языке XVIII в., однако, встречается ещё несколько оборотов, которые не могут быть объяснены приведённым значением. Ср.: ни синей порох 'о полном отсутствии чего-л.', один как [синей] порох в глазе кто у кого 'о ком-л. очень близком и дорогом, единственном', беречь как порох в глазе кого 'заботливо, бдительно охранять, оберегать кого-л.'. Словарь русских народных говоров и Словарь Российской Академии $\left(\mathrm{CAP}^{1}\right)$ приводят под словом порох следующую информацию, которая даёт более ясное представление о ранней семантике этого слова: Порох, м. 1. Пыль, сор... 2. Соринка, попавшая в глаз (СРНГ ХХХ: 83); ПОРОХЪ ... 1) Пыль; мълкая высохшая земля. ...Порохъ въ глазъ попаль (CAP $\left.{ }^{1} \mathrm{IV}, 999\right)$. Этому объяснению хорошо соответствует первый фразеологизм ни синей поpox 'о полном отсутствии чего-л.', изначально: 'нет даже черной (тёмной) пыли (пылинки)'. Характерно, что и прилагательное синий в этом выражении сохранило своё архаичное значение 'черный, тёмный' (Толстой 1973: 286; Иванова 1974: 288). Ср., например, следующие контексты:

(4) Девушка неубогая, грамоте и писать горазда, а пуще всего великая экономка: у нее ни синей порох даром не пропадет (Новиков, Живописец); Во всю жизнь мою не видывал я такого негодного ребенка, каков 
был этот до бесконечности изнеженный и избалованный мальчишка, в котором не находил я ни синя пороха доброго! (Болотов, Записки) u.a.

Более сложной является, однако, образная мотивация фразеологических оборотов один как [синей] порох в глазе кто у кого 'о ком-л. очень близком и дорогом, единственном' и беречь как порох в глазе кого 'заботливо, бдительно охранять, оберегать кого-л.'. М.И. Михельсон попытался объяснить её следующим образом: „что досаждает, озабочивает, за чем следишь заботливо, - дорогое” (Михельсон 1902, 1: 404). Эта интерпретация имеет определенную логику, особенно если учесть диалектное сравнение как порох в глазу 'досаждает', отмеченное В.И. Далем (Д ІІІ: 837). Нельзя, однако, исключить возможности того, что эти два выражения были созданы под влиянием других структурно- и семантически идентичных фразеологизмов. Ср.: один как глаз во лбу, беречь как глаза (очи), беречь как зеницу ока (зеница 'зрачок'). Образная основа приведённых выражений позволяет истолковать 'частицу черной пыли в глазу, которая находится в одиночестве или нуждается в защите' (один как [синей] порох в глазу, беречь как порох в глазу) как 'зрачок в глазу'.

Диалектные и исторические материалы позволяют также объяснить образную основу значительного числа русских фразеологизмов с компонентом живот: кончить (окончить, скончать, потерять) живот 'умереть', положить живот за кого 'умереть, погибнуть (обычно в бою) за кого-л., что-л.', в животе нет кого 'нет в живых кого-л.', отнять живот чей 'убить, лишить жизни кого-л.', лишить живота кого 'убить, лишить жизни когол', не на живот, а на смерть 'не щадя жизни (бороться, сражаться)' и др. Во всех этих оборотах компонент живот имеет значение 'жизнь', которое в современном русском языке устарело, но хорошо известно в диалектах, ср.: разлучить с животом 'убить, лишить жизни кого-л.', до своего живота 'до конца своей жизни', живота не надышу 'нерадостна жизнь', посылать по живот 'давать жизнь' (СРНГ IX: 157). Приведённые устойчивые словосочетания широко употреблялись и в русском языке XVIII-XIX в., ср.:

(5) А бедная свекровь моя так простудилась от этой мокроты, что и руки и ноги отнялись, и через два месяца живот свой окончила (Долгорукая, Записки); Не успел я, севши в свою коляску, со двора съехать, как и пошли в голове у меня мысли за мыслями и наконец такая дрянь, что я и животу своему почти не рад был (Болотов, Записки).

б) возможность показать различные изменения в структурно-семантической организации фразеологизмов. Так, особенностью русских фразеологических единиц ранних языковых эпох является более широкая вариантность, чем сегодня, что было связано с проникновением разговорных и диалектных 
элементов в язык. Фразеологизм ни рыба ни мясо употреблялся, например, в языке XVIII в. в двух вариантах: ни рак ни рыба и ни рыба ни мясо. Ср.:

(6) [Сторож:] Меня бросила и полюбила другого. Я и остался ни рак ни рыға (Нехачин, Неудачливый в любви подьячий); [Чужехват:] А ты, мой друг, ни то ни се, ни рыља ни мясо (Сумароков, Опекун).

Сегодня архаичный вариант ни рак ни рыба, отмеченный в словаре В.И. Даля (Д III: 1586), имеет, однако, более древнее происхождение, о чем свидетельствует тот факт, что и в некоторых других славянских языках этот оборот отмечен именно с компонентом рак. Ср.: чешск. nebýt ani ryba, ani rak; словац. ani ryba, ani rak; болг. ни риба, ни рак.

в) возможность выявления диалектных фразеологизмов в различные периоды развития языка. Так, например, значительная часть устойчивых словосочетаний XVIII в. восходит к диалектам. Установить диалектный характер фразеологизмов довольно трудно, однако данные Словаря Академии Российской (1789-1794), диалектных словарей XIX в. (Опыт областного словаря великорусского наречия - 1852; Дополнение к Опьту областного словаря великорусского наречия - 1858), Толкового словаря живого великорусского языка В.И. Даля и Словаря русских народных говоров все же позволяют это сделать. К устойчивым сравнениям диалектного происхождения можно отнести, например, выражения стоять как попест, охать как попест, поскольку они уже не употребляются в литературном языке XIX в. и отмечаются лишь в диалектах ${ }^{1}$. В произведениях XVIII в. они встречаются довольно часто, что объясняется сильным влиянием диалектов на литературный язык этого периода. Ср.:

(7) [Скопидомова:] Пгишол, давича, мой батька, к тебе из гатуши подъячей, а она тут же cmoum, как попест, и не уйдет (Подражатель); [Филат:] А мне так бедняку. Горюхе, батраку, Уж не осталося чово топерь и баять, Как только горевать да охать как попесту (Попов, Анюта).

Диалектный характер компонента отмечен и у выражения табалу бить 'бездельничать', которое зафиксировано в Словаре Академии Российской (CAP ${ }^{2}$ VI: 654) и уже там классифицируется как „простонародное”. Фразеологизм характеризуется, прежде всего, компонентом табала, который Р. Еккерт связывает с литовск. lit. tābalas 'деревянная чурка' (Eckert 1994: 15-21). По своей структуре и семантике фразеологизм хорошо вписывается в модель ,бить + деревянные чурки и т.д.” = ‘бездельничать', которую определил

1 „Попест... Лентяй. Кур.” (Опыт обл. слов. 1852: 170); „Попест. Кур. Увалень, лентяй, шалун" (Д ІІІ: 779). 
В.М. Мокиенко, ср.: бить баклуши, бить шабалу и т.д. (Мокиенко 1989: 78 и след.). В русском языке XVIII в. выражение табалу бить было заимствовано из диалектов. Его диалектный характер привёл к тому, что он все меньше и меньше использовался в процессе стандартизации русского языка и уже во второй половине XIX в. встречался только в диалектах. Ср. также данные в словаре В.И. Даля (Д IV: 706). В источниках XVIII в. это выражение отмечается довольно часто, ср:

(8) Никто не находил меня никогда сидевшим праздно или, по пословице говоря, бьюшим табалу и ходящим без дела в канцелярию (Болотов, Записки) u.a.

Выражение дать зорю кому ‘бить, наказывать побоями кого-л’ также восходит к диалектам. Его первоначальная мотивация до сих пор чётко не прояснена. М.И. Михельсон связывает этот оборот с игрой „зоренька”, в которой один игрок ловит других, а затем „бьёт” их витым полотенцем (жгутом) (Михельсон 1902, I: 315). Однако связь между выражением и игрой кажется мне второстепенной. В Словаре Академии Российской (САР) и в словаре В.И. Даля есть ещё два выражения, близких к фразеологизму дать зорю, а именно: Войти в зари, простонар. Разгорячиться от досады, притти в сердце (САР² III: 19) и Зари взяли кого, приводить в зари. Зарить, распалять, поджигать (Д I: 1566). Поскольку зоря является диалектным эквивалентом зари, можно предположить, что выражение дать зорю изначально означало 'дать жару'. Структурно-семантическая модель „нагреть кого-л.” = “избить' часто встречается в русской фразеологии, ср. дать жару, пару, баню, зною и др. Использование выражения дать зорю ограничивается преимущественно XVIII в.; в XIX в. оно зафиксировано только в диалектах (Д I: 1567). Ср.:

(9) [Простакова:] Теперь-то дам я зорю канальям своим людям. Теперьто я всех переберу поодиночке. Теперь-то допытаюсь, кто из рук ее [Софью] выпустил (Фонвизин, Недоросль).

3. Сделанные наблюдения показывают важность диалектных материалов при историческом исследовании фразеологического состава языка. Для получения достоверных результатов необходимо прежде всего создание исчерпывающей базы данных, включающей в себя помимо диалектных оборотов фразеологические факты из различных языковых эпох. Этимологию и историческое развитие фразеологизмов можно исследовать только путём изучения их вариантов из старых языковых периодов, синонимических и антонимических групп, устойчивых словосочетаний с теми же компонентами в диалектах, в фольклоре и в родственных и неродственных языках. Особую роль играют при этом варианты, позволяющие реконструировать первичный 
образ на основе структурно-семантических моделей. Большое значение для возникновения многих фразеологических оборотов имеют также экстралингвистические факты, так как фразеологизмы могут отражать многовековые явления материальной и духовной культуры народа. К сожалению, не всегда можно проследить историю фразеологической единицы во всех языковых эпохах, часто приходится довольствоваться гипотезами, которые кажутся относительно правдоподобными.

\section{SuMmary}

\section{Dialects as a Source of Historical Russian Phraseology}

A historical study of phraseologisms first requires taking into account all linguistic facts from the standard language, dialects, the language of folklore and professional as well as special languages. Its dialects are to be regarded as important linguistic material because, as B.A. Larin notes, the roots of Russian phraseology are to be sought in them. The dialectal material can thus in many respects complete missing historical information. Many dialects contain outdated phraseological variants, lexemes or meanings which can be revealing for the etymology of a phraseologism. Through the analysis of several examples this essay shows the possibilities that dialectal material offers for the historical etymological research of the phraseology of the Russian language. 


\author{
Magdalena Grupa-Dolińska @ \\ Uniwersytet Mikolaja Kopernika w Toruniu \\ magdalena.grupa1@gmail.com
}

\title{
OBCOJĘZYCZNE ELEMENTY WE FRAZEOLOGII Rosyjskiej GWary StaroobrzędowCów W Polsce ${ }^{1}$
}

Słowa klucze: staroobrzędowcy, frazeologia, rosyjska gwara, zapożyczenia, kalki frazeologiczne

Keywords: Old Believers, phraseology, Russian dialect, loan words, phraseological calques

Staroobrzędowcy, potomkowie Rosjan, którzy nie zaakceptowali reform patriarchy Nikona w zakresie liturgii i obrzędowości, na terenach Rzeczpospolitej zaczęli się osiedlać już pod koniec XVII w. Na terytorium Polski w jej współczesnych granicach pojawili się w XVIII w. Przenieśli się wówczas z kilku powiatów litewskich (kowieńskiego, wileńskiego i trockiego) na tereny północno-wschodniej Polski (Iwaniec 1977: 78). W latach 30. XIX w. część starowierców z Suwalszczyzny przeniosła się na Mazury, na znak protestu przeciwko zmianom wprowadzanym przez władze Królestwa Polskiego - poborom wojskowym i konieczności prowadzenia w parafiach staroobrzędowych ksiąg metrykalnych (Iwaniec 1977: 108). Wspomniane regiony dzieli stosunkowo niewielka odległość, jednak losy zamieszkujących je społeczności potoczyły się zupełnie inaczej. W czasie pierwszych osiedleń staroobrzędowców tereny okolic Suwałk i Augustowa stanowiły część Imperium Rosyjskiego, a po 1918 r. znalazły się w granicach Rzeczypospolitej. Region mazurski był natomiast częścią Prus Wschodnich aż do II wojny światowej (Гжибовский, Глушковский 2008: 200).

Ta część starowierskiej społeczności, która osiedliła się w Polsce, pochodzi z okolic Nowogrodu, Pskowa i Wielkich Łuk, co zostało ustalone na podstawie analizy zachowanych cech językowych. W momencie przybycia jej przedstawiciele posługiwali się gwarą właściwą tym terenom, należącą do zachodniego typu

Artykuł został napisany w ramach realizacji projektu ,Zasób frazeologiczny gwary staroobrzędowców w Polsce", sfinansowanego ze środków Narodowego Centrum Nauki przyznanych na podstawie decyzji nr DEC-2018/29/N/HS2/01903. 
gwar środkowowielkoruskich (tj. gwarą pskowską z pewnymi naleciałościami polskimi i białoruskimi) (Grek-Pabisowa 1968: 13).

Aktualnie ich rosyjska gwara poddawana jest coraz silniejszemu wpływowi polszczyzny, który przejawia się na wszystkich poziomach języka - najsilniej w warstwie leksykalnej (zob. np. Paśko-Koneczniak 2011a: 118-126; Paśko-Koneczniak 2011b; Grupa 2016b: 167-185; Grupa-Dolińska 2018: 703-720) i we frazeologii (zob. np. Grupa 2017: 113-122, 2018: 165-172).

Poza wpływem polskim w gwarze tej obecne są także elementy pochodzące z innych języków: w okolicach Augustowa i Suwałk - białoruskie i litewskie, natomiast na Mazurach - niemieckie. Ich obecność jest konsekwencją kontaktów starowierców z ludnością różnojęzyczną, do których dochodziło na poszczególnych etapach ich wędrówki z Rosji oraz już po osiedleniu się na terenach docelowych. Zagadnienie wpływów leksykalnych doczekało się wielu pogłębionych opracowań oraz szczegółowych studiów, natomiast wpływy w zakresie frazeologii nie były dotąd badane na szerszą skalę. Niniejszy artykuł stanowi próbę częściowego wypełnienia tej luki.

Celem opracowania jest prezentacja obcych elementów językowych, które notowane są w rosyjskiej gwarze staroobrzędowców. Za obce elementy językowe uważane są tu zarówno kalkowane w całości frazeologizmy, jak i kalkowane lub zapożyczone części frazeologizmu (konstrukcje, komponenty).

\section{Badania nad frazeologią rosyjskiej gwary staroobrzędowców w Polsce}

Analiza frazeologii gwary staroobrzedowców w Polsce jest stosunkowo nową inicjatywą. Choć badania nad językiem starowierców w Polsce prowadzone są już od przeszło pół wieku, na przestrzeni lat kompleksowego opisu doczekały się niemal wszystkie poziomy języka z wyjątkiem frazeologii. Najwcześniejszym źródłem notującym jednostki frazeologiczne jest monografia Irydy Grek-Pabisowej (1968), kolejną pracą dokumentującą, obok jednostek rodzimych, również frazeologizmy noszące znamiona wpływu polszczyzny jest słownik autorstwa I. Grek-Pabisowej i Ireny Maryniakowej (1980). Następnie w 2013 r. ukazał się artykuł Doroty Paśko-Koneczniak (2013), dotyczący wpływu polszczyzny na idiomatykę rosyjskiej gwary staroobrzędowców. Pewne uwagi na temat frazeologii pojawiły się także na marginesie badań nad innymi aspektami gwary staroobrzędowców, w monografii D. Paśko-Koneczniak (2011a) oraz w artykułach Stefana Grzybowskiego (Гжибовский 2011) i Michała Głuszkowskiego (2011b). Celem prowadzonych aktualnie badań jest kompleksowe opisanie systemu frazeologicznego, a ich dotychczasowe wyniki pozwoliły na poczynienie fragmentarycznych wniosków m.in. na temat zalet prowadzenia badań w perspektywie podłużnej w kontekście analizy frazeologii (Głuszkowski, Grupa 2016), roli tradycji w kulturze staro- 
obrzędowców, odzwierciedlonej w paremiach ich gwary (Grupa 2016a), a także uwag dotyczących rozpoznawania i cech charakterystycznych frazeologicznych kalk, półkalk i hybryd w omawianej gwarze (Grupa-Dolińska 2019). Ponadto zaprezentowane zostały pewne partie materiału odzwierciedlające wpływ języka polskiego na porównania frazeologiczne (Grupa 2017) oraz frazeologiczne kalki i półkalki notowane w mowie przedstawicieli średniego pokolenia staroobrzędowców (Grupa 2018).

Dzięki wysiłkom zespołu pracującego pod kierownictwem Stefana Grzybowskiego udało się utworzyć korpus około 400 godzin nagrań rozmów ze staroobrzędowcami. Materiał zbierany był regularnie od 1999 r. Niestety, przez wiele lat dociekania badaczy nie skupiały się na zagadnieniach związanych z frazeologią, przez co liczba zgromadzonych jednostek frazeologicznych nie jest dziś zbyt imponująca ${ }^{2}$. Materiał frazeologiczny gromadzony jest sukcesywnie od 2015 r., jednak tak późne podjęcie tej inicjatywy wiąże się z jeszcze jednym problemem: zmarła już spora część informatorów, w idiolektach których potencjalnie frazeologia mogłaby funkcjonować, a wśród tych żyjących coraz większą rolę pełni polszczyzna. W praktyce oznacza to, że młodsze pokolenie właściwie nie zna frazeologii swych przodków, zdarzają się w ich mowie jedynie pojedyncze przypadki tworzenia konstrukcji doraźnych kalkowanych z polszczyzny. Średnie pokolenie jest natomiast bardzo zróżnicowane pod względem sytuacji językowej. Można wśród nich znaleźć osoby władające rosyjską gwarą na równi z językiem polskim, jest jednak również spore grono, które komunikuje się niemal wyłącznie po polsku (w zależności od tematyki, sytuacji komunikacyjnej, innych czynników o charakterze socjolingwistycznym), więc i w tej sytuacji trudno uzyskać materiał frazeologiczny. $\mathrm{W}$ ich przypadku również mamy do czynienia z podejmowaniem prób utrzymania wypowiedzi w kodzie gwarowym, co stymuluje proces tworzenia doraźnych konstrukcji frazeologicznych kalkowanych z polszczyzny. Najwięcej materiału udało się uzyskać od przedstawicieli najstarszej generacji, choć i w ich przypadku napotykamy pewne trudności. Gromadzenie materiału frazeologicznego odbywa się przy wykorzystaniu kilku metod: ankietowej, wywiadu pogłębionego oraz obserwacji uczestniczącej. Częstokroć jednak w przypadku ankiet oraz wywiadów pogłębionych pojawiają się wątpliwości co do rzetelności zgromadzonego w taki sposób materiału. Po pierwsze, trudno uniknąć sugerowania odpowiedzi, a po drugie, zaprzyjaźnieni z nami informatorzy zdają się czasem udzielać takich odpowiedzi, które - ich zdaniem - chcemy usłyszeć. Innym problemem są także dysproporcje w zakresie zgromadzonego materiału od starowierców suwalsko-augustowskich i mazurskich. Jest to niestety problem nie do rozwiązania, ponieważ na Mazurach właściwie nie ma już osób posługujących się rosyjską

2 Do tej pory zgromadzono około 700 jednostek frazeologicznych, z czego blisko połowa nie została dotąd szerzej potwierdzona. 
gwarą (poza sferą religijną oraz wstawkami i schematycznymi fragmentami rozmów w sferze rodzinnej na tematy życia codziennego). Dysponujemy natomiast pewnym, również stosunkowo niewielkim, zasobem zapisów nagrań z lat 50.-60. XX w., w którym frazeologia sią pojawia.

\section{Elementy białoruskie}

Możliwa obecność elementów pochodzenia białoruskiego w rosyjskiej gwarze staroobrzędowców związana jest z kilkoma czynnikami, które można pogrupować ze względu na okres, w jakim pojawiało się największe prawdopodobieństwo ich przeniesienia do języka badanej grupy: 1) okres kontaktu rosyjskiej gwary z gwarami białoruskimi na terenach macierzystych staroobrzędowców, 2) okres migracji, 3) okres po osiedleniu się staroobrzędowców na ziemiach polskich, 4) czasy współczesne.

Po pierwsze, rodzima gwara starowierców (tzw. gwara pskowska) już na terenach macierzystych posiadała szereg cech wspólnych z gwarami białoruskimi, natomiast migracje przez tereny białoruskie nie tylko pozwoliły na utrzymanie tych cech, ale również na przenikanie do gwary nowych. I. Grek-Pabisowa w monografii z 1968 r. wskazywała, że:

Gwara, którą wynieśli [staroobrzędowcy - M.G.D.] ze swojego macierzystego terytorium, posiadała wiele cech wspólnych z cechami gwar białoruskich. Migracja na zachód przez tereny białoruskie sprzyjała utrwaleniu się tych cech oraz nabyciu nowych. Po osiedleniu się kontakty z ludnością białoruską nie ustały (np. powiat grodzieński), co również nie pozostało bez wpływu na omawianą gwarę (Grek-Pabisowa 1968: 12).

Zatem po drugie, elementy białoruskie do gwary staroobrzędowców trafiać mogły również na etapie migracji na tereny Rzeczypospolitej, a także już po osiedleniu się na nich - świadczyć o tym może ślad wpływu języków wschodniosłowiańskich na gwary polskie tych terenów (zob. np. Zdancewicz 1963: 231-266; Zdancewicz 1966; Grek-Pabisowa 1976/1999: 118). Staroobrzędowcy, opuszczając swą ojczyznę, podążali w różnych kierunkach, ci zaś, którzy osiedlili się na ziemiach polskich, docierali do nich dwiema drogami. Pierwsza z nich przebiegała przez pas krajów bałtyckich, spora część starowierców osiedliła się w pierwszym etapie migracji na Inflantach i w Kurlandii; na terenach należących przed wojną do Polski powstało wówczas wiele osad (m.in. w byłych powiatach jeziorskim, wiłkomirskim, święciańskim, poniewieskim, wileńskim, trockim, oszmiańskim, suwalskim, sejneńskim). Na ziemi suwalsko-sejneńskiej oraz w północnej części powiatu augustowskiego staroobrzędowcy osiedlili się już przed 1779 r. (Grek- 
-Pabisowa 1998/1999: 19-20). Druga ze wspomnianych dróg migracji prowadziła przez należące wówczas do Rzeczypospolitej ziemie białoruskie (osady w Starodubiu i Wietce na południe od Homla w rozwidleniu rzeki Soż), z których następnie pewna część staroobrzędowców zawędrowała do powiatów witebskiego, suraskiego, newelskiego, lepelskiego, a niektórzy z nich jeszcze dalej - na Suwalszczyznę (Grek-Pabisowa 1998/1999: 21). Obie grupy migrujące miały zatem kontakt z ludnością białoruską, choć charakteryzował się on różnym natężeniem.

Współcześnie trudno mówić o masowych kontaktach staroobrzędowców z Białorusinami, a jeżeli jakieś występują, to są to pojedyncze przypadki, które nie mają większego znaczenia dla gwary jako całości.

Zgromadzone frazeologizmy o możliwym pochodzeniu białoruskim można podzielić na dwie grupy: a) frazeologię notowaną w języku białoruskim (lub jego gwarach) wspólną dla języków wschodniosłowiańskich (przynajmniej niektórych), np.:

m 'axnuć ruk 'oj 'odpuścić' (ros. махнуть рукой, błrus. махнуць рукой, pol. machnać ręka): zn 'al'i što z nas né b'uź 'et inžyner 'of to tam pr'ipušč 'al'i, $m$ 'axal'i ruk'oj ńekat'oryji;

v'yćanuć n 'og'i 'umrzeć' (ros. вытянуть ноги, błrus. ногі выцягнуць, pol. wyciagnać nogi | kopyta): ńe m 'ajiš ź'enik, j́ej, i ne l'ečśa, bo jon kak ćeb' 'a v'ylečyt, to za dv'e néź el i n'og'i v'yćańiš;

\{komиś $\}$ zań 'ala d'uxa 'pozbawiło tchu' (ros. psk. дух занимает, błrus. духі займаe): mńe zań 'ała d'uxa;

oraz wspólny zasób frazeologii polskiej i białoruskiej, np.:

naś ić žat 'obu 'cierpieć po śmierci bliskiej osoby' (pol. nosić żałobę, błrus. жалобу насіиь 'хадзиіь у жалобным, чорным адзенні або з адзнакаю жалобы'): my žat 'obu b 'uźem naś 'ić tap' 'er', bo 'eta śastr 'a n'aša, n'aša pl'em' 'an:ica;

dav'acsa va zn 'ak'i 'dokuczać' (pol. dawać się we znaki, błrus. даващฺ̨a у знаки 'надоўга запомніцца'): $m$ 'ux'i 'et'i daj 'ucsa va zn 'ak' $i$;

\{kogoś\} gt'ava bal 'it 'o czyimś problemie' (pol. \{kogoś\} boli \{o coś\} gło$w a$, błrus. галава не баліиь | галоукка не баліць 'не турбавацца за лёс, учынкі, справы каго'): 'eta už'e mńe gt'ava bal' it.

W przypadku obu tych grup jednoznaczne rozstrzygnięcie, z którego zasobu dane frazeologizmy przeniknęły do gwary staroobrzędowców, wydaje się niemoż- 
liwe. Bardziej prawdopodobne jednak, że jednostki notowane zarówno w języku białoruskim, jak i rosyjskim lub jego gwarach przejęte zostały do gwary starowierców z podstawowego dla nich kodu, jakim są ruszczyzna ogólna i gwara pskowska. Nie bez znaczenia jest w tym wypadku także fakt, że to język rosyjski w większym stopniu oddziaływał na białoruski, również w zakresie frazeologii, a zatem nawet jeśli wymienione frazeologizmy trafiły do gwary starowierców za pośrednictwem języka białoruskiego, to mogły być zapożyczeniami wtórnymi, których pierwotnym źródłem była ruszczyzna. Podobne uwagi dotyczą wspólnego zasobu frazeologii polskiej i białoruskiej. Z uwagi na silne i długotrwałe oddziaływanie polszczyzny, a także brak nasilonych kontaktów z ludnością białoruskojęzyczną w dobie najnowszej, bardziej prawdopodobne wydaje się polskie pochodzenie wskazanych frazeologizmów (stanowiłyby one więc kalki frazeologiczne). Niemniej nie można ostatecznie wykluczyć możliwości białoruskiej proweniencji wspomnianych jednostek.

\section{Elementy niemieckie}

Wpływ na gwarę staroobrzędowców na Mazurach wywierała niemczyzna ogólna, a dokładniej jej potoczny wariant (Grek-Pabisowa 1983: 57). Zakłada się, że oddziaływanie niemczyzny rozpoczęło się tuż po osiedleniu się staroobrzędowców na tych terenach (ok. 1830 r.), trwało natomiast aż do końca II wojny światowej ${ }^{3}$, kiedy to Mazury należące uprzednio do Prus Wschodnich znalazły się w granicach administracyjnych Polski (Grek-Pabisowa 1983: 57; Jorroch 2014: 311).

Intensywność procesu oddziaływania języka niemieckiego na rosyjską gwarę nie zawsze była jednolita:

W pierwszych latach po osiedleniu się wpływ języka niemieckiego nie mógł być znaczny. Do 1843 r. nie obowiązywała staroobrzędowców służba wojskowa, szkoły z językiem niemieckim wprowadzono po $1876 \mathrm{r}$. Za okres silniejszych wpływów języka niemieckiego można przyjąć lata od ostatniego ćwierćwiecza w. XIX do r. 1945 (Grek-Pabisowa 1983: 58).

Obok języka niemieckiego, już od momentu przesiedlenia się staroobrzędowców na Mazury, na rosyjską gwarę wpływała polska gwara mazurska. Za jej pośrednictwem starowiercy poznali wiele pojęć nazywających elementy rzeczywistości w nowych realiach, poprzez medium mazurskie trafiło do ich gwary wiele

3 I. Grek-Pabisowa zauważa, że kontakty staroobrzędowców z językiem niemieckim na Mazurach nie ustały wraz z zakończeniem II wojny światowej, a trwały jeszcze kilka lat dłużej - do momentu, kiedy ludność niemiecka wyemigrowała do Niemiec (Grek-Pabisowa 1983: 57). 
germanizmów, co dodatkowo ułatwione było przez podobieństwo obu systemów językowych w porównaniu z językiem niemieckim (Grek-Pabisowa 1983: 59).

Obecność niemieckich elementów językowych podtrzymywały częste wyjazdy mazurskich staroobrzędowców do Niemiec oraz utrzymywanie kontaktów z rodziną tam mieszkającą. Efekt ten wzmacniał także wysoki prestiż języka niemieckiego w oczach starowierców. Jak pisze Anna Zielińska:

wszyscy chętnie go [języka niemieckiego - przyp. M.G.D.] używają, przyznają się do posługiwania się nim w gronie rodzinnym, zarówno przed wojną, jak i obecnie [...] (Zielińska 1996: 53).

Obecnie na Mazurach pozostało niewielu staroobrzędowców mówiących rosyjską gwarą, za to spora część z tych, którzy jeszcze żyją, posługuje się językiem niemieckim, o czym wspomina Anna Jorroch:

Staroobrzędowcy urodzeni do połowy lat 50. XX wieku mówią płynnie i naturalnie po niemiecku. U osób starszych, które najdłużej przebywały w otoczeniu niemieckojęzycznym, wpływy z polszczyzny są najmniej widoczne [w zakresie języka niemieckiego] (Jorroch 2014: 315).

Podstawowym językiem komunikacji używanym w sytuacjach codziennych jest dla staroobrzędowców mazurskich urodzonych po 1945 r. język polski (Jorroch 2014: 318).

W pracach poświęconych zapożyczonej z języka niemieckiego leksyce i sytuacji językowej staroobrzędowców mazurskich brak niestety wzmianek dotyczących frazeologii pochodzenia niemieckiego w rosyjskiej gwarze.

W zgromadzonym materiale odnotowałam tylko dwa przykłady frazeologizmów zawierających elementy pochodzące z języka niemieckiego:

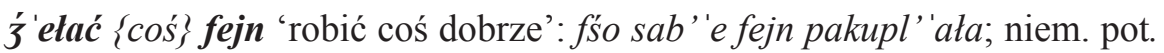
sich fein machen 'ładnie się ubrać, przyozdobić';

$\{k t o s\}$ m 'ajit $\boldsymbol{f}$ 'ugl'a 'mieć manię na punkcie czegoś': on m 'ajit pat tym zgl'endam f'ugl'a; niem. einen Vogel haben 'mieć fioła (niedobrze w głowie)'.

Należy zaznaczyć, że tak mała liczba zarejestrowanych frazeologizmów nie powinna być interpretowana jako dowód niewielkiego wpływu niemczyzny w tym zakresie. Współcześnie właściwie nie ma już możliwości poznania skali zjawiska - z uwagi na wciąż zmniejszającą się liczbę informatorów posługujących się rosyjską gwarą oraz zbyt późno podjęte prace nad gromadzeniem frazeologii. Istnieje duże prawdopodobieństwo, że przykładów jednostek frazeolo- 
gicznych motywowanych niemczyzną byłoby więcej, gdyby korpus nagrań był szerszy ${ }^{4}$.

\section{Elementy litewskie}

W rosyjskiej gwarze notuje się także pewne elementy z języka litewskiego, choć nie są one często spotykane. I. Grek-Pabisowa w monografii z 1983 r. zwróciła uwagę na niewielki udział słownictwa zapożyczonego z języków bałtyckich w zasobie leksykalnym starowierców. Badaczka wynotowała wówczas 12 pożyczek litewskich (np. głumn 'oj 'głupi; dokuczliwy' < lit. glùmas 'głupota, ogłupienie') i 2 łotewskie (np. barkan' 'ica < łot. burkāni 'marchew'), a wśród nich jeden związek wyrazowy zawierający element litewski: $d$ 'arbu spr 'av'it' 'sprawić lanie' < $<$ lit. dárbas 'praca, robota'(?) $)^{5}$, którego jednak nie odnaleziono we współczesnym materiale.

W zgromadzonym przeze mnie zasobie odnotowany został jeden frazeologizm zawierający element litewski:

nam 'azala l'upy $k a k$ j'olka 'o kobiecie z mocnym makijażem ust': an 'a nam 'azała l'upy kakj'ołka; l'upy; lit. lūpa 'warga'.

\section{Elementy polskie}

Możliwych dróg, poprzez które w różnych okresach elementy polskie docierały do rosyjskiej gwary, jest co najmniej kilka.

Największe znaczenie z punktu widzenia nasilenia oddziaływania polszczyzny miał etap, w którym doszło do znaczącej intensyfikacji kontaktów staroobrzędowców z polskim otoczeniem językowo-kulturowym, co bezpośrednio przełożyło się na skalę interferencji. Właśnie w tym okresie, dla którego umowną cezurą jest koniec II wojny światowej i terytorialne odcięcie polskich staroobrzędowców od

4 Korpus nagrań dokumentujących gwarę, który udało się zgromadzić na potrzeby niniejszej rozprawy, jest niewielki w porównaniu z materiałem ośrodków augustowskiego i suwalsko-sejneńskiego. Obejmuje materiał zarejestrowany w latach 50.-60. XX w. przez I. Grek-Pabisową oraz materiał współczesny z 2014 r., zgromadzony przez pracowników naukowych i studentów Uniwersytetu Mikołaja Kopernika w Toruniu. Podczas ekspedycji zorganizowanej w 2014 r. okazało się, że tylko kilku informatorów, do których udało się dotrzeć, komunikuje się nadal za pomocą rosyjskiej gwary, a część informatorów zgodziła się na rozmowy wyłącznie w języku polskim.

5 Znak zapytania pojawia się także w opracowaniu, z którego zaczerpnięty został przykład. 
współwyznawców w Litewskiej, Łotewskiej i Estońskiej SRR, a także z innych obszarów Związku Radzieckiego, pojawiło się w rosyjskiej gwarze najwięcej modyfikacji, co potwierdzają liczne publikacje naukowe badaczy języka staroobrzędowców, począwszy od lat 50. XX w. (zob. m.in. Grek-Pabisowa 1983; Zielińska 1996; Гжибовский 2011: 45-59; Głuszkowski 2011a: 107-117, 2011b; Paśko-Koneczniak 2011a: 118-126, 2011b).

Należy jednak podkreślić, że pewne elementy językowe z polszczyzny docierały do gwary staroobrzędowców na długo przed intensyfikacją kontaktów z Polakami, a nawet przed ich dotarciem na ziemie polskie. Grek-Pabisowa, analizując słownictwo gwary staroobrzędowców, zwróciła uwagę na występowanie pewnego zasobu wyrazów, które przeniknęły do rosyjskiej gwary staroobrzędowców jeszcze na ich terenach macierzystych ${ }^{6}$ (autorka określa je mianem polonizmów dawnych), np. al 'ej 'olej', kav'al 'kowal' (zob. Grek-Pabisowa 1983: 54). Wzajemna polsko-rosyjska interferencja związana jest również, co oczywiste, ze wspólną, niełatwą historią, wielowiekowym sąsiedztwem i ich konsekwencjami.

Polskie elementy językowe we frazeologii gwary staroobrzędowców podzielić można na dwie grupy: 1) frazeologiczne kalki i półkalki z polszczyzny, a wśród nich jednostki, które nazwać już można systemowymi oraz jednostki tworzone doraźnie, a także 2) polskie wstawki pojawiające się w ramach przełączania kodów.

Spośród przykładów frazeologicznych kalk i półkalk wydzielić można, jak już wspomniano, dwie podgrupy:

a) kalki i półkalki - zjawiska systemowe, które funkcjonują w gwarze od lat. Przy ustalaniu ich zasobu pomocny był Słownik gwary staroobrzędowców I. Grek-Pabisowej i I. Maryniakowej (1980) oraz fakt prowadzenia badań w perspektywie podłużnej. Ich systemowość ustalałam także dzięki analizie liczby poświadczeń w spontanicznej mowie. Do takich jednostek należą np.:

\section{KALKI FRAZEOLOGICZNE}

st'aryj byk 'o dorosłym mężczyźnie zachowującym się nieadekwatnie do wieku' (pol. stary byk): wygląd r'eb' 'ačyj m 'ajit, 'al'e r'ozum m'ajit st 'areva byk'a;

dastav 'ać b' 'etaj gar' 'ačk'i 'wściekać się' (pol. dostawać biatej goraczki): no to ja dast 'avat b' 'etaj gar' 'ačk' $i$;

ńe zvar 'ačyvać uv 'agi 'być obojętnym wobec kogoś lub czegoś, lekceważyć' (pol. nie zwracać uwagi): ńikt'o na 'eta ńe zvar 'ačyvat uv 'ag'i specj 'alna.

6 Więcej na temat polonizmów leksykalnych w gwarach rosyjskich - zob. np. Doroszkiewicz 1991; Wójtowicz 2012: 371-386. 


\section{PÓŁKALKI FRAZEOLOGICZNE}

\{komuś\} v'otas s gatav'y ńe spaź'ot '(komuś) nic się nie stanie' (pol. \{komиś\} włos z głowy nie spadnie, ros. Ни один волос не упадёm | не упал | с головы \{чвей, кого\}): tag gavar'il'i jag b'uз́eš m'eńše znać, ć'ixa śiź 'eć to v'ołaz z gałav'y m 'i ńe sp 'ańet, 'al'i kag b'uźeš mnok zn 'ać to žyć ńe b 'uźeš - adaptowane zapożyczenie spaź 'ot zamiast rosyjskiego ynadëm;

brać pad vńim 'anije 'uwzględniać' (pol. brać pod uwagę, ros. принимать во внимание): no $i$ 'eta aš'ypka balš aja 'eta b'yta aš'ypka, tak nee $m$ 'ožna b'yta pastup 'ać $i$ ź'etać, bo za što nar 'ot j'eta t'ože ś' ilna brat pad vńim 'ańije, što 'eta tag być ńe m 'ožet - o polskiej motywacji frazeologizmu świadczy konstrukcja składniowa z przyimkiem pad;

padnaś ić \{na kogoś\} r'uku 'stosować przemoc fizyczną' (pol. podnosić \{na kogoś\} rękę, ros. поднимать руку \{на кого\}): bo j'eśća mnok tak' 'ix, što na m'atku r'uku padn 'ośut - o polskim wpływie świadczy adaptowane zapożyczenie padnaś 'ić na miejscu rosyjskiego поднимать.

b) kalki i półkalki frazeologiczne tworzone ad hoc - na potrzeby danej konwersacji. Ten typ kalkowania występuje wówczas, kiedy informator nie chce dopuścić do zmiany kodu i w związku z tym dokonuje tłumaczenia odpowiedniego polskiego frazeologizmu za pomocą komponentów gwarowych (wiąże się to często z pojawieniem się nowych zapożyczeń), np.:

ź'ełać za pšyzvoj 'itku 'być osobą towarzyszącą parze zakochanych, zakłócającą ich intymność' (pol. robić za przyzwoitke): nu kak, m 'atka z b'aćkaj na krok mńe ńe atpušč 'al'i, kud 'y jan 'y išl' 'i, to i ja iš' ot, ja im z̧'etat b'ytta za pšyzvoj 'itku - występuje tu zapożyczony wyraz pšyzvojitka;

ńi s k'em ńe zaj́er 'aćsa 'nie wchodzić z nikim w konflikt' (pol. nie zadzierać $\{z$ kimś\} ): mój p'apa ńi s k'em ńe zaźer 'atśa;

gavar' 'ić pr 'osta $z \boldsymbol{m}$ 'ostu 'mówić otwarcie, konkretnie, bez zbędnej kurtuazji' (pol. mówić prosto z mostu): gavar' 'ić pr'osta z m 'ostu.

Z tym typem kalkowania mamy do czynienia również wtedy, gdy informatorowi brakuje kompetencji do pełnego odwzorowania frazeologizmu za pomocą gwarowych odpowiedników (lub po prostu odpowiedników brak), a jednocześnie chce on utrzymać stylistykę wypowiedzi, np.: 
ić 'ić pa trupach do celu 'być bezwzględnym, starać się osiągnąć cel, nie licząc się z nikim' (pol. iść po trupach do celu): i ǰet 'atoś tak, što l'uźi ńe zav' 'idyval'i t'olka išl' 'i pa trupach do celu;

pajć 'i $\{z$ kimś\} na udry 'kłócić się' (pol. pójść z kimś na udry): paš'ol na udry;

ż'elać wymyshy 'wymyślać, grymasić' (pol. robić wymysty): wymysty j'etajut.

Kolejnym przejawem wpływu polszczyzny na frazeologię rosyjskiej gwary staroobrzędowców jest zjawisko przełączania kodów.

$\mathrm{Na}$ podstawie zgromadzonego materiału można wyodrębnić trzy sytuacje, w których frazeologia pojawia się jako rezultat lub przyczyna przełączania kodów.

Pierwszą grupę stanowią sytuacje, w których informator, chcąc umożliwić lub ułatwić odbiór swojej myśli przekazywanej w wypowiedzi w postaci frazeologizmu, podejmuje się jego przetłumaczenia na język polski. Wprowadzone polskie frazeologizmy służą ponownemu przekazaniu myśli wyrażonej pierwotnie w gwarze, por.:

(1) b'es p'atk'i ńe patxaś'i / no bez kija nie podchodź' /

(2) kak paśćel' 'iś:a tak v'yśp 'iś:a / jak się pościelisz tak i się wyśpisz%.

Replika (1) i (2) prezentują sytuacje, w których informator najpierw użył gwarowego wariantu frazeologizmu, a następnie, ze względu na brak oczekiwanej reakcji ze strony polskiego rozmówcy, wypowiedział polski wariant powiedzenia najprawdopodobniej w przekonaniu, że wersja gwarowa nie została zrozumiana. Przykłady (3), (4), (5) ilustrują przypadki cytowania. W każdym z przytoczonych poniżej przypadków wraz $\mathrm{z}$ wprowadzeniem frazeologizmu nastąpiło całkowite przejście na język polski, zarówno na poziomie leksykalnym, jak i gramatycznym, por.:

(3) my gavar' 'im stoj st'uxaj / wlazła między wrony, kracz jak i one /;

(4) 'eta ńe dur'ak skaz'at / daj Boże / żebyś ty uczyl cudze dzieci /;

(5) pr'im 'eń 'al'i tak'oje apr'ed'el'eńe // co można wojewodzie, to nie tobie smrodzie / 'eta pa p'olsk'i / da wojewoda to 'eta abłastn'oj nač'alnik/.

7 W tym przypadku w polskim wariancie pojawia się kalka z języka rosyjskiego: się < <-s’a (Jak się pościelisz ... zamiast Jak sobie pościelisz ...). 
$\mathrm{Na}$ trzecią grupę składają się fragmenty wypowiedzi prezentujące wtrącający typ przełączania kodów. W wymienionych poniżej fragmentach (6)-(11) mamy do czynienia $\mathrm{z}$ analogiczną sytuacją, w której wypowiedź informatora prowadzona jest zasadniczo w gwarze, a frazeologizm zostaje do niej wprowadzony w formie polskiej bez zaburzania perspektywy składniowej języka-matrycy. Po wprowadzeniu polskiego wtrętu informator kontynuuje swą wypowiedź w gwarze, por.:

(6) j'eta tak prašt' o kakw mgnieniu oka/ 'etyn 'ašy tak kal 'ist'i st'ar'in:yji gavar' 'il'i što 'eta žyt'j'o to tak prax 'oźit sk'ora što w mgnieniu oka /;

(7) ja nie przywiazuję wagi za balš' 'oj tak;

(8) safśs' om 'inače / 'eta niebo a ziemia;

(9) i pam 'ažu jajc 'om i cynam 'onk'i nie z tej ziemi;

(10) ja i tak d'umała što nie dojdę do siebie;

(11) gavar' 'iła d'urńi vy / vy na glowy padli.

$* * *$

Podsumowując: ze względu na skomplikowane losy starowierskiej wspólnoty, wieloetapowe migracje i konieczność kontaktu z obcym otoczeniem językowo-kulturowym w jej gwarze notuje się sporo przykładów ilustrujących obce wpływy językowe: polskie, białoruskie i litewskie w przypadku staroobrzędowców regionu suwalsko-augustowskiego oraz niemieckie w regionie mazurskim. Oddziaływanie wspomnianych języków widoczne jest zwłaszcza w warstwie leksykalnej, ale także i we frazeologii. Najsilniej oddziałuje na frazeologię gwary staroobrzędowców polszczyzna, co związane jest oczywiście z faktem ich zamieszkiwania wśród polskich sąsiadów już od ponad dwóch wieków. Sporym utrudnieniem w przypadku analizy frazeologii gwary staroobrzędowców w Polsce są braki materiałowe, których niestety już nie sposób uzupełnić. W ramach podsumowania można pokusić się o stwierdzenie, że dokumentacja i analiza zasobu frazeologicznego rosyjskiej gwary staroobrzędowców w Polsce rozpoczęły się co najmniej o pół wieku za późno. 


\section{SUMMARY \\ Foreign Language Elements in the Phraseology of the Russian Dialect of Old Believers Living in Poland}

The Russian Old Believers on the Polish territory appeared in the $18^{\text {th }}$ century. Over the centuries they had contacts with the Belarusian-speaking, Lithuanian-speaking, Polish-speaking and in Masuria also German-speaking populations. These contacts resulted in the presence of foreign-language elements in their Russian dialect, most of all in the field of lexis, but also in the phraseology.

The aim of this article is to present foreign-language elements noted in the phraseology of the Russian dialect of the Old Believers living in Poland. 

Frazeografia gwarowa 



\title{
Gabriela Dziamska-Lenart (1)
}

\author{
Uniwersytet im. Adama Mickiewicza, Poznań \\ dzlenart@amu.edu.pl
}

\section{GWAROWE SŁOWNIKI FRAZEOLOGICZNE JEZZYKA POLSKIEGO - PRZEGLĄD}

Słowa klucze: frazeologia gwarowa, leksykografia, język polski

Keywords: dialect phraseology, lexicography, Polish language

Celem niniejszej pracy jest próba charakterystyki pewnego wycinka współczesnej leksykografii polskiej. Przedmiotem opisu są trzy publikacje, które można określić mianem gwarowych słowników frazeologicznych.

Dialektalna frazeologia $\mathrm{w}$ języku polskim ma bogaty dorobek naukowy ${ }^{1}$, na który składają się prace nielicznego grona badaczy: Huberta Górnowicza (1975a, 1975b), Jerzego Tredera (1986, 1989, 1991), Anny Tyrpy (2005, 2016), Macieja Raka (2006, 2007, 2016a), Artura Czesaka (1998), Lidii Przymuszały (2011, 2016) i Józefa Chojnackiego $(1995,2010,2012)$. Postulaty rejestrowania frazeologii gwarowej poszczególnych dialektów oraz opracowania słownika zbierającego całość gwarowego zasobu frazeologicznego pojawiały się w pracach wielu językoznawców (np. Treder 1991; Krawczyk 1982: 36; Czesak 1998; Sobierajski 1991: 72; Rak 2007: 183), zostały one częściowo zrealizowane przez trzech badaczy, którzy opublikowali następujące prace słownikowe: Są to: 1) Stownik frazeologiczny gwary Dębna w Górach Świętokrzyskich Macieja Raka (SFGD); 2) Stownik frazeologizmów i typowych połaczeń wyrazowych w gwarach ślaskich Lidii Przymuszały (SFŚl); 3) Frazeologia gwarowa Wielkopolski pótnocno-wschodniej Józefa Chojnackiego (FGW). Dokonując przeglądu tych słowników, zwrócę uwagę na następujące kwestie: ogólna koncepcja słownika, zakres jakościowy i ilościowy materiału zawartego w dziele, jego układ i sposób opracowania ${ }^{2}$.

1 Szczegółowy przegląd polskich dokonań w zakresie frazeologii gwarowej przynoszą artykuły Anny Tyrpy (2016) i Lidii Przymuszały (2011).

2 Dwa z wymienionych tu słowników (SFGD, SFŚl) były już przedmiotem mego zainteresowania w monografii Frazeografia polska. Teoria i praktyka (zob. Dziamska-Lenart 2018: 149-166). W niniejszym tekście, który stanowi odrębną i nową całość, wprowadzono liczne zmiany redakcyjne i merytoryczne, tok rozważań uzupełniono innymi przykładami. Część 


\section{Stownik frazeologiczny gwary Dębna w Górach Świętokrzyskich Macieja Raka (SFGD)}

Jest to pierwszy polski słownik poświęcony wyłącznie frazeologii gwarowej, wydany został w 2005 r. Krakowie (w wydawnictwie Scriptum), liczy 159 stron. Autor postawił przed sobą ambitny cel utrwalenia bogactwa gwarowej frazeologii, przez którą „przejawia się specyfika kultury materialnej i duchowej mieszkańców Dębna, wsi położonej w Górach Świętokrzyskich u stóp Łysicy” (SFGD: 7). W rozbudowanym wstępie omawia metodologiczne założenia i zasady redakcyjne słownika, charakteryzuje materiał źródłowy, przekazuje podstawowe wiadomości o systemie gwary Dębna i przedstawia je na tle cech gwary świętokrzyskiej, która należy do gwary kieleckiej dialektu środkowomałopolskiego.

Słownik ma charakter dyferencyjny, zawiera przemyślany i konsekwentnie zrealizowany opis 600 gwarowych jednostek frazeologicznych, typowych dla badanego obszaru i zarazem różnych od jednostek znanych polszczyźnie literackiej. Podstawę materiałową stanowią jednostki frazeologiczne wynotowane z korpusu nagrań magnetofonowych, z rozmów autora (czynnego użytkownika badanej gwary) z mieszkańcami Dębna. Fragmenty nagranych i zanotowanych tekstów posłużyły również jako ilustracje użyć frazeologizmów. Z uwagi na szeroki krąg adresatów i popularyzatorski charakter opracowania badacz zrezygnował z precyzyjnego oznaczania właściwości fonetycznych gwary, zastosował uproszczony, półfonetyczny zapis haseł i cytatów, wyjątkowo zachował znak $a ́$ - na oznaczenie a pochylonego.

Słownik stanowi przykład nowoczesnego opracowania leksykograficznego, twórczo wyzyskującego sprawdzone rozwiązania metodologiczno-redakcyjne, zastosowane w takich leksykonach, jak: Słownik gwary orawskiej Józefa Kąsia (KąśSGO), Stownik wspótczesnego języka polskiego pod red. Bogusława Dunaja (SWJP), Inny słownik języka polskiego pod red. Mirosława Bańki (ISJP), Stownik polskich leksemów potocznych pod red. Władysława Lubasia (SPLP). Nawiązując do tych opracowań, M. Rak prezentuje w swoim dziele frazeologizmy jako semantyczne odpowiedniki pojedynczych wyrazów, stanowią one samodzielne, odrębne hasła i są uporządkowane w kolejności alfabetycznej. W układzie tym bierze się pod uwagę pierwszy samodzielny człon jednostek frazeologicznych, nawet gdy jest członem fakultatywnym, zapisywanym wówczas w nawiasie okrągłym np. (INO) DZIADA I BABY BRAKUJE \{gdziesik\}. W układzie haseł uwzględniono też poszczególne komponenty frazeologizmów i odsyłacze ze wskazaniem pełnej postaci jednostki słownikowej. Oto przykład czterech kolejnych haseł:

informacji, zawartych we wspomnianej publikacji, a potrzebnych dla pełnej charakterystyki prezentowanych tu słowników - z konieczności - została powtórzona. 


\section{NA BYCY SKÓRZE BY (NAWET) NIE SPISÁt}

NABIĆ zob. fraz.: STRZELIĆ, A NIE NABIĆ

NADAWAĆ SIĘ \{do cegosik\} (JAK) DO MACANIÁ KUR

NADSTÁW DIABŁA (SFGD: 89).

Typowy artykuł hasłowy w SFGD przedstawia poniższy przykład:

BEZ KIJA \{do kogosik\} (LEPI) NIE PODCHODZIĆ dop. 'mówimy $\mathrm{z}$ niechęcią lub $\mathrm{w}$ żartach o kimś, że bez kija do niego lepi nie podchodzić, jeśli ta osoba jest wrogo nastawiona do innych, a także jest nieprzyjazna, nieprzystępna i zarozumiała': Márcin jes taki groźny, ze bez kija lepi nie podchódz [śmiech]. Tak napráwde ón ino udaje, jak głośni tupnies, to się zará wystrasy [...] (SFGD 2005: 24).

Postać hasłowa frazeologizmu zapisana jest wersalikami, przy czym w nawiasach okrągłych umieszcza się człon fakultatywny, a nawiasach klamrowych ujęte są człony zmienne wskazujące na wypełnienie pozycji składniowej przez samodzielne leksemy, sygnałem tego są gwarowe formy zaimków: cosik, ktosik, gdziesik, komusik. Ponadto w słowniku stosuje się nawiasy kwadratowe, w których znajdują się elementy wymienne (wariantywne) hasła np. DOGÁDAĆ SIE [NAGÁDAĆ SIE] \{z kimsik\} JAK GEŚ Z PROSIECIEM; SWARZYĆ SIE [KŁÓCIĆ SIE] O SKÓRKE ZE WSY.

Po postaci hasłowej frazeologizmu odnotowany jest skrót zawierający informację gramatyczną o tym, do jakiej kategorii części mowy można przypisać dany związek wyrazowy, inaczej mówiąc, jakim jednoleksemowym odpowiednikiem można go w tekście zastąpić. Do opisu właściwości gramatycznych frazeologizmów wyzyskano następujące kategorie części mowy: czasownik ( $c z$.), dopowiedzenie (dop.), modulant (mod.), operator metatekstowy (oper. met.), przymiotnik (prz.), przysłówek (przysł.), rzeczownik (rz.), wykrzyknienie (wykrz.). Po informacji gramatycznej następuje definicja mająca formę pełnego, rozbudowanego zdania zawierającego frazeologizm (wyróżniony czcionką pogrubioną) w jego naturalnym kontekście uwzględniającym typową dla niego łączliwość składniową i leksykalną.

Pomysł kontekstowego objaśniania znaczeń frazeologizmów zaczerpnięto z Innego stownika języka polskiego pod red. M. Bańki (ISJP). Ten sposób definiowania znaczeń umożliwia przekazanie ocen i opinii charakteryzujących dany związek pod względem stylistycznym i pragmatycznym. W definicjach zastosowano formuły, które z powodzeniem zastępują tradycyjne kwalifikatory stylistyczne i pragmatyczne, np.: 'mówimy złośliwie o kimś, że las bieli, jeśli w naszym mniemaniu 
jest nierozsądny, dziecinny i postępuje bezmyślnie'; 'mówimy z uznaniem, że ktoś jest ściśliwy grosa, jeśli jest oszczędny i pracowity'.

Z uwagi na to, że słowniki gwarowe odnotowują ginącą część słownictwa, ważną częścią artykułu hasłowego są ilustracje tekstowe haseł. W analizowanym dziele są to fragmenty autentycznych wypowiedzi użytkowników gwary, mieszkańców wsi Dębno. Cytaty są rozbudowane, kilkuzdaniowe, uzupełniają definicje i przynoszą informacje o charakterze etnograficznym.

W SFGD zwraca uwagę stosunkowo duża liczba frazeologizmów o funkcjach waloryzujących i wyrażających emocje, klasyfikowanych jako wykrzyknienia, dopowiedzenia oraz modulanty. Zawierają one bardzo często komponenty intensyfikacji i negatywnego wartościowania. Równie często odnotowywane są wyrażenia i zwroty używane w komunikacji międzyludzkiej, służące nawiązywaniu i podtrzymywaniu kontaktu między rozmówcami, np. COSIK \{ktosik\} MIÁŁ POWIEDZIEĆ, PRÁWDY NIE ZESCEKAĆ. Frazeologizmu tego używa się, jeśli w trakcie rozmowy ktoś zapomni, o czym chciał mówić. Z kolei związek wyrazowy IDŹ SPAĆ, BO PCHŁY NA DUPE CEKAJO jest kierowany do natarczywego gościa 'w sytuacji, gdy wypraszamy go, ponieważ zasiedział się w naszym domu do późna w nocy' (SFGD 2005: 64).

Zebrany w słowniku M. Raka materiał frazeologiczny jest oryginalny i interesujący. Dobór frazeologizmów dyferencyjnych pozwolił autorowi ukazać realia i obyczaje wsi świętokrzyskiej, a także uchronić od zapomnienia odchodzącą w przeszłość część słownictwa.

\section{Stownik frazeologizmów i typowych połaczeń wyrazowych $w$ gwarach ślaskich Lidii Przymuszaly (SFŚl)}

Słownik L. Przymuszały, wydany przez Uniwersytet Opolski w 2013 r., w zamierzeniu autorki stanowi dopełnienie Słownika gwar ślaskich, wielotomowego dzieła, które powstawało od 2000 r. pod red. Bogusława Wyderki (2000-2017). Przedmiotem badań L. Przymuszała uczyniła frazeologizmy występujące w mowie mieszkańców Śląska, a zatem jednostki frazeologiczne charakterystyczne tylko dla gwar, jak i frazeologizmy wspólnoodmianowe notowane w polszczyźnie ogólnej. Zdaniem autorki niedyferencyjny charakter słownika pozwala ukazać całe bogactwo dialektu śląskiego.

Obszerny (liczący 503 strony) słownik rejestruje bogaty i zróżnicowany pod względem formalnym materiał językowy, przynosi opis około 7 tysięcy idiomów i frazemów, czyli związków wyrazowych nieregularnych semantycznie oraz związków łączliwych. Wśród 6947 haseł - według obliczeń autorki - większość stanowią zwroty frazeologiczne, mniej liczne są wyrażenia i frazy, nienotowane 
są natomiast przysłowia. Podstawę materiałową leksykonu stanowi spis źródeł liczący ponad 170 pozycji bibliograficznych z XIX i XX w., które w większości złożyły się na kartotekę Słownika gwar śląskich, tworzoną od lat 60. ubiegłego wieku przez językoznawców, dialektologów, etnografów i badaczy folkloru związanych z Instytutem Śląskim i Uniwersytetem Opolskim. Autorka przyznaje, że nie prowadziła własnych badań terenowych, a materiał źródłowy wykorzystany w słowniku pochodzi z rękopiśmiennych i drukowanych źródeł dialektologicznych i etnograficznych oraz tekstów folklorystycznych. Ten obszerny zbiór źródeł badaczka dodatkowo wzbogaciła o materiał pochodzący z rękopisów śląskich paremiologów, który został utrwalony w Nowej księdze przysłów polskich i wyrażen przysłowiowych pod red. J. Krzyżanowskiego (NKPP).

We wstępie autorka akcentuje dokumentacyjny charakter swojej pracy i określa jej cel: słownik ma służyć ,,badaniom konfrontującym frazeologię śląską z frazeologią innych gwar oraz frazeologią języka ogólnego" (SFŚl: VII). Osiągnięcia zamierzonego celu nie ułatwiają jednak przyjęte w słowniku ogólne zasady opracowania artykułu hasłowego ani zastosowane szczegółowe rozwiązania redakcyjne i techniczne. Dyferencyjne hasła słownikowe nie zostały bowiem graficznie wyróżnione spośród haseł występujących w języku ogólnopolskim. Orientację $\mathrm{w}$ prezentowanym materiale językowym utrudnia też rezygnacja z gwarowego zapisu postaci hasłowych frazeologizmów. Frazeologizmy wspólne gwarom i językowi ogólnemu podawane są w postaci i pisowni literackiej, a związki, które nie mają odpowiednika ogólnopolskiego, autorka sprowadza „do takiej postaci, jaką miałyby w języku literackim, pomijając cechy fonetyczne właściwe gwarze” (SFŚl: XIV). W rezultacie przyjętego sposobu zapisu postaci hasłowych frazeologizmów trudno odróżnić frazeologizmy śląskie od ogólnopolskich, a zwłaszcza archaiczne jednostki ogólne od wyraźnie gwarowych.

SFŚl ma układ alfabetyczny, hasłem słownikowym jest jednostka frazeologiczna. W porządku alfabetycznym istotny jest pierwszy człon frazeologizmu, także fakultatywny, nawet wtedy, gdy nie jest on wyrazem samodzielnym znaczeniowo. Nie bierze się natomiast pod uwagę elementów zmiennych frazeologizmu w postaci zaimków ktoś, coś (zapisywanych jasną kursywą). Uwzględnia się przy tym odstępy między wyrazami (zastosowano układ alfabetyczny według zasady ,słowo po słowie"). Oto przykład kilku kolejno po sobie następujących haseł:

ani kudla po kimś nie zostało;

(ani) kupy się coś komuś nie dzierży;

komuś ani lepiej / tak w niebie nie będzie;

ani muk; 


\section{ani na lekarstwo;}

\section{(ani) na stona wodę nie zarobić (SFŚl: 5).}

W słowniku nie zanotowano haseł będących pojedynczymi wyrazami, przy których znajdowałyby się odsyłacze do pełnych postaci frazeologizmów. Ta bardzo istotna - z punktu widzenia odbiorcy słownika - cecha odróżnia układ alfabetyczny zastosowany w SFŚ1 od podobnego układu hasel, ale bardziej funkcjonalnego w SFGD. O tym, jak bardzo przydatne są jednoleksemowe hasła odsyłaczowe i jak dotkliwy jest ich brak, przekona się czytelnik, który zechce poszukać znaczenia frazeologizmu rzadzić po ślasku zapisanego na okładce wraz z innymi przykładami śląskich powiedzeń. Niestety, czytelnik nie znajdzie tego zwrotu, jeżeli będzie szukał pod literami: R (rzadzić), P (po), Ś (ślasku). Zanotowano tam pięć innych zwrotów zaczynających się od czasownika rządzić, niemal 100 innych wyrażeń zaczynających się od przyimka po (np. po ptakach, po sąsiedzku, po starej modzie, po stojączku, po śpiaczku, po świńsku), szukanego zwrotu nie ma również pod literą $\mathrm{S}^{3}$. Czytelnik, pozbawiony wskazówek, których dostarczyć by mogły hasła odsyłaczowe, zdany jest więc na przypadek lub żmudną lekturę słownika strona po stronie, by w końcu odnaleźć pod literą G zwrot gadać / rozprawiać / rządzić po śląsku 'mówić w gwarze śląskiej' (SFŚl: 144). Podobny problem może mieć odbiorca ze zwrotem znajdującym się na okładce w postaci nie mieć wszystkich doma, który w słowniku nie jest zanotowany pod literą $\mathrm{N}$, ale $\mathrm{w}$ innym miejscu (pod literą M), ponieważ autorka ustaliła dla niego następującą postać: ktoś mówi, jakby nie mial wszystkich doma 'ktoś mówi bez sensu, byle co; plecie głupstwa'. Wskazane przykłady udowadniają, że zastosowanie w słowniku frazeologicznym układu alfabetycznego nie jest rozwiązaniem optymalnym, gdyż układ taki bez dodatkowych odsyłaczy nastręcza trudności w odnalezieniu frazeologizmu, zwłaszcza w sytuacji, gdy poszukujący nie zna jego pełnej formy i początkowego komponentu.

Artykuł hasłowy w SFŚl zbudowany jest z następujących elementów: 1) hasła, czyli frazeologizmu wyróżnionego czcionką pogrubioną; 2) znaczenia frazeologizmu umieszczonego w łapkach (w przypadku jednostek wieloznacznych kolejne znaczenia poprzedzone są wytłuszczonymi cyframi arabskimi); 3) dokumentacji, czyli kontekstów użycia frazeologizmu wraz ze skrótami źródła i skrótami lokalizacji geograficznej. Cytaty zawierające frazeologizm przytaczane są w zapisie fonetycznym tak, jak zostały zanotowane w tekście źródłowym. Kolejne elementy (kwalifikatory i odsyłacze) nie są obligatoryjnym elementem struktury artykułu hasłowego.

3 Pod literą $S$ żaden z zanotowanych frazeologizmów nie ma w swym składzie komponentu rzeczownikowego Śląsk ani przymiotnikowego śląski. 
Zadaniem odsyłacza zob., który zamyka wiele artykułów hasłowych, jest wskazanie frazeologizmów wchodzących w relacje derywacji, a także łączenie haseł bliskich znaczeniowo (synonimicznych i wariantywnych), jak np.: być $\boldsymbol{n a} \boldsymbol{w y c u}$ gu / na wymowie [...]. Zob. iść na wycug, mieszkać na wycugu, na wycugu / na wytamku / na wysypie, pójść na wycug / na wymowę, siedzieć na wycugu; być na wysiadach u kogoś [...] Zob. chodzić / tazić na biesiady / na wysiady, iść na biesiady, polecieć na biesiady, przyjść na biesiady/na wysiady (do kogoś) (SFŚl: 35).

$\mathrm{Na}$ sposób rejestracji jednostek frazeologicznych istotny wpływ mają relacje, w jakich pozostają względem siebie analizowane jednostki. Istotne jest zwłaszcza odróżnienie relacji wymiennoczłonowości (stanowiącej o wariantywności) od relacji derywacji semantycznej. Autorka SFŚl przyjęła zasadę, że derywaty frazeologiczne stanowią odrębne jednostki hasłowe, w rezultacie tego założenia związki wyrazowe $\mathrm{z}$ komponentem werbalnym różniącym się aspektem notowane są oddzielnie i przy każdym z nich zastosowano odsyłacz do frazeologizmu z czasownikiem niedokonanym lub dokonanym. Efektem takiego rozwiązania jest dwukrotne notowanie wielu zwrotów, które w większości słowników frazeologicznych rejestrowane są w jednym artykule hasłowym. Dla przykładu, osobno odnotowane zostały zwroty: robić coś z taski na uciechę i zrobić coś z łaski na uciechę; chodzić po winszu i chodzować po winszu 'w Nowy Rok chodzić od domu do domu, składając życzenia, otrzymując w zamian drobny datek lub pożywienie'; chodzić na zaloty i chodzować na zaloty. Oddzielnie notowane są również liczne frazeologizmy bliskoznaczne z komponentami iść, pójść, przyjść, chodzić, być, mieć itp., np.: być gdzieś na wyćwice 'przebywać gdzieś, aby otrzymać surowe wychowanie' oraz dać kogoś na wyćwikę; dać komuś wyćwikę; dostać wyćwike (od kogoś); iść na wyćwikę; mieć wyćwikę; przyjść na wybleszczki 'przyjść pod dom weselny, aby patrzeć na wesele, czasami też otrzymać poczęstunek'; pójść na wybleszczki; chodzić na wybleszczki; iść na wybleszczki.

Zjawiska wariancji frazeologicznej ujmowane są w słowniku w zgodzie z tradycją leksykograficzną. Badaczka dopuszcza w wariantach różnice fonologiczne, różnice morfemów gramatycznych, słowotwórczych, różnice w zakresie stosowanych przyimków lub spójników, a także różnice komponentów leksykalnych, przy czym wymieniające się wyrazy powinny pozostawać $\mathrm{w}$ relacji synonimii. W słowniku znajdujemy postaci hasłowe $\mathrm{z}$ wariantem fleksyjnym: iść na hamster / na hamstry; z wariantem słowotwórczym: przyjść na odrobek / na odróbkę; $\mathrm{z}$ wariantem składniowym: brzęczeć (komuś) nad uchem / za uszami. Nowością w praktyce leksykograficznej jest włączanie w zakres wariancji frazeologicznej związków różniących się etymologią; w analizowanym leksykonie frazeologizmy mające w swoim składzie wyrazy będące zapożyczeniami z języków obcych uznawane są za warianty, np.: wziać coś na borg / na kredyt; oddać / podać / udać (kogoś) do gerychtu / do sądu; robić na trzy party / zmiany; oszczędzać / szporować $z$ grajcara / z korony na halerz 'być rozrzutnym'. 
Przyjęty w słowniku sposób zapisu różnych odmianek frazeologizmów gwarowych wynika zapewne $\mathrm{z}$ dokumentacyjnego charakteru opracowania. Zastosowane rozwiązania mają pozytywne, ale i negatywne aspekty. Z jednej strony przyczyniają się do kilkukrotnego powtarzania tych samych treści lub podobnych w odrębnych artykułach hasłowych, z drugiej zaś umożliwiają dokładne oddanie wariantów frazeologicznych wyekscerpowanych z niejednorodnego pod względem chronologicznym, geograficznym i genologicznym materiału źródłowego.

W zebranym materiale wyróżnić można bardzo bogato reprezentowaną grupę frazeologizmów z komponentami gwarowymi oraz równie liczną grupę związków frazeologicznych charakterystycznych dla gwar śląskich, które są zbudowane z komponentów wspólnoodmianowych. Do pierwszej grupy zaliczyć można np.: trzeba kogoś grabiami w tóżku hledać 'o kimś niskiego wzrostu'; chodzić hruba $i$ chodzić inaksza 'o kobiecie: spodziewać się dziecka; być w ciąży'; chytać mamlasy 'nic nie robić, próżnować'; podziwać się na kogoś jak bodlawa krowa 'popatrzeć na kogoś groźnie, spode łba'; dziwać się lewym okiem do prawej kabzy 'o kimś zezowatym: patrzeć zezem'; grać na czępiaczkę 'bawić się w berka kucanego'; do drugiej grupy natomiast włączyć można takie związki wyrazowe: gruchnać sobie po półce 'wypić kieliszek wódki'; gryźć swoje ucho 'utrzymywać się samodzielnie, z własnych zarobków'; góral komuś depcze po oczach 'ktoś robi się senny'; gorzkich jablek się najeść 'wiele wycierpieć'; głowę przypaść 'potknąć się'; głowa się komuś toczy 'ktoś ma zawroty głowy'; czerwieni się komuś grzebień 'ktoś wpada w złość'; mieć godziny w głowie 'być punktualnym'; dyrekcja komuś rośnie 'ktoś tyje, rośnie komuś brzuch; psuje kogoś dobrobyt'; podoić dębowa krowe 'nabrać z beczki kiszonej kapusty'.

Niezaprzeczalną zaletą analizowanego dzieła jest to, że utrwala ono i ocala przed zaginięciem frazeologizmy, które zawierają elementy archaiczne i osobliwości nieobecne już w języku ogólnym. Wiele z tych związków wyrazowych opisuje zachowania ludzi związane z dawnymi obrzędami, zwyczajami i świętami religijnymi, np.: jeść wielka tyżka 'być starostą weselnym'; kota wodzić 'tańczyć taniec weselny: najpierw ojciec z panną młodą, potem inni za nimi, trzymając się za chustki'; wodzić niedźwiedzia 'o korowodzie przebierańców: na zakończenie karnawału chodzić z muzyką od domu do domu, prowadząc na postronku mężczyznę przebranego za niedźwiedzia'; chodzić / łazić po czarnu 'chodzić w żałobie; nosić czarne ubrania na znak żałoby'; chodzić na prządki 'uczestniczyć we wspólnym przędzeniu'; dać na czepeczek 'zebrać, podarować pieniądze podczas wesela dla panny młodej'; chodzić po dyngusie / po sikaniu / po śmierguście 'obchodzić domy w poniedziałek wielkanocny, zbierając podarki (w postaci jajek) i oblewając się wodą'; chodzić po gaiczku 'w okresie Wielkanocy: nosić przystrojony świerczek lub brzózkę'; chodzić po kraszankach 'w okresie Wielkanocy: chodzić od domu do domu, zbierając datki w postaci jajek'. Słownik L. Przymuszały pokazuje, że zachowane we frazeologii ślady dziedzictwa kulturowego warte są upamiętnienia. 


\section{Frazeologia gwarowa Wielkopolski pótnocno-wschodniej Józefa Chojnackiego (FGW)}

Książka J. Chojnackiego, opublikowana w 2018 r. przez Wydawnictwo Akademii Humanistyczno-Ekonomicznej w Łodzi, liczy 230 stron i składa się ze słownika oraz czterech krótkich tekstów zawierających: 1) analizę strukturalną frazeologizmów gwarowych; 2) opis ich gramatycznych właściwości; 3) rozważania na temat klasyfikacji tematycznej zanotowanego słownictwa; 4) analizę podłoża emocjonalnego wyróżnionych kategorii frazeologizmów.

Słownik zawiera 1777 jednostek frazeologicznych: wyrażeń, zwrotów, fraz, przysłów oraz powiedzonek o różnym charakterze (zaklęcia, przekleństwa, pogróżki, żartobliwe odzywki). Autor, czynny użytkownik i obserwator gwary, mieszkaniec Kleczewa, zamieścił w leksykonie frazeologizmy funkcjonujące w komunikacji językowej mieszkańców wsi (w przeważającej większości przedwojennych chłopów i współczesnych rolników) zamieszkujących region północno-wschodniej Wielkopolski, a dokładniej: kilku gmin (Kleczew, Ślesin, Kazimierz Biskupi, Wilczyn, Ostrowite) znajdujących się w okolicach Konina.

W zgromadzonym materiale językowym można wyróżnić kilka warstw chronologicznych. Najstarsze z nich obejmują dwudziestolecie międzywojenne i lata okupacji niemieckiej (np.: jechać na bochyny; dostać terminotkę; być na alamyńcie; być na lamyńcie; kanary jadum; przesytać kurynde; iść na sztybel; Śmigty $R y d z$ zrobił hyc); następna warstwa dotyczy czasów Polski Ludowej, a najnowsza część frazeologizmów pochodzi z czasów współczesnych, odnosi się do bieżących zjawisk językowych, obserwowanych w polszczyźnie po 1989 r. Ciekawy zbiór frazeologizmów tworzą w słowniku wyrażenia, zwroty i powiedzenia z okresu Polski Ludowej (np.: ciocia unra; za Chiny ludowe; pakujcie walizki, bo koniec wasz bliski; ja Gomulka, ty Nikita, pocaluj mnie w dupe, będzie kwita; gniotsa, a nie tamiotsa; matka kupiyta mangaryny (margaryny), ale się wyźreta; górnik żyje krótko, ale dobrze; przodownicy to sa ludzie tacy, co pierdola dyscypline pracy; od coli robi się czarny pępek).

Oryginalnym rozwiązaniem zastosowanym w słowniku J. Chojnackiego jest podział na dwie części, pierwsza z nich jest wolna od wulgaryzmów, druga część zawiera tylko frazeologizmy z komponentem kwalifikowanym jako wulgarny.

Słownik ma układ gniazdowo-alfabetyczny. Artykuły hasłowe mają strukturę niejednorodną, w większości gniazd występuje tylko jeden frazeologizm wraz $z$ definicją semantyczną; jedynie przysłowia notowane są bez definicji. Postaci hasłowe frazeologizmów zapisywane są z uwzględnieniem wymowy gwarowej, ale bez stosowania alfabetu fonetycznego (np.: tedyńdź (odejdź) tebuzie ted tekna, bo cie tebrzygum; jechać po pijoku) lub w literackiej odmianie językowej (np.: przyszliśmy tu na ostatki, nie mamy ojca ani matki, dajcie nam, dajcie; nawinać kogoś na palec; chodzić na paluszkach; nie pali się). Stosowanie zapisu wymowy gwa- 
rowej w odniesieniu do niektórych frazeologizmów oraz w przykładach ilustrujących ich użycia tekstowe pozwala czytelnikom odróżnić jednostki, które występują najczęściej lub wyłącznie w postaci gwarowej od jednostek występujących również w polszczyźnie ogólnej.

Przyjrzyjmy się przykładowemu gniazdu:

\section{JEŚĆ}

Jeść jednym ząbkiem 'jeść bez apetytu; coś komuś nie smakuje, ktoś je z musu': Dzieci jedzą jednym ząbkiem, nie smakuje im.

Jod (jadł), joż (aż) mu się uszy trzynsły gw. 'ktoś jadł z apetytem; o kimś, kto był bardzo głodny'.

Tak dobrze jod (jadł) i zdech (zdechl) iron. daw. 'o człowieku, który dobrze prowadził jakąś działalność i nagle doznał niepowodzenia'; także: 'coś się nagle zepsuło, nastąpiła jakaś awaria'; zob. Chojnacki 1995: 32.

Z czym to się je? 'co to jest, do czego służy?'; por.: Czym, z czym to się je? SFPWN 139. (FGW: 61).

Fakultatywnymi elementami w artykułach hasłowych są: ilustracja przykładowa, kwalifikatory, odsyłacze (zob., por.) oraz dodatkowe objaśnienia dotyczące genezy lub typowych sytuacji, w których bywa używany frazeologizm, np. przy przysłowiu Nie ma domu, żeby nie było gomu znajdujemy objaśnienie staropolskiego słowa gomon 'gwar, zgiełk, wrzawa; swary; kłopot', a przy zwrocie być na tognaryi - definicję wyrazu ognaryja 'część wynagrodzenia, dawana służbie dworskiej w naturze'. Zamieszczając odsyłacze, autor odwołuje się do współczesnych słowników frazeologicznych, etymologicznych oraz do opracowań dialektologicznych, które zawierają materiał językowy przydatny do badań konfrontatywnych. Szczególnie często przywołuje formy ogólnopolskich wariantów, występujących w słownikach (SF; SF PWN) i w opracowaniach dialektologicznych (Treder 1986, 1989; Chojnacki 1995, 2010, 2012).

Spośród kwalifikatorów najczęściej stosowane są określenia dawny i gwarowy, często występują one razem. Poza tym są stosowane określenia: ironiczny, ordynarny, rzadki, sportowy, żartobliwy, np.: ciśnie koguś na dołyszku gw. 'boli kogoś żołądek'; patrzyć na ksiynżum stodołe gw. daw. 'chorować, wyglądać śmierci'; piaskoski wszystko wyciungnie gw. żart. 'po śmierci już nikt nie choruje, piasek „wyciągnie” wszystkie dolegliwości’. Średnio co drugi zanotowany związek wyrazowy został opatrzony kwalifikatorem. Z kolei cytaty ilustrujące użycie frazeologizmów znajdują się w około $30 \%$ haseł. 
Chociaż w słowniku odnotowane zostały frazeologizmy funkcjonujące w codziennej komunikacji mieszkańców okolic Konina, nie jest to słownik wyłączenie dyferencyjny. Wśród zgromadzonych form gwarowych występują również takie jednostki, które są odpowiednikami form rejestrowanych w słownikach ogólnych języka polskiego lub pojawiają się również w innych gwarach. Różnią się one od frazeologizmów ogólnopolskich zwykle co najmniej jednym komponentem leksykalnym, jak w poniższych przykładach: ani mnie ziębi, ani parzy; ciekawymu piyrszy wstymp do piekta; glupi jak stołowe giyry; patrzeć na koguś bykiym; o wilku mowa, a wilk wchodzi; rzucać się jak wsza na kotmiyrzu; znać się na czym jak wilk na gwiazdach ${ }^{4}$. Jednostki gwarowe, które w stosunku do ogólnopolskich odznaczają się różnicami formalnymi lub znaczeniowymi, opatrzone są odsyłaczami.

Porównując materiał frazeologiczny zarejestrowany w słowniku J. Chojnackiego z zasobem frazeologii ogólnopolskiej, można zauważyć, że najbogatszą warstwę stanowią w nim frazeologizmy nawiązujące do polszczyzny ogólnej. Drugą pod względem liczebności grupę tworzą frazeologizmy charakterystyczne dla gwary wielkopolskiej, np.: drzyć kalafe 'głośno płakać, krzyczeć'; zamknunć te kalafe 'przestać mówić'; taki (takiej) kuńdzie wszystko uńdzie (ujdzie) 'o sytuacji, w której jakaś osoba zachowuje się niepoprawnie, nie ponosząc żadnych konsekwencji'; wystroić się jak do tośpic 'ubrać się niestosownie, jak na daną sytuację, założyć strój zbyt elegancki'; patrzyć jak byk na pyrke 'brak u kogoś zdecydowania w jakiejś kwestii; nie wiadomo, co począć; co z tym zrobić'; pucnuńc babe w tytek na moście 'kto po raz pierwszy przybywa do jakiegoś miasta, musi pocałować babę w tyłek na moście - tak straszono dzieci'; wyglundać jak jaźwiec 'o kimś, kto ma długie włosy, jest nieostrzyżony'. Najmniej liczną grupę stanowią frazeologizmy nawiązujące do niemieckich konstrukcji składniowych i frazeologicznych np.: być jeszcze na fleku 'o starszej osobie, która jest jeszcze dość sprawna'; być frechownym/ frechowny gość 'o kimś nieprzystępnym, opryskliwym'; zrobione na glanc 'coś ładnie, bardzo starannie wykonane, coś dobrze wykończone'; fiker machen 'stosunek płciowy'; was ist das? kapusta i kwas 'udzielenie wymijającej odpowiedzi na jakieś pytanie’. We współczesnej frazeologii wielkopolskiej można również wyróżnić frazeologizmy powszechnie używane oraz frazeologizmy wychodzące $\mathrm{z}$ użycia.

Zebrany w słowniku J. Chojnackiego materiał językowy może posłużyć do próby odtworzenia minionych realiów i obyczajów, a także żywych do dziś przejawów kultury społeczności wiejskiej Wielkopolski. Widoczne na pierwszy rzut oka jest nastawienie antropocentryczne frazeologii gwarowej, większość zanoto-

4 Przytoczone frazeologizmy mają następujące warianty ogólnopolskie: coś kogoś ani nie ziębi, ani grzeje; ciekawość to pierwszy stopień do piekła; głupi jak noga stołowa; patrzeć na kogoś wilkiem; o wilku mowa, a wilk tu; znać się na czym jak kura na pieprzu; rzucać się, skakać jak wesz na grzebieniu. 
wanych frazeologizmów dotyczy człowieka, służy opisowi jego cech psychicznych i fizycznych, przy czym częściej jednostki te wyrażają krytykę bądź naganę niż pochwałę. Dzięki słownikowi czytelnicy mogą wyrobić sobie sąd o tym, jakie cechy i zachowania były w społeczności wiejskiej pożądane, a jakie oceniano negatywnie.

$$
* * *
$$

Prezentowane powyżej trzy słowniki rejestrują niezwykle interesujący materiał językowy, ukazują bogactwo ludowej frazeologii, wielość synonimów i wariantów stylistycznych; udowadniają, że gwarowe związki frazeologiczne różnią się od frazeologii słownictwa literackiego tak samo, jak słownictwo gwarowe odróżnia się od słownictwa literackiej polszczyzny. Zgromadzony w nich materiał językowy stanowi ginącą część słownictwa, dotyczy odchodzących w przeszłość realiów kultury duchowej i materialnej mieszkańców wsi, pozwala uchronić od zapomnienia rodzimą część dziedzictwa kultury ludowej. Odbiorcą omówionych słowników może być czytelnik niewyspecjalizowany. Materiał językowy jest w nich prezentowany w sposób jasny i przystępny. Analizowane słowniki stanowią przykłady opracowań, które powinny znaleźć naśladowców i zainspirować przyszłych badaczy do zebrania i opisu frazeologii gwarowej innych regionów Polski.

\section{SUMMARY \\ Dialect Phraseological Dictionaries of the Polish Language: A Review}

The article characterizes three lexicographic studies on the Polish dialect phraseology: 1) Maciej Rak's dictionary describing 600 phraseological units characteristic of the dialect of only one village in the Holy Cross Mountains; 2) Lidia Przymuszała's dictionary documenting almost 5000 phrases occurring in the Silesian dialects from the late 19th century to modern times; 3) Józef Chojnacki's dictionary, which collected about 1800 phrases functioning in the language communication of the inhabitants of north-eastern Greater Poland (near Konin). The linguistic material collected in the dictionaries is a dying part of the vocabulary, it concerns the realities of the spiritual and material culture of the villagers that are disappearing into the past, it helps to protect the native part of the folk culture heritage from oblivion. 


\author{
НАТАЛЬЯ АРЕФЬЕВА (1) \\ ОДЕССКИЙ НАЦИОНАЛЬНЫЙ УНИВЕРСИТЕТ \\ ИМЕНИ И.И. МЕЧНИКОВА, ОДЕССА, УКРАИНА \\ n.arefieva@onu.edu.ua
}

\title{
АКТУАЛЬНЫЕ ПРОБЛЕМЫ СОЗДАНИЯ \\ ФРАЗЕОЛОГИЧЕСКОГО СЛОВАРЯ РУССКИХ ГОВОРОВ \\ ОДЕСЩИНЫ
}

Ключевые слова: русские говоры Одесщины, далектная фразема, фразеологический словарь

Keywords: Russian dialects of Odessa region, dialect phraseological unit, phraseological dictionary

Фразеология русских говоров Одесской области Юга Украины - уникальный, малоисследованный языковой пласт.

Создание Фразеологического словаря русских говоров Одесщзинь как упорядоченной кодификации богатейшего по своему лингвистическому и этнокультурному наполнению материала в современных условиях, с одной стороны, сопряжено с целым рядом трудностей и проблем, с другой - представляется актуальным и своевременным. В этом ракурсе особое значение приобретают слова одесского учёного-диалектолога Людмилы Фёдоровны Баранник:

Перед русистами Одесского национального университета имени И.И. Мечникова стоят неотложные задачи по сбору, обработке, лексикографическому, текстологическому описанию и теоретическому исследованию собранного диалектного материала. Эти задачи требуют безотлагательного решения, так как под влиянием русского и украинского литературных языков диалектные особенности русских говоров Украины нивелируются, исчезают и в недалёком будущем могут быть безвозвратно утеряны для науки. Этого нельзя допустить, ибо диалектные данные - благодатный источник как для ретроспективных, так и современных исследований по лингвистике, этнографии, истории, лингвокультурологии (Баранник 2015: 19-20). 
Одной из серьёзных трудностей, с которыми столкнулся автор настоящего исследования в процессе создания словаря, - проблема отбора материала. Как уже было сказано в наших предыдущих публикациях, мы руководствовались широким подходом в определении диалектной фразеологической единицы (далее ДФЕ), см., напр.: (Арефьева 2017: 136, 2019: 488-489), а методика отбора материала в нашем исследовании предполагала, вслед за Ириной Анатольевной Кобелевой: „метод сплошной выборки языковых фактов, позволяющий учитывать не только лексикографированный языковой материал, но и материал, который содержится в иллюстративных фрагментах словарных статей” (Кобелева 2012: 5).

Учитывая тот факт, что в Словаре русских говоров Одесщины (далее СРГО) фрагменты иллюстративного материала часто исключались в целях экономии места, тщательное их сопоставление с материалами картотеки диалектологических экспедиций студентов и преподавателей кафедры русского языка Одесского национального университета имени И.И. Мечникова (далее КСРГО) и материалами к Словарю русских говоров Одесщины (далее МСРГО) позволило выявить и верифицировать немало ценного материала.

Одной из проблем отбора материала явилась проблема разграничения $\partial u$ алектной и просторечной фраземики, которая была решена нами в пользу включения последней в проектируемый словарь. Совершенно справедливыми в этом ключе мы считаем слова проф. Валерия Михайловича Мокиенко, который подчёркивает: „именно для фразеологизмов характерно расположение „на грани” диалектного и общенародного, и здесь лучше перейти эту грань [...], чем исключить выражения, актуальные для областной живой речи" (Мокиенко 2011: 193).

Одна из серьёзных проблем отбора фактов диалектной фраземики заключалась в сложности разграничения фразем, возникших в результате индивидуального творчества и не ставших общеупотребительными в данной местности, и общеупотребительных ДФЕ, что требовало от автора настоящей статьи дополнительных приёмов исследования - прямого опроса информантов, включении „спорных” фразеологических единиц в материалы фразеологического опросника в сочетании с привлечением широкого сопоставительного фона.

Известную сложность представляло разграничение пословиц, поговорок и диалектных фразем, возникших на базе песенного фольклора.

С определёнными трудностями была сопряжена и работа с материалами диалектной фонотеки: качество записи не всегда было высоким, что в отдельных случаях затрудняло идентификацию диалектной фраземы.

Отметим, что результативность выявления, семантизации и описания диалектной фраземики, „пошаговость” её параметризации во многом зависела от характера контекстного материала, фиксируемого в ходе полевых экспе- 
диций, в материалах КСРГО и СРГО с точки зрения его информативности. Так, Геннадий Александрович Раков, анализируя возможности и пути использования диалектных словарей различных типов в качестве источника для описания лексики народных говоров как системы, выделяет несколько видов контекстов: информативные (т.е. содержащие достаточно полные данные о семантике слова и его групповой принадлежности); малоинформативныле (не содержащие всех необходимых сведений о семантике лексических единиц, употреблённых в анализируемом отрезке) и неинформативные (не содержащие сведений, необходимых для составления словарной дефиниции исследуемого слова) (Раков 1990: 7-8). В последних двух случаях основанием для семантизации и дальнейшей параметризации ДФЕ исследуемых нами говоров служили другие источники.

Процесс выборки и верификации диалектной фраземики сопровождался сопоставлением с материалами Словаря русских народных говоров под ред. Ф.П. Филина, Ф.Г. Сороколетова и С.А. Мызникова (далее СРНГ), Фразеологического словаря русских говоров Сибири под ред. А.И. Фёдорова (ФСРГС), Большого толкового словаря донского казачества (БТСДК), Словаря украинских говоров Одесщины (СУГО), Словаря диалектизмов украинских говоров Одесской области А.А. Москаленко (СДУГОО), Фразеологического словаря русского языка под ред. А.И. Молоткова (ФСРЯ), Фразеологического словаря русского языка (сост. А.Н. Тихонов и др. - ФСРЯ 2007), Академического словаря русской фразеологии под ред. А.Н. Баранова и Д.О. Добровольского (АСРФ), Историко-этимологического словаря „Русская фразеология” под ред. В.М. Мокиенко (ИЭС), сборника И.М. Снегирёва Русские народные пословицы и притчи, Толкового словаря живого великорусского языка В.И. Даля (Д), двухтомного сборника Пословицы русского народа В.И. Даля (ПРН), Фразеологического словаря болгарского языка (К. Ничева, С. Спасова-Михайлова, К. Чолакова - ФРБЕ), Фразеологического словаря украинского языка (сост. В.М. Белоноженко и др. - ФСУМ и СФУМ 2003), Фразеологического словаря восточнослобожанских и степных говоров Донбасса В.Д. и Д.В. Ужченко (2013), Словаря стойких народных сравнений (А.С. Юрченко, А.А. Ивченко - ССНП), сборника Русские пословиць и поговорки М.А. Рыбниковой, фундаментальной сводной трилогии под ред. В.М. Мокиенко (Большой словарь русских поговорок - БСРП, Большой словарь русских народных сравнений - БСРНС, Большой словарь русских пословиц - БСРПС), Большого фразеологического словаря современного русского языка (отв. ред. В.Н. Телия - БФССРЯ). Также привлекались данные Нацииональных корпусов русского и украинского языков.

Обращение к данным общих, региональных и сводных словарей в процессе отбора языковых фактов, определения их эксплицитного и имплицитного содержания обусловило возможность коррекции (а во многих 
случаях - фиксации, последующей семантизации и дальнейшего грамматико-стилистического и этнокультурного описания, учитывающего междиалектную и межъязыковую интерференцию, прежде всего - украинско-русскую) отображённого разнородного и разнопланового фразеологического материала.

В процессе обработки и верификации фразем, зафиксированных в материалах СРГО и КСРГО, нами использовались следующие виды коррекции: 1) семантическая; 2) лексическая; 3) грамиатическая; 4) стилистическая, предполагающая коррекцию эмотивно-оченочного параметра и параметра частотности употребления ФЕ, его актуальности в живой речи диалектоносителей; 5) фонетическая; 6) акцентуационная. Во многих случаях использовалось их сочетание.

Рассмотрим каждый из этих видов.

1. Семантическая коррекция - наиболее распространённый и наиболее сложный, как нам кажется, вид обработки диалектного фразеологического материала, который в настоящем исследовании основывается на трёх составляющих - семантизации, собственно семантической коррекции и конкретизащчи значения ДФЕ.

1.1. Семантизация ДФЕ. Определение семантического наполнения фразеологизма возможно, как было сказано выше, при тщательном сопоставлении с материалами КСРГО, фонозаписями живой диалектной речи, в сопоставлении с материалами общих и региональных словарей. Так, выявление в иллюстративном материале СРГО поговорки локта̀mь как соба̀ки воेду из одно̀й кру̀жки (Ло̀кчим, как саба̀ки, ваду с адно̀й кру̀нки (СРГО 1: 288) лишь в сопоставлении с материалами КСРГО позволило на основании восстановленного фрагмента иллюстрации определить не только семантику рассматриваемой ДФЕ, но и её оценочные коннотации и лексикографировать фразеологизм в следующем виде: локта̀mь как соба̀ки во̀ду из одно̀й круюжки - погов. неодобр. 'об утрате религиозности, обусловленной совместным проживанием с представителями других конфессий (у старообрядцев)' Тяпѐрь мы фсе паүа̀ныле ста̀ли, а ра̀ньче зна̀ли вѐру... Ло̀кчем как соба̀ки во̀ду с адно̀й круишки. Ст. Некр. Вероятно, связано со старинным обычаем старообрядцев-липован выбрасывать кружку, если из неё пил кто-л. чужой или иноверец (СРГО 1: 288; КСРГО; ДФ № 18).

1.2. Собственно семантическая коррекция ДФЕ. Один из распространённых видов ошибочного толкования диалектной фраземы заключается в несоответствии содержания иллюстративного материала предлагаемому толкованию. Так, в КСРГО и МСРГО находим ДФЕ в затыллок, сопровождающуюся толкованием 'насильно' и иллюстрацией: Ма̀тка в затыोлок йийо̀ и врят жынuху (,вряд жениху” - ‘рядом с женихом’). Б. Пл. (КСРГО, МСРГО). Нетрудно заметить здесь несоответствие толкования ДФЕ семантическому и грамматическому наполнению контекста. Сопоставление с материалами других 
словарей, в данном случае - с материалами БСРП под ред. проф. В.М. Мокиенко позволило устранить расхождения и восстановить рассматриваемую фразему в следующем виде: в затыллок чей 'в один ряд с кем-л.': Матка в затыллок йийо̀ и врят жыниху̀. Б. Пл. (КСРГО, МСРГО). Ср.: в затыилок разг. 'в один ряд друг с другом' (БСРП: 247).

В лексикографированном материале СРГО нами отмечено и неразличение ДФЕ, сходных по структуре и фонетическому оформлению, но отличающихся по своему семантическому наполнению, что нетрудно было установить в ходе полевых исследований и сопоставлении с иллюстративным материалом КСРГО, не вошедшим в материалы словаря. Например, подворная лопамma и подгорная лопа̀ma объединяются в общем значении - 'лопата, употребляемая для работы в огороде' и сопровождаются иллюстрациями: Падворная лапата, каторай капають на гароди. Возн. Сафком, падгорнай лапатой. Введ. (СРГО 2: 44). Привлечение дополнительного материала, живой опрос информантов в расположенных поблизости сёлах Вознесенке и Введенке Саратского района Одесской области, жители которых являются носителями курского говора, дают основание утверждать, что в данном случае имеет место дифференциация видов лопаты как одного из важнейших орудий труда в сельской местности. Так, в значении 'штыковая лопата' употребляется номенклатурно-терминологическое устойчивое сочетание подворная лопа̀ma, тогда как подгорная лопа̀ma - в значении 'совковая лопата', что также подтверждается иллюстрацией, помещённой в СРГО: Раска̀ль - шыро̀кая, падго̀ная лапа̀ma. Возн. (СРГО 2: 139). Название последней ДФЕ этимологически сопряжено с диалектным глаголом подгорнуेть 'гребя, собрать в одно место или к чему-либо, куда-либо’ (СРГО 2: 44).

То же можно сказать и о ДФЕ как зря, зафиксированной в СРГО в значении 'кое-как, плохо' (СРГО 1: 249). Приводимые здесь же иллюстративные фрагменты (1. Враспалох палажыл как зря. Б. Пл., где положѝть врасполо̀- ДФЕ со значением 'напугать, потревожить'. 2. Если жывёти как зря, поп ни харо̀нит. Б. Пл. (СРГО 1: 249, 99)) позволяют говорить о многозначности фразеологизма и выводимости из контекста первого иллюстративного фрагмента еще одного значения - 'напрасно'. Многозначность данной фраземы, являющейся к тому же междиалектной, попавшей в русскую речь диалектоносителей Одесщины из материнских курско-орловских говоров, отражает и БСРНС под ред. В.М. Мокиенко. Ср.: как (что) зря - „неодобр. 1) Нов., Брян., Ветк. (Белор.), Курск., Орл. (делать что) 'Как попало, беспорядочно, небрежно плохо, кое-как'. НРЛ-91, 200; Манаенкова 1989, 82; СРНГ 11, 350; 12, 327; сог 14,$40 ; 2)$ Орл. 'Просто так, не подумав, не подготовившись'. Арсентьев КД 2, 84; 3 ) Брян., Волгоград. 'Попусту, напрасно, бесполезно, без толку'. СРНГ 12, 327; Глухов, 1987” (БСРНС 2008: 227). Таким образом, рассматриваемая нами ДФЕ может быть представлена в следующем виде: как 
зря - неодобр. 1) 'напрасно’: Враспалох палажыл как зря. Б. Пл.; 2) 'очень плохо’: Если жывёти как зря, поп ни харонит. Б. Пл.

1.3. Конкретизачия значения. В процессе обработки диалектного фразеологического материала семантическое наполнение ряда фразем было откорректировано и конкретизировано на основании глубокого интро- и ретроспективного анализа. Например, ДФЕ тязлловый нѐвод была включена в СРГО со значением 'разновидность невода' (СРГО 2: 234), однако в процессе верификации, опираясь на живую речь диалектоносителей и материалы КСРГО, удалось конкретизировать: мязлловый нѐвод - 'вид невода, перемещаемый в процессе ловли рыбы': Фсем дава̀ли нивада̀ - и ставныңя, и тяялавыңя. Троиц. Ставно̀й нѐват - э̀та про̀сто нѐват, а тѝялавый - эेта като̀рый тяүа̀ли. Троиц., 2019.

2. Лексическая коррекция. Неточное определение лексических границ ДФЕ зафиксировано нами как в материалах картотеки, так и в фундаментальных словарях. Отмечены случаи, когда следствием лексической коррекции становится коррекция семантическая. Один из ярких примеров - фразема чёрный вал в значении 'горе, несчастье', сопровождающаяся иллюстрацией: Каүда чёрный вал станить на ноүу харашо, таүда ани пра иүрушки забудуть. Усп. (КСРГО; БСРП: 70). Фрагменты иллюстраций, сопоставление с материалами общих и региональных словарей, глубокое комплексное этнолингвистическое исследование фразеологизма, положенное в основу статьи „Русский диалектный фразеологизм чёрный вал в этнокультурном освещении" (Арефьева 2018), позволили не только восстановить лексические границы рассматриваемой ДФЕ, но и иначе интерпретировать её внутреннюю форму. В конечном счёте, фразеологизм может быть представлен в следующем виде: чёрный вал станет на ногу [кому] - 'горе, несчастье, обычно связанные с незадавшейся семейной жизнью': Каүда чёрный вал станить на ногу харашо, таүда ани пра иүрушки забудуть. Усп. Подробнее об этом см. (Арефьева 2018).

Ещё один пример этого плана - региональная пословица Рабо̀ma не ведмѐдь, в лес не увойдёm 'работа не волк, в лес не убежит': Работта не ведмѐдь, в лес ни увайдёть. Возн. (КСРГО). В СРГО находим в качестве иллюстративного фрагмента лишь её усечённую часть: Работа в лес ни увайдёть (СРГО 2: 237). Сопоставление же с материалами КСРГО позволило восстановить ДФЕ в её целостном лексическом оформлении.

3. Грамматическая коррекция, включающая в себя морфологический и синтаксический виды коррекции.

3.1. Морфологический вид ошибки был зафиксирован нами как в материалах КСРГО, так и в СРГО. Так, именной компонент ДФЕ как дѝдька ходить - 'об очень плохо, неряшливо одетом человеке': Хо̀дить, как дйтька па ву̀лицам (Б. Пл.) имеет корневое д’, а не т’, как зафиксировано в СРГО (СРГО 
1: 169), поскольку заимствован из украинского языка, где слово „дидько” употребляется в значении 'чёрт' и является составной частью целого ряда фразем: дідька лисого, до дідька в зуби, до дідька лисого, якого дідька, дідько б тебе взяв, дідько ногу звихне и др. (СФУМ: 201-203).

3.2. Синтаксическая коррекиия. Проявляется в передаче характера глагольного управления, включении видовых форм глагола и т. п. К примеру, в СРГО находим ДФЕ идтѝ во двор 'идти жить в дом жены': Идтѝ во двор кармйть ати̧а̀ и мать (Павлов.) (СРГО 1, с. 241). Тщательное сопоставление с материалами КСРГО и записями живой диалектной речи позволило внести коррективы и лексикографировать данную фразему в следующем виде: идтѝ (прийтѝ) во двор к кому 'поселиться в доме жены после свадьбы (о молодом муже)': Идтѝ ва двор кармйть атциа̀ и мать. Павлов. Жынѝх пришо̀л к нам ва двор кармѝть атйа̀ и ма̀терь. Павлов. Ср.: пойти во двор - дон., орл. 'женившись, поселиться в доме жены' (БСРП: 175). То же можно сказать и о ДФЕ в завѐте нет, отображённой в СРГО в значении 'в помине нет' (СРГО 1: 205). Анализ иллюстративных фрагментов, зафиксированных в речи диалектоносителей, позволил определить синтаксические связи фразеологизма, включив его в проектируемый словарь в следующем оформлении: в завѐте нет у кого чего - экспресс. 'совсем нет, и в помине нет': У нас и в завети нет дёхтю. Рус. Ив. Интересно, что эту же фразему находим и в ФСРГС в несколько ином, более развёрнутом толковании: нет (не было) в завете - экспресс. 'совсем не знали о чём-либо; не было заведено, принято': - Помидоры-то мы и не садили: у нас этого и в завете не было (выделено нами - Н.А.) (ФСРГС: 74). Синтаксические связи фраземы, как видим, оказываются идентичными. В БСРП со ссылкой на КСРГО находим также: в завѐmе нет чего - одесск., сиб. 'не принято, не заведено что-л. где-л.' (БСРП: 238).

4. Стилистическая коррекциия. В процессе стилистической обработки диалектной фраземики нами учитывались как наличие у фраземы эмоционально-экспрессивной окрашенности и оценочного значения, так и актуальность её употребления.

4.1. Коррекция эмотивно-оценочного параметра ДФЕ. Имеет место при определении коннотативных оттенков ДФЕ и включении в их „фразеохарактеристику” соответствующих помет - „одобр.”, „неодобр.”, „экспресс.”, „шутл.” и т. п. Основана на анализе фрагментов иллюстраций, материалах фонозаписей, живого общения с носителями русских говоров, а также на сопоставлении с аналогичными фразеомоделями, по которым образуются фраземы с тождественной семантикой. Так, по свидетельству учителя В.А. Булгакова, коренного жителя с. Николаевка Тарутинского района Одесской области, лексемы, сопряжённые с концептуализацией сватовства как важнейшего элемента свадебной обрядности, транслируют ярко выраженные 
шутливые коннотации. Ср. ДФЕ пропѝmь невѐсту (доेчку) - шутл. 'просватать невесту'. В свадебной обрядности - положительный результат сговора родителей невесты с женихом и его родителями, завершающийся выпивкой' Прапѝли нявѐсту - значит ,, засва̀тали”. Никол., 2018. Прапѝли мы сасѐику до̀ку. Анат. (СРГО 2: 121; КА); запѝmь невѐсту в том же значении. Возн. (КСРГО), где глагольные партонимы пропить и запить, бытующие в данной местности, имплицируют шутливое отношение к происходящему (ср. также шутл. пропиться до исподнего 'потратить последние деньги на выпивку'; запива̀mb / запѝmb невѐсmy - дон., одесск., яросл. 'отмечать выпивкой удачное сватовство' (БСРП: с. 430).

Диалектная поговорка сим год не вмыва̀лся, на восьмой умыился (Спас.), зафиксированная в СРГО в качестве иллюстрации к слову „сим” (СРГО: 168) и не обнаруженная нами ни в одном из известных нам общих и региональных словарей, включена нами в материалы к Фразеологическому словарю русских говоров Одесщуины в значении 'о человеке, который наконец принял какоелибо важное решение, наконец заявил о чём-л. важном’ и сопровождается пометой „шутл.-ирон” по аналогии с поговорками семь лет молчал, на восьмой вскричал и семь лет мак не родился, а голоду не было (БСРПС: 482), также построенными на противопоставлении как одной из значимых когнитивных фразеомоделей.

4.2. Актуальность употребления ДФЕ корректируется, как правило, пометами „устар.” и „нов.”. К примеру, ДФЕ стоялая пряхха и лежалая npя̀xa - 'стоячая прялка, высокая' и 'низкая, горизонтальная прялка' соответственно, зафиксированные в СРГО (одна из них выделена нами в иллюстративном фрагменте: Бы̀ли на̀ии пря̀хи, ру̀ские стая̀лье, а немѐцкие нйзенькие, лежа̀лые (Возн.) (выделено нами - Н.А.) (СРГО 2: 194) отмечены нами как устаревшие в связи с фактическим исчезновением домашнего ткачества.

5. Фонетическая коррекция. Как правило, проявляется в выявлении фонетических вариантов ДФЕ (вокалических и консонантных, по Л.Ф. Баранник (Баранник 2015: 61)), в основе которого - сопоставление с материалами КСРГО, фонозаписей и процесс живого общения с диалектоносителями. Так, диалектная фразема y zурmе 'вместе, сообща' (Введ.) (СРГО 1: 152) в МФСРГО включена в виде двух фонетических вариантов, объединённых в одну словарную статью: y (в) гу̀mе 'вместе, сообща' (Введ.). По̀сле рабо̀ты мы в гурте атдыха̀им (Вас.). Нам вѐсяла в гу̀рте (Павл. Арцизского р-на, 1986).

В отдельных случаях фонетическая коррекция сопровождается и другими видами коррекции. Так, ДФЕ скла̀дывать в (у) крестый 'складывать крестообразно (о снопах)' (СРГО 1: 267), идентифицированная на основе иллюстративного материала СРГО, оказывается поливариантной на основе многочисленных иллюстративных фрагментов КСРГО, в которых отмечено несколько видов консонантной фонетической вариантности - соотношение 
к / $\mathbf{x}(к р е с т$ / хрест), апокопа - отпадение звука в конце слова (хрест - хрес), а также синтаксическая вариантность (складывать в кресты̀ - креста̀мu). Ср.: скла̀дывать в (у) крестьі (у (в) хресый (кресьі), хрестами)) 'складывать крестообразно (о снопах)': Сирпа̀ми жа̀ли и скла̀дывали ф кристы̀. Ст. Некр. Снапы̀ вяза̀ли, у кристы̀ скла̀дывали. Ст. Некр. Снапы скла̀дывали в крестьі. Ст. Некр. Коүда̀ мы дѐуками бьџли, снапь̀ христа̀ми скла̀дывали, а ни хо̀чиш снапь̀̀ вяза̀ть - склада̀шщь у капѝщ̧ь. Ст. Некр. Снапь̀ скла̀дывали хреста̀ми. Троиц. Мой сын касѝл, а я вяза̀ла и склада̀ла у хрисьі. Мирн. Стоүа̀ скла̀дывали в хрисьі̀. Ст. Некр. Снапь̀ пиривя̀зывали пиривёслами. Снапь̀ скла̀дывали христа̀ми. 15 снапо̀ф-хрест. 4 христа̀-капна̀. Троиц. (КСРГО).

Необходимо оговорить сразу, что, вслед за авторами фундаментального СРГО, нами не рассматривались фраземы, отличие которых от литературных фразем сводилось к регулярным диалектным фонетическим изменениям, если данные фраземы не стали общеупотребительными. Например, зафиксированный в материалах КСРГО фразеологизм позорить хвамйлию, отражающий характерную фонетическую особенность курских говоров (соотношение ф / хв в пользу последнего), был включён в МФСРГО в следующем виде: позорить фамѝлию чью - неодобр., чаще с отрицанием 'своими поступками, действиями и т. п. вызывать неодобрение, осуждение окружающих, бросая тем самым тень на своих предков': Я ко̀лька рас жину̀ абискура̀жывални пазо̀рь маюे хвамѝлию. Мур. Автором настоящей работы не учитывалось и диссимилятивное яканье как характерная особенность курских говоров, за исключением случаев, когда лексический компонент ДФЕ содержал другие формальные (в составе, строении, морфологии) отличия от лексем русского литературного языка. К примеру, фразема гуляты мянѝны, номинативный компонент которой является отражением именно этой диалектной фонетической особенности, унаследованной от материнских южнорусских диалектов, включена в МФСРГО, поскольку слово „мянины” стало общеупотребительным, а в его основе лежит афереза - усечение начальных гласных или согласных звуков, широко распространённое в русских говорах Юга Украины. Ср.,

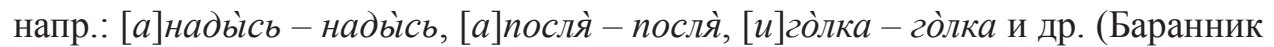
2015: 66). Таким образом, данная ДФЕ включена нами в МФСРГО в таком оформлении: гуляты мянѝны у кого 'праздновать день рождения': Да̀вече у ону̀чки мянйны гулялла. Серг. (КСРГО). Ср. также лексему „мянйнщик”'именинник' (Поозер. Новг. Сиб.), зафиксированную в СРНГ (СРНГ, вып. 19: 87).

6) Акиุентуационная коррекциия. Поскольку иллюстративный материал СРГО во многих случаях не сопровождается акцентуацией, основой данного вида коррекции стали сопоставление с материалами фонозаписей, КСРГО и живое общение с диалектоносителями, что дало возможность не только 
определить место ударения во всех лексических компонентах фразеологизма, но и зафиксировать наличие его „акцентуационных вариантов”. В качестве наглядного примера приведём диалектную фразему гориишный (горйшный и горыишный) ветер 'северный ветер': Bетры у нас бывають үарыішный и низо̀вый. Троиц. (СРГО 1: 139; КСРГО; КА), фиксируемую в СРГО в виде двух фонетических вариантов - горѝшный и горыйный ветер. Включение третьего варианта - горишный ветер стало возможным в результате полевых исследований, проведённых в с. Троицкое Беляевского района Одесской области в 2018 г. во время прямого опроса информанта с целью выявления контекста, определения мотивационной модели внутренней формы фразеологизма и степени его употребительности.

Приём языкового включения в беседе с этим же информантом позволил идентифицировать и лексикографировать ДФЕ не в сила̀x быть 'не иметь возможности делать что-либо из-за сильной занятости, плохого здоровья и т. п.': Я не ф сила̀x фсё ахватйть. Троиц., 2019 (КА), отличающейся от литературной фраземы нерегулярной (нестандартной) акцентуацией.

Таким образом, можно констатировать, что процесс лингвистической обработки обширного языкового материала является многоаспектным и многоплановым, а фразеологическая идентификация и кодификация включает в себя целый ряд этапов и процедур, конечная цель которых - системная комплексная характеристика выявленной диалектной фраземы.

\section{SUMMARY \\ Actual Problems of Creating Russian Dialects' Phraseological Dictionary of Odessa Region}

In this article the difficulties and problems faced by the author of this study in the process of creating the phraseological dictionary of Russian dialects of Odessa region are delighted.

It is noted that referring to the data of general and regional dictionaries in the process of selecting linguistic facts, determining their explicit and implicit content made it possible to correct (and in many cases fixation, subsequent semantization and further grammatical-stylistic and ethnocultural description that take into account inter-dialect and inter-lingual interference) the heterogeneous and diverse phraseological material presented in the projected dictionary.

In the process of verifying and analyzing dialect phraseological units, the author uses such types of correction as semantic, lexical, grammatical, stylistic, phonetic ones, accent correction or their combination. Each of these types is examined in detail.

The author comes to the conclusion that the process of linguistic processing of extensive linguistic material is multidimensional and multifaceted, and phraseolog- 
ical identification and codification include a number of stages and procedures, the ultimate goal of which is a system complex characteristic of the revealed dialect phraseological unit. 



\author{
FAbian Kaulfürst (D) \\ Serbski institut, Chóśebuz \\ fabian.kaulfuerst@serbski-institut.de
}

\title{
AWDIJOWY KORPUS MAMINORĚCNEJE DOLNOSERBŠĆINY AKO ŽRĚDLO ZA PŚESLĚŹOWANJE DOLNOSERBSKEJE DIALEKTALNEJE FRAZEOLOGIJE
}

Klucowe słowa: dolnoserbska dialektalna frazeologija, rěcny portal dolnoserbski.de, awdijowy korpus, frazeologiske jadnotki nimskego póchada, frazeologizmy w bilingualnych a multilingualnych kontekstach

Keywords: Lower Sorbian Dialectal Phraseology, Language Portal Dolnoserbski.de, Text and Speech Corpus, Phraseological Units of German Origin, Phraseologisms in Bilingual or Multilingual Contexts

\section{Zawjeźenje}

Dolnoserbšćina słuša k nejwěcej wobgrozonym rěcam w Europje. Licba maminorěcnych powědarjow (native speakers) drje jo mjaztym spadnuła pód 500, normalnje w starstwje wušej 80 lět. Glědajucy na toś tu rěcnu situaciju jo jadno z głownych tematiskich pólow Chóśebuskego wótźělenja Serbskego instituta dokumentacija rěcy. Pód adresu https://dolnoserbski.de póbitujo wóno wšake rěcne resurse. Nejwěcej recipěrujo se internetowy Nimsko-dolnoserbski słownik (Deutsch-niedersorbisches Wörterbuch, krotko DNW)1, kótaregož manuskript wopśimjejo tuchylu něźi 90000 lematow, jasnje wětšu licbu wóznamow a źasetki tysac pśikładow. W słowniku namakaju se teke tysace serbskich frazeologizmow, wjele z nich njejo było do togo w leksikografiskich źěłach wopisanych. Wětšy part wustupuju toś te jadnotki ako ekwiwalenty nimskich frazeologizmow w šyršem zmysle, casy pak teke ako wótpowědnik njefrazeologiskego nimskego wuraza resp. pśikłada ${ }^{2}$.

1 https://dolnoserbski.de/dnw. Wšykne w teksće pódane internetowe žrědła a pokazki su se slědny raz skontrolěrowali 24 I 2020 a wótbłyšćuju staw togo dnja.

2 By gódne było, toś ten material systematiski pśejś, frazeologizmy zidentificěrowaś a z wiźenja frazeologije leksikografiski wobźěłaś. 
Mimo togo namakaju se na wušej pomjenjonem portalu dolnoserbskich rěcnych resursow zdigitalizěrowane wersije (historiskich) dolnoserbsko-nimskich słownikow ${ }^{3}$. Hynac ako w śišćanych wersijach móžo se w online-wersiji teke za nimskorěcnym materialom słownikow pytaś. Frazeologiski material toś tych słownikow jo se identificěrowa ${ }^{4}$ a pó źěłach $\mathrm{z}$ wiźenja frazeologije wopisał. $\mathrm{Na}$ portalu jawi se toś ten „frazeologiski słownick ”é pód mjenim „Dolnoserbske rěcne wobroty a pśisłowa ${ }^{\text {ees }}$.

Dalšny źěł internetowego boka prezentěrujo wšake resurse zwězane z dolnoserbskim pšawopisom ${ }^{6}$. Mimo pśistupnjonych regulow, kótarež bazěruju na knigłach Manfreda Starosty 1982 a nowšych póstajenjach Dolnoserbskeje rěcneje komisije, jawi se how teke w Serbskem instituśe wuwijana software za pšawopisnu kontrolu a pšawopisny słownik. Slědny pśistupnijo zrazom serbske jadno- a wěcejsłowne wuraze DNWja a jo stakim serbskorěcny pśistup k materialoju togo dotychměst nejwobšyrnjejšego leksikografiskego wopisowanja dolnoserbskego słowoskłada.

Dalej póbitujo portal informacije wó dolnoserbskem wugronjenju ${ }^{7}$, pśistup $\mathrm{k}$ dolnoserbskemu tekstowemu korpusu ${ }^{8}$ a $\mathrm{k}$ digitalnej ediciji slědnego śišćanego wudaśa dolnoserbskeje Biblije z lěta $1868^{9}$.

Wětšyna na portalu póbitowanych rěcnych resursow póšěgujo se na standardnu dolnoserbšćinu. Wuwześe twóri awdijowy korpus maminorěcneje dolnoserbšćiny ${ }^{10}$, kótaryž jo głownje wusměrjony na dialektalnu dolnoserbšćinu. Za pśedlažecy nastawk njejo było móžno, tam zgromaźony material systematiski wupóceraś. Wótmysł jo skerjej na to pokazaś, až jo material online pśistupny a až mógu jen wědomnostniki pó cełem swěśe wužywaś za swóje slěźenja.

\section{Zakladne informacije wó awdijowem korpusu}

Pśedstajony specifiski korpus jo nastał w projekśe, kótaryž jo był financěrowany wót załožby VolkswagenStiftung we wobłuku wjelikego spěchowańskego progra-

3 Pód adresu https://dolnoserbski.de/ndw namakaju se słowniki Johanna Georga Zwahra (1847), Arnošta Muki (1911-1928), Bogumiła Šwjele (1961) a Manfreda Starosty (1999).

4 Glědajucy na somatisku frazeologiju jo słownik Starosty (1999) we formje nastawka wupócerał teke Szpila (2017).

5 https://dolnoserbski.de/nrs.

6 https://dolnoserbski.de/ortografija.

7 https://dolnoserbski.de/wugronjenje.

8 Korpus jo pśistupny pód adresu https://dolnoserbski.de/korpus a w šyršej měrje teke na bokach Českego národnego korpusa (https://kontext.korpus.cz, dotko).

9 https://dolnoserbski.de/biblija.

10 https://dolnoserbski.de/dobes. 
ma „Dokumentation bedrohter Sprachen” (krotko: DoBeS) ${ }^{11}$. W běgu projekta jo se nagrało 100 góźin awdijowego materiala z něźi 70 powědaŕkami a powědarjami. Teksty su se pó wěstych zasadach (pśir. Bartels, Thorquindt-Stumpf 2013: 48-56) ${ }^{12}$ transkriběrowali (dogromady něźi 700000 tokenow) a dodatnje pśestajili do nimšćiny. Transliteracija a pśełožk stej se z pomocu wósebneje anotaciskeje softwary za awdijowe a widejowe dataje ELAN ${ }^{13}$ zwězałej z pśisłušnymi źěłami awdijowych datajow. Stakim jo móžno, pytaś za serbskim abo nimskim wurazom a z namakanych tekstowych pasažow direktnje pśejś na wótpowědny zukowy dokład. Wušej togo jo se ze wšych tekstow wuzwóliło 20 pasažow, kótarež su se teke pśestajili do engelšćiny a su se dodatnje transkriběrowali z pomocu mjazynarodnego fonetiskego alfabeta IPA ${ }^{14}$.

Cełkowny material jo se gromaźe z materialami drugich wobgrozonych rěcow pśistupnił pód adresu https://archive.mpi.nl ${ }^{15}$. How mógu se downloadowaś cełkowne awdijowe nagrawanja we formaśe *.wav gromaźe z datajami we formaśe *.eaf a *.pfsx, kótarež su notne za źěło w softwarje ELAN.

Wobraz 1: Zukowa dataja z pśirědowanym serbskim a nimskim tekstom w programje ELAN

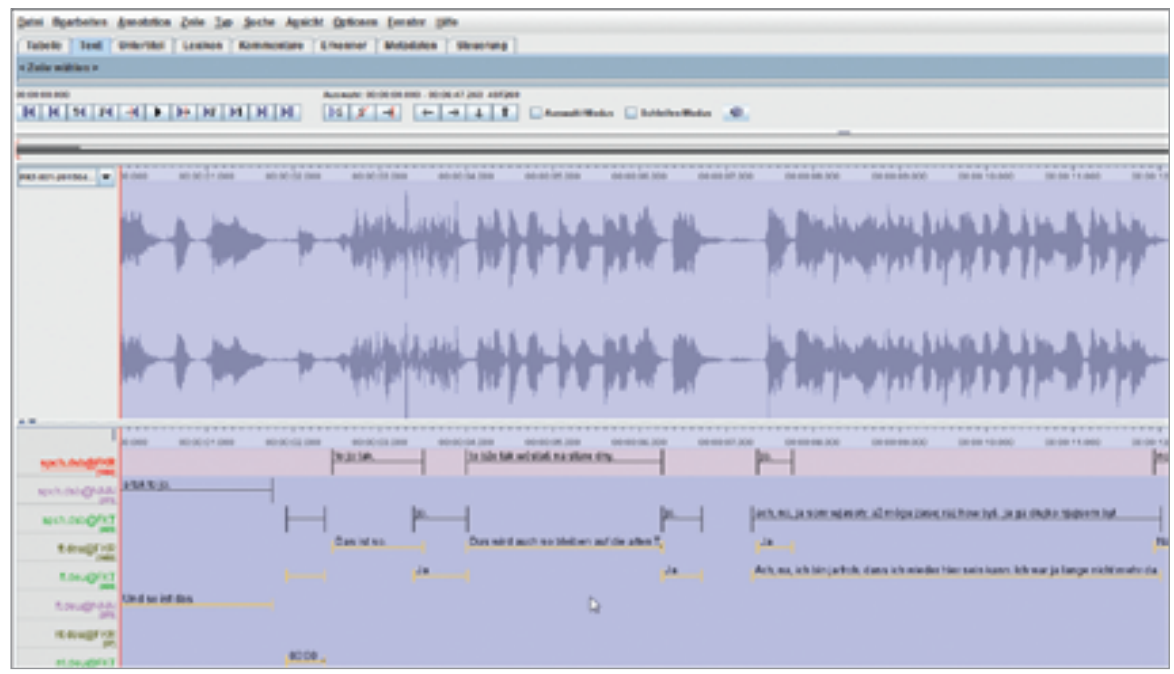

11 W Serbskem instituśe jo se źěłało na projekśe wót 2010 do 2017, na njom su byli na boce instituta głownje wobźělone Hauke Bartels, Kamil Thorquint-Stumpf, Marcin Szczepański a Jan Měškank. Wětšyna materiala jo se nazběrała wót dalšnych, wětšy part eksternych pomocnikow.

12 Někotare konwencije su dokumentěrowane pód adresu https://archive.mpi.nl/islandora/ object/lat\%3A1839_00_0000_0000_0022_1EBD_E/datastream/OBJ/download.

$13 \mathrm{https} / /$ tla.mpi.nl/tools/tla-tools/elan.

14 https://www.internationalphoneticalphabet.org.

15 Dalšna adresa, kótaraž pokazujo direktnje na dolnoserbski material a dokumentěrujo dalšne sobuźěłaśerje, jo https://hdl.handle.net/1839/b7cb7b41-8362-4488-b8cb-86fbfea6c7c7. 
Daty projekta pak su se pśistupnili z pomocu wósebnego wužywaŕskego interfaca teke pód adresu https://dolnoserbski.de/dobes. How móžo se material lažko a komfortabelnje pśepytaś. Pytański interface póbitujo wšake opcije: Pytaś móžo se za serbskimi (pytanje we wobłuku transkripcije), ale tejerownosći za nimskimi formami (pytanje we wobłuku pśełožka). Jo móžno nastajiś, lěc pyta se jano w rěcy nagrawanych informantow, abo teke we wugronjenjach eksploratorow. Dalšna opcija rezultěrujo z fakta, až su se mimo dolnoserbskich tekstow dodatnje do projekta zapśimjeli nagrawanja $\mathrm{z}$ pasma pśechadnych dialektow mjazy górno- a dolnoserbšćinu (głownje slěpjańskego dialekta): Jo móžno, wuzwólowaś mjazy pytanim we wšyknych rěcnych wariantach, jano w cysto dolnoserbskich tekstach abo jano w slěpjańskem dialekśe. Pytaś móžo se za konkretnymi formami, ale teke z pomocu zastupujucych symbolow (wildcardow) ${ }^{16}$. Gaž pišo se pytany wuraz mjazy nakósnyma smužkoma, mógu se teke wužywaś regularne wuraze (regular expressions) ${ }^{17}$.

Wobraz 2: Pytańske opcije pśistupa pód https://dolnoserbski.de/dobes
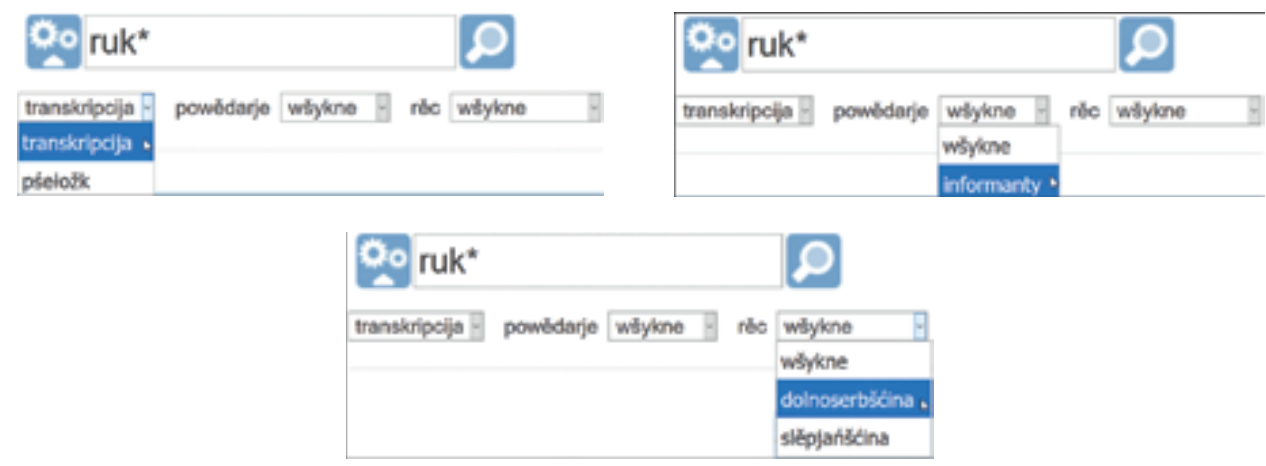

Pytanje wunjaso lisćinu rezultatow, kótaraž reprezentěrujo tekstowe pasaže, w kótarychž pytany wuraz se namakajo. Lisćina wopśimjejo slědujuce elementy: městno a datum nagrawanja ${ }^{18}$, informaciju wó tom, lěc słuša pasaža $\mathrm{k}$ rěcy informanta abo eksploratora, transkripciju pasaže, w kótarejž jo pytany wuraz wuzwignjony, a pśełožk pasaže. Wušej togo jo z tłocenim symbola głosnika móžno, pasažu direktnje słuchaś. Městno a datum fungěrujotej ako link, kótaryž pokazujo na transkripciju konkretnego interviewa. Tam jo móžno, se wó konteksće daneje pasaže informěrowaś. Wušej togo pódawaju se informacije wó głownych temach nagrawanja a jo móžno, cełe nagrawanje słuchaś.

16 Pód adresu https://dolnoserbski.de/dobes/pomoc su pytańske opcije dokradnjej wopisane.

17 Regularny wuraz/ru[kc].*/ namakajo mj. dr. formy ako ruk, ruka, ruki, ruku, ruce.

18 Jolic eksistěrujo za samski datum a za samske městno wěcej nagrawanjow, pódajo se w spinkoma dodatnje licba, ako identificěrujo konkretne nagrawanje, na pś. Hochoza, 2011-12-02 (2). 
Wobraz 3: Wurězk lisćiny rezultatow za pytany wuraz ruk*

\section{NapßaSowanje aruk*'s, wuslếdkl 1-25 wơt 188}

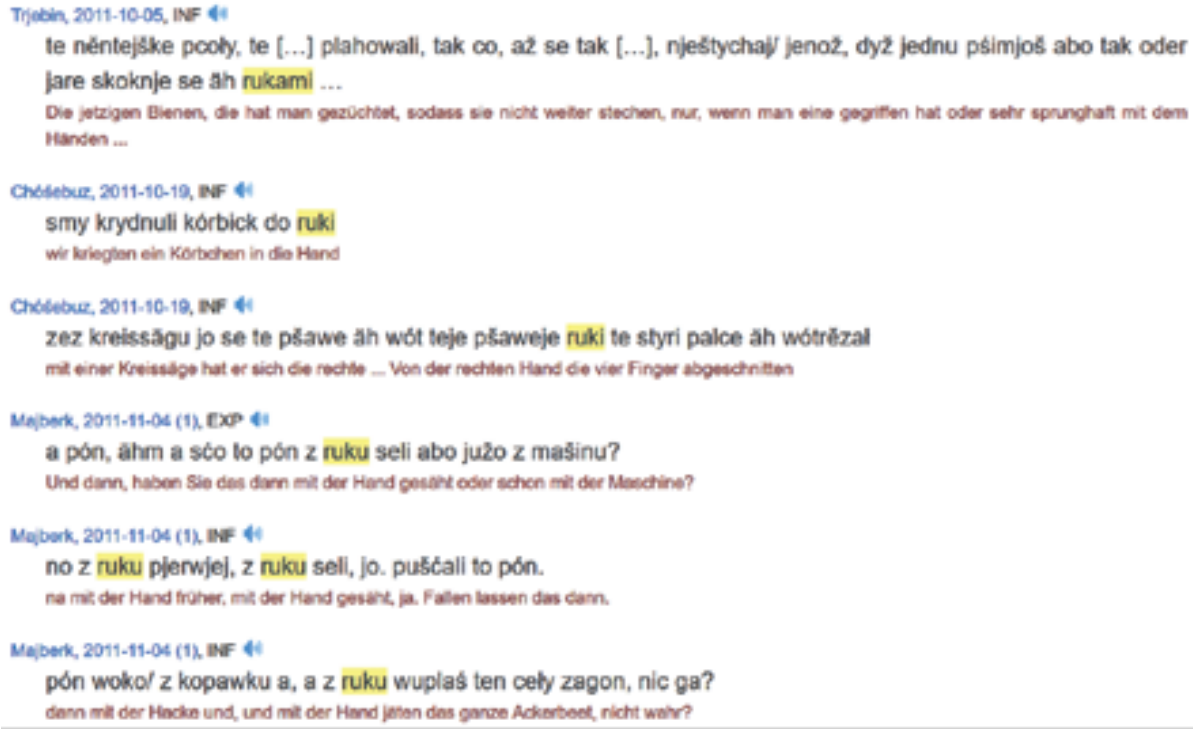

Tak pśistupnjony material zmóžnja linguistiske slěźenja na wšych móžnych pólach: Móžne su na pśikład studije k wugronjenju ${ }^{19}$, k (nic jano) dialektalnej leksice, k morfologiji a syntaksy. Slědujucy wótrězk pokazujo na zakłaźe gropneje analyze jadnučkego nagrawanja, až jo material teke gódny, aby frazeologi z njogo pócerali.

\section{Wuzwólone pśikłady frazeologije w nagrawanju FKT-001}

Wšykne slědujuce pśikłady póchadaju z nagrawanja FKT-00120. Nagrawało jo se 15 IV 2015 w Strjažowje. Informant FKR jo se 1929 naroźił w toś tej jsy a jo wětšy part swójogo žywjenja tam pśebywał. Za cas nagrawanja jo był 86 lět stary. Jogo mamina rěc jo dolnoserbšćina, mimo togo jo za cas nagrawanja ako dwójorěcny powědaŕ wobkněžył nimšćinu.

19 Material awdijowego korpusa jo na pśikład był wažny zakład pśi slěźenju glědajucy na dolnoserbsku ortoepiju (pśir. Kaulfürst 2019) a za skerjej na praksu wusměrjony, didaktiski internetowy bok wó dolnoserbskem wugronjenju, ako jo pśistupny pód adresu https://dolnoserbski.de/wugronjenje.

20 Direktny link: https://hdl.handle.net/1839/00-0000-0000-0021-AE06-5 resp. https://dolno serbski.de/dobes/tekst/237/0001. Nagrawanja su powšyknje zanonymizěrowane. Skrotconka FKT stoj za eksploratora. 
Wobraz 4: Wurězk transkripcije cełego nagrawanja 4. stuchaś cete nagrawanje (2:52:41)

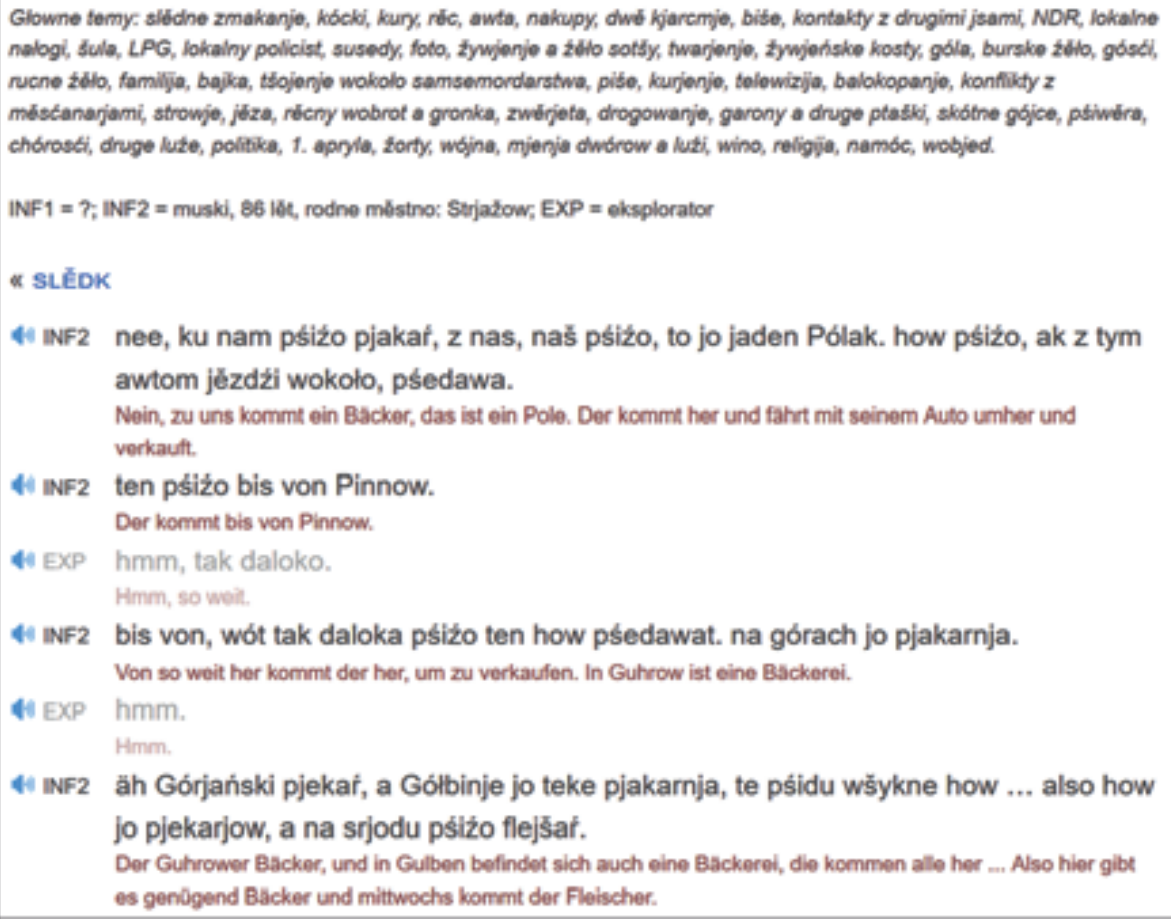

Tekst wopśimjejo wušej 20000 tokenow. Licba rozdźělnych słownych formow (types) wucynijo něži 2800, z nich jo pśibližnje 700 njestandardnorěcnych. Powědaŕ wobchada suwerenje ze swójeju mamineju rěcu. Pśi tom nadpadnjo wjelika licba rěcnych elementow, kótarež póchadaju z nimšćiny abo su pśez pósrědnjenje nimšćiny do (jogo) dolnoserbšćiny pśišli. Spektrum sega pśi tom wót dawno etablěrowanych póžyconkow (na pś. lazowat ${ }^{21}$ 'cytał') až k ad hoc zasunjonym citatam z nimšćiny. To jo typiski zjaw za aktualnu dialektalnu dolnoserbšćinu. Casy wustupujo w FKT-001 indigena leksika paralelnje k póžyconej. Tak stoj fraza to njej tak einfach 22 ('to njejo tak jadnore') pśisamem direktnje pódla to njej gänzlich tak lažko $o^{23}$ ('to njejo zewšym tak jadnore')24.

21 Na pśikład how: https://dolnoserbski.de/dobes/tekst/237/0441.

22 https://dolnoserbski.de/dobes/tekst/237/1082.

23 https://dolnoserbski.de/dobes/tekst/237/1084.

24 Dej se na to pokazaś, až njejo indigene słowo lažko dotychměst w dwójorěcnych (dolnoserbsko-nimskich a nimsko-dolnoserbskich) leksikografiskich žrědłach nimskemu einfach pśirědowane a wustupujo w nich jano ako ekwiwalent za (w někotarych kontekstach do dalokeje měry synonymne) leicht. 
Mimo jadnosłowneje leksiki nimskego póchada wužywa FKR rowno tak samorozymliwje teke wěcejsłowne wuraze a frazeologizmy nimskego póchada. Pla wšakich drje jadna se wó ad hoc citaty, pla drugich se zdajo, až su ako kšute jadnotki w dolnoserbskem rěcnem systemje informanta zakórjenjone.

W slědujucem pśedstajaju se konkretne wuzwólone pśikłady frazeologizmow w teksće FKT-001. Pśi tom pokazuju se eksemplariski teke take nimskego póchada a take, w kótarychž su słowa nimskego frazeologizma morfologiski adaptěrowane. Wustupuju teke hybridne frazeologizmy, w kótarychž narownajo se na pś. słowo spócetnje nimskego frazeologizma ze serbskem. Mjazy frazeologizmami, w kótarychž wužywa se do dalokeje měry indigeny serbski słowoskład, jo teke rěd kalkow resp. paralelnych frazeologizmow. Někotare z nich su drje rozšyrjone we wjelich rěcach.

Dalokož móžno pśedstajaju se frazeologizmy pó slědujucej šemje:

(cysło) originalny citat z FKT-001 \{pokazka na žrědło\} ${ }^{25}$

zakładna (słownikowa) forma frazeologizma $(\diamond)^{26}$ (ewentualnje pokazka na nimsku wariantu abo bliski nimski frazeologizm)

'wóznamowa definicija w dolnoserbskej rěcy'

‘wóznamowa definicija w pólskej rěcy'.

Jadnorosći dla pódawaju se frazeologizmy chronologiski, rozmjej pó rěźe tak, ako wustupuju w teksće FKT-001.

(1) to bźo tak wóstaś na stare dny \{.../0004\}

na stare dny (pśir. nimski: auf die / seine / meine / . . alten Tage)

'we wusokem starstwje'

'w starszym wieku, na starość'

(2) klěb njekśé wěce ... ab und zu raz krydnu \{.../0058\}

$\mathrm{ab}$ und $\mathrm{zu}^{27}(\diamond)$

'wótergi, casy'

'czasami'.

25 Pokazka na žrědło pódawa se mjazy kśidłatyma spinkoma w skrotconej formje. Adresa https://dolnoserbski.de/dobes/tekst/237/0058 pśikrotcyjo se na $\{\ldots / 0058\}$. Prědny źěł adrese wóstanjo stawnje njezměnjony. Slědne styri cyfry se póšěguju stawnje na prědnu sekwencu teksta, kótaraž se na wótpowědnem boce pokazujo.

26 Fakultatiwny symbol $(\diamond)$ pokazujo na to, až njejo dany frazeologizm (w konkretnej formje resp. z tym wóznamom) w leksikografiskem materialu pód https://dolnoserbski.de hyšći zregistrěrowany.

27 Pó transkripciskich pšawidłach korpusa maminorěcneje dolnoserbšćiny (pśir. Bartels, Thorquindt-Stumpf 2013: 51 sl.) pišu se młoge póžyconki how (tak ako w analyzěrowanem materialu) pó nimskej wašni ( $z u$ město zeserbšćonego $\mathrm{cu}$ ). 
Pytanje za wurazom ,ab und zu“e (z pazorkami) w korpusu maminorěcneje dolnoserbšćiny pokazujo, až jo toś ten frazeologizm w slědnej generaciji maminorěcnych powědarjow rozšyrjony a zatwarja se mimo wobgranicowanja do howacej dolnoserbskich sadow. Pódobnje jo z frazeologizmom pód dypkom (4).

(3) tak unter der woche abol na sobótu $\{. . . / 0155\}$

unter der Woche $(\diamond)$

'wót pónjeźelego do pětka'

'od poniedziałku do piątku'

(4) to jo pón nach und nach wordowato wšykno hynac napórane \{.../0174\}

nach und nach $(\diamond)$

'póněcom, pómałem'

'stopniowo'

(5) tog som wuknut ja znaś $\{\ldots / 0240\}$

někogo / něco znaś wuknuś ( $\downarrow$ (pśir. nimski: kennenlernen)

'někogo / něco póznaś'

'pozna(wa)ć kogoś / coś'.

Kalkowanje nimskego jemanden / etwas kennenlernen ako někogo / něco znaś wuknuś jo dosć zajmny a w dialektalnej dolnoserbšćinje (a teke górnoserbšćinje) dosć rozšyrjony zjaw, což se teke wótbłyšćujo w korpusu maminorěcneje dolnoserbšćiny.

(6) te su (...) se sami wzeli to žywjenje $\{\ldots / 0280\}^{28}$

wześ se to žywjenje (pśir. nimski: sich das Leben nehmen)

'wugbaś sebjemordaŕstwo'

'popełnić samobójstwo'.

Wužywanje formy spócetnego demonstratiwnego pronomena ako artikel jo (teke zwenka how citěrowanego frazeologizma) typiski zjaw dialektalneje serbšćiny. Wóno jo było teke w staršem pismojstwje rozšyrjone. Pó 1945 jo był toś ten nałog pśez puristiske naglědy do dalokeje měry ze standardneje rěcy wupórany. Wót 1980tych lět, rozmjej z pśiběrajuceju tendencu k liberalizěrowanju standardneje rěcy, se toś ta wósebnosć ludoweje rěcy w tekstach zasej šyri. ${ }^{29}$ Samski fra-

28 W FKT-001 wužywa FKR samski frazeologizm hyšći dalšne tśi raze: $\{. . / 1015,1037$, $1043\}$.

29 Na pśikład namakajo se w aktualnem nimsko-dolnoserbskem internetowem słowniku dokład frazeologizma wześ se to žywjenje z wužywanim formy to w funkciji artikla: Wón jo wopytat sebje to žywjenje wześ (https://dolnoserbski.de/dnw/woerterbuch/leben_g). 
zeologizm wustupujo pak teke w dialektalnej serbšćinje mimo artikla, pśirownaj na pśikład jo, młoge su se wzeli žywjenje $e^{30}$.

(7) młoge pśiźo mě tak do głowy, wěš? \{.../0305\}

někomu do głowy pśiś (pśir. nimski: jemandem in den Kopf kommen)

'domysliś se na něco, měś ideju'

'przyjść na myśl'

(8) a ten jo jět až do riśi pó kólasu \{.../0322\}

jěś (hyś, gnaś, ... $)^{31}$ až do riśi ( $\bullet$ (pśir. nimski: bis zum Arsch der Welt ${ }^{32}$ ) 'jěšs (hyś, gnaś, ...) do wjelgin zdalonego, bližej njedefiněrowanego cela' ‘jechać (iść, ...) gdzieś bardzo daleko, w nieokreślone miejsce’

(9) ten a ten źeń $\{\ldots / 0410\}$

ten a ten (źeń, ...) $)^{33}$ (pśir. nimski: der und der $[$ Tag, ...])

'wěsta, bližej njespecificěrowana wěc resp. wósoba'

'niekonkretna rzecz lub osoba'

(10) starki jo pśec gronit, pfleguj, heguj a pfleguj to zbóžko \{.../0782\}

někogo/něco hegowaś a pflegowaś ( $\downarrow$ (pśir. nimski: hegen und pflegen)

'wó něco/někogo se intensiwnje staraś'

'intensywnie się opiekować czymś/kimś’

(11) z tym wujkom rybach smej bytej $\{\ldots / 0870\}$

$\mathrm{W}^{34}$ rybach byś $(\diamond)$

'ryby łojś'

'łowić ryby'

30 https://dolnoserbski.de/dobes/tekst/092/0483.

31 Samski frazeologizm jo dokłaźony w FKT-001 hyšći raz: nět jědu až do riśi \{.../1173\}. Samski informant (FKR) wužywa jen z drugim werbom teke w dalšnem nagraśu: ow, pón sy lěśet [sic] až do riśsi (https://dolnoserbski.de/dobes/tekst/026/1173).

32 Glědajucy na dalšne dolnoserbske frazeologizmy, kótarež wopśimjeju sekwencu do riśi (pśir. https://dolnoserbski.de/nrs/pytanje?wuraz=riśi) a na strukturelne rozdźěle (do - bis zum), njejo drje notne, interpretěrowaś dolnoserbski frazeologizm ako pśikrotcony pśełožk nimskego.

33 W korpusu maminorěcneje dolnoserbšćiny dajo mj. dr. hyšći dokład ten a ten psalm (https://dolnoserbski.de/dobes/tekst/124/0108). Cesćej wšak wustupujo w cełkownem korpusu maminorěcneje dolnoserbšćiny njerozšyrjony frazeologizm ten a ten $\mathrm{z}$ wóznamom 'wěsta, bližej njespecificěrowana muskeca wósoba', na pś. to jo ten a ten gótowat (https:// dolnoserbski.de/dobes/tekst/036/0869).

34 Fonetiski jo prepozicija $w$ how nima. Wóna se togodla pó transkripciskich regulach za korpus maminorěcneje dolnoserbšćiny (pśir. Bartels, Thorquindt-Stumpf 2013: 51) w transkripśe njepišo. W słownikowej formje pak se wóna how weto pišo. 
(12) trajda ga dej byś tek zasej seta a wšo \{.../1022\}

a wšo ( $\bullet$ (pśir. nimski: und alles)

'a dalšne take / pódobne wěcy'

'i tym podobne'

(13) jo, młogi ${ }^{35}$ raz krydnut nawumjetowane $\{\ldots / 1069\}$

młoge/młogi raz (pśir. nimski: manchmal, manches Mal)

'casy, wótergi'

'czasami'.

W dypku (12) wobspomnjony frazeologizm $a$ wšo wužywa FKR w FKT-001 ze samskim wóznamom teke w reduplicěrowanej formje.

(14) tykańc a wšo a wšo $\{\ldots / 1089\}$

a wšo a wšo ( $\downarrow)$

'a dalšne take / pódobne wěcy'

'i tym podobne'

(15) ze wšyknym ženu, gaž jim riś zabólijo, duchteroju \{.../1189\}

gaž někomu riś zabólijo (

'njenotnje, dla lapalije'

'niepotrzebnie'

(16) ga ten buŕ ženjo? gaž ma głowu pód pažu \{.../1192\}

głowu pód pažu měś ( $\$$ (pśir. nimski: den Kopf unterm Arm tragen)

'byś wjelgin chóry'

'być bardzo chorym'

(17) ja mam to grono nět! \{.../1275\}

to grono měś (pśir. nimski: das Sagen haben)

'byś w poziciji rozkazowaś'

'mieć wpływ na coś/kogoś, decydować o czymś'

(18) tam bźomy musaś tu ${ }^{36}$ móšynku wócynjaś \{.../1403\}

tu móšynku wócynjaś ( $\downarrow$ ) (pśir. nimski: den Geldbeutel aufmachen)

'(wjele) (za)płaśiś'

'(dużo) (za)płacić'

35 W transkripciji stoj pó źinsajšnej standardnej rěcy młogi město realizěrowanego, dialektalnego mloge.

36 Pśirownaj komentar pód pśikładom (6). 
(19) gaž njebźo to a to pasěrowaś \{.../1437\}

to a to $(\diamond)$ (pśir. nimski: das und das)

'wěsta, bližej njespecificěrowana wěc'

'niekonkretna rzecz'

(20) to su fararjowe gótbje $\{\ldots / 1457\}$

fararjowe gółbje $\mathrm{e}^{37}\left(\right.$ ) (pśir. nimski: Pfarrers / Pastors [schwarze] Tauben ${ }^{38}$ )

'karwony'

'wrony'.

FKR pódajo na toś tom městnje direktnje sam wujasnjenje frazeologizma, gronjecy: ja pśec gronim, gaž karony leśe, fararjowe gótbje leśe \{.../1458\}

(21) jo wordowat ten kuždy na, za apryl póstany \{.../1587\}

$\mathrm{za}^{39}$ apryl pósłany wordowaś (pśir. nimski: in den April geschickt werden)

'staś se wopor aprylskego žorta'

'stać się ofiarą żartu primaaprilisowego'

(22) $\{N N\}$ jo endlich chyśita tu flintu $\{\ldots / 1726\}$

tu ${ }^{40}$ flintu chyśiś ( $\left.\downarrow\right)$ (pśir. nimski: die Flinte ins Korn werfen)

'rezigněrowaś, se powdaś'

'zrezygnować, poddać się'

(23) junge, junge, to jo byto ... \{.../1767\}

junge, junge ( $\bullet$ (pśir. nimski: Junge, Junge)

'wuraz zaźiwanja, njewóli'

'wyrażenie zdziwienia, oburzenia'

(24) ta jo była wěc ak dumm \{.../1824\}

wěc ak dumm ( $\bullet$ (pśir. nimski: mehr als/wie dumm ${ }^{41}$ )

'wjelgin głupy'

'bardzo głupi'.

37 Forma gółbje wótpowědujo pisnorěcnemu gołubje.

38 W nimšćinje póśěgujo se frazeologizm skerjej na druge ptaški, rozmjej (pśewažnje) na kawku a rědšej na wrona (pólski: kruk). To sugerěrujo nanejmjenjej internetowe pytanje z pytańskeju mašinu, na pś. za gronidłami Pastors Tauben resp. Pfarrers Tauben. Ewentualnje póśěgujo se frazeologizm powšyknje na corvidae (wronate ptaški).

39 W originalnem citaśe korigěrujo FKR spócetne $n a$ na $z a$. Pódobny frazeologizm, kótaryž wobkšuśijo, až słuša prepozicija $z a$ ku frazeologizmoju, wužywa informant teke na drugem městnje: ten jo za aprylom pósłany $\{\ldots / 1607\}$.

40 Pśirownaj komentar pód pśikładom (6).

${ }_{41}$ Forma mehr wie dumm jo wuraznje dialektalna resp. regionalnje wobchadnorěcna. 
Njeflektěrowana forma $\operatorname{dum}(\mathrm{m})$ jo typiska za dolnoserbske dialekty. Toś ta forma njejo w słownikach dotychměst zapisana. Město njeje namakajo se w nimsko-dolnoserbskem internetowem słowniku (ale jano w pśikładach pód nimskima gronidłoma dumm resp. Pille, nic ako rědowny ekwiwalent) dalšna póžyconka na zakłaźe nimskego dumm, kótaraž pak se normalnje dekliněrujo: dumny.

(25) wjele sy musat z glowy $\{\ldots / 2113\}$

z głowy (pśir. nimski: aus dem Kopf)

'ze spomnjeśa'

'na pamięć'.

Wušej togo namakaju se w teksće FKT-001 teke wšake rymowanki resp. gronka. W jadnom směše se wobydlarje susedneje jsy: Brjazynarje z gownom zupu warje $\{\ldots / 0195\}$. Druge se póśěgujo na familijowe mě (kótarež jo datowego šćita dla anonymizěrowane): $\{N N\}^{42}$ zabij bycka $\{\ldots / 1888\}$. Dalšne referěrujo na pówołanje: kopśaŕ wari muku z tej kopśowatej ruku $\{\ldots / 0302, \ldots / 0304, \ldots / 1846\}$.

Gropna analyza teksta FKT-001 glědajucy na frazeologizmy pokazujo, až jawi se w korpusu maminorěcneje dolnoserbšćiny (pó źěłach leksikografiski hyšći njezregistrěrowany) frazeologiski material, kótaryž mógał a dejał byś žrědło za pśeslěźowanje dolnoserbskeje (nic jano dialektalneje) frazeologije. By było gódne, cełkowny material systematiski pśejś, frazeologizmy zidentificěrowaś a klasificěrowaś, jich wóznamy zwěsćiś a je leksikografiski wopisaś. Pśi tom jo mimo cwiblowanja zajmne pšašanje, kak funkcioněruju z drugeje rěcy póžycone frazeologizmy w dwójorěcnem konteksće. Pśistupnjenje materiala w interneśe pód adresu https://dolnoserbski.de/dobes jo dobra góźba za zajmowanych frazeologow, aby se dłymjej z dolnoserbskeju frazeologiju zabrali.

\section{Internetowe žrědła (slědny raz wótwołane 24 I 2020)}

https://archive.mpi.nl („The Language Archive ${ }^{e c}$ Instituta Maxa Planck za psycholinguistiku w Nijmegenje)

https://dolnoserbski.de (dolnoserbske rěcne resurse Serbskego instituta)

https://hdl.handle.net/1839/00-0000-0000-0021-AE06-5 (persistentny identifier w nastawku bližej pśedstajonego teksta FKT-001 w „The Language Archive”)

https://hdl.handle.net/1839/b7cb7b41-8362-4488-b8cb-86fbfea6c7c7 (persistentny identifier dolnoserbskich rěcnych resursow w „The Language Archive”)

https://kontext.korpus.cz (boki Českego národnego korpusa, pśistupnje teke źéł dolnoserbskego tekstowego korpusa)

${ }^{42}$ Anonymizěrowane mě rymujo se na slědne słowo gronka bycka. 
https://tla.mpi.nl/tools/tla-tools/elan (software ELAN za kompleksne anotěrowanje widejowych a awdijowych resursow)

https://www.internationalphoneticalphabet.org (bok wó mjazynarodnem fonetiskem alfabeśe [IPA])

\section{SuMmary}

\section{The Text and Speech Corpus of Native Lower Sorbian As a Source for Research on Lower Sorbian Dialectal Phraseology}

This paper deals with the (dialectal) phraseology of Lower Sorbian, a highly endangered language currently spoken by fewer than 500 native speakers. It first introduces the Language Portal of the Cottbus department of the Sorbian Institute dolnoserbski.de. It goes on to present one module of this portal as a resource for linguistic research: a text and speech corpus of native Lower Sorbian containing 100 hours of speech recordings of the last generation of native (mostly dialect) speakers that have been transcribed and subsequently translated into German. These recordings can therefore be searched/accessed in both languages. In some selected parts a translation into English and a phonetic transcription using International Phonetic Alphabet (IPA) is also available. In order to demonstrate the value of this material for phraseological studies and to stimulate further research, this paper then quotes selected phraseologisms from one of these recordings. Many of them have not yet been lexicographically registered. As this paper shows, the direct use of phraseological units of German origin is a special feature of such dialectal texts and, more generally, that the use of phraseologisms in bilingual or multilingual contexts is a promising field of research in linguistics. 



\section{Frazeologia}

źródłem wiedzy o człowieku 

https://doi.org/10.12797/9788381382458.14

\author{
Ewa Mlynarczyk (1) \\ Uniwersytet Pedagogiczny im. Komisji Edukacji Narodowej, Kraków \\ ewa.mlynarczyk@up.krakow.pl
}

\title{
FRAZEMY OBRAZUJĄCE SPOSÓB PROWADZENIA GOSPODARSTWA DOMOWEGO (REKONESANS)
}

Słowa kluczowe: frazeologia, paremiologia, JOS, bieda, gospodarstwo domowe Keywords: phraseology, paremiology, linguistic image of the world, poverty, household

Na podstawie spetryfikowanych połączeń słownych, mających w większości ludową proweniencję, można odtworzyć wiele składników $\mathrm{JOS}^{1}$ związanych z różnymi realiami codzienności naszych przodków - z warunkami bytowymi, zajęciami, relacjami rodzinnymi, a także - ze sposobami gospodarowania, radzenia sobie, zwłaszcza w sytuacjach niedostatku, niewystarczających środków na utrzymanie rodziny $^{2}$. W niniejszej pracy obiektem bliższego oglądu będą wszystkie utrwalone połączenia słowne (frazemy w rozumieniu Wojciecha Chlebdy ${ }^{3}$ ), które dotyczą zasad prowadzenia gospodarstwa domowego. Jest to pojęcie obecne w naukach ekonomicznych, politycznych, a także w potocznej komunikacji. W polityce społecznej gospodarstwo domowe to

1 Kategorię językowego obrazu świata (JOS) rozumiem za Jerzym Bartmińskim jako „zawartą w języku interpretację rzeczywistości, którą można ująć w postaci sądów o świecie" (Bartmiński 2009: 76).

2 Składniki językowego obrazu niedostatku materialnego (biedy) utrwalonego w polskiej frazematyce zostały omówione w pracach m.in. Macieja Raka (2015: 239-250), Ilony Gumowskiej (2016) i Ewy Młynarczyk (2015, 2016, 2018). W pracach tych znajduje się też bogata literatura przedmiotu na ten temat. Cenne są także opracowania hasła bieda / biyda w słownikach: SGP (II: 153) i KąśILG (I: 268-273). Zagadnienia związane z materialnymi podstawami bytu są na tyle szeroko odzwierciedlone we frazeologii gwarowej i ogólnej, że mogą stać się podstawą wielu innych opracowań.

3 Wojciech Chlebda, kierując się jako jedynym kryterium konstytutywnym - „odtwarzalnością elementu językowego w danej sytuacji komunikacyjnej i dla nazwania danej wiązki sensów”, frazem rozumie jako „względnie trwałą formę językową, która w danej sytuacji stała się - niezależnie od swych cech strukturalnych i semantycznych - przyjętym (nierzadko jedynym) sposobem wyrażania danego potencjału treściowego (Chlebda 2010: 336). 
zespół osób razem zamieszkujących i wspólnie utrzymujących się, [...] W ramach gospodarstw domowych są realizowane ekonomiczne funkcje rodziny: produkcyjna (wytwarzanie dóbr i usług), aktywizacji zawodowej jej członków (np. w rodzinnym warsztacie pracy) oraz konsumpcyjna (wydatkowanie dochodów oraz spożycie dóbr i usług, zaspokajające potrzeby członków gospodarstw domowych) ${ }^{4}$.

Skupiając się na aspekcie konsumpcyjnym tego pojęcia, podjęłam próbę rozeznania, które frazemy utrwaliły sądy i przekonania na temat codziennego funkcjonowania gospodarstw domowych, wydatkowania dochodów celem zaspokajania potrzeb członków rodziny, spożycia dóbr i usług, czyli na tym, co potocznie nazywa się prowadzeniem domu.

Podstawowa trudność związana z gromadzeniem materiału badawczego dla tak wskazanego tematu polega na różnorodności frazemów, które mogą być nośnikami składników językowego obrazu tego wycinka rzeczywistości, bowiem sądy na temat prowadzenia domu zostały utrwalone $\mathrm{w}$ jednostkach $\mathrm{z}$ wielu różnych pól semantycznych. Przy wyborze komponentów, według których można dokonywać ekscerpcji materiału, badacz musi się przede wszystkim kierować własną intuicją i doświadczeniem. $\mathrm{Z}$ tych względów niniejszy szkic ma charakter wstępnego rozeznania $\mathrm{w}$ tematyce, a cytowane frazemy i przysłowia mogą być traktowane wyłącznie jako przykładowe, stanowiące punkt wyjścia do dalszych poszukiwań. Taką właśnie możliwość (wstępnego rozeznania) daje materiał pozyskany z Nowej księgi przystów i wyrażeń przysłowiowych polskich (NKPP), rejestrującej zróżnicowane chronologicznie, terytorialnie i stylistycznie jednostki. Ze względu na charakter niniejszego tomu, skupionego wokół problematyki frazeologii gwarowej, wzięłam pod uwagę przede wszystkim jednostki wielowyrazowe mające potwierdzenie w źródłach o charakterze dialektalnym ${ }^{5}$, ale uwzględniam także niektóre poświadczone tylko w polszczyźnie ogólnej. Zgromadzony materiał jest niejednolity terytorialnie, w większości są to jednostki wspólne dla polszczyzny ogólnej i gwarowej ${ }^{6}$ - moją intencją nie było jednak lokalizowanie frazemów bądź

4 https:/encyklopedia.pwn.pl/haslo/gospodarstwo-domowe;3906934.html(dostęp:25 XI2019).

5 Uzupełnieniem materiału z NKPP są w niniejszej pracy pojedyncze jednostki pozyskane w wyniku ekscerpcji słowników gwarowych: Słownika gwar polskich Jana Karłowicza (SKarł), Stownika gwar polskich powstającym w IJP PAN (SGP), Ilustrowanego leksykonu gwary i kultury podhalańskiej Józefa Kąsia (KąśILG), Stownika gwary zagórzańskiej (gorczańskiej) Józefy Kobylińskiej (SGG) wraz z suplementem (SGGSup). Pełny materiał ekscerpowany z wymienionych leksykonów zamierzam wykorzystać przy szerszym opracowaniu tematyki omawianej w pracy.

${ }_{6}$ Prezentując materiał, podaję postać jednostki uznaną w NKPP za inwariant (zapisany wytłuszczoną czcionką) - najczęściej jest to zatem postać funkcjonująca w języku ogólnym. Warianty wymieniane w artykule hasłowym NKPP (w tym gwarowe) są nośnikami tych samych składników JOS, co inwariant, więc ze względu na ograniczone ramy pracy przytaczam tylko przykładowe z nich - te, które różnią się sposobem obrazowania lub zróż- 
określanie ich przynależności do jednej z odmian języka, ale odczytanie utrwalonych w nich składników językowego obrazu gospodarstwa domowego.

Jakie zatem składniki JOS w tak określonym obszarze rzeczywistości można odczytać na podstawie zebranego materiału?

Przede wszystkim część frazemów jest ilustracją przekonania, że zapewnienie rodzinie podstaw materialnego bytu wiąże się z wieloma przeciwnościami i koniecznością radzenia sobie z różnymi trudnymi sytuacjami i warunkami, co najlepiej obrazuje frazem, u którego podstaw leży metaforyczny obraz mający swe źródło w realiach włókienniczych koniec z końcem wiązać (NKPP II: 114). Trud codziennego zaspokajania materialnych potrzeb rodziny ilustruje także frazem mieć na łoganiacke 'na bieżące potrzeby' (SGGSup 2019). Wiązało się to czasem z koniecznością ,,sztukowania”, szukania środków doraźnych bądź zaciągania długów, postawa taka była przedstawiana z ironią: Tu urwie, tu nadstawi (Tu urwie, tu załata. Wisła, XII, 1762; Tu urwij, tu daj. Sł. warsz. VII, 354; NKPP III: 103); Wykupit koszule, a suknia zastawit (NKPP II: 154); Kościót odzierasz, a dzwonnice pobijasz (Kościót złupić, a dzwonnicę pobijać. Dambrowski, Kaz.cz., I; Kościół pokryt, dzwonnice odart. Sł. warsz. VII, 907; NKPP II: 156).

$\mathrm{Na}$ filozofię prowadzenia gospodarstwa domowego niewątpliwie rzutowały trudności i okresy niedostatku, bieda (nędza) oraz jej perspektywa: Ucieka nędza przed tym, co oszczędza, a kto trwoni, wkrótce ja dogoni (warianty: Kto rachuje i oszczędza, nie zajrzy mu w oczy nędza. Ad; Kto się tata i oszczędza, nie zajrzy mu w oczy nędza. Ad; NKPP II: 753); ognać się (oganiać się) od biedy (KąśILG I: 270).

Wiele jednostek paremicznych zawiera przestrogę, że okres dostatku może łatwo się skończyć, los jest zmienny, stąd często występująca opozycja teraźniejszość-przyszłość wyrażana zazwyczaj leksykalnie poprzez antonimię: dziś-jutro. Mogą to być sądy o pewnym stopniu abstrakcji, np.: Dziś tak, jutro owak (Dzisio tak, a jutro siak. Broda, Prz. ciesz.; NKPP I: 546), lub poprzez obrazowanie na większym poziomie konkretyzacji: Dzisiaj lusztyk, dzisiaj husto ${ }^{7}$ a w spiżarni potem pusto (Dzisiá tego jako ber, jutro tego jako żber ${ }^{8}$. Cinciała, Prz.ciesz., 11; NKPP I: 544) ('dzisiaj zbytek, jutro głód'); Dziś zjedli kokosz, a nazajutrz gówno (Lepiej byto po jajku codziennie jeść równo, nie kokosz na wieczerzę, a nazajutrz gówno. Niezabitowski, Rkp. II; NKPP I: 546); Dziś sprawi, a jutro z tym do Żyda (NKPP I: 546) ('musi sprzedać, zastawić').

nicowanymi komponentami. Lokalizację dla jednostek cytowanych w NKPP pod jednym hasłem (inwariantu i wariantów) podaję tylko raz według wzoru: NKPP I: 54, w którym cyfra rzymska oznacza tom, a arabska - stronę. Skróty źródeł podaję za NKPP.

7 Lusztyk - stp. 'uczta, biesiada, zabawa, hulanka' (NKPP IV: 206); husto - gwar. 'gęsto, obficie' (NKPP IV: 192).

8 Ber-gwar. 'roślina z rodzaju prosa' (NKPP IV: 171); żber - ciesz. 'balia, ceber' (NKPP IV: 264). 
Realia związane z brakiem pieniędzy na najważniejsze potrzeby i oddawanie cenniejszych rzeczy pod zastaw lub kupowanie na kredyt utrwalone zostały w powiedzeniu: Dziś za pieniądze, jutro za darmo (na kredyt) (NKPP I: 546), które przypisywano karczmarzom (Przysłowie karczmarzów: Dziś za pieniądze, jutro za darmo. Linde, II, 281; Dziś za pieniądze, jutro na kredyt. Ad; Dzisio za pieniądze, jutro na bórg. Pauli, Rkp IV). W NKPP dodano komentarz: „napis do niedawna jeszcze oglądany na sklepikach wiejskich i małomiasteczkowych" (NKPP I: 546).

Perspektywa niedostatku znalazła również odzwierciedlenie w zwrocie na czarna godzine zbierać (chowaj grosine na czarna (na ciemna) godzinę. Ad; NKPP I: 694).

Ważne też było przewidywanie dalszej przyszłości - osiągnięcia wieku, w którym zdolności pomnażania dóbr bywają ograniczone: Kto za młodu oszczędza, ten na starość nie wie, co to nędza (Co za młodu uszporujesz, to na starość jakbyś naszet. Trzaskalik; NKPP II: 753).

Ta właśnie perspektywa - przewidywania możliwości dłuższych lub krótszych okresów niedostatku - powodowała, że podstawową akceptowaną społecznie zasadą prowadzenia gospodarstwa domowego była oszczędność. Taki sąd został mocno utrwalony w znanym powszechnie przysłowiu: Oszczędnościa i praca ludzie się bogaca (NKPP II: 1052), i mniej znanych: „Miej” nie przyjdzie tam, gdzie „oszczędzaj” nie byt (NKPP II: 753); Oszczędzaj-dlużej będzie (Gdy dziś potrzebę będziesz miat, patrz, by się na jutro oszczymiat. Biernat, 82; NKPP II: 753); Oszczędność wielki dochód (Oszczędność - najpewniejszy majątek. Goldstein, Przycz. II, 12; Kto dzieci uczy oszczędności, zostawia im więcej niż majątek. Pauli, Rkp. IV; NKPP II: 752).

Ludowa mądrość podpowiada, że najlepszą metodą oszczędzania jest odkładanie po trochu, małych kwot, drobnych rzeczy, które po pewnym czasie przyniosą dochód czy sporą korzyść, a w efekcie - bezpieczeństwo materialne. Najbardziej znanym przysłowiem wyrażającym tę myśl jest: Ziarnko do ziarnka, zrobi sie miarka (warianty: Ziarnko do ziarnka, bydzie miarka Prymus; Od ziorka do ziorka uzbiera się miorka Broda, Prz. Wlkp.; Zdebło do zdebła, a będze stóg, zôrko do zôrka, a będze brôg Roppel; NKPP III: 864). Podobne obrazowanie niosą przysłowia z innymi komponentami: Szczypta do szczypty (NKPP III: 390); Kropla do kropli, a będzie morze (Krupiejka ku krupierce, aż będzie sudek. Cinciała, Prz. ciesz., 21; I kropla coś do morza dorzuca. Sychta, SGK, II, 259; NKPP II: 207). To samo przekonanie niesie przysłowie w postaci rady: Odtóż po troszku $\boldsymbol{w}$ każda niedzielę, malo do mata to będzie wiele (NKPP II: 682). Taki sposób oszczędzania był wskazany zwłaszcza w odniesieniu do pieniędzy, co zostało utrwalone w zwrocie: grosz do grosza sktadać (ciutać) (ściskać grosz ku groszowi. Mączyński; składat grosik do grosika. Wiktor, WnS, I, 8; NKPP I: 739). Możliwość odłożenia większej kwoty, zrobienia zapasów bądź dokonania zakupów dzięki systematycznemu oszczędzaniu drobnych kwot ilustrują przysłowia: Grosz do grosza, kupi sie 
kokosza (Grosz do grosza, a bedzie kokosza. Broda, Prz. ciesz.; Grosz do grosza ściułany przysparza chleba, sukmany. Pauli, Rkp. III, IV; NKPP I: 739); Grosz dołóż, będzie butka (Przyłożywszy do ździeba szelag, będziesz miat kukietkę. Rys. cnt. 13; Przyłożywszy szelag, będzie żemta ${ }^{9}$. Kn., 875, 974; Przyłóż babkę ku babce, buda kapce. Schneider, II, 180; Przytóż do tego grosz, a będziesz miat butkę. Pauli, Rkp. IV; NKPP I: 740); Grosz do grosza, będzie pót trzosa (kwota i in.) (I po szelagu wiele się nabierze. Bratkowski; Tak po trosze, po trosze zbiera się grosze. Cejnowa, SKS, 11; Grosik do grosika tworzy dukacika Zieliński, Wista, XII, 314; Do grosika grosik, a zbierze się trzosik. Perzyński, PCz, 138; Pomału, po trosze do grosika grosze. Broda, Prz. ciesz.; Grejcar ku grejcaru, aż bedzie czeski; czeski ku czeskiemu, aż bedzie reński. Cinciała, Prz. ciesz., 16; NKPP I: 739); Gdzie grosz leży, drugi bieży (NKPP I: 736)

Oszczędność pieniędzy wiąże się z szacunkiem dla każdej, nawet najmniejszej kwoty, co zostało utrwalone w cytowanym wyżej przysłowiu: Kto się z groszem nie liczy, tego bieda wyćwiczy (NKPP I: 742) oraz w paremiach z komponentami oznaczającymi pieniądze o niskich nominałach (przede wszystkim grosz, ale też: grajcar, cent) przeciwstawianych tym, które mają (miały) większą wartość (szelag, talar, dolar, złoty): Kto nie szanuje grosza, ten szelaga niewart (Chto nie szanéje grosza, ten nie je talara wárt. Cejnowa, SKS, 3; Kto nie szanuje grajcara, ten niegodzien talara. Brz.; Chto nie szanuje centa ten dolara niewôrt. Derdowski; kto grosza nie szanuje, gorsza niewart. Osipowicz, Wista, XII; Chto grosza nie utci, nie je złotego wôrt. Sychta, SGK, I, 368; Kto grosza nie oszczędza, do złotego nie przyjdzie. Gamius, 128; Kto nie dba o grosze, niegodzien talara. Lompa, PLŚ, 18; NKPP I: 742); Po groszu zbierając, zbierzesz, po szelagu ciskając, rozciskasz (NKPP I: 744).

Inne przysłowia zawierają wskazówki dotyczące racjonalnego gospodarowania pieniędzmi - kierowania się zasadą minimalizmu życiowego: Kto kupuje, czego mu nie trzeba, nie ma potem za co kupić chleba (Kupuj zbytkowe rzeczy, a będziesz przedawat potrzebne; NKPP II: 249); Nim grosz wydasz, obejrzyj go trzy razy i schowaj (NKPP I: 743).

Przekonanie o konieczności oszczędnego trybu życia dotyczy nie tylko spraw finansowych, ale też innych spraw bytowych: jedzenia ${ }^{10}$, ubrania, wyposażenia domu. Pochodną przekonania o oszczędnym trybie życia jest wyraźna granica między dniem powszednim a świątecznym, co w szczególności dotyczy odzieży - stąd wskazówka, by część ubrań zakładać tylko okazyjnie i tym samym utrzymać je jak

9 Żemła, zemła - stp. 'bułka pszenna' (NKPP IV: 265).

10 W związku z tym, że w tomie Stowiańska frazeologia gwarowa (Rak, Sikora 2016) opublikowany został artykuł Językowy obraz pożywienia ludności wiejskiej w sytuacji niedostatku (Młynarczyk 2016), nie będę w tym miejscu omawiać składników JOS związanych z oszczędnościowymi zasadami żywieniowymi. 
najdłużej w dobrym stanie. Językowym świadectwem takich zasad są wyrażenia: od wielkiego święta (w wariantach: kapota / ubranie / suknia od wielkiego święta (NKPP III: 485); świętny (np. suknia), świętalny (np. żupan) (SKarł V: 368); na odświęt 'od święta np. obleczenie' (SKarł III: 409).

Podobną konotację ma przymiotnik kościelny 'odświętny, świąteczny': 'bielizna kościelna, w którą się ubiera do kościoła' (SGP II: 447). Przeciwieństwem odświętnych strojów były te, których używano na co dzień: Na powsednie nosza zapaski (SGP IV: 315): na kozdo ${ }^{11}$.

Inną zasadą, którą należało się kierować w używaniu ubiorów, było rozsądne pozbywanie się rzeczy starych: Dla nowej kapoty starej nie porz (NKPP II: 23); Nie zbywaj starej sukni, póki nowej nie sprawisz (Nie zbywaj starej koszuli, póki nowej nie sprawisz. Pauli, Rkp. III; NKPP III: 350); Starych trzewików nie wyrzucaj, póki nie masz nowych (Pospolicie mówią: nie zarzucaj starych trzewików, póki się na nowe nie zdobędziesz. Dambrowski, Kaz., cz. 2; Nie zachybuj starych butów, pokiel ni mosz nowych. Prymus; NKPP III: 541). Szczególną troską obejmowano buty jako najdroższy (w dawnych realiach) składnik ubioru. Obrazowość niektórych frazemów ilustruje fakt, iż oszczędzając obuwie, chodzono nawet boso, co mogło być jednak odbierane jako przesadna oszczędność, skąpstwo: Chodzi w samorodnych trzewikach (NKPP III: 541) 'boso'; Szkodniej trzewika niż nogi, mówi skapy i ubogi (NKPP III: 541); Nogi drze, a buty na kiju nosi (warianty: Nóg nie kupić, a za buty trzeba szewcowi płacić. Linde, I, 150; Nogi drze, a skórznie na paleci nosi. Cejnowa, SKS, 17; NKPP II: 634), 'nierozsądnie oszczędny'. Jedno z przysłów Kto na cudze buty czeka, musi dtugo boso chodzić (Gdo na cyzi strzewiki czáka, ten musi dlugo boso chodzić. Cinciała, Prz. ciesz., 15; Zanim cudze buty odziedziczysz, będziesz dlugo boso chodzit. Ad. 19; NKPP I: 218) przypomina o innym przejawie zaradności - młodszy członek rodziny czekał, aż jego starsze rodzeństwo „wyrośnie” z butów (lub z innych części garderoby). Opisowi takich sytuacji służyły zwroty, takie jak m.in. donosić \{po kimś\} buty / kurtkę / koszulę lub mieć \{po kimś\} buty / koszulę itp. Częste, znane ze wspomnień osób starszych, były również sytuacje, gdy rodzeństwo musiało dzielić się jedną parą butów, szczególnie zimą oraz w sytuacjach oficjalnych, np. przy chodzeniu do kościoła lub do szkoły.

Troska o obuwie jako drogi element ubioru, łatwo ulegający zniszczeniu, przewija się też w zwrocie Buty zedrzeć za czym (Buty drzeć na próżno. Sł. wil.; Za tem jenteresem buty zder. Milewska, Wista, XV, 208; NKPP I: 217), ilustrującym, iż załatwienie jakichś spraw (konieczność odwiedzenia urzędów i instytucji) oceniano przez pryzmat poniesionych kosztów, a te związane ze zniszczeniem butów były szczególnie dotkliwe.

11 Wyrażenie zasłyszane w okolicy Żywca. 
Językowym świadectwem oszczędnego trybu życia są również leksemy i frazemy nazywające konkretne czynności służące naprawie ubrań, butów czy garnków, pozwalające zachować je dłużej w stanie używalności, jak: zelować (buty) 'podbijać buty kawałkiem skóry, gumy, dawać nową zelówkę' (SJPD), przyszywać przyszczypki 'łaty do butów' (SJPD), cerować 'naprawiać dziury, rozdarcie w tkaninie lub skórze, gęstymi, przeplatanymi ściegami z przędzy lub nici' (SJPD), nicować 'przerabiać, odnawiać jakąś część garderoby, przewracając tkaninę na lewą stronę, na nice' (Kto da stara suknię nicować, musi na nowa grosz gotować NKPP III: 348), drutować (garnki) 'reperować garnki drutem' czy łatać 'przyszywać, wstawiać łaty, za pomocą łat naprawiać dziury; reparować' (SJPD).

Najbogatsze poświadczenie we frazematyce ma obrazowanie związane z łataniem odzieży - czasownik łatać zyskał w polszczyźnie ogólnej przenośne znaczenie 'pokrywać straty, poradzić sobie z trudnościami finansowymi', np.: dziury tatać (zatykać) (NKPP I: 547) 'zaspokoić najpilniejsze potrzeby'. Obrazowość związana z łataniem odzieży metaforycznie dotyczy różnych postaw ludzkich bądź zaleceń, szczególnie przezorności: zaszyj dziurkę, póki mała (NKPP I: 548), racjonalnego (bądź nieracjonalnego) gospodarowania Dziury dziura nie przykryje / nie zalata (NKPP I: 547), pokonywania niedostatków: Jak tako, polatawszy (NKPP II: 337) 'dokonać powierzchownych zmian'.

Pozytywnie wartościowano postępowanie osób, które naprawiały odzież, świadczyło to bowiem o ich oszczędnym sposobie życia, pozwalającym utrzymać status materialny na odpowiednim poziomie: Kto się tata $\boldsymbol{i}$ oszczędza, nie zajrzy $\boldsymbol{m u} \boldsymbol{w}$ oczy nędza (NKPP II: 753). Niektóre paremie odzwierciedlają sąd, że rzeczy reperowane są bardzo trwałe, a raczej są długo używane w gospodarstwie domowym: Dlużej tatanego niż nowego (NKPP II: 338); Latana suknia najtrwalsza (NKPP III: 349); Garnka nadtluczonego najdlużej (Garnek drutowany trwa najdlużej. Pauli, Rkp. IV; Garnek odrutować, musi gotować. Kunysz; Czasem skorupa garnczek przetrzyma. Ad.; NKPP I: 602). Pragmatycznie są to zapewne pocieszania kogoś (lub samego siebie), kto jest skazany na używanie naprawianych rzeczy. Podobnie można odczytać popularne do dzisiaj przysłowie będące rodzajem zwrotu motywującego do oszczędzania jedzenia, niewyrzucania resztek: Kto zjada ostatki, ten jest piękny i gladki (Gdo jodo ostatki, bywa szumny i gadki. Prymus; Gdo zgodo ostatki, bywa szwarny i gładki. Ondrusz, Prz. ciesz., 45; Kto jada przywary, to lubi swary, a kto ostatki, ten piękny i gładki. Kolberg, VIII, 257; NKPP II: 748). 


\section{Podsumowanie}

Analiza przykładowego materiału frazematycznego dała podstawę do rekonstrukcji niektórych utrwalonych w spetryfikowanych połączeniach słownych sądów na temat zasad prowadzenia gospodarstwa domowego. Jak wiadomo, na utrwalony w polskich paremiach obraz świata zasadniczy wpływ miała ludowa proweniencja większości z nich. Perspektywa chłopa borykającego się z trudnościami materialnymi mocno zaważyła na obrazowości i znaczeniach wielu frazemów, zwłaszcza tych dotyczących materialnych podstaw bytu. W sądach i przekonaniach na temat prowadzenia gospodarstwa domowego widoczne są filozofia minimalizmu życiowego i strategia przetrwania w trudnych warunkach wobec perspektywy (możliwości) pogorszenia się warunków życiowych, biedy, stąd podstawowe zasady: oszczędzania, zwłaszcza przez drobne odkładanie, racjonalnego wydawania pieniędzy, rozważnego używania odzieży, w tym szczególnie butów, a także korzystania z możliwości naprawy ubrań i sprzętu domowego (garnków).

Przedstawione frazemy oraz eksplikowane na ich podstawie sądy sygnalizują kierunki poszukiwań frazemów obrazujących sądy na temat prowadzenia gospodarstwa domowego. Wydaje się, że temat ten - sygnalizowany w niniejszym tekście - jest wart rozwinięcia i opracowania na podstawie bogatszego materiału.

\section{SUMMARY \\ Phrasemes Illustrating the Way of Running a Household (EXPLORATION)}

This paper presents the analysis of a sample phrasematic material, which provides a basis for the reconstruction of the linguistic image of running a household. Word combinations included in the investigation reflect a philosophy of life minimalism and foresight in case of a deterioration in living conditions or poverty. From this perspective, some basic rules connected with keeping house have emerged: savings, especially through putting aside small amounts, spending money reasonably, sensible use of clothes, particularly shoes, as well as making use of the option of having clothes and household appliances mended. 
https://doi.org/10.12797/9788381382458.15

\section{Lidia Przymuszala (1)}

Uniwersytet Opolski, Opole

lprzymuszala@uni.opole.pl

\section{GWAROWE FRAZEOLOGIZMY OKREŚLAJĄCE WIEK CZLOWIEKA (NA PRZYKŁADZIE MATERIALU ŚLĄSKIEGO)}

Słowa klucze: Śląsk, frazeologia gwarowa, pole tematyczne, wiek człowieka Keywords: Silesia, dialectal phraseology, thematic fields, age of Man

W strukturze semantycznej języka określenia wieku i etapów życia człowieka zajmują istotne miejsce. Pokazują to słowniki tematyczne poszczególnych odmian polszczyzny, a także tematyczne słowniki frazeologiczne. Przykładowo w Słowniku polszczyzny potocznej Janusza Anusiewicza i Jacka Skawińskiego w dwóch mikropolach Nazwy, określenia człowieka (makropole CZŁOWIEK) oraz Czas (makropole CZAS, PRZESTRZEŃ, MIARA) łącznie odnotowano 103 jednostki (leksemy i związki frazeologiczne), będące określeniami wieku człowieka i różnych etapów jego życia (Anusiewicz, Skawiński 1996: 17-27, 300-302). Słownik eufemizmów polskich Anny Dąbrowskiej (2005) określeń takich rejestruje 31'; Szkolny stownik tematyczny języka polskiego nie tylko dla uczniów Małgorzaty Iwanowicz i Edwarda Polańskiego (2011) około 100²; Słowniki frazeologiczny w układzie tematycznym $i$ alfabetycznym pod red. Alicji Nowakowskiej (2003) gromadzi 19 frazeologizmów ${ }^{3}$; kilkanaście odnotowanych zostało także w słowniku frazeologicznym Katarzyny Mosiołek-Kłosińskiej i Anny Ciesielskiej (2001)

Zwykle określenia te gromadzone są w mikropolu WIEK, będącym składową nadrzędnego pola CZŁOWIEK ${ }^{5}$.

1 Określenia odnotowane w makropolu CECHY FIZYCZNE CZŁOWIEKA, mikropole Określenia wieku, s. 31-34.

2 W słowniku tym subpole Etapy życia człowieka, znajdujące się w polu CZŁOWIEK, podzielono na grupy tematyczne: wiek, dzieciństwo, dorastanie, młodość, dojrzałość, starość, życie i śmierć, pokolenie (s. 98-109).

3 Makropole CZYNNOŚCI I STANY FIZYCZNE, mikropola Wiek (s. 69-70) oraz Śmierć (s. 71-73).

4 Makropole CZŁOWIEK, mikropole Życie i śmierć, s. 391.

5 Na temat struktury tematycznych słowników frazeologicznych języka polskiego i koncepcji opisu zgromadzonych w nich związków frazeologicznych (na przykładzie pola seman- 
Kwestii wieku człowieka poświęcono także nieco uwagi w artykułach naukowych. Zwłaszcza starość człowieka, a w szczególności bliska starości tematyka śmierci, była w centrum zainteresowań nie tylko polskich, ale również ukraińskich i rosyjskich językoznawców (np. Tambor 1988; Niewiara 1995; Wolny 2003; Przymuszała 2007; Блинова 2009; Поліщак 2010; Калько 2012; Nikołajczuk 2014). Artykuły podejmujące tę problematykę dotyczyły głównie językowego obrazu starości bądź śmierci i - w całości lub częściowo - poświęcone były analizie związków frazeologicznych odnoszących się do określonego etapu ludzkiego życia. Natomiast nigdy jeszcze przedmiotem naukowego oglądu nie uczyniono gwarowych związków frazeologicznych będących określeniami wieku.

Celem niniejszej pracy jest zatem semantyczno-formalna analiza wybranej grupy związków frazeologicznych odnotowanych w gwarach śląskich tworzących pole tematyczne o ogólnym znaczeniu WIEK I ETAPY ŻYCIA CZŁOWIEKA.

Materiał, liczący blisko 150 związków frazeologicznych, zebrany został na podstawie Stownika frazeologizmów i typowych połaczeń wyrazowych w gwarach śląskich mojego autorstwa (SFŚl), po części wyekscerpowany także z opublikowanych do tej pory tomów Stownika gwar śląskich pod red. Bogusława Wyderki (Wyderka 2000-2017) oraz kartoteki tegoż słownika.

Zgromadzone frazeologizmy powiązane wspólnym znaczeniem określającym trwanie życia ludzkiego od dzieciństwa, poprzez młodość, dojrzałość, aż po starość i śmierć podzielić można na pięć podpól: Dzieciństwo, Wczesna młodość, Dojrzatość, Starzenie się / Starość, Umieranie ${ }^{6}$.

W pierwszym z omawianych podpól właściwie poza wyrażeniami sytuującymi w czasie, jak: od malutkości, od chłopca, od matego, od małości, od mału, jako dziecko, za bajtla, za bajtlów, za dzieci, za dziecia, za dziecka, za chłopca, za syn$k a, z a$ szkalców, zaskakujący jest brak frazeologizmów nazywających małe dzieci i określających wczesny etap życia. To pole wypełniają przede wszystkim niezwykle liczne gwarowe leksemy z głównym semem 'małe dziecko', co pokazuje cykl artykułów Marzeny Muszyńskiej (2010, 2011a, 2011b, 2012) objęty wspólnym tytułem Określenia nazywające dzieci w gwarach Ślaska, w którym badaczka omówiła około 450 leksemów.

Zdecydowanie liczniejszą grupę stanowią związki odnoszące się do kolejnego etapu życia człowieka, jakim jest wczesna młodość, np.: w młodości, w młodych latach, z młodu, za młodu, za młodych lat, za dziewuchy, za frelki ${ }^{7}$, za młodego

tycznego Wiek człowieka i etapy jego życia) pisała Gabriela Dziamska-Lenart w artykule pt. Frazeologizmy określajace wiek człowieka w tematycznych słownikach frazeologicznych języka polskiego (2008: 121-128).

6 Zob. podział pola Bieg życia w koncepcji podziału tematycznego słownictwa współczesnej polszczyzny Barbary Batko-Tokarz (2019: 182-183).

7 Wyrażenie to oprócz znaczenia 'w młodości, będąc dziewczyną' znaczy również 'w latach panieńskich'. 
chłopca, za czyichś czasów, za czyichś młodych roków, za mnie. Należące do tego pola wyrażenia i zwroty o charakterze metaforycznym i metonimicznym wskazują zwykle na typowe cechy związane z wiekiem, jak niedojrzałość, niesamodzielność, naiwność, brak doświadczenia, brak możliwości samodzielnego podejmowania decyzji czy zależność od rodziców (zwłaszcza od matki): być przy maminym cycku, dzierżyć się maminego fartucha, dzierżeć się maminej sukni, dzierżyć się cycka , rozkaźnikowe ciag za matka dupki skrobać w znaczeniu 'odczep się, wynoś się, zmykaj; uciekaj, idź precz’ kierowane tylko do kogoś bardzo młodego, niedorosłego.

Obserwacje dotyczące fizyczności zawierają frazeologizmy: ogolić sie jelitem 'o kimś młodym, nie mającym jeszcze zarostu' oraz jeszcze komuś świeczka wisigwarowe świeczka to 'wydzielina z nosa, smarki', frazeologizm nawiązuje zatem do obrazu zasmarkanego dziecka, które wymaga jeszcze matczynej opieki. Związki żółto robić do pieluch, mieć jeszcze na dupie kolce od nocznioka, mleko mieć na brodzie, a kolce na dupie nawiązują do podlegającej tabu czynności wydalania i w sposób szczególnie dobitny podkreślają niedorosłość i brak samodzielności. Kolce na dupie, o których mowa w dwóch ostatnich frazeologizmach, to ślady kół (gwarowe kolca 'koła, kółka') od nocnika odciśnięte na pośladkach dziecka. W obu tych przypadkach zarówno mleko, jak i nocnik konotujące treści 'młody, niedorosły, niedojrzały, niedoświadczony' budują metaforyczny sens tychże związków.

Młody wiek człowieka opisują także frazeologizmy z komponentami odnoszącymi się do świata przyrody, jak np. obrazowe określenie kogoś bardzo młodego mieć jeszcze żółto $w$ dzióbie, nawiązujące do piskląt o żółtych dziobach; być zielony 'o człowieku: niedoświadczony, niedojrzały życiowo; głupi' (kolor zielony kojarzony jest zwykle z budzącą się do życia przyrodą, świeżością, młodością, brakiem dojrzałości), mieć (jeszcze) cielęcy rozum 'być niedojrzałym, naiwnym, niemądrym’, gdzie cielęciu stereotypowo przypisywane są naiwność, głupota, niesamodzielność (por. Rak 2007: 87).

Na bardzo młody wiek człowieka i związane z tym niedojrzałość oraz brak doświadczenia wskazują także frazeologizmy, które zawierają, niosący określone konotacje, komponent mleko: mieć mleko na brodzie, mieć mleko pod nosem, jeszcze mieć mleko w kątkach, tj. w kącikach ust; komuś jeszcze mleko ciecze po brodzie, jeszcze komuś z brody mleko kapie oraz lekceważąca forma kierowana do dorastającego chłopca utrzyj sobie mleko pod nosem, utrzyj sobie mleko z brody.

Osiąganie przez człowieka dojrzałości, przejście z etapu dzieciństwa do dorosłego życia pokazane jest we frazeologii jako proces, droga. Do dorosłości się dochodzi, dorosłość - jak cel - się osiąga: dojść do lat, przyjść do lat 'osiągnąć odpowiedni wiek; stać się pełnoletnim’. Wraz z pełnoletnością i osiągnięciem

Także ‘być nadmiernie uzależnionym od matki, zachowywać się jak dziecko’. 
dojrzałości (gwarowe $z$ rokami 'w miarę dorastania') człowiek staje się mądrzejszy, nabiera rozumu, co pokazują frazeologizmy: mieć za soba cielęce roki, mieć za soba głupie roki o znaczeniu 'dojrzeć', ale także 'zmądrzeć'.

Do omawianej grupy związków zaliczyć także można frazeologizmy, które nie wprost odsyłają do wieku człowieka - nie zawierają bowiem komponentów bezpośrednio odnoszących się do dojrzewania i dorosłości, a jednak uznać je można za pośrednio związane z tym właśnie etapem ludzkiego życia. Są to frazeologizmy z komponentem chleb: być na swoim chlebie, iść na swój chleb, żyć na swoim chlebiczku, zarobić na chleb. Pokazują one, że zdolność samodzielnego pozyskania chleba pozwala rozpocząć życie na własny rachunek, będąc tym samym wyznacznikiem dorosłości i niezależności od innych (przeważnie rodziców). A zatem związki te obok podstawowego znaczenia 'usamodzielnić się' wtórnie znaczą także ‘być / stać się dorosłym’ (Przymuszała 2017: 258).

Na pograniczu subpól Wczesna młodość i Dojrzatość lokują się związki odnoszące się do dorastającej dziewczyny, podlotka: dziewucha // dziewka do wydaju, dziewucha // panna na wydaniu, dziewka na wydanie, panna na wydaj, być na wydaniu. Osiągnięcie przez młodą kobietę wieku odpowiedniego do zamążpójścia było wyznacznikiem dojrzałości i dorosłości.

Na tle omówionych grup tematycznych uderza znaczna dysproporcja ilościowa związków frazeologicznych należących do kolejnego subpola, jakim jest Dojrzatość $c^{9}$. W zgromadzonym materiale odnotowałam zaledwie dwa związki frazeologiczne odnoszące się do dojrzałości człowieka: mieć (swoje) roki oraz mieć swój wiek 'być dojrzałym, pełnoletnim', także 'być w odpowiednim wieku do czegoś', np. (jak najczęściej pokazują konteksty) do zamążpójścia czy ożenku.

Kolejną grupę związków określających wiek człowieka stanowią frazeologizmy z pola Starzenie się / Starość. Są to odnoszące się do mężczyzn nazwy: stary dryś, stary grzyb, stary piernik, stary dziad, stary chłop, nazwanie starej kobiety stara skrobaka, a także: stary, ale jary, na starość, na stare lata, na stare roki, za starki, być przy latach, być w latach, mieć lato, mieć swoje lata, mieć lata (na karku), być starego bitu, tj. 'być starym' (znaczące także 'być starej daty, obyczajów', 'mieć niewspółczesne, niedzisiejsze poglądy'). Pokaźną grupę stanowią również określenia niemłodych osób, które nie wstąpiły w związek małżeński. Szczególnie licznie, co może dziwić, są tu reprezentowane określenia nieżonatych mężczyzn. Świadczy to o tym, że w tradycyjnym społeczeństwie wiejskim starokawalerstwo postrzegano bardziej negatywnie niż bycie starą panną: stara dziewa, stara dziewka, stara ciota, stara ciotka, stara panna - 'niemłoda kobieta, która nie wyszła za mąż'; stary buks, stary grześ, stary grzebieniarz, stary karlus, stary kater, stary kawaler, stary koń, stary pryk - 'niemłody mężczyzna, który się nie ożenił'. Do

9 Podobne spostrzeżenie poczyniła G. Dziamska-Lenart w odniesieniu do frazeologizmów polszczyzny ogólnej tworzących pola Starość i Młodość oraz Wiek średni (Dziamska-Lenart 2008: 126). 
starokawalerstwa odnoszą się także zwroty być bez cuchu, nie mieć cuchu ${ }^{10}$, czyli 'być starym kawalerem'.

Oprócz frazeologizmów o ogólnym znaczeniu 'stary' do grupy tej należą także związki wskazujące na stopień starości, z semem temporalnym 'bardzo stary': stary kozub ${ }^{11}$, stary jak grzech śmiertelny, stary jak świat, pamiętać Adama i Ewę.

Semantycznie bliskie tej grupie związków są także inne frazeologizmy, a mianowicie: być jedna noga w grobie, być na ostatnich butach, być na skonaniu, być na śmiertelnej pościeli, być na umarciu // na umrzyciu, cisnać do kierchowa, dtugo nie pociagnać, gotować się na śmierć, pracować ku śmierci, patrzeć do grobu, patrzeć śmiertce w oczy, śmiertka komuś zagląda w oczy, zaglądać na Abrahama, zaglądać na drugi świat, wisieć nad grobem, ostatkami gonić, pójść na Fryszowe płonki, śmierdzieć kierchowem, ujrzeć śmierć przed oczami, kostucha wywija nad kimś kosa, nie mieć wiele do góry, śmierć jest u dupy, śmierć kogoś powoniata, śmierć komuś z oczu wygląda, śmierć chodzi komuś do dupy na wiesiady ${ }^{12}$, śmiertka już na kogoś czeka, oczy się komuś we stup obracaja, świecić komuś gromniczke.

W ich strukturze znaczeniowej oprócz semu temporalnego 'stary / bardzo stary' obecny jest dodatkowy sem 'bliski śmierci', decydujący o usytuowaniu tychże jednostek w odrębnym jednak mikropolu Umieranie. We frazeologizmie pójść na Fryszowe płonki $i^{13}$ obok komponentów znaczeniowych 'stary', 'bliski śmierci' pojawia się ponadto sem ukonkretniający przyczynę śmierci, a mianowicie 'z powodu choroby'.

Omawiana grupa frazeologizmów o znaczeniu 'być bliskim śmierci' w wielu słownikach stosujących tematyczną klasyfikację materiału umieszczana jest nie w polu dotyczącym wieku i etapów życia człowieka, lecz w innych subpolach, np. w subpolu Śmierć (np. w słowniku eufemizmów A. Dąbrowskiej) lub Stany fizyczne (tak w Słowniku polszczyzny potocznej). Ponieważ do wydzielonego przeze mnie pola tematycznego nie zaliczam frazeologizmów o znaczeniu 'umrzeć' (jak np.: dostać deska w dupe, nabrać ślubu ze śmiertka, pojechać na drugi świat, pójść pod sosienki) ${ }^{14}$, w zaproponowanym przeze mnie podziale brak mikropola

10 Cuch w gwarach śląskich to: 1. 'przykry, odrażający zapach; odór'; 2. 'zmysł powonienia, węch'.

11 W gwarach śląskich wyraz kozub znaczy m.in.: 1. pogardliwie 'stara krowa lub koza'; 2. pejoratywnie 'człowiek przykry, nieznośny, uparty'; 3. pejoratywnie 'uparte zwierzę'.

12 Wiesiady 'pogawędka, plotki'.

13 Obrazowy frazeologizm pójść na Fryszowe płonki ('o kimś starym, schorowanym, bliskim śmierci') o peryfrastyczno-eufemistycznym charakterze zasadza się na relacji styczności i przeniesienia: sad Frysza sąsiadował bowiem z cmentarzem. Gwarowe płonka to 'dzika jabłoń', także 'owoc tego drzewa'.

14 Na temat gwarowych frazeologizmów o znaczeniu 'umrzeć' pisałam w artykule Narodziny i śmierć we frazeologii gwarowej (na przykładzie materiału ślaskiego). Zob. (Przymuszała 2007: 105-110). 
Śmierć. Za ostatni etap ludzkiego życia uznaję umieranie - rozumiane jako proces, jako etap pomiędzy życiem a śmiercią, zaś śmierć pojmuję jako ostateczny koniec życia, jako stan po życiu i po umieraniu.

Wśród zgromadzonych związków wyrazowych są też takie, których nie można zaklasyfikować do żadnego z wydzielonych podpól. Są to frazeologizmy o znaczeniu ogólnym, które mogą być używane dla określania osób w różnym wieku (Dziamska-Lenart 2008: 125), lub też frazeologizmy określające wiek człowieka w odniesieniu do innych osób: komuś leci któryś (np. siódmy, ósmy) krzyżyk, mieć ileś (np. siedem, osiem) krzyżyków; byto // jest komuś ileś lat // roków, komuś idzie któryś rok; będące kalką z języka niemieckiego (Jahre alt sein) konstrukcje być ileś lat stary, być w którymś (np. dziesiatym) roku stary, być ileś (np.: osiemdziesiąt) lat // roków, o znaczeniu 'mieć ileś lat'; jednacy starzy, być jednako stary, być jednako na starość, być tak // takim starym jak ktoś, mieć te same lata, czyli 'mieć tyle samo lat, być w tym samym wieku, być czyimś rówieśnikiem'.

Pod względem struktury formalnej związki wyrazowe należące do pola tematycznego WIEK I ETAPY ŻYCIA CZŁOWIEKA to wyrażenia sytuujące w czasie oraz określające człowieka w konkretnym etapie jego życia. Dominują tu jednostki z komponentem temporalnym stary, wskazującym na okres, którego dotyczą, wprost odsyłające do starości: stary koń, stary dziad, stary grzyb, stara panna. Liczną grupę stanowią także obrazowe, metaforyczne zwroty, zawierające w swej strukturze elementy stereotypowo kojarzone z określonymi etapami życia człowieka (pieluchy, nocnik - gwarowe noczniok, mleko, chleb, grób itp.), jak np.: żólto robić do pieluch, mieć jeszcze na dupie kolce od nocznioka, mieć mleko na brodzie, iść na swój chleb, wisieć nad grobem oraz zwroty zbudowane z komponentu werbalnego być lub mieć i komponentu nominalnego wiek, lata, roki (być przy latach, mieć lata na karku, mieć swoje roki, mieć swój wiek) (Dziamska-Lenart 2008: 126).

Analizowane frazeologizmy to jednostki o jednoznacznym wartościowaniu i wyraźnym nacechowaniu ekspresywnym. Właściwie we wszystkich subpolach przeważają związki mające charakter pejoratywny. W mikropolu Wczesna młodość frazeologizmy deprecjonują wartość tego okresu życia człowieka, podkreślając jego niezaradność oraz brak samodzielności i dojrzałości psychicznej. Natomiast frazeologizmy będące określeniami osób starszych mają charakter pogardliwy, lekceważący, ośmieszający. Eksponują one niedołężność, nieporadność starego człowieka, a także inne niepożądane cechy (jak np. zrzędliwość - stary piernik 'stary, zrzędliwy człowiek'), często wynikające z wieku, lub cechy niestosowne, niewłaściwe do wieku (jak np. niedojrzałe zachowanie - stary dryś 'człowiek starszy, zachowujący się w sposób nieodpowiedni do swego wieku’).

Należy stwierdzić, że w badanym materiale właściwie brak określeń pozytywnych. Wyjątek stanowi wyrażenie stary, ale jary, odnoszące się do kogoś niemłodego, ale zdrowego, silnego i sprawnego. 
Nacechowanie neutralne mają natomiast frazeologizmy o znaczeniu ogólnym, używane do określenia osób w różnym wieku oraz frazeologizmy, będące określeniami dorosłości. Jak wynika z materiału, wiek średni nie wzbudza tak silnych emocji, jak początkowy i końcowy etap życia, co znajduje także wyraz w niewielkiej liczebności jednostek tego mikropola.

Związki należące do omawianego pola charakteryzują się dużą obrazowością. Frazeologizmy opisujące dzieciństwo i wczesną młodość to głównie związki o charakterze metaforycznym. Zawarte w nich komponenty odsyłają najczęściej do świata przyrody, do fizyczności człowieka, do przedmiotów i sytuacji znanych mu z życia codziennego. Zwykle służy to ukazaniu cech związanych z wiekiem, jak np. we frazeologizmie mieć mleko pod nosem, w którym obserwacja dotycząca fizyczności użyta została w celu ukazania niedojrzałości duchowej młodego człowieka. Natomiast zwroty, które określają umieranie, mają zwykle charakter metonimiczny i peryfrastyczny, co wiąże się z silną tabuizacją tego okresu życia człowieka.

Zauważyć również trzeba, że w strukturze semantycznej niektórych związków opisujących wiek człowieka, oprócz semów temporalnych typu 'stary', 'młody' pozwalających sytuować je w jednym polu tematycznym, występują także komponenty nietemporalne, które sprawiają, że związki te sytuują się na styku dwóch pól (np. w przypadku frazeologizmów dotyczących umierania i śmierci) lub umieszczane są w zupełnie różnych polach, np. być zielony 'o człowieku: niedoświadczony, niedojrzały życiowo; głupi'. Związek ten składa się z komponentów 'młody' oraz 'głupi'. Głupota stereotypowo przypisywana jest osobom niedorosłym i niedojrzałym. Obecność semu 'głupi' powoduje, że związek ten może należeć nie tylko do pola WIEK, ale także do pola CECHY PSYCHICZNE CZŁOWIEKA.

Wieloznaczność i nieostrość znaczeniowa niektórych związków sprawiają, że czasami trudno przyporządkować je do konkretnego, jednego tylko pola ${ }^{15}$. Na przykład wyrażenie stary koń (znane również polszczyźnie ogólnej) odnosi się nie tylko do dorosłego mężczyzny lub mężczyzny, który nie wstąpił w związek małżeński, ale także w sposób poufały określa dorastającego chłopca. Podobną trudność sprawia wyrażenie za chłopca // za synka, znaczące zarówno 'w okresie kawalerskim', jak i 'w czasach chłopięcych', a także 'w czasach młodzieńczych'16. $\mathrm{Na}$ znaczenie związku stary $k t a k^{17}$, oprócz semu temporalnego 'stary', składają się jeszcze inne, pozostające względem siebie w relacji równorzędności, komponenty znaczeniowe, jak 'chudy', 'ruchliwy', ‘żywotny', pozwalające na umieszczenie

15 Podobne spostrzeżenia poczyniła G. Dziamska-Lenart (2008: 126).

16 Sam wyraz synek jest polisemiczny, mający znaczenia: 1. 'mały chłopiec'; 2. 'młody chłopak; podlotek'; 3. 'adorator, kawaler'; 4. 'narzeczony'.

17 Kłąk to wyraz wieloznaczny, znaczący m.in.: 1. 'szypułka ptasiego pióra'; 2. 'kiełek ziemniaka'; 3. 'pozostałość zebranych roślin; badyl, nać'; 4. 'nowo wyrosły pęd drzewa'. 
wyrażenia w różnych polach tematycznych, np. WIEK CZŁOWIEKA, ale także WYGLĄD czy ZACHOWANIE. Inny jeszcze frazeologizm nie jest dobrze z kimś 'ktoś jest ciężko chory, bliski śmierci' może być zarówno elementem pola Umieranie, jak i Choroba.

$\mathrm{W}$ omawianym materiale obok frazeologizmów zarejestrowanych tylko w gwarze (np.: być starego bitu, stary jak grzech śmiertelny, pamiętać Adama i Ewę, pójść na Fryszowe płonki, śmierć chodzi komuś do dupy na wiesiady) znalazło się także wiele związków wspólnoodmianowych, występujących również w polszczyźnie ogólnej, jak np.: mieć mleko pod nosem, trzymać się (gwarowe dzierżyć się) maminego fartucha, mieć żólto $w$ dziobie, stary, ale jary, stary koń, stary grzyb, stara panna. Zasób gwarowych jednostek należących do omawianego pola od jednostek języka ogólnego odróżnia wyraźnie zauważalny brak gwarowych określeń poszczególnych okresów życia człowieka, jak: cielęce // szczenięce lata, wiosna życia, jesień // zmierzch życia, wiek balzakowski, matuzalemowy wiek, trzeci wiek, podeszły wiek, sędziwe lata itp., tak licznych natomiast w polszczyźnie ogólnej.

$\mathrm{Na}$ zakończenie stwierdzić należy, że frazeologizmy dotyczące wieku człowieka, choć liczne, stanowią jedynie dopełnienie niezwykle pojemnego pola tematycznego, jakim jest WIEK I ETAPY ŻYCIA CZLOWIEKA, pola tworzonego głównie przez gwarowe leksemy o wyraźnym nacechowaniu ekspresywnym. W całościowym opisie wskazanego pola są to elementy wymagające jednak dalszych, pogłębionych badań.

\section{SUMMARY \\ Dialectal Idioms Determining the Age of the Human Being (Based on the Material of the Silesian)}

The article contains a semantic and formal analysis of a selected group of phraseological compounds (collected 150 units) recorded in Silesian dialects and talking about the human age. The collected phraseologies creating a thematic field of general importance AGE AND STAGES OF HUMAN LIFE are divided and characterized within five sub-fields: Childhood, Early youth, Maturity, The process of growing old / Senility and Death. The phraseology of the discussed field is characterized by big imagination, negative evaluation, strong expressive features, multi meaning and semantic blur. 


\author{
Katarzyna KonczewsKa (1) \\ Instytut Języka Polskiego Polskiej Akademit Nauk, Kraków \\ katarzyna.konczewska@ijp.pan.pl
}

\title{
ПАШЛІ БАБЫ АТАВАЮ...
}

\section{БАБА Ў ПАРЭМІЯХ ГАРАДЗЕНСКІХ БЕЛАРУСКІХ ГАВОРАК}

Ключавыя словы: беларускія гаворкі, парэміялогія, Гарадзеншчына, гендэрная праблематыка, стэрэатыпы

Keywords: Belarusian dialects, paremiology, Grodno Region, gender issue, stereotypes

\section{Уводзіны}

Здавалася б, прадстаўленая ў артыкуле тэма - вельмі актуальная і нават модная, бо знаходзіцца ў межах надзвычай папулярнай у наш час гендэрнай праблематыкі ${ }^{1}$. Але ж, напрыклад, у заходнееўрапейскай літаратуры па гендэрнай праблеме вобраз жанчыны калі і разглядаецца, то пераважна ў літаратуры і культуры. Пэўным выняткам з'яўляюцца кампаратыўнае даследаванне Сільвіi Скузы (Skuza 2012) пра стэрэатыпны вобраз жанчыны ў італьянскай і польскай фразеалогіi ды нядаўні невялікі артыкул Іны Каліты Вобраз бабы у кампаратыуйным ракурсе чэмскай і беларускай фразеалогіi (Каліта 2018). У польскім дыялектным мовазнаўстве да гэтага пытання звярталіся нешматлікія навукоўцы: Ядзвіга Вроніч даследавала становішча жанчыны ў народнай культуры на падставе гаворак (Wronicz 2001), Юзаф Консь разгледзеў вобразы мужчыны і жанчыны ў традыцыйнай вясковай супольнасці на матэрыяле гаворак Аравы (Кą́s 2002), Рэната Кухажык прааналізавала лексікасемантычнае поле „баба” ў Слоўніку гаворак Закапанага і ваколіи Юліуша Збароўскага (Kucharzyk 2009), а Ганна Тырпа звярнула ўвагу на вобраз жанчыны ў кантэксце табу ў польскіх гаворках (Krawczyk-Tyrpa 2001). Шырока прадстаўлена дадзеная праблематыка ў сучасных даследаваннях расійскіх навукоўцаў (Бобрикова 2013; Исаченко 2017; Кабакова 2019; Приходько 2016) і часткова - украінскіх (Четирба 2013; Куцик, Колечко 2015). У бела-

1 Сярод апошніх цікавых даследаванняў гл.: Гендер 2019; Walęciuk-Dejneka 2018. 
рускай літаратуры па гэтай праблеме, нягледзячы на дэклараванне актыўнага развіцця ў беларускім мовазнаўстве этнафразеалагічнага напрамку (Садоўская 2014), нам не ўдалося знайсці публікацый на падставе дыялектнага матэрыялу², нават у багатым даробку аднаго з найлепшых знаўцаў гарадзенскай дыялектнай фразеалогіі Міколы Даніловіча.

Цікава, што ў славянскай народнай парэміялогіi канатацыі вобраза баба - выключна пеяратыўныя³. Зрэшты, расійскія даследчыкі напрамкі гавораць пра лексему „баба” як маркёр нізкага сацьыяльнага статуса жанчыны (Исаченко 2017: 23). Сведчаць пра гэта і рускія прыказкі, у якіх баба дурная: Бабьи умы разоряют дом; Волос длинный, а ум короткий; з вельмі дрэнным характарам: C бабой не сговоришь; шмат гаворыць і хлусіць: У баб только суды да ряды; Бабьего вранья и на свинье не объедешь. У польскай мове пераважаюць падобныя ацэначныя катэгорыі (параўн. Pajdzińska 1995: 13) ${ }^{4}$.

Варта ў сувязі з гэтым прывесці словы Элізы Ажэшка, якая наступным чынам каментавала негатыўны вобраз бабы ў сабраных ёю ў гарадзенскім Прынёманні прымаўках і прыказках:

Od lekarzy wiem, że znaczna ilość chłopek, któżby się spodziewał! dotknięta bywa chorobami nerwowymi, nawet histerią. Znana powszechnie i istotna, niekiedy straszna kłótliwość bab wiejskich, w części przynajmniej, według zdania lekarzy, poczytywaną być winna za jeden z objawów nieuleczonej, a przez sposób życia utrwalanej i wzmagającej się histerii. [...] Najczęściej otaczający ją choroby w niej nawet nie podejrzewają, a objawy jej przypisują, stosownie do ich natury, lenistwu, rozpuście, lub co najczęściej bywa złości (Orzeszkowa 1890: 15).

На патрэбу дадзенага артыкула мы прасачылі, як рэалізуецца канцэпт баба ў матэрыялах найбольш вядомых збіральнікаў і даследчыкаў беларускіх гаворак на тэрыторыі Гарадзеншчыны ${ }^{5}$. Перад усім нас цікавіла, ці змянялася яго семантычная напаўняльнасць на працягу часу ${ }^{6}$. Наша даследаванне 3'яўляецца ў пэўнай ступені міжмоўным ${ }^{7}$ бо фальклорны матэрыял 3 тэры-

2 Згаданая праблематыка паяўляецца пераважна ў агульных публікацыях, прысвечаных фразеалогіi, часам як асобны раздзел (гл. Дзядова 2013: 132-145).

3 Як і ўвогуле ў фальклоры (гл. Uther 2004).

4 Гендэрная праблематыка ў моўным вобразе вясковай культуры: Piechnik 2009; Ziajka 2014.

5 Паколькі дадзенае праблемнае поле пераважна заставалася па-за ўвагай даследчыкаў, засяродзім на ім большую ўвагу.

6 У сувязі з выдавецкімі абмежаваннямі ў артыкуле прадстаўлены перад усім выяўлены дыялектны матэрыял і толькі ў нязначнай ступені яго аналіз, які будзе прадметам наступных публікацый.

7 Таму цытаты падаюцца на мове арыгінала. 
торыі сціслай Гарадзеншчыны ${ }^{8}$ быў зафіксаваны ў розных графічных, а нават моўных сістэмах: Іван Насовіч і Павел Шэйн рэестравалі яго ў дарэвалюцыйным варыянце рускай мовы, Міхаіл Федароўскі - сродкамі польскай мовы, Эліза Ажэшка частку сабраных прымавак падала ва ўласным перакладзе на польскую мову, а частку - па-беларуску, але ў запісы лацінкай. Урэшце, парэміі ў нататках Таццяны Сцяшковіч і Апанаса Цыхуна маюць шматлікія запазычанні з польскай мовы на ўсіх моўных узроўнях (Konczewska 2016).

\section{Гісторыя даследаванняў. Крыніцы}

Першыя зборнікі сабраных у этнаграфічных экспедыцыях прымавак і прыказак паявіліся ўжо ў першай палове XIX ст. Марцін Цяплінскі (Marcin Ossoryja) пакінуў пасля сябе рукапіс з некалькімі дзясяткамі тысяч парэмій пад назвай Słownik przysłowiów polskich i litewskich.

Гарадзеншына, з яе этнічнай і культурнай разнастайнасцю як вынікам нязвыкла складанага працэсу асадніцтва, была вельмі прывабнай для даследчыкаў. Міхаіл Федароўскі заўважыў, што „dla badań etnologicznych trudno o wdzięczniejsze niż tutaj pole" (Federowski 1897: IX) і падкрэсліў, што гэтыя тэрыторыі ,ze wszystkich dzielnic dawnej Polski Białoruś wraz z Rusią Litewską najmniej pod względem etnologicznym zbadane zostały" (Federowski 1897: VII). Належыць, аднак, звярнуць увагу на тое, што хаця актыўнае збіранне фальклорнага матэрыялу9 ${ }^{9}$ на землях сучаснай Беларусі распачалося ў апошнім дваццацігоддзі XIX ст. ${ }^{10}$, яно вялося пераважна па-за межамі гарадзенскага павету. Антоні Глінскі (Gliński 1853) натаваў казкі і паданні (разам больш за 47 запісаў) пад Навагрудкам, у ваколіцах Шчорсаў ${ }^{11}$. Ян Карловіч (Karłowicz 1887) даследаваў пераважна Віленскую і Мінскую губерніi, ваколіцы Вільна, Ліды, Свянцян і Навагрудка (54 запісы). Уладзіслаў Вярыга (Weryho 1889) занатаваў паданні на Лідчыне (30 запісаў) $)^{12}$. На сціслай Гарадзеншчыне ма-

8 Маецца на ўвазе абшар даўняга гарадзенскага павета, які існаваў у 1413-1939 гг.

9 Адным 3 першых збіральнікаў быў Саламон Рысіньскі, які на мяжы XVI і XVII ст. сабраў каля 1800 прыказак, у тым ліку ў ваколіцах Любчы (у тыя часы - Любеч) каля Наваградка (Rysiński 1618).

10 Аляксандр Ельскі падрыхтаваў бібліяграфію прац таго перыяду. Яна была апублікавана ў часопісе „Chwila” за 1886 г., з 17 па 23 нумары.

11 Шчорсы ў тыя часы былі рэгіянальным цэнтрам навуковага і грамадска-культурнага жыцця. Тут у палацы Іахіма Храптовіча мясцілася адна з буйнейшых тагачасных бібліятэк ВКЛ, у якой працавалі, між іншым, Адам Міцкевіч, Уладзіслаў Сыракомля, Ян Чачот, Іаахім Лялевель.

12 У тыя часы беларускі фальклор таксама збіралі: Аляксандр Рыпіньскі, Фелікс Зянковіч, Адам Кіркор, Яўстахі Тышкевіч, Уладзіслаў Дыбоўскі, Пётр Якса Быкоўскі. 
тэрыял збіралі нешматлікія даследчыкі: Ян Чачот (Czeczot 1837) ${ }^{13}$, Міхаіл Федароўскі (Federowski 1897-1981), Мітрафан Доўнар-Запольскі (Довнар-Запольский 1888) і Павел Шэйн (Шейн 1874a). Да таго ж сабраны імі матэрыял быў жанрава абмежаваны, пераважалі песні.

У пэўнай ступені крыніцай можа служыць Сборник белорусских пословии, составленный И.И. Носовичем у 1874 г. (Носович 1874) - асобнае, пашыранае выданне 1866 г. Варта заўважыць, што першую спробу публікацы гэтага зборніка, які налічваў 45 старонак, Іван Насовіч зрабіў ужо ў 1852 г. Даследчык звяртаў увагу на тое, што сярод вяскоўцаў ёсць асобы, якія на кожную акалічнасць маюць нейкае трапнае выслоўе. Адначасова падкрэсліваў, што сабраныя ім прыказкі актыўна ўжываюць не толькі сяляне, але і засцянковая шляхта, праваслаўнае духавенства, мяшчане ў гарадах і мястэчках, а таксама буйныя землеўладальнікі. Да таго ж, апошнія робяць гэта не толькі падчас размоў з сялянамі, але і ва ўласным асяроддзі.

У 1881 г. выйшаў зборнік 768 беларускіх парэмій, сабраных Уладзіславам Дыбоўскім у Навагрудскім павеце (Dybowski 1881). У IV томе Ludu białoruskiego na Rusi Litewskiej Міхаіла Федароўскага ${ }^{14}$ былі апублікаваны парэміi, сабраныя на шырокай тэрыторыі ў асяроддзі як сялян, так і шляхты.

Багаты матэрыял змешчаны ў цыкле эсэ Элізы Ажэшка Ludzie i kwiaty nad Niemnem (Orzeszkowa 1888-1891), што публікаваўся у 1888-1891 гадах у трох тамах (II, IV, V) часопіса „Вісла”. Сабраны пісьменніцай этнаграфічны і моўны матэрыял, як і аўтарскія антрапалагічныя заўвагі, з'яўляюцца надзвычай цікавымі. Рэдактары „Віслы” адзначалі: „Szanowna autorka podaje nazwy białoruskie przeważnie w postaci spolszczonej, tak jak je Polacy nadniemeński wymawiają. Są one tym godniejszym uwagi, że w obszernym słowniku białoruskim Nosowicza zaledwie kilka z nich się znajduje" (Orzeszkowa 1888: 5). У чарговым фрагменце эсэ Эліза Ажэшка занатавала: „Zaczęłam też zbierać przysłowia znajdujące się w mowie ludu tutejszego"15 (Orzeszkowa 1890: 4). Для нашых разважанняў цікава тое, што ў адной з частак цыкла пісьменніца змясціла заўвагі адносна артыкула Karola Matyasa Chtopskie serce 3 III т. „Віслы”. Горача палемізуючы з яго аўтарам, Эліза Ажэшка прыводзіла шматлікія вядомыя ёй асабіста прыклады 3 жыцця сялян ${ }^{16}$ і падкрэслівала, што іх сапраўдных рысаў характару належыць шукаць „w historii, w pieśni, w podaniach chłopskich,

13 Апрача песень, матэрыялы змяшчаюць 180 беларускіх прыказак.

14328 тыс. захаваных у архіве даследчыка запісаў, якія датычылі народнай парэміялогіi, былі апублікаваны толькі 13231.

15 У гэтым цыкле пісьменніца змясціла 175 прыказак, у дзвюх частках. Першыя 161 яна пераклала на польскую мову, а наступныя 14 падала ў арыгінале, у запісы лацінкай.

16 Пра беларускую вёску і сялян у святле карэспандэнцыі Э. Ажэшка гл.: Konczewska 2019. 
w języku chłopskim [...], w wielkiej ilości zgromadzonych, dobrze wybranych i stwierdzonych spostrzeżeń nad życiem i usposobieniem chłopów" (Orzeszkowa 1890: 31).

Пасля Элізы Ажэшка народная культура Гарадзеншчыны працяглы час была па-за ўвагай даследчыкаў ${ }^{17}$, а дыялектныя экспедыцыі ўзнавіліся толькі ў другой палове XX ст. намаганнямі навукоўцаў Гродзенскага дзяржаўнага ўніверсітэта імя Янкі Купалы: Таццяны Сцяшковіч, Паўла Сцяцко, Івана Лепешава, Міколы Даніловіча. Варта падкрэсліць значны ўнёсак у гэтыя даследаванні Апанаса Цыхуна, які падчас працы інспектарам адукацыі не толькі візітаваў школы Гродзенскага раёна, але і падрабязна натаваў мясцовую лексіку, парэміі, мікратапанімію. Гэтыя матэрыялы, апрацаваныя і выдадзеныя мовазнаўцамі з Гродзенскага дзяржаўнага ўніверсітэта (Цыхун 1993), з'яўляюцца адзінай сучаснай крыніцай лексічнага матэрыялу вузкага субрэгіёна.

Адным 3 першых пасляваенных апрацаванняў парэмій Гарадзеншчыны была публікацыя Таццяны Сцяшковіч Прыказкі, прымаўкі, фразеалагізмы, выслоўі народных гаворак Гродзенскай вобласиі (1968). У Матэрыялах да слоўніка Гродзенскай вобласці (Сцяшковіч 1972) быў дадатак „Прыказкі, прымаўкі, фразеалагічныя спалучэнні” (с. 578-618), а ў Слоўніку Гродзенскай вобласиі (Сцяшковіч 1983) - раздзел „Фразеалагізмы”, у якім матэрыял (647 фразеалагізмаў, з іх 330 дыялектных) быў, згодна з метадалогіяй таго часу, змешчаны ў алфавітным парадку, з паданнем значэння паасобных фразеалагізмаў, прыкладам іх ужывання і мясцовасцей, у якіх яны былі занатаваныя ${ }^{18}$.

\section{Заўвагі пра мову выбраных першакрыніц}

Міхаіл Федароўскі лічыў, што „wpływ polszczyzny na dialekt zachodniobiałoruski jest nierównie silniejszy, uwydatnia się on we wszystkich białoruskich powiatach guberni grodzieńskiej" (Federowski 1897: XI). Вельмі важным 3'яўляецца тое, што большасць запісаў даследчык рабіў асабіста, не карыстаючыся дапамогай карэспандэнтаў. Важна і тое, што ён дакладна перадаваў асаблівасці беларускай мовы, у адрозненні ад, напрыклад, Івана Насовіча,

17 Падкрэслім, што навукоўцы разумелі неабходнасць такіх даследаванняў (Довнар-Запольский 1893). У сваю чаргу Яўхім Карскі, аўтар трохтомнай публікацыі Беларусы і рэктар Варшаўскага ўніверсітэта, быў цесна звязаны з Гарадзеншчынай, бо пэўны час жыў у вёсцы Лаша пад Індурай каля Гродна.

18 У сувязі 3 абранай канцэпцыяй даследавання мы не прымаем пад увагу іншых слоўнікаў, у тым фразеалагічных Івана Лепешава ці Міколы Даніловіча. 
які пераважна не адлюстроўваў акання, якання, спецыфічных гукаў і г.д., замяняючы ix рускамоўнымі. У сувязі з такой практыкай, якой даволі часта карысталіся збіральнікі фальклору, Міхаіл Федароўскі звяртаў увагу, што „materiał tego rodzaju, przynajmniej dla badacza języka białoruskiego, nie posiada najmniejszej wartości” (Federowski 1902: VIII). Ян Карловіч таксама крытычна выказаўся пра публікацыю Паўла Шэйна (Karłowicz 1887):

Sposób, w jaki p. Szejn oddaje na piśmie mowę białoruską, pozostawia wiele do życzenia: brak mu wierności i konsekwencji. Tak np. zamiast a pisze o, e; po r używa miękkich samogłosek; w jednej i tej samej pieśni raz pisze u, drugi raz ú. Transkrypcja ta zaciera najwydatniejsze cechy białoruszczyzny, czyniąc ją wprawdzie na oko podobniejszą do wielkoruszczyzny, ale kosztem prawdy, o którą przecież każdemu zbieraczowi rzeczy ludowych głównie chodzić by powinno („Wisła” t. II: 235-236).

У сваю чаргу у прадмове да IV т. Ludu białoruskiego Федароўскага Станіслаў Панятоўскі з Працоўні дыялекталогіi падкрэсліў:

Nie będąc fachowym językoznawcą i zapisując teksty białoruskie na użytek etnografów, a nie dialektologów, i to w czasie, kiedy dialektologia nasza była jeszcze w powijakach, autor „Ludu białoruskiego” stosował polską pisownię konwencjonalną, uzupełniając ją stosunkowo niewielką ilością znaków diakrytycznych, nie zawsze zresztą szczęśliwie wybranych. W notatkach, pisanych w ciągu paru dziesiątków lat, pisownia ta ulegała wahaniom. [...] Mając ucho bardzo wrażliwe na różnice fonetyczne, zapisywał on na ogół bardzo starannie, jak to zaświadczają i obcy specjaliści, i zapisywał każdorazowo ściśle to, co słyszał. A ponieważ opowiadali mu nie tylko włościanie białoruscy, ale często i Polacy zbiałoruszczeni (np. szlachta zagrodowa i drobne mieszczaństwo) lub Białorusini silnie spolonizowani (np. długoletnia służba dworska), więc też nie ma mowy o bezwzględnej czystości czy poprawności białoruszczyzny w tekstach Federowskiego (Federowski 1935: IX-X).

\section{Рэалізацыя канцэпту „баба” ў парэміях}

У слоўніку Івана Насовіча (Носович 1870: 10) лексема баба мае наступныя значэнні: 1) жанчына ўвогуле, 2) замужняя жанчына, 3) маці бацькі або маці, 4) усялякая старая, 5) павівальная бабка, 6) pelicanus onocratilus, птушка неясыць, 7) прылада для забівання сваяў. Парэмій з уласна лексемай баба ў слоўніку змешчана няшмат: Тогды баба ворожищь стала, якъ хлБба не стало, Баба зъ руками, а Богъ съ помоччу, Баба капусту поливала (заахвочванне выпіць гарэлкі пасля кіслай капусты), Баба кочергу мБняла, три дни гуляла, Баба съ колесъ,колесамъ легчи, Баба яга - костеная нога, Бабинъ дурень, Бабскій ладъ, или бабскій строй, Бабскій угодникъ. 
У зборніку Міхаіла Федароўскага (Federowski 1935), апрача парэмій, змешчаны цікавыя аўтарскія заўвагі адносна ролі і месца жанчыны ў вясковай супольнасці. Напрыклад, у нататцы, што тычыцца праклёнаў, даследчык падкрэслівае:

Białorusin nierównie ma w swym repertuarze więcej aniżeli życzeń. Przejechawszy wzdłuż i wszerz większą połowę naszej rodzinnej ziemi, śmiało rzeknąć mogę, iż nigdzie nie zdarzyło mi się słyszeć tak strasznych przekleństw, jakie w tutejszych stronach niemal codziennie słyszeć się dają. Lud na pozór spokojny byle jednak sposobności nie pominie, żeby nie wygłosić całego zasobu klątw, a kobiety szczególnie celują w tym razie. W wymawianiu przekleństw jest coś pogańskiego, nie czynią tego bowiem w sposób krótki, dosadny a głośny, jak się to zwykle dzieje na Mazowszu i w wielu innych miejscowościach naszego kraju, lecz klątwa po klątwie wygłasza się tu przeciągłym i monotonnym głosem, co na uchu postronnego słuchacza nadzwyczaj nieprzyjemne i, że tak rzeknę, straszne sprawia wrażenie. (Federowski 1935: XI)

I яшчэ адна вельмі цікавая заўвага: „Rzadko żeby kobieta nosiła jaką „mianuszkę”, zwykle nazywane bywają po imieniu w zdrobniałej formie mimo późnej zgrzybiałej starości” (Federowski 1935: XI).

Якая ж баба ў карціне свету беларускага селяніна, адлюстраваным у сабраных Федароўскім парэміях?

Найчасцей лексема баба стаіць побач з кампанентам чоpm: Baba chitrejsza ad czorta, Baba najhorsza za czorta, Baba z kalos, a kalosa jak czort panios, Babi i czort z darohi ustupaje, Babi to i czort rady ni daść, Baby i sam czort ni pieramoża (ni zwajuje), Ci baba, ci diabat, to usio rauno, bo czortu szmat usieho treba i babi takża, Czort a baba adna rada, Diabat sotod saładziu i to babi nie dahadziu, I biez atos i biez kalos czort babu panios, I czort babu baicsie, Dzie baba panium, tam czort kamisaram, Dzie czort nie dojdzie tudy babu paszle, Upała baba z hary czuort jaje biary, Baba z piekła rodam.

Баба шмат гаворыць: Baby nie pierahaworysz, Brachliwaja baba jak suka, Kali skazau babcy, to tak jak usioj hruomadcy.

Вельмі жывучая: Baby i kijam (doubniaju) nie dabić.

Упартая: Ci budzie, ci nie bobu reszacina, aby baba huolau skłapaciła, Ni sieło, ni pało, padaj babi sało.

Неахайная: Dzie babau mnoho, tam chata niemieciena. 
Хцівая: Jak taja baba: zabrała usiu muku jeszcze kryudzilasie.

Гуляшчая: Jur babu biere, Szto ty babu straszysz adnym, kali jena dwum rada, Rada baba była szto dzied utapiusza, nawaryła, napiekła anuoż juon schapiusie.

Плаксівая: Zajac uciakać, a baba zaraz płakać.

Не ведае меры: Pazwol babi pahulać pawierch haławy puojdzia.

Дурная: Babski rozum (nieszczególny), Czamu babi nie dureć kali prystupaje, U baby wołas douhi da rozum karotki, U baby kuraczaja haława.

Непатрэбная абуза: Baba z kalos kalosam lehczej.

3 ёю лепш не звязвацца: Nie rusz babinych hrusz, baba natrasie, to sama pryniasie, Baba skacza a dzied płacza.

Няўмелая: Zabiłaby i baba tosia, kab udatosia.

Параўнанні з кампанентам баба: Baba jak zatkato da komina, Baba staraja jak szacior.

Парафразы: Babski ład (nieład), Babska chwaroba choć baluszcza ale minuszcza (пра цяжарнасць), Pajechała baba pa obaracień (пра смерць), To nie dziwo szto u baby siwo, heto dziuniej szto u dzieuki siwiej, Paszli baby atawaju (hulają, bawią się jak młode), Sorak let babin wiek.

Трэба заўважыць, што некаторыя з занатаваных даследчыкам парэмій даволі брутальныя:

Baby, baby - hanuczy, maładzicy - spadnicy, chlopcy - nahawicy

Dyli, dyli skrypaczka, upała baba z prypieczka, a dzied babu za ucho: ustawaj babo psia jucho

Dzied - hnied, baba ryża, baba dziedu sraku liża

Kozy nie bydlo, a baby ni ludzi

Baby ni ludzi, kozy ni żywina 
Эліза Ажэшка, як ужо згадвалася, прыказкі пачала натаваць падчас працы над збіраннем батанічнай наменклатуры, якую прадставіла ў цыкле Людзі $i$ кветкі над Нёманам у часопісе „Вісла”19. Многія 3 іх датычаць жанчыны, але 3 кампанентам баба ёсць толькі некалькі, даволі распаўсюджаных: Baba z wozu, kołom lżej, Na dwoje babka wróżyła, Przypomniała sobie baba dziewiczy wieczór i płakać zaczęła, Nie miała baba kłopotu, kupiła prosię.

У згаданых ужо слоўніках Таццяны Сцяшковіч і Апанаса Цыхуна прымаўкі, прыказкі і фразеалагічныя спалучэнні змешчаны ў асобных дадатках. Парэмій з кампанентам баба няшмат. Яна прадстае як хітрая і ўпартая: Баба i чорта змане, Баба і чорта перахітрыць, Як баба захоча, та і мёртвы зарагоча, Баба хату на вуліиу выкіруе. Яе прызначэнне - хатняя праца ('babski los'): Бабе дарога ад печь да парога. Баба гарлапаністая: Баба крычыць, пакуль горла не забаліизь, гаварлівая: Бабу не мужык, а язык б'е, абібок: Баба качаргу мяняла і то тры дні гуляла, абуза: Баба з возу, каню свята, Баба з калёс, калёсам лягчэй. Параўнанні: Баба п'яная як свіння худая, Насіџияа як баба з яешняю (быць надакучлівым).

\section{Падсумаванне}

У артыкуле прадастаўлены парэміі з кампанентам баба, выбраныя намі з дыялектных матэрыялаў, збіраных у XIX i XX ст.ст. на тэрыторыі сціслай Гарадзеншчыны. На дадзеным этапе даследавання нашай мэтай было прасачыць, як (і ці) змянялася рэалізацыя гэтага канцэпту. Аналіз выяўленых парэміялагічных адзінак дазваляе канстатаваць выключна пеяратыўнае значэнне лексемы баба ў матэрыяле ўсяго аналізаванага перыяду. Звяртае ўвагу тое, што ў больш сучасных матэрыялах парэмій з гэтым кампанентам усё менш. Мажліва, гэта вынік звужэння ўжывання дадзенай лексемы, што, аднак, не ўплывае на змену семантычнай напаўняльнасці. Цікава, што канцэпты ,жонка”, „гаспадыня”, „маці” не маюць выключна пеяратыўнай канатацыі. Адказ на гэтую семантычную загадку мы плануем пашукаць у кампаратыўным даследаванні парэмій з кампанентам баба ў іншых славянскіх мовах.

19 Больш падрабязна пра зацікаўленасць Ажэшка раслінным светам Прынёмання: Kleiber 2009; Konczewska 2018. 


\section{Summary}

The Concept of B $A$ ba in the Paremias of the Belarusian dialects of the Grodno Region

The article presents the implementation of the lexeme baba in Grodno Belarusian dialects. The analysis was made based on dialect materials of the entire period of study of the region. The article presents the history of research dialects and folklore in the region of Grodno, primary sources the paper and focuses on the negative connotations of the lexeme baba. 


\author{
Paulina Karpeta (1) \\ Uniwersytet Jagielloński, KraKów \\ paulina.karpeta@doctoral.uj.edu.pl
}

\title{
Frazeologia GWAROWA
}

\section{POGRANICZA MALOPOLSKO-MAZOWIECKIEGO}

Słowa klucze: frazeologia gwarowa, tradycja ludowa, dialektologia, pogranicze małopolsko-mazowieckie

Keywords: dialectal phraseology, folk tradition, dialectology, Lesser Poland-Masovian borderland

W niniejszej pracy zaprezentuję część samodzielnie zebranego materiału frazeologicznego, który funkcjonuje na terenie trzech mazowieckich wsi: Łazów, Majdowa i Ciechostowic, położonych na styku dwóch regionów - Małopolski i Mazowsza - w gminie Szydłowiec. Frazeologizmy gwarowe zebrałam podczas rozmów z mieszkańcami, którzy sprawnie posługują się zarówno gwarą, jak i polszczyzną ogólną.

Zgromadzony materiał narzucił schemat analizy. Wobec tego przedstawię frazeologizmy gwarowe:

a) wskazujące na cechy fizyczne i osobowościowe człowieka,

b) odnoszące się do obyczajów i zwyczajów wiejskich,

c) przechowujące anegdoty i komentarze sytuacyjne, które w ludyczny sposób utrwalają życie na wsi.

Wojciech Chlebda stwierdził, że pojęcie frazemu pozwala unifikować takie zjawiska językowe, jak np.: powiedzonko, przysłowie, zwrot wykrzyknikowy, slogan propagandowy, wtrącenie metatekstowe itp., które różnią się pod względem stylistycznym, treściowym i formalnym (Chlebda 2010: 336-337). W związku z tym terminu frazeologia gwarowa będę używała naprzemiennie z frazematyka gwarowa. Prezentowane jednostki wielowyrazowe podaję w zapisie półfonetycznym uwzględniającym podstawowe cechy gwarowe.

Frazeologizmy gwarowe wskazujące na cechy fizyczne i osobowościowe człowieka

Związki frazeologiczne cechują się antropocentryzmem - w pełni charakteryzują człowieka, który jest miarą otaczającego go świata (por. Rak 2016b: 95). 
Jerzy Bartmiński, pisząc o stylu potocznym, wspomina, że to właśnie w nim świat postrzegany jest przez pryzmat codziennych doświadczeń konkretnego człowieka: „to w tym stylu sprawdza się przede wszystkim starożytna formuła człowiek jest miarq wszechrzeczy" (Bartmiński 2010b: 125). Podejście krytykujące, napełnione ironią i chęcią ośmieszenia, można zauważyć we frazeologizmach gwarowych odnoszących się do takich atrybutów, jak np.:

a) włosy, np.: \{ktoś\} jest zarośnięty jak niedźwiedź 'uszczypliwie o osobie nieogolonej lub mającej zbyt długie włosy'; $\{k t o s ́\}$ mo pińć włosów na krzyz 'ironicznie o osobie mającej przerzedzone włosy';

b) zbyt niski wzrost, np.: \{ktoś\} wyglondo jak pinć minut na małym zegarku 'żartobliwie o osobie niskiej/małej';

c) atrakcyjność, np.: \{ktoś\} wyglondo jak musora spod krzoka 'ironicznie o osobie nieatrakcyjnej, brzydkiej'; \{ktoś\} wyglondo jakby go wrony podziobaty 'o osobie, której twarz pokrywają krosty i rany' itp.

Ponadto społeczność wiejska zauważa także wszelkie niedostatki związane $\mathrm{z}$ ubiorem. Z tego powodu negatywnie odnosi się do stroju, który jest nieodpowiednio dobrany do pogody, np.: \{ktoś\} wystroit się jak na bonki 'o osobie, która mimo niskiej temperatury na zewnątrz jest ubrana bardzo lekko, prawie w negliżu', lub do okazji, np.: \{ktoś\} wystroit sięjak glupi na imieniny 'o osobie, która jest nieelegancko ubrana lub części jej garderoby nie pasują do siebie’.

Poprzez napiętnowanie cech negatywnych wskazywano zachowania pożądane (por. Rak 2016b: 92). Postępowanie sprzeczne z przyjętymi wzorcami i zwyczajami zawsze oceniano negatywnie. Społeczność wiejska nie godziła się m.in. na:

a) bezcelowość działania, np.: \{ktoś\} loto jak kot z mecherom 'uszczypliwie o osobie niespokojnej, która nie może usiedzieć na miejscu’; $\{k t o s ́\}$ leci w der$d y$ 'o osobie, która biegnie bez opamiętania';

b) bezmyślność, np.: \{ktoś\} mo siecke we tbie 'z przekąsem o osobie nierozsądnej, niemądrej'; \{ktoś\} stucho \{cegoś\} jak świnia grzmotu 'ironicznie o osobie naiwnej, która wierzy we wszystko, co mówią inni'; $\{k t o s ́\}$ stoi jak lampa 'z pogardą o osobie stojącej bez ruchu; bez powodu';

c) niepanowanie nad emocjami oraz wulgarność, np.: \{ktoś\} drze sie jak stare gacie 'z przekąsem o osobie nadmiernie podnoszącej głos'; $\{$ ktoś\} zachowuje sie jak płacek zydoski 'ironicznie o osobie, która nie umie pohamować płaczu; szlocha'; $\{k t o s ́\}$ wyzywo $\{k o g o s ́\}$ od zodnych 'z pogardą o osobie wulgarnej';

d) lenistwo, np.: \{ktoś\} narobi \{cegoś\} tyle, co pies gnoju 'ironicznie o osobie, która potrafi zrobić niewiele rzeczy'; $\{k t o s ́\}$ robi $\{c o s ́\}$ tak, zeby Polska nie zgineła 'z przekąsem o osobie, która wykonuje swoją pracę niestarannie'; $\{k t o s ́\}$ jest ni do Boga, ni do ludzi 'o osobie osowiałej, która nie ma na nic ochoty';

e) skąpstwo, np.: \{ktoś\} odmierzo jak w aptece 'ironicznie o osobie chytrej'; \{ktoś\} strugo dziada 'pogardliwie o osobie, która nie lubi wydawać pieniędzy'; $\{k t o s ́\}$ zabijo dupe kołkiem 'o osobie przesadnie skąpej, oszczędzającej nawet na jedzeniu' itp. 
Takie podejście mieszkańców wsi jest podyktowane ustalonym porządkiem życia w małej społeczności. W związku z tym materiał frazematyczny pozwala także na zrekonstruowanie ludowego systemu aksjologicznego (aksjonormatywnego). Świat, który otacza społeczność wiejską, jest niezmienny, dany przez Boga, wobec którego należy zachować pokorę i skruchę (por. Lewicki, Pajdzińska 2010: 331). Ponadto związki frazeologiczne wyznaczają perspektywę wertykalną - to, co znajduje się w górze, wartościowane jest pozytywnie, natomiast wszystko, co umiejscowione jest na dole, przywodzi skojarzenia negatywne. Dotyczy to także części ciała, co wykazała Anna Krawczyk-Tyrpa w książce Frazeologia somatyczna w gwarach polskich. Zwiazki frazeologiczne o znaczeniach motywowanych cechami czesści ciała (Krawczyk-Tyrpa 1987) i w jej uzupełnieniu Frazeologia somatyczna. Zwiąki frazeologiczne o znaczeniach motywowanych cechami części ciała $w$ gwarach polskich (Tyrpa 2005).

Ma to swoje odbicie w postrzeganiu DOBRA i ZŁA. Uniżona postawa prostego człowieka względem Boga, który króluje w nadziemskiej krainie szczęśliwości, oraz pogardliwy stosunek do złych duchów zderzają się we frazeologii gwarowej (Tyrpa 2005: 332), np.: kto w niedziele pracuje, ten diablu ustuguje 'komentarz skierowany do kogoś, kto pracuje w dzień świąteczny'. Rytm życia na wsi wypełniony był bowiem pracą i modlitwą (ora et labora) oraz uzależniony od cyklu przyrody, o czym świadczą frazemy, np.: $\{k t o s ́\}$ wstaje do dnia 'o osobie, która wstaje o świcie, by wykonać jak najwięcej obowiązków danego dnia'.

Podobne podejście można zaobserwować w postrzeganiu elementów ludzkiego ciała. Frazeologia somatyczna, a więc taka, której komponentami są nazwy części ciała, dobrze pokazuje wertykalną i horyzontalną perspektywę postrzegania rzeczywistości (por. Tyrpa 2005: 30-31). Strategicznymi elementami gwarowych somatyzmów są:

a) głowa i jej części, np.: \{ktoś\} mo łeb jak sagon 'o osobie, która jest obciążona wieloma obowiązkami'; \{ktoś\} mo mocnom głowe do wódki 'o osobie, która może wypić dużą ilość alkoholu'; \{ktoś\} mo mula na głowie 'ze współczuciem o osobie, która ma problem, kłopot'; $\{k t o s ́\}$ susy $\{k o m u s ́\}$ głowie 'z pogardą o osobie natrętnej, naprzykrzającej się innym'; $\{k t o s ́\}$ mo w głowie jak w dupie po śliwkach 'ironicznie o osobie lekkomyślnej, nieodpowiedzialnej'; jedzynie rosnie \{komuś\} w gembie 'komentarz skierowany do osoby, która długo je'; $\{k t o s ́\}$ zamaluje $\{k o m u s ́\}$ w gembe 'o osobie, która chce kogoś spoliczkować'; b) narządy płciowe i wydalnicze, np.: dupa sie \{komuś\} rozprazyła 'ironiczny komentarz skierowany do osoby, która niespodziewanie podejmuje jakąś decyzję'; $\{k t o s ́\}$ zawraco $\{$ komuś\} dupe na lewo 'o osobie, która obarcza innych swoimi problemami'; \{ktoś\} mówi / godo jak do stupa, a stup jak dupa 'pogardliwie o osobie, która nie reaguje, gdy chcemy się z nią skomunikować'; $\{k t o s ́\}$ mo snopek przy dupie 'o osobie, która nie zamyka za sobą drzwi, zostawia je uchylone'. 
Na korzyść powyższej tezy przemawia opinia J. Bartmińskiego: „na odniesieniu do ciała człowieka opiera się orientacja przestrzenna - odróżnianie wymiaru pionowego góra-dół i wymiarów poziomych przód-tył oraz prawy-lewy, przy czym na te wymiary nałożone jest następnie potoczne wartościowanie dobry-zły" (Bartmiński 2010b: 125). Jednostki wielowyrazowe zawierające strategiczne elementy ciała ludzkiego są nacechowane emocjonalnie oraz posiadają funkcję perswazyjną, a także są w swym przekazie dobitne i wyraziste, np.: jenzyk chce $\{k o-$ muś\} w dupe uciec 'ironicznie o osobie, która jest niecierpliwa'; $\{k t o s ́\}$ musi mieć $w$ dupie ocy 'o osobie, która powinna być spostrzegawcza'.

Materiał frazematyczny, który do tej pory zaprezentowałam, pozwala dostrzec dwubiegunowe wartościowanie: dobry-zły. Jest to zdeterminowane czarno-białym postrzeganiem otaczającej rzeczywistości. A. Tyrpa skonkludowała to następującymi słowami: ,język, oprócz kodowania wiedzy o świecie i sposobu rozumowania, koduje też sądy. W języku zawarty jest obraz wartościowania rzeczywistości przez daną wspólnotę językowo-społeczną" (Tyrpa 2016: 23).

\section{Frazeologizmy gwarowe odnoszące się do zwyczajów i obrzędów ludowych}

Dialektolodzy zgodnie stwierdzają, że leksyka gwarowa, w tym również związki frazeologiczne, to skarbnica wiedzy o odległych dziejach kultury polskiej - oby-

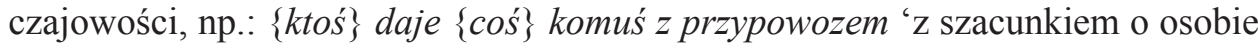
szczodrej'; \{ktoś\} chodzi jak pan młody / pani młodo 'z przekąsem o osobie, która ma dużo obowiązków'; rytuałach, np.: \{ktoś\} chodzi na chejtki 'o osobie, która spotyka się z innymi po to, żeby poplotkować'; witojta wszyscy po jednemu, bo jo nie wiym jak na imie któremu 'formuła powitalna wypowiadana najczęściej przez mężczyznę w miejscu, gdzie znajdowało się wiele osób, często nieznajomych' itp.

Tak więc frazematyka gwarowa jest pomostem łączącym teraźniejszość z przeszłością. Zdaniem Kazimierza Moszyńskiego: ,,wiedza, zdobyta przez nas dzięki badaniom nad dawną i współczesną kulturą, odda duże usługi ludzkości, gdyż pozwoli jej głębiej zrozumieć samą siebie i wyciągnąć z tego zrozumienia praktyczne konsekwencje" (KLS I: 1).

Ponadto mieszkaniec wsi starał się żyć w zgodzie z Bogiem oraz otaczającą go przyrodą. Baczne obserwacje środowiska naturalnego pozwalały na tej podstawie wysnuwać wnioski dotyczące pogody, dlatego tak wiele powiedzeń odnosi się do zjawisk atmosferycznych, np.: mgła jakby ktoś mlyko rozlot 'mówimy tak, gdy jest gęsta mgła'; takie ciepło, ze az sie pod nosym skrzepło 'ironiczna formuła kierowana zwykle do osoby, której wydaje się, że jest wystarczająco ciepło, by założyć lżejsze ubrania'; wieje jakby chciało głowe urwać 'mówimy tak, gdy wieje silny, porywisty wiatr'. 
Znaczna część przysłów dotyczy przede wszystkim roku liturgicznego i rolniczego. Przenikanie obu tych przestrzeni pomagało dobrze zaplanować prace na roli. Sferę tę właściwie obrazują frazemy, które odnoszą się do świętych, np.: jak na Matki Boski Gromnicny ciece, to sie zima powlece 'jeśli w uroczystość Matki Boskiej Gromnicznej (2 lutego) pada śnieg, to znaczy, że będzie jeszcze długa zima'; na Świynty Trójcy zima sie kuńcy, po Bozym Ciele drugo sie ściele 'żartobliwa formuła wypowiadana, by podkreślić, że niewiele czasu upłynie od jednej zimy do drugiej, ponieważ wraz ze świętem Trójcy Świętej kończy się zima, a po uroczystości Bożego Ciała zanosi się już na następną'; na świynty Katarzyny puste godziny 'w dniu św. Katarzyny (29 kwietnia) nie można niczego siać'; świynty Jan przynosi jagód dzban 'na św. Jana (24 czerwca) dojrzewają jagody w lesie'; po Jakubie kazdy w swoim gorcku dtubie 'mówimy tak, gdy już można coś zrobić, ugotować z własnych, dopiero co wykopanych ziemniaków (od 25 lipca)'; na świynty Wawrzyniec, to przez pole gościniec 'na św. Wawrzyńca (10 sierpnia) kończą się żniwa’ itp.

W powyższych frazemach widoczna jest siła tradycji, dzięki której mieszkańcy wsi łączyli istotne zwyczaje ludowe z datami świąt chrześcijańskich (por. Kwaśniewicz 1984: 161). Dzięki frazematyce gwarowej przechowywany jest ceremonialno-symboliczny charakter dorocznych zwyczajów i obrzędów, które, jak pisze Krystyna Kwaśniewicz, ,powracają cyklicznie w czasie, aby unaocznić fazy przejścia kończące lub zapoczątkowujące pewien nowy etap, okres, porę roku" (Kwaśniewicz 1984: 160).

\section{Frazeologizmy gwarowe przechowujące anegdoty i komentarze sytuacyjne}

Mieszkańcy wsi naturalnie i spontanicznie używają nacechowanych ekspresyjnie jednostek wielowyrazowych w rozmaitych sytuacjach. W związku z tym znaczną ich liczbę stanowią frazemy, którym początek dały legendy, anegdoty lub komentarze sytuacyjne. Wiele frazeologizmów gwarowych:

a) thumaczy konfiguracje i relacje międzyludzkie, np.: \{ktoś\} dobrot sie $\{z$ kimś\} jak zdatny z pewnym 'z przekąsem o osobach, które pasują do siebie pod każdym względem'; pomału, pomatu chtop do dzieci dosed 'żartobliwie o osobie, która z czasem nauczyła coś robić'; niemiło ksiendzu ofiara, to chodź ciele do dómu 'z przekąsem, gdy nie chcemy się komuś narzucać';

b) komentuje domowe zamieszanie, np.: ruch jak w Rzymie - jeden śpi, drugi drzymie 'żartobliwie, gdy grupa osób się krząta, a tak naprawdę nikt nic nie robi'; pocekojta wszyscy, niech sie jedno wyjscy 'zwrot sugerujący, by na kogoś zaczekać';

c) czerpie z obserwacji najbliższego otoczenia, np.: $\{k t o s ́\}$ ciongnie $\{k o g o s ́\}$ za jenzyk jak kota za ogón 'o osobie, która za wszelką cenę chce się czegoś dowie- 
dzieć'; \{ktoś\} musi miyć \{do kogoś\} byce nerwy 'pogardliwy zwrot do osoby, która nadużywa czyjejś cierpliwości’; \{ktoś\} przymierzo sie \{do czegoś/kogoś\} jak pies do jyża 'ironicznie o osobie lękliwej'; \{ktoś\} podskakuje jak wsa na grzebiniu 'o osobie, która nie panuje nad emocjami'; \{ktoś\} stoi jak goty na rogu stodoły 'ironicznie o osobie, która stoi bezczynnie'.

Warto zaznaczyć, że pewne sformułowania stają się z czasem niejasne, zawikłane lub niepasujące do współczesnych realiów, np.: \{ktoś\} zaglondo jak pies do jatki 'z przekąsem o osobie, która jest ciekawska'; \{ktoś\} otwiero drzwi do molu' 'o osobie, która otwiera drzwi na oścież'; \{ktoś\} kombinuje jak kóń pod górke 'o osobie, która używa wszelkich możliwych sposobów, by coś osiągnąć' itp. Na rzecz powyższej tezy trafnie przemawiają słowa Heleny Grocholi-Szczepanek: „dynamiczne zmiany w sferze agrarnej, zawodowej i wykształcenia pociągają za sobą przeobrażenia w kodzie językowym, co wpływa na wyraźne różnicowanie się sytuacji językowej na wsi” (Grochola-Szczepanek 2013: 47).

Ponadto warto zwrócić uwagę, że w omówionych frazemach bez trudu można odnaleźć językowe wykładniki stereotypizacji² (por. Bartmiński 2009: 93). Konfrontowanie cech osobowości człowieka ze stereotypowym postrzeganiem zwierząt (np. domowych) było popularne, dlatego na ważne sprawy lub przywary ludzi zakładano maskę postaci zwierzęcych - co wiąże się z wielowiekową tradycją obecną w bajkach i satyrach (por. Bartmiński 2009: 96). Interpretowanie rzeczywistości przez społeczność wiejską jest więc związane z przyjętym systemem wartości, norm i postaw, które kształtuje kategoria postrzegania, widzenia. J. Bartmiński konkluduje tę kwestię następująco: „w języku potocznym nazwy zwierząt występują w wyrażeniach porównawczych opartych na cechach stereotypowych [...], a w kolejności są wykorzystywane do tworzenia silnie wartościujących metaforycznych określeń ludzi o pewnych właściwościach [...]” (Bartmiński 2009: 98). W związku z tym zgromadzony materiał prezentuje liczne - uproszczone, schematyczne porównania człowieka - jego wyglądu i zachowania - do: kota, psa, świni, konia, bąka i niedźwiedzia.

$* * *$

Najstarsze pokolenia przyzwyczajone są do ustnego przekazu własnych doświadczeń i obserwacji, tak więc warto dodać, że kultura ludowa cechuje się oralnoś-

mal / mol 'miejsce; gospodarstwo, posiadłość' (SGP III: 102).

2 J. Bartmiński wskazuje, że ,wykładnikami stereotypizacji są: powtarzalność charakterystyki przedmiotu w różnych wypowiedziach [...] oraz utrwalenie tej charakterystyki w języku, a więc w znaczeniach słów, dające się uchwycić poprzez analizę wyrazów pochodnych (derywatów), metafor, frazeologii, przysłów, a także - reguł konstruowania spójnego semantycznie tekstu" (Bartmiński 2009: 93). 
cią. Walter J. Ong słusznie stwierdza, że cenne opowieści należy utrwalić i nie poddawać ich żadnym przekształceniom, ponieważ przechowanie ich w pamięci wymagało od naszych przodków wiele wysiłku (por. Ong 2011: 64-65). Ponadto wyjaśnia on, że „oralność, sytuując wiedzę w kontekście ludzkich zmagań, pozostaje zanurzona w świecie ludzkiego życia" (Ong 2011: 70). Dlatego właśnie w gwarach słowo ma o wiele większą wartość niż to, co jest zapisane. Pismo to nadal domena ludzi spoza wiejskiej społeczności. Maciej Rak pisał na ten temat następująco: „,W przypadku polskiej kultury ludowej badanie wyznaczników jej oralności powinno się opierać w dużej mierze na badaniu przysłów i frazeologizmów. [...] Warto więc zwrócić uwagę także na możliwość wykorzystania frazemów podczas badania polskiej kultury ludowej jako świadectwa kultury oralnej" (Rak 2016a: 39).

Potrzeba gromadzenia i opisywania frazematyki gwarowej powinna uwzględniać zmiany cywilizacyjne i przeobrażenia społeczno-ekonomiczne, które docierają na wieś, ponieważ znaczna część frazeologii gwarowej, tak jak pisałam powyżej, utraciła swą pierwotną motywację. Zwłaszcza najmłodsze pokolenie mieszkańców nie zdaje sobie sprawy, co dokładnie znaczą niektóre wielowyrazowe jednostki gwarowe.

\section{SUMmary \\ Dialectal Phraseology \\ of the Lesser Poland-Masovian Borderland}

This article presents phrase material collected by the indigenous researcher in three villages at the junction of two regions - Lesser Poland and Mazovia. The analysis of the phrases collected leads to showing the cultural and moral sphere of a specific rural community and consolidates its specificity. This approach makes it possible to see the interrelationships between the language, way of thinking and behavior of a person and the reality that surrounds him. In addition, it allows you to capture the remnants of oral folk culture preserved in dialectal phraseology. 



\author{
Ewa Sikora \\ Uniwersytet Pedagogiczny im. Komisji Edukacji Narodowej, Kraków \\ sikora.ewa1202@gmail.com
}

\title{
Frazeologia podhalańska W PAMIEtTNiKaCH I GAWĘDACH GÓRALI JAKO ŹRÓDLO REKONSTRUKCJI
} JEZYKOWEGO OBRAZU GLODU

Słowa klucze: językowy obraz świata, głód, etnolingwistyka, gwara podhalańska Keywords: linguistic picture of the world, hunger, ethnolinguistics, Podhale dialect

Podhalański głód był tematem mniej lub bardziej obszernych analiz zarówno etnografów (Wrześniowski 1882; Kantor 1907), jak i historyków (Cybulski 1984; Szuster 2016). Językoznawczego opracowania omawiane zagadnienie doczekało się stosunkowo niedawno. W 2015 r. ukazała się monografia Macieja Raka (2015), w której autor opisuje głód jako jeden z kulturemów podhalańskich (Rak 2015: 251-261). Rak zebrał i opisał podhalańskie frazemy, pieśni, winszowania oraz poświadczenia górali i etnografów. W związku z bogactwem materiałów, jakie zgromadził badacz, próba analizy językowego obrazu głodu na podstawie innych źródeł jest zadaniem niełatwym. Niemniej, po zapoznaniu się z bardzo interesującymi wspomnieniami napisanymi albo gwarą, albo interdialektem (por. Bartmiński 1977: 90; 1973: 265), podejmuję próbę rekonstrukcji składników głodu w tych właśnie tekstach.

Niniejsza praca stanowi część szerszych badań ukierunkowanych na rekonstrukcję językowego obrazu warunków bytowych górali. Jego celem jest przedstawienie cząstkowych wyników badań przeprowadzonych zgodnie $\mathrm{z}$ metodologią rekonstrukcji językowego obrazu świata (JOS) na podstawie trzech typów danych: systemowych, tekstowych i ankietowych (Bartmiński 2009: 151-166).

Dane systemowe pochodzą ze słowników ogólnych, etymologicznych i gwarowych: Słownika gwar polskich PAN (SGP), Stownika gwar polskich Jan Karłowicza (SKarł) oraz Leksykonu gwary i kultury podhalańskiej Józefa Kąsia (KąślLG), ponadto z Wielkiego stownika języka polskiego PWN (WSJP PWN), a także ze Stownika etymologicznego języka polskiego Franciszka Sławskiego (SESł) i Stownika frazeologicznego współczesnej polszczyzny Stanisława Bąby i Jarosława 
Liberka (SFWP). Wśród danych tekstowych, które posłużyły do rekonstrukcji językowego obrazu głodu, znalazły się materiały gwarowe zgromadzone w Archiwum Muzeum Tatrzańskiego. Większość z nich to rękopiśmienne pamiętniki, które odnosily się do XIX- i XX-wiecznych realiów życia na Podhalu. Uzupełnienie stanowią gawędy i materiały etnograficzne. Ponadto przeprowadzono badania ankietowe, które rzucą światło na pojmowanie istoty braku pożywienia przez współczesnych górali. Ze względu na ograniczenia formalne ich wynik zostanie przedstawiony w bardzo dużym uogólnieniu. Dodatkowo wzięto pod uwagę tzw. dane „przyjęzykowe”, które dotyczą wierzeń i zwyczajów praktykowanych na Podhalu. Eksploracja trojakiego typu danych (system, ankieta, tekst) jest próbą realizacji założeń metodologicznych dotyczących JOS, których opis i praktyczne zastosowanie można odnaleźć w licznych pracach Jerzego Bartmińskiego i innych badaczy nurtu etnolingwistycznego (Bartmiński 2009; Bartmiński, Lappo, Majer-Baranowska 2009). Wszystkie wspomniane słowniki, a także rozdział dotyczący głodu w monografii Kulturemy podhalańskie (Rak 2015) stanowią punkt odniesienia dla niniejszej analizy.

Głód jest wyrazem ogólnosłowiańskim. W polszczyźnie występuje od XV w. jako kontynuant prasłowiańskiego *gold ‘ 'łaknąć, pragnąć' (SEH: 218). W słowniku ogólnym głód zdefiniowany jest następująco: 'stan organizmu związany z niedoborem lub brakiem pożywienia; uczucie czczości spowodowane brakiem pożywienia', a także 'brak żywności spowodowany nieurodzajem, powodzią, wojną itp.' oraz 'pragnienie, żądza, dotkliwy brak czegoś' (WSJP PWN I: 1079). W SGP omawiany leksem występuje w dwóch pierwszych ogólnopolskich znaczeniach, jednak głodem nazywa się także 'post' (SGP VIII: 467). W pierwszej kolejności można zauważyć, że brak pożywienia rozumiany jest zarówno dosłownie, jak i metaforycznie. To drugie pojmowanie znaczenia głodu nie uobecnia się w gwarze podhalańskiej, przynajmniej na etapie przeprowadzonej analizy danych słownikowych i tekstowych, bowiem w Leksykonie definicja pod hasłem głód odsyła do ogólnopolskiego rozumienia tego wyrazu, a eksplikacja potwierdza, że jest to rozumienie dosłowne (dwa pierwsze znaczenia spośród trzech wyżej wymienionych). J. Kąś odnotowuje także drugie znaczenie 'okres nieurodzaju i głodu' (KąśILG III: 363). Z powyższego zestawienia wynika, że gtód w gwarze góralskiej jest rozumiany na dwa sposoby: jako krótkotrwałe, doraźne uczucie związane z brakiem pożywienia lub jako przewlekły stan w życiu człowieka czy całej społeczności. Ponadto ogólnopolski głód jest uzasadniony pojawieniem się klęsk żywiołowych czy wojen, natomiast $\mathrm{w}$ gwarze jest postrzegany jako pewien okres pojawiający się co jakiś czas, niekoniecznie następujący w wyniku szczególnych okoliczności.

W mowie górali podhalańskich występują wspólnoodmianowe derywaty oparte na temacie głód (w jego podstawowym znaczeniu), są to: przymiotnik głodny, przysłówek głodno i czasowniki głodować, głodzić również w stronie zwrotnej 
oraz w aspekcie dokonanym zagłodzić. Obecność powyższych wyrazów pochodnych znajduje potwierdzenie $\mathrm{w}$ analizowanych tekstach ${ }^{1}$ :

Przedwojenne czasy jak człowiek był głodny to we wojne i zacierki brakowało owsianej bo czeba było owies oddać (ZRaf: 32 ur. 1929²).

I coby nie iść po próżnicy [z Niemiec - E.S.] nabroł mąki, kasy, cukru, co ta móg (bo ftoz to wie, cy tam w dóma nie głodują), włożył to syćko na pur, a na som wierk piykny chomąt, bo był ś niego koniorz zamiyłowany (JPit: 115).

Myślelime zenas zagłodzą naśmierć każdy znas myślał cyjesce kiedy dosyta sie naje (JSta: 64).

Od głodu tworzone są także derywaty rzeczownikowe, które mają inne znaczenie niż wyraz podstawowy, np.: głodnik lub głodomór, czyli 'człowiek stale głodny, którego trudno nasycić' (KąśILG III: 351) Jednym z bardziej interesujących wyrazów jest głodek. To pozorne deminutiwum oznacza roślinę o białych lub żółtych kwiatach, której liście tworzą odziomkową rozetę (KąśILG VI: 257). Motywacją semantyczną do takiego nazwania głodka był moment kwitnienia, który przypada na okres przednówka, czyli czasu, kiedy góralom najczęściej doskwierał brak pożywienia. W gwarze funkcjonuje także formacja słowotwórcza mrzigłód, która posiada metaforyczne znaczenia. W Leksykonie pod tym hasłem można odnaleźć dwie definicje: 'człowiek stale głodny z powodu niedojedzenia' oraz 'pospolity chwast, rosnący bardzo gęsto' zwłaszcza między uprawianymi roślinami okopowymi (KąśILG VI: 257). Związek semantyczny mrzigłodu z wyrazem podstawowym w przypadku pierwszego znaczenia odnotowanego przez Kąsia pozostaje oczywisty: mrzigłod, czyli ktoś, kto mrze 'umiera' z powodu głodu, co jest podstawą do nadania przenośnego znaczenia dotyczącego ciągłego pragnienia posilenia się. Natomiast $\mathrm{w}$ drugim przypadku można przypuszczać, że obecność chwastu wśród roślin uprawnych mogła skutkować zmniejszeniem plonów, co wiązało się $\mathrm{z}$ brakiem żywności. Mrzigłód w tym znaczeniu znany jest również jako musec, musek, mysok czy muset (KąśILG VI: 257).

Głód należy do słownictwa tematycznego biedy. Grupę synonimiczną z tym leksemem w gwarze podhalańskiej tworzą wyrazy ogólnopolskie, takie jak: niedosyt, niedobór, łaknienie. Na uwagę zasługuje jednak synonim czasownika głodzić, czyli morzyć 'drastycznie ograniczać komuś jedzenie' (KąśILG VI: 230), występujący także w stronie zwrotnej, od którego pochodzi przymiotnik zamorzony bliskoznacznik leksemu głodny:

1 We wszystkich cytowanych tekstach zachowano oryginalną pisownię.

2 Niektóre pamiętniki nie są datowane, w takim przypadku podana zostaje data urodzenia autora. 
Zdarza się często, że góral sam mleka nie wypije, a koniowi go nie pożałuje, byle mu dobrze wyglądał i mógł go drożej sprzedać, bo ,zabiedzony, zamorzony koń to strata" (Kantor 1907: 49).

Z analizowanych tekstów wyekscerpowano frazemy z komponentem głód, które stały się podstawą do rekonstrukcji gwarowego obrazu omawianego pojęcia.

Składnikiem językowego obrazu głodu odtworzonego na podstawie tekstów jest jego uciążliwe trwanie w czasie i dokuczliwość. Dowodzi tego frazeologizm przymierać głodem:

ludność podhala była zmuszona jeździź zazywnościom do Miechowa byłatosprawa niełatwa i niebespieczna nieras niemcy ten zywność nam odbierali wracaliśmy znicym trzeba było nieros przymierać głodem zacym sie coś zdobyło (JSta: 21).

Zwrot ten - odnotowany w Słowniku gwar polskich (SGP VIII: 468) i Leksykonie Kąsia (KąśILG III: 363) - oznacza 'cierpieć niedostatek, żyć w nędzy; głodować'. Jego elementy semantyczne sugerują wyczerpujące i długotrwałe doświadczanie braku pożywienia. Podobne konotacje zawiera także metaforyczny zwrot personifikujący omawiane pojęcie: głód bije $\{k o g o s ́\}$. W SGP można odnaleźć podobnie brzmiący związek wyrazowy przebić głód, jednak w znaczeniu 'chwilowo zaspokoić pragnienie pożywienia się’ (SGP VIII: 468), natomiast w gwarze podhalańskiej frazem głód bije \{kogoś\} można zdefiniować jako 'przewlekłe i uciążliwe odczuwanie niedosytu':

Posłak tam do kancelaryje i powiedziałak, co mom chłopa i brata. Głód ik bije i bida przygnębio (MMrug: 128 ur. 1859).

O długotrwałości głodu świadczy także występowanie omawianego wyrazu w kolokacji z czasownikiem panować, którego elementy semantyczne - kategoria aspektu - sugerują dłuższe trwanie w czasie:

Niemcy rabują bydło zesypki owsa ziemniaków mleko do mleczarni za bezcen jajka od kur wełne z owiec wszystko zabierają, wywożą ludzi: w obozy chwytają ludzi do Niemiec na ciężkie roboty, pola stają się odłogiem, uprawy żadnej niema buty na przydział drewniaki głód panuje tak we wsi jak i na mieście chleba nigdzie niema (MJak: 12-13).

Cytowany tekst dowodzi tego, że głód swym zasięgiem obejmuje większą przestrzeń (głód panuje tak we wsi jak i na mieście), a jego obecność była rozumiana metaforycznie, bowiem czasownik panować kojarzy się z rządami surowego władcy, który podporządkowuje sobie ludzi.

Samo uczucie głodu, pojmowane już w wymiarze indywidualnym z punktu widzenia górala, także ma charakter permanentny. Odzwierciedla to często pojawia- 
jące się połączenie wyrazowe fort głodny. Przysłówek fort oznacza 'ciągle, wciąż, nadal, w dalszym ciągu' (SGP VII: 604):

Bo choć [boginki - E.S.] miały swoje dzieci, ale te ik dzieci były straśnie brzyćkie na gębie, a ku temu fort głodne, ze biyda ik było nakormić. Bez to tyz baby musiały straśnie uwazować na swoje dzieci i zaroz po krzcie iść ś nimi do kościoła na wywód (FSik: 33-34).

Oprócz długotrwałej dotkliwości i uciążliwości za językową cechę głodu można uznać także pewną skrajność, do której prowadzi przewlekłe odczuwanie niedosytu. W tekstach podhalańskich ten składnik JOS reprezentowany jest przez taki zwrot jak: skapceć / skapać z głodu, który w Leksykonie definiowany jest jako 'zmarnieć, zniszczeć z powodu głodu' (KąśILG X: 108):

Biydnemu nigdy nomniejsyj krzywdy nie zrobił - ba go jesce zratowoł. E! bo sie ta i jego za młodu biyda selniejako dość nacubrzyła. Gruntu nie było, a tu ociec i matka starzy, nie robili nic. Siostra, sietniok - co ledwo grul uskrobała. Brata poraziło, co z pościele nie śloz - trza było syćkik wyzywić, coby z głodu nie skapali (GSP: $130)$.

O dramatycznej konsekwencji długookresowego braku jedzenia świadczy także związek wyrazowy ginać / mryć z głodu, który znaczeniowo odpowiada frazemom: mrzeć głodem, umierać z głodu, czyli ‘być bardzo głodnym' (SGP VIII: 468).

Ginać / mryć z głodu nie odnosi się jedynie do znaczenia przenośnego, ale także opisuje rzeczywiste przypadki śmierci z braku pożywienia, co znajduje potwierdzenie w tekstach:

Ilu tu górali tłukło się po węgrzech, nieraz marli z głodu wracając do domu gdy zarobku na węgrach nie znaleziono (WBrz87 1938: 52).

Czasami zima trwała długo, przyszedł maj wielki maj a tu zimno i zima trwa już dawno siana hybiło. Stary Firek Gąsienica wsyeł na sopę, pozbieroł [proch] ze siana zamiot owcom i tak straśnie zabiadkoł: „Jezus Marjo zaginiemy”. Kie przyseł ciepły wiaterek ku północy, śnieg w mgnieniu oka zginął trawa się zaraz puściła i statek z głodu nie zginąl (WBrz87 1938: 42).

Frazem puknąc z głodu odnosi się do tego samego znaczenia, gdyż jedną z definicji czasownika puknać w gwarze podhalańskiej jest 'przestać istnieć, skończyć się' (KąśILG IX: 366):

Marysia: Jasiu, przyniesłak ci moskolicka, nawet i z masłem, specjalniek go lo tobie upiekła.

Jaś: No wiycie, wiycie, coz sie tak o mnie boicie, cobyk od głodu nie puknon? (FSik: 137). 
Wyekscerpowany z tekstów materiał pozwala określić głód jako niechcianego towarzysza człowieka. Jest on obecny podczas różnych czynności i oddziałuje niejako w tle ludzkiej aktywności. Dowodzi tego wyrażenie być (robić coś) o głodzie ‘być, robić coś, będąc głodnym' (SGP VIII: 469; KąśILG VII: 268):

Tego Staszka ja chciałem nauczyć rzeźby [...] widziałem jego zamiłowanie a niewiedziałem o tem ze brat jego jest temu przeciwny i namawia ojca by chłopcu jeść nie dawano i chłopak o glodzie był cały dzień a tak pragnął sie nauczyć (WBrz100 1940: 30).

Omawiany frazeologizm występuje także w niedyferencjalnej formie być (robić coś) o głodzie i o chłodzie (WSJP):

Przyjechaliśmy pod wieczór do Nowego Targu dalej pociągu nie było, więc nocowaliśmy u pewnych biednych ludzi, gdzie nam dali słomy na podłogę, Mama pościeliła własną chustkę i przespaliśmy do rana naturalnie o glodzie i o chłodzie (JKul: 19).

Ten związek frazeologiczny intensyfikuje dolegliwość związaną z odczuwaniem niedosytu podczas wykonywania różnych czynności. Podobnie jest w przypadku przysłówkowej wersji tego samego zwrotu, czyli głodno i chłodno (WSJP), który bywa także rozbudowany o stwierdzenie $i$ du domu daleko i oznacza 'bardzo niekorzystną sytuację, kiedy wszystko idzie źle' (SGP VIII: 425):

Ludzie przyśli na tom ziym późno, dopiero ftej, kie juz lepsej ziymi zacyno na dolinak brakować. A moze i temu, ze nie kcieli uginkać karku i woleli zyć chłodno i glodno, ale ślebodno (JPit: 7).

W tym przypadku głód został zestawiony ze ślebodą, czyli wolnością (KąśILG X: 494). Stanowi to dobitny przykład cenienia przez górali wolności, która miała większe znaczenie niż komfort czy zaspokajanie głodu - nie bez przyczyny więc ta wartość jest jednym z kulturemów podhalańskich (Rak 2015: 179-188).

Warto zauważyć, że leksem głodno wytwarza szersze konotacje, ponieważ już frazeologizm głodno i chłodno funkcjonuje jako 'wyrażenie używane na określenie niewygód, niedostatku, złych warunków bytowych' (WSJP). Zatem związek wyrazowy z przysłówkowym derywatem rzeczownika głód określa szeroko pojętą biedę. Intensyfikującą funkcję ma także zestawienie leksemu głód z przymiotnikowymi określeniami: strasny, okrutny, prowdziwy.

Analizowane pojęcie wykazuje łączliwość z wyrazami nacechowanymi negatywnie. Posługując się terminologią Jerzego Bartmińskiego, głód tworzy kolekcje z takimi słowami, jak: biyda, chłód, śmierzć, strak, sieroctwo czy wojna. Podane elementy zostały skategoryzowane w naturalne zespoły na podstawie jedności miejsca i czasu ich występowania (Bartmiński 2010b: 128). W tekstach gwaro- 
wych nagromadzenie tych określeń wzmacnia przekaz i zwraca uwagę na prezentowane treści:

Młode roki Frankowe przypadły na zły cas. Jesce nie skóńcył skoły, kie przysła wojna. Strak, biyda, głód i śmierzć (JPit: 113).

W lecie to ta jesce pół biedy, ale w zimie niek ta Pombóg zachowo. Zimno, głód i strak (JPit: 117).

I takie róźne myśli nachodzieły go dniami i nocami. Zbacowoł se swoje sieroctwo, wojne, biyde, kie nie było chleba (JPit: 142).

Teksty gwarowe można analizować także pod kątem ustabilizowanych połączeń słownych, które ilustrują sytuację niedoboru pożywienia, choć nie zawierają leksemu głód. Należą do nich m.in. stwierdzenia: ni ma co jeść, ni ma chleba:

Napisołek te pore słów ku pamięci tym, ftorzy ni mieli w doma co jeść, ba od małego dziecka musieli iść na słuzbe. A było takik na Podholu dość (FSik: 30).

W downyk casak we wsiak podhalańskik nigda nie było chleba za dość. Cym blizej hól, tym biydniej (JPit: 19).

Kolejnym elementem gwarowego obrazu głodu jest wskazanie jego źródeł. Według dawnych wierzeń górali klęskę nieurodzaju sprowadzał płanetnik, mający władzę nad chmurami. Był to baśniowy duch, mający moc sprowadzania gwałtownych burz, ulewnego deszczu i gradu, który niszczył plony, co w efekcie powodowało brak pożywienia (Pełka 1987: 72).

Składnikiem językowego obrazu głodu jest także czas jego występowania. $\mathrm{Z}$ relacji pamiętnikarskich wynika, że głód był szczególnie dotkliwy w czasie przednówka, czyli 'w okresie przedwiośnia, w czasie przed nowymi zbiorami' (HodSG: 200):

Wtej na Podholu była biyda, a nobarzyj dawoł sie we znaki przednówek. Ludzie warzyli warmuz. Było to takie jedzenie ryktowane z młodego ostu i inksej trowy, co rośnie na grzędzie pomiędzy grulami, kapustom i korpielami (FSik: 229).

O tym, że głód był szczególnie dotkliwy w tym okresie świadczy także przysłowie: wtedy głod, kiedy kwitniy bob, odnotowane w monografii Kulturemy podhalańskie (Rak 2015: 251).

Głód z natury rzeczy warunkował także pewne zwyczaje żywieniowe. W pamiętnikach można odnaleźć wiele nazw potraw i roślin służących do przyrządzania pożywienia. To zagadnienie stanie się tematem osobnej pracy, jednak w tym miejscu należy wspomnieć o tzw. głodowych pokarmach, do których należał wspomniany już warmuz, czyli posiekane i ugotowane liście różnych roślin, 
czasem z dodatkiem serwatki, mąki lub ziemniaków. Bywa on określany mianem głodowej zupy (Kustosz 2018: 158). Do przygotowania warmuzu używano m.in. lebiody / łobody, scyrboka, musetu, pokrzyw, sypułek. Zbierano także pyrz, którego kłącze w czasach głodu suszono i mielono na mąkę. Inną potrawą głodową był borsc z mlecu, gotowany z mlekiem i ziemniakami lub mąką owsianą. Pożywiano się także bryjom, kloskami czy zaciorkom. To jedzenie, choć ubogie, było jeszcze godne człowieka, jednak głód w swej skrajnej postaci zmuszał ludzi do spożywania znacznie gorszych rzeczy. Potwierdzają to relacje górali więzionych przez funkcjonariuszy władzy okupacyjnej. W sytuacji dręczącego braku pokarmu jedli oni spleśniałe produkty, łupiny czy nawet jedzenie przeznaczone dla psa:

poodejściu wartownika odebrałem ten rondel psu i zesmakiem tenpsi obiat sam zjadłem i tobył pierwszy muj dzień wwięzieniu cosobie dosyta się posielił (JSta: 65).

W końcu wojna sie końcyła i przyśli syćka du domu. Ale po poru dniak przyśli do niego towarzysio z bezpieki i wywieźli go jaze w góry Ałtaj. Tam przezył w strasnyk warunkak trzy roki. Opowiadoł późnij, ze coby przezyć, trza bylo nieroz jeść lupiny (JPit: 105).

Dręczący głód był także motywacją do niemoralnych zachowań podczas niemieckiej okupacji. Niektórzy górale, kuszeni perspektywą poprawy warunków bytowych, zdecydowali się przyjmować kenkarty i współpracować z zaborcą. Obrazuje to fragment pamiętnika, który zawiera metaforyczne przedstawienie kolaboracji z Niemcami:

Było dla nas Gurali straszne i zarazem bardzo smutne czasy poprostu mrozące krew wzyłach zetonasi ludzie dali sie moze zakromke chleba posmarowanego niemieckim masłem uwieść namowom krzeptowskiego i jego słurzalcom zaco puźniej ponieśli słuszną i zasłurzoną kare pszes naszą Polską Partyzantkę (JSta: 19).

Na podstawie powyższej analizy można stwierdzić, że głód zapadł w pamięć górali piszących wspomnienia. Wyekscerpowany materiał dowodzi tego, że omawiany leksem był używany najczęściej w znaczeniu prymarnym, chociaż obecne są wyrazy i frazeologizmy w użyciu metaforycznym. Brak jedzenia przez autorów pamiętników był wartościowany negatywnie, na co wskazuje także tworzenie kolekcji z nazwami pejoratywnych wartości, stanów emocjonalnych i doznań. Pojawiał się na dłużej jako wynik klęsk żywiołowych czy wojen lub po prostu trwał, bez względu na przyczynę. W świetle utrwalonych połączeń wyrazowych głód był czymś, co zjawiało się wbrew woli człowieka, trwało przeważnie dłuższy czas i wywierało niepożądany wpływ. Głód także zmuszał do niemoralnych, a nawet uwłaczających ludzkiej godności zachowań. 
Powyższy dawny obraz głodu można zestawić ze współczesnym rozumieniem tego pojęcia, opierając się na wynikach badań ankietowych. Zmiana punktu widzenia uwarunkowana zmianą doświadczeń życiowych młodych górali pozwoli wskazać różnice dotyczące długotrwałości głodu, jego dolegliwości i społecznej szkodliwości, a także ujawnić znaczenia przenośne analizowanego słowa i nowe konotacje. Współczesny obraz głodu stanie się przedmiotem kolejnych opracowań.

\section{SuMMARY \\ Podhale Phraseology in Diaries and Stories of Highlanders As a Source of Reconstruction of the Linguistic Picture of Hunger}

This article aims to reconstruct the components of the linguistic picture of hunger in the Polish Highlands. The crucial method used in the analysis is the linguistic picture of the world created by Jerzy Bartmiński and other scholars of the ethnolinguistic field. The realisation of these methodological assumptions consists in the exploration of the following: systematic data, survey data and textual evidence. Thereupon, the texts in Podhale dialect (diaries and stories) collected at the Tatra Museum Archives are analysed using the information from dialect dictionaries, phraseology dictionaries and other Polish language dictionaries, as well as the generalized survey results.

Based on the carried-out research, it can be concluded that hunger is printed in the highlanders' memory. The studied excerpts prove that this particular lexeme was mainly used in its basic meaning, although, phrases and idioms with a metaphorical indication can also be found. Lack of food was perceived as something negative as evidenced by the listings of pejorative names describing values, emotional states and experiences. Hunger visited the highlanders' houses as a result of natural disasters and wars, or it simply lasted regardless of its cause. After thorough consideration of idioms and phrases deeply rooted into the highlanders' dialect, hunger is portrayed as something that came against people's will, usually lasted for a long time and had bad influence - if forced its victims to behave immorally or even do things that were perceived to be degrading to human dignity. 

Sacrum i profanum 



\author{
Monika Bulawa (1) \\ Instytut Języka Polskiego Polskiej Akademit Nauk, Kraków \\ monika.bulawa@ijp.pan.pl
}

\title{
ŚWIĘTy WALENTy We FRAZEOLOGIZMACH
}

\section{PRZYSLOWIACH POLSKICH}

Słowa klucze: Święty Walenty, frazeologizmy, przysłowia, prognostyki

Keywords: St. Valentine, phrasemes, proverbs, weather proverbs

\section{Uwagi wstępne}

Opracowanie to, poświęcone funkcjonowaniu we frazeologizmach oraz paremiach postaci św. Walentego, powstało na marginesie moich zainteresowań gwarowymi nazwami chorób. Badając je, spotkałam się z nazwami padaczki, których jednym z komponentów było imię świętego: choroba / chorość / cierpienia / przypadek / słabość / stabota świętego Walentego. Ponieważ jednostki tego typu, znane też w dawnej polszczyźnie niegwarowej, motywowane są tym, że św. Walenty był patronem osób chorób na epilepsję, zwracają uwagę na fakt, że we współczesnej kulturze polskiej funkcjonuje on $\mathrm{w}$ zupełnie innej roli - a mianowicie patrona zakochanych, od którego imienia pochodzi nazwa ich święta, czyli walentynki.

W Polsce jest to zwyczaj stosunkowo nowy, upowszechniony dopiero po przemianach politycznych $1989 \mathrm{r}$. Mimo zachowanych w nazwie związków z postacią św. Walentego ma charakter całkowicie świecki, stanowiąc jeden z wielu przejętych przez Polaków elementów popkultury amerykańskiej. Można jednak zauważyć w Kościele katolickim pewne próby schrystianizowania tego zwyczaju i powiązania go z postacią męczennika, od którego imienia wziął swoją nazwę. W Krakowie ośrodkiem kultu św. Walentego w nowej roli jest kościół św. Floriana przy ul. Warszawskiej, gdzie znajduje się obraz tego świętego z pierwszej połowy XVIII w. oraz jego relikwiarz i gdzie co roku odbywają się specjalne nabożeństwa walentynkowe dla zakochanych ${ }^{1}$. Popularność walentynek wpłynęła również

1 https://krakow.wyborcza.pl/krakow/1,44425,6258009,Sw_Walenty_przejmuje_wladze_ u_sw_Floriana.html (dostęp: 4 X 2019). 
pobudzająco na kult św. Walentego w tych miejscach, w których był on niegdyś żywy, później zaś podupadł. Tak stało się np. w Chełmnie, gdzie w jednym z kościołów przechowywane były fragmenty kości czaszki świętego. Kult jego przygasł w XIX w., choć zachowana została tradycja wystawiania relikwiarza na widok publiczny w dniu 14 lutego. Od 2002 r., jak możemy dowiedzieć się ze strony internetowej parafii, „[...] Msza św. w Farze przed wystawionym relikwiarzem stała się jednym z punktów miejskich uroczystości walentynkowych"2.

Tak zmienne losy kultu św. Walentego w Polsce zachęcają do przyjrzenia się, jak dawniej patron ten funkcjonował w naszej kulturze i jakie znalazło to odzwierciedlenie we frazematyce oraz przysłowiach.

\section{2. Święty Walenty i jego obecność w kulturze ludowej}

O samym św. Walentym, męczenniku z pierwszych wieków chrześcijaństwa, wiadomo niewiele. Co więcej - istnieje nawet niepewność, czy pod tym mianem kryje się jedna osoba, czy też dwie różne. Jak podaje Księga imion $i$ świętych Henryka Frosa i Franciszka Sowy, do niedawna w Martyrologium Rzymskim pod dniem 14 lutego widniało dwóch męczenników, z których jeden śmierć poniósł w Rzymie, drugi zaś w Terni. Obecnie jednak przypuszcza się, że chodzi o jedną postać: albo o biskupa z Terni, którego kult dotarł do Rzymu, albo też - na odwrót - o męczennika rzymskiego, którego kult, gdy dostał się do Terni, ,„poczytany został za kult lokalny, oddawany pierwszemu biskupowi tego miasta" (Fros, Sowa 2007: 15).

Mimo że sam św. Walenty jest postacią raczej enigmatyczną, znane są wczesne świadectwa jego kultu. Na początku IV w. czczono już grób męczennika, nad którym papież Juliusz I wybudował bazylikę. Ogromną popularność zyskał święty w późnym średniowieczu. Brak pewnych informacji o nim nie przeszkodził w rozwoju kultu, który opierając się na legendach, objął kraje całej niemal Europy, docierając również do Polski. W naszym kraju rozwinął się przede wszystkim w diecezji przemyskiej, gdzie św. Walentego uznano za jej patrona (Fros, Sowa 2007: 16; zob. też: Jagla 2004: 156-157). Relikwie męczennika znajdują się m.in. we wzmiankowanym już krakowskim kościele św. Floriana oraz w kościele św. Mikołaja w Krobi (wprawdzie w 1993 r. ukradziono z niego srebrną trumienkę, w której przechowywany był relikwiarz; jednak szczęśliwie parafia dysponowała również dodatkowymi relikwiami, które mogły zastąpić te, które do tej pory były wystawiane do publicznego kultu3).

2 http://www.wnmpchelmno.pl/kult-sw-walentego (dostęp: 4 X 2019).

3 https://www.polityka.pl/tygodnikpolityka/spoleczenstwo/1524119,1,sw-walenty-opiekuje-sie-zakochanymi-z-krobi.read (dostęp: 4 X 2019). 
Jak już wspomniałam, był św. Walenty patronem od epilepsji, do którego modlono się o uleczenie z tej choroby oraz o uchronienie przed nią, por. np.: „Zwykli ludzie z nabożeństwa pościć ku ś. Apolonii i ku ś. Walentemu, aby ich bóg [sic] uchował, przez przyczynę ś. Apolonii od bolenia zębów, i przez zasługi św. Walentego od ciężkiéj onéj a okrutnéj niemocy” (SL VI: 214); „Mówiąc o wielkiéj chorobie, powinno się mówić: niech śpi jak święta ziemia, wielką chorobę miewa P. N. N. albo też: święty Walenty, wielką chorobę miewa P. N. N.” (SL VI: 214). Praktyka przedstawiona $\mathrm{w}$ drugim cytacie wiąże się $\mathrm{z}$ faktem, że padaczka była chorobą, której nazwa podlegała tabu językowemu, wynikającemu z obawy, iż jej wymówienie może przywołać chorobę (Krawczyk-Tyrpa 2001: 92-93; Buława 2019: 70, 387). Aby tego uniknąć, nie wypowiadano nazwy schorzenia, zastępowano ją jakimś określeniem omownym albo też - jeśli już nazwa była wymawiana - opatrywano ją formułką mającą zapobiec przywołaniu choroby. Z takimi właśnie formułami - znanymi też w kulturze ludowej (zob. Buława 2019: 387) mamy do czynienia w powyższym cytacie.

Jako uzdrowiciel św. Walenty występuje w legendach. W jednej z nich przywraca do zdrowia cierpiącego na padaczkę syna rzymskiego mówcy Kratona. W innej w pewien zimowy dzień opiekuje się chorym żebrakiem, ofiarując mu swój własny płaszcz. Jak się później okazuje, pod postacią żebraka ukrywał się sam Chrystus, który zwracając płaszcz Walentemu, w nagrodę za jego miłosierny uczynek obdarowuje go łaską uzdrawiania chorych na podagrę i padaczkę (Jagla 2004: 156). Również w ikonografii świętego akcentowano motyw jego uzdrowicielskiej mocy, przedstawiając go np. w towarzystwie leżącego u jego stóp epileptyka czekającego na cud wyleczenia (Jagla 2004: 158).

Przypuszcza się, że św. Walenty stał się patronem chorych na padaczkę na gruncie kultury niemieckiej w wyniku skojarzenia imienia tego świętego z niem. cz. fallen 'upadać, padać' (Brückner 1937: 1724; Jagla 2004: 157).

Również w źródłach etnograficznych i gwarowych znajdujemy informacje pokazujące, że święty ten funkcjonował w dawnej kulturze ludowej w roli patrona chorych na padaczkę i że do jego wstawiennictwa uciekano się w wypadku tej choroby (np. NT II 198; Wisła X: 342; Szychowska-Boebel 1972: 20). Istniała np. praktyka zamawiania mszy w kościele, któremu patronuje św. Walenty, oraz ofiarowywania świecy „na miarę chorego”: „Świecę tę zapalają podczas odprawiania mszy św., a równocześnie ze spalaniem się świecy, zmniejsza się i choroba. Gdy świeca zupełnie się wyświeci, choroba znika" (Spittal 1938: 129).

W jednym z tomów Ludu ... Kolberga znajdujemy informację, że dzień św. Walentego (14 lutego) był dniem, w którym chłopi udawali się na zabieg puszczania

4 „Chorobą św. Walentego przezwali Niemcy padaczkę [...], bo nazwa kilku świętych Walentych przypominała im ich «fallende Sucht», a myśmy to za nimi powtórzyli" (Brückner 1937: 172). 
krwi (uważany w medycynie ludowej nie tylko za zabieg leczniczy, ale też profilaktyczny). Takie objaśnienie tej praktyki podaje wspomniane źródło: „Ś. Walenty, patron chorób i padlicy; dla tego [sic] włościanie, co zaród chorób w krwi upatrują, zwykli w ten dzień krew puszczać" (Krak IV: 284).

Istniały ponadto w kulturze ludowej praktyki magiczne związane ze św. Walentym lub dniem jego wspomnienia, które miały chronić zboże przed szkodnikami (ptakami, myszami) lub chorobami. Są one następujące:

- należy zasiać 14 lutego na podwórzu trochę ziaren owsa, jęczmienia, jarej pszenicy, żeby ptaki i myszy nie wyjadały potem zboża w polu (PBTN III: 63);

- należy siać proso (Lud XII: 62; Zb VI: 276) oraz zboża jare, zwłaszcza jęczmień (PBTN III: 63), w tym dniu tygodnia, w którym w danym roku przypadało św. Walentego - nie będą wówczas jadły ich wróble (PBTN III: 63), bo nie będą wiedzieć, co to jest (Lud XII: 62), albo też dzięki temu uchroni się proso od śnieci (Zb VI: 276);

- należy przed siewem prosa zmówić pięć modlitw do św. Walentego, a w czasie siewu do nikogo się nie odzywać, aby ochronić proso przed wróblami (Zb VI: 276);

- należy w dniu św. Walentego przed wschodem słońca i po jego zachodzie obsiać popiołem zboże wzdłuż jego granicy - wówczas ,„śwenty Walenty bedzie wroble odganiał od tego zboza" (PBTN III: 63).

\section{3. Źródła materiału frazeologicznego i paremiologicznego}

Omawiane przeze mnie frazeologizmy oraz przysłowia pochodzą w większości z następujących źródeł:

- Ksiegga przystów Samuela Adalberga (KPP) oraz Nowa księga przystów polskich (NKPP); gdzie było to możliwe, korzystałam bezpośrednio z publikacji, z których zbiory te czerpały materiał: w takim wypadku odwołuję się do tych właśnie publikacji; przywołując przysłowia bezpośrednio za KPP oraz NKPP, podaję ich źródła wówczas, gdy wnoszą one informację na temat chronologii, gwarowego charakteru lub geograficznej lokalizacji danego przysłowia

- dwa zbiory przysłów ludowych: Przysłowia i zwroty powiedzeniowe z okolic Głogówka, zebrane przez Feliksa Plutę (PlutaPrzysł), Przysłowia $i$,pogodki” ludowe na Górnym Śląsku, zebrane przez Stanisława Wallisa (WallisPrzysł);

5 Oczywiście nie zawsze tytuły zbiorów, z których korzystano w KPP lub NKPP, pozwalają ustalić, jaki charakter (ogólnopolski czy gwarowy) mają zgromadzone w nich przysłowia.

${ }^{6}$ W wypadku materiałów gwarowych pozyskanych z tych oraz innych źródeł nie podaję szczegółowych lokalizacji, a jedynie informację, do jakiego dialektu należy gwara, w której dane przysłowie odnotowano. 
- Stownik gwar kaszubskich Bernarda Sychty (SGK).

Materiał XVII-wieczny pozyskany za pośrednictwem KPP oraz NKPP został poszerzony o frazeologizmy wyekscerpowane $\mathrm{z}$ następujących publikacji: - Szóste kazánie pokutne Adama Gdacjusza (SzKP), pisarza religijnego, duchownego luterańskiego; w kazaniu tym autor piętnuje grzech nadużywania imienia Pańskiego oraz złorzeczenia, stąd też dostarcza ono ciekawego zbioru przeklęć używanych w XVII-wiecznej polszczyźnie;

- opracowania Juliana Krzyżanowskiego (MG) oraz Doroty Adamiec (2007) (podobnie jak w wypadku materiału z KPP i NKPP korzystałam bezpośrednio ze źródeł, które przywoływali autorzy w tych opracowaniach).

W zebranym materiale imię świętego wystąpiło w formach: Walanty (w tekstach z XVI i XVII w.), Walenty oraz Walek.

\section{4. Święty Walenty we frazeologizmach i przysłowiach}

\section{1. Święty Walenty jako patron epileptyków}

Jak już wspomniałam, w dawnej polszczyźnie znane były nazwy padaczki motywowane patronatem św. Walentego. Jedna z nich wystąpiła w przeklęciu ${ }^{8}$ odnotowanym w XVII w.: Bodaj cię św. Walentego niemoc ${ }^{9}$ popadta! (KPP: 581). Choroba stanowi obok śmierci i niedoli jedną z trzech rzeczywistości, które przywoływane są w tego rodzaju aktach mowy jako kara dla osoby przeklętej (Engelking 2000: 246-262). Życzenie choroby wyrażane może być w nich w sposób ogólny, z użyciem hiperonimu (np.: Bodaj cię trzy choroby uttukty! (Lub I 26)), opisowy (np.: Bodaj ci się kiszki powykręcaly (Łęcz 11)) albo też z użyciem nazwy choroby (zob. takie formuły w: Engelking 2000: 246-248; Buława 2016a).

W przeklęciach tego ostatniego typu często występowały nazwy zarazy oraz paraliżu lub apopleksji (znane są one - z leksemami cholera oraz szlag - także współcześnie). W dawnej polszczyźnie oraz w gwarach można jednak znaleźć również przykłady na sięganie w nich po nazwy padaczki, choroby - podobnie jak wyżej wymienione - ciężkiej i niebezpiecznej, a więc także odpowiadającej celowi,

7 Od 2005 r. kaszubszczyzna ma status języka regionalnego. Zgodnie z tradycyjnym ujęciem uwzględniam jednak w swojej pracy również materiały kaszubskie (które zresztą - warto dodać - wciąż są wprowadzane do drukowanych po 2005 r. tomów Słownika gwar polskich PAN).

8 Terminu przeklęcie używam na określenie formuły słownej zawierającej życzenie złego losu (Engelking 2000: 132).

9 Niemoc świętego Walantego / Walentego 'padaczka' (SPXVI XVII: 381; SL III: 330). 
w jakim formułowane są przeklęcia, por.: Bodaj cię káduk $k^{10}$ porwat!; Bogdaj cię ciężka chorobá11 popádłá! (XVII w.) (SzKP 160-161); Bodaj cię wielga choroba ${ }^{12}$ tlukta! (Maz V 31); Bodaj cie padacka wziena (MPTL XXVI: 288).

Warto zauważyć, że choć sam Walenty nie występuje w przytoczonym przeklęciu w negatywnej roli, to jednak przywoływany jest w kontekście złorzeczenia. Jeszcze dalej w tym kierunku idą frazeologizmy, w których nie pojawia się nazwa choroby, ale samo imię patrona lub imię poprzedzone przymiotnikiem święty. Są to:

- porównanie ktoś płacze, jakoby go Walenty trząst: „Płakała, jakoby ją Walanty trząsł"13 (XVII w.) (PKR 216);

- przeklęcie bo(g)daj kogoś (święty) Walenty ciskat / popadt: „A bodajze cie święty Walanty ciskał, nigdyć ja tego nie cynię, ani będę cynił" (XVII w.) (PSM 274); „Juzem i maciezy [sic] łajał, co mię urodziła, bogdaj ją Walanty popadł” (XVII w.) (PKR 227); z elipsą: bodaj kogoś Walenty: „Bodaj że cię Walenty” (XVII w.) (W. Potocki, Ogród fraszek, za: NKPP III: 612).

Frazeologizmy te można interpretować na dwa sposoby. Po pierwsze, jako związki z eliptycznymi wersjami nazw padaczki z imieniem świętego, wersjami pozbawionymi hiperonimów typu choroba, niemoc, por.: ktoś płacze, jakoby go niemoc świętego Walentego trzęsła vs. ktoś placze, jakoby go Walenty trzast. Po takim przekształceniu dochodzi jednak do odwrócenia roli, w jakiej występuje święty - z patrona broniącego przed chorobą staje się jej sprawcą. Według drugiej interpretacji byłby to jednak nie „skutek uboczny” elipsy, lecz celowy zabieg. $\mathrm{Na}$ taką interpretację naprowadzają dawne niemieckie nazwy padaczki takie jak: St. Veltins-Rache ('zemsta świętego Walentego') oraz St. Veltins-Arbeit ('robota świętego Walentego'). Jak zauważa Jowita Jagla, historyk sztuki, badająca ikonografię patrona epileptyków, nastąpiło w ich wypadku

specyficzne dla religijności ludowej zamienienie pojęć, oparte na wierze w odwracalność mocy świętych. Należało ich czcić, ponieważ Wielcy Lekarze szybko przywracający ludzi do zdrowia mogli równie szybko odwrócić się od człowieka, który nie okazywał im szacunku. Co więcej, w ich mocy było „szafowanie” chorobą, z której leczyli - potrafili ją zesłać na ludzi w celu słusznego ich ukarania (Jagla 2004: 157).

10 Kaduk, zapożyczona $\mathrm{z}$ łaciny nazwa epilepsji, zaczęła funkcjonować później jako nazwa diabła; w przywołanym jednak przeklęciu, jak wyraźnie wskazuje kontekst, chodzi jeszcze o kaduk jako nazwę choroby.

11 Ciężka choroba 'padaczka' (SL I: 309; daw. SW I: 336).

12 Wielka choroba 'padaczka' (SL VI: 294; SW IV: 8), nazwa powszechna też w gwarach (SGP IV: 31-32).

13 W cytatach z PKR, PSM oraz ALS nie zaznaczam ewentualnego ucięcia ich początku lub końca. 
Przedstawione wyżej frazy bliskie są tych związków z imieniem patrona epileptyków, które można traktować jako wariantywne w stosunku do frazeologizmów z komponentem znaczeniowym 'diabeł' (zob. MG III: 154; Adamiec 2007: 114, 116, 119). Chodzi o związki z członem Walenty mające odpowiedniki, które zawierają rzeczownik diabeł lub jego bliskoznaczniki (szatan, zły duch), tożsame pod względem znaczenia, obrazowania oraz formy składniowej ${ }^{14}$. Do grupy tej należą:

- do Walentego: „Do Walantegoż, nie psesydzaj ze mnie” (XVII w.) (ALS 430); por.: do diabła / biesa (z czymś, z kimś) (Adamiec 2007: 116);

- idź do Walentego (z czymś): „Idźże do Walantego” (XVII w.) (PKR 189); „Idź do Walantego / Z twoją służbą" (XVII w.) (PKR 579); por.: idź do diabła (Adamiec 2007: 116);

- daj kogoś, coś Walentemu: „I sam coś, bez wątpienia, byłem śmierci blisko. / Gdziesi mię prowadzili tam do kollegium, / Dajże go Walantemu, toć tam barzo biją” (XVII w.) (PKR 336); „Dajze ich Walantemu” (XVII w.) (PKR 229); „Jednej skostowawszy krzusi się i spluwając mówi. Dajże je Walantemu, toć to rzeczy brzydkie, / Obiecuję, poruszą intestina wszytkie” (XVI w.) (PKR 99) (też: PKR 216, 219); por.: daj kogoś diabłu (Adamiec 2007: 119);

- porwano / porwan Walentemu / Walkowi: „Abo czasem imę wyć za cudzą oborą, / Jak wilkołek, to oni strachu sie nabiorą. / Wskok do połcia, wyślą mi sztukę mięsa dużą, / A porwano Walkowi, niechaj djabli służą" (XVII w.) (PKR 193); „Ho, porwan Walantemu, nie chcęć ja do niego” (XVII w.) (PKR 238); por.: porwono diabłu (Adamiec 2007: 117) ${ }^{15}$; porwoneś diabtu (SzKP 157);

- (święty) Walenty w kimś: ,Dobraś, Walanty w tobie” (XVII w.) (PKR 209); „Ciężkie niemocy, kordyjáki ${ }^{16}$, korfánty ${ }^{17}$, ś. Wálánty w tobie!” (XVII w.) (SzKP 161); por.: diabli / zły duch w kimś (,Dyabli w tobie! Zły duch w tobie!”) (SzKP 157) ${ }^{18}$;

- wie kogoś Walenty: „Trzeba nam zgoła chować uczone kantory, / To i onych będą mieć i nas za doktory. [...] A, a, wie ich Walanty, jako ich i chować” (XVII w.) (PKR 153-154); „A ja, wie go Walanty, kędy sie mam wrazić, / Jużem obszedł wszytek świat, już nie mogę łazić” (XVII w.) (PKR 202); „Ale

14 Odpowiedniki z leksemem diabet lub synonimicznym podaję z kazania A. Gdacjusza (SzKP) oraz z monografii D. Adamiec (2007), jako że zawierają one materiał odpowiadający chronologicznie frazeologizmom z członem Walenty (Walek).

15 „Znaczną wariancją formalną charakteryzuje się kolejne przekleństwo - frazeologizm, którego sens można sparafrazować 'niech coś przepadnie': diabłu porwony, diabłu porwono, porwan diabłu, porwon diabłu, porwono diabłu, porny diabłu, arwon diabłu. Częstokroć związek ten funkcjonuje jako wtrącony w tok wypowiedzi wykrzyknik" (Adamiec 2007: 117).

16 Kordyjaka 'bliżej nie określona choroba serca lub żołądka' (SPXVI X: 631).

17 Korfanty - śląska nazwa diabła (SESł II: 490).

18 Jak pokazuje materiał zebrany w SzKP, schemat składniowy coś w kimś mógł być w przeklęciach realizowany także z innymi elementami leksykalnymi, np.: „Fráncá w tobie!” (SzKP 161); „Piorun w tobie!” (SzKP 159). 
wie cię Walanty, szkoda z tobą chodzić" (XVII w.) (PKR 195); por.: wie kogoś diabet (Adamiec 2007: 114);

- Walenty komuś po kimśri ${ }^{19}$, Walantyż mi po tobie, po co żeś tu przyszła” (XVII w.) (ALS 428-429); por.: diabet / bies (byt / byto / będzie) (komuś) po czymś (Adamiec 2007: 69).

Jako przekształcenie imienia Walenty interpretowana jest też forma Walekko odnotowana w przeklęciu ksiadz Walekko w tobie (PKR 228) (MG III: 154; ALS 322).

Do używania przekleństw z imieniem Walenty odnosi się zapewne zwrot Walentymi ciskać, odnotowany w następującym cytacie: „Jeśli białogłowy będą o złych rzeczach myślić, Walentymi ciskać, takie pewnie wyrodków i cudów narodzą" (SL VI: 214).

Na tego rodzaju frazeologizmy zwrócił już uwagę J. Krzyżanowski, objaśniając je tym, że epilepsję przypisywano dawniej działaniu złego ducha: „Choroba, przeciw której uciekano się do wstawiennictwa św. Walentego, a która była dziełem diabła, sprawiła, że z biegiem czasu wyobraźnia ludowa poczęła obie te osobistości mieszać, że skoro to «choroba św. Walentego» czy po prostu Walka, a rezultat opętania przez diabła, to widocznie Walek jest imieniem owego złośliwego diabła" (MG III: 152-153). W ten sposób doszło do „przeosobliwej kontaminacji dwu przeciwnych wyobrażeń, sprawcy choroby i jej lekarza" (MG III: 153). Należy podkreślić, że do zaistnienia owej kontaminacji nie wystarczyłoby zapewne to, że św. Walenty był patronem od epilepsji, ważny był fakt, że imię jego występowało jako człon nazw tej choroby. Przeklęcie bodaj kogoś świętego Walentego niemoc popadła mogło ulec przekształceniu w bodaj kogoś Walenty popadt, co doprowadziło do powstania omawianych frazeologizmów wariantywnych.

J. Krzyżanowski przywołuje ponadto kilka cytatów z literatury sowizdrzalskiej, w których wyraz Walenty (Walek) wyraża ,zaprzeczenie o silnej barwie uczuciowej dającej wyraz niechęci, oburzeniu, gniewowi”, np.: „A Walentegoż by wilk miał w stodole działać!" - replika na wypowiedź Żaczka, który zapytany, czy chodzi do szkoły, odpowiada, że bywa tam równie często jak wilk w stodole; „Ho, Walkać mię witano, w dupęć mi to dano" - odpowiedź na pytanie, jak Wawrzek został przywitany w szkole (oba cytaty z Komedii o Wawrzku; więcej przykładów zob. MG III: 154-155).

Jako analogię do przedstawionego procesu semantycznego warto przywołać rozwój znaczeniowy zapożyczenia $k a d u k$, które przejęte zostało jako nazwa pa-

19 Komponent Walenty zastępuje tutaj zaimek nic (podobnie jak we frazeologizmie diabła wart). Dla frazy diabet / bies (byt / było / będzie) (komuś) po czymś D. Adamiec (2007: 69) podaje następujące znaczenie: 'nic dobrego, pożytecznego z czegoś nie wynikło / wyniknie; to wszystko na nic'. 
daczki (zob. przyp. 10), później nabrało zaś znaczenia ‘diabeł' (SESł II: 17-18), jak również inne tego rodzaju przekształcenia semantyczne, opisywane przeze mnie na materiale gwarowym, w wyniku których nazwa choroby zaczynała w danej gwarze być traktowana jako synonim rzeczownika diabet lub też funkcjonowała jedynie jako człon frazeologizmów wariantywnych w stosunku do jednostek z komponentem 'diabeł' (zob. Buława 2016b).

Biorąc pod uwagę kwestię rozpowszechnienia w polszczyźnie frazeologizmów z członem Walenty (Walek) ‘diabeł', należy zauważyć, że niemal wszystkie zostały wyekscerpowane z tekstów zaliczanych do literatury sowizdrzalskiej. Jak zauważa J. Krzyżanowski, występują one prawie wyłącznie w utworach rozgrywających się w środowisku chłopskim, autorzy zaś wkładają je zazwyczaj w usta chłopów: „Spostrzeżenie to wskazywałoby może, iż omawiane zwroty były charakterystyczne przede wszystkim dla «grubej mowy chłopskiej»" [...] (MG III: 155). Mają one ponadto zawsze nacechowanie komiczne (MG III: 156).

W materiałach gwarowych zgromadzonych w kartotece SGP nie znalazłam podobnych związków, z wyjątkiem gwar kaszubskich, gdzie znane były określenia walentyński diabeł (według definicji B. Sychty: 'bliżej nieokreślony zły duch, prawdopodobnie diabeł zadawany przez czarownicę ludziom w pożywieniu' (SGK VI: 50)) oraz walentyński (w użyciu rzeczownikowym). Używano ich w wykrzyknikach: do walamtyńsczëch djoblów! (SGK I: 211), oraz w przeklęciach: do kopë set walantyńskich djáblów, co bë jes jich zjád!, co bë jes walantyńskéło zjád, ale takiéło jak skopa! $!^{20}$ 'obyś diabła zjadł wielkiego jak skopa ${ }^{21}$ (SGK VI: 50-51), co dało asumpt do powstania zwrotu kląć walentyńskimi diabłami o znaczeniu 'mocno przeklinać' (SGK II: 169).

Przedstawione dotychczas związki odwoływały się - bardziej lub mniej bezpośrednio, czasami wręcz à rebours - do św. Walentego jako patrona chorych. $\mathrm{Z}$ tą też funkcją łączy się paremia $N a$ święty Walenty puszczaj krew choć z pięty (Ż. Pauli, Przysłowia i przypowieści ludu polskiego, za: NKPP III: 612) nawiązująca do wspomnianego wyżej zwyczaju upuszczania krwi w dniu tego właśnie świętego. U Adalberga znajdujemy również wariant tego przysłowia, mniej dla mnie jasny: Hej! św. Walenty wypuszcza z krwi tręty ${ }^{22}$ (węty) (XIX w.) (KPP: 581).

\subsection{Przystowia kalendarzowe}

Druga grupa zebranych przeze mnie jednostek to przysłowia kalendarzowe, w tym prognostyki, notowane zarówno w źródłach gwarowych, jak i o charakterze ogól-

20 Cytaty z SGK podaję w zapisie ortograficznym, jedynie z osobnymi znakami dla $a$ pochylonego (á), e pochylonego (é) oraz szwa (ë).

21 Skop 'kastrowany baran' (SGK V 54).

22 W gwarach tręt to nazwa trutnia. Nie wiadomo jednak, czy o tę jednostkę chodzi w przysłowiu. 
nopolskim. Przysłowia te nie odwołują się do żadnych specyficznych cech św. Walentego, a jedynie do dnia, w którym wypadało jego wspomnienie, czyli 14 lutego.

Przysłowia wiążą ten dzień albo z odwilżą, pogodą, która zaczyna zwiastować zbliżanie się zimy ku końcowi, albo - na odwrót - z mrozem. Do pierwszej grupy zaliczają się przysłowia przestrzegające przed jazdą w tym okresie po lodzie znajdującym się na rzece lub jeziorze - może bowiem być już zbyt słaby i się załamać:

- Na święty Walek nie masz pod lodem / nie ma (już) pod lodem / nie ma lód pod spodem balek ${ }^{23}$; przysłowie to notuje słownik Trotza: Na św. Walek nie masz pod lodem balek (za: KPP : 581), Słownik wileński (w brzmieniu jak wyżej) (SWil II: 1806) oraz Słownik warszawski: Na św. Walek nie ma lód pod spodem balek (SW VI: 328); występuje również w źródłach pokazujących przysłowia ludowe ${ }^{24}$, także przysłowia kaszubskie ${ }^{25}$;

- Święty Walek nie ma pod lodem balek (Śl WallisPrzysł 112); Świantygo Walka niy möu lód balka (Śl PlutaPrzysł 95); Na świętego Walka nie ma pod lodem balka (Ś1 WallisPrzysł 81; NKPP III: 612);

- Po świętym Walku niema [sic] pod lodem balku (J. Lompa, Przystowia i mowy potoczne ludu polskiego na Szlasku, za: KPP: 581); Po św. Walku lód już nie na balku (Śl WallisPrzysł 98);

- Ś́wiantyj Walek złómoł balek ${ }^{26}$ (Śl PlutaPrzysł 95); Świantyj Walek złómie balek (Ś1 PlutaPrzysł 95); Świantyj Walek złómie pod lodem balek (Ś1 PlutaPrzysł 95);

- Święty Walenty - połamie pod lodem pręty (Mp Zb VI 164).

Przysłowia kalendarzowe antonimiczne w stosunku do wyżej wymienionych, a zatem wskazujące na mróz panujący w dniu św. Walentego, są następujące:

- Świantyj Walek podeprze balek (Ś1 PlutaPrzysł 95); Świantyj Walek podtożót pod lód balek (Ś1 PlutaPrzysł 95);

- Święty Walenty odmrozil pięty (A. Pach, Przystowia podhalańskie, za: NKPP III: 612); Święty Walenty rad odmrozi pięty (J. Broda, Przysłowia cieszyńskie, za: NKPP III: 612).

Jako odwołanie do mrozu objaśniane jest w NKPP również przysłowie: Święty Walenty bywa nieugięty (W. Kunysz, Przystowia rzeszowskie, za: NKPP III: 612).

Mróz w dniu św. Walentego zapowiada, że zima będzie jeszcze długo trwała, stąd też przysłowia: Święty Walenty gdy odmrozi pięty, na wyżywienie sprzedawaj sprzęty (Śl WallisPrzysł 112; Mp Zb VI: 164); Gdy święty Walenty odmrozi pięty, to na żywność sprzedawaj sprzęty (Śl WallisPrzysł 42); Gdy święty Walenty odmrozi pięty, to na opat, wyżyienie i ubranie sprzedawaj sprzęty (M. Basa, Przysłowia

23 Ze względu na dużą liczbę poświadczeń zapisuję to przysłowie w postaci uogólnionej. W wypadku innych przysłów podaję bezpośrednio materiał.

24 Np.: Lub II: 167; Maz I: 116; Święt 571; Zb VI: 164.

25 Np.: Na swianty Walk ni ma ju pod lodem balk (SGK VI: 50).

26 W źródle forma balek zapisana od wielkiej litery. 
kieleckie, za: NKPP III: 612); Jak Walenty przymrozi pięty, trzeba sprzedawać na wyżywienie sprzęty (NKPP III: 612). Prawdopodobnie do sytuacji przedstawionej w wymienionych wyżej paremiach odnosi się też przysłowie $N a$ święty Walenty uciekaja z domu centy (J. Broda, Przysłowia wielkopolskie, za: NKPP III: 612).

Wśród prognostyków dominują przysłowia realizujące schemat „deszcz w dzień św. Walentego zapowiada mrozy":

- Gdy na święty Walenty deszcze, mrozy bywaja jeszcze (NKPP III: 612); Gdy na św. Walek dészcze - mrozy wróca jeszcze (Mp Zb VI: 164); Gdy na Walka sa deszcze, będzie ostry mróz jeszcze (Maz Maz I: 116; NKPP III: 612); Gdy na Walka są désce, Bedzie duzy mróz jesce (Mp Święt 571);

- Święty Walenty dysce, bedzie wiela mrozów jesce (J. Świętek, Brzozowa i okolice Zakliczyna, za: NKPP III: 612); Walek deszcze, mrozy wróca jeszcze (J. Ondrusz, Przysłowia cieszyńskie, za: NKPP III: 612);

- Kiedy Walka skropia deszcze, mrozy cię poszczypia jeszcze (NKPP III: 612);

- Jak się Walek zeszczy, mróz jeszcze potrzeszczy (NKPP III: 612);

- Gdy wśw. Walek deszcz pada, druga zimę zapowiada (KPP: 581);

- Na św. Walentego - bywa zwykle mróz niczego. Ale jak Walek się rozdészcze, pewne mrozy wróca jeszcze (Ś1 Zb VI: 164); Na świętego Walentego trzyma zwykle mróz niczego, lecz jak Walek się rozdeszcze, pewnie mrozy wróca jeszcze (NKPP III: 612).

Do przeciwstawnej sytuacji - wiążącej okres roku, w którym przypada dzień św. Walentego, z początkiem ocieplenia - odwołują się z kolei przysłowia:

- Jak Walenty nie poleje, to na wiosne masz nadzieję (NKPP III: 612);

- Scholastyka ${ }^{27}$ - mróz utyka, a nim Walek nam zaświęci, obaczyma, mróz kark skręci (Maz Maz I: 116; Mp Zb VI: 164); Scholastyka: Mróz utyka. Zanim Walek nám zaświéci, Obácywa - mróz kark skręci (Mp Święt 571).

W zebranym przeze mnie materiale znalazły się również dwa przysłowia, których interpretacja nie jest jednoznaczna. Pierwsze z nich występuje w dwóch wariantach:

- Święty Walek tych powali ${ }^{28}$, co patronem go nie znali (KPP: 581; Śl WallisPrzysł 112 29);

- Święty Walek tych powali, co patronem go nie zwali (Maz Maz I: 116; Wisła III: $\left.946^{30}\right)$.

W jednym ze źródeł przysłowie to (w wersji co patronem go nie zwali) opatrzone zostało komentarzem: „Gdyż często już lód jest wtedy tak słaby, że często

27 Dzień św. Scholastyki przypada 10 lutego.

28 Według J. Karłowicza mamy tu do czynienia z przypadkiem ,przystosowania imienia św. Walentego do wyrazu walić" (Wisła III: 946).

${ }_{29}$ Z nieco innym szykiem: Święty Walek tych powali, co go patronem nie znali.

30 Jako ,przysłowie ludowe”, bez lokalizacji. 
ani przejeżdżać ani przechodzić po nim nie można" (Maz I: 116). A zatem jeśli ktoś, nie wiedząc lub zapomniawszy o tym, że jest dzień św. Walentego, a więc dzień, kiedy lód już nie jest mocny, wejdzie lub wjedzie na zamarzniętą rzekę lub jezioro, ulegnie wypadkowi. W takim ujęciu przysłowie to również nawiązuje do motywu pogody panującej w dniu św. Walentego, tyle że w sposób pośredni. Inaczej interpretuje je J. Krzyżanowski (MG III: 152), według którego odnosi się ono do epilepsji (tak samo w NKPP III: 612). Według tej interpretacji fraza Święty Walek tych powali odnosiłaby się zatem do upadku chorego na ziemię podczas ataku choroby. Podobnie - czyli jako przysłowie odnoszące się do epilepsji - NKPP III: 612 traktuje przysłowie: Św. Walek narobić może kalek (SW II: 207; Krak IV: $\left.284^{31}\right)$. Jednak również w tym wypadku chodzić może o tę samą sytuację, do której odnosi się - według innej interpretacji - przysłowie Święty Walek tych powali, co patronem go nie znali / nie zwali.

W zebranym materiale znalazła się ponadto paremia Każdy Walenty ma swoje wykręty (Wp Zb II: 175), nie nawiązująca do indywidualnych cech św. Walentego, lecz będąca jedynie przekształceniem znanego przysłowia Każdy święty ma swoje wykręty.

Na marginesie poruszanej w tej pracy problematyki warto dodać, że w wykorzystanych przeze mnie zbiorach paremiologicznych zawarte były również jednostki, w których występowało imię Walenty (Walek), które jednak nie odnosiły się do świętego o tym imieniu. Są to: Walek czubit Maćka, Maciek czubi Walka (KPP: 581, z objaśnieniem: „T.j. szczęście jest zmienne; raz ten, drugi raz ów górą); Grzmij, Walenty; Rżnij, Walenty, Bóg się rodzi” (NKPP III: 611, z objaśnieniem: „Zachęta do działania; także zwrot karciany”).

$* * *$

Podsumowując przedstawiony materiał, należy stwierdzić, że w polskiej frazeologii oraz paremiologii występują odwołania do postaci św. Walentego w dwóch funkcjach: jako opiekuna epileptyków, którego imię stanowiło komponent dawnych nazw padaczki, oraz jako patrona dnia 14 lutego. W wypadku tej pierwszej funkcji doszło do specyficznego odwrócenia roli świętego, którego imię zaczęło funkcjonować we frazeologizmach jako nazwa diabła. $Z$ tego rodzaju przekształceniami spotykamy się $\mathrm{w}$ literaturze sowizdrzalskiej. W gwarach kaszubskich przymiotnik utworzony od imienia świętego występował w przeklęciach i wykrzyknikach jako określenie rzeczownika diabeł lub też samodzielnie (w wyniku substantywizacji). Przysłowia kalendarzowe, w tym prognostyki, odnoszące się

31 W tym źródle w postaci: Święty Walek-narobić może kalek-(ów). 
do dnia św. Walentego poświadczone są zarówno w źródłach reprezentujących polszczyznę ogólną, jak i w zbiorach przysłów ludowych.

\title{
Wykaz skrótów geograficznych
}

\author{
Maz - Mazowsze \\ Śl - Śląsk \\ $\mathrm{Mp}$ - Małopolska \\ Wp - Wielkopolska
}

\section{Summary \\ St. Valentine in Polish Phrasemes and Proverbs}

There are references to St. Valentine in Polish phraseology and paremiology in which he has two functions: as a guardian of epileptics whose name used to be included in old names of epilepsy and as a patron of February 14. In the first case there was a specific reversal of the role of a saint as his name started to appear in phrasemes to denote the devil. This kind of transformations can be encountered in the seventeenth century picaresque literature. In Kashubian dialects the adjective formed from the name of the saint could be found in swearwords and expletives to define the noun devil or independently (as a result of substantivisation). It has been proved that calendar proverbs, including the forecasting ones that refer to St. Valentine's day, exist both in sources that represent General Polish as well as collections of folk proverbs. 



\author{
Emil Poplawski [1] \\ Instytut Języka Polskiego Polskiej Akademit Nauk, Kraków \\ emil.poplawski@ijp.pan.pl
}

\title{
ROK ROLNICZO-GOSPODARSKI W ŚWIETLE PRZYSLÓW W GWARACH POLSKICH (OD ŚW. ELIASZA - 20 LIPCA, Do ŚW. TOMASZa - 21 grUdNia)
}

Słowa klucze: przysłowie kalendarzowe, gwary polskie, kalendarz liturgiczny, święto liturgiczne, kultura ludowa

Keywords: proverb related to the calendar, Polish local dialects, liturgical calendar, liturgical festival, folk culture

Przysłowia - poza innymi swoimi walorami - pozwalają na wgląd w kulturę materialną i duchową uobecniającą się $\mathrm{w}$ danym czasie i na określonym terenie. Przechowują bowiem wiedzę i przekonania ludzi wynikające zwykle z obserwacji otoczenia czy praktyki życiowej. Ta wiedza i przekonania, wyrażane w lapidarny sposób i w formie łatwej do zapamiętania, ujawniają się i utrwalają w codziennej komunikacji językowej. Uwzględnienie takiej perspektywy badawczej w postrzeganiu przysłów sytuuje podejmowane rozważania na gruncie lingwistyki kulturowej ${ }^{1}$.

W zasobie polskich paremii, notowanych w języku literackim i w gwarach, sporą grupę stanowią przysłowia kalendarzowe. Zalicza się je do tzw. przysłów niewłaściwych, czyli takich, które nie mają wszystkich cech przypisywanych paremiom $^{2}$. Charakteryzując się dydaktyzmem, małą zmiennością ${ }^{3}$ i powszechnością, nie posiadają - obok dosłownego - znaczenia alegorycznego (ważniejszego w przypadku przysłów właściwych) oraz - przez fakt, że nie przekazują abstrak-

\footnotetext{
Te uwagi można odnieść również do frazeologizmów.

Ustalenia te przejmuję z NKPP (I: VIII-IX).

3 W niniejszym referacie pole obserwacji ograniczyłem do jednostek notowanych w dialektach polskich. Na gruncie gwar przysłowia (jak też frazeologizmy) wykazują dość dużą wariantywność. Dzieje się tak z powodu specyfiki analizowanego materiału. Gwara to nieskodyfikowana, ustna odmiana języka. W związku z tym jest bardziej podatna na modyfikacje i zniekształcenia.
} 
cyjnych treści - nie odwołują się do prostych obrazów, które miałyby je dobitnie wyrazić (cecha obrazowości).

Przysłowia kalendarzowe (zarówno te notowane w języku literackim, jak i w gwarach) wpisują się w grupy tematyczne dotyczące różnych aspektów rzeczywistości, np.: pogody; życia przyrody; pracy na roli, w gospodarstwie; życia (ludzi, zwierząt, roślin) zgodnego z cyklem przyrody (i przyjętymi obyczajami) czy sytuacji bytowej człowieka ${ }^{4}$. Paremie odnoszące się do prowadzenia gospodarstwa wiejskiego ${ }^{5}$ można ułożyć właśnie zgodnie z kalendarzem. Wówczas rysuje się przed nami rok rolniczo-gospodarski.

W niniejszym referacie skupię się na drugiej części roku, obejmującej czas od drugiej połowy lipca do drugiej połowy grudnia i uwzględnię przysłowia notowane - poza gwarami - też w języku literackim. Pierwsza część tych analiz została opublikowana $\mathrm{w}$ tomie pokonferencyjnym Język $w$ regionie, region $w$ języku 2 (Popławski 2017). Obejmowała ona czas od drugiej połowy lutego (od wspomnienia św. Macieja Apostoła - 24 lutego ${ }^{6}$ ) do końca czerwca (do wspomnienia św. Pawła Apostoła - 29 czerwca) $)^{7}$

\section{Lipiec}

Kilka przysłów wiąże się z trzema dniami świątecznymi w lipcu. Pierwszym z nich jest liturgiczne wspomnienie św. Eliasza, obchodzone 20 dnia tego miesiąca. Do wskazanego święta odnoszą się dwie paremie dotyczące uprawy ziemi: Ilij! nie psuj roli ${ }^{8}$ oraz $\mathrm{Na}$ święty Eliasz do potudnia przeoruj, po potudniu w za-

4 W swojej pracy dotyczącej frazemów z biblijnymi nazwami osobowymi w gwarach polskich, w której opisałem przeszło 250 przysłów (wśród prawie 500 jednostek), ujawniło się ponad 20 grup tematycznych paremii (Popławski 2014).

5 W mojej pracy (Popławski 2014) są to przysłowia zakwalifikowane do czterech grup tematycznych dotyczących: pracy na roli, w gospodarstwie; pracy na roli, w gospodarstwie i pogody; pracy na roli i życia przyrody oraz pracy na roli, w gospodarstwie i życia zgodnego z cyklem przyrody.

6 Obecnie wspomnienie św. Macieja Apostoła obchodzone jest 14 maja. Do czasu reformy kalendarza liturgicznego, dokonanej w 1969 r., wypadało ono 24 lutego (do dziś termin ten utrzymali luteranie i starokatolicy). W przysłowiach notowanych zarówno w języku literackim, jak i w gwarach, odnoszących się do tego świętego, utrwaliła się wcześniejsza data jego wspomnienia w liturgii.

7 Dokumentacja źródłowa i geograficzna przysłów prezentowanych w obu częściach opisu roku rolniczo-gospodarskiego znajduje się w przywoływanej już mojej pracy dotyczącej frazemów z biblijnymi nazwami osobowymi w gwarach polskich (Popławski 2014).

8 Przysłowie to ma proweniencję wschodniosłowiańską. Do gwar polskich trafiło w wyniku kontaktów grup etnicznych. Zachowała się w nim oryginalna postać imienia (ros. Илия; scs. Ilija, Illja, Elija, Olija; stukr. Илья, Илиа, Илїя). 
gon orz. Pierwszą z nich Oskar Kolberg tak objaśnia: „Od dnia [...] św. Eliasza [...] nie czas już przeorywać, tj. drugi raz orać pod żyto, ale trzeba już w zagon orać, tj. trzeci raz” (Maz V: 54). NKPP wiąże ją z pogodą, thumacząc: „Tzn. nie daj deszczu, bo już czas kończyć orkę pod nowy zasiew" (NKPP I: 554). Do tych samych prac polowych, przygotowujących glebę do siewu roślin ozimych, odnosi się druga jednostka.

Kolejnym dniem w omawianym miesiącu, z którym wiążą się interesujące nas tu proverbia, jest liturgiczne wspomnienie św. Jakuba Większego (Starszego) Apostoła, które wypada 25 lipca. Dwa przysłowia wskazują na czas żniw: Na świętego Jakuba bywa już z żytem próba oraz Na/przyjdzie święty Jakub, stanie (w stodole żyta) sto kup 9 . Jedno natomiast odnosi się do pogody: Na Jakuba deszcz, ztych żniw wieszcz.

Ostatnim lipcowym świętem, z którym wiąże się rolnicza paremia, jest liturgiczne wspomnienie św. Tymona, ucznia apostołów, obchodzone 28 dnia tego miesiąca. Zawiera ona wskazówkę, że należy już przygotowywać glebę do siewu jęczmienia: Pamiętając na Tymona, sprawuj role pod jęczmiona ${ }^{10}$. Roślinę tę sieje się w pierwszej kolejności jako zboże ozime, w pierwszej połowie września.

\section{Sierpień}

W sierpniu kilka proverbiów odnosi się do liturgicznego wspomnienia św. Bartłomieja Apostoła, które wypada 24 dnia tego miesiąca. Jedno z nich wyraźnie wskazuje na zakończenie żniw: (Na [święty]) Barttomiej (owsy/wszystko/żyto) (z pola) ciapie/pottumi/potumiej/ttumiej/uttumi. Józef Gluziński opatruje to przysłowie następującym komentarzem: W téj porze źdzbła i kłosy kolankują się, łamia i zginaja ku ziemi, a przeto szkoda plonu, który opieszała ręka dotąd nie zbiera (Gluz 570). Przed odwlekaniem koszenia zboża do wspomnienia św. Bartłomieja przestrzega jeszcze inna paremia: Na świętego Bartłomieja czajka uciecze i chłop już zboża w polu nie usiecze.

Święto św. Bartłomieja stanowiło także czasowy punkt orientacyjny w zasiewach oziminy. Wskazówkę tę zawierają proverbia: Jak Barttomiej nie zasieje, nie pokropi Idzi [1 września], to się zboża, głównie żyta/ to się żyta mało w polu widzi

$9 \quad$ Wyraz kupa (oraz derywaty kupeczka, kupka) ma w gwarach m.in. znaczenie 'pewna liczba snopów zboża ustawionych w określony sposób'. Jest to też jedno ze znaczeń leksemu kopa zarówno w języku literackim, jak i w polszczyźnie dialektalnej. Stosownych poświadczeń gwarowych dostarcza kartoteka SGP (KSGP).

10 W artykule hasłowym Jęczmień w SW wśród form M. Im znajduje się m.in. zapis jęczmiona, opatrzony uwagą: o jęczmieniu na polu (SW II: 176). 
oraz Na Barttomieja deszcz, siedlaczku11 siej, kiej chcesz. Drugą jednostkę notowano w Cieszyńskiem. Ze względu na dwa znaczenia na tym terenie gwarowego przyimka kiej: 1. 'kiedy'; 2. 'gdy, jeśli' (SCiesz 146) - możliwe jest dwojakie rozumienie tego przysłowia. Koniec sierpnia to bardzo wczesny termin siewu zbóż ozimych, toteż rolnik ma jeszcze pewien czasowy zapas i nie powinna go martwić niesprzyjająca aura.

O możliwości podejmowania zasiewów pól przypominają też dwie inne paremie: Na świętego Barttomieja otwiera się siew i knieja oraz Na święty Barttomiej śmiało żyto siej!

Okazuje się, że święto św. Bartłomieja wiąże się nie tylko z gromadzeniem uzyskanych plonów ziemi, lecz także ze zbiorem innych dóbr natury. Informuje o tym proverbium: Bartosz ${ }^{12}$ każe jaja sktadać w kosz. W źródle, w którym je odnotowano, czytamy jeszcze: Pod koniec sierpnia chowaja jaja na zime (SGK I: 21). Postępowanie takie budzi jednak wątpliwości, czy możliwe jest tak długie przechowywanie jaj.

\section{Wrzesień}

Z kolei z wrześniem wiąże się spora grupa przysłów odnoszących się do dwóch dni świątecznych. Pierwszy z nich to wspomnienie św. Mateusza Apostoła i Ewangelisty obchodzone 21 dnia tego miesiąca. Upływające lato w naturalny sposób warunkuje finalizację części prac w gospodarstwie. Jedna z paremii wskazuje na ostatnie w sezonie miodobranie: Święty Mateusz dodaje chłodu i raz ostatni podbiera miodu. Inna ostrzega przed kończącym się czasem siewu żyta ozimego: Święty Mateusz - siałbym żyto - nie rychło już!

Najliczniejsza grupa jednostek skupia się wokół wspomnienia św. Michała Archanioła, które wypada 29 września. Koniec tego miesiąca to czas, w którym zboże i siano powinny już znajdować się w stodołach. W związku z tym mamy przysłowia: Bierz, Michale, co Pan Bóg daje; Kiepskillichy ten gospodarz, co/ który na święty Michat (dopiero) kopy z pola spychat; Michałkowe sianko/siano, marcinkowe żytko - kata/licha warte wszystko; Napominat Michat, chlopie, z pola spychaj ${ }^{13}$; (Na) święty Michat (kopy [do stodót]) (z pola) (wszystko) pospychat/ spychat. Uprzątnięte po ostatnim pokosie łąki służyły za pastwiska. Nierzadko usuwano z nich płoty czy znaki graniczne dzielące ziemię poszczególnych gospo-

11 Siedlok 'bogaty rolnik' (SCiesz 282, derywatu siedloczek w tym słowniku brak). W źródle, z którego pochodzi to przysłowie, mamy zapis: siedloczku.

12 Jest to wariant imienia Bartłomiej, który się usamodzielnił (por. Grzenia 2008: 68-69).

13 Jednostkę tę w zapisie: Napominoł Michoł, chłopie, z pola spychoj, zawdzięczam anonimowemu Recenzentowi, za co składam w tym miejscu podziękowanie. 
darzy i na gruntach tych, czasowo traktowanych jako wspólne, wypasano zwierzęta hodowlane. Zwyczaje te utrwaliły się w kilku paremiach: Po świętym Michale granic nie ma wcale; Po świętym Michale już nikt o łąki nie staje; Po (świętym) Michale już wszędzie pasali// możesz paśćl można paśćl pasie sięl wolno paść (panu) (i) (już) na/po/w (całym) kale/kawale/potrawie/powale/skale/wale; Święty Michat granice/płoty/wiechy porozpychat/pospychat. Jan P. Dekowski (1959: 159-160) podaje, że jeszcze na początku XX w., w centralnej Polsce, nad Pilicą, po zebraniu siana $\mathrm{z}$ drugiego pokosu, teren pastwisk powiększano o uprzątnięte łąki. Na obszarach tych mogli wypasać swoje zwierzęta wszyscy mieszkańcy wsi do nastania pory zimowej. Zdarzało się, że nie każdy gospodarz zdążył zwieźć siano do dnia liturgicznego wspomnienia św. Michała. W takich sytuacjach nie czekano na uprzątnięcie pola, tylko realizowano zwyczajowe prawo: Po świętym Michale to ci w potraw walę. Etnograficzny opis Dekowskiego (1959: 160) nie pozostawia w tym względzie wątpliwości. W związku z pełną swobodą w zakresie miejsca wypasu powstało nawet żartobliwe przysłowie: Po Michale może paść i na powale, po Jadwiżce i na wieszce ${ }^{14}$. Jego drugi człon odnosi się do wspomnienia św. Jadwigi Śląskiej, obchodzonego 15, a obecnie 16 października.

U schyłku września powinien też dobiegać końca siew oziminy. Jedna z paremii zawiera arbitralne stwierdzenie: Przed Michałem maja być siewy w kraju całym. Być może zatem inne przysłowie: Po świętym Michale siej żyto choćby i na skale - w świetle tej konstatacji - ma charakter ironiczny. Znamiona drwiny związanej z późnym siewem żyta ozimego nosi także przywołana już paremia: Michałkowe sianko/siano, marcinkowe żytko - kata/licha warte wszystko. W swojej drugiej części odnosi się ona do jeszcze późniejszego terminu - liturgicznego wspomnienia św. Marcina z Tours, biskupa, które przypada 11 listopada.

Lud wierzył, że odgłos gromu w święto św. Michała Archanioła zwiastuje obfite plony w kolejnym roku. Przekonanie to utrwaliło się w przysłowiu: Grzmot $w$ dzień świętego Michała - żyzność przyszła, Bogu chwała. Być może więc w związku z nim pozostaje paremia: Jak grzmot po świętym Michale, to siej żyto na skale.

W czasie, w którym wypada wspomnienie św. Michała Archanioła, skupiają się istotne etapy prac w gospodarstwie. Z tych względów zbiór proverbiów odnoszących się do wskazanego dnia wyraźnie przewyższa liczebnością grupy jednostek związane z innymi świętami. Nie bez znaczenia jest też żywy od wieków kult św. Michała $^{15}$.

14 Komponenty humorystyczne pojawily się już we wcześniej przywoływanej wariantywnej paremii: Po (świętym) Michale już wszędzie pasali// możesz paśćl można paśćl pasie sięl wolno paść (panu) (i) (już) na/po/w (całym) kale/kawale/potrawie/powale/skale/wale.

15 Na możliwość wyprowadzenia wniosków wynikających ze zróżnicowanej liczby przysłów kalendarzowych odnoszących się do poszczególnych dni zwracał uwagę anonimowy Recenzent. 


\section{Październik}

Z nastaniem jesieni kończą się prace polowe. Do tego faktu nawiązują dwa przysłowia odnoszące do liturgicznego wspomnienia św. Łukasza Ewangelisty, które wypada 18 października. Szczególnym ze względu na formę jest zdialogizowana jednostka: (Na) (święty) Luka16/Lukasz, czego (jeszcze) (po polu/ w dole) szukal szukasz? ([- (Ano/Oto) rzepy!] - A boś/Alboś (to) jej (dziadu) (w dole/sklepie) ślepy?/ Czyś i w domu ślepy?)/ (- Rachuję zagony, który nie zasiany). Czasem ogranicza się ona jedynie do pytania retorycznego. Uwag objaśniających wymagają padające odpowiedzi. Ze względu na wieloznaczność leksemu rzepa w gwarach polskich warianty tego przysłowia różnią się znaczeniowo na poszczególnych obszarach dialektalnych. W wersji notowanej na Śląsku chodzi zapewne o buraka. W południowej części dialektu małopolskiego - o ziemniaka. Natomiast na pozostałych obszarach - po prostu o rzepę ${ }^{17}$. Dodajmy, że zbiór każdej z tych roślin uprawnych przypada mniej więcej około liturgicznego wspomnienia św. Łukasza. Natomiast w ramach wariantywnego komponentu dót/sklep występują synonimy. Oba leksemy w części gwar nazywają piwnicę pod domem lub poza domem ${ }^{18}$. Z kolei odpowiedź: Rachuję zagony, który nie zasiany jest być może efektem kontaminacji z notowanym $\mathrm{w}$ wielu wersjach $\mathrm{w}$ polszczyźnie dialektalnej przysłowiem Pojechat Marek// święty Marek idzie/poszedt/wyszedt na folwarek, oglada zagony, który dobrze zasiany ${ }^{19}$. Podobne wersje paremii odnoszących się do świąt św. Łukasza i św. Marka notowano w dialekcie wielkopolskim.

Proverbium $\mathrm{Na}$ święty Łuka schowaj pług $i$ włók $a^{20}$ wyraźnie wskazuje na koniec pracy na roli.

16 Jest to forma historyczna. O historii imienia Łukasz patrz w: Malec 1995: 81; Fros, Sowa 1998: 675; Grzenia 2008: 219.

17 Dokumentacja źródłowa i geograficzna tego przysłowia znajduje się w: Popławski 2014: 122-123. Semantykę słowa rzepa w gwarach polskich syntetycznie ujmuje MSGP: 1. 'burak': Śl. 2. 'ziemniak': Mp pd. Na innych terenach funkcjonuje ono w takim samym znaczeniu jak w języku literackim ('Brassica rapa'). Znaczenie to nie zostało odnotowane w MSGP ze względu na dyferencyjny charakter tego słownika.

18 Słowo dót poświadczone jest w gwarach polskich m.in. w następujących znaczeniach: 'podziemne pomieszczenie, służące do przechowywania ziemniaków (często oparte na drewnianej konstrukcji); piwnica': a. 'pod domem': Mp pd (Podhale), wsch i śr; b. 'poza domem': głównie Mp i Maz, sporadycznie Śl i Wp oraz 'jama na ziemniaki zasypywana na zimę ziemią; kopiec': głównie Mp pd, śr i pn-wsch, Maz pd, Wp pn-zach. Por. SGP VI 216-217 (znaczenia 4. i 5. hasła I. Dót). Sklep 'piwnica pod domem lub poza domem': Mp pn-zach, Maz, Wp, Kasz - MSGP 255. Por. też: MAGP I m. 9 s. 24-27; XII m. 560-561 s. $35-46$.

19 Dokumentacja źródłowa i geograficzna tego przysłowia znajduje się w: Popławski 2014: 131-132. Przywołuję je również w pierwszej części opisu roku rolniczo-gospodarskiego w świetle przysłów w gwarach polskich (Popławski 2017: 295).

20 Włóka 'brona drewniana' (SKarł VI: 138). Objaśnienie to dotyczy m.in. interesującego nas przysłowia. 
Dwa przysłowiowe pouczenia dotyczące działań w gospodarstwie, które należy podjąć przed zimową porą, wiążą się ze świętem apostołów św. Szymona i św. Judy Tadeusza, obchodzonym 28 października: Jak już dzień przyjdzie świętego Szymona i Judy, już to zegnać należy z pól bydło do budy oraz Na Szymona i Judę czas obgacić/opatrzyć budę ${ }^{21}$.

\section{Grudzień $^{22}$}

Zbiór prezentowanych przysłów dopełnia jednostka odnosząca się do wspomnienia św. Tomasza Apostoła, która dotyczy również zwierząt hodowlanych: Na święty Toma ${ }^{23}$ będa wieprze doma (bo je ze żolędzi chtop do dom przypędzi). Do czasu reformy kalendarza liturgicznego, dokonanej w 1969 r., dzień wspomnienia tego świętego wypadał 21 grudnia. Obecnie - 3 lipca. W paremiach notowanych zarówno w języku literackim, jak i w gwarach, odnoszących się do św. Tomasza, utrwaliła się wcześniejsza data jego wspomnienia w liturgii (por. Popławski 2014: 180-184) ${ }^{24}$. W świetle tych wyjaśnień przywołana jednostka staje się bardziej zrozumiała. Jeśli chodzi o drugi, fakultatywny człon przysłowia, to jedno ze źródeł informuje, że dawniej wypasano wieprze w lasach, gdzie rosły dęby (BibWarsz 1861 III: 639).

\section{$* * *$}

W formie przedstawionych proverbiów ujawniają się typowe cechy obserwowane w zbiorze przysłów kalendarzowych. Wśród formuł inicjalnych pojawiają się najczęściej: Na świętego Barttomieja, Jakuba; Na święty Barttomiej, Eliasz, Jakub, Łuka/Łukasz, Michat, Toma czy po prostu Na Barttomieja, Jakuba, Szymona i Judę, a poza wymienionymi - Po (świętym) Michale oraz Przed Michatem. Warto

21 Rymujący się z nazwą osobową Juda wyraz buda może mieć w obu przywołanych przysłowiach inne znaczenie. W pierwszym nazywa budynek przeznaczony dla zwierząt hodowlanych, w drugim może odnosić się do domu mieszkalnego, jak i do budynku dla zwierząt (por. hasło buda, zwłaszcza zn. 1. i 5., w SGP III: 45-48).

22 Przysłowia odnoszące się do listopada nie ujawniły się w zebranym materiale.

23 Ta skrócona forma imienia Tomasz często występuje w przysłowiach odwołujących się do dnia wspomnienia św. Tomasza Apostoła właśnie ze względu na rym Toma - doma (por. NKPP III: 520; Popławski 2014: 180-181). O formie Toma patrz w: Malec 1994: 332-333; 1995: 128 oraz Grzenia 2008: 310.

24 Z podobnymi sytuacjami spotykamy się w przysłowiach odnoszących się np. do św. Macieja Apostoła (por. Popławski 2014: 125-128), o czym już wspomniałem w przypisie 6., czy św. Benedykta (por. Popławski 2017: 294). 
odnotować w tym miejscu jednostkę mającą cechę welleryzmu: Napominat Michat, chtopie, z pola spychaj.

Każda opisywana paremia zawiera rym, zwykle dokładny, np.: Bartłomiejaknieja, Bartosz - kosz, chtodu - miodu, deszcz - wieszcz, Eliasz - orz, Jakuba próba, Judy - budy, Łuka - wtóka, Łuka/Lukasz - szuka/szukasz, Michale - kalel kawale/powale/skale/wale, Michat - spychat/wpychat, Toma - doma, Tymona jęczmiona, uciecze - usiecze, żolędzi-przypędzi, żytko-wszystko.

Zaprezentowana grupa przysłów (w obu częściach przeprowadzonego opisu) daje przynajmniej częściowy, paremiologiczny obraz roku rolniczo-gospodarskiego. Wiele aspektów pracy na roli i w gospodarstwie znalazło swoje odbicie w przywołanych jednostkach. Przedstawione przysłowia propagują - mówiąc współczesną polszczyzną - dobre praktyki w zakresie prowadzenia gospodarstwa wiejskiego. Wskazują słuszny sposób postępowania dotyczący uprawy ziemi i hodowli zwierząt. Punktem odniesienia opisanych paremii jest konkretny dzień, co sprawia, że zawierają one precyzyjne pouczenia, ostrzeżenia czy zasady. Uporządkowanie ich zgodnie z kalendarzem tworzy niezwykle przystępny podręcznik dobrego gospodarza.

\section{Kalendarzowe zestawienie opisywanych przysłów}

\section{LIPIEC}

20

Ilij! nie psuj roli

Na święty Eliasz do poludnia przeoruj, po południu w zagon orz 25

Na świętego Jakuba bywa już z żytem próba

$\mathrm{Na}$ /przyjdzie święty Jakub, stanie (w stodole żyta) sto kup

Na Jakuba deszcz, ztych żniw wieszcz

28

Pamiętając na Tymona, sprawuj rolę pod jęczmiona

\section{SIERPIEŃ}

24

(Na [święty]) Bartlomiej (owsy/wszystko/żyto) (z pola) ciapie/pottumi/potumiej/ ttumiej/uttumi

Jak Barttomiej nie zasieje, nie pokropi Idzi [1 września], to się zboża, głównie $\dot{z} y$ tal to się żyta mato w polu widzi

Na Barttomieja deszcz, siedlaczku siej, kiej chcesz

Na świętego Bartłomieja czajka uciecze i chłop już zboża w polu nie usiecze 
Bartosz każe jaja składać w kosz

Na świętego Barttomieja otwiera się siew i knieja

Na święty Barttomiej śmiało żyto siej!

\section{WRZESIEŃ}

21

Święty Mateusz dodaje chtodu i raz ostatni podbiera miodu

Święty Mateusz - siałbym żyto - nie rychto już!

29

Bierz, Michale, co Pan Bóg daje

Kiepski/lichy ten gospodarz, co/który na święty Michat (dopiero) kopy z pola spychat

Michałkowe sianko/siano, marcinkowe [11 listopada] żytko - kata/licha warte wszystko

Napominat Michat, chtopie, z pola spychaj

(Na) święty Michat (kopy [do stódot]) (z pola) (wszystko) pospychat/spychat

Po Michale może paść i na powale, po Jadwiżce i na wieszce

Po świętym Michale granic nie ma wcale

Po świętym Michale już nikt o taki nie staje

Po (świętym) Michale już wszędzie pasali//możesz paść/ można paść/ pasie sięl wolno paść (panu) (i) (już) na/po/w (catym) kale/kawale/potrawie/powale/ skale/wale

Po świętym Michale siej żyto choćby i na skale

Po świętym Michale to ci w potraw wale

Przed Michałem maja być siewy w kraju catym

Święty Michat granice/ptoty/wiechy porozpychat/pospychat

Święty Michat (już) (do beczki) kapuste (do dotu) spychat/wpychat

Grzmot $w$ dzień świętego Michała - żyzność przyszła, Bogu chwała

Jak grzmot po świętym Michale, to siej żyto na skale

\section{PAŹDZIERNIK}

18

(Na) (święty) Łuka/Lukasz, czego (jeszcze) (po polu/ w dole) szuka/szukasz? ([- (Ano/Oto) rzepy!] - A boś/Alboś (to) jej (dziadu) (w dole/sklepie) ślepy?/

Czyś $i$ w domu ślepy?)/ (- Rachuję zagony, który nie zasiany)

Na święty Łuka schowaj pług i włóka

28

Jak już dzień przyjdzie świętego Szymona i Judy, już to zegnać należy z pól bydto do budy

Na Szymona i Judę czas obgacićlopatrzyć budę 


\section{GRUDZIEŃ}

21

Na święty Toma będa wieprze doma (bo je ze żołędzi chłop do dom przypędzi)

\section{Summary \\ Farm Year in the Light of Proverbs in Polish local Dialects \\ (from St. EliJah - 2 July to St. Thomas - 21 December)}

The paper recorded almost 40 proverbs related to the calendar referring to working in the field and on a farm from Polish local dialects. They are connected with the second half of the year. They refer to the 9 saint feast days: Elijah (20 July), James the Greater (Elder) (25 July), Tymon (28 July), Bartholomew (24 Aug), Matthew (21 Sept), Michael (29 Sept), Lucas (18 Oct), Simon and Juda Tadeusz (28 Oct), Thomas (21 Dec). 
https://doi.org/10.12797/9788381382458.21

\author{
Renata Dźwigol (D) \\ Uniwersytet Pedagogiczny im. Komisji Edukacji Narodowej, Kraków \\ renata.dzwigol@up.krakow.pl
}

\title{
DiABELSKI CZYLI JAKI?
}

\section{KILKA SLÓW O MOTYWACJI NAZW. UWAGI WSTĘPNE}

Slowa klucze: diabeł, frazeologia, zestawienia frazeologiczne, nazwy

Keywords: devil, phraseology, phraseological summaries, names

Wyrażenia frazeologiczne mające status nazw (pospolitych), jednostki dwuelementowe, w których jeden z komponentów ma znaczenie 'diabel' lub 'diabelski', nazywają różne elementy świata - mieszczące się w obrębie natury oraz kultury. Jednostki te były już przedmiotem opisu w dwóch artykułach ${ }^{1}: O$,,diabelskich" nazwach i nazwaniach (Dźwigoł 2014) oraz Nazwy z zakresu kultury materialnej motywowane pojęciami z zakresu kultury duchowej (Dźwigoł 2016). W pierwszym zaprezentowane zostały poszczególne obiekty opatrzone „diabelskimi” nazwami. W drugim omówiono nazwy z obszaru kultury materialnej motywowane trzema pojęciami z zakresu kultury duchowej, z których pierwsze to DIABEŁ (dwa pozostałe to ANIOŁ i BÓG). W niniejszym opracowaniu chciałabym przedstawić motywację semantyczną „diabelskich” nazw w jak najbardziej syntetyzujący sposób - tak aby ukazać pewne tendencje nazewnicze, które da się zaobserwować w tej grupie frazeologizmów. Nie będę zatem skupiać się jedynie - jak to miało miejsce $\mathrm{w}$ drugim z przywołanych artykułów - na wszechstronnym omawianiu motywacji poszczególnych nazw.

Analizowane jednostki włączane są do szeroko ujmowanego zasobu frazeologicznego polszczyzny. Według klasyfikacji frazeologizmów autorstwa Andrzeja M. Lewickiego byłyby: po pierwsze, wyrażeniami rzeczownikowymi, tj. frazeologizmami pełniącymi w zdaniu funkcję rzeczownika (podział frazeologizmów morfologiczno-syntaktyczny - ze względu na funkcję pełnioną w zdaniu), po drugie, zestawieniami frazeologicznymi, jednostkami podobnymi do terminów,

1 W obu artykułach zostały omówione nie tylko nazwy dwuelementowe, ale także jednoelementowe oraz więcej niż dwuelementowe nazwania. 
a stanowiącymi (wraz z innymi typami jednostek) pogranicze frazeologii (podział semantyczny frazeologizmów - ze względu na funkcjonowanie znaczenia).

Jednostki te należałoby zaliczyć do nazw nieoficjalnych, zwyczajowych, tradycyjnych, ludowych, które to nazwy (nie w pełni synonimicznie) określane bywają również jako: gwarowe, regionalne, obiegowe, potoczne ${ }^{2}$. Tego typu nazwy w XIX i XX w. były przedmiotem zainteresowania folklorystów i etnografów, którzy uwzględniali je w zbieranych, a następnie publikowanych materiałach, prezentujących kulturę ludową poszczególnych okolic czy regionów. Były przedstawiane w formie słowników, np.: Słownik nazwisk zoologicznych i botanicznych polskich, zawierajacy ludowe oraz naukowe nazwy i synonimy polskie [...] Erazma Majewskiego (1894), Słownik zielarski (nazwy naukowe i ludowe) Kazimierza Gierynga (1938). Współcześnie gromadzą je - na tworzonych w tym celu stronach internetowych - hobbyści, np.: miłośnicy zbierania grzybów (i propagowania wiedzy na ten temat) ${ }^{3}$, pasjonaci nie tylko przyrody (często z racji wykonywanego zawodu), ale i tradycji, zauroczeni ludowymi nazwami i chcący ocalić je od zapomnienia ${ }^{4}$, zwolennicy ziołolecznictwa, leśnicy. Nieznany z imienia i nazwiska autor tekstu zatytułowanego Nazewnictwo grzybów - naukowe, oficjalne i potoczne, zamieszczonego na portalu Grzyby.pl, słusznie zauważa, że nazwy zwyczajowe są naszym dziedzictwem kulturowym. Można dodać, że przejawem tradycji i kultury ludowej, bowiem znajomość grzybów wśród ludności wiejskiej oparta jest na tradycji

2 W języku potocznym funkcjonują najczęściej nazwy jednowyrazowe, na co zwróciła uwagę Barbara Bartnicka-Dąbkowska (1964), por. też: (Kopczyński, Ławrynowicz 2000: 141).

3 Zob. np.: Nazewnictwo grzybów-naukowe, oficjalne i potoczne oraz Wspótczesne potoczne (ludowe) nazwy grzybów, portal Grzyby.pl, https://grzyby.pl/nazwy-grzybow.htm, https:// grzyby.pl/slownik-wspolczesnie-uzywane-potoczne-ludowe-nazwy-grzybow.htm (dostęp: 25 VI 2019). Autorzy portalu zauważają, że nazwy zwyczajowe, zwane także ludowymi, są najmniej precyzyjne, ale też i najczęściej używane. Jako przykład podają m.in. zwyczajową (potoczną) nazwę szatan, która może oznaczać: dla jednych goryczaka żółciowego (Tylopilus felleus), dla innych borowika szatańskiego (Boletus satanas), a dla jeszcze innych każdego ,podejrzanie wyglądającego" borowika o czerwonym trzonie lub porach lub o siniejącym miąższu (https://grzyby.pl/nazwy-grzybow.htm, dostęp: 25 VI 2019). Zob. też: fora internetowe: Zwyczajowe i regionalne nazwy grzybów, Forum NaGrzyby.pl. Największe i najstarsze forum grzybiarzy, https://forum.nagrzyby.pl/viewtopic.php?t=6755\&start=375 (dostęp: 25 VI 2019); Miejscowe (potoczne, ludowe, zwyczajowe) nazwy grzybów, Bio-forum.pl, https://www.bio-forum.pl/messages/2/260.html (dostęp: 25 VI 2019).

4 Zob. Stownik polsko-potocznoludowy niektórych roślin i chwastów przygotowany przez Michała Gawłowskiego, zamieszczony na portalu Wielkopolskiego Ośrodka Doradztwa Rolniczego (http://old.wodr.poznan.pl/index.php?option=com_k2\&view=item\&id=4224:s\%C 5\%82ownik-polsko- $\%$ E2\%80\%93-potocznoludowy-niekt $\% \mathrm{C} 3 \%$ B3rych-ro $\% \mathrm{C} 5 \% 9 \mathrm{Blin}$-ichwast $\% \mathrm{C} 3 \% \mathrm{~B} 3 \mathrm{w} \&$ Itemid=174, dostęp: 25 VI 2019), zawierający: 1. nazwę polską, 2. nazwę potoczną, ludową, 3. nazwę łacińską danej rośliny. Autor podaje, że nazwy pozyskał z Atlasu chwastów dla praktyków opublikowanego przez Tomasza Czubińskiego i Adama Paradowskiego (2016). 
właśnie, na wiedzy pozyskanej od rodziców i dziadków. Znane są te gatunki, które występują na danym terenie. Do jadalnych lub niejadalnych (a nawet - zbieranych i niezbieranych) zaliczane są w odniesieniu do lokalnej, najczęściej rodzinnej tradycji (a nie np. na podstawie wiedzy pozyskanej ze specjalistycznych opracowań mykologicznych, np. atlasów grzybów). Slawista Przemysław Jóźwikiewicz zwraca zaś uwagę, iż „Grzyby jako składowa świata przyrody [...] wraz z wieloma innymi elementami wpisują się [...] w pojęcie językowego obrazu świata, a antropocentryczny aspekt ich nazewnictwa jest jednym z ważniejszych, przede wszystkim w odniesieniu do regionalnych czy zwyczajowych nazw grzybów" (Jóźwikiewicz 2016: 202). Kazimierz Kopczyński oraz Maria Ławrynowicz przypominają, że ludowe nazwy grzybów powstają wskutek obserwacji cech charakterystycznych (istotnych poznawczo) poszczególnych gatunków, równocześnie wyrażają osobisty i emocjonalny stosunek do grzybów (Kopczyński, Ławrynowicz 2000: 141). Wszystkie powyższe uwagi można odnieść do całej grupy nieoficjalnych, tradycyjnych, ludowych nazw.

Nazwy te stały się obiektem badań, prowadzonych zresztą nie tylko przez językoznawców. Pozostając w obszarze nazewnictwa grzybów, wymienić można: Polskie ludowe nazwy grzybów Barbary Bartnickiej-Dąbkowskiej (1964), Ludowe nazwy grzybów w Polsce Ewy Referowskiej-Chodak ${ }^{5}$ (2015), Polskie regionalne nazwy grzybów Kazimierza Kopczyńskiego ${ }^{6}$ i Marii Ławrynowicz ${ }^{7}$ (2000), jak również prace Jerzego Kuźmiuka $(1989,1991,1993,1995)^{8}$ traktujące o potocznych, regionalnych, a także gwarowych nazwach grzybów na Białostocczyźnie. Przegląd prac dotyczących nazw roślin przedstawia w swojej monografii Polskie gwarowe nazwy dziko rosnacych roślin zielnych na tle stowiańskim Jadwiga Waniakowa (2012).

W tym miejscu należałoby wyraźnie podkreślić, że nie wszystkie ludowe czy gwarowe nazwy mają gwarowe pochodzenie - są autentycznie gwarowe, tj. powstałe na gruncie gwar. Uwypukla to zagadnienie Waniakowa:

[...] znaczna część gwarowego słownictwa botanicznego jest kontynuacją nazw staropolskich, wiele $\mathrm{z}$ nazw to różnego rodzaju zapożyczenia z języków ościennych [...], część pochodzi z polszczyzny ogólnej [...], a zatem nie zawsze „użytkownik gwary" tworzy nazwy roślin i w nich odbija swoje opinie o świecie (Waniakowa 2012: 13).

5 Autorka jest pracownikiem Szkoły Głównej Gospodarstwa Wiejskiego, z wykształcenia nie jest językoznawcą.

6 Autor jest psychologiem, członkiem Polskiego Towarzystwa Mykologicznego, http://www. ptmyk.pl/?page_id=269; http://www.grupaherbaria.pl/eksperci-t27/kazimierz-kopczynskit36 (dostęp: 25 VI 2019).

7 Autorka jest mykologiem zatrudnionym w Uniwersytecie Łódzkim.

8 Autor prezentuje materiały będące uzupełnieniem opracowania Bartnickiej-Dąbkowskiej (1964) oraz Atlasu gwar wschodniostowiańskich Białostocczyzny (t. I: 1980/2014). 
Omawiana w referacie tendencja nazewnicza (tworzenie „diabelskich” nazw) jest spotykana nie tylko w polskich dialektach. Mogę zaryzykować stwierdzenie, że ma uniwersalny charakter - z zastrzeżeniem, że zagadnienie to nie zostało przeze mnie gruntownie zbadane. Tak ukształtowane nominacje formułowane były po łacinie - jako łacińskie nazwy gatunkowe, a następnie kalkowane do polszczyzny, np.: bot. morsus diaboli 'czarcikęs łąkowy' $\rightarrow$ czartowe gryzienie (Spólnik 1990: 14, 107), djåbli prëgrizk (SGK I: 215); anat. morsus diaboli 'strzępy zębate jajowodu' $\rightarrow$ diabla sztuczka (SW I: 456); bot. Boletus satanas 'borowik szatański' $\rightarrow$ $\rightarrow$ szatański grzyb, diabelski/ diabli grzyb (Bartnicka-Dąbkowska 1964: 4710). Występują także w języku angielskim (oraz w innych językach europejskich), z którego przenoszone są do polszczyzny, np.: bot. Devil's claw 'hakorośl rozesłana' (Harpagophytum procumbens $)^{11} \rightarrow$ diabelskil czarci pazur, diabelski szpon ${ }^{12}$; bot. Devil's fingers 'okratek australijski' (Clathrus archeri) $\rightarrow$ diabelskie palce ${ }^{13}$, palce diabła ${ }^{14}$; zool. Tasmanian Devil (Sarcophilus harrisii) $\rightarrow$ diabet tasmański; Devilstick 'trzy kijki służące do wykonywania żonglerskich pokazów' $\rightarrow$ diabelskie kijki; Devil's Food Cupcakes 'czekoladowe muffiny' $\rightarrow$ diabelskie babeczki ${ }^{15}$ ).

Do prezentowanego w tej pracy materiału włączyłam nie tylko nazwy gwarowe (jako gwarowy potraktowałam materiał kaszubski pochodzący ze Stownika gwar kaszubskich na tle kultury ludowej Bernarda Sychty - SGK ${ }^{16}$ ), ale i obiegowe nazwy poświadczone w polszczyźnie niedialektalnej, bowiem unaoczniają one te same tendencje nazewnicze (mechanizmy nominacyjne), co nazwy ludowe, gwarowe. Niejednokrotnie trudno jednoznacznie wskazać motywację semantyczną danej nazwy. O jej utworzeniu - czy użyciu - mógł zdecydować nie jeden charakterystyczny dla obiektu nazywanego aspekt, a kilka innych jego aspektów być może równie charakterystycznych w świadomości twórcy czy użytkownika nazwy. Dla niektórych poszczególnych nazw można podać kilka różnych motywacji semantycznych i często trudno przesądzić, którą z nich należałoby traktować jako prymarną, a które jako wtórne (wobec niej). To sprawiało trudności podczas analizowania materiału. Starałam się je przezwyciężyć, wskazując motywację naj-

9 Czarcikęs łakowy był nazywany radix morsus diaboli 'korzeń nadgryziony przez diabła'.

10 Szatański grzyb, czortowy grzyb to nazwy borowika ponurego.

11 Por. niem. Teufelskralle.

12 http://www.luskiewnik.pl/autoimmunologia/new-page-8.htm (dostęp: 25 VI 2019).

13 Diabelskie palce - grzyb, do którego lepiej się nie zbliżać, tekst na portalu Interia.pl, https:// menway.interia.pl/styl-zycia/ciekawostki/news-diabelskie-palce-grzyb-do-ktorego-lepiej-sie-nie-zblizac,nId,2288472 (dostęp: 25 VI 2019).

14 Maciej Wernio, „Palce diabła” to grzyb, którego możesz, ale nie chcesz spotkać w polskich lasach, tekst na portalu Noizz.pl, datowany 24 IX 2019, https://noizz.pl/nauka-i-technologia/okratek-australijski-grzyb-wygladajacy-jak-osmiornica/rrxf9ck (dostęp: 25 VI 2019).

$15 \mathrm{https}$ //wypiekibeaty.com.pl/devils-food-cupcakes-diabelskie-babeczki/(dostęp: 25 VI2019).

16 Obecnie (od 2005 r.) kaszubszczyzna ma status języka regionalnego. 
bardziej prawdopodobną w przypadku danej nazwy (moim zdaniem). Podawałam również inne możliwe motywacje - decydujące o tym, że nazwę można potraktować jako wielomotywacyjną.

\section{Motywacja „diabelskich” nazw - ze względu na przebieg procesu nominacyjnego (co decydowalo o nadaniu danemu obiektowi „diabelskiej” nazwy?)}

Można wskazać trzy tendencje nazewnicze, które ukazują, czym „diabelskie” nazwy mogły być motywowane:

1. Obiekt nazywany, a najczęściej pewne jego cechy wywołują skojarzenia z diabłem, co zostaje w nazwie obiektu uwidocznione.

2. Związek obiektu $\mathrm{z}$ diabłem $\mathrm{w}$ wierzeniach lub magii, lub obrzędach ludowych zostaje oddany w jego nazwie.

3. Charakterystyka, kategoryzacja, wartościowanie obiektu dokonywane przez człowieka skutkują użyciem „diabelskiej” nazwy.

Ze względu na ograniczone rozmiary pracy omówię jedynie pierwszą z tych tendencji nazewniczych, w tym celu przedstawię te „diabelskie” nazwy, które ją obrazują. Dwie pozostałe tendencje nazewnicze zostaną ukazane (i zilustrowane odpowiednimi nazwami) w osobnym opracowaniu.

\section{Obiekt nazywany, a najczęściej pewne jego cechy wywołują skojarzenia z diabłem, co zostaje w nazwie obiektu uwidocznione}

\section{- wygląd obiektu nazywanego (podobieństwo do diabła)}

W wyglądzie obiektu nazywanego dostrzeżona została cecha, którą skojarzono $\mathrm{z}$ charakterystyczną cechą wyglądu diabła ${ }^{17}$. Zgromadzony materiał nazewniczy pokazuje, że taką cechą (w powszechnym mniemaniu) były rogi, rzadziej - pazur.

Hakorośl rozesłana (Harpagophytum procumbens) - diabelski pazur, czarci pazur, sporad. diabelski szpon ${ }^{18}$ (ang. Devil's claw, niem. Teufelskralle). Owoc

17 Typowymi cechami wizerunku diabła, utrwalonymi w polskiej demonologii ludowej, są: czarna, kosmata (ciało pokryte sierścią), osmalona postać (diabeł bywa też kojarzony z ciemnym oraz czerwonym kolorem), nienaturalny wzrost, bujna czupryna (zazwyczaj czarna, znacznie rzadziej ruda), rogi na głowie, długi ogon, pazur u małego palca (lub pazury, szpony u wszystkich palców rąk i nóg), końskie kopyto u nogi, kulawość, ogniste ślepia (czerwone, głęboko osadzone oczy), brak dziurek w nosie, ogień buchający z pyska, odór siarki i smoły. W tym wizerunku najmocniej uzewnętrzniały się nieludzkie (zwierzęce) cechy anatomiczne: rogi, ogon, pazur, kopyto.

$18 \mathrm{https}$ //apteline.pl/artykuly/czarci-diableski-pazur-na-bolace-stawy-i-kregoslup-naturalny-srodek-przeciwzapalny-i-przeciwbolow/ (dostęp: 25 VI 2019). 
tej egzotycznej, afrykańskiej rośliny (byliny) to duża niełupka, po dojrzeniu zdrewniała i bardzo twarda, wyposażona w liczne rozgałęzione, haczykowate, ostre wyrostki, które są zakończone dwoma ostrymi i zakrzywionymi haczykami. Wyschnięte owoce łatwo przyczepiają się do skóry i sierści zwierząt, powodując silne zranienia, a niekiedy nawet śmierć. Współcześnie, również w Polsce, roślina jest wykorzystywana do produkcji preparatów leczniczych

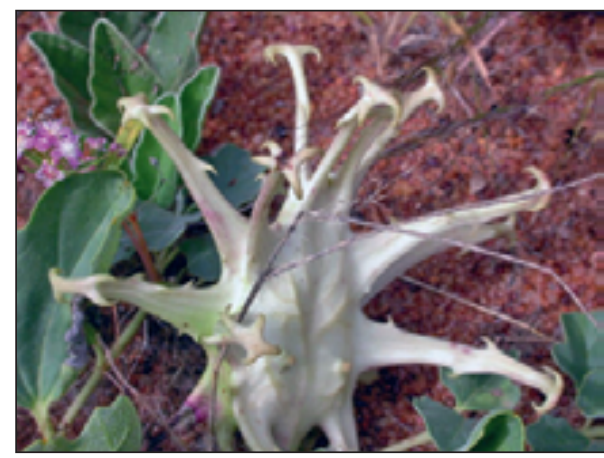

Hakorośl rozesłana (Harpagophytum procumbens) o działaniu przeciwzapalnym i przeciwbólowym (kapsułek, maści), w których nazwach handlowych pojawiają się wyrażenia diabelski pazur, czarci pazur.

Manta (Manta birostris) - diabel morski (Zgółk VIII: 344; Grabda, Heese 1991: $\left.10^{19}\right)$. Jedna z największych ryb. Występuje w ciepłych wodach oceanów Spokojnego, Atlantyckiego i Indyjskiego. Osiąga długość od 3 do 5 metrów, rozpiętość płetw wynosi około 7 metrów, a ciężar ciała około 2 ton. Ten najbardziej znany gatunek manty (drapieżnej ryby należącej do płaszczek ${ }^{20}$ ) swą nazwę zawdzięcza zapewne obecności płetw głowowych, które sprawiają wrażenie rogów. Ryba obdarzona jest niezwykłą siłą, podrażniona potrafi uderzeniem płetw roztrzaskać dużą łódź, nieprowokowana nie jest niebezpieczna.
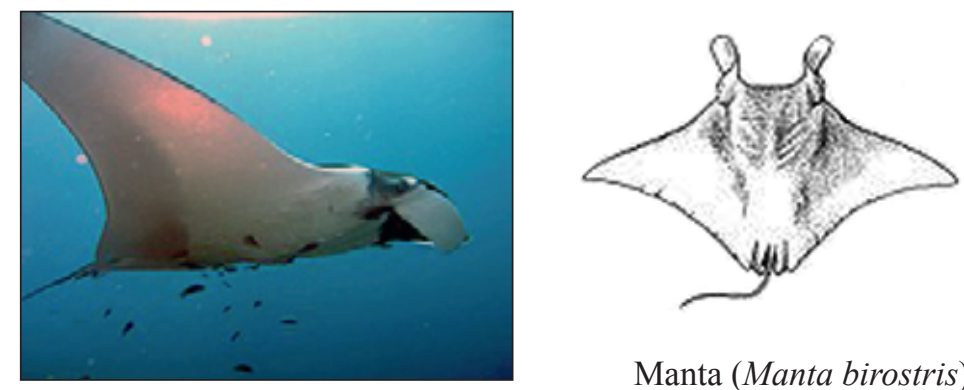

Manta (Manta birostris)

19 Por. zamieszczoną w tym opracowaniu (we wstępie) opinię: „Należy zdecydowanie dążyć do wyeliminowania szeregu nazw zapożyczonych z innych grup zwierzęcych, mimo częstego ich stosowania [...]: biały koń (Hemibardus labeo), lis morski (Alopias vulpinus) $\mathrm{i}$ in. Chyba warto się pokusić o zmianę aniołów morskich na skwatiny czy diabłów morskich na manty. [...] Większość [...] nazw jest najczęściej zapożyczona z obcego nazewnictwa, gdy były tworzone pod wpływem pierwszych impulsów spotkania z przyrodą morską [...]. Nazwy te są najczęściej wynikiem infantylnego stosunku do przyrody morza i nie ma potrzeby ich kultywować”.

20 Diabeł morski żywi się też planktonem. 
Storczyk szerokolistny (Orchis latifolia) - purtkove rogi, także purtkove pëski (SGK IV: 230) [dosł. 'diable pyski, mordy' - R.D.]. Nazwa ma być aluzją do osobliwej budowy kwiatu storczyka, szczególnie do listków kwiatu, z których trzy wznoszą się do góry tworząc hełm, a dwa układają się po bokach hełmu. W wyobraźni Kaszubów hełm ten skojarzył się z rogatą głową diabła (SGK IV: 230). Roślina występuje w całej Polsce, na wilgotnych torfowych łąkach, jej kwiaty nie mają zapachu.

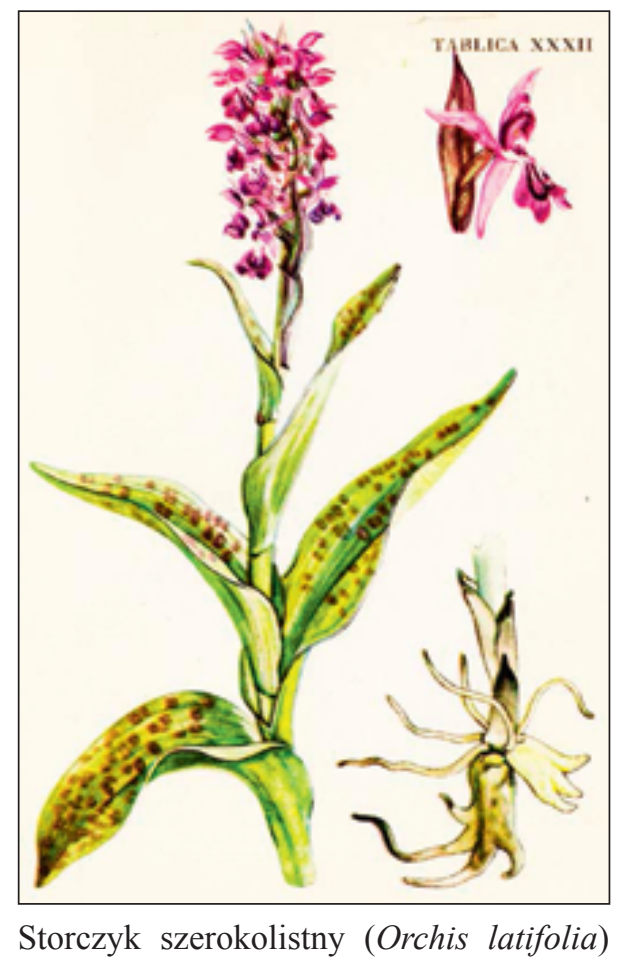

Amonit - diabli róg (SW I: 324). Amonity to wymarłe głowonogi, przeważnie o symetrycznej płaskospiralnej skorupie. Występują w skałach pochodzenia morskiego z okresu od dewonu do końca kredy ${ }^{21}$. W tym przypadku trudno mówić o podobieństwie nazwanego obiektu do diabelskich rogów, które w naszej kulturze mają jednak inny kształt (zob. np. Grąbczewski 1990). Z tego względu tę nazwę należy potraktować jako powstałą w wyniku skojarzenia całego obiektu nazywanego $^{22} \mathrm{z}$ diabłem (diabeł ma rogi) - w przeciwieństwie do innych przywołanych nazw, gdzie owo skojarzenie wywoływała jakaś charakterystyczna cecha obiektu, którą z diabłem (na zasadzie podobieństwa) zestawiano.

21 Amonity - paleont. (Ammonoidea), wymarłe mięczaki z gromady głowonogów (Cephalopoda), mające skorupę (muszlę) przeważnie spiralnie skręconą, o średnicy od $1 \mathrm{~cm}$ do ok. 2 $\mathrm{m}$, podzieloną przegrodami na komory, które żyły od okresu dewońskiego do końca okresu kredowego (SWO: 28).

22 Co warto podkreślić. 


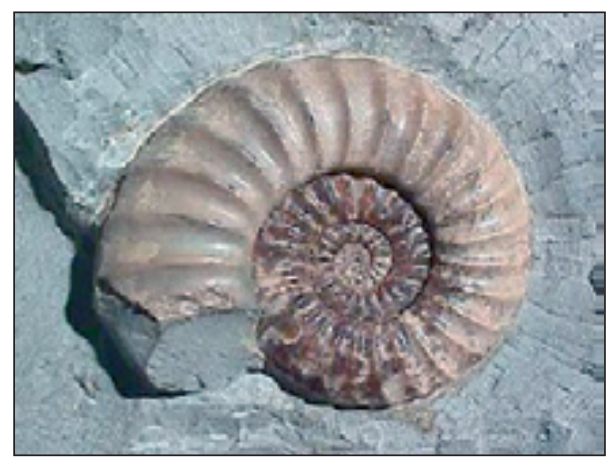

Amonit

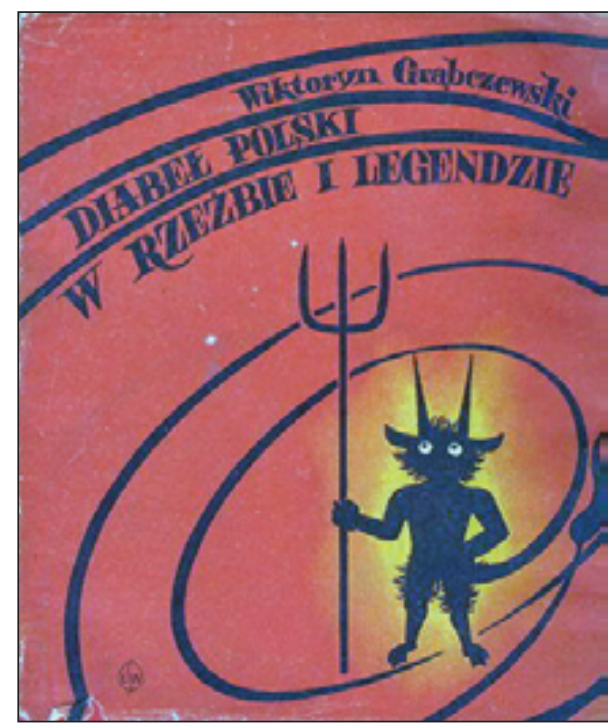

Okładka książki

\section{- inne cechy obiektu nazywanego wywołujące skojarzenia $\mathrm{z}$ diablem}

Innymi cechami obiektu nazywanego, które wywołały skojarzenia z diabłem (uwidocznione następnie w nazwie obiektu) były: tryb życia - nocny, a także miejsce przebywania: ostępy leśne.

Sowa - bestri purtk (SGK IV: 229) [dosł. 'pstrokaty, różnobarwny diabeł' R.D.]. W przypadku sowy za cechę, która mogła wywołać asocjacje z diabłem, należałoby uznać nocny tryb życia tego ptaka. Niewykluczone jednak, że dwie inne cechy również mogły odegrać jakąś rolę podczas tworzenia nazwy: siedliskiem sowy są lasy, najczęściej stare, gęste drzewostany (z którymi i diabeł w przekazach ludowych jest kojarzony), a niektóre z sów (precyzyjniej: niektóre gatunki sów, np. uszatka zwyczajna) mają specyficznie uformowane pióra na głowie, przypominające jednym uszy, innym - być może diabelskie rogi?

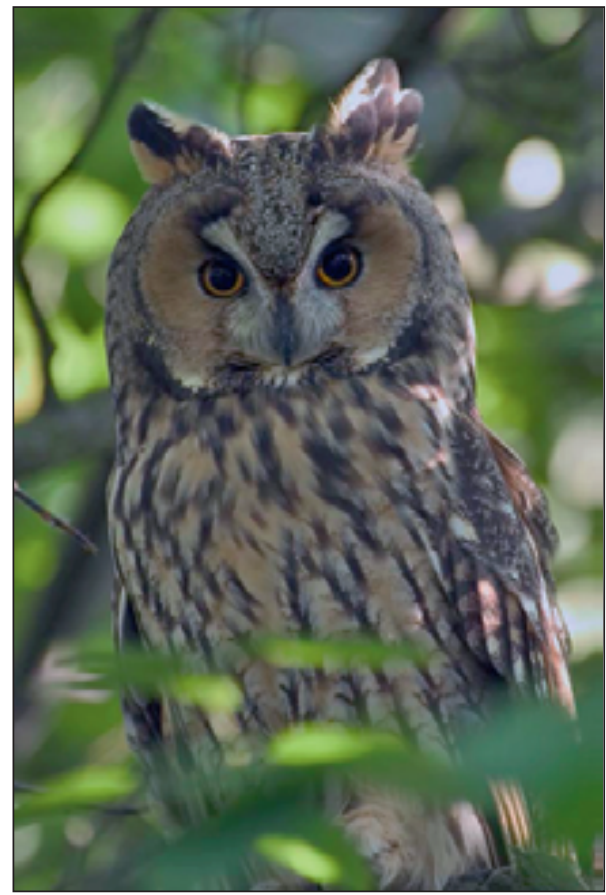




\section{Uwagi końcowe}

Przedstawiony w pracy mechanizm nominacyjny był wykorzystywany podczas tworzenia nazw roślin, zwierząt (ryby, ptaki) oraz innych obiektów ze świata natury (amonity). Stosowano go, gdy dostrzegano podobieństwo nazywanego obiektu do diabła w zakresie wyglądu (diabelskie rogi, diabelski pazur), a także czasu największej aktywności (noc) oraz miejsca przebywania (gęste zarośla leśne). Warto dodać, że ostatnia z zaprezentowanych nazw, nazwa sowy, nawiązuje - ale poprzez swoiste zaprzeczenie - do wyobrażenia diabła jako istoty demonicznej powszechnie kojarzonej z kolorem czarnym (wygląd diabła) ${ }^{23}$ : bestri purtk dosł. 'pstrokaty, różnobarwny diabeł' (co można tłumaczyć: sowa nie jest takiego koloru jak diabeł), co nie dziwi, ponieważ sowa nie jest ptakiem o jednolitym czarnym upierzeniu. W przypadku manty o wyborze „diabelskiej” nazwy (diabet morski) mogło decydować również to, że w powszechnym odczuciu nie jest to ryba prototypowa, na co wskazują jej ogromne rozmiary oraz specyficzny wygląd. Wykorzystaną w procesie nominacji 'diabelskość' można by zatem w tym przypadku zinterpretować jako kategorię (semantyczną), za pomocą której człowiek wyłącza tę istotę żywą z klasy ryb oraz ukazuje swój do niej stosunek (obawa, strach, może też fascynacja ogromnymi rozmiarami?).

Nazewnictwo nienaukowe, obiegowe, ludowe charakteryzuje m.in. to, że jedna nazwa może się odnosić do kilku różnych obiektów (desygnatów). I tak diabet morski to nie tylko nazwa manty, ale także: 1. żabnicy (Lophius piscatorius) ${ }^{24}$, ryby zamieszkującej dna morskich głębin, żyjącej w ciemnościach, o niezwykłym, nietypowym wyglądzie (głowa z szerokim otworem gębowym wypełnionym zębami stanowi większą część ciała) (SJPD I: 420); 2. ryby noszącej nazwę kur diabet (Myoxocephalus scorpius) ${ }^{25}$, reliktowej ryby z rodziny głowaczowatych, o nagim ciele (bez łusek) i dużej głowie, uzbrojonej w trzy pary kolców oraz ostre wyrostki, a także o zmiennym ubarwieniu, żywiącej się rybami i skorupiakami, długiej do 30-60 cm, która występuje m.in. w Bałtyku; ryba ta jest bardzo żarłoczna (żywi się rybami i dużymi skorupiakami), a wyjęta z wody wydaje burczące dźwięki (Zgółk VIII: 344; SGK III: 113; SGP V: 511); 3. każdego zwierzęcia o odstraszającym wyglądzie, żyjącego w morzu (Zgółk VIII: 344).

Wszystkie przedstawione w tej pracy nazwy mają charakter metaforyczny. Pod względem formalnym reprezentują dwie grupy:

23 Nie bez znaczenia pozostaje też symbolika tego koloru w kulturze ludowej i judeochrześcijańskiej (diabeł jako demon zła).

24 W opracowaniu E. Grabdy i T. Heesa (1991: 61) została podana jedynie nazwa żabnica nawęd (nazwa diabet morski nie została odnotowana).

25 W opracowaniu E. Grabdy i T. Heesa (1991: 105) została podana jedynie nazwa kur diabel (nazwa diabet morski nie została odnotowana). 
- nazwy z komponentem 'diabelski' (diabelski pazur / czarci pazur / diabelski szpon, diabli róg, purtkowe rogi / purtkowe pyski)

- nazwy z komponentem 'diabeł' (diabet morski, bestri purtk).

Znakiem naszych czasów jest, że w użyciu pozostają te „diabelskie” nazwy, które do polszczyzny zostały przejęte z języka angielskiego, natomiast nazwy gwarowe, ludowe we współczesnej polszczyźnie są recesywne.

\section{SUMmary \\ Devilish Meaning What? \\ A Few Words About the Motivation of Names}

Phraseological expressions which have the status of common names (nomina appellativa), two-component units, in which one of the parts bears the meaning 'devil' or 'devilish', denote various elements of the world, which fit into the field of nature and culture. These units have already been discussed in two papers: $O$,,diabelskich" nazwach i nazwaniach and Nazwy z zakresu kultury materialnej motywowane pojęciami z zakresu kultury duchowej. The former is dedicated to particular objects which have 'devilish' names. The latter concentrates on the terms from the field of material culture, which are motivated by three notions from the area of spiritual culture: DIABEE ('devil') ANIOŁ ('angel') and BÓG ('God'). The following paper focuses on semantic motivation of 'devilish' names in a possibly most synthetic way - i.e. in order to show naming tendencies (nominal mechanisms), which can be observed in this group of phraseological units. The following items should be listed: 1. the named objects, and most frequently some of its qualities evoke associations with devil, which is visible in the name, 2. the link between the object and devil in beliefs, magic or folk rituals is reflected in the name, 3. categorization, evaluation of the object made by man results in using a 'devilish' name. The paper concentrates on the first of those nominal mechanisms, presenting names which picture it. The other two mechanisms will be the subject of a separate work. 
Studia przypadków 



\author{
AnNa TyrPa (10 \\ Instytut Języka Polskiego Polskiej Akademit Nauk, Kraków \\ anna.tyrpa@ijp.pan.pl
}

\title{
WÓZ ALBO PRZEWÓZ - STUDIUM PRZYPADKU
}

Słowa klucze: frazeologia gwarowa, motywacja idiomu, wóz albo przewóz, przewóz jako nomen appellativum, Przewóz jako nomen proprium

Keywords: dialectal phraseology, motivation of idiom, wóz albo przewóz, przewóz as nomen appellativum, Przewóz as nomen proprium

Frazem wóz albo przewóz jest powszechnie znany i używany we współczesnej polszczyźnie. Słownik współczesnego języka polskiego pod red. Bogusława Dunaja definiuje go tak jako ,wyrażenie używane w chwili podjęcia jakiegoś wyboru, decyzji o niewiadomych skutkach" i ilustruje przykładem: Spróbuj jutro zdać ten egzamin. Wóz albo przewóz! (SWJP: 1244) ${ }^{1}$. W gwarach są poświadczenia tej jednostki ze Śląska cieszyńskiego (Ondrusz 1960: 220) i z powiatu konińskiego (KSGP). Znaczenie wyrazu wóz nie budzi wątpliwości. Ale co w tym frazemie znaczy przewóz? Zaglądamy znów do Słownika współczesnego języka polskiego i znajdujemy definicję: ,,przewiezienie kogoś lub czegoś z jednego miejsca na drugie; transport” z przykładami: przewóz lądowy, wodny, morski (SWJP: 897). Ale gdy podstawimy zamiast słowa przewóz jego synonim transport, uzyskujemy wyrażenie bez sensu: ,wóz albo transport”.

Niedawno pojawiła się taka interpretacja przysłów z tego kręgu:

Przewóz to jazda połączona z osiągnięciem punktu docelowego drogi, odnotowana w wielu wariantach przysłów ze sformułowaniem wóz $\boldsymbol{i}$ przewóz, oznaczającym metaforycznie prawo wyboru, a odwołującym się do czynności przewiezienia kogoś lub czegoś, np. Masz wóz i przewóz (NKP wóz 25a; wóz 25); Lepszy wóz niż przewóz (NKP wóz 25c); Jedyn ma rad wóz, drugi zaś przewóz (NKP wóz 25d) (Smyk 2016: 380).

Nie sądzę, aby było to dobre wyjaśnienie motywacji frazemów. Przeprowadziłam mały sondaż wśród kolegów językoznawców, ale nikt nie umiał podać właś-

1 Zgodnie z sugestią Recenzenta tej pracy dodaję uwagę, że frazem wóz albo przewóz należy do licznej rodziny jednostek rodzimych zbudowanych na mechanizmie paronomazji. 
ciwego znaczenia wyrazu przewóz. Ja też żyłabym w nieświadomości, gdyby nie fakt, że przypadło mi w udziale opracowanie hasła przewóz do Słownika gwar Ostródzkiego, Warmii i Mazur. Przekonałam się wtedy, że w gwarach wyraz przewóz oznacza wprawdzie transport, ale zwłaszcza przez wodę, co ilustruje pieśn: A gdy sia wyspała, Raniusiańko wstała, Poszła do jeziora, Przewozu żóndała ${ }^{2}$. Co więcej, słowo przewóz znaczy też 'środek transportu, czyli łódka lub prom', a na dowód kolejny cytat z pieśni ludowej: wysiodoj dziewczyno z przewozu mojego (SGOWM VII: 91). Znaczenie to potwierdzają zapisy gwarowe ze Śląska (Symoni-Sułkowska 1972: 20) i z powiatu niżańskiego (Gaj-Piotrowski 1967: 169). Jest to znaczenie stare, notowane już w XVI w., definiowane jako 'środek transportu do przeprawy przez wodę' (SPXVI XXXII: 363). Słownik języka polskiego pod redakcją Witolda Doroszewskiego określa je jako dawne i podaje następujące przykłady użycia: Tymczasem przewóz był na drugiej stronie Wisty; Lina od przewozu; Narzadzenie przewozu aż do wieczora potrwać musi (SJPD VII: 451).

Tak więc przewóz we frazemie wóz albo przewóz oznacza prom lub łódź. Przy takim rozumieniu jasny staje się sens. Człowiek ma do wyboru dwa środki transportu: wóz, czyli drogę lądową, lub prom, czyli drogę wodną. Trzeba sobie zdawać sprawę, że dawniej nie było tylu mostów i drugi brzeg osiągano głównie dzięki pływającym środkom transportu.

Powszechność pokonywania odległości przez wodę spowodowała powstanie jeszcze innych znaczeń wyrazu przewóz. Przewozem nazywano przystań nad rzeką lub jeziorem, skąd wyruszały promy lub łodzie, co zilustrujemy cytatami z gwary: Ja dtugo musiała na przewozie stojać, bo przewoźniki sie dzieś zabrali (Drohiczyn nad Bugiem, KSGP) i z pieśni: A kiedy ja przewiózł, Nie miała czym płacić, I musiała swój wianeczek U przewozu stracić (SSiSL I/2: 342). Te przystanie zwane przewozami dały nazwę wielu miejscowościom leżącym nad wodą. Spis miejscowości Polskiej Rzeczypospolitej Ludowej wymienia 28 wsi o nazwie Przewóz (Spis 928). W onomastycznym kompendium Nazwy miejscowe Polski przy opisie wielu wsi o nazwie Przewóz widnieją informacje, takie jak: „Wieś leży nad Pilicą”, „Wieś leżała nad Wartą”, „Wieś leży na Wisłą”, „Wieś leży przy ujściu Noteci do Gopła” (Nazwy IX: 320-321), co dowodzi, że właśnie przewóz, czyli przystań nad rzeką, motywuje toponim. Ciekawa jest wzmianka w Słowniku geograficznym Królestwa Polskiego (SGKP IX: 186) o wsi Przewóz nad Wisłą, w powiecie garwolińskim: „Jest w tej wsi przewoźników 8 , którzy żadnej roboty nie powinni odprawować, tylko przewozić na promie na potrzebę dworską". Oczywiście taka usługa była płatna, oto cytat z Kaszub: Za przewuóz przez jezoro uon muszi dwa

2 Ewa Masłowska i Stanisława Niebrzegowska, autorki artykułu Rzeka piszą: „Częsty w pieśniach motyw przewozu przez rzekę ma sens erotyczny. Dziewczyna za przewóz przez rzekę płaci wiankiem" (SSiSL I/2: 330). 
talary zapłacec (LPW I: 678). W rezultacie opłata zwana jest przewozem: Nie wiedzieli nawet tego, że płacił „przewóz” za nich i za siebie (SGW 352).

Powszechną nazwą człowieka trudniącego się przewożeniem ludzi na drugi brzeg jest przewoźnik (KSGP), w pieśniach przewoźniczek (KSGP), a sporadyczną - przewozowy (Symoni-Sułkowska 1972: 18).

Po wykazaniu, że przewóz w połączeniu wóz albo przewóz znaczy 'łódź lub prom', możemy powrócić do frazeologii gwarowej. Spotykamy tam kilka jeszcze frazemów z parą leksemów wóz i przewóz. Osiem razy poświadczona jest postać Masz wóz i przewóz, przy czym raz objaśniona jest przez gwarowego informatora: jak kces to możes, jak nie kces, to nie (Limanowskie, KSGP), a raz przez badacza: daje ci wolność, rób co chcesz, innej rady, ani pomocy dać ci nie moge (Święt: 677).

Ogólny schemat ktoś ma wóz i przewóz realizuje się jeszcze na kilka sposobów: 1. Rebok mo wolny wóz i przewóz (Kaszuby, NKPP III: 112). Tu wolność wyboru wyrażona przez dwie możliwości - podróż lądową lub wodną, została jeszcze wzmocniona przymiotnikiem wolny.

2. Każdy ma wóz i przewóz. Rób, co chcesz. Wola twoja, Paplin nasz (Sychta 1959: 31). To przysłowie zostało objaśnione w przypisie: „każdy za siebie odpowiada". Wyrażenie Wola twoja jest synonimiczne wobec poprzedniego zdania Rób, co chcesz, natomiast w połączeniu z Paplin nasz stanowi żartobliwe przysłowie będące aluzją do nazwy wsi Wola pod Pelplinem. Właściwa forma przysłowia to Wola twoja, Paplin mój (Sychta 1959: 120-121).

3. Chto ma wóz, ma i przewóz Bernard Sychta objaśnił jako 'należy się zdecydować, tak czy owak' (SGK IV: 193). Tu można by przypuszczać, że przewóz nie jest 'wodnym środkiem transportu' lecz możliwością jazdy, będącą konsekwencją posiadania wozu.

Następnym schematem jest ktoś daje komuś wóz i przewóz. Postać Dam ci wóz i przewóz (Ukraina, NKPP III: 769) nie jest objaśniona, ale można się domyślać, że chodzi o sytuację, w której ktoś daje komuś drugiemu dwie możliwości do wyboru. Zwrot ten pojawia się jeszcze w pewnej ludowej opowieści z Warmii:

Mniáł łojciec syna. [...] urzóndziuł go do gbura za pastórza. Na łodchodnam dáł mu ,wóz i przewóz":

- Mój synie, nie bóndz wybrédny i zjédz wszystko, co ci dadzó (Steffen 1937: 36).

Dalszy ciąg tej historii był taki, że syn zjadał całą zawartość misek stawianych przez gospodynię na stole, chociaż sprawiało mu to trudność, bo tak zrozumiał polecenie ojca. Ojcu chodziło tylko o to, by syn nie grymasił. Jak więc interpretować: dat mu ,wóz i przewóz”? Chyba tak, że jest to rozkaz, któremu należy bezwzględnie być posłusznym.

W końcu zanotowane na Śląsku cieszyńskim przysłowie Jedyn mo rod wóz, drugi przewóz (NKPP III: 769) mówi o prawie wyboru według upodobania. 
Analiza frazemów gwarowych z parą leksemów wóz i przewóz pokazuje, że właśnie w gwarach można czasem znaleźć objaśnienie związków frazeologicznych wprawdzie obecnych w ogólnej polszczyźnie, ale o zatartej motywacji. Omawiane tu jednostki są stare, ich pierwsze zapisy pochodzą z pierwszej połowy XIX w. (NKPP III: 769). W gwarach zostały utrwalone, a zapisane na wsi teksty potoczne czy pieśni ludowe pozwalają odkryć ich ukryty sens.

\section{SUMMARY}

\section{Wóz albo PRZEWóz - CASe STUdy}

The expression wóz albo przewóz, which is a call for making a decision (English counterpart: sink or swim), is well-known and frequently used, but its motivation has blurred. Dialectal records make it possible to reconstruct it. One of the meanings of the word przewóz is 'a means of transport for crossing water, i.e. a boat or a ferry'. This meaning was maintained in folk dialects. Thus, wóz albo przewóz means an alternative - you can either choose wóz (cart) and travel on land, or przewóz (ferry/boat), and travel on water. 


\section{ЕЛЕНА НИчИПОРчИК ๑}

ГОМЕЛЬСКИЙ ГОСУДАРСТВЕННЫЙ УНИВЕРСИТЕТ ИМЕНИ Ф. СКОРИНЫ

ГОМЕЛЬ, БЕЛАРУСЬ

evnich@gmail.com

\section{ДИАЛЕКТНЫЕ ЛЕКСИКАЛИЗОВАННЫЕ ПРЕДЛОЖНО-ПАДЕЖНЫЕ СОЧЕТАНИЯ С КОМПОНЕНТОМ БЕЗ В РУССКОМ ЯЗЫКЕ}

Ключевые слова: словарь, лексикализованные предложно-падежные сочетания, диалектные предложно-падежные сочетания, компонент без, субстантивный компонент, значение

Keywords: dictionary, lexicalized prepositional-nominal combinations, dialectal prepositional-nominal combinations, component bez, substantive component, meaning

Лексикализованные предложно-падежные сочетания - это воспроизводимые, а не формируемые свободным притяжением двухкомпонентные единицы номинации, состоящие из предложного и субстантивного компонентов, например: в бегах, в сердияах, без бошля, без передыики, без ума, до зарезу, до нитки, из-под поль, на брудершафт, на носу, на ножах, на рожон, на ходу, от балды, под каблуком, под хмельком, со вкусом, с кондачка, с развальцем. Переосмысленность, оценочность, экспрессивность, устойчивая сочетаемость с определенным словом, свойственная одним предложно-падежным сочетаниям, и отсутствие такого рода характеристик у ряда других лексикализованных предложно-падежных сочетаний лишают единства всю массу отпочковавшихся от падежных парадигм сочетаний существительного с предлогом. Отсюда противоречия в определении языкового статуса такого рода знаковых единиц, проявляющиеся в лексикографической практике.

С одной стороны, лексикализованные предложно-падежные сочетания как неоднокомпонентные знаковые единицы, деривационная база которых представлена сопряжением незнаменательного и знаменательного слов, фиксируются во фразеологических словарях. С другой стороны, лексикализованные предложно-падежные сочетания, будучи слитными единицами обозначения, эквивалентными слову, приводятся в толковых словарях и словарях синонимов. Фиксация лексикализованных предложно-падежных сочетаний 
в одном ряду со словами, как правило, требует от лексикографа определения частеречной принадлежности этих формально сложных по структуре знаковых единиц. Такая задача решается порой не однозначно. К примеру, в Современном толковом словаре русского языка Татьяны Ефремовой предложно-падежное сочетание под хмелько́м дефинируется следующим образом: наречие качеств.-обстоят. разг. 1. В состоянии легкого опьянения. 2. Употребляется как несогласованное определение (СТСРЯ). В словаре синонимов Виталия Тришина это предложно-падежное сочетание квалифицируется как прилагательное и к нему приводится состоящий из 38 позиций список синонимичных языковых единиц, среди которых есть как собственно слова, так и другие предложно-падежные сочетания, квалифицируемые как прилагательные: в кураже, в поддатии, в подпитии, весельй, вмазанный, во хмелю, вполпьяна, выпивши, выпивший, дринканутылй, кирнутый, клюкнувший, клюнувший, на втором взводе, на кураже, на первом взводе, навеселе, нетрезвый, остаканенный, под газом, под градусом, под куражсм, под мухой, под парами, подвыпивший, подгулявший, поддавший, поддатылй, подзаправленньй, подзаряженный, подзахмелевший, подкумаренный, подогретый, подшофе, принявиий, пьяныій, тепленький (ССА). Подобного рода проблема свидетельствует, скорее всего, о том, что не все процессы в языке достигают своего завершения, некоторые единицы стягиваются во множества, функционально обладая центростремительной силой, структурно - центробежной. Природа знаковых единиц, форма и содержание которых оказываются „в разладе”, и становится, как правило, предметом дискуссий.

В последнее время в лингвистике наблюдается тенденция преодолеть сложившееся положение, связанное с перманентной открытостью вопроса о языковом статусе лексикализованных предложно-падежных сочетаний. Находит распространение идея квалификации лексикализованных предложнопадежных сочетаний как единиц синкретичной, переходной языковой природы (Пасечник 2005; Городнянская 2013; Копотев, Стексова 2016). Иными словами, выдвинутые в свое время известными лингвистами, а впоследствии и когнитологами идеи об отсутствии непереходимой границы между свободными и несвободными сочетаниями (Балли 1961; Аничков 1997), о наличии разной степени слитности компонентов несвободных сочетаний и разной степени устойчивости комплексных единиц языка (Виноградов 1977; Копыленко, Попова 1978), о целесообразности описания семантики выражений с разной степенью идиоматичности в рамках тех же формальных моделей, что и регулярные ,ядерные” шаблоны и правила (Fillmore, Kay 1993), о необходимости пересмотра понятия „идиоматичность” (Баранов, Добровольский $2008)$ позволили более пристально присмотреться к периферийным, „полуоформленным” единицам в системе языка, к тому, что оказывается „между" языковыми уровнями, ,работает” на преодоление разрыва между речью 
и языком. Заметна тенденция обращения к термину идиома в расширительном значении, активизация использования наряду с термином эквивалент слова и в противовес ему термина коллокация, то есть активизация обращения к понятиям, имеющим отношение к весьма протяженному ряду явлений, квалификация языковой природы которых не предполагает стремления придать процессам идиоматизации, фразеологизации некую уникальность. Эта тенденция находит специфическое отражение в лексикографической практике. С одной стороны, появляются специальные словари, в которых фиксируются неоднокомпонентные единицы языка, эквивалентные слову: Словарь эквивалентов слова (СЭС), Толковый словарь сочетаний, эквивалентных слову (ТССЭС), Дискурсивные слова русского языка: опыт контекстно-семантического описания (ДСРР), Корпусной словарь неоднословных лексических единиц (оборотов) (КСНЛ). С другой стороны, появляются словари, в которых фиксируются сочетания, выделяемые на основе высокой степени „притяжения” компонентов, частотности их совместной встречаемости: Словарь сочетаемости слов русского языка (СССРЯ), Слово в тексте. Словарь коллокаций (устойчивых словосочетаний) русского языка с англо-русским словарем ключевых слов (СВТ), The BBI Combinatory Dictionary of English (BBI), Oxford Collocations Dictionary for Students of English (OCD), COBUILD English Collocations Dictionary on CD-ROM (CECD) и мн. др.

Авторы книги с весьма говорящим названием Исключение как правило: Переходные единицы в грамматике и словаре (Копотев, Стексова 2016) утверждают, что причины наличия в языке значительного количества единиц, размывающих границы между языковыми уровнями, и прежде всего между лексикой и грамматикой, заключаются в том, что идиоматизация, как один из постоянных процессов конвенциализации речевого потока языковым сообществом, является не исключением из правила, а естественным языковым механизмом, и действие этого механизма может давать разного рода результаты. Идиоматизация

в одном случае приводит к возникновению предельно обобщенного правила (например, без + Род. пад.), в другом - к менее общему (без + [шапки, пальто $]$ ), а в третьем не приводит к обобщению, оставаясь уникально-идиоматическим: (встреча) без галстуков. Языковые правила в этом смысле есть не что иное, как обобщение (генерализация) речевого потока. Начало этого - совместная встречаемость единиц в речевом потоке, а строгое языковое правило - лишь одна из возможностей завершения этого процесса (Копотев, ГСтексова 2016).

С авторами этого положения нельзя не согласиться. Действительно, процесс генерализации в речевой цепи может приводить к разным результатам, и подтверждением этому является, в частности, семантика лексикализованных предложно-падежных сочетаний, свидетельствующая о незавершенно- 
сти перехода этих единиц из разряда грамматических в разряд лексических или, по крайней мере, непоследовательной завершенности этого процесса.

Наше внимание привлекло то, что в разных мотивационных базах, лежащих в основе формирования значений лексикализованных предложно-падежных сочетаний, семантика предлога не подвергается деактуализации, а прямо или опосредованно воздействует на содержательный план лексикализованной единицы.

Для анализа роли предлога в формировании семантики лексикализованных единиц мы обратились к диалектным предложно-падежным сочетаниям с компонентом без. В качестве источника материала был использован Большой словарь русских поговорок, составленный В.М. Мокиенко и Т.Г. Никитиной (БСРП). Нужно отметить специально, что соединение в рамках одного словаря книжных, разговорных, просторечных, жаргонных и диалектных единиц, отражающих стремление авторов к максимальному охвату фразеологического материала, дает замечательную возможность изучения каждой их стилистически маркированных групп устойчивых сочетаний в сопоставлении.

Первая задача, которая, на наш взгляд, способствует формированию некоторого системного представления об изучаемом объекте, заключается в выяснении доли диалектных лексикализованных предложно-падежных сочетаний в общем корпусе предложно-падежных сочетаний, подвергшихся лексикализации в языке. В качестве „пробного шара”, используемого для совершения такого рода наблюдений, произвольно нами были выбраны, кроме сочетаний с предложным компонентом без, сочетания с предложными компонентами в и до.

Оказалось, что все три группы лексикализованных предложно-падежных сочетаний с предлогом без, в и до показали преобладание территориальноограниченных (региональных) сочетаний над разговорными, просторечными, жаргонными, книжными (результаты количественного анализа отражены в диаграммах, приведенных ниже). Доля книжных лексикализованных предложно-падежных сочетаний необычайно мала, лексикализованные сочетания с предлогом до, маркированные книжной коннотацией, вообще не зафиксированы. Напрашивается вывод, что основным источником пополнения национального языка лексикализованными предложно-падежными сочетаниями являются диалекты. 
Диаграмма 1 - Количественное соотношение стилистически маркированных лексикализованных предложно-падежных сочетаний с компонентом без в БСРП

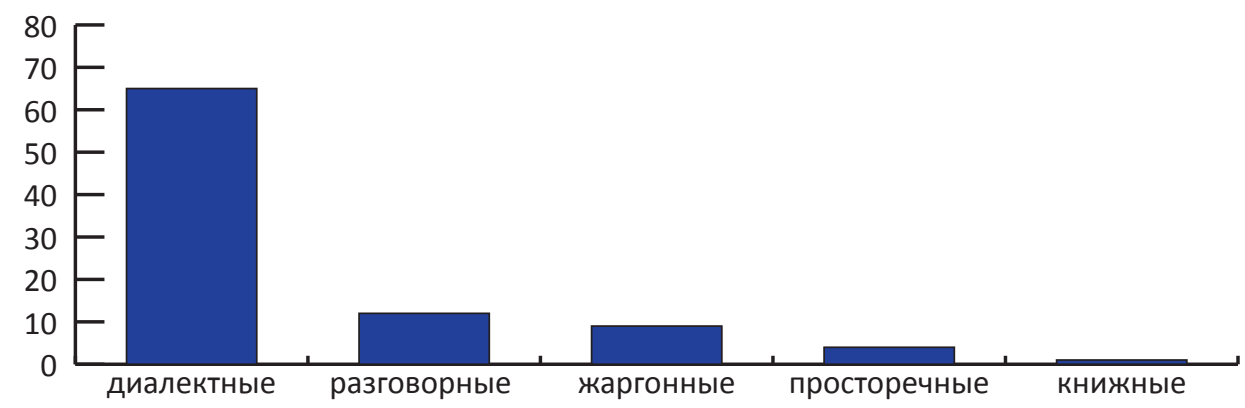

Диаграмма 2 - Количественное соотношение стилистически маркированных лексикализованных предложно-падежных сочетаний с компонентом в в БСРП

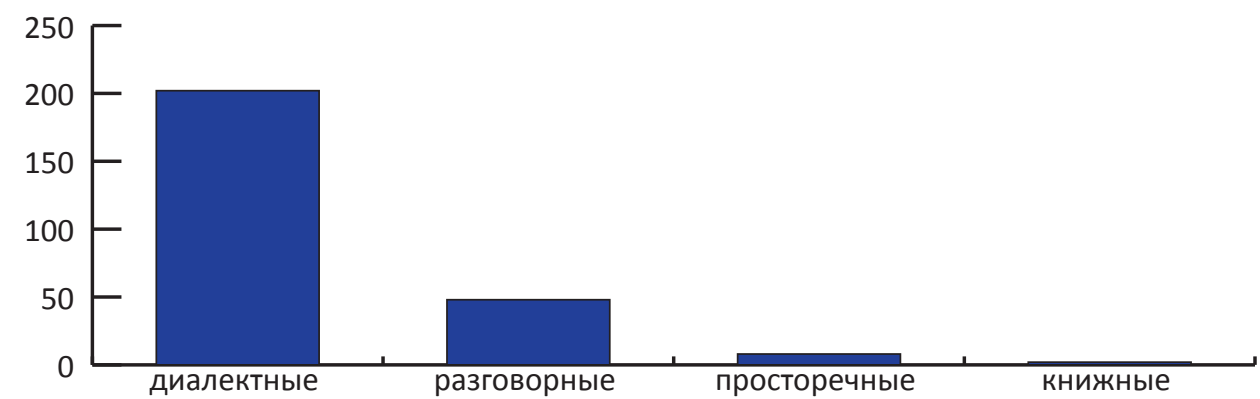

Диаграмма 3 - Количественное соотношение стилистически маркированных лексикализованных предложно-падежных сочетаний с компонентом до в БСРП

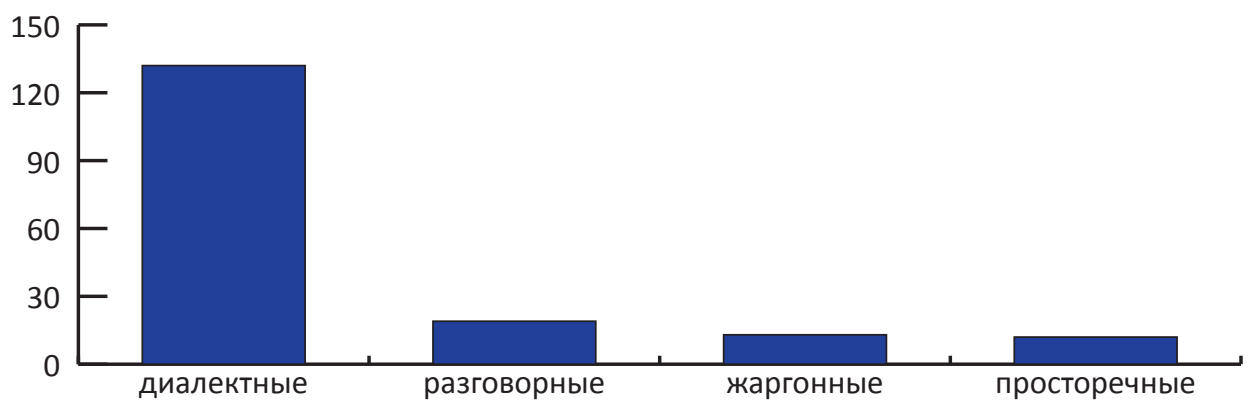

Выявилась и другая особенность формирования лексикализованных предложно-падежных сочетаний. Чем многозначнее предлог в системе языка, тем большее количество сочетаний этого предлога с существительными подвергается лексикализации.

Так, по данным Толкового словаря русского языка Дмитрия Ушакова (ТСРЯ), предлог в способен реализовать в русском языке 21 значение, 
предлог $\partial о-4$ значения, предлог без - 3 значения. Как видно их четвертой диаграммы, самое большое количество диалектных лексикализованных предложно-падежных сочетаний, зафиксированных в анализируемом нами словаре (БСРП), представляют сочетания с предложным компонентом 8 202 единицы. Количество диалектных сочетаний с предложным компонентом $\partial о-132$ единицы, диалектных сочетаний с предложным компонентом без - 64 единицы.

Диаграмма 4 - Количественное соотношение диалектных лексикализованных предложно-падежных сочетаний с компонентами в, до, без в БСРП

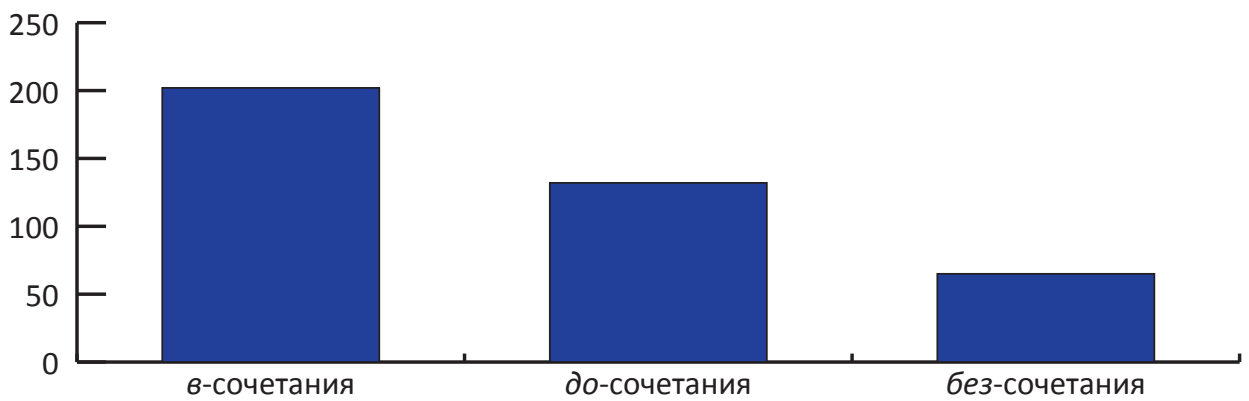

Что же показывает семантический анализ диалектных предложно-падежных сочетаний с компонентом без в плане семантической релевантности этого компонента?

Как известно, основное значение предлога без в русском языке - это значение отсутствия (ТСРЯ). Предлог в речи свободно сочетается с существительными самой разнообразной семантики - с именами, обозначающими лиц, предметы, количество, меру и др.

Интересно, что идеография субстантивных компонентов в лексикализованных предложно-падежных сочетаниях с компонентом без существенным образом отличается от идеографии субстантивных компонентов, сочетающихся с предлогом без в составе пословичных выражений русского языка. Причина заключается в разных функциях, которые реализуют эти единицы. В пословицах выносится оценка ситуации отсутствия; синтаксические структуры, представляющие логемы Без X плохо (кому-то / всем); Без Y не обойтись (в каком-либо деле) / ничего не сделаешь, используются для утверждения ценности отсутствующего объекта. В ряду таких объектов люди (Без друга жить - самому себе постылым быть ; Жена без мужа всего хуже; Без матки пчелки - пропащие детки), орудия труда (Без сохи и бороны и иарь хлеб

1 Приведенные здесь пословицы извлечены из Большого словаря русских послович (БСРПС). 
не найдет; Без топора не плотник, без иглы не портной), продукты питания (Без хлеба куска везде тоска; Без соли хлебать что немилого изеловать), идеальные объекты (Без ума голова - ногам пагуба; Без ума - не в пользу и сума; Без труда нет плода, Без любви как без солниа). Предлог без в составе таких структур используется преимущественно (но не исключительно, сравн.: Нет стада без бодливой коровы; В семье не без урода) для выделения из мира того объекта, ценность которого утверждается. Лексикализованные сочетания с без-компонентом, функционирующие в качестве автономных языковых единиц, реализуют не идентифицирующую, а характеризующую функцию. К какому объекту могут быть приложимы характеристики, выражаемые лексикализованными предложно-падежными сочетаниями, зависит во многом от того, какими лексико-грамматическими характеристиками обладает субстантивный компонент, сочетающийся с предлогом без.

Большая часть существительных, представленных в диалектных предложно-падежных сочетаниях, - это отглагольные существительные со значением отвлеченного процессуального признака: без выходу, без запросу, без ладу, без обсеку, без обузды, без опромети, без осторожки, без отрыва, без переносу, без переставу, без побегу, без покиду, без приберегу, без провороту, без расклону и др. Такие сочетания примыкают к глаголам и реализуют значение качественной характеристики действия. Параметры характеризующей оценки разнообразны: трудно / легко, быстро / медленно, активно / вяло, сильно / слабо, дискретно / недискретно и т.п.:

Без болезни. Кар. (Волог.). Легко, без труда (БСРП).

Без расклону. Горьк. Напряжённо, не отдыхая (работать) (БСРП).

Без осторожки. Кар., Яросл. Смело, без страха, без опасения (БСРП).

Без обузды. Олон. Необузданно, неудержимо (БСРП).

Без переставу. Пск. Не переставая (БСРП).

Без утиху. Сиб. Беспрерывно, постоянно (БСРП).

Нетрудно убедиться в том, что выражаемые лексикализованными предложно-падежными сочетаниями характеристики действий имеют отношение к понятию меры и всегда представляют некоторое отклонение от условного нуля, середины, принимаемой за точку отсчета. К аналогичным выводам приходит Олеся Сурикова в результате анализа словообразовательных дериватов с префиксом без: „...негативно префигированная лексика (в частности содержащая приставку без-), призванная номинировать аномалии, в конечном 
счете и называет отклонения от порядка - в той или иной его ипостаси (норма $\approx$ порядок, правило)" (Сурикова 2016: 52). Прозрачная мотивированность таких лексикализованных сочетаний говорит об их композициональности, об актуальности значения негации, реализуемого предлогом. Толкование лексикализованных сочетаний подтверждает это: в дефинициях сочетаний встречаются слова с предлогом без, приставкой без- / бес-, частицей не; значение отклонения от нуля и интенсификации проявления того или иного признака подчеркивается словом очень.

Лексикализованные предложно-падежные сочетания, состоящие из предложного компонента без и отглагольного существительного, могут реализовать оценочное значение, связанное с градуальностью, и при оценке состояний человека, интеллектуальных, физических характеристик человека. Как показывают наблюдения, в этом случае мотивированность тоже прозрачная, предложный компонент участвует в формировании квалификативно-оценочных значений, реализуя каритивную семантику:

Без прохвату. Кар. Очень крепко, беспробудно (спать) (БСРП).

Без (безо) внимания. Печор. 1. Без сознания, в обморочном состоянии. 2. Крепко, без снов (спать) (БСРП).

Без задачи. Дон. О человеке без воображения, не способном творчески, оригинально мыслить (БСРП).

Без перехвата. Яросл. Об очень полном человеке (БСРП).

Значительно реже лексикализованные предложно-падежные сочетания с предлогом без имеют в своем составе существительные с предметной или вещественной семантикой: без бобов, без льку, без шапки, без водь и др. Практически во всех случаях наблюдается переосмысление субстантивного компонента (метонимическое и / или метафорическое) при актуальности значения отрицания, реализуемого предложным компонентом без. Кроме того, вторичное значение, которое реализуется субстантивным компонентом, это, как правило, значение, свойственное данному компоненту и в составе других устойчивых единиц.

Без бобов. Сиб. Легко, без затруднений; не гадая, наверняка (знать, узнать) (БСРП); сравн.: гадать на бобах - 'строить беспочвенные предположения, ни на чём не основанные догадки; мучиться в догадках, предположениях’ (БСРП). 
Без лькк. Ряз. Сразу, без промедления (БСРП); сравн.: лька не вязать 'об очень пьяном человеке, не способном координировать свои движения и связно говорить', 'о человеке, говорящем заплетающимся языком', 'о неумелом, неловком человеке' (БСРП).

Без коклюш. Обл. Прямо и открыто, без шуток и вздора (говорить, сказать что-либо) (БСРП); сравн.: в коклюшки играть, то же, что гнуть коклюшки - ‘лгать, обманывать кого-либо' (БСРП); первичное значение слова коклюшка - 'палочка с утолщением на одном конце и с шейкой и пуговкой на другом для плетения кружев’ (СТСРЯ), вторичные значения - Ряз. 'глупость, ерунда, вздор' (СРНГ: 89); 'шутка, балясы' (ТСЖВЯ).

Без водыл. Горьк. Честно, без обмана (БСРП); сравн.: лить воду - 'лгать; говорить пустое, пустословить' (ФСРЛЯ).

Без кивера (киверу). Кар. В беспамятстве (БСРП) - 'без памяти' $\rightarrow$ ‘без головы' $\rightarrow$ 'без кивера'.

Без шапки. Пск. Интенсивно, напряжённо (работать) (БСРП) - 'без того, что может мешать работе’ $\rightarrow$ ‘без шапки'. 2. Кар. Неодобр. О человеке в крайней степени опьянения (БСРП) - 'без способности держать себя в руках' $\rightarrow$ 'без головы' $\rightarrow$ 'без шапки'.

Пользователь языка осознает „игровую” специализацию лексикализованной единицы даже в том случае, когда семантический сдвиг происходит в одном „предметном” поле - наименование части используется для обозначения целого: Без копейки Прикам. Бесплатно, даром (отдать, взять что-л.) (БСРП).

Переосмысление наблюдается и во всех сочетаниях предлога без с соматизмами, правда, не во всех случаях мотивированность оказывается прозрачной: носителю литературного языка для верного понимания диалектного лексикализованного сочетания потребуются специальные - регионально маркированные компетенции; сравн.:

Без рук. Урал. В состоянии сильной усталости от тяжёлой физической работы (БСРП).

Без глаз. Ряз. В отсутствие кого-либо (БСРП).

Без брюха [хохотать, быть]. Пск. Шутл. Сильно, заразительно смеяться, хохотать (БСРП). 
Без когтей. Кар. Неодобр. О неумелом, не привыкшем к труду человеке (БСРП).

Лексикализованные сочетания с компонентом-соматизмом, бытующие в просторечии и диалектных вариантах языка, могут находиться в синонимических отношениях: Без головы. 1. Прост. Без головного убора. 2. Прост. Презр. О глупом, несообразительном человеке. 3. Прост. Не обдумывая, безрассудно (делать что-л.). 4. Арх. В бессознательном состоянии (БСРП).

Реже наблюдаются случаи лексикализации предложно-падежного сочетания в разных диалектах со значениями, находящимися в отношениях контраста (явление междиалектной антонимии). Сравн.:

Без ног. 1. Кар. О человеке, который не может ходить из-за болезни ног.

2. Пск. Очень быстро, изо всех сил (бежать) (БСРП).

Как видим, модели интерпретации сочетания разнятся, поскольку в одном случае актуализации подвергаются семы ядерные, в другом - периферийные, в то же время и в одной, и в другой мотивирующей базе находит проявление признак негации: ноги - 'орган, обеспечивающий перемещение человека в пространстве' $\rightarrow$ без ног - 'без способности ходить'); ноги - 'орган, обеспечивающий поступательное перемещение человека в пространстве по поверхности' $\rightarrow$ без ног 'обретающий способность перемещаться быстро, „лететь” над поверхностью, не чувствуя ног’.

Наиболее важной нематериальной субстанцией для человека в наивной картине мире является душа. По-видимому, этим объясняется и многозначность слова душа в языке, и вытекающая из нее широкая сеть разного рода ассоциаций, используемых для характеристик человека посредством обращения к слову душа.

Сочетание без души в разговорном страте общенародного русского языка имеет следующие значения: 1) 'в восторге, восхищении'; 2) 'забыв все на свете'; в просторечии - 3) 'неохотно, без желания'; в диалектах: Пск. 4) 'сделанный недобросовестно, некачественно'; 5) Волг., Перм., Пск., Ряз. 'о чувстве тревоги, беспокойства, страха'. 6) Курск. 'о состоянии сильной усталости'; 7) Пск. 'очень быстро, изо всех сил'; 8) Волг. неодобр. 'о чёрством, бездушном человеке'; 9) Кар. 'о добром, простодушном человеке' (БСРП).

Первое и второе значения (устаревающие), которыми обладает сочетание без души в общенародном употреблении, очень близки и формируются, вероятно, на основе понимания души как как некоторого двойственного по своей природе регулятора человека - психического мира, включающего чувственную и рассудочную сферы (см., например, предан душой и телом 
своему делу (РМР), душа - 'внутренний, психический мир человека, его сознание' (СРЯ: 157), 'внутренний мир человека, мир его чувств, переживаний, настроений’ (БТСРЯ). Воспринимать что-либо или предаваться чемулибо без души может интерпретироваться в таком случае как 'предаваться чувству, отрешившись от сознания'. В просторечии же, напротив, лексикализованное сочетание без души означает такое отношение к чему-либо, при котором человек не испытывает внутреннего чувственного порыва, лишен стремления, волевого импульса. В то же время и в первой, и во второй мотивирующей базе каритивная семантика предлога без оказывает воздействие на содержание лексикализованной единицы, интенсифицируя выражаемые признаковые значения.

Развитие контрастных значений у выражения без души в разных диалектах языка (Волг. 'о чёрством, бездушном человеке' и Кар. 'о добром, простодушном человеке') также может объясняться актуализацией разных сторон феномена души, „лишенность” каждой из которых определяет контрастирующие поведенческие стереотипы: без души могут сказать о человеке, лишенном живого чувства, душевного отклика, и о человеке бесхитростном, лишенном какой-либо корысти, способном отдать все, как пишет Олеся Сурикова, о человеке, „способном отдать душу” (сравн.: зафиксированное в другом словаре без души́ (арх.) 'бесхитростно, откровенно, по-хорошему' (Сурикова 2016: 109).

И в остальных значениях, которые проявляются у сочетания без души в разных диалектах, каритивная семантика (отсутствия доброго отношения (4) / душевного равновесия (5) / сил (6) / вообще души в максимально напряженном (,отдающем” душу) теле (7)), формируемая предлогом без, обнаруживает себя в мотивирующей базе.

Проявляется каритивная семантика и в сочетаниях предлога без с пространственными и временными знаковыми единицами.

Без краю. Сиб. 1. Постоянно, всё время. 2. Без ограничения, очень много (БСРП).

Без nоры. Костром. В неподходящее время (БСРП).

Без (безо) время (времени). Арх., Кар. (Волог., Ленингр.), Курск., Ряз., Пск., Яросл. 1. Раньше обычного, преждевременно; 2. Не вовремя (БСРП).

Итак, к каким выводам мы можем прийти в результате анализа диалектных лексикализованных сочетаний с компонентом без?

1. Роль предложного компонента в формировании семантики диалектного лексикализованного предложно-падежного сочетания велика. Чем боль- 
шее количество отношений может выражать предлог в системе языка, тем больше в языке лексикализованных сочетаний с этим предлогом.

2. Лексикализованные сочетания с предложным компонентом без в русском языке возникают в связи с реализацией потребности дать характеристику и / или оценку человеку, его действиям, состояниям.

3. Идеография субстантивных компонентов в диалектных предложно-падежных сочетаниях с компонентом без существенным образом отличается от идеографии субстантивных компонентов, отмеченных в сочетаниях с предлогом без в составе пословичных выражений, что подтверждает специфичность функций лексикализованных предложно-падежных сочетаний с данным компонентом.

4. Степень идиоматичности предложно-падежного сочетания с компонентом без определяется семантическими признаками субстантивного компонента: слова с конкретным значением отражают тенденцию к переосмыслению их семантики, слова с абстрактной семантикой (чаще отглагольные) дешифруются в буквальном смысле.

5. Во всех диалектных лексикализованных предложно-падежных сочетаниях с компонентом без сохраняется актуальность семантики этого компонента.

\section{Список принятых условных сокращений}

Арх. - Архангельская область

Волг. - Волгоградская

Волог. - Вологодская область

Горьк. - Горьковская (ныне Нижегородская область)

Кар. - Республика Карелия

Костром. - Костромская область

Курск. - Курская область

Ленингр. - Ленинградская область

Обл. - областное

Перм. - Пермская область

Прикам. - Прикамье

Прост. - просторечное

Презр. - презрительное

Пск. - Псковская область

Ряз. - Рязанская область

Сиб. - Сибирское

Урал. - Урал

Яросл. - Ярославская область 
SUMmary

The Dialectal Lexicalized Prepositional-Nominal Combinations With the Component BEZ in the Russian Language

The article considers the question of peculiarity of the linguistic status of lexicalized prepositional-nominal combinations, of the proportion of dialectal lexicalized combinations of such type in the Russian language. The main attention is given to the analysis of role of the component bez in the formation of the semantics of dialectal lexicalized prepositional-nominal combinations. The thesis of the syncretical linguistic nature of the lexicalized combinations is confirmed by the conclusions of the relevance of the meaning of prepositional component bez in the motivational basis of the lexicalized units regardless of whether the substantive component is reinterpreted or not. The degree of idiomatization of the lexicalized combinations with the prepositional component bez reveals the dependence from the lexical-grammatical characteristics of the substantive component. The verbal nouns with the meaning of an abstract processual feature are realized, as a rule, in a direct sense. The semantics of the lexicalized combinations of the preposition bez with the titles of artifacts and somatisms is formed on the basis of realization semantic potential of such naming units, as well as on the basis of various models of reinterpretation of the sign-oriented units with a presentive meaning. 



\author{
Katarzyna Bolęba-Bocheńska (1) \\ Uniwersytet JaGiellońSKi, KRAKóW \\ katarzyna.boleba@student.uj.edu.pl
}

\title{
JĘZYKOWO-KULTUROWY OBRAZ CHWASTÓW UTRWALONY W POLSKICH FRAZEMACH GWAROWYCH
}

Słowa klucze: chwasty, frazematyka, frazematyka gwarowa, językowy obraz świata Keywords: weeds, phrasematic, dialectal phrasematic, linguistic image of the world

\section{Wstęp}

Chwasty to szczególny rodzaj roślin - choć mogą być piękne, skutecznie utrudniają ludziom, zwłaszcza rolnikom, życie. W Innym słowniku języka polskiego są one zdefiniowane jako „rośliny dziko rosnące w ogrodzie lub na polu uprawnym i utrudniające uprawę innych roślin" (ISJP I: 180). Chwastami mogą być zarówno marchwie na polu ziemniaków, jak i piękne róże rosnące wśród np. bratków.

Celem niniejszej pracy jest zrekonstruowanie językowo-kulturowego obrazu chwastów utrwalonego w polskich frazemach gwarowych. Przez frazem, podobnie jak Wojciech Chlebda, rozumiem „względnie trwałą formę językową, która w danej sytuacji stała się - niezależnie od swoich cech strukturalnych i semantycznych - przyjętym (nierzadko jedynym) sposobem wyrażania danego potencjału treściowego" (Chlebda 2010: 336). W tym pojęciu zawierać się będą zarówno stereotypowo pojmowane związki frazeologiczne, jak i przysłowia. Frazemy są bardzo użytecznym źródłem służącym do rekonstrukcji językowego obrazu świata (JOS), który można zdefiniować jako

zawartą w języku, różnie zwerbalizowaną interpretację rzeczywistości dającą się ująć w postaci zespołu sądów o świecie. Mogą to być sądy „utrwalone” w gramatyce, słownictwie, w kliszowych tekstach np. przysłowiach, ale także sądy ,presuponowane", tj. implikowane przez formy językowe utrwalonej na poziomie społecznej wiedzy, przekonań, mitów, rytuałów (Bartmiński 2009: 12).

Frazemy gwarowe zwykle utrwalają obraz świata mieszkańca wsi, nierzadko rolnika. Jego perspektywa jest ograniczona tym, co znano z własnego doświadczenia oraz z opowieści przodków. 
Podstawę materiałową niniejszej pracy stanowią frazemy zawierające ogólnopolskie nazwy chwastów wyekscerpowane z kartoteki Słownika gwar polskich PAN (KSGP), opracowań etnograficznych, słowników gwarowych oraz zbiorów przysłów. Pod uwagę wzięto tylko te rośliny, które są prototypowe dla danej kategorii. Choć pole znaczeniowe chwastów jest szerokie, nie wszystkie znajdujące się w nim rośliny lud uważa za szkodniki, np. w rosnących wśród zbóż chabrach wyprofilowano nie fakt, że mogą utrudnić rolnikom pracę, a to, że są pięknymi kwiatami, w powstaniu których (według ludowych wierzeń) brały udział anioły, a nie diabeł, twórca kąkolu i ostu (por. SSiSL II/3: 75).

$\mathrm{Z}$ punktu widzenia rolników chwasty są roślinami nie tyle nieprzydatnymi, ile wręcz szkodliwymi, mimo że nierzadko posiadają wartości odżywcze, mogą zapewnić przetrwanie w czasie głodu, o właściwościach leczniczych nie wspominając. Dla pracujących na roli pojawienie się chwastów oznacza nie tylko zwiększenie natężenia pracy, lecz przede wszystkim realne zagrożenie utraty części pożywienia. Nic więc dziwnego, iż negatywny stosunek do nich utrwalony jest nawet $\mathrm{w}$ ich nazwach, które często zawierają leksem diabelski. Według niektórych wierzeń to właśnie diabeł powołał do życia niektóre chwasty po to, by utrudnić ludziom życie. Tak o oście wypowiada się pani Zofia Kosatka:

Ze wszystkich roślin, co rosną na świecie, najbiedniejszy jest oset. Jak powiadają starzy, zasiał go diabeł na złość Panu Bogu, a ludziom na ciężkie utrapienie. Rośnie on wszędzie, ale najwięcej w zbożu u niedbaluchów, bo tam mu najlepiej. Rośnie bujnie, mimo że nieustannie tępią go ludziska (ZK).

Samo słowo chwast jest hiperonimem dla m.in. kacolu, ostu oraz pokrzywy i dużo rzadziej pojawia się we frazemach gwarowych niż nazwy konkretnych roślin. Wynika to z faktu, iż oznaczanie konkretnych gatunków było niezwykle istotne i pozwalało rozpoznać rodzaj zagrożenia. W zebranym materiale nie ma więc wielu frazemów zawierających słowo chwast, znajdują się tam jedynie trzy jednostki: Nie siać chwastu, a rodzi się (KPP: 65), Nietrudno o chwast (KPP: 65) oraz Chwast się nie zepsuje (KPP: 65). Przysłowia te mają charakter paraboliczny.

$\mathrm{Z}$ jednej strony są to dość oczywiste prawdy o roślinach - o sposobie ich wzrastania, odbywającym się bez ingerencji człowieka, o ich dużej trwałości, zwłaszcza jak na organizm pozostawiony bez opieki, który musi radzić sobie, wyłącznie pasożytując na otaczających go zbożach. $Z$ drugiej zaś strony utrwalono obraz chwastów jako roślin diabelskich, a więc reprezentujących wszystko, co ma negatywne konotacje. Podmiot zauważa, że podobnie jak nietrudno o chwast, tak nietrudno o zło. Choć są one niechciane, udaje im się przetrwać. Źródłem takich porównań jest ewangeliczna przypowieść o pszenicy i chwaście (Mt 13, 24-30), według której siewca zasiał na swej roli pszenicę, zaś nocą nieprzyjaciel wysiał wśród niej chwasty. Rolnik jednak nie od razu pozbył się tego, co szkodliwe, a cierpliwie czekał, aż wyrośnie pszenica - na wycięciu chwastów mogłoby bo- 
wiem ucierpieć także zboże. Nawiązania do tej przypowieści pojawiają się właśnie w przysłowiach ludowych.

\section{Oset}

Oset z punktu widzenia botaniki jest kwiatem. Tak naprawdę trudno ustalić, co właściwie oznacza nazwa oset. Józef Rostafiński uważał, że jest to „tak ogólna nazwa, że nie można jej odnieść do żadnego gatunku obu tych subtelnie różnych rodzajów" (Rostafiński 1900: 335). Halina Pelcowa w Slowniku gwar Lubelszczyzny (SGL V: 332-334) wydzieliła aż siedem haseł oset oznaczających - w naukowym obrazie świata - różne rośliny. W niektórych rejonach roślinę określa się nasieniem diabelskim, gdyż w jego powstaniu - w folklorze kaszubskim i lubelskim brał udział sam diabeł:

Kiedy Pan Bóg stworzył świat i rozdawał różne nasiona ludziom, zwierzętom i ptakom, także diabłu cisnął kilka ziarnek owsa i hreczki, a wtedy rzekł św. Michał, że to szkoda dla diabła, bo i to się ludziom przyda, a diabłu będzie dość ostu i pokrzywy. Bóg pozwolił odebrać to diabłu, św. Michał dogonił diabła, gdy właśnie powtarzał sobie „Mój owies, moja hreczka”, a tak nagle go zapytał o to, co on plecie, że diabeł zapomniał przydzielonych mu nasion, a anioł przypomniał, że on powtarzał „mój oset, moja pokrzywa”. Diabeł w to uwierzył i pobiegł dalej, krzycząc „mój oset, moja pokrzywa" (SFisch: 34).

Natomiast według demonologii żydowskiej oset to tylko jedno ze stadiów postaci walczących z Bogiem, które ostatecznie przekształca się w demona:

samiec hieny po siedmiu latach staje się nietoperzem, nietoperz po siedmiu latach wampirem, wampir po siedmiu latach ostem, oset po siedmiu latach kolcem (lub być może, wężem), kolec (lub wąż) po siedmiu latach staje się demonem (Gebert 1989: 14).

W zebranym materiale oset ma wyłącznie negatywne konotacje. Dla rolnika pojawienie się chwastu oznacza intensyfikację pracy. Oset wykorzystano do zobrazowania biedy oraz zachowań ludzi.

O osobach nieprzyjaznych można powiedzieć [Mity] jak oset $w$ pszenicy (KPP: 311) - porównanie ma charakter ironiczny, osoba wypowiadająca się tak o kimś wykazuje pogardę do tego, o którym orzeka. Według Mazurów Maciora [jest] gorsza niz kolacy oset (MMD: 53). Frazeologizm utrwala stereotyp złych relacji między żoną a teściową, która utrudnia życie bardziej niż roślina mogąca odebrać rodzinie chleb.

We frazemach z ostem często profiluje się jego kolce. Nie zawsze jednak służą one do zobrazowania negatywnych cech. Przykładem tego jest frazeologizm 
Oset \{komuś\} wlazł w nogi (KSGP). Używa się go do opisania osoby wykonującej ciężką fizycznie pracę, której nogi, muszące utrzymać ciężar ciała, są zmęczone, obolałe, przez co nie są w stanie pełnić swojej funkcji. Można tu dostrzec analogię do drogi ustanej cierniami, czyli trudnej do pokonania.

Kolce ostu zostały także użyte do zobrazowania osoby konfliktowej. O kobiecie opryskliwej, pyskatej na Kaszubach mówi się Ona tak kole, jakby oset miała w pysku (SGK III: 243). Mamy tu do czynienie z kognitywną metaforą argumentacji jako wojny. Słowa są niczym raniące pociski (por. Lakoff, Johnson 2010: 30-32), a osoba wypowiadająca je - niczym żołnierz zaprogramowany do walki. Na powiązanie ostu z agresywną mową wskazuje też zagadka z drugiego końca Polski - od Lasowiaków - Stoi na drodzel Na jednej nodze,/ Jak się go tknie,/ To bardzo klnie (PrezLas).

Inne frazeologizmy służące do krytykowania ludzkich działań to Kto oset sieje, ten oset zbiera (Pomierska 2013: 524), które można sparafrazować 'kto zło sieje, do tego zło wraca', oraz Kto oset sieje, zboża nie zbiera (Pomierska 2013: 587) - 'kto zło sieje, nie otrzyma dobra'. W ostatnim przytoczonym frazemie można dostrzec krytykę osoby leniwej, niepotrafiącej zadbać o swój interes - ten, kto w odpowiednim momencie nie przygotuje się na niedostatek, będzie cierpiał głód. Według kaszubskich wierzeń właściciele pól pełnych tego chwastu charakteryzują się słabą wolą (SGK III: 342).

Negatywny stereotyp tego chwastu utrwalono także we frazemie Zasiat pszenice, zebrat oset (Pomierska 2013: 587). Z jednej strony mamy tu obraz osoby, która nie potrafi sobie poradzić w życiu i dopilnować interesów, z drugiej natomiast pokazano, jak bezwartościowy jest oset jako roślina. Wynika to z faktu, że nie spożywano go nawet wówczas, gdy brakowało jedzenia. Ma to swoje potwierdzenie w badaniach dotyczących pożywienia. Łukasz Łuczaj twierdzi, że ostrożeń polny, czyli jedna z roślin, które nazywano ostem, był rzadko używany jako pożywienie głodowe (Łuczaj 2008: 52), jednak na Podhalu przyrządzano z niego potrawę zwaną warmuzem. Było to jedzenie ubogie w wartości odżywcze, gdyż poza chwastem dodawano do niej zioła oraz ziemniaki lub mąkę owsianą - taki rodzaj pokarmu miał jedynie szybko zaspokoić głód (SFisch: 243). Na Kaszubach mówiono $W$ biedzie nawet oset się przyda (Pomierska 2013: 524) oraz Oset to biednego człowieka bulewka (SGK III: 243).

Pozytywnie oset przedstawiono w tylko jednym frazemie - Gdzie rośnie dziewanna, tam uboga panna; a gdzie rośnie oset, tam panna ma kroćset (Kolb IV: 94). Wartość chwastu nie wynika z jego właściwości, lecz z zestawienia z rośliną jeszcze gorzej postrzeganą przez lud - dziewianną. Ta bowiem rośnie na mało żyznych glebach, więc wzięcie za żonę kobiety bez dobrej ziemi nie jest opłacalne zarówno dla młodego kawalera, jak i jego rodziny. Oset natomiast, jak można było wcześniej zauważyć, często jest zestawiany z wymagającą lepszych warunków do rozwoju pszenicą. Upraszczając więc ludowy model myślenia, korzystnie jest 
ożenić się z panną, u której na polu rośnie oset, ponieważ rodzinie nie będzie zagrażał głód.

\section{Kąkol}

Kąkol - z punktu widzenia botaniki - to kwiat z rodziny goździkowatych. Współcześnie jest to gatunek rośliny bliskiej zagrożenia, znajdującej się od 2016 r. na polskiej czerwonej liście. Dziś dąży się do tego, by kąkol nie wyginął, w celu zachowania w przyrodzie różnorodności gatunkowej, dlatego coraz częściej wysiewa się roślinę w warunkach sprzyjających jej rozwojowi. Sposób widzenia rośliny ulega przeobrażeniom. Dla rolników kąkol był przede wszystkim chwastem, który nie tylko utrudniał codzienną pracę, lecz także realnie zagrażał zbożom, a więc mógł być przyczyną głodu. Roślina jest biblijnym symbolem zniszczenia i zła. Na Kaszubach człowieka bezwartościowego określa się kąkolnikiem (por. SGK II: 229).

Kąkol w gwarach nazywany jest także diabelskim kwiatem. Jadwiga Waniakowa uważa, iż nazwa jest metaforyczna, pełni funkcję ostrzegawczą. Pewną rolę może także grać tu tabu, ponieważ mamy do czynienia właściwie z omówieniem nazwy (Waniakowa 2012: 109). Związek chwastu z siłami nieczystymi utrwalił się w wierzeniach ludowych. Na przykład na Kaszubach wierzy się, że właściciele pól pełnych kąkolu są nawiedzani przez Szatana, który namawia ich do popełnienia grzechu. O chwaście mówi się: Kąkol to diabelska pszenica (Pomierska 2013: 457).

Źródła kojarzenia kąkolu ze złem należy szukać we wcześniej wspomnianej Ewangelii św. Mateusza ${ }^{1}$. W niektórych wersjach tłumaczeń tekstu, np. Biblii gdańskiej, znajdziemy konkretną nazwę rośliny zasianej przez nieprzyjaciela - jest nią właśnie kąkol. Przypowieść utrwaliła negatywny obraz rośliny, przy okazji stając się źródłem licznych frazemów, w których zestawiono chwast z pszenicą. Wynika to z parabolicznego charakteru utworu. Dzięki nawiązaniu do motywów z codziennego życia i wykreowaniu postaci, z którymi projektowani odbiorcy mogą się identyfikować, udało się w prosty sposób omówić wartości. Pod postacią gospodarza kryje się sam Bóg, pszenicą są ludzie wierzący, zaś kąkolem - pozbawieni łaski wiary. Jest to zapowiedź tego, iż tylko dobrzy wejdą do Królestwa Niebieskiego, jednak na prostszym poziomie przypowieść obrazuje istnienie dobra i zła na ziemi. Bez jednego nie byłoby drugiego, co utrwalone jest we frazeologizmie ogólnogwarowym Nie ma pszenicy bez kąkolu / Nie ma żyta bez kąkolu. Podobny obraz świata widać w przysłowiach: Na jednym polu kąkol ze zbożem roście

W niektórych wersjach tłumaczenia możemy spotkać się z wersją o pszenicy i chwaście. 
(SGK II: 229), Przy pszenicy musi być kąkol (KPP: 454). Winę za pojawienie się zła na świecie ponosi oczywiście diabeł. Bóg zaś czyni świat pięknym i dobrym, zapewniając swym dzieciom dobrobyt: Pan Bóg sieje pszenicę, a diabet w niq miesza kąkolu połowice (KPP: 454), Pan Bóg pszenicę mnoży, a djabeł kąkol sporzy (KPP: 454). Frazemy przechowują jednak wiarę zwycięstwo dobra nad złem, które w końcu przestanie się rozprzestrzeniać i siać zniszczenie - Do czasu kąkol rośnie z pszenica (KPP: 454).

Poza wymiarem symbolicznym kąkol jest przede wszystkim rośliną utrudniającą pracę rolników. Pozbycie się chwastu jest czasochłonne i męczące, gdyż Kąkol nie przepadnie (Pomierska 2013: 457). Podobnie jak w biblijnej przypowieści istnieje ryzyko, że walcząc ze złem (kąkolem) zniszczy się także to, co dobre i życiodajne - Kiedy się wyrywa kakol, to i się pszenicy poderwie (SGK: 229).

W odróżnieniu od pszenicy, która najczęściej jest zestawiana z chwastem, oraz innych zbóż, Kąkol rośnie bez roboty (Pomierska 2013: 457), jednak jego wyeliminowanie wymaga sporego nakładu pracy. Choć podkreśla się, iż z kąkolu chleba nie będzie (SGK: 229), nasiona chwastu - w odróżnieniu od np. ostu - były elementem potraw głodowych (SFisch: 187). Ponadto roślina zapewniała pożywienie w sposób pośredni - wierzono, iż obwiązanie nim bezowocnego drzewa w końcu przyniesie owoc (SFisch: 188).

\section{Pokrzywa}

Pokrzywa okazuje się rośliną niezwykle interesującą, jeśli porównamy jej właściwości z obrazem świata utrwalonym choćby we frazematyce. $Z$ jednej strony - bez przeglądu zielników, nawet współcześnie - wiemy, iż ma właściwości lecznicze, do dziś używa się jej zarówno w przemyśle farmaceutycznym, jak i kosmetycznym, z drugiej zaś - wciąż dla wielu (rolników) pozostaje wyłącznie chwastem.

Pokrzywę znano już w starożytności. W Rzymie wiązano ją z rozpustą - była poświęcona Wenus. Używano jej jako afrodyzjaku w celu wzmożenia lubieżności. Sproszkowana pozytywnie działała na sprawność seksualną mężczyzn (por. Goulfier: 8). Według wierzeń germańskich pokrzywa poświęcona była Donarowi, władcy piorunów, zaś według Skandynawów - Thorowi, władcy burz. Roślina chroniła ludzi przed tym, czym władali jej bogowie. Jej związki z burzą są także widoczne w materiałach z ostatnich stuleci. Na Kaszubach pokrzywę zwyczajną (Urtica dioica L.) nazywa się piorunową pokrzywą. W Chełmskiem przed nawałnicą lub burzą okładano domy przygotowanymi z rośliny wianeczkami, co miało chronić przed uderzeniem pioruna (Kolb XXXIV: 193). W Wielickiem i Bróbeckiem pokrzywę pali się, by rozpędzić czarne chmury (Gustawicz 1882: 303).

Niezwykle szerokie zastosowanie pokrzywa miała u Słowian. Stosowano ją jako środek do wypędzania demonów i wszelkiego zła. Aby ciemne moce opuściły człowieka, stosowano różne metody. Jedną z nich było: 
bicie samego tylko bolącego czy chorego członka albo miejsca na ciele. Zwykle, aby to bicie uczynić dla choroby tern dotkliwszem, używało się do ćwiczenia parzącej pokrzywy [...]. Choć zabieg taki, stosowany przez lud do nagiego ciała, może, dzięki jadowi zawartemu w pokrzywie a przytępiającemu nieco ból, przynieść chwilową ulgę cierpiącemu, jest jednak genetycznie z bezwzględną niemal pewnością przesądny. [...] Lud wyobraża sobie, że dosięgają one [baty - K.B.B.], kogo należy; jak zwykle bowiem rozstrzyga w takich wypadkach nie to, co się dzieje przed oczami, lecz to, co się ma na myśli (KLS II: 204).

Pokrzywa była dobrym narzędziem do tego typu praktyk, ponieważ parzyła. Bicie nią nie tylko wypędzało demona, lecz także wypalało ewentualne pozostałości po nim.

Pokrzywę święciło się w oktawę Bożego Ciała, rzadziej w Matki Boskiej Zielnej. Jej moc wzrastała w noc świętojańską - wtedy dla uniemożliwienia czarów kładzie się pod oknami i drzwiami chaty oraz budynków gospodarczych pokrzywę, by wiedźma pokłuła sobie oczy (SFisch: 266). Zatykano nią także strzechy i ściany oraz wyparzano garnki do gotowania mleka, by nie uległo ono zepsuciu (SFisch: 266).

Pokrzywa ma także korzystny wpływ na działanie ludzkiego organizmu, co potwierdza nie tylko medycyna ludowa, lecz także konwencjonalna. Już w XVI w. pisano o tym, iż roślina wzmaga płodność nie tylko ludzi, ale i zwierząt oraz chroni przed poronieniami (por. SFisch: 266). Można tu dostrzec związek z przekonaniem starożytnych, iż chwast jest afrodyzjakiem poprawiającym sprawność seksualną mężczyzn.

Pokrzywę stosowano także w leczeniu duszności. Dziś wiemy, iż tę właściwość zawdzięczamy obecności w niej pochodnych tyrozyny o działaniu antyhistaminowym. Udowodniono, iż ,ekstrakt z pokrzywy wykazuje działanie hamujące aktywność enzymów kilku kluczowych reakcji zapalnych powodujących objawy alergii sezonowej" (Jakubczyk et al. 2015: 193).

Pokrzywy używano również do zwalczania objawów reumatyzmu i bólu kości (por. SFisch: 267). Leczenie polegało na biciu chorego zielem w bolące miejsca. Współcześnie wiemy, iż „wyciąg korzenia pokrzywy zwyczajnej zawiera inhibitory elastazy leukocytowej, cyklooksygenazy oraz 5-lipooksygenazy, dzięki czemu wykazuje działanie przeciwzapalne" (Jakubczyk et al. 2015: 194).

Biorąc pod uwagę rolę, jaką odgrywała pokrzywa w leczeniu chorób i ochronie przed siłami nieczystymi, trudno uwierzyć w jej negatywny stereotyp utrwalony we frazemach. Wyprofilowano w nich to, że roślina parzy oraz że postrzega się ją jako chwast. Właściwości te, podobnie jak w przypadku innych roślin, wykorzystano - w większości przypadków - do opisu zachowań ludzi.

Według wierzeń kaszubskich Pokrzywę Pan Bóg stworzyt w gniewie i dlatego pali (SGK I: 343). Znalezienie się wśród nich nie przysporzyłoby z pewnością nikomu radości - przeciwnie - byłoby powodem do złości, stąd frazem Cieszyć 
się / mieć się / stać jak nagi / sagi (SGK I: 131; SFŚl: 78, 241; FGW: 32), odnotowywany głównie na Śląsku i Kaszubach, służący do opisania osoby niezadowolonej, pozbawionej radości, znajdującej się w sytuacji dla niej niekomfortowej. Na Pomorzu o kimś takim można powiedzieć także, że zachowuje się Jakby go pokrzywami popalit (KPP: 416), zaś na Śląsku - Zły jak pokrzywa (SFŚl: 489).

Pokrzywy są symbolem zła, a to - jak wiadomo - rozprzestrzenia się szybciej niż dobro. Jednak w tej walce nie doszło do zwycięstwa żadnej z sił. Nawet gdy zła jest więcej, I przy liliach pokrzywy się rodza. Wybór roślin nie jest tu przypadkowy. Pokrzywa symbolizuje grzech, jest niczym zaraza, która rozprzestrzenia się bez żadnej kontroli. Lilia jest zaś synonimem niewinności i delikatności. Przez ich zestawienie wzmocniono przekaz przysłowia. Zło - podobnie jak chwasty - należy tępić, ponieważ pozostawione samo sobie może wyeliminować to, co pożyteczne, o czym przypomina frazem By nie mróz na złe pokrzywy, bytby ten fast zawsze żywy (Kolb VIII: 250). W ostatecznym starciu - podczas Sądu Ostatecznego zwycięży dobro i Doczeka się sierpa pokrzywa (KPP: 363).

\section{Podsumowanie}

Jak można zauważyć na przykładzie analizowanego materiału, chwasty w ludowym obrazie świata są bez wątpienia bardzo nisko wartościowane. Wynika to z faktu, iż pojawienie się ich na polu może zagrozić rosnącym na nim zbożom, czego konsekwencją jest mniej zbiorów, a więc i mniej pożywienia. Jedzenie leży u podstaw hierarchii potrzeb człowieka, a głód nie pozwala zaspokoić potrzeb wyższego rzędu. Rośliny w pierwszej kolejności traktowano jak jedzenie, dopiero później jako dobro materialne.

Utrwalony we frazemach obraz za jakiś czas może ulec zmianie, wszak mamy dziś większą wiedzę na temat właściwości roślin i korzyści, jakie można osiągnąć, spożywając np. pokrzywę. Ponadto praca rolników staje się coraz bardziej zmechanizowana, a eliminacja chwastów - łatwiejsza ze względu na dostępność środków chemicznych. Warto wspomnieć, iż zmiany idą w kierunku bioróżnorodności, a więc i ochrony roślin uznawanych przez wieki za szkodliwe. Jako ludzkość jesteśmy jednak dopiero na początku procesu uświadamiania sobie znaczenia poszczególnych gatunków dla klimatu, więc na rzeczywiste zmiany w języku, a zwłaszcza $\mathrm{w}$ formułach, tekstach kliszowanych, przyjdzie nam jeszcze zaczekać. 


\section{SUMMARY \\ Linguistic and Cultural Image of Weeds \\ Preserved in the Polish Dialectal Phrasemes}

This paper is intended to show and analyze Polish dialectal phrasemes with weeds. The purpose of this study was to investigate linguistic and cultural image of them. Data were excerpt from Kartoteka Stownika gwar polskich, sets of proverbs and dialectal dictionaries. The authoress analyzed phrases with three species of weeds: thistle, cockle and nettle. In folk beliefs the weeds protected against. They were used to health protection. Despite of them weeds are of low value, because they were a threat to other plants that were of high value (mainly grain). The weeds were hard to pull out, grew by themselves (in folk beliefs the creator of them is the devil), so the farmer must work harder. The phrases with weeds describe the negative traits of human (laziness, rudeness) and the human axiology system. 



\author{
НАТАЛІЯ КОВАЛЕНКО (1) \\ КАМ'ЯНЕЦЬ-ПОДІЛЬСЬКИЙ НАЦІОНАЛЬНИЙ УНІВЕРСИТЕТ ІМЕНІ ІВАНА ОГІЄНКА \\ КАМ'ЯНЕЦЬ-ПОДІЛЬСЬКИЙ, У КРАЇНА \\ ndm.kovalenko@gmail.com \\ БОРИС КОВАЛЕНКО (D) \\ КАМ' ЯНЕЦЬ-ПОДІЛЬСЬКИЙ НАЦІОНАЛЬНИЙ УНІВЕРСИТЕТ ІМЕНІ ІВАНА ОГІЄНКА \\ КАМ'ЯНЕЦЬ-ПоДІЛЬСЬКИЙ, УКРАЇНА \\ kovalenko.bor@gmail.com
}

\title{
СИМВОЛІКА ЛЕКСЕМИ МАК \\ У ФРАЗЕОЛОГІЧНІЙ КАРТИНІ СВІТУ
}

Ключові слова: фразеологізм, семантика, мотивація, діалект, фразеологічна картина світу, мак

Key words: phraseological unit, semantic, motivation, dialect, phraseological picture of the world, mak 'poppy'

Фразеологічну картину світу різних слов'янських лінгвокультур в аксіологічному аспекті досліджували наприкінці XX - на початку XXI ст. такі мовознавці, як Леонід Авксентьєв, Микола Алефіренко, Галина Богданович, Ганна Вежбицька, Наталія Венжинович, Ірина Гнатюк, Ірина Голубовська, Людмила Дядечко, Віталій Жайворонок, Анатолій Івченко, Ольга Лящинська, Валерій Мокієнко, Юрій Прадід, Олена Селіванова, Вероніка Телія, Віктор Ужченко, Дмитро Ужченко та ін.

Великим потенціалом фразеотворення і метафоричного перенесення характеризуються назви рослин (їх складові частини), що поширені на великих територіях чи в певних ареалах. На сьогодні зафіксовано та описано фітоніми більшої території України: північного наріччя (Ганна Козачук, Олена Малахівська, Микола Никончук, Руслана Омельковець, Марина Поістогова, Марина Ткачук), південносхідного (Павло Гриценко, Любов Фроляк, Лілія Москаленко, Ганна Скорофатова), південнозахідного (Йосип Дзендзелівський, Олена Миголинець, Інна Гороф'янюк, Іван Сабадош). 
Близько 40 тисяч українських наукових і народних назв рослин подав у словнику Юрій Кобів, де зокрема зафіксовано такі номінації маку: мак д'икий, мачок, мак-самос'ийка, мак-тріскавецьь, м'ачок полев'ий, бат'и n'етр 'єв, вид 'ун, видух, ви(i)д 'юк, діркач, жер, здрік' $а$ ('y)н, зірк'ач, мак діркатий, мак з 'аячий, мак n'ад 'али(i)шний, мак польов' 'ий, самос 'ад, тр 'єскавець, тріск'yн, хр 'уставець та ін. (Кобів 2004). Зауважимо, що на рівні фразеологізмів українських говорів не виявлено вживання назв видів рослини, спостерігаємо лише номінацію мак.

Олена Левченко описала особливості рослинної символіки, зокрема полісимволічність лексеми мак у складі фразеологізмів на рівні літературних слов'янських мов, і виявила істотні відмінності в порівнюваних мовах, міжмовну асиметрію (Левченко 2005: 198-199). Олександр Назаренко дослідив різнопланові значення фразеологізмів, у складі яких $є$ назви „ментальних” для українців рослин, зокрема верби, калини $і$ маку, опираючись на приклади літературних одиниць, поданих у Фразеологічному словнику української мови; визначив, що уявлення та асоціації, які колись виникли, закріплювались у мові, символізувались і стали загальнонародними (Назаренко 2005: 136). Дослідження на рівні українського діалектного мовлення відсутні.

Мета цієї наукової розвідки - на основі записів українського діалектного мовлення, лексикографічних праць дослідити особливості вживання та просторове поширення сталих виразів із компонентом мак, з'ясувати, які особливості рослини є джерелом фітонімічних метафор і фразеологізмів.

Символіка маку, як і калини, в українській культурі є дуже давньою, відома вона і в світовій міфології через яскраво червоний колір квітки, красиве, але недовге цвітіння, надзвичайну плодовитість, форму та будову плода, снодійні властивості.

Особливу символіку цієї квітки, часте зображення знаходимо і в українських вишиванках: ну виешиевайу $i$ хре стом / $i$ глад'y // a ўс'о йе / $i$ зв 'ip' $i$ йе / і тойво / і узори / $і$ кв 'іти / маки / усс'о йе // найб'іл'те л'убл'у / рушни ки виешиевати найб 'іл'ше л'убл'y (с. Пищатинці Борщівського району Тернопільської області).

Завдяки родючості мак часто використовували як обрядовий атрибут у сімейних і календарних святах. Додавання маку до куті - обрядової страви iз пшеничних зерен (відомої для багатьох народів світу), що готують і подають напередодні Різдва Христового, випікання коржа 3 прісного тіста із тертим маком і цукром до свята Маковія (свято Першого Спаса) підтверджують велике обрядово-звичаєве та ритуальне значення маку як оберега дому, родини, символа безкінечного Всесвіту. Наприклад, у розповіді мешканки Західного Поділля про кутю є згадка про мак: ми називали йійі пшеиниц'ойу // те иер кажут кут'а може де у котр'ім се ил'i/аў нас / то назиевали просто пше ини'а з маком / з гор 'іхами // а зара то ууже г̆ із 'уму дайут / $i$ того / халви 
/ а колис' не $e^{u}$ було сего (с. Пищатинці Борщівського району Тернопільської області); у наддністрянських говірках: голоўне пшеиниц'y / пше ниц'у варили / давали меду / маку / гор 'ix 'iў мололи / пшеиниц'у тоўкли і так готували пше ниц'y (с. Сновидів Бучацького району Тернопільської області); про святкування Маковія (Першого Спаса) розповідає носій подільських говірок: йакми с'ваткуйемо с 'вато Cпаса / то ўс'i готуйуй'а до него // сего дн 'а уус' $i$ пиечут ' пиероги і не сут' до иеекки с 'ватити // тоже нен сут' до цееркви мак / моркву / цибул'у / йаблука / л'ікарствиене з'іл'а / цее вас'іл'ки і чорнобриуци'i (смт Сатанів Городоцького району Хмельницької області).

Вдалося записати спогад від носія західноподільської говірки про традицію святити мак і його магічну здатність захищати оселю від усіх потойбічних сил і у Великодні свята: ўс’i ставали кругом с кошиками коло изеркви / бат 'ушка с'в' атиў тото уцс'о / читаў молитву / $i$ потому ўже кропиў кошики / опходиў три рази кругом цеекви с п'іс 'н'ами угс'акими / $i$ тоди ууже m'i с'в'ачен'і кошики несли доудому // також с'в'атили с 'іл' / мак // колис' ше наш тато / наш'і йак були ше жив' $i$ / о // то уусе приходили доудому / брали ту с 'іл' $і$ мак $і$ за сходом сон 'u’'а йшли і опсипали уус'о подв 'іра кругом / усс 'i будинки опсипали солеў // то казали шо н 'ійак'i зл'і сили не иудут с 'i ч'іпл'ети хати / о / і громовиц’ $і$ будут обминати (с. Гаврилівці Кам’янець-Подільського району Хмельницької області).

Фразеологічні одиниці мають яскраве експресивно-стилістичне маркування, більші виразні можливості й тому часто використовуються в розмовному мовленні, вони здатні концентрувати характеристику важливої, на думку інформанта, інформації.

Фразеологізми як одиниці „утримують” в собі світогляд українців, який може мати загальнолюдську символіку та власне національні категорії культури, можуть набувати нових семантичних відтінків. Важливо, що фразеологізми з компонентом мак, завдяки спостережливості та допитливості українців, образно-узагальнювальному мисленню, етнопам'яті про давні дохристиянські звичаї та обряди, можуть презентувати стереотипи та оцінки зовнішнього вигляду людини, іiі поведінки та мовлення, морально-етичні якості, соціальні відносини, а також характеристики природних явищ, навколишнього світу.

Із найдавніших часів люди вірили, що мак захищає від усілякого зла. Освячений мак (особливо дикорослий) має особливу силу і здатність відганяти нечисту силу від оселі, домашніх тварин, пасіки. Таким маком у Великодні свята, на Маковія (14 серпня) господарі обсівали людей і худобу.

У фольклорних пісенних текстах макові квіти, як і калинові, символізують здоров’я, радість, дівочу красу і чистоту, а водночас - сон і смерть; квіти маку вплітали у косу, щоб голова не боліла і щоб волосся було пишним. Віддавна люди вірили, що мак захищає від усілякого зла (Войтович 2002: 437, 439). 
Червоний мак символізує красу та молодість, а тому поширеними $є$ компаративні вирази, які, за різними джерелами, є символом красивої дівчини (ССКУ: 138); із квітучим маком порівнюють і юнака-молодця (Войтович 2002: 439); це узагальнений символ краси, молодості й молодецтва (В.Д. Ужченко, Д.В. Ужченко 2007: 285) - як маків извіт (ФСУМ : 939). У сучасних говірках збережено побутування таких порівнянь, наприклад: у гуцульських -

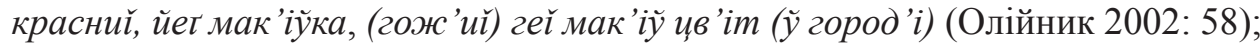
такий, як мак 'рум'яний' (ГСЛ: 379); буковинських - як (єк) маківка 'гарна, красива (про дівчину, жінку)' (ФПЧ: 248), як (єк) (ніби, мов) маківка 'гарна, красива (про дівчину, жінку)’ (ФПЧ: 223); західнополіських - розцв 'ів йак мак 'про вродливого хлопця', гарна йак мак'івка / макувка 'про вродливу дівчину’ (Мацюк 2013: 127). Ремарку „народно-поетичне” подано в словниковій статті збірника фразеологізмів російської мови до одиниці как (что) маков цвет (Федоров 2011: 127). Зафіксовано навіть перенесення означення для но-

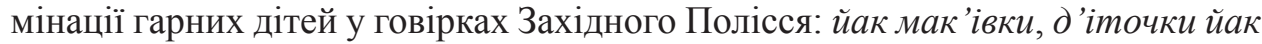
мак'івочки (Мацюк 2013: 127).

Цілком очікуваним є вживання фразеологізмів із компонентом мак на позначення поняття 'соромитися, почервоніти від сорому': західнополіські - йак маковка 'почервоніння на лиці', чирвоний йак мак, чирвона йак мак 'почервоніти на лиці' (Мацюк 2013: 127), середньополіські - зацвісти маком 'засоромитися' (Доброльожа 2010: 104); наддністрянські - як маків извіт (Романюк 2002: 129), подільські - поче иввон'іти йак мак 'почервоніти від сорому’ (Коваленко 2019: 193).

Сучасним мешканцям Поділля і Волині знайомий вираз сядь маком!, яким звертаються до дітей з вимогою заспокоїтись, не бешкетувати, тихо посидіти. У Словнику украӥнської мови сісти маком - 1) потрапити в біду, опинитися в скрутному становищі; 2) зазнати поразки, невдачі (СУМ 4: 601); у сучасному діалектному мовленні це підтверджено записами 3 наддніпрянських говірок - 'потрапити у скрутне становище' (Чабаненко 2001: 128); середньополіських - сидіти маком 1) 'скрутне становище', 2) 'мовчати' (Доброльожа 2010: 105); буковинських - cicmu/сидіти (стояти) маком 1) заспокоїтися, не рухатися, сидіти (стояти) непорушно (про людину), 2) потрапити в скрутне становище; зазнати поразки, невдачі (ФПЧ: 198).

У лексикографічних працях $з$ інших говорів знаходимо чимало відтінків значень чи нових інтерпретацій, зокрема, у гуцульських говірках - cuдітu маком 'сидіти дуже тихо, без зайвих рухів' (ЛЛПЖ: 432); подільських c’істи маком, стати маком 'осоромитися' (Коваленко 2019: 193); бойківських - маком сісти 'про велику кількість дітей, яких потрібно погодувати' (маком сіли - усьо з '̈̈л) (Матіїв 2013: 425). На нашу думку, мотиваційну основу аналізованого виразу найвдаліше виявляє речення з гуцульської говірки, що трансформувалося у фразеологізм: сиді́mu ти́хо, як би ма́ком сі́яв ‘сидіти непорушно, тихо’ (ГСЛ: 556) - сісти маком. 
У Словнику символів культури Украӥни знаходимо інформацію про глибинний зв'язок рослини зі хтонічними істотами і навіть смертю: маком сіcmu - 'загинути' (ССКУ: 138), хоч в інших лексикографічних працях такого значення виразу не знайдено.

У минулих поколінь українців найприємніші спогади про дитинство пов'язані із солодкими смаколиками з маком, які готували лише у великі свята, тому вираз з маком щзо-небудь має значення 'дуже смачне' (Аркушин 2003: 103). Носій західноподільської говірки розповідає: пееккли бат 'ки наши' / пенлли / ше ми дуже л'убили / йак бат 'ки пе "кли корж'і з маком // йак наступаў n'icm / то уу перший ден' посту об'ізат 'іл'но майе бути пече н 'і корж' $i$ з маком // мак терли ў мак'ітр'i $і$ туди додавали иукру / в'ін буў солоткий $i$ розводили йійі водичкойу / а корж’і пенли (с. Велика Кужелева Дунаєвецького району Хмельницької області).

Мак у домашніх стравах на свято був ще й ознакою селянського добробуту та заможності: запрайл'айут кут'y гуํ’хами / маком / котр'і терли у мак'ітрах / тай чим багат'ша кут'а / тим багат'ша і с'імйа (с. Грушка Кам'янець-Подільського району Хмельницької області). Саме тому з маком означає 'добре, щасливо', а не з маком, за Словником украӥнськой мови 'важко, погано' (СУМ 4: 601); наприклад, у наддніпрянських говірках не з маком 'погано, скрутно’ (Чабаненко 2001: 88), у середньополіських не з маком 'не пощастило’ (Доброльожа 2010: 105).

У розповідях із Західного Поділля знаходимо: тай тоже ше було бе $e^{u_{3}}$ маку // ше шейіс' ат другий / третиц р'ік було без маку було / тоже ие було $m$ 'ашко (с. Лошківці Дунаєвецького району Хмельницької області). На Лемківщині поширеними були вирази ани ма́рний мак не вхабъіти 'зубожіти' (Ступінська 2000: 138), ани мака не мати 'зовсім нічого’ (Ступінська 2013: 136); ани мака 'зовсім нічого не мати' (Вархол, Івченко 1990: 80); у середньополіських говірках про бідну, але з гонором людину кажуть: гола спина - аби коржі з маком (ФСГЖ: 169). Отже, у фраземах завдяки образності мислення акцентовано на маленькому розмірі макової зернини. Ця особливість плоду маку є основою витворення низки одиниць, що виражають різні ступені вияву ознаки чи стану, наприклад, говорячи про поганий зір, носії лемківських говірок констатують: не выдіти за мако́вой зерно 'погано бачити' (Ступінська 2000: 157), середньонаддніпрянських - не мати в роті ні росинки, ні макового зернятка ‘бути дуже голодним' (Чабаненко 2001: 90).

У всіх говорах української мови відомий загальноукраїнський фразеологізм дулю з маком (з дієсловами дати, показати та ін.), що має значення 'абсолютно нічого не дати, не зробити і т. ін.' (СУМ 2: 434). У більшості говорів південнозахідного наріччя маємо варіанти фразем із лексемами фiгa, pblia, фiza (порівняймо з польським figa z makiem - 'абсолютно нічого' (Космеда 2017: 309)): лемківські - ф’іта з маком 'нічого' (Турчин 2011: 324), 
достати фылу макову 'абсолютно, зовсім нічого' (Ступінська 2013: 80), гуцульські - фіта з маком (ЛЛПЖ: 752), а фігі з маком не хоч? А pity з маком! (Лесюк 2008: 164); буковинські - фіта з маком (niд ніс) 1) зі сл. буде, вийшла та ін. 'нічого'; 2) зі сл. показати, зробити, заробити та ін. 'нічого не зробити, не виконати обіцянки' (ФПЧ: 213); волинські - фіга (дулька) з маком 'нічого' (Кірілкова 2013: 176). Компонент дуля більше (або паралельно з фіга) вживають у східнослобожанських говірках - дулі з маком та пироги з таком 'нічого' (В.Д. Ужченко, Д.В. Ужченко 2013: 188), середньонаддніпрянських - ду́л'y з ма́ком 'нічого' (Лонська 2011, 243), буковинських дуля з маком (nid ніс) (ФПЧ: 84); у середньополіських говірках фразеологізм дуля з маком пояснюють як 'невдача' (Доброльожа 2010: 63). У східностепових говірках побутує вираз ду́л'а тоб'i з ма́ком з більш конкретизованим значенням 'відмовляти у проханні': коли́ у те́бе шчос' про́с 'ат ' таке́ / шо не хо́чеи дава́ти / то в душ'і́ і поду́майеш / ду́л'а тоб'ї з ма́ком / приеду́муйеш причи́ну / шоб в'ідмо́вити (Кушмет 2010: 44).

Записи діалектного матеріалу фіксують приклади можливих слів-супровідників до аналізованого виразу, наприклад, у східнослобожанських говірках дулі з маком їсти - 'голодувати' (В.Д. Ужченко, Д.В. Ужченко 2013: 188), на території Західного Поділля зафіксовано вираз заробити дулю з маком зі значенням 'нічого не заробити', у лемківських - ани марний мак не вхабыти ‘зовсім нічого' (Ступінська 2013: 57).

Споживання маку як додатку до страв пов'язано з процесом його підготовки - розтиранням у макітрі, власне назва цього хатнього начиння і мотивована лексемою мак, а тому в подільських говірках втерти маку означає 'набити' (Коваленко 2019: 193); буковинських - потерти на мак кого 'побити, суворо покарати кого-небудь' (ФПЧ: 177); східнополіських - утерти маку 1) провчити когось, 2) побити (Доброльожа 2010: 105), так само в літературній мові - втерти маку 'суворо покарати, побити (ФСУМ: 158); терти мак (на голові) 'завдавати кому-небудь болю різким натискаючим рухом великого пальця по волоссі на голові’ (ФСУМ: 880). У говірках Східної Слобожанщини на позначення дії 'побити, покарати' побутує вираз дати маку (В.Д. Ужченко, Д.В. Ужченко 2013: 313).

Фраземи семантичних рядів на позначення кількісних понять „багато”, „мало” набувають експресивності за допомогою конотативної модальності. Саме такі одиниці переконливо демонструють категоріальну експресивність, „узагальнене посилення якості чи кількості сигналу залежно від деякого аргумента, тобто тієї додаткової інформації, що призводить до цього посилення" (Телия 1986: 123).

Експресивність мовних одиниць на позначення поняття „багато” базується на наочно-чуттєвих уявленнях через зіставлення 3 дійсністю, наприклад, через конкретне суб'єктивне уявлення про велику кількість когось або чо- 
гось, пов'язане з великою кількістю маку в маківці: лемківських - як в головціi маку 'дуже багато, безліч', як ма́ку 'багато чого-небудь' (Ступінська 2013: 136; Вархол, Івченко 1990: 80); гуцульських - як ма́ку 'дуже багато’ (ГСЛ: 379); східнослобожанських - як маку в маковиці 'дуже багато', як маку насіяно (В.Д. Ужченко, Д.В. Ужченко 2013: 314). У південноволинських та гуцульських говірках фраземи цього семантичного ряду мають внутрішню форму, значення якої розшифровується так: дуже велика кількість кого-небудь, чого-небудь, що не піддається підрахуванню через дрібність і чисельність: як на стакан маку 'багато’ (Кірілкова 2013: 161), гуцульських - як ма́ку за трейц̧а́рь 'дуже багато' (ГСЛ: 216), йат маку за трейщ̧ар' (Олійник 2002: 153).

Завдяки конотативній модальності досягається експресивне забарвлення і фразем протилежного до вищеописаного значення - 'мало; ніскільки'. В основі етимологічного образу досліджуваних фразем - конкретне народне уявлення про плід маку як найменшу одиницю виміру „мало”, порівняймо: у лемківських говірках - як єде́н мак ‘дуже мало’ (Ступінська 2013: 136; Вархол, Івченко 1990: 80), мак навеце 'зовсім мало, трохи' (Ступінська 2013: 136), áни за ма́рний мак 'мізерна кількість чого-небудь' (Ступінська 2013: 137), ани за марный мак 'дуже мало’ (Вархол, Івченко 1990: 80); гуцульських - за ма́кове зе́рно 'дуже маленький, дрібний; ніскільки, нічого' (ГСЛ: 380); середньополіських - на макове зерня 'обмаль чогось' (Доброльожа 2010: 74).

Більш узагальнене значення фразеологізму, що уможливлює його вживання в різних дискурсивних площинах, спостерігаємо в буковинських і лемківських говірках - на (за) макове зерно (зерня, мак-зерно) 'зовсім, абсолютно’ (ФПЧ: 140), за маковой зерно 'нітрохи, ніскільки’ (Ступінська 2013: 101). Із таким самим значенням, але з ремарками застарілий і просторічний описано фразеологізм маковое зерно у фразеологічному словнику російської літературної мови (Федоров 2011).

Для підсилення супровідного слова зі значенням 'дуже, сильно' вживаються фразеологізми так же бы мак зберати 'дуже, надзвичайно' (Ступінська 2013: 136), якбы маком засіяти 'уживається для підсилення ознаки, дуже' (Ступінська 2013: 95), в етимологічній основі яких - образ дуже дрібного насіння, яке неможливо порахувати, на невизначеній за розмірами земельній площі.

Дефініція слова мак ніяк не обмежує культурної конотації фразеологізмів із таким компонентом завдяки безпосередньому зв'язку зі світоглядом українського народу, наділенню елементів оточуючого світу символічними властивостями. Фразеологізм загальнонародного вжитку тихо (тиша), хоч мак (маком) сій декодовано в Словнику украӥнської мови з такими значеннями: а) ‘дуже тихо’; б) ‘безвітряно’ (СУМ 4: 601). У говірковому мовленні за- 
фіксовано: гуцульські - хоч мак сій 'дуже тихо, безмовно'; лемківські - ти́хо як бы мак сіяв 'дуже тихо’ (Вархол, Івченко 1990: 80; Ступінська 2000: 101), середньополіські - хоч мак сій 'тихо’ (Доброльожа 2010: 105); порівняймо, у польській мові cicho (cisza) jak makiem zasial (Космеда, Гоменюк, Осіпова 2017: 291).

Фразеоактивність досліджуваного концепту засвідчують і поширення значень для характеристики явищ та станів природи, зокрема, на позначення поняття 'дуже ясно, світло’: у гуцульських говірках - ви́дко, хоч мак збира́й (ГСЛ: 379); буковинські - хоч (хоть) мак збирай (ФПЧ: 222); лемківських так же́би мак збера́ти 'дуже гарно видно’ (Ступінська 2000: 102), так шобы i мак збера́ти 'дуже світло’ (Вархол, Івченко 1990: 80). Антонімічний компонент сіяти (до збирати) у східнослобожанських говірках є у складі фразеологізму хоч мак посій (nосип) на позначення поняття 'дуже чисто' (В.Д. Ужченко, Д.В. Ужченко 2013: 314).

Стебла рослини, макові квіти та плоди, крім проаналізованої вище символіки, можуть бути основою для метафоричної номінації слабких розумових здібностей людей, очманіння, нездатності до якоїсь роботи через їх реальну снодійну дію на людину аж до втрати життя. Незрілий мак дурманить голову, а тому „став натяком на глупоту - ̈̈ж, дурню, бо цее з маком” (Войтович 2005: 439). Мовні одиниці з такими значеннями зафіксовані в більшості говірок, наприклад: у східнослобожанських - наїстися маку 'здуріти, очманіти', маку об’̈̈стися 'збожеволіти', у маку не досидів 'хто-небуть хворий на голову, дурнуватий' (В.Д. Ужченко, Д.В. Ужченко 2013: 314); східностепових - ма́ку найістиес'а 'говорити дурниці' (Кушмет 2010: 39), середньонаддніпрянських - маку наӥвся (Івченко 1996: 49).

Ключовим словом у семантичному ряду ‘дурний, нерозумний', найчисельнішому в українській фразеологічній картині світу, є лексема голова, де зосереджена розумова діяльність, наприклад: у гуцульських говірках - голоукка йек мак'іўка / а розуму даси' б’ix (Олійник 2002: 61). Загальнослов'янську структурно-семантичну фразеомодель “мати + щось непотрібне (віmер/каnycma/nулі/дурман та ін.) + в голові = дурний” доповнюють приклади із середньополіських говірок: в голові мак росте 1) молода людина; 2) неуважна людина (Доброльожа 2010: 104); старий, а в голові мак цввіте 1) енергійна людина; 2) дурна людина (Доброльожа 2010: 105); східнослобожанські - маки в голові иявітуmь (ростуть) 'у кого-небудь не все гаразд з розумовими здібностями’ (В.Д. Ужченко, Д.В. Ужченко 2013: 313); середньонаддніпрянські мак у голов•і u’'в·іте 'нерозумний' (Лонська 2011: 244).

Плід маку нагадує голову людини (так як і макітра, баняк в етнофразеологіï), порівняймо: баняк не варе, в макітрі карузеля крутиия, дати по макітрі), тому цілком очікуваним є побутування таких фразем: $\epsilon$ маківка товста в кого 'розумний', маківочка варе (варить) 'хто-небудь розумний' 
(В.Д. Ужченко, Д.В. Ужченко 2013: 314). Ймовірно, що тут конотативно представлений відголосок „старого світу” - давніх уявлень про матір як голову роду, його маківку (Жайворонок 2006: 350), а тому стати на маківку означає ‘зробити щось незвичайне' (В.Д. Ужченко, Д.В. Ужченко 2013: 315).

Снодійні властивості маку образно передано в компаративних фразеологізмах, зафіксованих на Поділлі ще в середині XIX ст., спить, як маку випив; спить, як маку наівся (Номис: 499), і в сучасному мовленні - спати йак маковин'а напитис'а 'міцно спати' (Коваленко 2019: 193); у говірках лемків - як кідь бы маковыня ся напьл 'дуже міцно, безпробудно' (Ступінська 2013: 153), спа́mи як кідь бы са маковіння на́пив 'дуже кріпко спати' (Вархол, Івченко 1990: 80). Загальновживаний характер виразу підтверджено у Фразеологічному словнику української мови: спить як (мов, ніби і т. ін) після маківки (маківок, маку) ‘міцно, дуже добре' (ФСУМ: 460). Про спокійний сон і затишок йдеться у сталих виразах, де $є$ порівняння з маківкою - міцним плодом маку: у західнополіських говірках - заснути, йак в маковц’ $i$ 'мати міцний сон' (Аркушин 2003: 103), спит 'йак у макувции / в макови’ i / у мак'івиз'i 'міцний сон' (Мацюк 2013: 127); середньополіських - засну́m', йак у ма́кувцุи 'про міцний сон' (Громик 2002: 157), та й загалом йак в макуви’'i (Аркушин 2003: 103) означає 'міцно, добре, спокійно' в говірках Західного Полісся та як у маковці Південної Волині (Кірілкова 2013: 94).

Евфемістичність як важлива ознака фразеологізмів підтверджена і в виразі-відповіді на дитяче питання „Звідки я взявся?”, записаному, щоправда, тільки на території східнослобожанських говірок: із маківки 'про народження дитини' (переважно в розмові з малими дітьми) (В.Д. Ужченко, Д.В. Ужченко 2013: 314).

Уявлення про певну ситуацію в процесі спілкування, характеристика різної мовленнєвої поведінки людини найяскравіше реалізуються у фраземіці. Прикметно, що до семантичного поля „Мовлення людини” належать і сталі вислови $з$ досліджуваним компонентом мак, наприклад, загальновживаними є: з медом та маком промовити (сказати і т. ін.) 'облесливо сказати' (СУМ 4: 601), вискочити (висунутися) як козак (як голий) з маку (4: 601) / як Кузьма (ФСУМ: 104) 'недоречно, недоладно або невчасно сказати що-небудь'; порівняймо, яким ключовим лексемам віддають перевагу носії говірок: східноподільських - вискочив, як Пилип (Марко, Сень, Кіндрат) з маку 'зненацька втрутитися в чужу розмову’ (Доленко 1975a: 103), выскочив Панько з маку ‘сказати щось несподівано або недоладно' (Доленко 1975б: 137); центральнополіських - вискочив козак з маку (ФСГЖ: 88). Характеризуючи чиюсь недоречну репліку чи намагання різко змінити тему розмови, в говірках Середнього Полісся кажуть: тринди-ринди, з маком корж / коржі з маком (Доброльожа 2010: 91), а на території Східної Слобожанщини нести бредовину з маком - 'обманювати, брехати' (Ужченко 2013: 72). Усі три компоненти 
фразеологізму з волинської говірки є важливими у творенні образної картини 'говорити про когось погане, пліткувати' - чорний мак сіять (Кірілкова 2013: 154).

Характеристики переміщення людини в просторі, iї поведінки чи звичок засобами фразеології виявляють одиниці, які в своєму складі мають основний образний компонент мак, наприклад: ходити по маку 'повільно рухатися' (ФСГЖ: 105), збератися як рак на мак 'повільно збиратися' (Вархол, Івченко 1990: 80), мак перетрясати 'довго шукати в домі речі, що повинні бути на місці' (Доленко 1975б: 154), заливатися в дрібний мак 'пити до безтями; пиячити' (ЛЛПЖ: 432).

Отже, фразеологізми відіграють велику роль у творенні мовної картини світу етносу, адже саме вони є виразниками „лінійки” оцінності (позитивної чи негативної). Народні спостереження, що реалізувалися у віруваннях, повір'ях і звичаях, вербалізувалися в образній основі багатьох фразеологізмів із компонентом мак. За матеріалами словників визначено, що в досліджуваних фразеологізмах українських говірок актуалізовано різні характеристики людини (розум, мовлення, зовнішність, поведінка, вчинки), а також абстрактні поняття (мало, багато, нічого), стани природи (тихо, безвітряно, ясно); підтверджено збіг структури та семантики одиниць, але збереження фонетичних, лексичних діалектизмів, архаїзмів.

\section{Summary \\ Symbolism of Lexeme Mak in the Phraseological Picture of the World}

Phraseological units with components of the names of plant world make up a large part of the common linguistic phraseological system, reflecting the various spheres of human life, and therefore confirm the conclusions of linguists on the moving of phraseological paradigm towards anthropocentrism.

The article the peculiarities of the use and spatial distribution of floronomen mak 'poppy' in the structure of phraseological units of Ukrainian literary language and dialect are researched. The material used for the study was lexical and phraseological dictionaries of dialects and records of texts from native speakers of Ukrainian, made by the author. The lexicographic works confirm the extraordinarily rich fund of phraseologisms, the active variation of these units in the areal projection, and also make it possible to study the phraseological component within a fixed combination of words and beyond. It has been specified that the names and symbols of mak 'poppy', its flower, fruit and stem can serve as the basis for the metaphorical nomination. 


\section{Bibliografia}

Abramowicz M., Bartmiński J., Chlebda W., 2009, Językowo-kulturowy obraz świata Stowian na tle porównawczym. Założenia programu „, A” (10 VI 2009), „Etnolingwistyka” 21, s. 341-342.

AdAmiec D., 2007, Frazeologia religijna okresu baroku (na tle tendencji kulturowych epoki), Kraków.

Aitchison J., 1991, Ssak, który mówi. Wstęp do psycholingwistyki, thum. M. Czarnecka, Warszawa.

Akartel G.M., 2011, Specjalizacje złodziejskie w świetle quasi-semantyzmów (na materiale polskiego i rosyjskiego żargonu przestepczego), „Acta Polono-Ruthenica” 16, s. 287-296.

ALS: S. Grzeszczuk (oprac.), Antologia literatury sowizdrzalskiej XVI i XVII wieku, wyd. 2 zm., Wrocław-Warszawa-Kraków 1985.

Anusiewicz J., DąBrowska A., Fleischer M., 2000, Językowy obraz świata i kultura. Projekt koncepcji badawczej, [w:] A. Dąbrowska, J. Anusiewicz (red.), Język a Kultura, t. 13: Językowy obraz świata i kultura, Wrocław, s. 11-44.

Anusiewicz J., Skawiński J., 1996, Słownik polszczyzny potocznej, Warszawa-Wrocław.

BachmannovÁ J., 1986, K výzkumu a popisu nářeční frazeologie, „Naše řeč” 69, č. 1, S. $1-5$.

Bachmannová J., 1998, Podkrkonošský slovnik, Praha.

BACHMANNOVÁ J., 2011, Regionální nářečni slovník a problémy jeho zpracování (na materiálu z Podkrkonoši ), [w:] Z. Holub, R. Sukač (red.), Dialektologie a geolingvistika v současné střední Evropě, Frýdek-Místek-Kleinwächter-Opava, s. 79-87.

Baroko 2017: Baroko v Jižních Čechách. Soběslavská Blata, České Budějovice 2017.

Bartels H., Thorquindt-StumpF K., 2013, Ein neues Ton- und Textarchiv des muttersprachlich-dialektalen Niedersorbischen, „Lětopis” 60, H. 1, s. 39-60.

BARTMIŃSKi J., 1973, O języku folkloru, Wrocław-Warszawa-Kraków-Gdańsk.

BARTMIŃSKI J., 1977, O derywacji stylistycznej (na przykładzie poetyckiego interdialektu folkloru i ,gwary” w literaturze), „Zeszyty Naukowe UJ. Prace Językoznawcze” 54 , s. $87-110$.

BARTMIŃSKi J., 1990, Folklor - język - poetyka, Wrocław.

BARTMIŃski J., 1998, Podstawy lingwistycznych badań nad stereotypem - na przykładzie stereotypu matki, [w:] J. Anusiewicz, J. Bartmiński (red.), Język a Kultura, t. 12: Stereotyp jako przedmiot lingwistyki. Teoria, metodologia, analizy empiryczne, Wrocław, s. 63-83.

BARTMIŃski J., 2007, Stereotypy mieszkaja w języku. Studia etnolingwistyczne, Lublin. BARTMIŃSKI J., 2009, Językowe podstawy obrazu świata, wyd. 3, Lublin. 
BARTMIŃski J., 2010a, Pojęcie ,językowy obraz świata” i sposoby jego operacjonalizacji, [w:] P. Czapliński, A. Legeżyńska, M. Telicki (red.), Jaka antropologia literatury jest dzisiaj możliwa?, Poznań, s. 155-178.

BARTMiński J., 2010b, Styl potoczny, [w:] J. Bartmiński (red.), Wspótczesny język polski, wyd. 3, Lublin, s. 115-134.

BARTMIŃSKI J., 2018, O założeniach i postulatach lingwistyki kulturowej (na przykładzie definicji PRACY), „Półrocznik Językoznawczy Tertium. Tertium Linguistic Journal" 3, nr 1, s. 26-55, DOI: 10.7592/Tertium2018.3.1.Bartminski.

Bartmiński J., Bielińska-GardZiel I., 2015, Polski językowo-kulturowy obraz DOMU i jego profile, [w:] LASiS I, s. 89-121.

BARTMIŃSKi J., ChleBdA W., 2018, Obrazy EUROPY w języku polskim i w tekstach polskich dyskursów publicznych, [w:] LASiS II, s. 169-215.

Bartmiński J., LAPPo I., Majer-Baranowska U., 2009, Stereotyp Rosjanina i jego profilowanie we współczesnej polszczyźnie, [w:] J. Bartmiński (red.), Stereotypy mieszkaja w języku. Studia etnolingwistyczne, Lublin, s. 262-298.

Bartmiński J., NiebrZegowska-Bartmińska S., 2016, PRACA w kręgu wartości stowiańskich i europejskich, [w:] LASiS III, s. 13-42.

BARTMiŃski J., NieBrZEgOwSKA-BARTMIŃsKA S., 2019, WOLNOŚĆ w polskiej lingwokulturze, [w:] LASiS IV, s. 181-244.

Bartnicka-DąiBKowska B., 1964, Polskie ludowe nazwy grzybów, Wrocław.

BATKO-TOKARZ B., 2019, Tematyczny podział słownictwa współczesnego języka polskiego. Teoria, praktyka, leksykografia, Kraków.

BBI: M. Benson, E. Benson, R. Ilson, The BBI Combinatory Dictionary of English, Moscow 1990.

BibWarsz 1861 III: Tworzymir [Chociszewski], Przysłowia ludu wielkopolskiego, zawierajace spostrzeżenia na różne dni, miesiace i pory roku, „Biblioteka Warszawska. Pismo poświęcone naukom, sztukom i przemysłowi” 1861, t. III, s. 619-642.

Bittnerová D., Schindler F., 2003, Česká př́sloví. Soudobý stav konce 20. století, Praha.

BogusŁawski A., 1989, Uwagi o pracy nad frazeologia, [w:] Z. Saloni (red.), Studia z polskiej leksykografii współczesnej, t. III, Białystok, s. 13-31.

BRÜCKNER A., 1937, Encyklopedia staropolska, t. I, Warszawa.

BuŁaWA M., 2016a, Nazwy chorób epidemicznych w przeklęciach gwarowych, „LingVaria” nr 2 (22), s. 249-264, DOI: 10.12797/LV.11.2016.22.16.

BuŁawa M., 2016b, Paralusz i inne ,odmiany złośliwych diabłów”, czyli o zwiąkach między choroba a diabłem we frazeologii gwarowej, [w:] M. Rak, K. Sikora (red.), Stowiańska frazeologia gwarowa, „Biblioteka LingVariów”, t. 23, Kraków, s. 229-248.

BuŁawa M., 2019, Nazwy chorób w gwarach polskich, Kraków.

CECD: COBUILD English Collocations Dictionary on CD-ROM, London 1995.

Chlebda W., 1991, Elementy frazematyki. Wprowadzenie do frazeologii nadawcy, Opole.

Chlebda W., 2005, Szkice o skrzydlatych słowach. Interpretacje lingwistyczne, Opole.

Chlebda W., 2010, Frazematyka, [w:] J. Bartmiński (red.), Współczesny język polski, wyd. 3, Lublin, s. 335-342.

Chlebda W., 2018, Czy mikroteksty moga być obiektami frazeografii (przekładowej)?, [w:] A. Pstyga, T. Kaganowicz, M. Buchowska (red.), Słowo z perspektywy językoznawcy $i$ thumacza, t. 7: Frazeologia z perspektywy językoznawcy i thumacza, Gdańsk, s. $40-53$. 
Chlebda W., 2020a, Frazeologiczne zaplecze językowego obrazu świata, [w:] M. Rak, V.M. Mokienko (red.), Stowiańska frazeologia gwarowa II, „Biblioteka LingVariów", t. 28, Kraków, s. 63-72.

Chlebda W., 2020b, Nieskończona frazeologia. Esej o początkach, [w:] W. Chlebda (red.), Polsko-rosyjski słownik par przekładowych. Tom zbiorczy „Podręcznego idiomatykonu polsko-rosyjskiego" (z. 6-10), Opole [w druku].

Chojnacki J., 1995, Frazeologia w gwarze wsi Budzisław Kościelny, [w]: Z. Krążyńska, Z. Zagórski (red.), Język polski - historia i współczesność, Poznań, s. 27-34.

Chojnacki J., 2010, Mowa mieszkańców Kleczewa, [w:] J. Stępień (red.), Szkice z dziejów Kleczewa i ziemi kleczewskiej, t. I, Kleczew, s. 233-248.

ChoJnacki J., 2012, Gwara Ślesina, [w:] E. Jeglińska (red.), Z problematyki etnograficznej Ślesina i okolic, Ślesin, s. 168-192.

Cybulski N., 1894, Próba badań nad żywieniem się ludu wiejskiego w Galicji, Kraków.

Czachur W., 2011, Dyskursywny obraz świata. Kilka refleksji, „Tekst i Dyskurs - Text und Diskurs" 4, s. 79-97.

Czeczot J., 1837, Piosnki wieśniacze znad Niemna i Dźwiny, w 2 cz., Wilno.

CzesaK A., 1998, Frazeologia gwarowa - problemy i postulaty, [w:] S. Gala (red.), Teoretyczne, badawcze i dydaktyczne założenia dialektologii, „Prace Wydziału I Językoznawstwa, Nauki o Literaturze i Filozofii”, nr 99, Łódź, s. 285-293.

Czubiński T., Paradowski A., 2014, Atlas chwastów dla praktyków, Poznań.

ČEL: F.L. ČelakovsKÝ, Mudrosloví národu slovanského ve príslovích, Praha 1852/2000.

ČElakovský F.L., 1949, Mudrosloví národu slovanského ve príslovích. Připojena jest sbirka prostonárodních českých pořekadel, Praha.

ČERMÁK F., 1982, Idiomatika a frazeologie češtiny, Praha.

ČERMÁK F., 2008, Frazeologie a idiomatika česká a obecná. Czech and General Phraseology, Praha.

ČIžmÁrová L., 2018, Kouzla a čáry v českých nárečcich, Praha.

ČJA 1, 1992, 2004: J. Balhar a kol. (ed.), Český jazykový atlas, 1. díl., Praha 1992, 2004 [https://cja.ujc.cas.cz/CJA1/].

Dąirowska A., 2005, Słownik eufemizmów polskich czyli W rzeczy mocno, w sposobie tagodnie, wyd. 2, Warszawa.

Dejna K., 1980, Ile mamy języków polskich?, „Język Polski” LX, s. 30-43.

Dekowski J.P., 1959, Pasterstwo nad Pilica, [w:] K. Zawistowicz-Adamska (red.), Prace i Materiały Etnograficzne, t. XIII, Wrocław, s. 149-277.

Dembowski B., 1894, Słownik gwary podhalskiej, Kraków [odbitka z tomu V „Sprawozdań Komisji Językowej Akademii Umiejętności w Krakowie"].

DNS: Z. Holub, Doudlebské nářeči a slovník, České Budějovice 2004.

Dobrowolski K., 1933, Włościańskie rozporządzenie ostatniej woli na Podhalu w XVII i XVIII w. Studia i materiały, Kraków.

Doroszewski W., 1954, Z zagadnień leksykografii polskiej, Warszawa.

DoroszKiewicz M., 1991, Studia nad wptywami polskimi na rosyjska leksyke gwarowa, Wrocław.

Duden 2008: Duden. Redewendungen. Wörterbuch der deutschen Idiomatik, 3., überarb. und aktualisierte Auf., Hrsg. v.d. Dudenredaktion, „Duden in 12 Bänden”, Bd. 11, Mannheim-Leipzig-Wien-Zürich 2008.

Dyвowski W., 1881, Przysłowia białoruskie z powiatu nowogródzkiego, „Zbiór Wiadomości do Antropologii Krajowej” V, s. 3-23. 
DziamsKa-Lenart G., 2008, Frazeologizmy określajace wiek człowieka w tematycznych słownikach frazeologicznych języka polskiego, [w:] M. Aleksiejenko, M. Hordy (red.), Słowo, tekst, czas IX. Człowiek w przestrzeni słownika i tekstu. Materiaty IX międzynarodowej konferencji naukowej (Szczecin, 8-10 listopada 2007 r.), Szczecin, s. 121-128.

Dziamska-Lenart G., 2018, Frazeografia polska. Teoria i praktyka, Poznań.

Dźwigot R., 2014, O diabelskich nazwach $i$ nazwaniach, [w:] L. Bednarczuk, H. Chodurska, A. Mażulis-Frydel (red.), Polono-Slavica in honorem Maria Wojtyła-Świerzowska, „Krakowskie Studia Slawistyczne” II, Kraków, s. 77-90.

DźwigoŁ R., 2016, Nazwy z zakresu kultury materialnej motywowane pojęciami z zakresu kultury duchowej, [w:] E. Młynarczyk, E. Horyń (red.), Dialog z Tradycja, t. V: Językowe dziedzictwo kultury materialnej, Kraków, s. 15-33.

ECKert R., 1994, Die litauische Herkunft des russischen Phrasems бить табалу, [w:] E. Eichler, K. Krüger, A. Thiele (Hrsg.), Wort und Text. Slavistische Beiträge zum 65. Geburtstag von Wolfgang Sperber, Frankfurt am Main, s. 15-21.

EngelKing A., 2000, Klatwa. Rzecz o ludowej magii słowa, Wrocław.

FAI: F. Čermák, Frazém a idiom, [w:] P. Karlík, M. Nekula, J. Pleskalová (red.), CzechEncy - Nový encyklopedický slovník češtiny [https://www.czechency.org/slovnik/ FRAZ\%C3\%89M\%20A\%20IDIOM].

FederowsKi M., 1897-1981, Lud białoruski na Rusi Litewskiej. Materiaty do etnografii słowiańskiej zgromadzone w latach 1877-1905, t. I-VIII, Kraków-Warszawa.

FGW: J. Chojnacki, Frazeologia gwarowa Wielkopolski pótnocno-wschodniej, Łódź 2018. Fillmore Ch.J., Kay P., 1993, Construction Grammar Coursebook. Chapters 1 thru 11, Berkeley, CA.

Fink-Arsovski Ž., KovaČEvić B., HRnJAK A., 2010, Bibliografija hrvatske frazeologije. I CD s popisom frazema analiziranih u znanstvenim i stručnim radovima, Zagreb.

FlajŠHAns V., 2013, Česká prrísloví. Sbírka př́sloví, prípovídek a pořekadel lidu Českého v Cechách, na Moravě a v Slezsku, díl I: Př́sloví staročeská, díl I (A-N), díl II (O-Ru), 2-é, rozšířené vyd., předml. V. Mokienko, kom. V. Mokienko, L. Stěpanova, ed. V. Mokienko, L. Stěpanova, Olomouc.

FlizaK S., 1937, Dziadowskie obiady, „Lud”, 35, s. 53-55.

Formule: F. Čermák, Formule, [w:] P. Karlík, M. Nekula, J. Pleskalová (red.), CzechEncy - Nový encyklopedický slovník češtiny [https://www.czechency.org/slovnik/ FORMULE].

Fros H., Sowa F., 1998, Księga imion i świętych, t. 3 (H-Ł), Kraków.

Fros H., Sowa F., 2007, Księga imion i świętych, t. 6 (W-Z), Kraków.

FSIK: F. Sikoń, Coby nie zabocyć, Rabka Zdrój 2011.

Furdal A., 1973, Klasyfikacja odmian współczesnego języka polskiego, Wrocław.

GaJdA S., 1982, Podstawy badań stylistycznych nad językiem naukowym, Warszawa-Wrocław.

Gaj-Piotrowski W., 1967, Kultura społeczna ludu z okolic Rozwadowa, „Prace i Materiały Etnograficzne. Wydawnictwo Polskiego Towarzystwa Ludoznawczego", t. XXVI, Wrocław.

GawŁowski M., Słownik polsko-potocznoludowy niektórych roślin i chwastów, http://wodr. poznan.pl/component/k2/item/4224/-słownik-polsko---potocznoludowy-niektó rych-roślin-i-chwastów. 
Gazda F., 1938, Babiogórskie pieśni z Zawoi w uktadzie na 3 i 4 głosy równe, Kraków.

GeBert K., 1989, „,...by się pług nie złamat”. Uwagi o demonologii żydowskiej, „Polska Sztuka Ludowa", nr 1/2, s. 12-19.

GIERYNG K., 1938, Stownik zielarski (nazwy naukowe i ludowe), Wilno.

GLIŃski A.J., 1853, Bajarz polski, Wilno.

GLuz: Gluziński J., 1856, Włościanie polscy uważani pod względem charakteru, zwyczajów, obyczajów i przesądów z dołączeniem przysłowiów powszechnie używanych, [w:] Archiwum domowe do dziejów i literatury krajowej, z rękopismów i dzieł najrzadszych zeb. i wyd. K.W. Wójcicki, Warszawa, s. 392-576.

GŁuszKowski M., 2011a, Czy gwara staroobrzędowców regionu suwalsko-augustowskiego jest wciąz rosyjska?, „Zeszyty Łużyckie” nr 45, s. 107-117.

GŁuszkowski M., 2011b, Socjologiczne i psychologiczne uwarunkowania dwujęzyczności staroobrzędowców regionu suwalsko-augustowskiego, Toruń.

GŁuszkowski M., Grupa M. 2016, Socjolingwistyczne badania podtużne bilingwizmu staroobrzędowców mieszkających w Polsce, [w:] R. Dębski, W.T. Miodunka (red.), Bilingwizm polsko-obcy. Od teorii i metodologii badań do studiów przypadków, Kraków, s. 33-47.

GoláŇová H., 2013, Nářeční slovník jihozápadního Vsetínska, dipl. prace, Univerzita Karlova v Praze, Filozofická fakulta, Ústav českého jazyka a teorie komunikace, Praha [https://dspace.cuni.cz/bitstream/handle/20.500.11956/53334/140027701.pdf ?sequence $=4 \&$ isAllowed $=\mathrm{y}]$.

Goulfier G., b.r., Pokrzywa w ogrodzie i kuchni, b.m.

GóRnowicz H., 1975a, Frazeologia w gwarach w stosunku do języka literackiego na przykładzie gwar malborskich, [w:] M. Karaś (red.), Słownictwo gwarowe a kultura, Wrocław, s. 79-84.

GóRNOwicz H., 1975b, Idiomatyzmy frazeologiczne $w$ gwarach malborskich $w$ stosunku do języka ogólnopolskiego, „Prace Filologiczne”, t. 25, Warszawa, s. 397-406.

Grabda E., Heese T., 1991, Polskie nazewnictwo popularne. Kragouste i ryby (Cyclostomata et Pisces), Koszalin.

Grek-PABIsowa I., 1968, Rosyjska gwara starowierców w województwach olsztyńskim i białostockim, Wrocław-Warszawa-Kraków.

GreK-PABISOwA I., 1976/1999, Gwara starowierców a pótnocno-wschodnie gwary białoruskie (cechy fonetyczne), [w:] eadem, Staroobrzędowcy. Szkice z historii, języka, obyczajów. Wybór prac z okazji 45-lecia pracy naukowej, Warszawa 1999, s. 117-124.

Grek-PABISOwA I., 1983, Słownictwo rosyjskiej wyspy gwarowej staroobrzędowców mieszkajacych w Polsce, Wrocław.

Grek-PABISOwA I., 1998/1999, Światowe migracje staroobrzędowców (od wieku siedemnastego do czasów współczesnych), [w:] eadem, Staroobrzędowcy. Szkice z historii, języka, obyczajów. Wybór prac z okazji 45-lecia pracy naukowej, Warszawa 1999, s. 13-32.

Grek-Pabisowa I., Maryniakowa I., 1980, Stownik gwary starowierców mieszkajacych w Polsce, Wrocław.

Grigas K., 1987, Patarliu paralelès. Lietuviu patarlès su latviu, baltarusiu, rusu, lenku, vokiečiu, anglu, lotynu, prancūzu, ispanu, atitikmenimis, Vilnius.

Grochola-SzczePaneK H., 2013, Badania języka mieszkańców wsi w kontekście przemian społecznych, ,Socjolingwistyka” 27, s. 43-53. 
Gruchmanowa M., Walczak B. (red.), 1997, Stownik gwary miejskiej Poznania, Warszawa-Poznań.

Grupa M., 2016a, Rola tradycji w kulturze staroobrzędowców mieszkających w Polsce na podstawie powiedzeń i przysłów funkcjonujacych $w$ ich gwarze, „Zeszyty Łużyckie" nr 50, s. 343-355.

GRUPA M., 2016b, Wpływ języka polskiego na leksykę medyczna w gwarze staroobrzędowców regionu suwalsko-augustowskiego, „Acta Baltico-Slavica” 40, s. 167-185.

GRupA M., 2017, Wpływ polszczyzny na porównania frazeologiczne rosyjskiej gwary staroobrzędowców w Polsce, [w:] A. Kołodziej (red.) Słowiańszczyzna dawniej i dziś język, literatura, kultura. Monografia ze studiów slawistycznych III, Červený Kostelec, s. 113-122.

Grupa M., 2018, Frazeologiczne kalki i półkalki w mowie przedstawicieli średniego pokolenia staroobrzędowców regionu suwalsko-augustowskiego, [w:] A. Pstyga, T. Kananowicz, M. Buchowska (red.), Słowo z perspektywy językoznawcy $i$ tłumacza, t. VII: Frazeologia z perspektywy językoznawcy i tłumacza, Gdańsk, s. 165-172.

GruPA-DoliŃSKa M., 2018, Wptyw polszczyzny na terminologie techniczna $w$ rosyjskiej gwarze staroobrzędowców regionu suwalsko-augustowskiego, „Slavia Orientalis” LXVII, nr 4, s. 703-720.

GruPA-Dolińska M., 2019, Frazeologiczne kalki, pótkalki i hybrydy w mowie dwujęzycznej społeczności staroobrzędowców mieszkających w Polsce, „LingVaria” XIV, nr 1 (27), s. 249-258, DOI: 10.12797/LV.14.2019.27.16.

Grybosiowa A., 1999, O współczesnym stosunku do normy językowej, „Poradnik Językowy" z. 8-9, s. 6-13.

Grzenia J., 2008, Słownik imion, Warszawa.

Grzywnowicz K., 2002, Grzyby i ludzie czyli Od etnomykologii do mykotechnologii, Lublin.

GSP: W. Wnuk, Gawędy skalnego Podhala, Kraków 1981.

GumowsKa I., 2016, Językowy obraz biedy w zwiazkach frazeologicznych i paremiach o charakterze gwarowym, [w:] M. Rak, K. Sikora (red.), Stowiańska frazeologia gwarowa, „Biblioteka LingVariów”, t. 23, Kraków, s. 267-277.

Gustawicz B., 1882, Podania, przesady, gadki i nazwy ludowe w dziedzinie przyrody (część druga), „Zbiór Wiadomości do Antropologii Krajowej”, t. 6, s. 201-317.

Hajšman J., 2017, Plzeňsko-český slovník. Pročpa tudlecto řikáme?, Plzeň.

Hajšman J., Mazný P., 2018, Plzeňský místopis. Depa a pročpa se takhle řiká?, Plzeň.

Halliday M.A.K., 1980, Uczenie się znaczeń, tłum. H. Bartoszewicz, [w:] G.W. Shugar, M. Smoczyńska (red.), Badania nad rozwojem języka dziecka. Wybór prac, Warszawa, s. 514-556.

HodSG: S. Hodorowicz, Stownik gwary górali Skalnego Podhala, Nowy Targ 2004.

Holub Z., 2007, Od jazykové analýzy jazyka mladého Čelakovského a Kamarýta k frazeologii, [w:] F. Krejča, J. Podlešák (red.), Josef Vlastimil Kamarýt. Život, dílo, doba. Sborník př́spěvki̊ ze stejnojmenné konference konané ve dnech 21.-22.3.2007 v Jihočeském muzeu v Českých Budějovicích a v Kulturním a informačním centru města Velešin / Velešín, České Budějovice-Velešín, s. 147-158.

Holub Z., 2009, Odraz lidové kultury v jazyce Klostermannova románu Mlhy na Blatech, [w:] V. Viktora, M. Hálková, P. Doležalová (red.), V ráji realistickém. Sborník př́spěvků ze sympozia věnovaného Karlu Klostermannovi a realismu v české literature, Klatovy, s. 127-143. 
Homolka J., Malí S., ŽÁčEK J., 1981, Borovany v pověstech a současnosti, Borovany.

HRUŠKA J.F., 1907, Dialektický slovník chodský, „Archiv pro lexikografii a dialektologii" 7, Praha.

ISJP: M. Bańko (red.), Inny słownik języka polskiego, t. 1-2, Warszawa 2000.

IwANIEC E., 1977, Z dziejów staroobrzędowców na ziemiach polskich XVII-XX w., Warszawa.

Iwanowicz M., PolańSKi E., 2011, Szkolny słownik tematyczny języka polskiego nie tylko dla uczniów, Łódź.

Iwczenko J., 2009, Diabet we frazeologii polskiej i rosyjskiej. Motywy główne, „Acta Polono-Ruthenica" 14, s. 385-396.

JAGLA J., 2004, Boska Medycyna i Niebiescy Uzdrowiciele wobec kalectwa i chorób człowieka. Ikonografia „Patronów od Chorób” i „Świętych Miłujacych Żebraków” w sztuce polskiej XIV-XVII w., Warszawa.

Jakobson R., 1972, Poetyka w świetle językoznawstwa, tłum. M.R. Mayenowa, [w:] H. Markiewicz (opr.), Współczesna teoria badań literackich za granica. Antologia, t. 2, Kraków, s. 22-69.

JAKuBCZYK K. et al., 2015, Pokrzywa zwyczajna (Urtica dioica L.) - charakterystyka botaniczna, biochemiczna $i$ właściwości prozdrowotne, „Pomeranian Journal of Life Science" 2, s. 191-198.

JANČÁKovÁ J., 1970, Vydrovo „tit’ácké” nářeči po 50 letech, „Naše řeč” 53, č. 4-5, S. 243-251.

JINDŘICH J., 2007: J. Kotal (red.), Chodský slovnik, Plzeň.

JKuL: J. Kula, ur. 1914, Wspomnienia górali, zebrał W. Wincławski, Archiwum Muzeum Tatrzańskiego im. dra Tytusa Chałubińskiego w Zakopanem, sygn. AR/NO/9.

Jorroch A., 2014, Molenna w Wojnowie - tu języki pulsuja życiem, „Zeszyty Łużyckie” 48, s. 311-327.

JóźwIKIEWICz P., 2016, Oficjalne ukraińskie i polskie nazwy grzybów jadalnych, „Roczniki Humanistyczne" LXIV, z. 7, s. 201-217, DOI: 10.18290/rh.2016.64.7-13.

JPiт: J. Pitoń, Drzewiej i dziś, Rabka Zdrój 2010.

JSta: J. Staszel, 1971, Pamiętnik, Archiwum Muzeum Tatrzańskiego im. dra Tytusa Chałubińskiego w Zakopanem, sygn. AR/NO/638.

KÁch 1924: E.M., „Naše řeč”, [Hovorna], roč. 8; č. 2, s. 62, č. 3, s. 94.

KAdYJEWSKA A., 2001, Problematyka obrazu świata $w$ badaniach języka pisarza (na przykładzie pism Cypriana Norwida), [w:] A. Pajdzińska, R. Tokarski (red.), Semantyka tekstu artystycznego, Lublin, s. 321-332.

KANIA S., ToKARSKi J., 1984, Zarys leksykologii i leksykografii polskiej, Warszawa.

Kantor J., 1907, Czarny Dunajec. Monografia etnograficzna, „Materiały antropologiczno-archeologiczne i etnograficzne", t. IX, Kraków, s. 17-229.

Karaś H., 2010, Dialektyzmy a regionalizmy, [w:] Karaś H. (red.), Dialekty i gwary polskie. Kompendium internetowe [www.gwarypolskie.uw.edu.pl].

KarŁowicz J., 1887, Podania i bajki ludowe zbierane na Litwie, Kraków.

Kaulfürst F., 2019, Pśinosk $k$ dolnoserbskej ortoepiji na zakłaźe projekta awdijowych datajow za nimsko-dolnoserbski internetowy stownik, „Lětopis” 66, H. 1, s. 3-41.

KĄś J., 2002, Wizerunek mężczyzny i kobiety w tradycyjnej społeczności wiejskiej (na materiale gwar orawskich), [w:] M. Skarżyński, M. Spiczakowska (red.), Rozmaitości językowe ofiarowane prof. dr. hab. Januszowi Strutyńskiemu z okazji Jego jubileuszu, Kraków, s. 101-109. 
KąśILG: J. Kąś, Ilustrowany leksykon gwary i kultury podhalańskiej, t. I-XII, Bukowina Tatrzańska-Kraków-Nowy Sącz 2015-2019.

KĄŚSGO: J. Kąś, Słownik gwary orawskiej, Kraków 2003.

KLeIBer A., 2009, Eliza Orzeszkowa - pisarka i piewczyni nadniemeńskiej flory, „Białoruskie Zeszyty Historyczne" 12, s. 290-305.

Klemiensiewicz Z., 1953, O różnych odmianach współczesnej polszczyzny. Próba charakterystyki odmian współczesnej polszczyzny z uwzględnieniem przypuszczalnych warunków ich początkowego rozwoju, Warszawa.

KLS: K. Moszyński, Kultura ludowa Stowian, cz. 1: Kultura materialna, Kraków 1929; cz. 2: Kultura duchowa 1, Kraków 1934, Kultura duchowa 2, Kraków 1939.

KolB IV: O. Kolberg, Kujawy. Obraz etnograficzny, t. 2, Kraków 1867.

Kolв VIII: O. Kolberg, Krakowskie. Obraz etnograficzny, t. 4, Kraków 1875.

Kolb XXXIV: O. Kolberg, Chetmskie. Obraz etnograficzny, t. 2, Kraków 1891.

KonCZEwSKA K., 2016, Frazeologizmy i paremie białoruskich gwar grodzieńskich jako źródło rekonstrukcji obrazu świata mieszkańców wielonarodowościowego regionu, [w:] M. Rak, K. Sikora (red.), Stowiańska frazeologia gwarowa, „Biblioteka LingVariów", t. 23, s. 109-123.

KonczewsKa K., 2018, Nawy roślin w cyklu esejów „Ludzie i kwiaty nad Niemnem” Elizy Orzeszkowej, [w:] M. Mączyński, E. Horyń, E. Zmuda (red.), W kręgu dawnej polszczyzny, t. VI, Kraków, s. 191-213.

KonczewsKa K., 2019, Białoruskie wsie Grodzieńszczyzny i ich mieszkańcy w listach Elizy Orzeszkowej w kontekście postulatów „, młodych” pozytywistów warszawskich, [w:] A. Janicka (red.), Pozytywiści warszawscy, seria II: Świat, Europa, Polska, Białystok, s. 447-459.

KopCZyŃSKi K., Ławrynowicz M., 2000, Polskie regionalne nazwy grzybów, [w:] M. Lisiewska, M. Ławrynowicz (red.), Monitoring grzybów, Poznań-Łódź, s. 133-142.

Koutná J., 1998, Co pro nejmilejšiho pana strejce vydáno bylo... Př́spěvek k úrovni stravováni měštanů v 18. století, „Zlatá stezka” 5, s. 285-291.

KovÁŘ D., 2008, Českobudějovicko - I. levý břeh Vltavy, České Budějovice.

KozIara S., 2018, W stronę retoryki. W poszukiwaniu nowych sposobów opisu dziedzictwa biblijnego w języku polskim, „Roczniki Humanistyczne” LXVI, z. 6, s. 57-73.

KPP: S. Adalberg (oprac.), Księga przysłów, przypowieści i wyrażeń przysłowiowych polskich, Warszawa 1889-1894.

KRAK: O. Kolberg, Lud. Jego zwyczaje, sposób życia, mowa, podania, przysłowia, obrzędy, gusła, zabawy, pieśni, muzyka i tańce, seria V-VIII: Krakowskie, cz. I-IV, Kraków 1871-1875.

KrawczyK A., 1982, Frazeologia w „Stowniku gwar polskich”, „Biuletyn Slawistyczny" 7, s. 33-37.

KRAwCZYK A., 1985, Co wiemy o frazeologii gwarowej, „Z Problemów Frazeologii Polskiej i Słowiańskiej” III, s. 129-137.

KrawCZYK-Tyrpa A., 1987, Frazeologia somatyczna w gwarach polskich. Zwiazki frazeologiczne o znaczeniach motywowanych cechami części ciała, „Prace Instytutu Języka Polskiego" 53, Wrocław.

KrawCZyK-Tyrpa A., 2001, Tabu $w$ dialektach polskich, Bydgoszcz.

KRŠKová M., 1950, Rozprávky, Praha.

KRŠKovÁ M., 1957, Dobráci, filuti, meláci, Praha. 
KRŠKOvÁ M., 1974, Blatské rozprávky, České Budějovice.

KrzyżAnowsKi J., 1980a, Przysłowie i bajka w folklorze polskim, [w:] idem, Szkice folklorystyczne, t. 3: Wokół legendy i zagadki. Z zagadnień przysłowioznawstwa, Kraków, s. $102-120$.

KrzyżANOwSKi J., 1980b, Przysłowie i zagadka, [w:] idem, Szkice folklorystyczne, t. 3: Wokót legendy i zagadki. Z zagadnień przysłowioznawstwa, Kraków, s. 121-122.

KRZYŻANOWSKI J., 1980c, W krainie bajki, [w:] idem, Szkice folklorystyczne, t. 2: W kręgu pieśni. W krainie bajki, Kraków, s. 133-395.

Ǩ̌iž P., 2008, Specifika slovníku rodilých mluvčich ve vybraných obcích na Domažlicku, dipl. prace pro 2. stupeň ZŠ, Katedra českého jazyka a literatury, Pedagogická fakulta, Jihočeská univerzita v Českých Budějovicích, České Budějovice.

KSGP: kartoteka Słownika gwar polskich, redagowanego i wydawanego przez Pracownię Dialektologii Polskiej Instytutu Języka Polskiego PAN w Krakowie (wersja elektroniczna: https:// rcin.org.pl/dlibra).

Kucharzyk R., 2009, Baba w Słowniku gwary Zakopanego i okolic Juliusza Zborowskiego, „Język Polski” LXXXIX, z. 4-5, s. 339-347.

Kustosz D., 2018, Historia badań etnobotanicznych i spis roślin dziko rosnacych użytkowanych na Podhalu, „Etnobotanika Polska” 8, s. 99-162.

Kuźmiuk J., 1989, Nazwy grzybów w języku potocznym okolic Bielska Podlaskiego, „Białostocczyzna", t. 4, nr 4 (16), s. 34-36.

Kuźmiuk J., 1991, Regionalne nazwy grzybów jadalnych między Biebrzą a Narwia na Białostocczyźnie, „Białostocczyzna”, t. 6, nr 2 (22), s. 30-32.

Kuźmiuk J., 1993, Etymologia nazw grzybów znanych na Białostocczyźnie, „Białostocczyzna", t. 8, nr 2 (30), s. 79-85.

Kuźmiuk J., 1995, Nazwy niektórych grzybów w gwarach między Bugiem a Narwia, [w:] M. Kondratiuk (red.), Badania dialektów i onomastyki na pograniczu polsko-wschodniosłowiańskim, Białystok, s. 131-141.

KüPPER H., 1993, Wörterbuch der deutschen Umgangssprache, 1. Aufl. [1987], 5. Nachdr., Stuttgart-Dresden.

KwaśnIEwicz K., 1984, Zwyczaje i obrzędy doroczne, „Etnolingwistyka Polska”, t. 28, z. 1, s. $157-199$.

Lakoff G., Johnson M., 2010, Metafory w naszym życiu, tłum. i wstęp T.P. Krzeszowski, Warszawa.

LASiS: J. Bartmiński (red.), Leksykon aksjologiczny Słowian i ich sąsiadów, t. I: DOM, red. J. Bartmiński, Iwona Bielińska-Gardziel, Beata Żywicka, Lublin 2015; t. II: EUROPA, red. W. Chlebda, Lublin-Opole 2018; t. III: PRACA, red. J. Bartmiński, M. Brzozowska, S. Niebrzegowska-Bartmińska, Lublin 2016; t. IV: WOLNOŚĆ, red. M. Abramowicz, J. Bartmiński, Lublin-Warszawa 2019; t. V: HONOR, red. P. Sotirov, D. Ajdaczić, Lublin 2017.

Lewicki A.M., 2010, Językoznawstwo polskie w XX wieku, [w:] J. Bartmiński (red.), Wspótczesny język polski, wyd. 3, Lublin, s. 619-656.

Lewicki A.M., PAjdzińska A., 2010, Frazeologia [w:] J. Bartmiński (red.), Współczesny język polski, wyd. 3, Lublin, s. 315-333.

Lichtenberg J., 2001, Die bulgarischen Phraseologismen. Auswahlbibliographie mit einem Index zur Geschichte und Etymologie, ,Vergleichende Studien zu den Slavischen Sprachen und Literaturen" 8, Frankfurt am Main. 
LompaPrzysŁ: J. Lompa, Przysłowia i mowy potoczne ludu polskiego w Szlązu, nakładem i drukiem Wawrzyńca Pisza, Bochnia 1853.

Lord A.B., 2010, Pieśniarz i jego opowieść, tłum. P. Majewski, Warszawa.

LPW: F. Lorenz, F. Hinze, Pomoranisches Wörterbuch, t. I: A-P, Berlin 1958.

LuB: O. Kolberg, Lud. Jego zwyczaje, sposób życia, mowa, podania, przysłowia, obrzędy, gusła, zabawy, pieśni, muzyka i tańce, seria XVI-XVII: Lubelskie, cz. I-II, Kraków 1883-1884.

LuD XII: 57-81: J. Sulisz, Zapiski etnograficzne z Ropczyc, „Lud” XII, 1906.

ŁAZIŃSKi M. (red.), 2008, Słownik zapożyczeń niemieckich w polszczyźnie, Warszawa.

ŁęCZ: O. Kolberg, Lud. Jego zwyczaje, sposób życia, mowa, podania, przysłowia, obrzędy, gusła, zabawy, pieśni, muzyka i tańce, seria XXII: Łęczyckie, Kraków 1889.

Łuczaj Ł., 2008, Problemy taksonomiczne w polskich badaniach etnobotanicznych, „Lud” XCII, s. 43-64.

Mager J.A., 2017, Hyjta Konopů v Mrákově, „Zlatá stezka” 24, s. 275-289.

MAGP: Mały atlas gwar polskich, oprac. przez Pracownię Atlasu i Słownika Gwar Polskich Zakładu Językoznawstwa PAN w Krakowie, t. I-II, pod kier. K. Nitscha, t. III-XIII, pod kier. M. Karasia, Wrocław 1957-1970.

MAJEwski E., 1894, Słownik nazwisk zoologicznych i botanicznych polskich, zawierajacy ludowe oraz naukowe nazwy $i$ synonimy polskie, używane dla zwierzat $i$ roślin od $X V$-go wieku aż do chwili obecnej, źródtowo zebrane $i$ zestawione z synonimami naukowemi łacińskiemi w podwójnym porządku alfabetycznym i pomnożone porównawczym materyałem zaczerpniętym z innych języków słowiańskich, zebrał i ułożył E. Majewski, t. I: Słownik polsko-łaciński, Warszawa.

Malec M., 1994, Imiona chrześcijańskie w średniowiecznej Polsce, Kraków.

MALEC M., 1995, Stownik etymologiczno-motywacyjny staropolskich nazw osobowych, cz. II: Nazwy osobowe pochodzenia chrześcijańskiego, Kraków.

Marczyк M., 2003, Grzyby w kulturze ludowej, Wrocław.

Maz: O. Kolberg, Mazowsze. Obraz etnograficzny. Mazowsze stare: Mazury, Podlasie, cz. I-V, Kraków 1885-1890.

Mel'Čuk I., 1995, Phrasemes in Language and Phraseology in Linguistics, [w:] M. Everaert et al. (red.), Idioms. Structural and Psychological Perspectives, Hillsdale, MI, s. $167-232$.

MG: J. Krzyżanowski, Mądrej głowie dość dwie słowie. Pięć centuryj przysłów polskich i diabelski tuzin, t. 1-3, Warszawa 1975.

MJAK: M. Jakubiec, 1927, Wspomnienia górali, zebrał W. Wincławski, Archiwum Muzeum Tatrzańskiego im. dra Tytusa Chałubińskiego w Zakopanem, sygn. AR/NO/9.

MŁynarczyk E., 2015, Polski obraz biedy utrwalony w jezzyku $i$ w kulturze, „Etnolingwistyka" 27, s. 147-165.

MŁynARCZYK E., 2016, Językowy obraz pożywienia ludności wiejskiej w sytuacji niedostatku, [w:] M. Rak, K. Sikora (red.), Stowiańska frazeologia gwarowa, „Biblioteka LingVariów", t. 23, Kraków, s. 253-266.

MŁynarczyk E., 2018, Bieda w potocznej komunikacji językowej Polaków, [w:] A. Piotrowicz, M. Witaszek-Samborska, K. Skibski (red.), Kultura Komunikacji Językowej V: Kultura komunikacji potocznej w językach słowiańskich, Poznań, s. 221-230.

MMD: T. Oracki (oprac.), Mądrzejszy Mazur niż diabeł. Zbiór przysłów i wyrażeń przysłowiowych polskich z terenu Warmii i Mazur, Olsztyn 1977. 
MMrug: W. Jostowa, Zżycia góralskiej biedoty w XIX w, „Wierchy” 1953, r. 22, s. 110-131. Mokienko V.M., 1993, Phraseologische Germanismen im Russischen, „Zeitschrift für Slawistik" 38, H. 3, s. 346-360, DOI: 10.1524/slaw.1993.38.3.346.

Mokienko V.M., 2018, Wo der Hund begraben liegt. Studien zur slawischen Parömiologie und Phraseologie, Burlington-Greifswald.

MosioŁek-KŁosińska K., Ciesielska A., 2001, W kilku słowach. Słownik frazeologiczny języka polskiego, Warszawa.

MSGP: J. Wronicz (red.), Mały słownik gwar polskich, Kraków 2010.

Muka E., 1911-1928, Stownik dolnoserbskeje rěcy a jeje narěcow, St. Petersburg-Praga.

Müldner-Nieckowski P., 2007, Frazeologia poszerzona. Studium leksykograficzne, Warszawa.

Mussner M., 2010, Jedem Tierchen sein Pläsierchen. Phraseme mit Tierbezeichnungen im Komponentenbestand im Vergleich zwischen den Sprachen Deutsch, Französisch und Italienisch, Diss. Leopold-Franzens-Universität, Innsbruck.

MuszyŃska M., 2010, Określenia nazywajace dzieci w gwarach Śląska (IV). Analiza przemian leksykalnych - wyniki ankiety, „Studia Śląskie” 69, s. 327-351.

MuszyńsKa M., 2011a, Okréślenia nazywające dzieci w gwarach Ślaska. Leksemy opisujace wyglad, [w:] K. Kossakowska-Jarosz (red.), Kalejdoskop tematów śląkich. Zbiór studiów filologicznych, Opole, s. 237-245.

MuszyńsKa M., 2011b, Okré́lenia nazywające dzieci w gwarach Ślaska (I). Formacje opisowe i deminutywno-hipokorystyczne, „Rozprawy Komisji Językowej Wrocławskiego Towarzystwa Naukowego" 38, s. 75-93.

MuszyŃSKA M., 2012, Okréślenia nazywające dzieci w gwarach Ślaska (II). Leksemy dotyczace niegrzecznych chłopców, „Rozprawy Komisji Językowej Wrocławskiego Towarzystwa Naukowego" 39, s. 17-36.

NAUŠ B., 2005-2006, Jak žárští kluci hráli čampla při pasení krav, „Zlatá stezka” 12-13, s. $341-342$.

Nazwy: K. Rymut, B. Czopek-Kopciuch (red.), Nazwy miejscowe Polski. Historia. Pochodzenie. Zmiany, t. IX: Po-Q, Kraków 2013.

NiebrZEGOWSKA-BARTMIŃSKa S., 2014, Od separacyjnego do holistycznego opisu językowego obrazu świata. Na marginesie dyskusji nad kształtem artykułów w Leksykonie aksjologicznym Słowian i ich sąsiadów, [w:] I. Bielińska-Gardziel, S. Niebrzegowska-Bartmińska, J. Szadura (red.), Wartości w językowo-kulturowym obrazie świata Stowian i ich sąsiadów 3. Problemy eksplikowania i profilowania pojęć, Lublin, s. 71-102.

NiebrZegOwSKA-BARTMiŃSKA S., 2017, Jakie dane sa relewantne etnolingwistycznie?, „Etnolingwistyka” 29, s. 11-29.

Niewiara A., 1995, Starość starości, czyli wstęp filologiczny, [w:] A. Nawarecki, A. Dziadek (red.), Starość. Wybór materiałów z VII konferencji pracowników naukowych i studentów Instytutu Nauk o Literaturze Polskiej UŚ, Katowice, s. 10-14.

NikoŁajczuk K., 2014, Starość człowieka w polskiej frazeologii, [w:] S. Gajda, I. Jokiel (red.), Polonistyka wobec wyzwań współczesności. V Kongres Polonistyki Zagranicznej, Brzeg-Opole, 10-13 lipca 2012 r., t. II, Opole, s. 346-354.

Nitsch K., 1916, Fonetyka międzywyrazowa. Małopolskie ch, „Monografie Polskich Cech Gwarowych", nr 1 i 2, Kraków.

NKPP: J. Krzyżanowski (red.), Nowa księga przysłów $i$ wyrażeń przysłowiowych polskich, t. 1-4, Warszawa 1969-1978. 
Nowakowska A. (red.), 2003, Stownik frazeologiczny w układzie tematycznym i alfabetycznym, Wrocław.

NT II: K. Nitsch, Wybór polskich tekstów gwarowych, wyd. 2 zm., Warszawa 1960.

OвIReк S., 2010, Uskrzydlony umyst. Antropologia słowa Waltera Onga, Warszawa.

OCD: J. Crowther, S. Dignen, D. Lea (eds.), Oxford Collocations Dictionary for Students of English, Oxford 2002.

Ondrusz J., 1960, Przysłowia i przymówiska ludowe ze Śląska Cieszyńskiego, „Prace i Materiały Etnograficzne. Wydawnictwo Polskiego Towarzystwa Ludoznawczego", t. XV, cz. 2, Wrocław.

ONG W.J., 2011, Oralność i piśmienność. Słowo poddane technologii, tłum. i red. J. Japola, Warszawa.

Orzeszkowa E., 1888-1891, Ludzie i kwiaty nad Niemnem, „Wisła”, 1888, t. II, z. 1, s. 1-15, s. 675-703; 1890, t. IV, s. 1-31; 1891, t. V, s. 235-247.

OттеN F., 2002, Russische Phraseologie im europäischen Kontext, „Zeitschrift für Slawistik" 47 H. 3, s. 344-362.

PAJDzIŃsKa A., 1995, Motywacja semantyczna przymiotników wartościujących, „Etnolingwistyka" 7, s. 5-20.

PAśKo-KoneczniaK D., 2011a, Dynamika zmian w rosyjskiej gwarze staroobrzędowców w ośrodku suwalsko-augustowskim, „Zeszyty Łużyckie” 45, s. 118-126.

PAśKo-KoneCZniaK D., 2011b, Wpływ polszczyzny na zasób leksykalny rosyjskiej gwary staroobrzędowców na Suwalszczyźnie, Toruń.

PaśKo-KoneCZniaK D., 2013, Wpływ języka polskiego na idiomatyke rosyjskiej gwary staroobrzędowców na Suwalszczyźnie, [w:] J. Mędelska, E. Titarenko (red.), Dialog kultur. Języki wschodniosłowiańskie w kontakcie z polszczyzna i innymi językami europejskimi, Bydgoszcz, s. 49-57.

PBTN III: S. Dworakowski, Kultura społeczna ludu wiejskiego na Mazowszu nad Narwia, cz. I: Zwyczaje doroczne i gospodarskie, Białystok 1964.

PeŁka L., 1987, Polska demonologia ludowa, Warszawa.

Petráñová L., 2015, Kniha pamětihodných přihod královského města Domažlic 1631-1859, „Český lid”, Vol. 102, No. 3, s. 375-377.

Petrášek O., ŠTudlarová Z., 2017, Př́běhy z jižních Čech-Novohradsko a Doudlebsko, Praha.

PIECHNIK A., 2009, Wizerunek kobiety $i$ mężczyzny w językowym obrazie świata ludności wiejskiej (na przykładzie gminy Zakliczyn nad Dunajcem), Kraków.

Piela A., 2018, Słownik frazeologizmów z archaizmami. Pamiatki przeszłości, Warszawa.

Pirrainen E., 2009, Dialektale Phraseologie. Randerscheinung, Ergänzung oder Herausforderung einer modernen Phraseographie?, [w:] C. Mellado Blanco (red.), Theorie und Praxis der idiomatischen Wörterbücher, Tübingen, s. 83-100.

PKR: K. Badecki (oprac.), Polska komedja rybattowska, Lwów 1931.

PlutaPrzyse: F. Pluta, Przysłowia i zwroty powiedzeniowe z okolic Głogówka, „Kwartalnik Opolski” XII, 1966, z. 3, s. 91-97.

Pomierska J., 2013, Przysłowia kaszubskie. Studium z paremiografii i paremiologii, Gdańsk.

PopŁawski E., 2014, Frazemy z biblijnymi nazwami osobowymi w gwarach polskich, Kraków. 
PopŁAwSKI E., 2016, Święty Mikołaj w polskiej gwarowej przestrzeni paremiologicznej. Glosa do kulturowego wizerunku biskupa Miry, [w:] M. Rak, K. Sikora (red.), Słowiańska frazeologia gwarowa, „Biblioteka LingVariów”, t. 23, Kraków, s. 183-194.

PopŁawski E., 2017, Rok rolniczo-gospodarski w świetle przystów w gwarach polskich (od św. Macieja - 24 lutego, do św. Pawta - 29 czerwca), [w:] B. Osowski et al. (red.), Język w regionie, region w języku 2, Poznań, s. 289-303.

PPM: F. Čermák, Propoziční a polypropoziční monosubjektový frazem, [w:] P. Karlík, M. Nekula, J. Pleskalová (red.), CzechEncy - Nový encyklopedický slovník češtiny [https://www.czechency.org/slovnik/PROPOZI\%C4\%8CN\%C3\%8D\%20A\%20 POLYPROPOZI\%C4\%8CN\%C3\%8D\%20MONOSUBJEKTOV\%C3\%9D\%20 FRAZ\%C3\%89M].

PrezLas: Gazetka Gimnazjum nr 3 w Tarnobrzegu, 2005, „W świecie Lasowiaków, dawnych mieszkańców naszej ziemi”.

Przymuszala L., 2007, Narodziny i śmierć we frazeologii gwarowej (na przykładzie materiału śląskiego), [w:] W. Chlebda (red.), Frazeologia a językowe obrazy świata przełomu wieków, Opole, s. 105-110.

Przymuszala L., 2011, Stan badań nad polska frazeologia gwarowa, „Studia Slavica”, t. 15 , s. 219-226.

Przymuszala L., 2016, Miejsce frazeologii w słownikach gwarowych, „Prace Filologiczne", t. 68, s. 345-256.

PrzymuszaŁa L., 2017, Kulinaria we frazeologii śląskiej, „Rozprawy Komisji Językowej Łódzkiego Towarzystwa Naukowego", t. LXIV, Łódź, s. 247-264.

PSM: K. Badecki (oprac.), Polska satyra mieszczańska. Nowiny sowiźrzalskie, Kraków 1950.

RAK M., 2006, Frazeologia gwarowa w ujęciu leksykograficznym - problemy i postulaty, „Język Polski” LXXXVI, z. 1, s. 11-19.

RAK M., 2007, Językowo-kulturowy obraz zwierząt utrwalony w animalistycznej frazeologii gwar Gór Świętokrzyskich i Podtatrza (na tle porównawczym), Kraków.

RAK M., 2009a, Kultura ludowa Podtatrza w zwierciadle frazeologii (wybrane zagadnienia), „Annales Universitatis Mariae Curie-Skłodowska” XXVII, sectio FF, [druk 2012], s. 113-128.

RAK M., 2009b, Święci w podhalańskich przysłowiach, [w:] A. Janus-Sitarz (red.), W trosce o dobra edukację. Prace ofiarowane Profesor Jadwidze Kowalikowej z okazji 40-lecia pracy naukowej, Kraków, s. 289-303.

RAK M., 2015, Kulturemy podhalańskie, „Biblioteka LingVariów”, t. 19, Kraków.

RAK M., 2016a, Czego nadal nie wiemy o frazeologii gwarowej?, [w:] M. Rak, M. Sikora (red.), Stowiańska frazeologia gwarowa, „Biblioteka LingVariów”, t. 23, Kraków, s. 31-42.

RAK M., 2016b, Wartościowanie $w$ animalistycznej frazematyce gwar polskiego Podtatrza, [w:], M. Rak, K. Sikora (red.), Stowiańska frazeologia gwarowa, „Biblioteka LingVariów", t. 23, Kraków, s. 89-108.

RAK M., 2020, Beliefs and Habits in the Podhale Phraseology, Kraków [w druku].

RAK M., Sikora K. (red.), 2016, Słowiańska frazeologia gwarowa, „Biblioteka LingVariów", t. 23, Kraków.

RČEní: F. Čermák, Rčení, [w:] P. Karlík, M. Nekula, J. Pleskalová (ed.), CzechEncy-Nový encyklopedický slovník češtiny [https://www.czechency.org/slovnik/RČENÍ]. 
Referowska-Chodak E., 2015, Ludowe nazwy grzybów w Polsce, „Studia i Materiały CEPL w Rogowie" 17, z. 44/3, s. 217-238.

RichterovÁ P., 2005-2006, Konopická v Bušanovicích, „Zlatá stezka” 12-13, s. 231-240. Ř́ín R., 2002, Doudlebský lexikon, dipl. prace, Pedagogická fakulta, Jihočeská univerzita, České Budějovice.

RÖHRICH L., 2001, Lexikon der sprichwörtlichen Redensarten, 5 Bd., Freiburg-Basel-Wien. Rosenkranz H. 1988, Der volkskundliche Aspekt im Dialektwörterbuch, [w:] B. Wilhelmi (red.), Diaklektlexikographie. Berichte und Analysen zur Arbeit an Dialektwörterbüchern, „Wissenschaftliche Beiträge de Fridriech-Schiller-Universität Jena”, Jena.

Rostafiński J., 1900, Symbola ad historiam naturalem medii aevi. Plantas, animalia, lapides et cetera simplicia medicamenta quae in Polonia adhibebantur inde a XII usque ad XVI saeculum: (quattuor cum tabulis), cz. 1, Cracoviae.

Rysiński S., 1618, Proverbiorum polonicorum a Solomone Rysinio collectorum centuriae decem et octo, Lubecae ad Chronum.

SANANlaskut 1997: K. Laukkanen, P. Hakamies, M. Kuusi (leikkaaja), Sananlaskut, 3. painos. Helsinki 1997.

SČFI: F. Čermák et al., Slovník české frazeologie a idiomatiky, t. 1-4, Praha 2009; t. 5: Onomaziologický slovnik, Praha 2017.

SCIESz: J. Wronicz (red.), Słownik gwarowy Śląska Cieszyńskiego, Ustroń 2010.

SEBor: W. Boryś, Słownik etymologiczny języka polskiego, Kraków 2005.

SEBR: A. Brückner, Słownik etymologiczny języka polskiego, Kraków 1927.

SEH: K. Długosz-Kurczabowa, Wielki słownik etymologiczno-historyczny języka polskiego, Warszawa 2008.

SESŁ: F. Sławski, Słownik etymologiczny języka polskiego, t. I-V, Kraków 1952-1982.

SF PWN: A. Kłosińska (red.), Słownik frazeologiczny PWN, Warszawa 2005.

SF: S. Skorupka, Słownik frazeologiczny języka polskiego, t. 1-2, Warszawa 1967-1968.

SFGD: M. Rak, Słownik frazeologiczny gwary Dębna w Górach Świętokrzyskich, Kraków 2005.

SFisch: M. Kujawska et al., Rośliny w wierzeniach ludowych. Stownik Adama Fischera, Wrocław 2016.

SFŚL: L. Przymuszała, Słownik frazeologizmów i typowych połaczeń wyrazowych w gwarach ślaskich, Opole 2013.

SFWP: J. Bąba, J. Liberek, Słownik frazeologiczny współczesnej polszczyzny, Warszawa 2002.

SGG: J. Kobylińska, Słownik gwary gorczańskiej (zagórzańskiej), Kraków 2001.

SGGSup: J. Kobylińska, Stownik gwary gorczańskiej (zagórzańskiej), suplement, maszynopis udostępniony przez Autorkę.

SGK: B. Sychta, Stownik gwar kaszubskich na tle kultury ludowej, t. I-VII, Wrocław-Warszawa-Kraków 1967-1976.

SGKP: Słownik geograficzny Królestwa Polskiego i innych krajów słowiańskich, red. B. Chlebowski, W. Walewski wg planu F. Sulimierskiego, t. I-XV, Warszawa 1880-1902.

SGL: H. Pelcowa, Słownik gwar Lubelszczyzny, t. I-V, Lublin 2012-2017.

SGOWM: Słownik gwar Ostródzkiego, Warmii i Mazur, t. I-VII, red. Z. Stamirowska (t. I-III), H. Perzowa, D. Kołodziejczykowa (t. IV-V), D. Kołodziejczykowa, K. So- 
bolewska (t. VI), K. Sobolewska (t. VII), Wrocław-Warszawa-Kraków-Gdańsk 1987 (t. I), Wrocław-Warszawa-Kraków 1991 (t. II), Warszawa-Kraków 1993 -2018 (t. III-VII).

SGP: Stownik gwar polskich, t. I-X, red. M. Karaś (Źródta, t. I), J. Reichan (t. II-IX, z. 2), S. Urbańczyk (t. II-V), J. Okoniowa (t. VI-IX, z. 2), B. Grabka (t. VII-X, z. 2), R. Kucharzyk (t. IX, z. 2 - t. X, z. 2), Wrocław-Warszawa-Kraków 1977-1991 (t. I-III), Kraków 1992-2019 (t. IV-X, z. 2).

SGW: B. Wieczorkiewicz, Słownik gwary warszawskiej XIX wieku, Warszawa 1966.

Sierociuk J., 2001, Czy istniat prasłowiański język poetycki? „Poznańskie Studia Polonistyczne. Seria Językoznawcza" 8, Poznań, s. 127-137.

SierociuK J., 2008, Czy pierwsi twórcy literatury polskiej mogli mieć wzorce rodzime, „LingVaria” III, nr 1 (5), s. 99-107.

SJPD: W. Doroszewski (red.), Stownik języka polskiego, t. I-XI, Warszawa 1958-1969.

SKarŁ: J. Karłowicz, Słownik gwar polskich, t. I-VI (t. IV-VI do druku przygot. J. Łoś), Kraków 1900-1911.

Skubalanka T., 1976, Założenia analizy stylistycznej, [w:] H. Markiewicz, J. Sławiński (red.), Problemy metodologiczne wspótczesnego literaturoznawstwa, Kraków, s. $250-273$.

Skuza S., 2012, Stereotypowy obraz kobiety $w$ paremiach oraz frazeologii polskiej $i$ włoskiej, Poznań.

SL: S.B. Linde, Słownik języka polskiego, wydanie drugie, poprawne i pomnożone, t. I-VI, Lwów 1854-1860.

SŁAwSP: F. Sławski (red.), Słownik prasłowiański, t. 1-8, Wrocław 1974-2001.

Sмүк K., 2016, Co się włoży do woza, to się i wiezie. Obraz fury w polskich przysłowiach, [w:] E. Młynarczyk i E. Horyń (red.), Dialog z tradycja, t. V: Językowe dziedzictwo kultury materialnej, Kraków, s. 375-397.

Sobierajski Z., 1991, Podstawowe założenia metodyczne Słownika ludowego Wielkopolski, „Prace Filologiczne”, t. 36, s. 65-77.

SpIs: Spis miejscowości Polskiej Rzeczypospolitej Ludowej, Warszawa 1967.

Sittal S., 1938, Lecznictwo ludowe w Załoźcach i okolicy, „Rocznik Podolski” I, s. 62-225 (online: https://www.wbc.poznan.pl/publication/109770).

SPLP: W. Lubaś (red.), Słownik polskich leksemów potocznych, t. 1-10, Kraków 2001-2016.

SPóLNIK A., 1990, Nazwy polskich roślin do XVIII wieku, Wrocław-Warszawa-Kraków-Gdańsk-Łódź.

SPXVI: Stownik polszczyzny XVI wieku, red. M.R. Mayenowa (t. I-XXXIV), K. Mrowcewicz (t. XXXV-XXXVI), Wrocław-Warszawa-Kraków 1966-1994 (t. I-XXII), Warszawa 1995-2012 (t. XXIII-XXXVI).

SSiSL: Słownik stereotypów i symboli ludowych, koncepcja całości i red. J. Bartmiński, zast. red. S. Niebrzegowska [od cz. 3. Niebrzegowska-Bartmińska], t. I: Kosmos, cz. 1: Niebo, światła niebieskie, ogień, kamienie, 1996; cz. 2: Ziemia, woda, podziemie, 1999; cz. 3: Meteorologia, 2012; cz. 4: Świat, światło, metale, 2012; t. II: Rośliny, cz.1: Zboża, 2017; cz. 2: Warzywa, przyprawy, rośliny przemysłowe, 2018; cz. 3: Kwiaty, 2019; cz. 4: Zioła, 2019, Lublin.

SSJČ: B. Havránek et al. (red.), Slovník spisovného jazyka českého, t. 1-8, Praha 1989 [https://ssjc.ujc.cas.cz].

Stachowski M., 2018, Polskie baśka, rosyjskie башкá, ukraińskie бáшкá 'głowa'i ich etymologia w stowniku Maxa Vasmera, „Przegląd Rusycystyczny” 2 (162), s. 126-132. 
Starosta M., 1982, Niedersorbische Orthographie und Interpunktion. Regeln, 2., bearb. Aufl., Bautzen/Budyšyn.

Starosta M., 1999, Dolnoserbsko-nimski stownik, Bautzen/Budyšyn.

StefFen A., 1937, Opowiadania komiczne i podania z Warmii, Kraków.

STĚPANOVA L., 1998, Historie a etymologie českých rčení, Praha.

StĘPNIAK K., 1993, Stownik tajemnych gwar przestępczych, London.

Sтүк J., 1988, Ewolucja chłopskiego systemu wartości. Analiza historyczno-socjologiczna, Lublin.

Sтүк J., 1993, Chłopski świat wartości. Studium socjologiczne, Włocławek.

Sтүк J., 1999, Chłopi i wieś polska w perspektywie socjologicznej i historycznej, Lublin.

SW: J. Karłowicz, A.A. Kryński, W. Niedźwiedzki (red.), Słownik języka polskiego, t. I-VIII, Warszawa 1900-1927.

SWIL: A. Zdanowicz et al., Stownik języka polskiego, t. I-II, Wilno 1861.

SWJP: B. Dunaj (red.), Stownik wspótczesnego języka polskiego, Warszawa 1996.

SWO: J. Tokarski (red.), Stownik wyrazów obcych PWN, Warszawa 1989.

SүснтA B., 1955, Element morski w kaszubskiej frazeologii, „Język Polski” XXV, z. 1, s. $1-8$.

Sychta B., 1959, Wesele kociewskie, Gdynia.

Symoni-SuŁKowsKa J., 1972, Zróżnicowanie stowotwórcze i leksykalne nazw z zakresu transportu i komunikacji w gwarach polskich, „Prace Językoznawcze Polskiej Akademii Nauk", t. LXV, Wrocław.

SzKP: A. Gdacjusz, Szóste kazánie pokutne, [w:] idem, Wybór pism, oprac. H. Borek, J. Zaremba, Warszawa-Wrocław 1969, s. 152-162.

SzPILA G., 2017, Dolnołuzycka frazeologia somatyczna, „Slavia Occidentalis” 74, nr 1, s. $135-155$.

Szuster G., 2016, Góralsko strawa. Pożywienie na Podhalu w XIX i XX w., [w:] P. Jędrzejewski et al. (red.), Wiktualy, kuchnia, kultura jedzenia w perspektywie historycznej, Kraków, s. 280-295.

Szychowska-Boebel B., 1972, Lecznictwo ludowe na Kujawach (Materiaty i rozważania), Toruń.

ŚwIĘT: J. Świętek, Lud nadrabski (od Gdowa po Bochnię). Obraz etnograficzny, Kraków 1893.

ŠIMÁNeK J., 2015, Putování Doudlebskem za jeho písmáky, České Budějovice.

ŠITNEROVÁ P., 2008, Českobudějovická periodika (1918-1939) (se zaměřením na vybranou problematiku), dipl. prace pro 2 . stupeň ZŠ, Katedra společenských věd, Pedagogická fakulta, Jihočeská univerzita, České Budějovice.

ŠTIFTER J., 2018, Oči Doudlebska př́běh Karla Hlubučka (1905-1968), České Budějovice.

ŠvestKová L., 1957, K otázce př́zvuku na předposlední slabice v nářečí na Volyňsku, „Slovo a slovesnost” 18, s. 164-175.

ŠwJela B., 1961, Dolnoserbsko-němski stownik, Bautzen/Budyšyn.

TAMBOR A., 1988, Metonimiczne zwiqzki frazeologiczne oznaczajace śmierć w języku francuskim i polskim, ,Annales Universitatis Mariae Curie-Skłodowska. Sectio FF Philologiae" VI, s. 353-360.

Tetour B., 2005-2008, Církevní rok na Prachaticku podle zápisů knih ohlášek bohoslužeb z 19. století: doba vánoční, „Zlatá stezka” 12-13 (2005-2006), s. 217-229, 11 (2004), s. 179-184, 14 (2007), s. 143-159, 15 (2008), s. 203-226. 
TREDER J., 1986, Ze studiów nad frazeologią kaszubska (na tle porównawczym), Gdańsk.

Treder J., 1989, Frazeologia kaszubska a wierzenia i zwyczaje (na tle porównawczym), Wejherowo.

Treder J., 1991, Nowa dziedzina badawcza: frazeologia gwarowa, „Zeszyty Naukowe WSP w Opolu. Językoznawstwo" 3, s. 501-506.

TYrPA A., 2005, Frazeologia somatyczna. Zwiazki frazeologiczne o znaczeniach motywowanych cechami części ciała w gwarach polskich, Łask.

Tyrpa A., 2016, Co wiemy o frazeologii gwarowej w 2015 roku?, [w:] M. Rak, K. Sikora (red.), Słowiańska frazeologia gwarowa, „Biblioteka LingVariów”, t. 23, Kraków, s. $13-30$.

Ulrychová M., 2012, Jindřich Šimon Baar a lidová píseň, [w:] J. Přribylová, L. Uhlíková (ed.), Od folkloru k world music. Hudba a bariéry. Sbornik z kolokvia [http://image. folkoveprazdniny.cz/2012/kolokvium2012/sbornik2012_06_Ulrychova.pdf].

Urbańczyk S., 1979, Prace z dziejów języka polskiego, Wrocław.

Uther H., 2004, The Types of International Folktales. A Classification and Bibliography, „FF Communications”, vol. CXXXIII-CXXXV, Helsinki.

WACEwicz S., 2013, Ewolucja języka - wspótczesne kontrowersje, [w:] P. Stalmaszczyk (red.), Metodologie językoznawstwa, t. I: Ewolucja języka. Ewolucja teorii językoznawczych, Łódź, s. 11-26.

Walęciuk-Dejneka B., 2018, Folk Image of Woman. The Perspective of Otherness. Folklore and Literature, trans. A. Monies-Mizera, O. Terez, Kraków-Siedlce.

WallisPrzyst: S. Wallis, Przysłowia $i$,pogodki” ludowe na Górnym Śląsku, przedm. S. Bąk, „Prace i Materiały Etnograficzne”, t. XV, cz. 1, Wrocław 1960.

Walter H., Mokienko V.M., 2011, (K)Ein Buch mit sieben Siegeln. Historisch-etymologische Skizzen zur deutschen Phraseologie, Greifswald.

Wander K.F.W., 1987, Deutsches Sprichwörterlexikon. Ein Hausschatz für das deutsche Volk, Bd. I-V, Leipzig 1867-1889, Ndr. Darmstadt 1964; Ndr. Kettwig, 1987 [http:// www.zeno.org/Wander-1867/].

Waniakowa J., 2012, Polskie gwarowe nazwy dziko rosnacych roślin zielnych na tle słowiańskim. Zagadnienia ogólne, Kraków.

WBrz100: W. Brzega, Wspomnienia i różne zapiski z lat 1914-1940, Archiwum Muzeum Tatrzańskiego im. dra Tytusa Chałubińskiego w Zakopanem, sygn. AR/97-102.

WBrz87: W. Brzega, Wspomnienia i różne zapiski z lat 1914-1940, Archiwum Muzeum Tatrzańskiego im. dra Tytusa Chałubińskiego w Zakopanem, sygn. AR/87-96.

Weryho W., 1889, Podania białoruskie, wstęp J. Karłowicz, Lwów.

WiLKoń A., 2000, Typologia odmian językowych współczesnej polszczyzny, wyd. 2, popr. i uzup., Katowice.

WisŁa III: 946-948: J. Karłowicz, Przegląd czasopism, „Wisła” III, 1889.

WisŁA X: 342-344: M. Parczewska, Lecznictwo ludowe, „Wisła” X, 1896.

Wolny M., 2003, Językowy obraz starości ludzi i zwierząt w polszczyźnie, [w:] A. Dąbrowska (red.), Język a Kultura, t. 15: Opozycja homo-animal w języku i kulturze, Wrocław, s. 189-199.

Wóstowicz M., 2012, Zapożyczenia z języka polskiego w słownikach gwar rosyjskich połowy XIX wieku, [w:] D. Paśko-Koneczniak (red.), Współczesne badania nad kultura, literatura i językiem rosyjskim, Toruń, s. 371-386. 
Wronicz J., 2001, Pozycja kobiety w kulturze ludowej na podstawie słownictwa gwarowego, [w:] E. Teodorowicz-Hellman (red.), Kvinnan i polska språket. Kobieta w języku polskim, Stockholm, s. 75-88.

Wronicz J., 2016, Status gwary w języku polskim, „Socjolingwistyka” XXX, s. 53-60.

Wrześniowski A., 1882, Tatry i Podhalanie, „Pamiętnik Towarzystwa Tatrzańskiego” 7 , s. $1-53$.

WSJP PWN: S. Dubisz (red.), Wielki słownik języka polskiego PWN, t. I-V, Warszawa 2018.

WSJP: P. Żmigrodzki (red.), Wielki słownik języka polskiego [https://wsjp.pl/index.php? pwh=0].

Wyderka B., 2000-2017, Stownik gwar ślaskich, t. I-XVI, Opole.

Wyderka B., 2014, O rozwoju polskich dialektów, „Poznańskie Studia Polonistyczne. Seria Językoznawcza” 21 (41), z. 2, s. 103-113.

ZaOrÁleK J., 1947/2000, Lidová rčení, Praha.

Zв II: 3-182: A. Petrow, Lud ziemi dobrzyńskiej, jego charakter, mowa, zwyczaje, obrzędy, pieśni, przysłowia, zagadki itp., „Zbiór Wiadomości do Antropologii Krajowej” II, 1878.

Zв VI: 159-200: Meteorologia ludowa, czyli zdania i przysłowia ludu naszego, stużace do przepowiadania stanu pogody, zebrane przez D. Wierzbickiego, „Zbiór Wiadomości do Antropologii Krajowej” VI, 1882.

Zв VI: 201-317: B. Gustawicz, Podania, przesady, gadki $i$ nazwy ludowe $w$ dziedzinie przyrody, „Zbiór Wiadomości do Antropologii Krajowej” VI, 1882.

ZвorSGZ: J. Zborowski, Stownik gwary Zakopanego i okolic, Zakopane-Kraków 2009.

ZDANCEWICZ T., 1963, Gwary powiatu sejneńskiego na tle procesów osadniczych. Materiaty do dziejów ziemi sejneńskiej, Białystok, s. 231-266.

ZDANCEwicz T., 1966, Wplywy białoruskie w polskich gwarach pod Sejnami, Poznań.

ZGóŁK: H. Zgółkowa (red.), Praktyczny słownik współczesnej polszczyzny, t. I-L, Poznań 1994-2005.

ZiAJKA B., 2014, Językowo-kulturowy obraz świata społeczności wiejskiej utrwalony w przezwiskach i przydomkach (na przykładzie nieoficjalnych antroponimów mieszkańców Zagórza i wsi okolicznych w powiecie chrzanowskim), Kraków.

ZielińsKa A., 1996, Wielojęzyczność staroobrzędowców mieszkajacych w Polsce, Warszawa.

ZK: Z. Kosatka, Oset i jego żale, [w:] A. Kępińska (red.), Kultura ludowa regionu [http:// www.dialektologia.uw.edu.pl/index.php/mambots/?11=mapa-serwisu $\& 12=\& 13=$ $\& 14=\& 15=$ sieradzkie-tworczosc, dostęp: 6 VIII 2019].

ZRAF: Z. Rafacz, ur. 1929, Wspomnienia górali, zebrał W. Wincławski, Archiwum Muzeum Tatrzańskiego im. dra Tytusa Chałubińskiego w Zakopanem, sygn. AR/NO/9.

ZwaHR J.G., 1847, Niederlausitz-wendisch-deutsches Handwörterbuch, Grodk/Spremberg. ŻuK G., 2010, Językowy obraz świata $w$ lingwistyce polskiej przełomu wieków, [w:] M. Karwatowska, A. Siwiec (red.), Przeobrażenia w języku i komunikacji medialnej na przełomie XX i XXI wieku, Chełm, s. 239-257.

ŻyWiczYŃski P., WACEWICZ S., 2015, Ewolucja języka. W stronę hipotez gesturalnych, Torun. 
Аничков И.Е., 1997, Идиоматика в кругу лингвистических наук, [в:] И.Е. Аничков, Труды по языкознанию, Санкт-Петербург, с. 101-145.

АРефьевА Н.Г., 2017, Фразеологическая картина мира сквозь призму лингвокультурных кодов (на материале русских говоров Одесщинь), „Мова” № 27, c. $135-140$.

АРефьевА Н.Г., 2018, РУсский диалектный фразеологизм чёрный вал в этнокультурном освещении, „Мова” № 30, с. 22-28.

АРеФьевА Н.Г., 2019, О проекте Фразеологического словаря русских говоров Одесщи$H b l$, [в:] С.Н. Стародубец, В.Н. Пустовойтова, С.М. Пронченко (ред.), Идиолект русской языковой личности как отражение лингвокультурной ситуации в славянском пограничье, Новозыбков, с. 485-492.

Аркушин Г., 2003, Сказав, як два зв'язав. Народні вислови та загадки із Західного Полісся $і$ західної частини Волині, Люблін-Луцьк.

АСРФ: А.Н. Баранов, Д.О. Добровольский (ред.), Академический словарь русской фразеологии, Москва 2015.

БАБич Н., 1970-1971, Фразеологія украӥнської мови, Чернівці.

БАБич Н., 1978, Лексичні варіанти фразеологічних одиниць буковинських говірок (особливості компонентного складу $і$ функціонування), „Проблеми дослідження діалектної лексики і фразеології”, с. 87-88.

БАлли Ш., 1961, Франиузская стилистика, Москва.

БАрАнник Л.Ф., 2015, Лексика русских переселенческих говоров Одесской области, функциионрующих в разноязычном окружении, Одесса.

БАРАНОв А.Н., ДоБРОвольскИй Д.О., 2008, Аспекты теории фразеологии, Москва.

БЕРезович Е.Л., 2003, К семантической реконструкции некоторых русских диалектных вербальных формул ('Типун тебе на язык!'), [в:] Ж.Ж. Варбот и др (ред.), Этимология 2000-2002, Москва, с. 165-177.

Березович Е.Л., Кучко В.С., 2017, Менять шило на мыло. Диалектологический комментарий к фразеологизму, „Вестник Пермского университета. Российская и зарубежная филология”, т. 9, вып. 3, с. 5-15.

Бирих А. (ред.), 2009, Субстандартные варианты славянских языков, Frankfurt am Main.

Бирих А.К., 2020, Диалекты как источник русской исторической фразеологии, [в:] M. Rak, V.M. Mokienko (ред.), Stowiańska frazeologia gwarowa II, „Biblioteka LingVariów", т. 28, Kraków, c. 101-108.

Бирих А.К., Волков С.С., НикитинА Т.Г., 1993, Словарь русской фразеологической терминологии, ред. В.М. Мокиенко, Мünchen.

Блинова И.С., 2009, Концепт „старость” в русской и немеикой лингвокультурах, дисс. по ВАК РФ 10.02.20, канд. филолог. наук, Волгоград.

БМС: А.К. Бирих, В.М. Мокиенко, Л.И. Степанова, Русская фразеология. Историкоэтимологический словарь, ред. В.М. Мокиенко, 3-е изд., испр. и доп., Москва 2005.

БоБриковА Ю.В., 2013, Наименования внешности женщины в русских говорах: сопоставительный анализ, „Ученые записки Комсомольского-на-Амуре государственного технического университета", номер 11-2 (14), с. 46-50.

Бондалетов В.Д., 1987, Арготизмы в словарях русского языка, Рязань. 
Бондалетов В., 2002, Субстандартная фразеология, [в:] M. Aleksiejenko, W. Mokijenko, H. Walter (ред.), Słowo, tekst, czas - VI. Nowa frazeologia w nowej Europie. Новая фразеология в новой Европе, Szczecin-Greifswald, c. 465-474.

БСРНС: В.М. Мокиенко, Т.Г. Никитина, 2008, Большой словарь русских народньхх сравнений, Москва.

БСРП: В. Мокиенко, Т. Никитина, Большой словарь русских поговорок, Москва 2007.

БСРПС: В. Мокиенко, Т. Никитина, Е. Николаева, Большой словарь русских пословиц, Москва 2010.

БТСДК: Большой толковый словарь донского казачества, Москва 2003.

БТСРЯ: С. Кузнецов, Большой толковый словарь русского языка [http:/gramota.ru/ slovari/info/bts/].

БФСРЯ: В.Н. Телия (ред.), Большой фразеологический словарь русского языка, Москва 2006.

БФССРЯ: В.Н. Телия (ред.), Большой фразеологический словарь современного русского языка. Значение. Употребление. Культурологический комментарий, Москва 2014.

ВАльтеР Х., 2007, Русская фразеология как консервант немеиких фразеологизмов, [в:] МАПРЯЛ 2007: Мир русского слова и русское слово в мире. Материаль ХI Конгресса Международной ассочиачии преподавателей русского языка и литературы. Варна, 17-23 сентября 2007 г., т. 2: Проблемы фразеологии. Русская лексикография: тенденциии развития, София, с. 62-65.

ВальтеР Х., Мокиенко В.М., 2004, Социолекты в славянском языковом пространстве, „Университетский вестник” 6, с. 54-75.

ВАрХол Н., Івченко А., 1990, Фразеологічний словник лемківських говірок Східної Словаччини, Братіслава.

ВАхитов С.В., 2001, Лекиия о русском сленге, Уфа.

Венжинович Н., 2007, Лінгвокультурологічний аспект вивчення фразеології у творах Івана Чендея, „Сучасні проблеми мовознавства та літературознавства”, вип. 2, c. $208-212$.

Венжинович Н., 2012, Національно-культурна специифіка фразем у творах Петра Скуния, „Науковий вісник Ужгородського університету. Серія: Філологія. Соціальні комунікації”, вип. 28. с. 164-166.

Венжинович Н., 2016, Фраземіка в повісті I. Нечуя-Левицького „Кайдашева сім'я” як джерело відтворення ментальних рис українців, „Мовознавчий вісник”, вип. 21, с. 61-66.

Виноградов В., 1977, Об основных типах фразеологических единиц в русском языке, [в:] В. Виноградов, Лексикология и лексикография: избранные труды, Москва.

Войтович В.М., 2002, Украӥнська міфологія, Київ.

Гендер 2019: 3.3. Мухина, А.В. Белова, Н.А. Белова, С.В. Канныкин (ред.), Гендер в фокусе антропологии, этнографии семьи и сочиальной истории повседневности, Москва 2019.

ГжиБовский С., 2011, Русский островной говор в польском языковом окружении, [в:] С. Гжибовский, В.А. Хорев, М. Волос (ред.), Русско-польские языковые, литературные и культурные контакты, Москва, с. 45-59.

Гжиьовский С., Глушковский М., 2008, Социолингвистическая ситуация старообрядиев в деревнях Габове Гронды и Бур, [в:] Л.Л. Касаткин (ред.) Русские старообрядиьь. Язык. Литература. Исторя, Москва, с. 200-215. 
ГороднянскАЯ П., 2013, Многоаспектный анализ лексикализованных предложно-падежных словоформ адвербиального характера в русском языке, Абакан.

Грачев М.А., 2003, Словарь тысячелетнего русского арго, Москва.

Грачев М.А., 2005, От Ваньки Каина до мафии. Прошлое и настоящее уголовного жаргона, Санкт-Петербург.

Грачев М.А., Мокиенко В.М., 2008, Русский жаргон. Историко-этимологический словарь, Москва.

Григорович Л.А., 2015, Региональная жаргонная лексика в современной лексикографии, „Культура речи” 4, с. 50-53.

Громик Ю., 2002, Фразеологізми середньополіської говірки села Липно Ківериівського району Волинської області, „Волинь-Житомирщина. Історико-філологічний збірник з регіональних проблем", вип. 8, с. 152-170.

Грыньлат 1976: Прыказкі і прымаукі у дзвюх кнігах, складанне, сістэматызація тэкстаў, ўступны артыкул і каментарыі М.Я. Грынблата, т. 1-2, Мінск 1976.

ГСЛ: Н. Хобзей та ін., Гуцульські світи. Лексикон, Львів 2013.

Грещук В., 2019, Гуиульська діалектна лексика та фраземіка в украӥнській художній мові. Словник, т. 1, Івано-Франківськ.

Д: В.И. Даль, Толковый словарь живого русского языка, 3-е изд., т. I-IV, Москва 1955

ДЕмський М., 1994, Українська фраземіка (дериваџійна база, семантико-граматичні особливості), Ужгород.

Денисов П., Морковкин В., 2002, Словарь сочетаемости слов русского языка, Москва.

Дзядова А.С., 2013, Чалавек у люстэрку беларускай фразеалогіi i парэміялогіi. Манаграфія, Віцебск.

Довровольский В.Н., 1914, Смоленский областной словарь, Смоленск.

ДоврольОЖА Г., 2010, Фразеологічний словник говірок Житомирщини, Житомир.

Довнар-ЗАПольский М., 1888, Белорусская свадьба и свадебные песни. Этнографический этюд, Киев.

ДовнАр-ЗАПольский М., 1893, Значение этнографического изучения Гродненской губернии, Гродно.

Доленко М.Т., 1975a, О диалектной фразеологии Подолья Украинской ССР, „Вопросы фразеологии. Труды Самаркандского гос. университета им. Алишера Навои”, вып. 272, № 8, с. 14-20.

Доленко М.Т., 1975б, Материаль для словаря диалектных фразеологизмов Подолья, „Вопросы фразеологии. Труды Самаркандского гос. университета им. Алишера Навои”, вып. 272, № 8, с. 131-161.

ДСРР: А. Баранов и др., Дискурсивные слова русского языка: опыт контекстно-семантического описания, ред. К. Киселева, Д. Пайар, Москва 1998.

ДФ: Диалектные фонозаписи, Кафедра русского языка Одесского национального университета имени И. И. Мечникова.

Дьячок М.Т., 2000, Диалектная лексика в современных русских арго, [в:] Наука. Университет. Материаль Первой научной конференции, Новосибирск, с. 69-72 [http://philology.ru/linguistics2/dyachok-00.htm].

Д'якова Т., 2011, Фразеологічна репрезентація мовної картини світу в украйнських східнослобожанських говірках, Луганськ.

ЖАйворонок В.В., 2006, Знаки української етнокультури. Словник-довідник, Київ. 
Жуков В.П., 1991, Словарь русских пословиц и поговорок, 11-е изд. (стереотип.), Москва.

ЗЕмская Е.А., Розина Р.И., 1994, О словаре современного русского жаргона, „Русистика" № 1-2, с. 96-112.

Иванова Т.А, 1974, К истории фразеологизмов, включающих словосочетание синь порох, [в:] Ф.П. Филин (ред.), Вопросы исторической лексикологии и лексикографии восточнославянских языков. Сборник статей. К 80-летию чл.-кор. АН СССР С.Г. Бархударова, Москва, с. 285-290.

ИСАЧеНКО О.М., 2017, Лексикографический образ Женщины и способы верификации словарных стереотипов, „Вестник Новосибирского государственноого университета", т. 16, номер 9: Филология, с. 22-39.

Іваноў Я.Я., РАманава Н.К., 2006, Беларуска-нямецчкі парэміялагічны слоўнік, Магілёў.

Івченко А., 1996, Українська народна фразеологія. Ареали, етимологія, Харків.

Івченко А.О., 1998, Історія та етимологія украӥнської фразеології. Бібліографічний покажчик (1864-1998), Харків.

Івченко А., 1999, Украӥнська народна фразеологія. Ономасіологія, ареали, етимологія, Харків.

КА: Картотека Арефьевой.

КАБАКОвА Г., 2019, У истоков гендерного неравенства. По материалам восточнославянского фольклора, [в:] 3.3. Мухина и др. (ред.), Гендер в фокусе антропологии, этнографии семьи и социальной истории повседневности, Москва, c. $115-121$.

КАлітА І.У., 2018, Вобраз бабы ў кампаратыуциным ракурсе чэшскай $і$ беларускай фразеалогіi, [в:] О.Б. Переход (ред.), Славянские языки. Системно-описательный и соииокультурный аспекты исследования. Сборник научных трудов по материалам VIII Международной научной конференщии. Брест, 26-27 ноября 2015 года, ч. 1, Брест, с. 24-28.

КАлугина Е.Н., 2013, Понятийно-теоретический аспект исследования языкового субстандарта, „Научный диалог” № 5 (17): Филология, с. 261-269.

КАлько В., 2012, Концепти молодість і старість в українській мові (на матеріалі паремій), „Лінгвістичні студії: Збірник наукових праць” 24, с. 110-114.

Кёстер-Тома 3., 1993, Стандарт, субстандарт, нонстандарт, „Русистика” № 2, c. $15-31$.

Кірілкова Н.В., 2013, Словник волинської фразеологї̈, Острог-Рівне.

КобелевА И.А., 2012, Современная русская диалектная фразеология. Лексико-грамматический и лексикографический аспекты, Сыктывкар.

КовІв Ю.Й., 2004, Словник украӥнських наукових і народних назв судинних рослин, Київ.

КовАЛЕНКО Б.О., КОВАЛЕНКО Н.Д. (УкЛ.), 2019, Фразеологізми в ідіостилі Анатолія Свидницького. Словник, Кам'янець-Подільський.

КоваленКо Н.Д., 2001, Фраземіка говірок Західного Поділля, Київ.

Коваленко Н.Д., 2019, Фразеологічний словник подільських і суміжних говірок, Кам'янець-Подільський.

Ковшова М.Л., 2015, Лингвокультурологический метод во фразеологии. Кодьл культуры, Москва. 
КоПотев М.В., СтекСова Т.И., 2016, Исключение как правило. Переходные единииь в грамматике и словаре, Москва.

КоПЫЛЕНКо М.М., ПоПовА З.Д., 1978, Очерки по общей фразеологии, Воронеж.

КосмеДА Т., ГОменюк О., ОсіповА Т., 2017, Короткий украӥнсько-польський словник усталених виразів: еквіваленти слова, фразеологізми, прислів'я та приказки, Познань-Харків.

Котова М.Ю., 2000, Русско-славянский словарь пословии с английскими соответствиями, ред. П.А. Дмитриев, Санкт-Петербург.

КСНЛ: Корпусной словарь неоднословных лексических единиц (оборотов) [http:// ruscorpora.ru/new/obgrams.html].

КСРГО: картотека Словаря русских говоров Одесщины, Кафедра русского языка Одесского национального университета имени И.И. Мечникова.

Кудинова Т.А., 2010, Стандарт и субстандарт в языке. К обоснованию понятий, „Научная мысль Кавказа”, № 3, с. 136-140.

Кулжинскій Г., 1866, О сборникт западнорусскихъ пословищъ и приговорокъ, „Гродн[енскія] Губ[ернаторства] Вьд[омости]”, номер 41.

Куцик О., КолЕчко М., 2015, Концептуалізація образу жінки в украйнській та російській пареміології, [w:] Рідне слово в етнокультурному вимірі. Збірник наукових працьь, Дрогобич, с. 131-140.

Кушмет М., 2010, Матеріали до фразеологічного словника українських східностепових говірок (на матеріалі говірки с. Оленівки Волноваського району Донецької області), „Донецький вісник Наукового товариства ім. Шевченка”, т. 28. Донецьк, с. 34-50.

ЛАвер В., 1991, Фраземика украинских диалектов карпатского региона, Киев.

ЛАрин Б.А., 1977, Очерки по фразеологии. (О систематизации и методах исследования фразеологических материалов), [в:] Б.А. Ларин, История русского языка и общее языкознание, Москва, с. 125-149.

ЛАРІн Б., 1959, Про народну фразеологію, „Українська мова в школі”, № 5, с. 30-36. ЛЕвченко О., 2005, Фразеологічна символіка: лінгвокультурологічний аспект, Львів. ЛЕПЕшАў І.Я., 2004, Этылмалагічны слоўнік фразеалагізмаў, Мінск.

ЛЕсюк М., 2008, Мовний світ сучасного галицького села (Ковалівка Коломийського району), Івано-Франківськ.

ЛЛПЖ: Н. Хобзей, О. Сімович, Т. Ястремська, Г. Дідик-Меуш, Лексикон львівський: поважно і на жарт, Львів 2009.

Лонська Л., 2011, Народна фразеологія як елемент збереження етнокультури, [в:] Л.М. Полюг (ред.), Філологічний вісник уманського державного педагогічного університету імені Павла Тичини: зб. наук. пращь, вип. 1, Умань, с. 240-249.

Ляцкий Е.А., 1898, Материаль для изучения творчества и быта белорусов, Москва. МАтї̈в М.Д., 2013, Словник говірок ичентральної Бойківщини, Київ-Сімферополь.

МАцюк 3., 2013, Що сільце, то нове слівце. Словник фразеологізмів Західного Полісся, Луцьк.

Михельсон М.И. 1902-1903, Русская мысль и речь. Своё и чужое. Опыт русской фразеологии. Сборник образных слов и иносказаний, Санкт-Петербург, т. 1, 1902, т. 2, 1903.

Мıняйло Р.В., 2001, Активні процеси в ареальній фразеологї Сходу Украӥни, Донецьк. 
Мокиенко В.М., 1994, Субстандартная фразеология русского языка и некоторые проблемы ее лингвистического изучения, „Revue Russe” 7, с. 53-75.

Мокиенко B.M., 1980, Славянская фразеология, Москва.

Мокиенко В.М., 1986, Образы русской речи. Историко-этимологические очерки фразеологии, Ленинград.

Мокиенко В.М., 1989, Славянская фразеология, 2-е изд., испр. и доп., Москва.

Мокиенко В.М., 1999, В глубь поговорки, Санкт-Петербург.

Мокиенко В.M., 2003, Новая русская фразеология, Opole.

Мокиенко В.М., 2006, Давайте говорить правильно! Словарь пословиц. Краткий словарь-справочник, Санкт-Петербург.

Мокиенко В.М., 2007, Образы русской речи, 3-е изд., испр., Москва.

Мокиенко В.М., 2011, Проект „Фразеологического словаря русских народных говоров”, „Проблемы истории, филологии, культуры”, № 3, Магнитогорск, c. $190-198$.

Мокиенко В.М., 2018, Структурно-семантическая модель в „Полном фразеологическом словаре русских народных говоров”, [в:] Лексический атлас русских народных говоров (Материалы и исследования), Санкт-Петербург, с. 305-312.

Мокиенко В.М., 2020, Диалектная и историческая фразеология: перспективы взаимодействия, [в:] M. Rak, V.M. Mokienko (ред.), Słowiańska frazeologia gwarowa II, „Biblioteka LingVariów”, т. 28, Kraków, c. 83-91.

Мокиенко В.М., НикитинА Т.Г., 2000, Большой словарь русского жаргона, Санкт-Петербург.

Мокиенко В.М., Никитина Т.Г., 2007, Большой словарь русских поговорок, Москва.

Мокиенко В.М., НикитинА Т.Г., НикоЛАевА Е.К., 2010, Большой словарь русских пословиц, Москва.

Мокиенко В.М., НикитинА Т.Г., 2018, К концеепции полного словаря народной фразеологии: проблемы макроструктурирования, „Вопросы лексикографии”, № 14, Томск, с. 80-106.

МСРГО: Материалы к Словарю русских говоров Одесщины, Кафедра русского языка Одесского национального университета имени И.И. Мечникова, машинопись.

НАЗАРенко О., 2005, Вираження національних ментальних рис у фразеотематичних групах „воля”, „,природа”, „Studia Methodologica” 15, Тернопіль, с. 133-137.

Никитина Т.Г., 2017, Диалектный материал как объект фразеологической этимологии и средство этимологизаџии фразеологизмов в словаре, „Электронный научно-образовательный журнал ВГСПУ «Грани познания»”, № 5 (52), ноябрь, c. 71-75 [www.grani.vspu.ru].

Номис: М. Номис (укл.), Приказки, прислів'я, і таке інше, Київ 1993.

Носович И.И., 1870, Словарь белорусского наргчия, Санкт-Петербург.

Носович И.И., 1874, Сборник бълорусскихъ пословицъ, Санкт-Петербург.

Олійник М.Я., 2002, Фразеологія гуиульських говірок [дис. на здобуття наук. ступеня канд. філол. наук.], Львів.

Осипов Б.И., (ред.), 2003, Словарь современного русского города, Москва.

ОЭСРФ: Н.М. Шанский, В.И. Зимин, А.В. Филиппов, Опыт этимологического словаря русской фразеологии, Москва 1987.

ПАПшш В., 2004, Семантико-функиіональна природа фразеологізмів у художній прозі закарпатоукраӥнських письменників (40-90 pp. ХХ cm.), Ужгород. 
ПАсЕчник А., 2005, Лексикализованные предложно-падежные сочетания и их репрезентация в лексикографии, Краснодар.

Плетнєва О., 2004, Фразеологія говірок ичентральної Слобожанщини (структурносемантичний аспект), Харків.

Полшщк Л., 2010, Концеепт , час ” у чеській фраземіціi, „Проблеми слов’янознавства”, вип. 4, с. 259-264.

ПотеПня Д.М. (ред.), 2009, Лексикография русского языка. Учебник для высших учебных заведений Российской Федерации, Санкт-Петербург.

ПП 1-4: М.М. Пазяк (упор.), Прислів'я та приказки, т. 1: Природа. Господарська діяльність людини, 1989, т. 2: Людина. Родинне життя. Риси характеру, 1990, т. 3: Взаємини між людьми, 1991, т. 4: Українські прислів'я, приказки та порівняння з літературних пам'яток, 2001, Київ.

ПрадІд Ю., 1992, Із спостережень над діалектною фразеологією (на матеріалі бойківських говірок), „Мовознавство”, № 5, с. 44-47.

Приемышева М.Н., 2009, Тайные и условные языки в России XIX в., ч. 1-2, Санкт-Петербург.

Приходько В.К., 2016, Лексические средства описания внешнего вида женщинь в аспекте рассмотрения эстетической категории ,„прекрасное/безобразное” (на материале русских говоров Приамурья), „Сибирский филологический журнал" 3, с. 172-181.

ПРН: В.И Даль, Пословицьь русского народа, в 2 т., Москва 1984.

РАков Г.А., 1990, Проблемы и методы исследования диалектной лексической семантики как системы, Свердловск.

РМР: М. Михельсон, Русская мысль и речь. Свое и чужсе. Опыт русской фразеологии [https://dic.academic.ru/dic.nsf/michelson_new/].

Романюк Н.В., 2002, Фразеологія верхньонаддністрянських говірок нижньої течії річки Бистрииі, дис. на здобуття наук. ступеня канд. філол. наук, Запоріжжя.

САдоўскАя А., 2014, Да пытання аб развіщиі этнафразеалогіi у Беларусі, [w:] Слова у кантэксие часу. Да 85-годдзя прафесара А. І. Наркевіча. Зборнік навуковых праи, Мінск, с. 87-95.

CAP: Словарь Академии Российской, т. I-VI, Санкт-Петербург 1789-1794.

Сьорник 1874: Сборникъ бглорусскихъ пословицъ, составленный И. И. Носовичемъ, „Сборникъ отдъленія русскаго языка и словесности императорской Академіи Наукъ” XII, № 2, Санкт-Петербург.

CВТ: Е. Борисова, Слово в тексте. Словарь коллокаиий (устойчивых словосочетаний) русского языка с англо-русским словарем ключевых слов, Москва 1995.

СДУГОО: А.А. Москаленко, Словник діалектизмів украӥнських говірок Одеської області, Одеса 1958.

Скрипник Л., 1971, Фольклорні елементи в українській фразеології, „Мовознавство”, № 2, c. 58-65.

Снег.: И.М. Снегирев, Русские народные пословицы и притчи, Москва 1848.

Сок.: М.И. Соколова, Народная мудрость. Пословицы и поговорки, Новосибирск 2009.

СоловьевА Л.В., 2001, Не в бровь, а в глаз. Пословицы и поговорки Псковской и Ленинградской области. Бабушкины байки, Гатчина. 
СПП: В.М. Мокиенко, Т.Г. Никитина (сост.), Словарь псковских пословиц и поговорок, науч. ред. Л.А. Ивашко, Санкт-Петербург 2001.

СР: Рукописный сборник „Древних русских пословии”, опубликованный Е.Р. Романовылм, кн. 1. Вильна, 1910, кн. 2. Вильна, 1912.

СРГО: Ю.А. Карпенко (отв. ред.), Словарь русских говоров Одесщинь, Одесса 2000-2001.

СРНГ: Словарь русских народных говоров, Ленинград-Санкт-Петербург 1965-2016.

СРЯ: С. Ожегов, Словарь русского языка, Москва 1987.

CCA: В. Тришин, Словарь синонимов ASIS [https://dic.academic.ru/dic.nsf/dic_synonims/].

ССКУ: В.П. Коцура, О.І. Потапенка, М.К. Дмитренка (ред.), Словник символів культури України, Київ 2002.

ССНП: О.С. Юрченко, А.О. Івченко, Словник стійких народних порівнянь, Харків 1993.

СССРЯ: П. Денисов, В. Морковкин, Словарь сочетаемости слов русского языка, Москва 2002.

СТСРЯ: Т. Ефремова, Современный толковый словарь русского языка [https://dic. academic.ru/contents.nsf/efremova/].

СтупннськА 2013: Г.Ф. Ступінська, Я.В. Битківська, Фразеологічний словник лемківських говірок, ред. Г.Ф. Ступінська, В.Я. Ступінський, Тернопіль 2013.

СтупннськА Г.Ф., 2000, Фразеологія лемківського говору української мови, дис. на здобуття наук. ступеня канд. філол. наук., Тернопіль.

СУГО: О.І. Бондар (голов. ред.), Словник українських говорів Одещчини, Одеса 2001.

СУМ: Словник украӥнської мови, в 11 т., Київ 1970-1980.

Сурикова О., 2016, Лексические единиць с приставкой и предлогом без в русских народных говорах и фольклоре: семантико-мотиваџионный и этнолингвистический аспекты, Екатеринбург.

СФУМ: В.М. Білоноженко та ін. (уклад.), Словник фразеологізмів украӥнської мови, Київ 2003.

Сцяшковгч Т.Ф., 1968, Прыказкі, прымаўкі, фразеалагізмы, выслоўі народных гаворак Гродзенскай вобласиі, Гродна.

Сцяшковіч Т.Ф., 1972, Матэрыялы да слоўніка Гродзенскай вобласиі, Мінск.

Сцяшковгч Т.Ф., 1983, Слоўнік Гродзенскай вобласиі, Мінск.

СЭС: Р. Рогожникова, Словарь эквивалентов слова: наречные, служебные, модальные единства, Москва 1991.

Телия В.Н., 1986, Коннотативный аспект семантики номинативных единии, Москва.

Толстой Н.И., 1973, О реконструкции праславянской фразеологии, [в:] Славянское языкознание. VII Международньй съезд славистов. Доклады советской делегачии, Москва, с. 272-293.

ТСЖВЯ: В. Даль, Кока - смысл, толкование, значение слова, [в:] Толковый словарь живого великорусского языка [http://v-dal.ru/word_s-40743.html].

ТСРЯ: Д. Ушаков, Толковый словарь русского языка [https://dic.academic.ru/contents. nsf/ushakov/].

ТССЭС: Р. Рогожникова, Толковый словарь сочетаний, эквивалентных слову: Около 1500 устойчивых сочетаний русского языка, Москва 2003.

Турчин Є., 2011, Словник села Тилич на Лемківщчині, Львів. 
Ужченко В.Д., 2003, Східноукраӥнська фразеологія, Луганськ.

Ужченко В.Д., Ужченко Д.В., 2007, Фразеологія сучасної української мови, Київ.

Ужченко, В.Д., Ужченко Д.В., 2013, Фразеологічний словник східнослобожанських i степових говірок Донбасу, Луганськ.

ФЕдоров А., 2011, Фразеологический словарь русского литературного языка [http:// frazbook.ru/2011/02/08/].

ФПЧ: Г. Кузь та ін. (укл.), Фразеологізми та паремї Чернівеччини. Матеріали до словника, Чернівці 2017.

ФРБЕ: К. Ничева, С. Спасова-Михайлова, К. Чолакова, Фразеологичен речник на българския език, в 2 т., София 1974-1975.

ФСГЖ: Г. Доброльожа, Фразеологічний словник говірок Житомирщини, Житомир 2010.

ФСРГС: А.И. Фёдоров (ред.), Фразеологический словарь русских говоров Сибири, Новосибирск 1983.

ФСРЛЯ: А. Федоров, Фразеологический словарь русского литературного языка [https://phraseology.academic.ru/].

ФСРЯ: А.И. Молотков (ред.), Фразеологический словарь русского языка, Москва 1968.

ФСРЯ 2007: А.Н. Тихонов (сост.), Фразеологический словарь русского языка, Москва 2007.

ФСУМ: В.М. Білоноженко та ін. (укл.), Фразеологічний словник украӥнської мови, у 2-х кн., Київ 1993.

Химик В.В., 2004, Большой словарь русской разговорной речи, Санкт-Петербург.

Цыхун А.П., 1993, Скарбы народнай мовы, Гродна.

ЧАБАнЕнко В., 1978, Фразеологія говірок Нижньої Наддніпрянщини, „Проблеми дослідження діалектної лексики й фразеології української мови”, с. 105-106.

ЧАБАнЕнко В.А., 2001, Фразеологічний словник говірок Нижньої Наддніпрянщини, Запоріжжя.

ЧЕтирьА М., 2013, Образ жінки в оцінних фразеологічних одинииях украӥнської мови. Гендерний аспект, „Studia Ukrainica Posnaniensia” I, c. 47-53.

Шейн П.В., 1874a, Бълорусскія народныя пъсни, съ относящимися къ нимъ обрядами, обычаями и суевтьріями, съ приложеніемъ объяснительного словаря и грамматическихъ примъчаній, Санкт-Петербург.

Шейн П.В., 1874б, Материль для изучения быта и языка русского населения северо-западного края, т. I, ч. 1: Бытовая и семейная жизнь белоруса в обрядах и песнях, Санкт-Петербург.

ШекАСюК Б.П., 2009, Новый немецко-русский фразеологический словарь, изд. 2-ое, перераб. и доп. Москва.

Шкуран О., 2011, Національно-культурне підгрунтя компаративних фразеологізмів східнослобожанських та східностепових говірок Середнього Подінців'я, Луганськ.

Шпилевский П., 1853, Бълорусскія пословицьь, Санкт-Петербург.

ШСП: Ю.А. Ермолаева и др. (сост.), Школьный словарь живых русских пословии, гл. ред. В.М. Мокиенко, ред. Е.К. Николаева, Е.И. Селиверстова, Санкт-Петербург 2002. 
AnIČKov I.E., 1997, Idiomatika v krugu lingvističeskih nauk, [v:] I.E. Aničkov, Trudy po âzykoznaniû, SAnKt-Peterburg, s. 101-145.

Aref'Eva N.G., 2017, Frazeologičeskaâ kartina mira skvoz' prizmu lingvokul'turnyh kodov (na materiale russkih govorov Odesŝiny), „Mova” № 27, s. 135-140.

Aref'Eva N.G., 2018, Russkij dialektnyj frazeologizm čërnyj val vètnokul'turnom osveŝenii, „Mova” № 30, s. 22-28.

Aref'Eva N.G., 2019, O proekte Frazeologičeskogo slovarâ russkih govorov Odesŝiny, [v:] S.N. Starodubec, V.N. Pustovojtova, S.M. Prončenko (red.), Idiolekt russkoj âzykovoj ličnosti kak otraženie lingvokul'turnoj situacii v slavânskom pograniče, Novozybkov, s. 485-492.

ArkuŠIn G., 2003, Skazav, âk dva zv 'âzav. Narodnì vislovi ta zagadki iz Zahidnogo Polìssâ i zahidnoï častini Volinì, Lublin-Luc'k.

ASRF: A.N. Baranov, D.O. Dobrovol'skij (red.), Akademičeskij slovar' russkoj frazeologii, Moskva 2015.

BABIČ N., 1970-1971, Frazeologîa ukraïns'koï movi, Černìvcì.

BABIČ N., 1978, Leksični varianti frazeologičnih odinic' bukovins'kih govìrok (osoblivosti komponentnogo skladu i funkcionuvannâ), „Problemi doslìdžennâ dìalektnoï leksiki ì frazeologiii”, s. 87-88.

BALli Š., 1961, Francuzskâ̂ stilistika, Moskva.

BARANNIK L.F., 2015, Leksika russkih pereselenčeskih govorov Odesskoj oblasti, funkcionirû̂sihi v raznoâzyčnom okruženii, Odessa.

Baranov A.N., Dobrovol'skij D.O., 2008, Aspekty teorii frazeologii, Moskva.

BEREzovič E.L., 2003, K semantičeskoj rekonstrukcii nekotoryh russkih dialektnyh verbal'nyh formul ('TIPUN tebe na âzyk!'), [v:] Ž.Ž. Varbot i dr. (red.), Ètimologiâ 2000-2002, Moskva, s. 165-177.

Berezovič E.L., KučKo V.S., 2017, Menât' šilo na mylo. Dialektologičeskij kommentarij k frazeologizmu, „Vestnik Permskogo universiteta. Rossijskaâi zarubežnaâ filologiâ", t. 9, vyp. 3, s. 5-15.

BFSRÂ: V.N. Teliâ (red.), Bol'šoj frazeologičeskij slovar' russkogo âzyka, Moskva 2006.

BFSSRÂ: V.N. Teliâ (red.), Bol'šoj frazeologičeskij slovar' sovremennogo russkogo âzyka. Značenie. Upotreblenie. Kul'turologičeskij kommentarij, Moskva 2014.

BIRIH A. (red.), 2009, Substandartnye varianty slavânskih âzykov, Frankfurt am Main.

BIRIH A.K., 2020, Dialekty kak istočnik russkoj istoričeskoj frazeologii, [v:] M. Rak, V.M. Mokienko (red.), Stowiańska frazeologia gwarowa II, „Biblioteka LingVariów", t. 28, Kraków, s. 101-108.

Birih A.K., Volkov S.S., Nikitina T.G., 1993, Slovar' russkoj frazeologičeskoj terminologii, red. V.M. Mokienko, München.

Blinova I.S., 2009, Koncept ,, starost'” v russkoj i nemeckoj lingvokul'turah, diss. po VAK RF 10.02.20, kand. filolog. nauk, Volgograd.

BMS: A.K. Birih, V.M. Mokienko, L.I. Stepanova, Russkaâ frazeologiâ. Istorikoètimologičeskij slovar', red. V.M. Mokienko, 3-e izd., ispr. i dop., Moskva 2005.

Bobrikova Û.V., 2013, Naimenovaniâ vnešnosti žensiny v russkih govorah: sopostavitel'nyj analiz, „Učenye zapiski Komsomol'skogo-na-Amure gosudarstvennogo tehničeskogo universiteta", nomer 11-2 (14), s. 46-50. 
Bondaletov V.D., 1987, Argotizmy v slovarâh russkogo âzyka, Râzan'.

Bondaletov V., 2002, Substandartnaâ frazeologiâ, [v:] M. Aleksiejenko, W. Mokijenko, H. Walter (red.), Stowo, tekst, czas - VI. Nowa frazeologia w nowej Europie. Novaâ frazeologiâ v novoj Evrope, Szczecin-Greifswald, s. 465-474.

BSRNS: V.M. Mokienko, T.G. Nikitina, 2008, Bol'šoj slovar' russkih narodnyh sravnenij, Moskva.

BSRP: V. Mokienko, T. Nikitina, Bol'šoj slovar' russkih pogovorok, Moskva 2007.

BSRPS: V. Mokienko, T. Nikitina, E. Nikolaeva, Bol'šoj slovar' russkih poslovic, Moskva 2010.

BTSDK: Bol'šoj tolkovyj slovar' donskogo kazačestva, Moskva 2003.

BTSRÂ: S. Kuznecov, Bol'šoj tolkovyj slovar' russkogo âzyka [http://gramota.ru/slovari/ info/bts/].

ČABANEnKo V., 1978, Frazeologiâ govìrok Nižn'ö̈ Naddnìprânŝini, „Problemi doslìdžennâ dìalektnoï leksiki j frazeologiï ukraïns'koï movi”, c. 105-106.

ČABANENKo V.A., 2001, Frazeologičnij slovnik govìrok Nižn'ö̈ Naddnìprânŝini, Zaporìžžâ.

ČETIRBA M., 2013, Obraz žìnki v ocìnnih frazeologičnih odinicâh ukraïns'koï movi. Gendernij aspekt, „Studia Ukrainica Posnaniensia” I, s. 47-53.

Cyhun A.P., 1993, Skarby narodnaj movy, Grodna.

D: V.I. Dal', Tolkovyj slovar' živogo russkogo âzyka, 3-e izd., t. I-IV, Moskva 1955.

D’Âkova T., 2011, Frazeologična reprezentaciâ movnoï kartini svitu v ukraïns'kih shidnoslobožans'kih govirkah, Lugans'k.

D'ÂČOK M.T., 2000, Dialektnaâ leksika v sovremennyh russkih argo, [v:] Nauka. Universitet. Materialy Pervoj naučnoj konferencii, Novosibirsk, s. 69-72 [http://philology. ru/linguistics2/dyachok-00.htm].

Dems'Kis M., 1994, Ukraïns'ka frazemika (derivacijna baza, semantiko-gramatični osoblivosti), Užgorod.

Denisov P., Morkovkin V., 2002, Slovar' sočetaemosti slov russkogo âzyka, Moskva.

DF: Dialektnye fonozapisi, Kafedra russkogo âzyka Odesskogo nacional'nogo universiteta imeni I. I. Mečnikova.

Dobrol'ožA G., 2010, Frazeologičnij slovnik govirok Žitomirŝini, Žitomir.

Dobrovol'SKiJ V.N., 1914, Smolenskij oblastnoj slovar', Smolensk.

Dolenko M.T., 1975a, O dialektnoj frazeologii Podol'â Ukrainskoj SSR, „Voprosy frazeologii. Trudy Samarkandskogo gos. universiteta im. Ališera Navoi”, vyp. 272, № 8, s. 14-20.

Dolenko M.T., 1975b, Materialy dlâ slovarâ dialektny hrazeologizmov Podol'â, „,Voprosy frazeologii. Trudy Samarkandskogo gos. universiteta im. Ališera Navoi”, vyp. 272, № 8, s. 131-161.

Dovnar-ZAPOL'SKiJ M., 1888, Belorusskaâ svad'ba i svadebnye pesni. Ètnografičeskij ètûd, Kiev.

Dovnar-ZAPOL'SKIJ M., 1893, Značenie ètnografičeskogo izučeniâ Grodnenskoj gubernii, Grodno.

DSRR: A. Baranov i dr., Diskursivnye slova russkogo âzyka: opyt kontekstno-semantičeskogo opisaniâ, red. K. Kiseleva, D. Pajar, Moskva 1998.

DzÂDova A.S., 2013, Čalavek u lûstèrku belaruskaj frazealogì ì parèmîalogìi. Managrafiâ, Vìcebsk. 
FEDORov A., 2011, Frazeologičeskij slovar' russkogo literaturnogo âzyka [http://frazbook. $\mathrm{ru} / 2011 / 02 / 08 /]$.

FPČ: G. Kuz'taìn (uk1.), Frazeologizmi ta paremiï Černiveččini. Materiali do slovnika, Černìvcì 2017.

FRBE: K. Ničeva, S. Spasova-Mihajlova, K. Čolakova, Frazeologičen rečnik na blgarskiâ ezik, v 2 t., Sofiâ 1974-1975.

FSGŽ: G. Dobrol'oža, Frazeologičnij slovnik govirok Žitomirŝini, Žitomir 2010.

FSRÂ 2007: A.N. Tihonov (sost.), Frazeologičeskij slovar' russkogo âzyka, Moskva 2007.

FSRÂ: A.I. Molotkov (red.), Frazeologičeskij slovar' russkogo âzyka, Moskva 1968.

FSRGS: A.I. Fëdorov (red.), Frazeologičeskij slovar' russkih govorov Sibiri, Novosibirsk 1983.

FSRLÂ: A. Fedorov, Frazeologičeskij slovar' russkogo literaturnogo âzyka [https://phra seology.academic.ru/].

FSUM: V.M. Bìlonoženko ta ìn. (ukl.), Frazeologičnij slovnik ukrä̈ns'kö̈ movi, u 2-h kn., Kiïv 1993.

Gender 2019: Z.Z. Muhina, A.V. Belova, N.A. Belova, S.V. Kannykin (red.), Gender vfokuse antropologii, ètnografii sem'i i social'noj istorii povsednevnosti, Moskva 2019.

GoRodnÂNSKAÂ P., 2013, Mnogoaspektnyj analiz leksikalizovannyh predložno-padežnyh slovoform adverbial'nogo haraktera v russkom âzyke, Abakan.

GračEv M.A., 2003, Slovar' tysâčeletnego russkogo argo, Moskva.

GračEv M.A., 2005, Ot Van'ki Kaina do mafii. Prošloe i nastoâsee ugolovnogo žargona, Sankt-Peterburg.

GraČEV M.A., Mokienko V.M., 2008, Russkij žargon. Istoriko-ètimologičeskij slovar', Moskva.

ĠREŜUK V., 2019, Gucul's'ka dialektna leksika ta frazemika v ukraïns'kì hudožnì movì. Slovnik, t. 1, İvano-Frankìvs'k.

Grigorovič L.A., 2015, Regional'nâ̂ žargonnaâ leksika v sovremennoj leksikografii, „Kul'tura reči” 4, s. 50-53.

Gromiк Û., 2002, Frazeologizmi seredn'opolìs'koï govìrki sela Lipno Kìvercìv'kogo rajonu Volins'koï oblasti, „Volin'-Žitomirŝina. İstoriko-fillologičnij zbìrnik z regìonal'nih problem", vip. 8, s. 152-170.

GryndLat 1976: Prykazki ì prymaukì ǔ dzvûh knìgah, skladanne, sistèmatyzaciâ tèkstaǔ, ǔstupny artykul i kamentaryì M.Â. Grynblata, t. 1-2, Mìnsk 1976.

GSL: N. Hobzej ta ìn., Gucul's'ki sviti. Leksikon, L'vìv 2013.

GžIBOvskiJ S., 2011, Russkij ostrovnoj govor v pol'skom âzykovom okruženii, [v:] S. Gžibovskij, V.A. Horev, M. Volos (red.), Russko-pol'skie âzykovye, literaturnye i kul'turnye kontakty, Moskva, s. 45-59.

GžıbovskiJ S., GlušKovskij M., 2008, Sociolingvističeskaâ situaciâ staroobrâdcev v derevnâh Gabove Grondy i Bur, [v:] L.L. Kasatkin (red.), Russkie staroobrâdcy. Âzyk. Literatura. Istorâ, Moskva, s. 200-215.

Нıмік V.V., 2004, Bol'šoj slovar' russkoj razgovornoj reči, Sankt-Peterburg.

IsAČENKO O.M., 2017, Leksikografičeskij obraz ženŝiny i sposoby verifikacii slovarnyh stereotipov, „Vestnik Novosibirskogo gosudarstvennoogo universiteta”, t. 16, nomer 9: Filologiâ, s. 22-39.

İvANoǓ Â.Â., Ramanava N.K., 2006, Belaruska-nâmecki parèmiâlagičny sloǔnik, Magilëǔ. 
Ivanova T.A, 1974, K istorii frazeologizmov, vklûčâ̂îih slovosočetanie sin' poroh, [v:] F.P. Filin (red.), Voprosy istoričeskoj leksikologii i leksikografii vostočnoslavânskih âzykov. Sbornik statej. K 80-letiû čl.-kor. AN SSSR S.G. Barhudarova, Moskva, s. $285-290$.

ÌvČENKo A., 1996, Ukraïns'ka narodna frazeologiâ. Areali, etimologîa, Harkìv.

ÌvČENKO A.O., 1998, İstoriâ ta etimologiâ ukraïns'koï frazeologï. Bibliografičnij pokažčik (1864-1998), Harkìv.

İvČENKO A., 1999, Ukrä̈ns'ka narodna frazeologiâ. Onomasiologîa, areali, etimologîa, Harkìv.

KA: Kartoteka Aref'evoj.

Kabakova G., 2019, U istokov gendernogo neravenstva. Po materialam vostočnoslavânskogo fol'klora, [v:] Z.Z. Muhina i dr. (red.), Gender v fokuse antropologii, ètnografii sem'i i social'noj istorii povsednevnosti, Moskva, s. 115-121.

Kalìta İ.U., 2018, Vobraz baby ǔ kamparatyǔnym rakurse čěšskaj i belaruskaj frazealogì,, [v:] O.B. Perehod (red.), Slavânskie âzyki. Sistemno-opisatel'nyji sociokul'turnyj aspekty issledovaniâ. Sbornik naučnyh trudov po materialam VIII Meždunarodnoj naučnoj konferencii. Brest, 26-27 noâbrâ 2015 goda, č. 1, Brest, s. 24-28.

KAL'KO V., 2012, Koncepti molodist' i starist' v ukraïns'kij movi (na materiali paremij), „Lìngvìstičnì studiï: Zbìrnik naukovih prac"” 24, s. 110-114.

Kalugina E.N., 2013, Ponâtijno-teoretičeskij aspekt issledovaniâ âzykovogo substandarta, „Naučnyj dialog” № 5 (17): Filologiâ, s. 261-269.

KëSTER-Toma Z., 1993, Standart, substandart, nonstandart, „Rusistika” № 2, s. 15-31.

Kìrìlkova N.V., 2013, Slovnik volins'koï frazeologï, Ostrog-Rìvne.

Kobeleva I.A., 2012, Sovremennaâ russkaâ dialektnaâ frazeologiâ. Leksiko-grammatičeskij i leksikografičeskij aspekty, Syktyvkar.

Koвìv Û.J., 2004, Slovnik ukraïns'kih naukovih ì narodnih nazv sudinnih roslin, Kï̀v.

Kopotev M.V., Steksova T.I., 2016, Isklûčenie kak pravilo. Perehodnye edinicy v grammatike $i$ slovare, Moskva.

Kopylenko M.M., Popova Z.D., 1978, Očerki po obŝej frazeologii, Voronež.

Kosmeda T., Gomenûk O., Osìpova T., 2017, Korotkij ukrä̈ns'ko-pol's'kij slovnik ustalenih viraziv: ekvivalenti slova, frazeologizmi, prislìv 'â ta prikazki, Poznan'-Harkìv.

Koтоva M.Û., 2000, Russko-slavânskij slovar' poslovic s anglijskimi sootvetstviâmi, red. P.A. Dmitriev, Sankt-Peterburg.

Kovalenko B.O., Kovalenko N.D. (uk1.), 2019, Frazeologizmi v idiostili Anatoliâ Svidnic'kogo. Slovnik, Kam ânec'-Podìl's'kij.

Kovalenko N.D., 2001, Frazemika govirok Zahidnogo Podillâ, Kiïv.

Kovalenko N.D., 2019, Frazeologičnij slovnik podil's'kih i sumižnih govirok, Kam`ânec'-Podil's'kij.

Kovšova M.L., 2015, Lingvokul'turologičeskij metod vo frazeologii. Kody kul'tury, Moskva.

KSNL: Korpusnoj slovar' neodnoslovnyh leksičeskih edinic (oborotov) [http://ruscorpora. $\mathrm{ru} /$ new/obgram.html].

KSR GO: kartoteka Slovarâ russkih govorov Odesŝiny, Kafedra russkogo Âzyka Odesskogo nacional'nogo universiteta imeni I.I. Mečnikova.

KuciK O., KolečKo M., 2015, Konceptualizaciâ obrazu žìnki v ukraïns'kì ta rosìjs'kij paremiologï, [w:] Ridne slovo v etnokul'turnomu vimìì. Zbirnik naukovih prac', Drogobič, s. 131-140. 
Kudinova T.A., 2010, Standart i substandart v âzyke. K obosnovaniû ponâtij, „Naučnaâ mysl' Kavkaza”, № 3, s. 136-140.

KuLŽINSKìj G., 1866, O sbornikě zapadnorusskih poslovic i prigovorok, „Grodn[enskiâ] Gub[ernatorstva] Věd[omosti]”, nomer 41.

KuŠMET M., 2010, Materiali do frazeologičnogo slovnika ukraïns'kih shidnostepovih govirok (na materiali govirki s. Olenivki Volnovas'kogo rajonu Donec'koï oblasti), „Donec'kij vìsnik Naukovogo tovaristva ìm. Ševčenka”, t. 28, Donec'k, s. 34-50.

LÂCKIJ E.A., 1898, Materialy dlâ izučeniâ tvorčestva i byta belorusov, Moskva.

LARìn B., 1959, Pro narodnu frazeologîu, „Ukraïns'ka mova v školì”, № 5, s. 30-36.

LARIN B.A., 1977, Očerki po frazeologii. (O sistematizacii i metodah issledovaniâ frazeologičeskih materialov), [v:] B.A. Larin, Istoriâ russkogo âzykai obŝee âzykoznanie, Moskva, s. 125-149.

LAVER V., 1991, Frazemika ukrainskih dialektov karpatskogo regiona, Kiev.

LEPEŠAǓ İ.Â., 2004, Ėtymalagičny sloǔnik frazealagizmaǔ, Mìnsk.

LesûK M., 2008, Movnij svit sučasnogo galic'kogo sela (Kovalìva Kolomijs'kogo rajonu), İvano-Frankìvsk.

LEVČENKO O., 2005, Frazeologična simvolika: lingvokul'turologičnij aspekt, L'vìv.

LLPŽ: N. Hobzej, O. Sìmovič, T. Âstrems'ka, G. Dìdik-Meuš, Leksikon l'vìvs'kij: považno i na žart, L'vìv 2009.

Lons'KA L., 2011, Narodna frazeologiâ âk element zberežennâ etnokul'turi, [v:] L.M. Polûg (red.), Filologičnij vìsnik Umans'kogo deržavnogo pedagogǐčnogo universitetu imeni Pavla Tičini: zb. nauk. prac', vip. 1, Uman', s. 240-249.

Macû́ Z., 2013, Ŝ sil'ce, to nove slivve. Slovnik frazeologizmìv Zahìnogo Polìssâ, Luc'k. Matï̀v M.D., 2013, Slovnik govirok central'nö̈ Bojkivŝini, Kiïv-Sìmferopol'.

Minel'son M.I. 1902-1903, Russkâ̂ mysl' i reč'. Svoë $i$ čužoe. Opyt russkoj frazeologii. Sbornik obraznyh slov i inoskazanij, Sankt-Peterburg, t. 1, 1902, t. 2, 1903.

MìnÂJlo R.V., 2001, Aktivni procesi v areal'nì frazeologï Shodu Ukraïni, Donec'k.

Mokienko V.M., 1980, Slavânskâ̂ frazeologiâ, Moskva.

Mokienko V.M., 1986, Obrazy russkoj reči. Istoriko-ètimologičeskie očerkifrazeologii, Leningrad.

Mokienko V.M., 1989, Slavânskaâ frazeologiâ, 2-e izd., ispr. i dop., Moskva.

MoкIENKo V.M., 1994, Substandartnaâ frazeologiâ russkogo âzyka i nekotorye problemy ee lingvističeskogo izučeniâ, „Revue Russe” 7, s. 53-75.

Mokienko V.M., 1999, V glub' pogovorki, Sankt-Peterburg.

Mokienko V.M., 2003, Novaâ russkaâ frazeologiâ, Opole.

Mokienko V.M., 2006, Davajte govorit' pravil'no! Slovar' poslovic. Kratkij slovar'-spravočnik, Sankt-Peterburg.

Mokienko V.M., 2007, Obrazy russkoj reči, 3-e izd., ispr., Moskva.

Mokienko V.M., 2011, Proekt „Frazeologičeskogo slovarâ russkih narodnyh govorov”, „Problemy istorii, filologii, kul'tury”, № 3, Magnitogorsk, s. 190-198.

Mokienko V.M., 2018, Strukturno-semantičeskaâ model'v „,Polnom frazeologičeskom slovare russkih narodnyh govorov", [v:] Leksičeskij atlas russkih narodnyh govorov (Materialy i issledovaniâ), Sankt-Peterburg, s. 305-312.

Mokienko V.M., 2020, Dialektnaâ i istoričeskaâ frazeologiâ: perspektivy vzaimodejstviâ, [v:] M. Rak, V.M. Mokienko (red.), Słowiańska frazeologia gwarowa II, „Biblioteka LingVariów", t. 28, Kraków, s. 83-91. 
Mokienko V.M., Nikitina T.G., 2000, Bol'šoj slovar' russkogo žargona, Sankt-Peterburg. Mokienko V.M., Nikitina T.G., 2007, Bol'šoj slovar' russkih pogovorok, Moskva.

Mokienko V.M., Nikitina T.G., 2018, K koncepcii polnogo slovarâ narodnoj frazeologii: problemy makrostrukturirovaniâ,, ,Voprosy leksikografii”, № 14, Tomsk, s. 80-106.

Mokienko V.M., Nikitina T.G., Nikolaeva E.K., 2010, Bol'šoj slovar' russkih poslovic, Moskva.

MSR GO: Materialy k Slovarû russkih govorov Odessiiny, Kafedra russkogo Âzykaodesskogo nacional'nogo universiteta imeni I.I. Mečnikova, mašinopis'.

NAZARENKo O., 2005, Viražennâ nacional'nih mental'nih ris u frazeotematičnih grupah „,volâ”, „priroda”, „Studia Methodologica” 15, Ternopil', s. 133-137.

Nikitina T.G., 2017, Dialektnyj material kak ob"ekt frazeologičeskoj ètimologii i sredstvo ètimologii i sredstvo ètimologizacii frazeologizmov v slovare, ,Èlektronnyj naučno-obrazovatel'nyj žurnal VGSPU «Grani poznaniâ»", № 5 (52), noâbr', s. 71-75 [www.grani.vspu.ru].

Nomis: M. Nomis (uk1.), Prikazki, prisliv'â, ì take inše, Kï̈v 1993.

Nosovič I.I., 1870, Slovar' belorusskogo narěčiâ, Sankt-Peterburg.

Nosovič I.I., 1874, Sbornik bělorusskih poslovic, Sankt-Peterburg.

OĖSRF: N.M. Šanskij, V.I. Zimin, A.V. Filippov, Opyt ètimologičeskogo slovarâ russkoj frazeologii, Moskva 1987.

OLìsNIK M.Â., 2002, Frazeologiâ gucul's'kih govìrok [dis. na zdobuttâ nauk. stupenâkand. filol. nauk.], L'vìv.

Osipov B.I., (red.), 2003, Slovar' sovremennogo russkogo goroda, Moskva.

PAPì̌ V., 2004, Semantiko-funkcional'na priroda frazeologìzmìv u hudožnì prozì zakarpatoukraïns'kih pis'mennikiv (40-90 rr. XX st.), Užgorod.

PASEČNIK A., 2005, Leksikalizovannye predložno-padežnye sočetaniâ $i$ ih reprezentaciâ v leksikografi, Krasnodar.

Pletnêva O., 2004, Frazeologîa govìrok central'noï Slobožanŝini (strukturno-semantičnij aspekt), Harkiv.

Polî̀̂K L., 2010, Koncept času čes'kì frazemici, „Problemi slov`ânoznavstva”, vip. 4, s. 259-264.

PotepnÂ D.M. (red.), 2009, Leksikografiâ russkogo âzyka. Učebnik dlâ vysših učebnyh zavedenij Rossijskoj Federacii, Sankt-Peterburg.

PP 1-4: M.M. Pazâk (upor.), Prisliv 'â ta prikazki, t. 1: Priroda. Gospodars'ka diâl'nìst' lûdini, 1989, t. 2: Lûdina. Rodinne žittâ. Risi harakteru, 1990, t. 3: Vzaêmini miž lûd'mi, 1991, t. 4: Ukraïns'ki prisliv'â, prikazki ta porivnânnâ z literaturnih pam ‘âtok, 2001, Kiïv.

PRADìD Û., 1992, İz sposterežen' nad dialektnô̂ frazeologiêû (na materìali bojkìv'kih govìrok), „Movoznavstvo”, № 5, s. 44-47.

PriemyŠEva M.N., 2009, Tajnye i uslovnye âzyki v Rossii XIX v., č. 1-2, Sankt-Peterburg. PRIHOD'Ko V.K., 2016, Leksičeskie sredstva opisaniâ vnešnego vida žensininy $v$ aspekte rassmotreniâ èstetičeskoj kategorii ,prekrasnoe/bezobraznoe” (na materiale russkih govorov Priamur'â), „Sibirskij filologičeskij žurnal” 3, s. 172-181.

PRN: V.I Dal', Poslovicy russkogo naroda, v 2 t., Moskva 1984.

Rakov G.A., 1990, Problemy i metody issledovaniâ dialektnoj leksičeskoj semantiki kak sistemy, Sverdlovsk. 
RMR: M. Mihel'son, Russkaâ mysl' i reč'. Svoe i čužoe. Opyt russkoj frazeologii [https:// dic.academic.ru/dic.nsf/michelson_new/].

RoMANÛK N.V., 2002, Frazeologiâ verhn'onaddnistrâns'kih govìrok nižn'oï tečïrìcki Bistrici, dis. na zdobuttâ nauk. stupenâ kand. fîlol. nauk, Zaporì̌žâ.

SAdoǓskaÂ A., 2014, Da pytannâ ab razviccì ètnafrazealogì ǔ Belarusì, [v:] Slova ǔ kantèksce času. Da 85-goddzâ prafesara A. İ. Narkeviča. Zbornìk navukovyh prac, Mìnsk, s. 87-95.

SAR: Slovar' Akademii Rossijskoj, t. I-VI, Sankt-Peterburg 1789-1794.

SBornik 1874: Sbornik bělorusskih poslovic, sostavlennyj I. I. Nosovičem”, „Sbornik Otděleniâ russkago âzyka i slovesnosti Imperatorskoj Akademii nauk"’’ XII, № 2, Sankt-Peterburg.

SCÂŠKovìč T.F., 1968, Prykazkì, prymaǔki, frazealagìzmy, vysloǔi narodnyh gavorak Grodzenskaj voblasci, Grodna.

ScÂŠKovì̌ T.F., 1972, Matèryâly da sloǔnika Grodzenskaj voblascì, Mìnsk.

ScÂŠKovič T.F., 1983, Sloǔnik Grodzenskaj voblasci, Mìnsk.

SDUGOO: A.A. Moskalenko, Slovnik dialektizmiv ukrä̈ns'kih govirok Odes'koï oblastì, Odesa 1958.

ŠEJN P.V., 1874a, Bělorusskiâ narodnyâ pěsni, s otnosâsimisâ $k$ nim obrâdami, obyčâ̂mi i suevěriâ s priloženiem" obâsnitel'nogo slovarâi grammatičeskih" priměčanìj, Sankt-Peterburg.

ŠEJN P.V., 1874b, Materily dlâ izučeniâ byta i âzyka russkogo naseleniâ severo-zapadnogo krâ̂, t. I, č. 1: Bytovaâ i semejnaâ žizn' belorusa v obrâdah i pesnâh, Sankt-Peterburg.

ŠEKASÛK B.P., 2009, Novyj nemecko-russkij frazeologičeskij slovar', izd. 2-oe, pererab. i dop. Moskva.

SÈS: R. Rogožnikova, Slovar' èkvivalentov slova: narečnye, služebnye, modal'nye edinstva, Moskva 1991.

SFUM: V.M. Bìlonoženko ta ìn. (uklad.), Slovnik frazeologizmìv ukrä̈ns'koï movi, Kï̈v 2003.

SKripNik L., 1971, Fol'klornì elementi v ukrä̈ns'kij frazeologï̈, „Movoznavstvo”, № 2, S. $58-65$.

ŠKURAN O., 2011, Nacional'no-kul'turne pidg̀runtâ komparativnih frazeologìzmìv shidnoslobožans'kih ta shidnostepovih govirok Seredn'ogo Podìnciv 'â, Lugans'k.

SNEG.: I.M. Snegirev, Russkie narodnye poslovicy i pritči, Moskva 1848.

SOK.: M.I. Sokolova, Narodnaâ mudrost'. Poslovicy i pogovorki, Novosibirsk 2009.

Solov'eva L.V., 2001, Ne v brov', a v glaz. Poslovicy i pogovorki Pskovskoj i Leningradskoj oblasti. Babuškiny bajki, Gatčina.

ŠPILEVsKij P., 1853, Bělorusskiâ poslovicy, Sankt-Peterburg.

SPP: V.M. Mokienko, T.G. Nikitina (sost.), Slovar' pskovskih poslovic i pogovorok, nauč. red. L.A. Ivaško, Sankt-Peterburg 2001.

SR GO: U.A. Karpenko (otv. red.), Slovar' russkih govorov Odessininy, Odessa 2000-2001.

SR: Rukopisnyj sbornik „Drevnih russkih poslovic”, opublikovannyj E.R. Romanovym, kn. 1. Vil'na 1910, kn. 2. Vil'na 1912.

SRÂ: S. Ožegov, Slovar' russkogo âzyka, Moskva 1987.

SRNG: Slovar' russkih narodnyh govorov, Leningrad-Sankt-Peterburg 1965-2016. 
SSA: V. Trišin, Slovar' sinonimov ASIS [https://dic.academic.ru/dic.nsf/dic_synonims/].

SSKU: V.P. Kocura, O.İ. Potapenka, M.K. Dmitrenka (red.), Slovnik simvolìv kul'turi Ukraïni, Kiïv 2002.

SSNP: O.S. Ûrčenko, A.O. İvčenko, Slovnik stìjkih narodnih porìvnân', Harkìv 1993.

ŠSP: Û.A. Ermolaeva i dr. (sost.), Škol'nyj slovar'živyh russkih poslovic, gl. red. V.M. Mokienko, red. E.K. Nikolaeva, E.I. Seliverstova, Sankt-Peterburg 2002.

SSSRÂA: P. Denisov, V. Morkovkin, Slovar' sočetaemosti slov russkogo âzyka, Moskva 2002.

STSRÂ: T. Efremova, Sovremennyj tolkovyj slovar' russkogo âzyka [https://dic. academic. $\mathrm{ru} /$ contents.nsf/efremova/].

STUPìns'Ka G.F., 2000, Frazeologiâ lemkivs'kogo govoru ukraïns'koï movi, dis. na zdobuttâ nauk. stupenâ kand. fillol. nauk., Ternopil'.

Stupìss'Ka 2013: G.F. Stupìns'ka, Â.V. Bitkìvs'ka, Frazeologičnij slovnik lemkivs'kih govìrok, red. G.F. Stupìns'ka, V.Â. Stupìns'kij, Ternopil' 2013.

SUGO: O.İ. Bondar (golov. red.), Slovnik ukrä̈n'kih govorìv Odeŝini, Odesa 2001.

SUM: Slovnik ukraïns'koï movi, v 11 t., Kiïv 1970-1980.

SuRIKOva O., 2016, Leksičeskie edinicy s pristavkoj i predlogom bez v russkihnarodnyh govorah $i$ fol'klore: semantiko-motivacionnyj i ètnolingvisti-českij aspekty, Ekaterinburg.

SVT: E. Borisova, Slovo v tekste. Slovar' kollokacij (ustojčivyh slovosočetanij) russkogo âzyka s anglo-russkim slovarem klûčevyh slov, Moskva 1995.

TELIÂ V.N., 1986, Konnotativnyj aspekt semantiki nominativnyh edinic, Moskva.

Tolstou N.I., 1973, O rekonstrukcii praslavânskoj frazeologii, [v:] Slavânskoe âzykoznanie. VII Meždunarodnyj s"ezd slavistov. Doklady sovetskoj delegacii, Moskva, s. 272-293.

TSRÂ: D. Ušakov, Tolkovyj slovar' russkogo âzyka [https://dic.academic.ru/contents.nsf/ ushakov/].

TSSÈS: R. Rogožnikova, Tolkovyj slovar' sočetanij, èkvivalentnyh slovu: Około 1500 ustojčivyh sočetanij russkogo âzyka, Moskva 2003.

TSŽVÂ: V. Dal', Koka - smysl, tolkovanie, značenie slova, [v:] Tolkovyj slovar' živogo velikorusskogo âzyka [http://v-dal.ru/word s-40743.html].

TurČIn Ê., 2011, Slovnik sela Tilič na Lemkivŝini, L'vìv.

UžČENKO V.D., 2003, Shidnoukraïns'ka frazeologîa, Lugans'k.

UžČENKO V.D., UžČENKo D.V., 2007, Frazeologîa sučasnoï ukraïns'koï movi, Kiïv.

UžČENKo, V.D., Užčenko D.V., 2013, Frazeologičnij slovnik shidnoslobožans'kihì stepovih govirok Donbasu, Lugans'k.

VAhitov S.V., 2001, Lekciâ o russkom slenge, Ufa.

VAL'TER H., 2007, Russkaâ frazeologiâ kak konservant nemeckih frazeologizmov, [v:] MAPRÂL 2007: Mir russkogo slova i russkoe slovo v mire. Materialy XI Kongressa Meždunarodnoj associacii prepodavatelej russkogo âzykai literatury. Varna, 1723 sentâbrâ 2007 g., t. 2: Problemy frazeologii. Russkaâ leksikografiâ: tendencii razvitiâ, Sofiâ, s. 62-65.

VAL'TER H., Mokienko V.M., 2004, Sociolekty v slavânskom âzykovom prostranstve, „Universitetskij vestnik" 6, s. 54-75.

VARHol N., İvČENKo A., 1990, Frazeologičnij slovnik lemkivs'kih govirok Shidnoï Slovačči$n i$, Bratìslava. 
VenŽINOviČ N., 2007, Lingvokul'turologičnij aspekt vivčennâ frazeologiï u Tvorahivana

Čendê, ,Sučasnì problemi movoznavstva ta literaturoznavstva”, vip. 2, s. 208-212.

VenžInovič N., 2012, Nacional'no-kul'turna specifika frazem u tvorah Petraskuncâ, „Naukovij vìsnik Užgorods'kogo unìversitetu. Seriâ: Fìlologîa. Socìal'nì komunìkaciii”, vip. 28, s. 164-166.

VenžInOviČ N., 2016, Frazemìka v povistì İ. Nečuâ-Levic'kogo „Kajdaševa sìm 'â” âk džerelo vidtvorennâ mental'nih ris ukrä̈nciv, „Movoznavčij vìsnik”, vip. 21, s. 61-66.

Vinogradov V., 1977, Ob osnovnyh tipah frazeologičeskih edinic v russkom âzyke, [v:] V. Vinogradov, Leksikologiâ i leksikografiâ: izbrannye trudy, Moskva.

VoJTovič V.M., 2002, Ukraïns'ka mifologiâ, Kiïv.

ZEMSKAÂ E.A., Rozina R.I., 1994, O slovare sovremennogo russkogo žargona, „Rusistika” № 1-2, s. 96-112.

ŽAJvoronok V.V., 2006, Znaki ukraïns'koï etnokul'turi. Slovnik-dovidnik, Kïv.

Žukov V.P., 1991, Slovar' russkih poslovic i pogovorok, 11-e izd. (stereotip.), Moskva. 


\section{Biblioteka "LingVariów”}

t. 1: Listy Jana Baudouina de Courtenay do Henryka Ułaszyna z lat 1898-1929, oprac. M. Skarżyński i M. Smoczyńska, Kraków 2007.

t. 2: Wręu języka. Materiały konferencji „Słowotwórstwo - słownictwo - polszczyzna kresowa” poświęconej pamięci Profesor Zofii Kurzowej. Kraków 16-17 maja 2008 r., pod red. M. Skarżyńskiego i M. Szpiczakowskiej, Kraków 2009.

t. 3: Język z różnych stron widziany. Materiały ogólnopolskiej doktorancko-studenckiej konferencji naukowej ,Z zagadnień metodologii badań językoznawczych”. Kraków 10-11 marca 2008 r., pod red. M. Skarżyńskiego i A. Czelakowskiej, Kraków 2009.

t. 4: J. Godyń, Studia historycznojęzykowe, edytorskie, kulturalnojęzykowe, Kraków 2009.

t. 5: Polszczyzna mówiona ogólna i regionalna. Materiały ogólnopolskiej konferencji naukowej, Kraków, 25-26 września 2008 r., pod red. B. Dunaja i M. Raka, Kraków 2009.

t. 6: A. Czelakowska, Opisy fleksyjne w gramatykach polskich lat 1817-1939, Kraków 2010.

t. 7: H. Ułaszyn, Z Kopiowatej na katedry uniwersyteckie. Wspomnienia, Z rękopisu opracował, opatrzył przypisami i wydał M. Skarżyński, Kraków 2010.

t. 8: A. Czelakowska, M. Skarżyński, Materiaty do dziejów polskiego językoznawstwa. Listy Jana Baudouina de Courtenay, Jana Łosia, Kazimierza Nitscha, Jana Rozwadowskiego, Henryka Ułaszyna, Kraków 2011.

t. 9: Symbolae grammaticae in honorem Boguslai Dunaj, pod red. R. Przybylskiej, J. Kąsia i K. Sikory, Kraków 2010.

t. 10: Silva rerum philologicarum. Studia ofiarowane Profesor Marii Strycharskiej-Brzezinie z okazji Jej jubileuszu, pod red. J.S. Gruchały i H. Kurek, Kraków 2010.

t. 11: M. Rak, Materiały etnograficzne z Podhala Ignacego Moczydłowskiego, Kraków 2011.

t. 12: T. Kurdyła, Funkcje formantów rzeczownikowych w polszczyźnie ludowej (na przykładzie trzech wsi podkarpackich), Kraków 2011.

t. 13: W. Cockiewicz, Metaforyka Leśmiana (Analiza lingwistyczna), Kraków 2011.

t. 14: Badania historycznojezzykowe. Stan, metodologia, perspektywy, pod red. B. Dunaja i M. Raka, Kraków 2011.

t. 15: Języki słowiańskie w ujęciu socjolingwistycznym. Prace przygotowane na XV Międzynarodowy Kongres Slawistów, Mińsk 2013, pod red. H. Kurek, Kraków 2013.

t. 16: K. Tutak, O dedykacjach $w$ drukach polskich XVI $i$ XVII w. (grafia i interpunkcja), Kraków 2013.

t. 17: Badania dialektologiczne. Stan, perspektywy, metodologia, pod red. M. Raka i K. Sikory, Kraków 2014.

t. 18: M. Sagan-Bielawa, Dziedzictwo pozaborowe. Społeczna świadomość językowa Polaków w Drugiej Rzeczypospolitej, Kraków 2014.

t. 19: M. Rak, Kulturemy podhalańskie, Kraków 2015.

t. 20: A. Sieradzka-Mruk, ,Radość i nadzieja, smutek i trwoga” w nabożeństwie drogi krzyżowej. Wybrane aspekty ewolucji dyskursu religijnego w XX wieku na przyktadzie leksyki dotyczącej uczuć, Kraków 2016. 
t. 21: Materiały do dziejów polskiego językoznawstwa. II: Jan Baudouin de Courtenay, Teksty mniej znane, Wybór, przekład i opracowanie M. Skarżyński, Kraków 2016.

t. 22: M. Rak, Materiały do etnografii Podhala, Kraków 2016.

t. 23: Słowiańska frazeologia gwarowa, pod red. M. Raka i K. Sikory, Kraków 2016.

t. 24: M. Karaś, Ze studiów leksykologicznych i onomastycznych. Wybór i opracowanie J. Reichan i M. Rak, Kraków 2017.

t. 25: M. Rak, Materiały do dziejów polskiej dialektologii i etnologii. Listy Cezarii Baudouin de Courtenay-Ehrenkreutz-Jędrzejewiczowej, Adama Fischera, Antoniego Kaliny, Izydora Kopernickiego, Kazimierza Nitscha, Seweryna Udzieli, Juliusza Zborowskiego, Kraków 2018.

t. 26: M. Skarżyński i E. Smułkowa (oprac., wstęp i przypisy), Materiały do dziejów polskiego językoznawstwa III. Korespondencja Kazimierza Nitscha i Antoniny Obrębskiej-Jabłońskiej 1925-1958, Kraków 2018.

t. 27: J. Labocha, Składnia żądania we współczesnej polszczyźnie mówionej, Kraków 2019.

t. 28: Słowiańska frazeologia gwarowa II, pod red. M. Raka i V.M. Mokienki, Kraków 2020.

\section{Biblioteka „LingVariów”. „Seria Glottodydaktyka”}

t. 1: Programy nauczania języka polskiego jako obcego. Poziomy A1 - C2. Praca zbiorowa pod red. I. Janowskiej, E. Lipińskiej, A. Rabiej, A. Seretny i P. Turka, Kraków 2011; wyd. 2. poprawione, Kraków 2016.

t. 2: T. Czerkies, Tekst literacki w nauczaniu języka polskiego jako obcego (z elementami pedagogiki dyskursywnej), Kraków 2012.

t. 3: B. Ligara, W. Szupelak, Lingwistyka i glottodydaktyka języków specjalistycznych na przykładzie języka biznesu. Podejście porównawcze, Kraków 2012.

t. 4: A. Prizel-Kania, Rozwijanie sprawności rozumienia ze słuchu w języku polskim jako obcym, Kraków 2013.

t. 5: E. Lipińska, A. Seretny, Integrowanie kompetencji lingwistycznych $w$ glottodydaktyce. Na przykładzie nauczania języka polskiego jako obcego/drugiego. Poradnik metodyczny z ćwiczeniami, Kraków 2013.

t. 6: P.E. Gębal, Modele kształcenia nauczycieli języków obcych w Polsce w Niemczech. W strone glottodydaktyki porównawczej, Kraków 2013.

t. 7: P.E. Gębal, Krakowska szkoła glottodydaktyki porównawczej na tle rozwoju glottodydaktyki ogólnej i polonistycznej, Kraków 2014.

t. 8: A. Seretny, Stownictwo w dydaktyce języka. Świat słów na przykładzie języka polskiego jako obcego, Kraków 2015.

t. 9: D. Gałyga, Skuteczność nauczania cudzoziemców języka polskiego jako obcego na przykładzie działalności Instytutu Polonijnego Uniwersytetu Jagiellońskiego w latach 1996-2004, Kraków 2015.

t. 10: Umiejętność rozumienia i tworzenia tekstów w świetle Standardów wymagań egzaminacyjnych oraz Europejskiego systemu opisu ksztatcenia językowego. Monografia zbiorowa pod red. E. Lipińskiej i A. Seretny, Kraków 2015. 
t. 11: M. Stawicka, W poszukiwaniu nowej równowagi w nauczaniu języków obcych w szkole wyższej na przykładzie projektu edukacyjnego English++, Kraków 2015.

t. 12: Ttumaczenie dydaktyczne w nowoczesnym kształceniu językowym. Monografia zbiorowa pod red. E. Lipińskiej i A. Seretny, Kraków 2016.

t. 13: Języ, literatura i kultura polska w świecie. Monografia zbiorowa pod red. W. Miodunki i A. Seretny, Kraków 2016.

t. 14: Bilingwizm polsko-obcy dziś. Od teorii i metodologii badań do studiów przypadków. Monografia zbiorowa pod red. R. Dębskiego i W. T. Miodunki, Kraków 2016.

t. 15: O lepsze jutro studiów polonistycznych w świecie. Glottodydaktyka polonistyczna dziś, pod red. I. Janowskiej i P.E. Gębala, Kraków 2016.

t. 16: W.T. Miodunka, Glottodydaktyka polonistyczna. Pochodzenie - stan obecny - perspektywy, Kraków 2016.

\section{Sprzedaż prowadzi \\ WYDAWNICTWO KSIĘGARNIA AKADEMICKA}

ul. św. Anny 6, 31-008 Kraków

tel./faks: 12 431-27-43, 12 421-13-87

e-mail: akademicka@akademicka.pl

Księgarnia internetowa: https://akademicka.pl 
